\title{
Living for the City
}

Social Change and

Knowledge Production in the

Central African Copperbelt

Miles Larmer 


\section{Living for the City}

Living for the City is a social history of the Central African Copperbelt, considered as a single region encompassing the neighbouring mining regions of Zambia and the Democratic Republic of Congo. The HautKatanga and Zambian Copperbelt mine towns have been understood as the vanguard of urban 'modernity' in Africa. Observers found in these towns new African communities that were experiencing what they wrongly understood as a transition from rural 'traditional' society - stable, superstitious and agricultural - to an urban existence characterised by industrial work discipline, the money economy and conspicuous consumption, Christianity, and nuclear families headed by male breadwinners supported by domesticated housewives. Miles Larmer challenges this representation of Copperbelt society, presenting an original analysis that integrates the region's social history with the production of knowledge about it, shaped by both changing political and intellectual contexts and by Copperbelt communities themselves. This title is available as Open Access on Cambridge Core.

Miles larmer is Professor of African History in the Faculty of History and African Studies Centre, St Antony's College, University of Oxford, and Research Fellow in the Department of Historical and Heritage Studies at the University of Pretoria. A Fellow of the Royal Historical Society, he is the author of The Katangese Gendarmes and War in Central Africa, with Erik Kennes (2016), Rethinking African Politics: A History of Opposition in Zambia (2011) and Mineworkers in Zambia: Labour and Political Change in Post-Colonial Africa, 1964-1991 (2007). 


\section{Living for the City}

Social Change and Knowledge Production in the Central African Copperbelt

MILES LARMER

University of Oxford and University of Pretoria

\section{国 CAMBRIDGE}




\section{CAMBRIDGE UNIVERSITY PRESS}

University Printing House, Cambridge CB2 8BS, United Kingdom

One Liberty Plaza, 20th Floor, New York, NY 10006, USA

477 Williamstown Road, Port Melbourne, VIC 3207, Australia

314-321, 3rd Floor, Plot 3, Splendor Forum, Jasola District Centre, New Delhi - 110025, India

103 Penang Road, \#05-06/07, Visioncrest Commercial, Singapore 238467

Cambridge University Press is part of the University of Cambridge.

It furthers the University's mission by disseminating knowledge in the pursuit of education, learning, and research at the highest international levels of excellence.

www.cambridge.org

Information on this title: www.cambridge.org/9781108833158

DOI: $10.1017 / 9781108973120$

(C) Miles Larmer 2021

This work is in copyright. It is subject to statutory exceptions and to the provisions of relevant licensing agreements; with the exception of the Creative Commons version the link for which is provided below, no reproduction of any part of this work may take place without the written permission of Cambridge University Press.

An online version of this work is published at doi.org/10.1017/9781108973120 under a Creative Commons Open Access license CC-BY-NC-ND 4.0 which permits re-use, distribution and reproduction in any medium for non-commercial purposes providing appropriate credit to the original work is given. You may not distribute derivative works without permission. To view a copy of this license, visit https://creativecommons.org/licenses/by-nc-nd/4.0

All versions of this work may contain content reproduced under license from third parties.

Permission to reproduce this third-party content must be obtained from these thirdparties directly.

When citing this work, please include a reference to the DOI 10.1017/9781108973120

This book is based on research that has received funding from the European Research Council (ERC) under the European Union's Horizon 2020 research and innovation programme (grant agreement number 681657: 'Comparing the Copperbelt: Political Culture and Knowledge Production in Central Africa').

First published 2021

A catalogue record for this publication is available from the British Library.

ISBN 978-1-108-83315-8 Hardback

Cambridge University Press has no responsibility for the persistence or accuracy of URLs for external or third-party internet websites referred to in this publication and does not guarantee that any content on such websites is, or will remain, accurate or appropriate. 
For my mother, Gillian Larmer (1946-2020) 


\section{Contents}

List of Figures

page viii

Acknowledgements

ix

List of Abbreviations and Acronyms

xiii

Introduction $\quad 1$

1 Imagining the Copperbelts 34

2 Boom Time - Revisiting Capital and Labour in the Copperbelt 65

3 Space, Segregation and Socialisation 96

4 Political Activism, Organisation and Change in the Late Colonial Copperbelt

5 Gendering the Copperbelt 162

6 Nationalism and Nationalisation 195

7 Copperbelt Cultures from the Kalela Dance to the Beautiful Time 227

8 Decline and Fall: Crisis and the Copperbelt, 1975-2000 261

9 Remaking the Land: Environmental Change in the Copperbelt's History, Present and Future 292

$\begin{array}{ll}\text { Conclusion } & 321\end{array}$

References $\quad 336$

Index $\quad 372$ 


\section{Figures}

0.1 Map of the Copperbelt region.

3.1 Map of Likasi, Zaire, 1980 (detail from).

3.2 Map of Mufulira, 1961.

5.1 Protesting wives of mineworkers. Times of Zambia, 7 July 1981. page 33

111

112

182

viii 


\section{Acknowledgements}

More than most monographs, this book rests on the collective efforts of the brilliant team of researchers it has been my privilege and pleasure to work alongside during the five years (2016-2021) of the 'Comparing the Copperbelt' project. Each of these researchers brought distinctive insights and made major contributions to the project as a whole and to this volume in particular. Stephanie Lämmert conducted important new research on religious belief in Zambia and clarified my understanding of spiritual practice on the Copperbelt. Iva Peša, our de facto team leader in many ways, devised and implemented our interview strategy, carried out significant archival research on both sides of the border and influenced my explanation of the region's environmental and agricultural history, presented here in Chapter 9. Benoît Henriet was vital to developing project research and partnerships in Haut-Katanga, conducting many interviews and shaping my understanding of the post-colonial university. Enid Guene identified and carried out the interviews with the painters, musicians and artists of other kinds that are central to Chapter 7. Rachel Taylor likewise conducted interviews with Katangese social welfare officers cited in Chapter 5 and helped develop my comparative analysis of community development. Together with Claire Phillips, our outstanding project administrator, they have made this work possible, though I of course bear full responsibility for all its weaknesses and errors.

Our collective work has been enabled, in turn, by our co-researchers Grant Chisapa and Pierrot Monzi Kalonga, as well as the many other Congolese and Zambian interlocutors and translators who were vital to the research process. They, like their predecessors who are among the subjects of this book, brought to the project not only their skills but also their insights and experience as members of Copperbelt societies, greatly enriching it as a result. Access to local archival sources and interviewees was equally enabled by dozens of local partners, among 
whom I would highlight my old friend Charles Muchimba, Research Director of the Mineworkers' Union of Zambia, former MUZ Kitwe Branch Chairman Lesa Kanyanta and Josephine Lukwesa in Mufulira.

Colleagues at the University of Lubumbashi, particularly Professors Donatien Dibwe dia Mwembu and Germain Ngoie Tshibambe, provided crucial intellectual guidance and practical assistance throughout the entire project. Colleagues in the History Department of the University of Zambia, particularly Professor Walima Kalusa, Professor Bizeck J. Phiri and (elsewhere at UNZA) Dr Hikabwa Chipande, provided valuable guidance and critical analysis of my approach. At Copperbelt University (CBU), Professors John Lungu and Owen Sichone and Drs Robby Kapesa and Edna Kabala Litana were equally important influences on our research, helping to organise the 2018 Kitwe conference and hosting presentations on the project. The study has equally been enabled by archivists at the following institutions: the African Studies Centre in Leiden; the Archives Africaines housed at the Belgian Ministry of Foreign Affairs; the Belgian Archives Générales du Royaume; the personnel archives of the Gécamines company in Likasi; the International Library of African Music (ILAM) at Rhodes University in Grahamstown, particularly its Director, Dr Lee Watkins; the archives of the International Monetary Fund in Washington, DC; the National Archives of Zambia in Lusaka; officials and councillors at Mufulira district council, who made council records available; and last but by no means least, the archivists of the ZCCM-IH archives in Ndola, particularly Lembani Chagona and Dennis Kangwa.

This research was equally made possible by my colleagues at the University of Oxford who variously encouraged me to apply to the ERC, advised on the project's approach and enabled the lengthy period of research leave required for its implementation. Past and present colleagues and students in Oxford's Faculty of History, the African Studies Centre and St Antony's College to whom I am particularly indebted include: Wale Adebanwi, Harriet Aldrich, Jocelyn Alexander, Idalina Baptista, William Beinart, James Belich, Paul Betts, Peter Brooke, Nic Cheeseman, Patricia Clavin, Martin Conway, David Damtar, John Darwin, the late (and greatly missed) Jan-Georg Deutsch, Roger Goodman, Erin Gordon, Pekka Hämäläinen, Thomas Hendriks, Tim Livsey, Sebabatso Manoeli, Aileen Mooney, Rachel Murphy, Katharina Oke, David Pratten, 
Richard Reid, Ramon Sarró, Jonny Steinberg, Miles Tendi and John Watts.

My early ideas about this subject have since 2015 been presented at research centres, seminars and conferences. The arguments and analyses presented here have been greatly improved by the questions, comments and criticism of participants and discussants at those events and others held at the University of Oxford and elsewhere. These include the International Institute of Social History, Amsterdam (March 2015); the Université Libre Brussels (December 2015); the University of Cambridge (February 2016); the UK African Studies Association conference (September 2016); the Nordic Africa Institute (December 2016); the University of Leipzig (May 2017); the European Conference on African Studies (June 2017); the Southern African Institute for Policy and Research, Lusaka and Copperbelt University, Kitwe (both July 2017); the University of Lubumbashi (January 2018); the Centre of Social Studies at the University of Coimbra (March 2019); the University of Lausanne (May 2019); the Southern African Historical Society (June 2019); the African Studies Association of the United States (November 2019); and L'École des hautes études en sciences sociales in Marseille (November 2019). I am grateful to the editors of the journals Labour History and Comparative Studies in Society and History for allowing the inclusion of revised material from articles published in those journals, as well as to the anonymous reviewers of those journals, and of this manuscript, for their helpful comments and criticisms.

The first draft of this manuscript was written while I was an associate member of the Institut des Mondes Africains (IMAf) in Aix-enProvence in 2019-2020. I am particularly grateful to Henri Médard, who ensured I had working space at the Universite Aix-Marseille and who, with Valérie Golaz and others, provided extraordinary support and friendship during the year in general and - at a suitable distance during 'confinement' in particular. I would also like to thank Maria Marsh and her colleagues at Cambridge University Press for their unstinting support of this project.

In addition to those mentioned above, my understanding of the evidence, ideas and analysis presented here has been enormously improved by discussions with the dozens of historians and social scientists who have generously engaged with the 'Comparing the Copperbelt' project's activities, events and publications. I would 
particularly like to thank the following individuals: Mostafa Abdelaal, Kate Alexander, David Anderson, Miguel Bandeira-Jeronimo, Karin Barber, Stefano Bellucci, Stefan Berger, Hélène Blaszkiewicz, Filip de Boeck, Gavin Bridge, Deborah Bryceson, Alexander Caramento, Geert Castryck, Jennifer Chibamba Chansa, Andreas Eckert, Nicole Eggers, Kristien Geenen, Jan-Bart Gewald, David M. Gordon, Zoe Groves, the late Patrick Harries, Gavin Hilson, Marja Hinfelaar, Nancy Rose Hunt, Bogumil Jewsiewicki, Emery Kalema, Sarah Katz-Lavigne, Erik Kennes, Rita Kesselring, Vito Laterza, Amandine Lauro, Baz Lecocq, Brian J. Leech, Emma Lochery, Reuben Loffman, David Maxwell, Tom McNamara, Duncan Money, Christian Müller, Steffi Marung, James Musonda, Patience Mususa, Joël Noret, Margaret O'Callaghan, Francesca Pugliese, Katrien Pype, Corey Ross, Benjamin Rubbers, Jeff Schauer, Sishuwa Sishuwa, Miyanda Simabwachi, Christian Straube, Martin Thomas, Thomas Turner, Sarah van Beurden, Daniela Waldburger and Luise White. 


\section{Abbreviations and Acronyms}

\begin{tabular}{|c|c|}
\hline $\mathrm{AAC}$ & Anglo-American Corporation \\
\hline AAI & Amis de l'Art Indigène \\
\hline AGRIS & Société Agro-Industrielle \\
\hline AMWU & African Mineworkers' Union \\
\hline ANC & Congolese National Army \\
\hline Asadho & Association africaine des droits de l'homme \\
\hline BAA & Archives Africaines, Belgium \\
\hline $\mathrm{BCK}$ & Chemin de fer du bas Congo au Katanga \\
\hline $\mathrm{BFr}$ & Belgian Francs \\
\hline CAF & Central African Federation \\
\hline $\mathrm{CBE}$ & Citizens for a Better Environment \\
\hline $\mathrm{CBU}$ & Copperbelt University \\
\hline CCTA & $\begin{array}{l}\text { Combined Commission for Technical Cooperation in } \\
\text { Africa South of the Sahara }\end{array}$ \\
\hline CEC & Centres Extra-Coutumier \\
\hline Ceproma & Cercle pour la Promotion de Marungu \\
\hline CEPSE & $\begin{array}{l}\text { Centre D’Exécution des Programmes Sociaux et } \\
\text { Économiques }\end{array}$ \\
\hline CEPSI & Centre d'Études des Problèmes Sociaux Indigènes \\
\hline $\mathrm{CIE}$ & Indigenous Enterprise Council \\
\hline CIPEC & $\begin{array}{l}\text { Intergovernmental Council of Copper-Exporting } \\
\text { Countries }\end{array}$ \\
\hline CNS & Sovereign National Conference \\
\hline Conakat & Confédération des associations tribales du Katanga \\
\hline Cosccet & $\begin{array}{l}\text { Le Comité de Suivi pour la Contribution des } \\
\text { Communautés et Eglises à la Transformation Humaine }\end{array}$ \\
\hline DRC & Democratic Republic of Congo \\
\hline DSP & Division Spéciale Présidentielle \\
\hline ECZ & Environmental Council of Zambia \\
\hline EIA & Environmental Impact Assessment \\
\hline EIS & Environmental Impact Statement \\
\hline
\end{tabular}




$\begin{array}{ll}\text { EPA } & \text { Environmental Protection Agency } \\ \text { FULREAC } & \begin{array}{l}\text { Fondation de l'Universite de Liège pour les Recherches } \\ \text { Scientifiques au Congo Belge et au Ruanda-Urundi }\end{array} \\ \text { Gassomel } & \text { Groupement des associations de l'empire lunda } \\ \text { GCM } & \text { Gécamines La Générale des Carrières et des Mines } \\ \text { GRZ } & \text { Government of the Republic of Zambia } \\ \text { IAS } & \text { Institute for African Studies } \\ \text { IBRD } & \text { International Bank for Reconstruction and } \\ & \text { Development } \\ \text { ICI } & \text { International Colonial Institute } \\ \text { IFI } & \text { International Financial Institution } \\ \text { ILAM } & \text { International Library of African Music } \\ \text { ILO } & \text { International Labour Organisation } \\ \text { IMF } & \text { International Monetary Fund } \\ \text { IMNZ } & \text { Institute of National Museums of Zaire } \\ \text { Indeco } & \text { Industrial Development Corporation } \\ \text { INÉAC } & \text { Institut Nationalpour L'Étude Agronomique du Congo } \\ & \text { Belge } \\ \text { JMPR } & \text { Jeunesse du Mouvement Populaire de la Révolution } \\ \text { KCM } & \text { Konkola Copper Mines } \\ \text { KPC } & \text { Katanga Provincial Council } \\ \text { MASA } & \text { Mines African Staff Association } \\ \text { MMD } & \text { Movement for Multi-party Democracy } \\ \text { MNC } & \text { Mouvement Nationale Congolaise } \\ \text { MPR } & \text { Mouvement Populaire de la Révolution } \\ \text { MUZ } & \text { Mineworkers' Union of Zambia } \\ \text { MWU } & \text { [European] Mineworkers' Union } \\ \text { Namboard } & \text { National Agricultural Marketing Board } \\ \text { NAZ } & \text { National Archives of Zambia } \\ \text { NCCM } & \text { Nchanga Consolidated Copper Mines } \\ \text { NGO } & \text { Non-Governmental Organisation } \\ \text { NRANC } & \text { Northern Rhodesian African National Congress } \\ \text { NRCSS } & \text { Northern Rhodesian Council for Social Services } \\ \text { PCBs } & \text { Polychlorinated Biphenyls } \\ \text { PF } & \text { Patriotic Front } \\ \text { RLI } & \text { Rhodes-Livingstone Institute } \\ \text { RMCA } & \text { Royal Museum of Central Africa } \\ \text { RRC } & \text { Race Relations Committee } \\ \text { RST } & \text { Rhodesian (later Roan) Selection Trust } \\ & \end{array}$


SGM Société Générale des Minerais

SNCC Société Nationale des Chemins de Fer du Congo

SNCZ Société Nationale des Chemins de Fer du Zaire

SNEL Société Nationale d'Electricité

Somika Société Minière du Katanga

SOZACOM Société Zairoise de Commercialisation des Minerals

SRK Steffen, Robertson and Kirsten

TEPSI Commission Provincial pour le Travail et le Progrès des

Indigènes

UCS Usines Chimiques de Shituru

UFERI Union des Fédéralistes et Républicains Indépendants

UMCB United Missions to the Copperbelt

UMHK Union Minière du Haut-Katanga

UMHKA Union Minière du Haut-Katanga Archives

UMU United Mineworkers' Union

UNAZA University of Zaire

UNESCO United Nations Educational, Scientific and Cultural

Organization

UNIP United National Independence Party

UNTZA Union Nationale des Travailleurs du Zaire

UNZA University of Zambia

UPP United Progressive Party

WB World Bank

WHO World Health Organization

ZBS Zambian Broadcasting System

ZCCM Zambia Consolidated Copper Mines

ZCCM-IH Zambia Consolidated Copper Mines - Investment

Holdings

ZCTU Zambia Congress of Trade Unions

ZIT Zambia Institute of Technology

ZMU Zambia Mineworkers' Union

ZNBC Zambia National Broadcasting Corporation 


\section{Introduction}

In the mid-twentieth century, thousands of women moved from diverse communities across central Africa to new towns in an area historically associated with Lamba, Lunda and other societies, some of whom had produced valuable minerals there. These women, many joined by their husbands and families, engaged in a wide range of economic activities including subsistence and commercial farming but also informal trade and labour. Over the next decades - as their number swelled to tens and then hundreds of thousands - they built vibrant communities based on new forms of social, cultural and religious association and identities. They and their families had, however, to contend with repression and attempts at political domination by illegitimate authorities over which they lacked control, severe market fluctuations in the buying power of their customers and the environmental effects of their neighbours' activities on their health, land and economic opportunities.

This is a history of the Central African Copperbelt that is every bit as representative as one that is far better known. The dominant history of the Copperbelt region, encompassing the mining towns of HautKatanga (in today's Democratic Republic of Congo - DRC) and neighbouring Zambia, is of male migration for wage labour - first temporary and later permanent - to new industrial mines run by Western companies, intimately connected to the colonies that drew their borders, ruled them and enabled the exploitation of their mineral wealth. Male migrants, this history tells us, brought their families to new company towns, where they founded ethnic associations, political parties and trade unions, and where they secured improved living conditions, funded by the revenue generated by expanding production of copper and later cobalt. With national independence came mine nationalisation, but this was followed by economic decline commensurate with falling mineral prices and the late twentieth century saw corrupt privatisation processes and (in the DRC) military conflict that accelerated the collapse of these communities. 
The latter history dominates our imagination of the Copperbelt for a number of reasons, some obvious, some less so. The region mattered for global capital and policy-makers insofar as it produced strategic minerals: copper that enabled the global post-Word War Two boom and modern warfare, supplying the uranium used on Hiroshima and Nagasaki. It came to the attention of company and colonial officials (and their post-colonial successors) when its residents rioted, struck work and organised politically, disrupting the flow of minerals and threatening their control over it. For social scientists, some of whom were funded by and some of whom were critical of these mine companies and states, this version of the Copperbelt provided revealing evidence of social change enabled by new urban contexts, change that needed careful management and specific policy interventions. ${ }^{1}$ Later, the Copperbelt provided a cautionary tale of skewed development, unsustainable consumption and over-dependence on a wasting resource. $^{2}$ By the 1980s this inspiring hyper-modern space had become a dinosaur, in need of external aid and reform: social scientists now explained the failure of Copperbelt modernity and charted its residents' efforts to challenge or to manage their decline, as well as their nostalgia for its better times. ${ }^{3}$

1 Among the many important early studies in this area, see: Jean-Luc Vellut, 'Les Bassins Miniers de L'Ancien Congo Belge'. Essai D’Histoire Économique et Sociale (1900-1960)', Les Cahiers du CEDAF (Brussels: CEDAF, 1981); Charles Perrings, Black Mineworkers in Central Africa: Industrial Strategies and the Evolution of an African Proletariat in the Copperbelt, 1911-1941

(New York: Africana Publishing, 1979); Arnold L. Epstein, Politics in an Urban African Community (Manchester, UK: Manchester University Press, 1958); J. Clyde Mitchell, 'The Kalela Dance: Aspects of Social Relationships Among Urban Africans in Northern Rhodesia', Rhodes Livingstone Institute Papers No. 29 (Manchester, UK: Manchester University Press, 1959); Pierre Caprasse, Leaders Africains en Milieu Urbain (Brussels: CEPSI, 1959); Arthur Doucy and Pierre Feldheim, Problèmes du Travail et Politique Sociale au Congo Belge (Brussels: Editions de la Librairie Encyclopédique, 1952).

2 Robert H. Bates, Unions, Parties and Political Development: A Study of Mineworkers in Zambia (New Haven, CT: Yale University Press, 1971); Philip Daniel, Africanisation, Nationalisation and Inequality (Cambridge: Cambridge University Press, 1979).

3 James Ferguson, Expectations of Modernity: Myths and Meanings of Urban Life on the Zambian Copperbelt (Berkeley: University of California Press, 1999); Donatien Dibwe dia Mwembu, Bana Shaba Abandonnés par Leur Père: Structures de L'Autorité et Histoire Sociale de la Famille Ouvrière au Katanga, 1910-1997 (Paris: L'Harmattan, 2001); Benjamin Rubbers, Le Paternalisme en Question: Les Anciens Ouvriers de la Gécamines face à la lIbéralisation du 
If these external characterisations were the only reason for the hegemony of this one-sided vision of Copperbelt society and the marginalisation of the historical experiences highlighted in the opening paragraph, then the primary task of this study would be to displace them by a sustained consideration of Copperbelt stories that have not been told, adding to the historical record the 'hidden' or 'invisible' histories of, among other things, women's work, informal communities, farming and the despoliation of land by pollution. And this book does do this by extending the social history of the Central African Copperbelt to these and other topics that have not been the sustained focus of scholarly and institutional attention, of what is termed here official or elite 'knowledge production'.

And yet the dominant history of the Copperbelt, of men and mining, of politics and economics, of boom and bust, modernity and its fall, is also the history that has been narrated and told, in the past and today, by Copperbelt residents both to social scientists and to each other. The mythic modernist narrative identified and eloquently critiqued by James Ferguson two decades ago is one that, despite its evident distortion of the complex, open-ended realities of recent Copperbelt history, underwrites the dominant political, social and cultural discourses of the region. ${ }^{4}$ The simplistic, distorting, modernist narrative of a binary transition from rural village life - supposedly traditional, static, superstitious, communal and reciprocal - to the modern, materialistic, capitalist, individualist and Christian town - while now happily rejected by post-modern, postcolonial social science, has underpinned the aspirations of politicians, the demands of protestors and the songs and paintings of Copperbelt musicians and artists and, in an era of sustained decline, still does so today.

This is then the dominant history of the region both because of the distorting and silencing effects of intellectual knowledge production (with its Western gaze, colonial archive, white researchers and male subjects) and because Copperbelt communities have produced their own knowledge that, while differing from the binaries of 'tradition/ modernity' in subtle and important ways, nonetheless largely

Secteur Minier Katangais (RD Congo) (Paris: L'Harmattan, 2013); Patience Mususa, 'There used to be order: life on the Copperbelt after the privatisation of the Zambia Consolidated Copper Mines', unpublished PhD thesis, University of Cape Town (2014).

4 Ferguson, Expectations of Modernity. 
articulates its own modernist narrative from below. This book will, therefore, in presenting an intertwined history of Copperbelt society and the production of knowledge about that society from within and without, attempt to explain the relationship between the two. It argues that, from the start, popular and elite ideas about the region have been intimately interconnected and mutually constitutive, even if profoundly unequal in their reach and influence. African communities, which provided policy-makers and social scientists with the raw material for their understanding and articulations of historical and social change, had their own diverse ideas about and claims for social advancement that they articulated in forms that resonated with those with power over them and who they sought to influence. The language of urban social change - of civilisation, citizenship, status and development - infused the individual and collective self-expression of Copperbelt communities and informed the ways they explained the relationship between past, present and hoped-for future.

The fact that the Copperbelt is such an intensively studied region is both a reason for this study and the underlying basis of it. Readers are, however, entitled to ask what they can possibly learn about the Central African Copperbelt that they don't already know. The book's claim to innovation and originality rests on the following three interlinked approaches.

\section{Historicising the Cross-Border Copperbelt}

Despite the many common factors linking - as well as important differences between - the Zambian and Congolese Copperbelt regions, they have, with very few exceptions, been studied separately: their presence in their respective colonies (Northern Rhodesia and Belgian Congo) and nation-states has been taken for granted by a methodological nationalism that assumes their relationship to these states and downplays or ignores their parallel developments and, more importantly, the extent to which this has been a single region, linked by flows of people, minerals, goods and ideas, divided by a (post)colonial border that has then itself acquired a range of meanings and values for its resident communities. ${ }^{5}$

5 For a characteristically insightful engagement with the cross-Copperbelt region, see Luise White, Speaking with Vampires: Rumor and History in Colonial Africa (Berkeley: University of California Press, 2000), pp. 269-306. 
This study aims to both holistically analyse the Copperbelt region and to compare its two component parts, drawing out their similarities and divergences and the way these have been shaped by the interaction of material differences and the way those differences have been imagined and given meaning. These date back to the early (pre-colonial) exploitation of the region's mineral wealth, when it provided a significant basis for the growth of important Luba and Lunda kingdoms in what is today the DRC. Whereas in Katanga prominent outcrops provided access to significant copper ore, to the south most copper sulphide ores lay deeper underground and could not be mined effectively without industrial technology. This led to a vital difference in the way that copper mining is imagined: whereas in Zambia copper is largely associated with externally imposed industrial-scale mining and migrant labour, in Katanga the historical memory of indigenous pre-colonial mining partly shaped the late-colonial political discourse of its secession and the ethnicisation of Katangese politics.

The early development of Copperbelt industrial mining was, however, deeply interlinked by the overlapping capital formations of three principal mining companies and their parallel prospecting initiatives. The early development of Katangese mines was likewise enabled by the recruitment of labour from Northern Rhodesia's Northern Province, primarily Bemba and neighbouring populations that would later form the largest part of the labour force of Northern Rhodesia's own mine industry as it developed from the late 1920s. ${ }^{6}$ Labour recruitment, a general problem in a region of sparse population, was addressed (as across southern Africa) by recruitment agencies but - from the early 1920 s - in divergent ways. The suppression of the 1919 white workers' strike in Katanga led the mine company Union Minière $d u$ HautKatanga (UMHK) and the Belgian state to encourage 'nationalist' recruitment: a smaller number of Europeans from Belgium itself and an emphasis on attracting African migrants from Belgian Congo and Ruanda-Urundi. ${ }^{7}$ During the 1920 s and 1930s UMHK invested in mechanisation and labour stabilisation, skilling its African workers and extending their contracts but also encouraging them to bring

6 Enid Guene, 'Copper's Corollaries: Trade and Labour Migration in the Copperbelt (1910-1940)', Zambia Social Science Journal, 4, 1 (2013).

7 John Higginson, A Working-Class in the Making: Belgian Colonial Labor Policy, Private Enterprise, and the African Mineworker, 1907-1951 (Madison:

University of Wisconsin Press, 1989), pp. 61-112. 
their families to settle in Katanga's mining camps. South of the border, in accordance with southern African racial thinking, recruits to the mines of the Anglo-American Corporation (AAC) and Rhodesian Selection Trust (RST) were treated as temporary migrants with no rights in town until the 1940s. While the number of European workers in Katanga was effectively contained, white labour in Northern Rhodesian mines steadily increased in the inter-war period: this divergence resulted partly from the more basic nature of (mostly) open pit mining north of the border, while to the south (mainly) underground mining required greater technical skills. There, the European Mineworkers' Union (MWU) secured an agreement that barred Africans from jobs currently held by Europeans. By 1945, while UMHK employed 1,100 European mineworkers in the most senior roles, there were in 1956 still c.7,000 whites employed in Northern Rhodesian mines: as a result of a 'colour bar', Africans were less able to advance to more senior roles. ${ }^{8}$

In the mid-twentieth century, rapid social and economic change in sub-Saharan Africa ignited interlinked debates regarding the impact of colonial rule, education, urbanisation and migration on African ideas, identity and associational life. ${ }^{9}$ Africans developed new ideas and organisations - sometimes under European paternalistic guidance and sometimes expressly against their direction - to defend themselves from violence and exploitation, claim a place within the colonial and capitalist order and challenge (partially or entirely) its legitimacy on moral, legal, cultural and political grounds. ${ }^{10}$ On the Copperbelt this took

8 Perrings, Black Mineworkers in Central Africa, pp. 117-29.

9 It is clearly impossible to provide a satisfactory account here of relevant literature on these vast topics. For the nature of colonialism see A. Adu Boahen, African Perspectives on European Colonialism (Baltimore, MD: Johns Hopkins University Press, 2011); Martin Chanock, Law, Customs and Social Order: The Colonial Experience in Malawi and Zambia (Cambridge: Cambridge University Press, 1985); and Crawford Young, The African Colonial State in Comparative Perspective (New Haven, CT: Yale University Press, 1994).

10 For foundational work in this area see Thomas Hodgkin, Nationalism in Tropical Africa (London: Frederick Mueller, 1956) and James S. Coleman, Nationalism and Development in Africa: Selected Essays (Berkeley: University of California Press, 1994). For social and political organisation in colonial Northern Rhodesia, see Robert I. Rotberg, The Rise of Nationalism in Central Africa: The Making of Malawi and Zambia, 1873-1964 (Cambridge, MA: Harvard University Press, 1967) and, more recently, Jan-Bart Gewald, Marja Hinfelaar and Giacomo Macola (eds.), Living the End of Empire: Politics and Society in Late Colonial Zambia (Leiden: Brill, 2011). For the DRC see 
a specific form that reflected its experience of urban migration and focussed on - but was not limited to - wage labour in the mining industry and the communities associated with them. From the 1940s, Bemba political leadership became prominent in Northern Rhodesian mining towns and Bemba-speaking mineworkers would play a leading role in union organisation and in Zambian nationalism in the 1950s. In a similar vein, Kasai Baluba migrants flocked to work in the Katangese mines and were stereotyped, like the Bemba, as culturally receptive to 'modern' wage labour by state officials and, in particular, Catholic missionaries, who played a far greater role in shaping UMHK social policy than their mission counterparts in Northern Rhodesia. ${ }^{11}$

The growing (though unequal) literacy and educational opportunities available to some Copperbelt residents certainly generated an increasingly vibrant intellectual life that can be usefully compared with the 'public spheres' of west and east Africa, analysed to such powerful effect by, in particular, Karin Barber, Stephanie Newell and Emma Hunter. ${ }^{12}$ Mission-educated Africans, like their counterparts elsewhere, used new cultural and political associations to establish a fragile place for

René Lemarchand, Political Awakening in the Congo (Berkeley: University of California Press, 1964) and Georges Nzongola-Ntajala, The Congo from Leopold to Kabila: A People's History (London: Zed Books, 2002). For the role of labour unions in colonial Africa, see Frederick Cooper, Decolonization and African Society: The Labor Question in French and British Africa (Cambridge: Cambridge University Press, 1996).

11 Key works in the literature on colonial ethnic identification include Terence O. Ranger, 'The Invention of Tradition in Colonial Africa', in Eric Hobsbawm and Terence Ranger, The Invention of Tradition (Cambridge: Cambridge University Press, 1983), pp. 211-63; Leroy Vail (ed.), The Creation of Tribalism in Southern Africa (Oxford: James Currey, 1989), particularly the chapters by Bogumil Jewsiewicki (on the Congo) and Brian Siegel (on the Lamba); Thomas Spear, 'Neo-Traditionalism and the Limits of Invention in British Colonial Africa', Journal of African History, 44, 1 (2003), pp. 3-27; and Terence O. Ranger, 'The Invention of Tradition Revisited: The Case of Colonial Africa', in Terence O. Ranger and Olufemi Vaughan (eds.), Legitimacy and the State in Twentieth Century Africa. Essays in Honour of A. M. H. KirkGreene (London: Palgrave Macmillan, 1993), pp. 62-111.

12 Karin Barber, Print Culture and the First Yoruba Novel: I. B. Thomas's 'Life Story of Me, Segilola' and Other Texts (Leiden: Brill, 2012); Stephanie Newell, Literary Culture in Colonial Ghana: 'How to Play the Game of Life' (Bloomington: Indiana University Press, 2002) and 'Articulating Empire: Newspaper Readerships in Colonial West Africa', New Formations, 73 (2011), pp. 26-42; and Emma Hunter, Political Thought and the Public Sphere in Tanzania: Freedom, Democracy and Citizenship in the Era of Decolonization (Cambridge: Cambridge University Press, 2015). 
themselves within the late colonial order, reflecting on their changing identity and what it meant to be both African and modern in a context in which the attributes of 'modernity' were characterised as inherently Western. By the late 1940s and 1950s a literate Copperbelt public, mission-educated and politically active, was organising in Katanga's cercles and Northern Rhodesia's welfare associations (see Chapter 4) and articulating their views about social change in new periodicals, most still run by European publishers or the mine companies themselves, which are discussed in Chapter $5 .^{13}$

Meanwhile, a steady expansion in the social services provided to mineworkers' families in the UMHK 'camps', including early childcare and housing for larger families, was predicated on the notion that the modern nuclear family would provide the ideal domestic environment for productive and apolitical workers. ${ }^{14}$ The threat of radicalisation, symbolised in the 1941 mineworkers' strike, was equally countered by an authoritarian system of surveillance and propaganda. In Northern Rhodesia meanwhile, a similar strike in 1940 was taken as a sign that 'migrant' Africans needed urban settlement and modern political associations, leading to post-World War Two British sponsorship of African trade unionism. ${ }^{15}$

As can be seen, similar historical dynamics and material circumstances were imagined, both by Copperbelt residents and those who ruled them, in both similar and distinctive ways, leading to interventions and ideas that fed back into these societies and further shaped their development. Two broad ideas of Copperbelt society - presented here in a necessarily simplified way and elaborated on further throughout this book - would, as a result, develop on either side of the border. In Haut-Katanga, the early and sustained intervention of

13 A particularly important study is provided by Deborah Kallmann, 'Projected Moralities, Engaged Anxieties: Northern Rhodesia's Reading Publics, 1953-1964', International Journal of African Historical Studies, 32, 1 (1999), pp. 71-117.

14 Donatien Dibwe dia Mwembu, Histoire des Conditions de Vie des Travailleurs de L'Union Minière du Haut-Katanga/Gécamines (1910-1999) (Lubumbashi: Presses Universitaire de Lubumbashi, 2001). The term 'camp' continued to be used long after these areas had become permanent areas of their respective towns and cities, but was ultimately replaced by 'cité'.

15 Helmuth Heisler, 'The Creation of a Stabilized Urban Society: A Turning Point in the Development of Northern Rhodesia/Zambia', African Affairs, 70, 279 (1971), pp. 125-45. 
UMHK in shaping this new urban society was to some extent successful: generations of residents of mine cités have internalised and reproduced iterations of the idea that the company, UMHK and its successor Gécamines, was the 'mother and father' of their workers and their families. This patrimonial loyalty nonetheless enabled those residents to make specific, limited claims on the company and other actors. ${ }^{16}$ The suppression of implicitly redistributive political association - indeed, of any meaningful independent organisation outside company and state control - led, as elsewhere in the Belgian Congo, to the dominance of ethnicity as the framework of political aspiration, influencing the ethnic violence of the early 1960s and early 1990 s that resulted from effective elite manipulation of these identities. In Northern Rhodesia, in contrast, the provision - by the mid-1950s - of a broadly comparable system of social welfare was perceived to be the result not of company generosity but instead of industrial combination and action by mineworkers and their families. The marginalisation of the indigenous Lamba population, and the relative unimportance of historical memory of pre-colonial mining societies, meant the absence of the building blocks necessary for the construction of a 'Copperbelt' ethno-nationalism rooted in autochthonous claims. The continued colour bar, and the white supremacist threat posed by the Central African Federation (CAF) which in 1953 unified Northern Rhodesia with Nyasaland and settler-controlled Southern Rhodesia, accelerated the development of a multi-ethnic African nationalism in which the Copperbelt's residents and their labour organisations played a central role. ${ }^{17}$ This self-consciously cosmopolitan materialist identity has been central to Zambian Copperbelt political culture ever since.

These very different ideas of Copperbelt society would not, however, have taken the form they did if it had not been for the central role played in their articulation, documentation and crystallisation by those who studied and disseminated knowledge about these places.

16 Dibwe dia Mwembu, Histoires des Conditions, p. 58; R. Brion and J.-

L. Moreau, De la Mine à Mars: La génèse d'Umicore (Tielt: Lanoo, 2006), pp. 273-5.

17 Miles Larmer, Rethinking African Politics: A History of Opposition in Zambia (Farnham: Ashgate, 2010), pp. 27-34. 


\section{Comparative Knowledge Production in the Belgian and Anglophone Academies}

In the early colonial period, the 'fact' that all Africans lived in 'tribes' was a central assumption in much European colonial policy-making, particularly that of Britain and Belgium. The classification and documentation by colonial officials, missionaries and ethnographers of 'tribal' cultures, languages, laws and structures across much of the continent constituted a massive exercise in knowledge production, a process that helped fix and give socio-political meaning to identities that were hitherto more contested and subject to continuous historical change. Such identities, despite recognition of their 'constructed' nature, continue to be central to political contestation and affiliation in post-independence Africa to the present day. ${ }^{18}$ As has been increasingly recognised, a vital role in the construction of these identities was played by African intermediaries - chiefs, their councillors, translators and other middle-men - who for various reasons supplied Europeans with the raw historical and cultural material that enabled them to distinguish one 'tribe' from another. ${ }^{19}$

This process of tribal documentation can be usefully compared with the social scientific analysis of late colonial Copperbelt society between the late 1940s and the early 1960s. As already indicated, the Central African Copperbelt has been central to academic analysis of modern urban historical change in Africa. Copper production, driven by global demand and enabled by European imperialism, transformed market relations and brought, social scientists agreed, modern industry to an African interior otherwise isolated from progressive historical change. The African mineworkers recruited to produce that copper likewise provided an ideal type of nascent working-class identity. A new urban society was understood to be developing in its new towns, producing in turn a modern social and political consciousness. Political nationalism and economic nationalisation of strategic mining resources were equally seen as flowing directly or indirectly from mining-led

18 See, for example, Mahmood Mamdani, Citizen and Subject: Contemporary Africa and the Legacy of Late Colonialism (Princeton, NJ: Princeton University Press, 1996); Gabrielle Lynch, I Say to You: Ethnic Politics and the Kalenjin in Kenya (Chicago, IL: Chicago University Press, 2011).

19 Benjamin Lawrance, Emily L. Osborn and Richard L. Roberts (eds.), Intermediaries, Interpreters, and Clerks: African Employees in the Making of Colonial Africa (Madison: University of Wisconsin Press, 2006). 
development. Socialist-oriented academics looked to the incipient African working class to develop into a vanguard of radical progressive change and, when this apparently did not occur, sought to explain this 'failure' in ways that characterised African workers as divergent from an implicit or explicit norm of class consciousness. ${ }^{20}$

Social scientists on both sides of the border identified parallel problems associated with industrialisation and urbanisation, but came to markedly different conclusions regarding the capacity of Africans to manage their own transition to these new urban identities. In challenging racialised notions south of the border, Rhodes-Livingstone Institute (RLI) scholars such as Epstein and Clyde Mitchell asserted the adaptability of Africans to modern town life. ${ }^{21}$ Less well known, at least in Anglophone circles, is the parallel process of colonial knowledge production in the Belgian academy. ${ }^{22}$ The Centre d'Etudes des Problèmes Sociaux Indigènes (CEPSI) was established in 1946 by liberal Catholic academics who were critical of settler colonialism. Working with major companies, particularly UMHK, CEPSI researchers focussed on absenteeism and poor labour productivity, which they associated with Africans' difficulties in coming to terms with the demands of modern life in urban centres of extra-coutumier ('non-customary') existence. ${ }^{23}$ Work by CEPSI and RLI researchers, although reaching contrasting conclusions, was decisively shaped by the political context of the late colonial period in which modernisation theory assumed that historical or developmental progress in nonWestern societies would follow the same path from largely rural agricultural societies to urbanised industrialised ones as that supposedly

20 Giovanni Arrighi and John S. Saul (eds.), Essays on the Political Economy of Africa (New York: Monthly Review Press, 1973). For subsequent discussion of the labour aristocracy thesis in Africa, see Richard Sandbrook and Robin Cohen (eds.), Development of an African Working-Class (London: Longman, 1975). For its application to central Africa, see Jane L. Parpart, 'The Labour Aristocracy in Africa: The Copperbelt Case 1924-1967', African Economic History, 13 (1984), pp. 171-91.

21 Epstein, Politics in an Urban African Community; J. Clyde Mitchell, Cities, Society and Social Perception: A Central African Perspective (Oxford: Clarendon Press, 1987).

22 Marc Poncelet, L'Invention des Sciences Coloniales Belges (Paris: Karthala, 2008); Benjamin Rubbers and Marc Poncelet, 'Sociologie Coloniale au Congo Belge: Les Études sur le Katanga Industriel et Urbain à la Veille de L'Indépendance', Genèses, 2, 99 (2015), pp. 93-112.

23 Rubbers and Poncelet, 'Sociologie Coloniale au Congo Belge', pp. 95-7. 
taken by Western countries in the eighteenth and nineteenth centuries. ${ }^{24}$ In practice, the Copperbelt region developed, as we will see, in highly uneven ways, far from the confident imaginings of some social scientists or the racialised nightmares of others: mineworkers did not surrender ties to rural areas of origin; extractive mining did not stimulate wholesale industrial development; and tens of thousands of migrants scratched out a precarious living in 'squatter' areas. People, goods, wealth and culture continued to flow between villages and mining towns, creating unstable hybrid cultures that combined reconstructed ethnic identities with displays of self-consciously 'modern' materialism. Nonetheless, as social scientific research about Copperbelt societies developed in significant new ways over the coming decades, it continued to be shaped, as Ferguson has shown, by these influential but ultimately distorted notions of urban modernity. ${ }^{25}$

This is not, however, to argue that there have not been important developments in the social scientific and historical understanding of the region since the influential heyday of RLI-CEPSI research. Indeed, as the structure of this book indicates, new ideas and approaches that developed and/or became influential in the academy were continually applied to each new iteration of Copperbelt research in the context of the region's political independence, reflecting both global and local social, economic and political changes and, equally, innovations and trends in the intellectual outlook and methodological approaches of those who sought to understand them. For example, Marxistinfluenced researchers sought in the 1970s to identify a late-colonial 'working class in the making' and then tried to explain why one of Africa's most proletarian societies did not subsequently develop a fully fledged class consciousness (Chapters 2 and 4). Development economists meanwhile blamed the region's economic problems on an 'urban bias' created by politically influential Copperbelt wage-earners and consumers (Chapters 6 and 8). Feminist-influenced researchers identified the prominent role of women in Copperbelt labour and

24 For 'take-off' theories of development see Walt W. Rostow, The Stages of Economic Growth: A Non-Communist Manifesto (Cambridge: Cambridge University Press, 1960). The leading critic of such 'high modernist' developmentalist thought is James S. Scott: Seeing Like a State: How Certain Schemes to Improve the Human Condition Have Failed (New Haven, CT: Yale University Press, 1999).

25 Ferguson, Expectations of Modernity. 
political movements and revealed the gender dynamics underlying both company policies and societal change (Chapter 5). The rich cultural output of Haut-Katanga's towns was examined during the 1970s and 1980s, with visual art, theatre and music providing insights into the articulation of social identity (Chapter 7). The severe and sustained downturn of the 1980s onwards brought a new set of interventions to the region, as donors and international finance institutions (IFIs) sought to 'adjust' Copperbelt modernity to its new economic realities, but also made researchers suddenly aware of the region's profoundly uneven urbanisation (Chapter 8): Ferguson's own research, conducted in the midst of this downturn, should be understood in this context. One of those coping mechanisms, a supposed turn to urban farming, was in fact central to Copperbelt society from the start, its belated 'discovery' demonstrating the extent to which its actual development has been continually misunderstood by those who (re)searched for their generation's version of African urban modernity (Chapter 9). In historicising the long sweep of Copperbelt research over the past fifty years, the aim here is at least partly to assess the accuracy or otherwise of its analysis and the extent to which it deviates from social reality. In doing so, however, the study's central aim is to identify how social scientific research has characterised the Copperbelt in both enduring and changing ways, and to show how specific characterisations have been influenced by, among other things, the inheritance of the foundational texts of urban modernism, successive trends and emphases in both international and national policy and academic praxis, and the ideas and practices of Copperbelt societies themselves.

In analysing intellectual output about the region, this volume also analyses how the two parts of the Copperbelt have themselves been compared with each other and for what purpose: what role did this comparison play and to what purpose were those conclusions put? An influential body of global intellectual history has demonstrated the ways in which the colonial state was constituted through interimperial processes in which academic and colonial experts met in forums such as the International Colonial Institute (ICI), which from its establishment in 1892 enabled the dissemination of knowledge about techniques of empire across imperial boundaries. ${ }^{26}$ Although

26 Benoit Daviron, 'Mobilizing Labour in African Agriculture: The Role of the International Colonial Institute in the Elaboration of a Standard of Colonial 
such inter-imperial comparative processes can be found in many phases of European imperialism, the 'late colonial state', under pressure from nationalist movements and international critics to justify its existence, was particularly invested in developmental initiatives rooted in 'scientific' knowledge production and international co-operation within the emerging United Nations framework. ${ }^{27}$ Miguel Bandeira Jerónimo has, for example, shown how Portuguese imperialist officials sought knowledge, respectability and justification for their activities via participation in structures such as the International Labour Organisation (ILO). ${ }^{28}$ Belgian colonial practice in the inter-war and post-World War Two periods equally engaged with such interimperial and international processes, while British officials gathered regularly to compare their understanding of common problems in what was increasingly understood as a rapidly changing colonial reality. ${ }^{29}$ At inter-African conferences in the 1950s and 1960s organised by the Combined Commission for Technical Cooperation in Africa South of the Sahara (CCTA), French, Belgian, British, Portuguese, Rhodesian and South African officials assembled to address the problems of managing African labour: ${ }^{30}$ it is not coincidental that two of these events took place in Elisabethville (1950) and Lusaka (1957), since both Haut-Katanga and the Northern Rhodesian Copperbelt towns were key examples of labour challenges that could provide comparable

Administration, 1895-1930', Journal of Global History, 5, 3 (2010), pp. 479-501.

27 Crawford Young, The African Colonial State in Comparative Perspective (New Haven, CT: Yale University Press, 1994); John Darwin, 'What Was The Late Colonial State?', Itinerario, 23, 3-4 (1999), pp. 73-82; Frederick Cooper and Randall M. Packard (eds.), International Development and the Social Sciences: Essays on the History and Politics of Knowledge (Berkeley: University of California Press, 1998).

28 Miguel Bandeira Jerónimo and José Pedro Monteiro, 'Internationalism and the Labours of the Portuguese Colonial Empire', Portuguese Studies, 29, 2 (2013), pp. 142-63. See also the special issue of the Journal of Imperial and Commonwealth History 48, 5 (2020) on 'Imperialism, Globalization and (Inter)Colonial Encounters in Africa', edited by Miguel Bandeira Jerónimo and Damiano Matasci.

29 Eva M. Schalbroek, 'The Commission for the Protection of the Natives and Belgian colonialism in the Congo (1908-1957)', unpublished DPhil thesis, University of Cambridge (2019); Anon, 'Report on the Conference on Urban Problems in East and Central Africa held at dola, Northern Rhodesia, in February, 1958', Journal of African Administration, 10, 4 (1959), pp. 182-252.

30 Isebill V. Gruhn, 'The Commission for Technical Co-Operation in Africa, 1950-65', Journal of Modern African Studies, 9, 3 (1971), pp. 459-69. 
lessons. Researchers from CEPSI and RLI were active and influential participants in such conferences and UMHK's interventionist policies in particular provided a supposedly ideal case of 'social engineering. ${ }^{31}$ Its pioneering stabilisation and community development programmes were admired by Northern Rhodesian officials as a model to follow and learn from, but one that, they felt, could not be implemented in their own mines where organised African mineworkers, 'tainted' by the negative influences of white mineworkers and the consumer economy, would challenge every aspect of its implementation (see Chapter 3). As would often prove the case, the comparison between the two regions served to emphasise their differences rather than identify their evident similarities and linkages.

In academic knowledge production too, the need to understand the Copperbelt as a single region enabling comparative analysis was widely advocated but rarely practised. The work of Charles Perrings is a noteworthy exception to the rule, with virtually all studies accepting rather than challenging the cartographic assertion of colonial and national borders. ${ }^{32}$ Researchers from RLI and CEPSI, while meeting periodically on the inter-imperial stage, remained largely rooted in their metropolitan and/or linguistic political and academic milieux and did little to consider the extent to which the people they studied lived across the border region. Subsequent generations of researchers have equally operated under the shadow of methodological nationalism, producing enlightening work on one or more 'Copperbelt' town but failing to assess the significance of cross-border ties or the relevance to their subjects of the mining region as a whole. It is only recently that the potential for insightful comparative analysis is again being fully realised. ${ }^{33}$

31 Jacques J. Maquet, 'Aspects Sociaux de L'Industrialisation a Elisabethville, Cycle d'Etude sur les Problems D'Urbanisation en Afrique', UNESCO conference, Addis Ababa, 25 April-5 May 1962.

32 Perrings, Black Mineworkers in Central Africa.

33 For a recent exception, see Enid Guene, 'Copper, Borders and Nation-Building: The Katangese Factor in Zambian Political and Economic History', African Studies Centre Leiden, African Studies Collection, 67 (2017). As well as the University of Oxford 'Comparing the Copperbelt' project, the WorkinMining project headed by Benjamin Rubbers is the most significant recent analysis of both Copperbelt regions: www.workinmining.ulg.ac.be (accessed 3 December 2019). See also the project on employment-tied housing in (post) colonial housing based at the University of Vienna, which includes case studies 
While new postcolonial leaders sought to integrate the two regions more fully into new nation-states, this was more easily said than done. The rulers of the Katangese secession (1960-3), a fundamental challenge to the unity of independent Congo, relied on relationships with their late colonial neighbours in the Central African Federation and funded the Northern Rhodesian African National Congress (NRANC). The resulting conflict led the new rulers of independent Zambia to see Katanga/Congo as a dangerous 'other', a negative lesson from which Zambia should differentiate itself. While the two mining regions followed parallel trajectories over the coming decades - partial and then full-scale nationalisation alongside growing political interference in company operations; the devastating effect of the downturn and sustained unprofitability of copper mining from the mid-1970s to the 2000s; falling formal employment and related social decline; and, in the late 1990s, corrupt privatisation and disastrous neo-liberal policies the meanings made by local societies about these changes contrasted sharply on either side of the border. While the resultant socio-economic grievances reinforced the Zambian Copperbelt's identity as a locus of political opposition and activism, in Haut-Katanga mineworking communities generally avoided the overt politicisation of their complaints and sought, as Benjamin Rubbers has shown, to express them in polite entreaties to a mine company most continued to regard as a caring parent that had temporarily abandoned them. ${ }^{34}$ This study seeks to explain why these similarities, alongside significant differences and divergences, are given such contrasting interpretations by Zambian and Katangese Copperbelt residents.

As noted above, processes of official and academic production of knowledge about African societies, although rooted in the structures and often serving the purposes of colonial capitalist domination, were in fact shaped or co-produced, in profoundly unequal circumstances, by a range of African intermediaries. ${ }^{35}$ In many significant studies of the role of anthropology and the wider social sciences in colonial Africa, the relationship between European researchers and African

of Zambia and Haut-Katanga: https://housing.univie.ac.at (accessed

3 December 2019).

34 Benjamin Rubbers, 'Claiming Workers' Rights in the Democratic Republic of Congo: The Case of the Collectif des Ex-agents de la Gécamines', Review of

African Political Economy, 37, 125 (2010), pp. 329-44.

35 Lawrance et al. (eds.), African Intermediaries. 
experts, chiefs and/or assistants is understood as central. ${ }^{36}$ For Northern Rhodesia, Lyn Schumaker in particular has demonstrated that the work and ideas of the RLI's African research assistants were vital to their findings. Schumaker's revealing exploration of RLI research processes, however, also shows the ways in which the mine communities under investigation, clearly recognising the political stakes of this work, were able to decide what was observed and, as a consequence, shape the findings that were reached. ${ }^{37}$ As Chapter 1 will elaborate, the RLI's tendency to focus research attention disproportionately on the most 'advanced' male African mineworkers was one that resulted from a shared desire by African researchers and influential African research subjects to present a particular view of their communities to the world. More generally, the increasing recognition that (largely) Western academic and official writing about African societies has been shaped in significant ways by those societies themselves, in ways that Western researchers were often unaware of, helps us appreciate that the boundary between elite and popular forms of knowledge about these societies is, like the Copperbelt border itself, one that was often permeable.

\section{Analysing the Intersection of Social History and Knowledge Production from Above and Below}

In his landmark study of Zambian Copperbelt society, Expectations of Modernity, James Ferguson discusses the challenge of comprehending, from an anthropological perspective, a community closely linked to the global economy and characterised by migration and a cosmopolitan culture. ${ }^{38}$ Many if not most Copperbelt residents understood their society as one in which socio-economic change, migration and cultural

36 Bruce Berman, 'Ethnography as Politics, Politics as Ethnography: Kenyatta, Malinowski, and the Making of Facing Mount Kenya', Canadian Journal of African Studies, 30, 3 (1996), pp. 13-44; Mwenda Ntarangwi, Mustafa Babiker and David Mills (eds.), African Anthropologies: History, Critique and Practice (London: Zed Books, 2006); Andrew Bank and Leslie J. Bank (eds.), Inside African Anthropology: Monica Wilson and her Interpreters (New York: Cambridge University Press, 2013).

37 Lyn Schumaker, Africanizing Anthropology: Fieldwork, Networks, and the Making of Cultural Knowledge in Central Africa (Durham, NC: Duke University Press, 2001).

38 Ferguson, Expectations of Modernity, passim. 
mixing were the norm. They were then, Ferguson found, adept at explaining social change, using local dialects of the language of urban modernity that dominated modernist social science and that was the subject of Ferguson's critique. My own experience, in periodic visits to the region from the early 1990s to the present day, has been similar: Zambian Copperbelt residents articulate both what they see as the underlying nature of their society and the ways it has been affected by recent changes in strikingly sociological ways. Theirs, they argue, is a modern and urban place in which development has created, among other things, multi-ethnic societies in which 'tribal' conflict is consequently unthinkable. Respondents stress the centrality of the money economy, of the ways that breadwinners carry financial responsibilities for their immediate families and wider kinship networks, and how these have changed over time. Comparisons between people, societies, areas and periods are commonly articulated in a way that consistently draws on a popular version of modernist discourse. As one typical example, here is interviewee Leonard Nkhuwa comparing two Zambian towns in the 1950s: 'Chipata was not well developed compared to Luanshya whose mines were developed with better infrastructure. Chipata relied on farmers so it was less developed'. ${ }^{39}$ In Haut-Katanga too, a variant on this discourse can be found when urban residents like Dieudonné Kalenga explain the appeal of artwork depicting village life as '[w]orks that evoked the reality of the traditional world; our ancestors ... life in our traditional society'. ${ }^{40}$

Copperbelt residents have had over decades longstanding and multiple contacts with researchers, whose ideas about the Copperbelt have been shaped by these residents and whose own perceptions have permeated local understandings of social reality. This is a community that has always explained itself to the wider world, representing itself in self-conscious ways that focus on its distinctive or novel character (relative to the rural societies from which most residents, their parents or grandparents migrated) and how this has evolved over time. This book will seek to demonstrate that the distinctiveness and novelty of Copperbelt urbanity was an idea that had both been articulated and internalised by Copperbelt residents

39 Interview, Leonard Nkhuwa, Mufulira, 17 July 2018.

40 Interview, Dieudonné Kalenga, Likasi, 8 June 2018. 
themselves, to help them make sense of their changing social reality and make claims - political, economic or cultural - about it.

The popular discourses of Copperbelt society about itself, fragmented and often undocumented as they have been, are clearly not one thing nor even a series of clearly distinct things, but it is possible to generalise about some of their most evident tropes. Communities and their leading actors have, from the start, represented them as modern spaces with values and practices distinct from the rural communities from which they or their families migrated. Living in the city required different ways of being, some of which - wage labour and new forms of family life - were prominent in the academic characterisation of Copperbelt society, but some of which - the hosting of rural kin and the necessity of conducting economic activities outside the mine, for example - were decidedly not. What it meant to live this new life, to claim a place for oneself, one's family or community, was understood in distinct ways by the diverse Copperbelt population. Ferguson's typological distinction between 'cosmopolitan' and 'localist' respondents is a useful starting point, but in practice both tendencies - for example, the celebration of the opportunities available in town alongside regret at the loss of reciprocal family life in the village - may be observed in the narration of one life history or in the lyrics of a single song. In this respect, mine labour might generate opportunities for advancement but equally involve exploitation and a loss of selfmastery. Becoming a UMHK-trained housewife could give women a respectable place in urban society, but equally tied one to a subordinate gendered role. Life outside the mine township as a marketeer or small businessperson was simultaneously risky and liberating. While some life experiences lead to a positive, Whiggish interpretation of historical change, more negative ones, both individually and collectively, create nostalgia for idealised boom times that were never the reality, at least for the majority of Copperbelt urbanites who lived outside the mine company system. Popular attitudes to the state, company, union, church, social class and ethnic identity, indeed to urban society as a whole, varied over time and between sections of that society in ways that, in a single history, can only be glimpsed.

Nonetheless, as befits a comparative analysis, strands of this popular articulation took related but distinctive forms in our two Copperbelt regions. As already noted, the specific meaning of and values associated with these new communities varied in Haut-Katanga and Zambia 
respectively, partly for the reasons outlined above. In Haut-Katanga the 'authoritarian paternalism' of UMHK/Gécamines seems to have influenced the relatively benign perspective of many cité residents: to generalise, they saw (and see) themselves as the beneficiaries of company largesse, but equally recognised that personal and/or familial progress through this system rested in the hands of ethnic intermediaries and was therefore partly dependent on patronage. In Zambia, while there is today nostalgia for the ' $\mathrm{ZCCM}^{\text {,41 }}$ model, the socio-economic progress of its communities was, it is believed, more the result of the actions of its residents, whether collectively in political or labour organisation, or individually, via hard work and sacrifice, than of company patronage and welfare. While many Zambian Copperbelt residents are bitter at the hand that economic fortune and/or political manipulation has dealt them, they reject the notion that ethnic favouritism or bias has been to blame, consistent with their culture of multiethnic workplace and community solidarity.

It is then tempting to ask the question, which came first: the social scientific representation of the 'modern' Copperbelt or the popular one? This is in any case a question that is impossible to answer but it is, in my view, not a useful starting point: African communities, like communities everywhere, have always articulated their history through origin stories that enable them to reflect on change over time, as a way of explaining their contemporary reality. The creation of such stories was not an equal or open process nor one that directly reflected social reality, since elites always sought to make claims in relation to these histories, whether to confirm or challenge the existing social order. It was rather a process that drew specific meanings from social reality and silenced others, but which itself changed over time in revealing ways. These everyday approaches to and techniques of identity formation and historically based claim-making travelled with migrants to the mining camps of the early twentieth century and were evidently at work in Africans' interactions with the Copperbelt social scientific post-World War Two boom. The social changes of that period were understood by social scientists and African societies alike as representing something 'new' and 'modern' relative to an essentialised rural past, a past that was marked by profound social disruption and change but

41 From 1982 the nationalised mine companies were brought into a single corporation, Zambia Consolidated Copper Mines (ZCCM). 
which was rendered static and stable in a colonial relationship to the dynamic present. $^{42}$

The RLI/CEPSI wave of social scientific writing and activity made available new technologies through which these societies could be represented. This enabled an expansion in the repertoire of claimmaking narratives of African communities. Labour unions, ethnic associations and political parties built on the evidence they gathered of African 'civilisation' and modernity to pursue their claims for economic or political advancement. This dynamic relationship between popular and official or academic representation has unfolded ever since, as Copperbelt communities have influenced and been represented in a palimpsest of ways by an ever-changing intellectual praxis and policy environment, whose only consistency is the comparison of the changing present and the stable past, in which, however, the specific content of 'past' and 'present' and the temporal boundary between them is ever shifting. For example, as the period of 'decline' (Chapter 8) has extended - notwithstanding brief booms and jobless recoveries - to the present day, the nostalgic recall of the modernist urban 'belle époque' (once a period of disruptive change, now a halcyon of social stability) has sharpened and extended backwards to encompass the lived experience of all but the oldest Copperbelt residents, with decline generally associated only with the period since mine privatisation in the late 1990s. This is despite clear evidence, in archives and earlier studies, that a real and sustained economic decline set in from the late 1970s and had come to directly affect living standards by the 1980s. Likewise, the widely identified disruptive effects of post-privatisation social change on generational relations, explicitly compared with a supposedly stable and cohesive past, ignores overwhelming evidence of enduring anxiety about juvenile crime and/ or delinquency, identified by successive Copperbelt observers and residents as a 'new' and worrying phenomenon in the 1950s, 1970s and 1990s alike. Drawing attention to such inconsistencies between memory and contemporaneous evidence identifies the performative and selfconscious nature of popular historical claim-making, but the aim in

42 The characterisation by social scientists of rural or 'traditional' African society as existing in a 'timeless' or 'past' relationship to a normative Western/ modern present was first elaborated by the leading ethnographer of urban Katanga, Johannes Fabian, Time and the Other: How Anthropology Makes Its Object (New York: Columbia University Press, 2014 [1983]). 
doing so is both to address where they obviously deviate from or obscure wider social realities and to draw attention to their ubiquity, central as they have always been in making sense of life in a permanently precarious urban society.

Through such an approach, this analysis seeks to unlock a central problem of writing social history in an era of post-colonialism and post-modernist thought. For much of the twentieth century, historians and social scientists saw society as an essentially material reality that could be measured, observed and recorded: innovative methodologies, for example quantitative data collection and later interviews and oral testimony, were developed to overcome the limits of state archives, but it was generally assumed that it was both possible and necessary to capture a close approximation of social reality. Many historians of African mining in general and of the Copperbelt in particular built on these assumptions to produce important studies that nonetheless depended largely on the archive to tell mine history through the prism of capital-labour relations. ${ }^{43}$

Since the 1970s post-modern turn and in particular the seminal influence of Said's 'Orientalism', historians of the global South have become acutely aware of the ways in which the production of knowledge by imperial actors about non-Western societies played a central role in justifying and shaping colonial projects. ${ }^{44}$ The centrality to colonialism in Africa of information gathering and production,

43 Harold Wolpe, 'Capitalism and Cheap Labour-Power in South Africa: From Segregation to Apartheid', Economy and Society, 1, 4 (1972), pp. 425-56; Charles Van Onselen, 'Worker Consciousness in Black Miners: Southern Rhodesia, 1900-1920', Journal of African History, 14, 2 (1973), pp. 237-55; Bill Freund, Capital and Labour in the Nigerian Tin Mines (Harlow, UK: Longman, 1981). For the Copperbelt see, for example, Higginson, A WorkingClass in the Making; Patrick Harries-Jones, Freedom and Labour: Mobilization and Political Control on the Zambian Copperbelt (Oxford: Basil Blackwell, 1975 ) and Elena Berger, Labour, Race and Colonial Rule: The Copperbelt from 1924 to Independence (Oxford: Oxford University Press, 1974).

Edward Said, Orientalism (London: Pantheon, 1978). Among the most relevant works influenced by Said are Dipesh Chakrabarthy, Provincializing Europe: Postcolonial Thought and Historical Difference (Princeton, NJ: Princeton University Press, 2000) and Partha Chatterjee, The Nation and Its Fragments: Colonial and Postcolonial Histories (Princeton, NJ: Princeton University Press, 1993). For Africa, see the work of Valentin Y. Mudimbe, most notably The Invention of Africa: Gnosis, Philosophy and the Order of Knowledge

(Bloomington: Indiana University Press, 1988) and Achille Mbembe, especially On the Postcolony (Berkeley: University of California Press, 2001). 
classification and research has been well established, as has its consequences for how researchers should approach the official archive (for which also see below). ${ }^{45}$

For the Copperbelt, the work of Ferguson and - for Haut-Katanga Benjamin Rubbers have contributed hugely to our understanding of how knowledge production around the question of African 'adaptation' to 'modern' society played an important role in both social change and in academic presentations of the region. Meanwhile the 'cultural turn' focussed attention on the lives of mineworkers outside the workplace, encompassing their ongoing connections to rural areas of origin and their familial and spiritual lives. ${ }^{46}$ In this regard, one of the most important urban social history projects carried out anywhere in Africa is the 'Mémoires de Lubumbashi' project, led by Donatien Dibwe dia Mwembu and Bogumil Jewsiewicki and based at the University of Lubumbashi. This pioneering project consciously transgresses the conventional divide between academic research (e.g. oral histories) and popular culture in its characterisation of popular theatre, painting and music as representing valid histories of the city. It has brought together university historians, artists and musicians, and members of Lubumbashi's diverse society in events, workshops and performances that emphasise the co-creation of historical understandings and discourses. ${ }^{47}$

More generally, however, the limitations of post-colonial approaches, identified by many observers, are certainly relevant here: there is in them a tendency to shift attention away from marginalised

45 Helen Tilley, Africa as a Living Laboratory: Empire, Development, and the Problem of Scientific Knowledge, 1870-1950 (Chicago, IL: University of Chicago Press, 2011); Ann Laura Stoler, Along the Archival Grain: Epistemic Anxieties and Colonial Common Sense (Princeton, NJ: Princeton University Press, 2008).

46 Patrick Harries, Work, Culture and Identity: Migrant Laborers in Mozambique and South Africa, c.1860-1910 (Portsmouth, NH: Heinemann, 1994); Carolyn Brown, 'We Were All Slaves': African Miners, Culture, and Resistance at the Enugu Government Colliery (Portsmouth, NH: Heinemann, 2003).

47 Donatien Dibwe dia Mwembu and Bogumil Jewsiewicki, Le Travail Hier et Aujourd'hui: Mémoires de Lubumbashi (Paris: L'Harmattan, 2004);

Donatien Dibwe dia Mwembu, 'Historical Knowledge Production at the University of Lubumbashi (1956-2018)', in Miles Larmer, Enid Guene, Benoît Henriet, Iva Peša and Rachel Taylor (eds.), Across the Copperbelt: Urban and Social Change in Central Africa's Borderland Communities (Oxford: James Currey, 2021), pp. 296-320. 
societies themselves and towards the producers of knowledge, privileging their place in the historical record even while criticising their views and impact. They also tend to create a division between an evidently artificial distorted imperial history, shown to be implicitly or explicitly false, and an intrinsically authentic subaltern social reality that, whether documented or not, is still out there waiting to be discovered. If, however, we appreciate that knowledge production, in its various forms, is the way that communities make sense of and advance claims in relation to social history, that it is social history, then we can potentially overcome these problems. This is to deny neither the realities of material injustice and exploitation, nor the distortions resulting from Western-dominated forms of knowledge production, whether generally or in the specific example of Copperbelt society. It is, however, argued that in historicising the meanings attributed to those realities by both intellectual observers and African residents of the Central African Copperbelt, documenting how they have changed over time and identifying the occasional interactions between these structurally unequal but nonetheless equally energetic producers of knowledge about these societies, we may better appreciate the ways in which historical meaning comes to be attributed to social reality.

It should, however, be stressed that this study does not generally seek to reconstruct the specific instances when academic researchers and African community 'met' and exchanged ideas about Copperbelt society. While a number of such direct encounters are noted, for example Hugh Tracey's 'discovery' of popular musicians and Johannes Fabian's sustained engagement with Katangese painters and theatrical performers (Chapter 7), there are equally instances where elite and popular knowledge production about specific topics, most strikingly gender relations (Chapter 5), while touching on parallel themes, reached deafeningly distinct conclusions. Indeed, the vast majority of academic, governmental and non-governmental researchers, having engaged with Copperbelt communities in diverse ways while gathering knowledge, tended to disseminate that knowledge only to their Western (and later African) academic colleagues, governments and other elite audiences, doing little or nothing to make it available to the communities that were vital to its production. Awareness of these bodies of knowledge certainly leaked out to Copperbelt actors and were taken up opportunistically to reinforce identities and to advance claims, but it is impossible to capture in all instances the exact ways in which 
that occurred. The aim here is then to capture and historicise the intellectual ecosystem in which ideas about the Copperbelt circulated and changed, reflecting and influencing societal change in doing so, rather than to 'track and trace' the myriad specific examples of ideational transmission.

Nor does this study pretend to be a fully realised intellectual history of the multiple elite producers of knowledge whose works are discussed. While insightful research on, most particularly, the RLI and CEPSI researchers (by Schumaker and Poncelet and Rubbers respectively) has demonstrated the influence of personal background, academic training and political orientation on their findings, the breadth and range of the analytical framework means that to produce an equivalent analysis of the intellectual influences of the dozens of academic and policy-oriented researchers cited herein would be well beyond the bounds of a single-volume history and certainly the capabilities of its author. Instead, the aim is to shift the centre of intellectual history from its privileged and (usually) Western perspective to its field of production, so as to analyse successive intellectual historical contexts within which both popular and elite knowledge production took place, and that knowledge itself. This approach, influenced by the 'Mémoires de Lubumbashi' project but taking a very different direction, intentionally collapses the conventional barrier separating the producers of knowledge from the subjects of it: as a result, many of the academics whose works are analysed in this study are both cited in regard to the research they have carried out and situated as actors in the history of knowledge production about the region.

\section{Sedimentation in Historical Writing: Structure, Methodology and Sources}

In order to reflect this interaction between social history and knowledge production, this book is organised into a structure that is at once tightly thematic and loosely chronological. Each chapter focusses on a specific discourse of representation of 'the Copperbelt' that emerged at a particular time in the region's history and that was, for a time, relatively important or even hegemonic, both in the historical and/or social scientific study of it and - in different ways - in the popular imagination.

This way of ordering the book is not, however, designed to suggest that one intellectual paradigm was simply replaced by its successor. 
Writing about mining societies presents the obvious but nonetheless irresistible analogy of geological time for our understanding of historical change. ${ }^{48}$ Historical and historiographical change, like geological sedimentation, lays down layers of understanding and representation that, though partly buried beneath successive layers in turn, may still be accessed by later generations, whose perspective and positionality towards each successive form of historical representation has itself been ineluctably changed by the new layers on which they and their social reality now stand. Analogous to this, Patience Mususa shows how technological innovation revalued Copperbelt 'waste', in the form of the dumps of processed rock scattered across the Copperbelt landscape, and in doing so created opportunities for new forms of precarious and gendered labour whose meaning and legitimacy depended on its shifting economic value. ${ }^{49}$ Just as technological innovations enabled the re-evaluation of the value of the mining past, so changes to social reality, which are always a globally connected process in the Copperbelt, can lead marginalised elements of that past of hitherto little value in claim-making to be brought to the fore. The only consistent factor in this ever-shifting landscape of contemporary memory is historical claim-making of one kind or another, rooted in the relationship between present and past but always emphasising some aspects of historical experience while silencing others.

A revealing example is environmental damage or pollution: as Chapter 9 shows, the emission of sulphur dioxide and other 'waste' from copper mining and smelting activities into adjacent Copperbelt communities affected the health and well-being of residents from the start. Unlike workplace health however, which was the subject of ILO conventions and state and mine company regulation, it attracted little international attention. Mine companies successfully 'offshored' the issue and thereby successfully avoided responsibility for its effects. It likewise remained a subject absent from both academic research and

48 A related (and brilliant) use of the 'sedimentation' concept can be found in Thomas Bierschenk, 'Sedimentation, Fragmentation and Normative DoubleBinds in (West) African Public Services', in Thomas Bierschenk and Jean-Pierre Olivier de Sardan (eds.), States at Work: Dynamics of African Bureaucracies (Leiden: Brill, 2014), pp. 221-45.

49 Patience Mususa, 'Contesting Illegality: Women in the Informal Copper Business', in Alastair Fraser and Miles Larmer (eds.), Zambia, Mining, and Neoliberalism: Boom and Bust on the Globalized Copperbelt (New York: Palgrave Macmillan, 2010), pp. 185-208. 
significant policy or political attention. For Copperbelt residents, 'senta' or 'kachoma' (sulphur dioxide pollution) was an everyday hazard that damaged crops and affected Copperbelt communities in unequal ways. But if it led to grumbling and even discontent, it did not generate overt protests or find its way into the minutes of community or union meetings. This was until the late 1980s, when extractive pollution - the subject of concern in Western countries for some decades - came, in the context of mine privatisation, to be expressed in the form of Environmental Impact Assessments (EIAs). Environmental NGOs and local campaigners raised awareness of the hazards of mine activities and, on the ground, Copperbelt communities articulated their concerns regarding pollution, not only in relation to contemporary mining but also the past: who would pay for damage inflicted by earlier companies and political regimes? While there is a clear realisation that the ill-effects of mine activity on Copperbelt communities has an extensive history, interviews focussed on the past reveal a general silence about pollution as a historical concern: it is, instead, an issue of today, whose ambiguous and even contradictory relationship to the recently buried past is still being unearthed.

This example suggests that, for any particular set of actors at a specific time, a historical framework of understanding may suddenly be 'uncovered' and revalued as the basis of claim-making, for reasons that can be explained in reference to its particular circumstances. An important example is the politicisation of ethnic difference in HautKatanga. Locally this found expression in articulation of the competition between 'autochthons' and 'outsiders' in the political violence of the early 1960s and again in the early 1990s. As will be explained in Chapter 4, in the early 1960s Katangese secessionists sought to resist the growing political authority of Kasaian migrants to mining towns by constructing a Katangese 'national' identity rooted in a reading of a pre-colonial past in which powerful kingdoms generated wealth and authority, partly by means of copper mining. ${ }^{50}$ The exclusionary nature of this nationalist discourse underwrote the secession and fuelled the repression of Kasaian residents of Katanga's mining towns. For decades after, such tensions in Haut-Katanga's mining towns were largely quiescent: while ethnic associational activity was

50 Miles Larmer and Erik Kennes, 'Rethinking the Katangese Secession', Journal of Imperial and Commonwealth History, 42, 4 (2014), pp. 741-61. 
central to social belonging in urban Katanga, it was largely delegitimised as an overt form of politicking in Mobutu's Zaire. ${ }^{51}$ In the early 1990s however, as Mobutu's regime faced growing political opposition, this buried seam of autochthonous sentiment was deliberately excavated as the basis of a local political movement that led to the killing of c.5,000 'Kasaians' (many born in Katanga) and the displacement of around one million from towns including Kolwezi and Likasi. ${ }^{52}$ Ethnic violence of this scale has never occurred in the Zambian Copperbelt and, from the perspective of most of our respondents, is unthinkable. It is clear, however, that earlier waves of more limited political violence - that between the United National Independence Party (UNIP) and the African National Congress (NRANC) in the early 1960s for example, and between UNIP and the United Progressive Party (UPP) a decade later - involved ethnically based mobilisation that was, however, downplayed in an official politics wherein accusing one's opponents of 'tribalism' was more powerful than openly deploying it oneself. This did not reflect anything structurally distinct in the Zambian Copperbelt's political economy but rather the legitimising nature of an anti-ethnic discourse among its self-consciously cosmopolitan populace, one that has existed uneasily alongside the more covert use of 'tribalist' discourse in political life.

As befits the history of a region that, alongside its own local dynamics, has been constructed in regional, national, continental and global terms, this study utilises a wide range of analytical scales. The focus is at times on the global economy, from the post-World War Two positioning of the Copperbelt as a region of industrial modernity in the African 'bush' to an ailing patient in need of urgent treatment in the 1980s. The ambiguous relationship of both regions to their respective

51 The 'de-ethnicisation' of Zairian politics is discussed in detail in Crawford Young and Thomas Turner, The Rise and Decline of the Zairian State (Madison: University of Wisconsin Press, 1985), pp. 149-57.

International Crisis Group, Katanga: The Congo's Forgotten Crisis (Nairobi/ Brussels: International Crisis Group, 2006), p. 1; Sandrine Vinckel, 'Violence and Everyday Interactions Between Katangese and Kasaians: Memory and Elections in Two Katanga Cities', Africa, 85, 1 (2015), pp. 78-102; Donatien Dibwe dia Mwembu, 'État de la question sur le conflit Katangais-Kasaïen dans la province du Katanga (1990-1994)', in B. Jewsiewicki and Leonard N'Sanda Buleli (eds.), Constructions, Négociations et Dérives des Identités Régionales dans les États des Grands Lacs Africains: Approche Comparative (Laval: Université Laval, 2005), pp. 9-48. 
colonial states and nation-states - as the key generator of wealth for their development and (as a result of that wealth) as a politically powerful region requiring more effective integration - is an equally important frame of analysis. In considering the Central African Copperbelt as a single region, the approach is simultaneously holistic and comparative: the study aims to show what was true for the region as a whole; how differences between the two parts of the region developed and were maintained in a process of social and ideational change; and how the cross-border perception of the two regions shaped the mutual understanding of each other. At times the analysis shifts to a sustained focus on the specific experience of either the Zambian or Katangese Copperbelt, the better to grasp the noteworthy differences in their history alongside their parallel trajectories. Finally, the focus is at times on the specific experience of residents of Mufulira and Likasi, two mining towns in Zambia and DRC respectively, in which intensive research and interviews have been carried out so as to enable consideration of the ways they have experienced both social change and changing ideas about Copperbelt society.

If we recognise that all existing social scientific and historical analysis of the region has been inextricably shaped by the context in which it has been produced, then it becomes vital, while making use of that analysis, to simultaneously place it in its own historical and intellectual context. This evidently applies to the modernist literature of the 1950s and early 1960s and in this regard the study builds on Ferguson's seminal analysis of RLI scholarship. It, however, extends this approach to encompass scholarship on Haut-Katanga and to cover a much longer period. This includes the decline of recent decades in which, not coincidentally, post-modernist scholarship including that of Ferguson has resonated with the experience and perception of crisis, a perception that both reflects a real decline in living standards but also a modernist nostalgia for a golden age that exists more in historical memory than historical experience.

Archival evidence about the Central African Copperbelt must equally be understood as reflective of the context in which it was produced, to be read both 'with' and 'against' the grain and interpreted as a form of knowledge production. The region is comparatively wellendowed with records: unsurprisingly, mine companies produced vast swathes of paperwork documenting their activities for investors, political authorities and their own officials. These have been assiduously 
archived for the colonial period and, to a lesser extent, the decades since political independence: the ZCCM-IH archives in Ndola are a particularly impressive repository, while the UMHK archives in Brussels are equally important if less extensive. The Gécamines period is, however, less well archived and considerable effort has gone in to accessing those company records that are still available, in Belgium but also Lubumbashi and Likasi. Governmental records for Northern Rhodesia/Zambia and Belgian Congo/Haut-Katanga follow a similar pattern, with few relevant materials available for the period after the declaration of the Zambian one-party state in 1972 and equally during Mobutu's rule of Congo/Zaire from 1965. One exception is the UNIP archives, the records of the former Zambian ruling party that, thanks to the efforts of dedicated researchers and the British Library Endangered Archives programme, are now available to researchers online. ${ }^{53}$ A similarly welcome process is now underway for the records of the Mineworkers' Union of Zambia (MUZ). A range of other written records, from those of the IMF and World Bank in Washington, DC to the Mufulira town council, are also utilised. All these archives are of course skewed in their foci and analytical frameworks in exactly the ways that are critiqued here and elsewhere: towards the site of mine production, the male mineworker and the formal organisation of labour, state and capital. These archives must therefore be equally read for their lacunae and distortions as much as for their assiduous record-keeping on certain subjects: in this regard company archives are particularly revealing for the way that mineworkers' wives, a central target of corporate intervention (Chapter 5), are nonetheless virtually absent from the record as historical subjects.

The logical next step in accessing such 'hidden' experiences for the historian of Africa is of course the oral history or interview. Such interviews certainly have the capability of reading in the experiences and perceptions of marginalised groups and of challenging established perspectives. They are themselves an important part of the fabric of Copperbelt historiography and have been used by generations of researchers whose work is in part the subject of this study. As well as dozens of interviews with specific actors in Copperbelt society, from social welfare officers to musicians and visual artists, the

53 British Library Endangered Archives Project, UNIP archives: https://eap.bl.uk/ project/EAP121/search (accessed 3 December 2019). 
analysis makes use of $c .110$ extended interviews with long-term residents of both Mufulira and Likasi carried out in 2018, together with other interviews conducted by members of the 'Comparing the Copperbelt' research team between 2017 and 2019. The majority of these, conducted in a combination of Kiswahili, CiBemba, French, English and other languages, made use of a fixed set of open-ended questions to elucidate interviewees' understanding of their lived experiences and of the historical changes they had witnessed (see the References section). While in no way a representative sample of Copperbelt demographics today or in the past, these interviewees included roughly equal numbers of women and men, those who made their living within and outside the mining complex, and from a wide range of economic, educational and ethnic backgrounds. Where an interviewee's specific work or life experience is relevant to the issue on which they are cited in this text, this is elaborated on there, but otherwise interviewees are cited as commenting on their own experience or understanding.

Given the wider analytical framework of this study, it will be evident that these interviews were not treated as providing self-evident truths about the nature of Copperbelt social history, nor are they consciously counterposed to the official archive or to academic studies in any systematic way. Interviewees are assumed to be influenced by the historical context in which they have lived and the forms of knowledge about it to which they had access and which indirectly framed their experience. Interviews are therefore regarded as performative events in which our interviewees - like their predecessors over sixty or more years of such research - articulated their understanding of the region's history in relation to their personal experience, their perception of interviewers' intentions and background, and the potential of the interview process to advance their own circumstances. In this text, selective use is therefore made of interview material that sheds light on the social history of the Central African Copperbelt, but attention is also drawn to the ways in which the emphases and ellipses in interviewee narratives both reflect the history of knowledge production in the region and seek to shape that knowledge in this, the latest iteration of it.

Clearly the most challenging aspect of any study of this type is to gain access to the contemporaneous perception and articulation of lived experience in the period under study. Capturing the precise 
moments in which popular and elite knowledge about Copperbelt societies coalesced, conversed with and/or confronted each other is not a realistic aim. This volume instead seeks to place forms of popular texts - the publications and pamphlets of political activists, the speeches of union officials and the song lyrics of musicians, among others - in comparative conversation with academic and official discourse about the nature of historical change in Copperbelt society. Following the argument outlined above, these popular texts are not presented as a more authentic understanding of these processes than official discourses but should rather be understood as performative characterisations of historical change that underpin claims about the relationship between past, present and future. Nonetheless, it may be observed that, while elite knowledge production has tended to essentialise the binary discussed above - between a traditional, rural and stable past and a modernising, dynamic urban present - popular knowledge has commonly engaged with that same binary in more creative, even playful, ways that shed particular light on the ways in which historical change is perceived and acted upon.

Finally, given the evident fact that this study is only the latest in a long history of knowledge production processes conducted by Western scholars on and about Copperbelt societies, its own positionality and limitations should already be clear but must be explicitly acknowledged. The knowledge produced here certainly relies on the (male, white European) author's engagement with African-authored scholarship that has decisively shaped his own understanding of Copperbelt society, and with dozens if not hundreds of local interlocutors, intermediaries and influencers from that society, a few of whom are mentioned in the Acknowledgements. Much of the labour that went into this volume was that of African researchers who, in a more equal world, would be the authors of their own studies of Copperbelt society, and whose initiatives and ideas have decisively shaped this volume and the wider outputs of the 'Comparing the Copperbelt' project. ${ }^{54}$ While some scholars and activists argue that the resultant works of knowledge such as this one should reflect this labour by naming each such worker as a co-author of resultant publications, my own approach is to

54 For all project outputs, see https://copperbelt.history.ox.ac.uk (accessed 3 December 2019). 


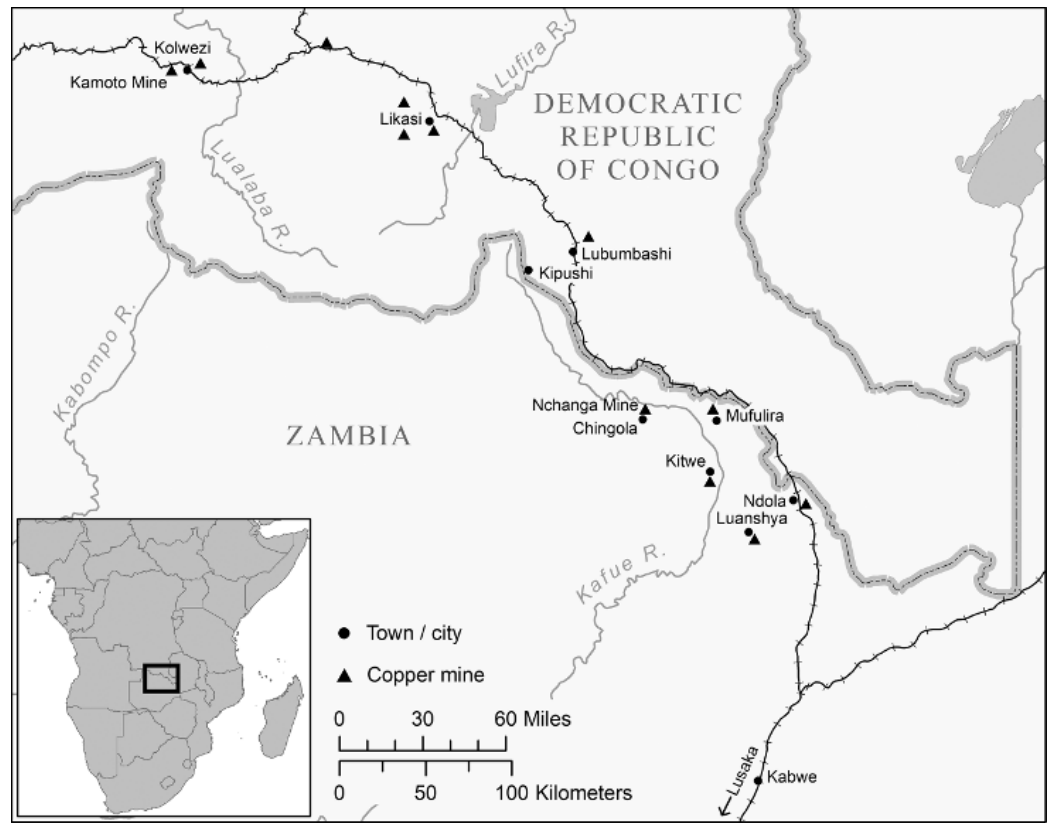

Figure 0.1 Map of the Copperbelt region. Rachel Taylor. First published in M. Larmer, E. Guene, B. Henriet, I. Peša, R. Taylor (eds.), Across the Copperbelt: Urban and Social Change in Central Africa's Borderland Communities (Oxford: James Currey, 2021).

treat this published text as the outcome of my personal and undeniably privileged reflections on Copperbelt social history, for which no one is responsible but myself. In this way the aim is to lay bare the continuing inequalities in academic knowledge production about African societies, as a very modest contribution to overcoming them. 


\section{Imagining the Copperbelts}

\section{Introduction}

The exploration and settlement of the Central African Copperbelt in the early twentieth century, while not the focus of this study, was foundational for the subsequent development of Copperbelt society and how it was understood. While the novelty of social life in its new mine camps and towns was clear to all observers, European officials and missionaries in particular saw them within a racialised framework that counterposed African backwardness to European modernity. Mining towns were, from this perspective, inherently Western spaces in which Africans were out of place and in need of close surveillance and discipline, albeit in contrasting forms. Katanga's mines pioneered a model of African urban settlement and family life in the 1920s and 1930s, while Northern Rhodesian mine companies sought unsuccessfully to retain a migrant system and retain the 'rural' identity of African urbanites.

African protests and strikes, and the changed context of the postWorld War Two world, led in the late 1940s and 1950s to a huge expansion in efforts - by mine companies, late colonial states and their intellectual advisors - to effectively urbanise the growing African population of Copperbelt towns. New social scientific institutions conducted an unprecedented wave of research on the urban African experience. While some researchers asserted that Africans were adapting successfully to this 'modern' milieu, establishing new institutions and cultural forms, others believed Africans needed official instruction in how to be urban and worried that their dislocation from supposedly stable rural norms would create alienation and discontent. This chapter provides a necessarily brief overview of key themes in the vast body of RLI and CEPSI research - building on the more detailed work by Schumaker, Ferguson, and Rubbers and Poncelet - and 
identifies aspects of their imaginaries of Copperbelt societies, formed in this period, that would go on to shape the way that African life in its towns was understood over the next half-century.

The chapter demonstrates that this body of research, while diverse in its assumptions, methods and conclusions, was fundamentally shaped by its engagement with African societies themselves: not only indigenous research assistants, but also the agency and ideas of African elites who understood the political consequences of academic knowledge production and sought to shape it in ways that would support their own perspective and interests. Copperbelt migrants shared some of the notions of the colonial authorities about urban society: that it represented a new form of social organisation that needed to be understood and navigated, and that knowledge about it should be disseminated to new arrivals, via familial and ethnic support and socialisation networks. Through an analysis of a single African-authored work of fiction, the chapter argues that African migrants, far from seeing Copperbelt life as outside their experience, consistently and creatively generated their own understandings of urban society that both overlapped and contrasted with official and academic discourses.

\section{Formative Influences: Copperbelt Imaginations in the Early Twentieth Century}

Colonial rule of Africa in the early twentieth century was an evidently self-conscious process in which Western actors believed the imposition of effective authority on and exploitation of Africans required forms of governance, education and development that were distinct, both from those in existence in Africa at the moment of colonial conquest and from those practised in Western societies. The decades-long debates among European colonial administrators over indirect rule, chiefly authority and assimilation versus adaptation were underwritten by assumptions of difference between Europeans and Africans in the form and/or level of 'civilisation', grounded in pseudo-scientific race theory and their own understanding of Europe's recent history of social, political and economic change. ${ }^{1}$

1 For indirect rule and colonial governance, see (among many others) Heather J. Sharkey, 'African Colonial States', in John Parker and Richard Reid (eds.), Oxford Handbook of Modern African History (Oxford: Oxford University Press, 2013), pp. 151-70; Adiele Eberechukwu Afigbo, The Warrant Chiefs: 
There is no space here to challenge this viewpoint by providing even a meaningful summary of the pre-colonial history of Central Africa: it will hopefully be sufficient to state that the 'Copperbelt' of the eighteenth and nineteenth centuries had experienced enormous creative innovation in forms of political authority, from the Luba kingdom to the Lunda Commonwealth. Trade in copper and other minerals and goods had linked these polities to the Atlantic and Indian Oceans, before global trading links and influences had fuelled inter- and intraAfrican societal conflict and the rise of the Yeke warlord state of Msiri in southern Katanga, all of which made the Copperbelt in general and its Congolese part in particular a zone of exceptional historical flux. ${ }^{2}$

Colonial rule nonetheless rested on a general assumption that existing African societies were essentially static and ahistorical small-scale social systems in which patriarchal authority, customary law and cultural norms went largely unchallenged from within. Europeans disagreed about whether this was a good thing and debated whether Africans should be disrupted out of their traditional order by the imposition of tax, labour or law, or preserved in it and protected from the forces of modernity raging around them. The extent to which this debate mattered is itself debatable: colonialism in practice, while certainly uneven in its impact across the continent, demanded that Africans work and pay taxes and adhere to reconstituted versions of 'native' authority now uneasily integrated into the colonial order, arguably regardless of the outpourings of European observers searching for ways to preserve or remake African authority and identity in the face of what they understood as a qualitatively new, revolutionary wave of social change for which Africans themselves were allegedly wholly unprepared. Nonetheless, the writings of missionaries, European

Indirect Rule in Southern-Eastern Nigeria 1891-1927 (London: Longman, 1972); Gregory Mann, 'What was the Indigénat? The "Empire of Law" in French West Africa', Journal of African History 50, 3 (2009), pp. 331-53; and Justin Willis, 'The Administration of Bonde, 1920-60: A Study of the Implementation of Indirect Rule in Tanganyika', African Affairs, 92, 366 (1993), pp. 53-67.

2 For this period, see Jan Vansina, Kingdoms of the Savannah (Madison: University of Wisconsin Press, 1966), chapters 6 and 8 and, more recently, David M. Gordon, Nachituti's Gift: Economy, Society, and Environment in Central Africa (Madison: University of Wisconsin Press, 2006), esp. chapter 1, and Giacomo Macola, The Gun in Central Africa: A History of Technology and Politics (Athens: Ohio University Press, 2016). 
administrators and company officials on these topics, rooted in their distorted perception of race, authority and historical change, were deeply influential on how social change in general and specific phenomena such as wage labour, urbanisation and cosmopolitan society came to be understood in mid-twentieth-century colonised Africa in general and in the Central African Copperbelt in particular. The notion that preexisting African societies had common, longstanding 'customs', ensuring a stable social order overseen by recognised politico-legal authorities, would prove central to societies' efforts to implement and contest supposedly 'modern' legal, economic, political frameworks in both colonial and post-colonial Africa. ${ }^{3}$

Because deviation from the supposed stable norms of the African rural social order attracted the attention of Western observers, the camps that grew up around the new copper mines of Haut-Katanga in the 1910s and the Northern Rhodesian Copperbelt from the late 1920s, as well as the African societies that provided labour to them (and other workplaces in southern Africa), were the concern and the subject of analysis by missionaries and company and colonial officials. Missionaries generally saw African and European civilisations as essentially different, or believed African society was lagging behind but following in the path of European modernisation. Either way, the pre-colonial society that was now fast disappearing under the pressure of its superior Western counterpart was romanticised as not only appropriate to the 'primitive' level of African development, but free of the social ills of urban society:

Whatever may be said for or against the tribe as a primitive form of governmental control, it must be recognised as a successful expedient for the integration of community life; everybody was domiciled, fed and clothed according to the standards of the group, crime was rare, prostitution, orphanage and pauperism were altogether unknown. ${ }^{4}$

3 The role of custom was of course a central focus in the work of Max Gluckman, founder of the Manchester school of anthropology and the second director of the Rhodes-Livingstone Institute: most notably in Max Gluckman, Custom and Conflict in Africa (London: Basil Blackwell, 1956). Among many subsequent studies, see Chanock, Law, Customs and Social Order; Abner Cohen, Custom and Politics in Urban Africa: A Study of Hausa Migrants in Yoruba Towns (Abingdon: Routledge, 2004 [1969]); and Elizabeth Thornberry, 'Virginity Testing, History, and the Nostalgia For Custom in Contemporary South Africa', African Studies Review, 58, 3 (2015), pp. 129-48.

4 J. Merle Davis, Modern Industry and the African (London: Macmillan, 1933), p. 45. 
'Tribal' societies were however equally considered in need of urgent reform to remove harmful 'traditional' practices such as forced labour and polygamy. Creating new legal orders to govern Africans living in town was however fraught with complications: since 'normal' African tribes were believed to be ethnically homogeneous and immobile, the lines of authority in multi-ethnic urban migrant societies were evidently compromised. Where would the line be drawn between European and African law? Which customs would apply when Africans of different origin encountered one another? How would urban Africans enter into contracts of employment or marriage, or acquire housing or credit? The ways in which the authorities approached these questions were informed by an assumption that urban Africans were people out of place: they needed to be in possession of internal passports known as 'situpa', which identified their chief and village of origin, and a contract of employment to justify their presence in town. ${ }^{5}$ The ways the authorities in the two parts of the Copperbelt managed these problems developed in markedly different ways, reflecting their distinct colonial cultures and the differential development of their mining industries, differences that would have a profound long-term impact on Copperbelt society.

The Belgian administration of Congo was haunted by the failure of King Leopold's Congo Free State and sought to justify its continued governance of this vast territory by 'improving' the lives of its indigenous inhabitants. ${ }^{6}$ Inter-war Belgian Congo saw significant interventions in the health and social care of its African population. When the Katangese mining company UMHK struggled to recruit sufficient African workers to its operations, it seemed logical to lengthen their contracts from six to twelve months and, with the encouragement of the colonial administration and the Catholic Church, to invest in the stabilisation of their residence in its mining camps. ${ }^{7}$ Meanwhile, UMHK production was periodically constrained by recruiting problems. Colonial officials collaborated with recruiters to provide

5 Passes of this kind were used to control African movement and employment across southern-central Africa until independence and, in South Africa, until the mid-1980s.

6 Matthew G. Stanard, Selling the Congo: A History of European Pro-Empire Propaganda and the Making of Belgian Imperialism (Lincoln: University of Nebraska, 2012).

7 Vellut, 'Les Bassins Miniers'; Bruce Fetter, The Creation of Elisabethville (Stanford, CA: Hoover Institution Press, 1976). 
increased labour, but ongoing shortages forced the company into mechanising aspects of production as early as 1913 . The skill base of African workers, and a wage scale that rewarded such skills, was raised with the aim of replacing their expensive and politically suspect white counterparts following strike action in $1919 .{ }^{8}$ Union Minière du HautKatanga and its state and church partners helped arrange marriages for single mineworkers, incentivised married life with the provision of larger houses for married workers and provided an increasingly elaborate system of natal and child care - the latter drawing on Belgian colonial natalist policies but here developed to their greatest extent via the revenue generated by mining. ${ }^{9}$ The Benedictine mission headed by the towering figure of Father Jean Felix de Hemptinne would play a decisive role in this process from 1925, when it was granted authority to open its first school for African boys in Elisabethville. ${ }^{10}$ Subsidised by the Belgian state, Benedictine education inculcated the 'civilised' values that would be necessary to live a moral life in town. Ultimately the most advanced Africans, educated and having adopted a Western lifestyle, could acquire 'évolué' status. In the Congolese context, the definition of évolués was endlessly debated by policymakers and advisors in relation to whether colonial policy should cherish and protect African civilisation on its own terms, or if Africans should be assimilated into European civilisation. ${ }^{11}$

However, beneath the focus on welfare and education lay the unresolved question of social adaptation and transition: what forms of political authority and social organisation were appropriate to the supposedly new urban African societies of Haut-Katanga's mining towns? The Belgian solution to these problems was intervention: the careful management of all aspects of migration and urban life. Mine police controlled entry into and out of the 'camps' and monitored who was living in each house built by the company. This would over time develop into a fully-fledged system of what Dibwe dia Mwembu characterises as authoritarian paternalism, in which every aspect of work and social life

8 Perrings, Black Mineworkers in Central Africa, pp. 29-31.

9 For Belgian colonial childcare more generally, see Nancy Rose Hunt, “"Le Bebe en Brousse": European Women, African Birth Spacing and Colonial Intervention in Breast Feeding in the Belgian Congo', International Journal of African Historical Studies, 21, 3 (1988), pp. 401-32.

10 Fetter, The Creation of Elisabethville, p. 105.

11 Daniel Tödt, 'The Lumumba Generation: African Bourgeoisie and Colonial Distinction in the Belgian Congo' (In Press, Berlin: De Gruyter, 2021). 
was carefully managed so as to produce an ideal modern urban worker with a family to match. ${ }^{12}$ The company system of hegemonic, protective control would replace the authority of the patriarchal chief and the stable rural social order. Many Africans, however, lived in the 'cité indigene', the town area outside mine control where African life was freer but also more precarious. This spatial division between ordered mine space and more autonomous urban areas would remain central to the hierarchies and ideational understandings of Copperbelt towns for many decades (see Chapter 3). Such urban areas were revealingly known as 'centres extra-coutumier' (CECs), a name infused with colonial anxiety about ensuring effective authority in the absence of customary order. ${ }^{13}$

By the late 1920s thousands of mineworkers and tens of thousands of other Africans were essentially urban residents, but they were denied wider rights of, for example, property ownership by the segregationist policies of Belgian colonialism. As soon as they arrived in town, African residents created their own mutual 'self-help' associations organised along kinship or ethnic lines. The public manifestation of such urban associations, for example in the form of 'tribal dances', was the subject of official concern, as was the potential for the merger of ethnic identities into something generically 'noncustomary': attempts were made to bring all such activities under closer official control by, for example, relocating dances to the CEC centre. Meanwhile, the creation of the Cercle Saint-Benoit by the Benedictines represented an attempt to promote a multi-ethnic elite identity among Catholic-educated white-collar workers who were or who aspired to become évolués. ${ }^{14}$ Mine companies encouraged the integration of Africans from different backgrounds by promoting the use of Kiswahili as a common urban language and housing them together - an ethos of 'tshanga-tshanga' or ethnic mixing. Simultaneously they sought to keep mineworkers in touch with their rural societies by encouraging the performance of distinct 'tribal' dances. ${ }^{15}$ It should be stressed that this interventionist approach in

12 Dibwe dia Mwembu, Bana Shaba.

13 Fetter, Creation of Elisabethville, pp. 132-4.

14 Jean Omasombo Tshonda et al. (eds.), Katanga Vol 1, Peuples et L'Occupation de L'Espace (Tervuren: Musée Royal de l'Afrique Centrale, 2018), p. 163.

15 Dibwe dia Mwembu, 'Histoire des Conditions de Vie', p. 25. 
no way resolved the inherent contradictions of managing urban African life.

In Northern Rhodesia meanwhile, debate over such questions initially focussed on the loss of productive male labour from rural areas and the dislocating effects on patriarchal authority of cash-rich young workers: chiefs and missionaries bemoaned this impact and, as Merle Davis' quote above shows, looked back nostalgically at the rural order supposedly being lost in the face of powerful modernising forces. While many Africans remained in town for lengthy periods, pass laws and short-term contracts prevented African migrants from establishing secure residence or permanent employment. Rural depopulation was a concern shared by Katangese observers, who sought to stabilise urban communities so as to limit the constant outflow of rural migrants to town in an otherwise uncontrolled manner.

For many European observers, urban mining communities were places of disorder, sin and unchecked materialism among Africans who lacked the socialisation needed to manage their households and morals. A particular concern in Northern Rhodesia was the negative influence on Africans of the thousands of white mineworkers who, in contrast to Haut-Katanga, continued to dominate skilled mine jobs and who successfully defended a colour bar at work and residential segregation in mine and non-mine areas alike. ${ }^{16}$ Northern Rhodesian mine companies, suspicious of what they regarded as liberal missionaries and resistant to any influence over their activities of a colonial state officially dedicated to the protection of 'native' interests, liaised with their workforce via 'tribal elders', later 'tribal representatives' ${ }^{17}$ These were respected older men, some from aristocratic backgrounds, who were chosen to represent mineworkers in a variation on the British policy of indirect rule practised in rural areas. ${ }^{18}$

16 Duncan Money, “'No matter how much or how little they've got, they can't settle down": a social history of Europeans on the Zambian Copperbelt, 1926-1974', unpublished DPhil thesis, University of Oxford (2016).

17 Northern Rhodesia was established in 1924 as a British protectorate, in theory protecting its African population from the settler-driven demands for labour and land experienced in Southern Rhodesia.

18 Interview, Morris Chimfutumba, Mufulira, 13 July 2018. For indirect rule on the Northern Rhodesian Copperbelt see Walima T. Kalusa, 'Death, Christianity, and African Miners: Contesting Indirect Rule in the Zambian Copperbelt, 1935-1962', International Journal of African Historical Studies, 44, 1 (2011), pp. 89-112. 
In sharp contrast to the de facto Benedictine alliance with UMHK, African Christian activity south of the border ran ahead of its European missionary counterpart: in 1925 the Union Church, the first of any kind on the Northern Rhodesian Copperbelt, was established by African migrants in Mindolo, near Ndola. Eschewing the denominational mission franchises of Northern Rhodesia's rural communities, Union Church leaders established branches in all the main mine compounds. ${ }^{19}$ European missions were largely absent from the Copperbelt until the recommendations of the Merle Davis report prompted the establishment of the multi-denominational United Missions to the Copperbelt (UMCB) in 1936. Its missionaries remained reluctant to involve themselves in an ethnically mixed urban community where, they believed, the lines of traditional authority were unclear and where migrants had already developed their own interpretations of Biblical scripture. United Missions to the Copperbelt's social outreach activities received modest government funding but little support from mine companies, which worried that missionaries would stir up discontent among their African workforce.

In both regions, the global Depression of the 1930s threw thousands of Africans out of work and conjured the spectre of unemployed urban 'natives', unmoored from indigenous authority and ripe for radicalisation. Chauncey suggests that, though the disruptive effects of the Depression on suddenly retrenched African mineworkers were relatively brief, they had a disproportionate and lagging impact on the Northern Rhodesian government's desire to avoid stabilisation. ${ }^{20}$ During World War Two, however, the Central African Copperbelt emerged as a globally strategic economic location, providing vital minerals for the military and industrial war effort. Wartime demands meant that rural areas and populations were more directly exploited for agricultural produce, accelerating rural depopulation and, in a context of rapidly rising prices, putting living standards under profound pressure. Colonial policymakers

Denis M'Passou, Mindolo. A Story of the Ecumenical Movement in Africa (Lusaka: Baptist Printing Ministry, 1983), pp. 1-5; Stephanie Lämmert, 'Reimagining the Copperbelt as a Religious Space', in Larmer et al., Across the Copperbelt, pp. 347-72.

20 George Chauncey Jr., 'The Locus of Reproduction: Women's Labour in the Zambian Copperbelt, 1927-1953', Journal of Southern African Studies, 7, 2 (1981), pp. 135-64, p. 157. 
increasingly perceived the vulnerability of their new urban African communities to subversive influences, ranging from communism to messianic independent churches, that might undermine their loyalty to the colonial project.

Understanding of such threats was influenced by the growing importance of the human sciences in colonial policymaking: sociological theories developed to explain Western industrial society were now combined with religious and political interpretations to diagnose problems and offer solutions. The 1940 Northern Rhodesian strike provided clear evidence, for the Forster Commission of Inquiry, that Africans were in towns to stay and that it was necessary to adopt urban stabilisation policies similar to those well established in Katanga, to manage the dangerous new phenomena of

the skilled native ... who stands on the threshold of the enjoyment of the luxuries of our civilisation, he is the man who is the most affected by any rise in the cost of living ... he is also the person that we can expect industrial trouble from in the future. ${ }^{21}$

At the same time, Northern Rhodesian policymakers sought to keep workers in touch with their rural communities of origin and insisted they return to their villages at the end of their working lives. Five years earlier, the inquiry into the more limited 1935 Copperbelt riots also prompted urgent soul-searching about the dangerously bifurcated nature of African society and the stark choice facing mine companies and policymakers. One compound manager told the subsequent Commission: 'These people form a definite social group quite shorn of anything tribal, they live in a world entirely different to the other natives. ${ }^{, 2}$ The failure of tribal representatives to warn of the impending unrest suggested, in the testimony of the Provincial Commissioner to the Inquiry, that

a situation existed on the mines which was particularly dangerous, undesirable, and quite unique in my experience. Because if natives riot on occasion of tax without any indication that they are dissatisfied, with no attempt to make representation of their grievances, without even making an attempt to evade

21 Forster Commission of Inquiry, quoted in Perrings, Black Mineworkers in Central Africa, p. 224.

22 Quoted in Jane L. Parpart, Labour and Capital on the African Copperbelt (Philadelphia, PA: Temple University Press, 1983), p. 47. 
payment, then I say that a spirit prevails among these natives which is altogether novel. ${ }^{23}$

The inquiry report stated: 'The choice lies between the establishment of native authority, together with frequent repatriation of natives to their villages; or alternatively, the acceptance of definite detribalization and industrialization of the mining under European urban control'. ${ }^{24}$

In Haut-Katanga, the 1941 mineworkers' strike, arising in similar wartime conditions to that in Northern Rhodesia one year earlier, was assessed in very different ways (see Chapter 4). For government and UMHK officials it was not an expression of new urban identity but rather a sign of disorder in mine camps in which societal and familial norms had been disturbed. The solution was therefore a radical expansion in the company's existing programme of social intervention. This would build on its pioneering but limited efforts at urban stabilisation and family support, which were now combined with policy lessons drawn from wartime and post-World War Two Western Europe, deployed in Congo to combat the negative social effects of extreme inequality and the ethnicisation of political extremism, via a limited tripartism bringing together company, state and worker representatives.

These events and the policy response to them will be further elaborated in Chapter 4. Here, it is worth noting that one official response to the 1935 revolt was the establishment of the RhodesLivingstone Institute (RLI) to advise the authorities on new challenges to racial relations in Northern Rhodesia. In Haut-Katanga, likewise, the establishment of the Centre d'Études des Problèmes Sociaux Indigènes (CEPSI) heralded a massive investment in knowledge production predicated on the notion that the urban communities of central Africa were generating new and urgent social problems that, in the optimistic spirit of the time, could be understood and addressed by the right forms of scientifically informed intervention.

23 Western Province Commissioner Goodall, evidence to 1935 Commission of Inquiry, quoted by Epstein, Politics in an Urban African Community, p. 30.

24 Government of Great Britain, 'Report of the Commission appointed to inquire into the disturbances in the Copperbelt, Northern Rhodesia. October, 1935' (London: HMSO, 1935), p. 41. 


\section{RLI and CEPSI in Late Colonial Context}

The Rhodes-Livingstone Institute was formally established in 1938, officially to contribute towards 'scientific efforts ... to examine the effect upon native African society of the impact of European civilization', primarily through the applied use of social anthropology. ${ }^{25}$ The Centre d'Études des Problèmes Sociaux Indigènes, as has already been noted, was founded eight years later, with similar aims of applying the tools and insights of social science more generally. While both institutes had broad remits for the study of African societies in Belgian Congo and Northern Rhodesia (and indeed, in the RLI's case, further afield in British-ruled Africa), the Central African Copperbelt was a primary focus of their collective attentions. It provided a compelling case study of European impact and consequential social change on African society and, as an area of political and economic importance, attracted considerable research funding. The Northern Rhodesian government was an early funder of the RLI; while Anglo American was sceptical about the RLI's liberal social scientists, CEPSI received significant support from UMHK.

Researchers for RLI and CEPSI were in turn influential in international and inter-imperial networks of research and policymaking in areas such as housing, labour and social welfare, reflecting the wider late colonial concern about the distinct problems of urban Africans. The RLI's Clyde Mitchell and CEPSI's Arthur Doucy and René Clémens were, for example, present alongside Georges Balandier, whose pioneering sociological analyses of Brazzaville equally highlighted the urban African experience, at a landmark UNESCO conference held in Abidjan in 1954 on urbanisation and industrialisation. ${ }^{26}$ In practice however, there was comparatively little practical interimperial co-operation between the different research institutes addressing these issues, and certainly between the contrasting conclusions of CEPSI and RLI analyses of Copperbelt societies.

The work of the RLI and, to a lesser extent, CEPSI must itself be one of the most studied (and restudied) sets of social scientific research

25 Quoted in Godfrey Wilson, 'Anthropology as a Public Service', Africa: Journal of the International African Institute, 13, 1 (1940), pp. 43-61, p. 43.

26 See, for example, Georges Balandier, Afrique Ambiguë (Paris: Plon, 1957). The papers from this conference were published as UNESCO, Social Implications of Industrialisation and Urbanization South of the Sahara (Paris: UNESCO, 1956). 
activity anywhere. This chapter does not pretend to offer anything approaching a comprehensive history of their ideas, organisation, methods and activities, which have in any case been expertly analysed and historicised elsewhere. ${ }^{27}$ Its more limited aim is to identify key themes in the work and approach of both institutes that, it is argued, shaped subsequent perceptions of the Copperbelt's form of urban modernity. Further specific themes central to their work - including political participation, economic power and consumption, familial relations and personal development - will be explored in subsequent chapters.

\section{'Endless Becoming' - African Societies in Transition}

A central assumption in the work of both CEPSI and RLI researchers was that new urban African societies such as the Copperbelt's mining towns were experiencing a rapid transition from one type of society to another. Migrants who had grown up in small villages with personalised social relations, agricultural economies, customary law, reciprocal exchange of goods, patriarchal authority, localised belief systems, homogeneous cultures and stable social orders had relocated to towns marked by myriad manifestations of modernity: industrial labour rewarded by cash wages, enabling the purchase of consumer goods; Western legal and political systems; Christianity and the nuclear family; and exposure to foreign cultures and cosmopolitan communities with diverse customs. Wilson's 1941 study of the Broken Hill mining compound starts from the classic functionalist assumption that 'society is an equilibrium, a balanced or coherent system of groups, relationships and institutions, all inextricably connected with and determining one another'. Africans with their origins in such balanced societies now

Ferguson, Expectations of Modernity; Schumaker, Africanizing Anthropology; Poncelet, L'Invention des Sciences Coloniales Belges; Rubbers and Poncelet, 'Sociologie Coloniale au Congo Belge'; Bruce Kapferer, 'Situations, Crisis, and the Anthropology of the Concrete: The Contribution of Max Gluckman', Social Analysis, 49, 3 (2005), pp. 85-122; Jan Kees van Donge, 'Understanding Rural Zambia Today: The Work of the Rhodes-Livingstone Institute', Africa, 55, 1 (1985), pp. 60-76; Richard P. Werbner, 'The Manchester School in South-Central Africa', Annual Review of Anthropology, 13 (1984), pp. 157-85; Hugh Macmillan, 'The Historiography of Transition on the Zambian Copperbelt - Another View', Journal of Southern African Studies, 19, 4 (1993), pp. 681-712. 
found themselves thrust into 'a heterogeneous world, stratified into classes and divided into states, and so find themselves suddenly transformed into the peasants and unskilled workers of a nascent nationstate'. ${ }^{28}$ Epstein described the scale of change in characteristically evocative terms: 'Where once there was only bush with scattered African villages linked by a network of winding paths, there are now large towns of multi-racial composition, linked with one another, and with the outside world, by road and rail, telephone and wireless. ${ }^{29}$ This transition was understood to be an accelerated or truncated version of the modernisation of Western Europe between the seventeenth and nineteenth centuries that had encompassed religious disenchantment, enclosure of the commons, urban migration and the increasing domination of materialist values and broader social identities based on class and nation. Authors stressed the rapidity and dislocating effects of these changes: Doucy and Feldheim, for example, stated that 'in the industrial centres ... three different worlds collide: the customary and traditional African, the West and the transitional world'. ${ }^{30}$ Powdermaker asserted that there was 'in this part of Africa' a drastic broadening of space via contact and communication with other cultures, the regulation of time, the money economy, the nuclear family, the undermining of respect for elders by new hierarchies based on education, wealth and status, all combining to change the dominant social unit from 'tribe' to 'nation'.

More recent social change in the contemporaneous West was also an influence on these thinkers: sociological research that supported the post-World War Two growth of statist developmental intervention inspired researchers to recommend or apply such approaches to Central Africa. The extent to which the West, either historically or in the current period, was a useful analogy was, however, the subject of some disagreement. The notion - today an indisputable and indeed uncontroversial historical truth - that African societies had themselves always been historically dynamic, had mutated and changed to meet

28 Godfrey Wilson, The Economics of Detribalization in Northern Rhodesia (Livingstone, Zambia: Rhodes-Livingstone Institute, 1941). Broken Hill, later Kabwe, was outside the Copperbelt region itself.

29 Epstein, Politics in an Urban African Community, p. xi.

30 Doucy and Feldheim, Problèmes du Travail, p. 8.

31 Hortense Powdermaker, Copper Town: Changing Africa (New York: Harper and Row, 1962), pp. 15-18. Powdermaker was not officially a RLI researcher but worked closely with the Institute. 
changing societal challenges, and had shaped and been shaped by relevant global dynamics (religious, economic and political) in the centuries preceding colonial annexation, was almost wholly absent from these analyses.

A key concern was therefore whether Africans were able to manage this unprecedented transition, to adapt to its requirements and become functioning members of modern societies. Wilson was concerned that externally driven economic change was running ahead of African society's ability to adjust, so that 'men and women alike find themselves morally and intellectually unprepared for the new conditions'. ${ }^{32}$ Max Gluckman, Wilson's successor as RLI director, stressed, however, the centrality of the new urban context in shaping African behaviour and identity in his memorable phrase, 'An African townsman is a townsman, an African miner is miner: he is only secondarily a tribesman'. ${ }^{33}$ While some researchers shared Gluckman's optimism about African adaptability, many were concerned about social dissonance and dislocation in the transitional period. There was a desire to avoid the negative side effects of modernisation as it had unfolded in the West, which (depending on one's political orientation) might encompass social deprivation, for example slum housing or poor child socialisation, or industrial and social unrest and political 'extremism'. More concretely, an immediate concern of researchers working with mine companies was 'productivity', the extent to which African mineworkers could adjust to the demands of skilled employment and continuously improve their abilities. In a central African industry whose prime advantage had been the cheapness of its African workforce, higher wages would need to be earned by major improvements in this area (see Chapter 2).

There was, it must be stressed, significant variation in CEPSI, RLI and official thinking about adaptation and transition between the two colonies and in the relatively short period between the establishment of these institutions and the end of colonial rule. More conservative observers initially characterised urban Africans as orphaned children, unmoored from their patriarchal norms, unable to adjust to the complex urban order and therefore vulnerable to the social evils of

32 Wilson, 'Economics of Detribalization', p. 14.

33 Max Gluckman, 'Tribalism in Modern British Central Africa', Cahiers d'études africaines, 1, 1 (1960), pp. 55-70. 
modern life. Albert Gille, Provincial Commissioner for Coquilhatville, extolled the vital role of CESPI in overcoming the 'evils' that were 'undermining Native society' and the need to address the 'African's inability to react, freely and rationally, against the factors of modern life, in all its aspects, invading and dislocating his own'. ${ }^{34}$ Gille rejected any comparison with the West and saw the truncated process of African adjustment as uniquely problematic:

Can one begin to compare the mentality, the needs, the stage of historic evolution, of working classes or war victims in Belgium, with those of our Natives? Our Natives' tribal mentality in process of disintegration, seeking new outlets; the social instability of the majority; their psychological and professional instability; their moral code wavering between ancestral fetichism [sic] and the new Christian appeals; their family institutions and, even to-day, the inefficiency of their political framework; the inadequacy of population statistics; the heterogeneity of races; the juxtaposition of locations and European settlements, giving rise to a psychological and social complexity which is absolutely sui generis; are these not facts for which no parallel exists in Europe ${ }^{35}$

Notwithstanding their varying perspective, there was a general consensus that this difficult transition needed to be guided by interventions by the European authorities - the colonial powers, the mine companies and their allies in the church, educational and social services - to avoid social malaise and ensure Africans became modern at the appropriate pace and to the extent of their ability. Overtly racialised characterisations of distinct African and European 'civilisations' were increasingly displaced by late colonial discourses of managed development and ostensibly depoliticised by the application of rational social scientific analysis to inform policy. Gille asserted in 1950:

We are working for a long-term development in which gradual gains may, in the course of generations, filter down into the masses and establish themselves. Thus they will serve as a sure stepping-stone to future advances towards new stages of progress, avoiding all disequilibrium. ${ }^{36}$

34 Albert Gille and Ferdinand Grévisse, 'The Social and Scientific Role of C.E.P.S. I.', African Affairs, 49, 195 (1950), pp. 151-7, p. 151. These authors were

Belgian colonial administrators, the latter a senior administrator in Kolwezi and Jadotville/Likasi.

35 Gille and Grévisse, 'Social and Scientific Role', p. 152.

36 Gille and Grévisse, 'Social and Scientific Role', p. 153. 
A rushed process of transition therefore would be disastrous, creating social and even psychological anomie. Doucy and Feldheim's rejection of trade unionism and the continuing need for colonial paternalism showed that CEPSI thinking was at times not incompatible with the earlier and still influential ideas of de Hemptinne and complemented Belgium's postponement of envisaged decolonisation to the far future (see Chapter 4). ${ }^{37}$ As Rubbers and Poncelet argue, the adaptation argument rested on the characterisation of the rural village and the urban mine town as not only geographically distinct but representing distinct evolutionary stages. ${ }^{38}$ In Clémens' understanding of life in Katuba, a CEC in Elisabethville, Africans were migrants not simply into urban towns but into European culture and civilisation, forcing a brutal acceleration of their historical development that left them psychologically disoriented and in need of European guidance. ${ }^{39}$ While RLI researchers such as Clyde Mitchell found evidence, following Gluckman, of the adaptability of African society and culture to its new urban setting, they equally accepted the underlying notion that industrial towns were inherently 'modern' and contrasted them, implicitly or explicitly, to 'traditional' rural Africa. Powdermaker, while showing the apparent compatibility of 'modern' and 'traditional' life, nonetheless also counterposes them:

Now traditional and modern orders exist side by side. Men who participated in a tribal dance on Sunday afternoon might be dancing on Saturday night to jazz music at the Welfare Hall. Witchcraft-thinking did not prevent people from using the services of the clinic and hospital. They listened to modern songs and to current news and stories over the radio, and used their traditional proverbs and folk tales to make a point in colloquial conversation.... The goal of individual careers was new, but it had not eliminated traditional duties to kindred. Many people went to church, but they also followed some traditional customs at birth, puberty, marriage, and death.... Some people tended to be more traditional and others more modern in their general orientation [but] the traditional and modern were found not only in disparate groups, but within the same individual. ${ }^{40}$

37 Doucy and Feldheim, Problèmes $d u$ Travail.

38 Rubbers and Poncelet, 'Sociologie Coloniale au Congo Belge'.

39 René Clémens, 'Le Développement des Sciences Sociales et le Congo Belge', CEPSI Bulletin, 31 (1955), pp. 87-96.

40 Powdermaker, Copper Town, p. 7. 
In numerous CEPSI articles published throughout the 1950s, insightful empirical research was overshadowed by this explicit framework. An otherwise informative analysis of indigenous trading in the CEC area of Elisabethville, for example, had as its underlying assumption that Africans could only learn to become entrepreneurs through their exposure to white counterparts:

The modern monetary economy in which we have plunged the Black without the transition that was experienced by generations of Europeans has provoked, among those living in the cities, a rupture with their clan links and a distortion of their customary rules.... The coexistence of these two groups will provoke an acculturation by the less evolved group. ${ }^{41}$

Because the resultant survey assumed that African businesspeople learnt trading methods from their European counterparts, it made no effort to discover whether they did so or not.

\section{Applying Social Science: The Political Uses of Knowledge Production}

The RLI and CEPSI researchers were themselves well aware of the political significance of their work and, as well as producing findings, they often wrote and spoke about the wider consequences of their findings for African society and for political change. For CEPSI, Grévisse claimed:

While functional ethnology contents itself with observing the evolution of Native society under the influence of outside forces, C.E.P.S.I. goes further. It is trying to take an active part in determining the direction and the rhythm of this evolution, by grasping the realities of Native life as a whole, by watching the forces in action, and by noting how they react on each other. ${ }^{42}$

Initially, however, human agency in this process was confined to European 'government officials, missionaries, directors of large business concerns, traders and settlers'. ${ }^{43}$ These agents had a duty to 'define their attitude to the Native, whom they ask to join them in some form of partnership. For this partnership it is essential that the Native be freed from his old ways of thought, and given new aptitudes, new

41 Anon, 'Le Commerce Indigène au CEC d'Elisabethville', CEPSI Bulletin, 28 (1955), pp. xli-lxxv.

42 Gille and Grévisse, 'Social and Scientific Role', p. $154 . \quad 43$ Ibid. 
ambitions and new wants'. ${ }^{44}$ Therefore, CEPSI was an overtly 'practical' institute and in this respect differed somewhat from the RLI, but both institutions believed that the gathering and effective dissemination of applied research - the production of knowledge - was a vital ingredient in societal progress. ${ }^{45}$

As much that was customary was falling away in the face of the supposedly unstoppable forces of modernity, it was ever more vital to document what was happening and what was being lost. The CEPSI Bulletin devoted a great deal of space to administrator Ferdinand Grévisse's encyclopaedic descriptions of African 'tribes', which encompassed their distinct histories, food, material life, clothes, housing, labour and economic activities. This, 'at a time when industrialization is ... gradually leading to innovations that a policy of integration presupposes, ... preserves for autochthones more than a vague memory of the orientation of the spirits of their ancestors'. ${ }^{46}$ The envisaged audience for this research, beyond white officials and settlers, was then African elites themselves who - it was assumed - were themselves incapable of carrying out the preservation and documentation of their own culture (see especially Chapter 7).

As a corollary of this, African 'tribes' were profiled for and ranked by their ability to adjust to the demands of modern industrial society. In Northern Rhodesia, the Lamba, the indigenous inhabitants of the Copperbelt who had responded to the presence of the mines with significant commercial agricultural activity and thereby avoided being drawn into mine labour, were as a result stereotyped as being unsuited to modern life. ${ }^{47}$ In contrast, the Bemba - pioneers of mine migration to Katanga and then the Northern Rhodesian mines - and the Luba Kasai - who migrated to the Katangese mines in large numbers from the 1930s - were championed by their respective Catholic mission interlocutors as particularly well suited for industrial labour. This ethnic approach to labour profiling was given a scientific makeover in 1950s Katanga with UMHK's introduction of psychological testing of new

44 Gille and Grévisse, 'Social and Scientific Role', p. 155.

45 Rubbers and Poncelet, 'Sociologie Coloniale au Congo Belge'.

46 F. Grévisse, 'Notes Ethnographiques Relatives à Quelques Populations Autochthones du H-K Industriel', CESPI Bulletin, 32 (1956), pp. 65-207.

47 Brian Siegel, "The "Wild" and "Lazy" Lamba: Ethnic Stereotypes on the Central African Copperbelt' in Leroy Vail (ed.), The Creation of Tribalism in Southern Africa (Oxford: James Currey, 1989), pp. 350-71. 
recruits. Intelligence testing meanwhile enabled the comparison of IQ results for children in Elisabethville and Kolwezi primary schools with those of their counterparts in Belgium and the United States. ${ }^{48}$ Occupational psychology was also practised in Northern Rhodesia's mines, though it appears this focussed primarily on white mineworkers. ${ }^{49}$

A key concern, for CEPSI as for policy-makers, was the preservation of peri-urban African development in the hinterlands of the mining towns, both to provide alternative forms of employment to migrants and to ensure these towns could feed themselves. Initiatives to stimulate agricultural entrepreneurship however foundered, it was argued, on African conservatism: 'They could never be strong enough to disengage the indigenous population from its primitive methods of work, so that it remains practically frozen in a subsistence economy. 50 Consistent with CEPSI's applied approach, Clémens himself founded, with UMHK funds, an experimental village on the outskirts of Elisabethville to which Africans were encouraged to relocate from the cités indigenes: this was to be, in Clémens' term, a 'kibboutz-bantou', a model horticultural centre that would give birth to a 'new Bantu agriculturalist' under European supervision. ${ }^{51}$

Over time, it must be emphasised, this research evolved considerably: while CEPSI assumptions about African cultural mindsets never fully dissipated, the evident ability of Africans to adapt to the urban industrial context of Haut-Katanga led to an increasing emphasis on context-specific findings and the development of innovative research methods that enabled more effective analysis of societies in flux. As Rubbers and Poncelet rightly argue, CEPSI researchers were increasingly critical of many colonial practices - of settlers, administrators and

AGR2 Brussels, UMHK archives (hereafter UMHKA), File 672: Centre de psychologie et pédagogie, 1954-8. See also Amandine Lauro, “"The British, The French and Even the Russians Use These Methods": Psychology, Mental Testing and (Trans)Imperial Dynamics of Expertise Production in Late Colonial Congo', in Larmer et al., Across the Copperbelt, pp. 267-95.

Schumaker, Africanizing Anthropology, p. 160. Psychological testing of workers in late colonial Africa is analysed in the work of Kerstin Stubenvoll on Cameroon: www.ilo.org/wcmsp5/groups/public/-dgreports/-inst/documents/p roject/wcms_220106.pdf (accessed 11 September 2020).

50 René Wauthion, 'Pour le Developpement d'une Economie Rurale dans L'Hinterland des Grands Centres Industriels du Haut-Katanga: Contribution a une Initiative du CEPSI', CEPSI Bulletin, 34 (1956), pp. 5-21.

51 Rubbers and Poncelet, 'Sociologie Coloniale au Congo Belge', p. 98. 
others - but never (until the last, hurried days of decolonisation) questioned the Belgian presence in Congo. ${ }^{52}$

The RLI's own commitment to what its researchers regarded as progressive social change is equally evident. They strongly disagreed with colonial officials' characterisations of town life: far from being places of disorder, they believed urban Africans were making new forms of social order. Typically, Epstein notes in regard to African advancement into skilled mine jobs, 'the local Africans showed a capacity for adjusting themselves to the conditions of the new society'. ${ }^{53}$ And they were aware that the stakes were high: if Africans were shown, against the racial prejudices of administrators and most white settlers, to be capable of full participation in 'modern' society, they could not then be denied political participation up to and including the independence of their countries.

\section{Elites and Évolués}

Many of the more optimistic social scientific findings regarding African adaptation and participation, however, rested on research that focussed largely or solely on the most skilled or advanced sections of urban African society, évolués in Belgian official parlance. In postWorld War Two Congo, attempts to clarify évolué as a legal category were supported by those who sought to encourage an indigenous bourgeoisie, but opposed by those who thought it would fuel class identification. ${ }^{54}$ While educated Congolese, like their Northern Rhodesian counterparts, sought to claim an advanced position by the formation of elite associations, they continued to be marginalised in political decision-making. This marginalisation contrasted sharply, however, with their disproportionate prominence in CEPSI analysis, as subjects but also increasingly as research assistants. Doucy and Clémens, whose fieldwork in Congo was restricted to brief sojourns from their university positions in Liège and Brussels, relied for their data on information provided by European but also évolué researchers. ${ }^{55}$ Robert Dethier's 1961 study 'Une famille de citadins au Katanga', Rubbers and Poncelet note, was an analysis of the

52 Rubbers and Poncelet, 'Sociologie Coloniale au Congo Belge', p. 99.

53 Epstein, Politics in an Urban African Community, p. 101.

54 Schalbroek, 'The Commission for the Protection of the Natives', pp. 201-9.

55 Rubbers and Poncelet, 'Sociologie Coloniale au Congo Belge', p. 104. 
Katuba-based family of an évolué who had himself been involved in previous social studies carried out by the University of Liège. ${ }^{56}$ This was a not atypical example of the blurring of boundaries between researcher and subject.

Similar dynamics can be identified in much RLI work on the Copperbelt. Epstein's seminal Politics in an Urban African Community focussed explicitly on 'a small group of urban leaders, composed largely of younger and better educated men'. ${ }^{57}$ In a society in transition away from rural African tradition and towards an inherently Europeanised modernity, it was thought logical to make this group the primary subject of analysis:

the leadership of these men was accepted by urban Africans because, by virtue of their education, their proficiency in English, and their more obvious approximation to European standards in dress and habit, they were not only the intermediaries between the mass of the African people and the European authorities, but also because they pointed the way forward to a new order of society. ${ }^{58}$

While it was widely assumed that class divisions would ultimately replace those of 'tribe', in this transitional period educated Africans, aspiring to European lifestyles but politically excluded from them by colonialism and racial segregation, provided leadership to what Clyde Mitchell characterised as a unified African political class:

In this situation the 'white collar' workers will become the African political leaders because they can speak English and can present their grievances and make their demands known in terms easily intelligible to Europeans. ... the Africans on the Copperbelt as a political class are not yet divided by either tribal or socio-economic class affiliations. ${ }^{59}$

Epstein was, however, aware of the potential tensions arising from such elite representation: 'the very factors which brought the Union leaders into the position of power have now come to be regarded by many Africans as an index of the distance which separates these leaders from the people'. ${ }^{60}$ This was a partial acknowledgement of the

56 Robert Dethier, Une Famille de Citadins au Katanga (Liège: Institut de sociologie, 1961); Rubbers and Poncelet, 'Sociologie Coloniale au Congo Belge', p. 104.

57 Epstein, Politics in an Urban African Community, p. xv. 58 Ibid., p. xvi.

59 Clyde Mitchell, 'The Kalela Dance', pp. 17-18.

60 Epstein, Politics in an Urban African Community, p. xvi. 
otherwise dismissive racialised attitude of British colonial administrators who, in viewing social progress as essentially Europeanisation, understood such 'advanced' Africans as by their very advancement alienated from the mass of the African population.

Later CEPSI researchers such as Caprasse drew on the more progressive insights of the RLI to analyse what he identified as a shift from 'tribal' or cultural associations rooted in tradition to more modern associational forms that rejected simple imitation of European institutions and involved 'an awareness of their own worth and a willingness to take back their destiny in areas largely beyond the control of the European'. ${ }^{61}$ The continuing focus on leadership during transition meant that the resulting research largely ignored, or made sweeping assumptions about, the majority of African residents of Copperbelt towns, notably women and those not in formal employment. It also meant that this small male African elite shaped the context and findings of RLI/CEPSI research to a striking extent, both as subjects and as researchers.

\section{African Agency in RLI/CEPSI Knowledge Production}

Consistent with this argument, Schumaker's study of the everyday work of RLI researchers demonstrates and stresses the extent to which the Institute's research rested on the activity and insights of African research assistants. Schumaker writes of the cadre of RLI African researchers, many of whom she interviewed:

Whatever their actual union sympathies, RLI assistants dressed and talked like members of the breakaway staff association and, like them, sometimes expressed contemptuous attitudes toward miners.... The research assistants also saw miners as among the least 'enlightened' of urban Africans, 'kept back' by mine management in order to make them easier to control as workers. ${ }^{62}$

Schumaker finds that the innovative urban survey work of the RLI necessitated the employment of many more African research assistants than was the case in conventional anthropology, making them

61 Caprasse, Leaders Africains en Milieu Urbain, quoted in Rubbers and Poncelet, 'Sociologie Coloniale au Congo Belge', p. 102.

62 Schumaker, Africanizing Anthropology, p. 217. Emphasis added. 
disproportionately influential. ${ }^{63}$ Powdermaker similarly acknowledged her dependence on her research assistants, young men educated at Lusaka's elite Munali secondary school, in shaping her research in Luanshya in 1953-4. ${ }^{64}$ These RLI assistants, some of whom had themselves been labour migrants and mine clerks, had of course their own positionality: they were comparatively educated in a context where formal schooling bestowed high status and they generally preferred like their Western counterparts - to conduct research among men they identified with, the small number of educated or advanced Africans. Similarly, Rubbers and Poncelet note that CEPSI's Belgian researchers worked closely with literate Congolese research assistants and regarded évolués as 'privileged informants in their research'. ${ }^{65}$

For their part, African research assistants saw themselves as political actors who understood their research to be politically relevant and influential. Its successful conduct was itself dependent on this perceived political influence. One such RLI research assistant, Jacques Chiwale, in an interview with Schumaker in 1992,

emphasized that their political involvement was what made the urban research possible at all. Their membership in the miners' union, in the Northern Rhodesian ANC, and later in UNIP - or their contacts with friends in these organizations - gave these assistants access to urban compounds that were increasingly coming under nationalist or union control. ${ }^{66}$

Such access, however, often depended on convincing political activists of the impact of their research. Schumaker argues: 'They promoted the idea that social research would help to improve living conditions and provide ammunition for debates with colonial officials, a strategy that they employed to get informants to cooperate with their work., ${ }^{67}$ Union or party leaders challenged RLI researchers to demonstrate the utility of their research and made access to field sites conditional on this. One such encounter was described to Clyde Mitchell by his research assistant $\mathrm{M}$. B. Lukhero:

63 Schumaker, Africanizing Anthropology, p. 35.

64 Hortense Powdermaker, Stranger and Friend: The Way of an Anthropologist (New York: W.W. Norton, 1966), p. 289; cited in Karen Tranberg Hansen, 'After Copper Town: The Past in the Present in Urban Zambia', Journal of Anthropological Research, 47, 4 (1991), pp. 441-56, p. 442.

65 Rubbers and Poncelet, 'Sociologie Coloniale au Congo Belge', p. 100.

66 Schumaker, Africanizing Anthropology, p. 215. ${ }^{67}$ Ibid., p. 214. 
We were asked to climb on top of the table one by one in order to be seen by people. The [Union Branch] Secretary introduced our work and told people it was of great importance and that our Department was not 'connected' with the government. One question was put to me by one man 'Do you belong to government' I said 'We have nothing to do with the Boma and we do not belong to them at all. We only ask for cooperation from every concerned organization'. 68

While Lukhero's description of this encounter suggests a certain pleasure in gaining access by claiming his research would advance the cause of the African urban community, it can equally be read as evidence that African mine communities and their leaders were not only aware of the political importance of applied research, but also that they sought to influence it in ways that would advance their own position and their characterisation of Copperbelt society. Indeed, 'The union management, in particular, expressed an interest in social research and at one point requested that Epstein conduct a study of its organization'. ${ }^{69}$ It can then be argued that African interlocutors - research assistants but also the wider elite of educated, senior political and intellectual leaders - were decisive in shaping the RLI portrayal of Northern Rhodesian Copperbelt society as adaptable, urbanised, materialistic and implicitly proto-nationalistic in its outlook.

Meanwhile, across the border in Katanga, a different set of African political elites had equally grasped the importance of social scientific research and sought links with its leading figures. Rubbers and Poncelet detail the connections between, for example, Balubakat leader Jason Sendwe and Arthur Doucy, who advised Sendwe during the crucial Round Table conference that paved the way to Congolese independence. René Clémens became an advisor to Moïse Tshombe, president of Conakat and of the Katangese secessionist state. ${ }^{70}$ Meanwhile the anthropologist Bruno Crine-Mavar, carrying out research in the Lunda capital Musumba, supplied, in Bustin's words, 'the Mwaant Yaav and his entourage with a good deal of the theoretical and scientific ammunition they needed to enhance the credibility of the imperial

68 M. B. Lukhero to J. Clyde Mitchell, Mitchell papers, quoted in Schumaker, Africanizing Anthropology, p. 216. 'Boma' refers to the local government office that symbolised colonial authority.

69 Mitchell papers, cited in Schumaker, p. 220.

70 Rubbers and Poncelet, 'Sociologie Coloniale au Congo Belge', p. 100. 
concept', ${ }^{71}$ that is, the notion that the Lunda polity should be understood as an 'empire' under the singular authority of its ruler, the Mwaant Yaav. The comparatively prominent role of ethnically oriented indigenous leaders in Katanga - relative to their Northern Rhodesian counterparts - may also help explain why CEPSI researchers were less convinced than their RLI counterparts about the degree to which the urban towns they studied had 'adapted' to modernity. Association with academic research was, in both contexts, much more than a badge of respectability: African elites understood, from their observation of and belated participation in late colonial policy-making, that apparently disinterested knowledge production was a vital resource in advancing and giving authority to contemporary political arguments and claims. Following national independence African leaders and states would seek to nationalise the production of knowledge about their societies for exactly this reason (Chapter 6).

\section{African Perspectives}

What then of the wider African Copperbelt community? It is tempting, when critiquing the perspective of Western colonial and social scientific observers, to contrast its ahistoricism and its use of modernist artificial binaries to a 'real' African perspective that will provide an accurate characterisation of the underlying realities of Copperbelt society, if only we can ask the right questions or develop the correct research tools. The reality is, as suggested above, that African understanding of and assertions about urbanisation and social change shared many of the notions of Western observers regarding, among other things, differences between rural and urban societies, counterposed notions of tradition and modernity, and the seismic impact of European colonisation and modernisation on African societies. This does not mean that these were hegemonic ideas that had been passively transmitted from European knowledge production to Africans as a 'derivative discourse'. ${ }^{72}$ Diverse sections of African societies had always had

71 Edouard Bustin, Lunda under Belgian Rule (Cambridge, MA: Harvard University Press, 1975), p. 193, where his name is given as Fernand Crine; Bruno Crine-Mavar, 'Histoire Traditionnelle du Shaba', Cultures au Zaïre et en Afrique, 1 (1973), pp. 17-26.

72 Partha Chatterjee, Nationalist Thought and the Colonial World: A Derivative Discourse (Minneapolis: University of Minnesota Press, 1993 [1986]). 
their own ideas about historical and social change and were as invested as Europeans in deploying and articulating knowledge for social, cultural and political purposes, the relationship of which to 'reality' was always an indirect one in need of critical assessment.

Accessing those ideas from the historical present is, however, fraught with difficulties. The number of our interviewees with their own memories of migration during the late colonial period is inevitably small, and interviews with older residents are themselves infused with the experiences of a lifetime during which dominant ideas of Copperbelt society have circulated and interacted with personal change, which has necessarily shaped the perceived relationship between past and present. It is nonetheless clear that African migrants always had their own notions about what it meant to move to the Copperbelt towns, either to pursue temporary economic opportunities or to make a new life in the city. What can be observed is that everyday African analysts of Copperbelt life observed distinctions between the 'rural' and the 'urban', but explained their meaning and the social consequences of those meanings in diverse ways. Very few African migrants took a conscious decision to migrate permanently from village to town: many more explored the opportunities of urban education or employment in an open-ended way and many of these returned periodically to the village for its lower costs, family support, easier availability of food and specifically for marriage (see also Chapter 5). ${ }^{73}$ Ilunga wa Kumwanza came from his village near Luena to Lubumbashi for schooling in the 1950s and split his time between the city, where he studied to be a mechanic, and transporting goods back to the village that he visited for fishing and holidays as he saved for his education: fighting during the Katangese secession forced him back to the village where he helped on his father's farm. ${ }^{74}$

New arrivals were then concerned with the immediate challenges of securing a place to stay and a way to earn a living and, in the medium term, with advancing their own economic and social standing, improving their housing and educating their children. These were activities that, as this book will show, could be pursued, depending on one's abilities, opportunities and constraints, via formal employment or by

73 Interviews: François Batabata Nsenga, Likasi, 7 June 2018; Fridah Mwale, Mufulira, 6 July 2018.

74 Ilunga wa Kumwanza, interview, Likasi, 8 June 2018. 
trading and farming in town, peri-urban area or village, and for families a combination of these activities and places over time. African migrants nonetheless appreciated that town life could be difficult to understand for new arrivals: their initial hosts, often older relatives, uncles or sisters for example, would advise them on such things as seeking employment or moving around town without a situpa, or navigating the systems of surveillance in UMHK's mining camps, patrolled by mine police. ${ }^{75}$ Washeni Mweni, for example, came to Mufulira in the 1950s looking for employment, following his sister who was married to a mineworker and staying in their mine house (breaking company rules in doing so). He went looking for employment and found gardening work at the home of a local white resident. ${ }^{76}$

Living in town, whether temporarily or permanently, certainly required knowledge of how its explicit rules, implicit practices and social and cultural norms compared with those of the village. A kind of everyday socialisation was indeed practised and associational structures, both informal and more formal and often ethnic in character, sprang up to support new arrivals from specific rural areas or societies. Patson Katwisi's evocative account of his arrival in Chingola in 1959 is a case in point:

for me and other people of my age ... we only used to hear of certain things such as that there was a train but we had no idea what it was like. We could also only imagine what it looked like through the descriptions of the people who had seen it and [who] then came to the village. From them, we also learnt about cars and aeroplanes but never saw them. When we got on the bus, we never used to sleep for twelve hours ... because we wanted to see everything and ask questions concerning what we saw. When we arrived in Chingola, it being a mining town had the railway quite close to the mining area as well as other buildings and structures which to me looked foreign and I am sure to many other people. When my brother came to pick me up ... I could speak to him using my own language and he knew I never knew anything so he took his time to explain things to me. ${ }^{77}$

A very particular insight into those rules and practices, and how they circulated among new migrants, is provided in Namusiya at the Mines,

75 Interviews: Maxwell Mukupa, Mufulira, 11 July 2018; Séraphin Musoka, Likasi, 6 June 2018.

76 Washeni Mweni, interview, Mufulira, 13 July 2018.

77 Patson Katwisi, interview, Mufulira, 3 July 2018. 
the first novel to be published in colonial Zambia. Written in Ila by Enoch Kaavu in 1944 and translated into English for publication in 1949, the book tells what might be considered the quintessential Copperbelt story: the migration from village to mine town by its titular protagonist. ${ }^{78}$ Namusiya experiences the new sights and sounds, conditions and rules, opportunities and hazards of life and work in the mines, as well as other aspects of urban life central to academic and political understanding of its inherent modernist novelty: rail travel, pass documents, tribal representatives, work discipline and the cash economy, township organisation and social life, the temptations of the beer hall and prostitution, and the salvation of Christianity and modern marriage. As Macola eloquently argues, ${ }^{79}$ Namusiya represents a pioneering articulation of Ferguson's 'localist' cultural style and is emblematic of much early Zambian fiction in its rhapsodic celebration of rural values and rejection of the initially compelling but ultimately hollow material existence of town life, as conveyed in this quote: 'As a result of his long stay in the mines Namusiya became largely detribalised. He forgot many of the customs of his people and learned to follow European ways of life'. ${ }^{80}$

It is equally noteworthy that Namusiya is provided with his knowledge of both formal patterns of working life and the unwritten rules of social and sexual behaviour by a series of mainly African patrons and interlocutors, rather than via the formal structures established by mine companies to socialise their workers. African ideas and claims about this period of historical change circulated unevenly and unequally though Copperbelt society and spaces, informed by and informing (at one or more steps removed) the ideas and writings of European producers of knowledge about those societies. Popular song, in particular, provided an important avenue for the expression of ideas about migrant life (see Chapter 7). This does not of course mean that Africans uncritically replicated those ideas, any more than the other way around: they had their own diverse perspectives, ideological and cultural notions, and positionality, which shaped the ways in which they understood and articulated their understanding of African society. Namusiya, like the works of social scientists, was published in a context, not a vacuum: it

78 Enoch Kaavu, Namusiya at the Mines (London: Longman, 1949).

79 Giacomo Macola, 'Imagining Village Life in Zambian Fiction', Cambridge Anthropology 25, 1 (2005), pp. 1-10.

80 Kaavu, Namusiya at the Mines, p. 52. 
was, for example, co-translated into English by Robinson Nabulyato, an 'advanced African' who was in the 1950s one of the first African members of Northern Rhodesia's Legislative Council and who was later speaker of the Zambian national assembly for two decades. It was not, however, recalled by interviewees and no claim is made here that it itself influenced popular understandings of migration and urban integration among new urban settlers. It then does not provide an 'authentic' view of African urban migratory experience, but rather draws attention to the ways in which the production of knowledge that asserted particular views about Copperbelt life was a central part of its social history from the start.

\section{Conclusion}

This chapter, in providing a necessarily truncated history of ideational constructions of Copperbelt society in the early-to-mid twentieth century, has emphasised the extent to which most European observers saw these urban societies as inherently novel: capitalist, Westernised, modern and therefore 'unAfrican'. Policy makers, missionaries and European intellectuals concerned themselves with the negative consequences of rural-to-urban migration for existing African societies and for the morality and behaviour of migrants themselves. African unrest and protest reinforced the need for enhanced understanding of urban African communities and prompted an unrivalled project of social scientific knowledge production in the late colonial Copperbelt. Researchers, while disagreeing about the capacity of Africans to adapt to their new urban condition and about the form and degree of European assistance required to do so, generally agreed that Copperbelt towns represented a qualitatively different social order to migrants' villages of origin, requiring in turn new forms of association, behaviour and outlook among their new residents.

The chapter, while recognising Schumaker's insights regarding the extent to which RLI research was shaped by African research assistants, goes further in arguing that the African intellectual and societal context played a central role in shaping the findings of both RLI and CEPSI researchers. This took different forms in the two Copperbelt regions, with RLI research asserting earlier and more strongly the adaptability of African society and culture to the inherently new realities of urban life, while CEPSI research continued to emphasise the 
need for ongoing official intervention to ensure that Africans could live successful and ordered lives in town. Meanwhile, African urbanites as a whole compared and reflected on the similarities and differences between village and town life, but recognised more than most researchers that these were connected societal contexts in which change was the historical norm rather than an exception. These contrasting ideas about the nature of the new urban African order would continue to shape both the social and ideational history of the Copperbelt over the coming decades. 


\section{Boom Time - Revisiting Capital and Labour in the Copperbelt}

\section{Introduction}

The post-World War Two heyday of social scientific research on the Central African Copperbelt was shaped by a sustained period of global economic growth, the 'long boom'. This enabled a steady growth in copper production and company profits and, to a lesser extent, mine employment, living standards and the wider manifestations of urbanisation identified by policy-makers and academics. ${ }^{1}$ Politically, the long boom both resulted from and enabled a period of unprecedented co-operation between global capital, nation-states and organised labour, which sought to prevent or manage capitalism's propensity for economic crises, ensure effective governmental support for economic 'development' and more fairly distribute the benefits of growth between companies, workers and wider society. Variations of this 'tripartite' or Keynesian model of economic co-operation, with its origins in World War Two but applied in overcoming post-war austerity and combating the ills of poverty and backwardness, were implemented across the world until the mid-1970s, a 'win-win' policy wherein wages, profits and tax revenue could supposedly all rise simultaneously.

In late colonial and post-colonial sub-Saharan Africa, such cooperation took the form of development planning, a set of policies rooted in the assumed desirability of following a Western path, through stages that 'developing' economies could take to achieve 'take-off' towards advanced industrialisation. This influential approach disregarded the fact that no Western economy had developed in this way and that the distinct inter-linked imperial histories of Western and

1 For the history of the global 'long boom' and the subsequent long downturn, see Robert Brenner, The Economics of Global Turbulence (London: Verso, 2006). 
African economies meant that they started from very different places. ${ }^{2}$ Contemporaneous analysts of the Copperbelt nonetheless extrapolated from the region's soaring economic growth and output to suggest that it was developing a Western-style industrial economy and society. Today, after nearly three decades of economic stagnation and decline, the Copperbelt's long boom is recalled nostalgically as a golden age of growth, development and shaped prosperity. As this chapter will show, both the optimistic vision and the fond memory are significantly at odds with the region's actual, highly uneven socio-economic development during the 'long boom', a period in which copper mining failed to stimulate a self-sustaining industrial economy comparable with those of the West.

There are many reasons why the Copperbelt's own long boom did not provide the basis for fully fledged regional or national industrialisation. The failure of Zambia's mining industry to spark sustained national development has been the subject of sustained analysis: while some claim that state interference and political manipulation undermined the industry's competitiveness, others argue that a coherent industrial policy could have overcome mineral dependency. ${ }^{3}$ While these explanations help us understand the failures of postindependence economic development, both downplay the structural difficulties of transforming a mining industry created in the interests of Western-controlled global markets, in which the colonial extraction of raw or semi-processed minerals was designed to serve already established metropolitan industrial economies. What matters for this study is that, even during the period of the Copperbelt's now fondly remembered golden age, the inability of copper and cobalt mining to provide the basis for large-scale formal employment and self-sustaining

2 Cooper and Packard (eds.), International Development and the Social Sciences; Michael Jennings, 'Building Better People: Modernity and Utopia in Late Colonial Tanganyika', Journal of Eastern African Studies 3, 1 (2009), pp. 94-111.

3 For the former, see Christopher S. Adam and Antony M. Simpasa, 'The Economics of the Copper Price Boom in Zambia', in Fraser and Larmer, Zambia, Mining and Neo-Liberalism, pp. 59-90. See also Christopher Adam, Paul Collier and Michael Gondwe (eds.), Zambia: Building Prosperity from Resource Wealth (Oxford: Oxford University Press, 2014). For the latter, see Gabriel Pollen, 'From total factor productivity to structural change: interrogating economic growth and structural transformation from a developing country perspective with reference to Zambia', unpublished $\mathrm{PhD}$ thesis, School of Oriental and African Studies (2018). 
economic development was already evident to many state and company observers.

This chapter provides a brief history of the Copperbelt's supposed 'long boom', emphasising the precarity of its actual development and showing that contemporary policy-makers stressed the inability of mining to stimulate the wider economy. ${ }^{4}$ The post-World War Two mining industry did not itself create substantial new jobs and, during the downturn of the late 1950s, growing unemployment was a major concern for governments and mine companies alike. The need to increase productivity was explained in characteristically modernist terms, with workers blamed for their insufficiently evolved understanding of the work regime. While UMHK sought to improve its workforce by the application of 'scientific' knowledge, it was only in the late 1950s that Northern Rhodesia's companies systematically invested in educating and training their African workforce. Following political independence, Zambia and Congo both saw their mining industries as vehicles for national development, but the constraints of a (post-) colonially connected mining industry undermined their governments' attempts to do so.

This chapter also explores the profoundly uneven nature of urban employment, showing that the high living standards stereotypically attributed to Copperbelt communities were in fact the preserve of an unrepresentative group of skilled African mineworkers who were, as we have seen, the disproportionate focus of policy and academic attention. As interviewees reveal, most mineworkers, and the overwhelming majority of Copperbelt residents, scraped a precarious living through low-paid work and informal trading. The emphasis on a Westernised model of urban formal growth and employment concealed the region's dependence on extraction - from the land certainly, but also from the wider 'urban' economy that was beyond the immediate purview of the mine, but dependent on it. The booming Copperbelt economy, often represented and recalled as a shared story of success, rested, in fact, on a highly stratified system of profound inequality and precarity. It is today more clearly understood that in capitalist economies in general and 'peripheral' economies in particular, formal employment was

4 This chapter draws on arguments and material first developed in my article 'Permanent Precarity: Capital and Labour in the Central African Copperbelt', published in Labor History, 58, 2 (2017), pp. 170-84. I am grateful to the journal's editors for permitting the reproduction of material here. 
never the norm and that various forms of 'informal' or 'precarious' labour were and remain as central to the functioning of these economies as 'advanced' wage labour. ${ }^{5}$ In historicising the representation of capital and labour in late colonial and early post-colonial Africa, it is clear that a range of actors - states, multi-national companies, trade unions, the International Labour Organisation (ILO) and social scientific analysts - saw wage labour as a key signifier of capitalist modernisation, yet refused to recognise 'unemployed' Africans (many of whom were, in fact, 'informally' employed) as legitimate urban residents.

\section{A Late Colonial Economic Boom: Growth Without Development}

There is no doubt that the Copperbelt experienced profound economic expansion and demographic change in the post-World War Two period. Fuelled by global economic expansion, UMHK copper production, for example, doubled, from 150,840 tonnes in 1947 and 247,000 tonnes in 1956 to 302,300 tonnes in $1960 .{ }^{6}$ Cobalt production also rose considerably. ${ }^{7}$ Mineral production made a huge contribution to the soaring value of Congolese exports, which rose from BFr 10 billion in 1948 to BFr 27 billion in $1956 .{ }^{8}$ In Northern Rhodesia, where 268,551 tonnes of copper were produced in 1941, production rose to 700,000 tonnes by independence in 1964. The African workforce of Northern Rhodesia's mines numbered 26,023 in 1940, rising to 37,237 by 1954 and 38,465 by $1961 .^{9}$ The workforce of UMHK was more stable: having employed 16,300 workers as early as 1930 , the company's training polices enabled it to achieve greater output with a similar number of workers - in 1952 it employed 19,008 African

5 Nick Bernards, 'Placing African Labour in Global Capitalism: The Politics of Irregular Work', Review of African Political Economy, 46, 160 (2019), pp. 294-303. For an interesting recent attempt to classify informal labour in these circumstances, see Shahram Azhar and Danish Khan, 'Rethinking Informal Labor in Peripheral Capitalism: The Dynamics of Surplus, Market, and Spatiality', Labor History, 61, 3-4 (2020), pp. 320-34.

6 Dibwe dia Mwembu, Bana Shaba, p. 15.

7 Dibwe dia Mwembu, Histoire des Conditions de Vie, p. 48.

8 Dibwe dia Mwembu, Histoire des Conditions de Vie, pp. 55-6.

9 ZCCM-IH Archives (hereafter ZCCM-IH), 16.3.7A, 'African Labour Recruiting and Unemployment, Labour Exchanges, Oct 1960-Dec 1980', Central African Federation Study Group on Unemployment, 1961, p. 4. 
workers, a figure that rose to 23,312 in $1958 .^{10}$ The wider population grew much quicker: Northern Rhodesia's urban Copperbelt population tripled between 1946 and 1956, with some towns such as Bancroft (Chililabombwe) created from scratch. ${ }^{11}$

This rapid growth fuelled the representation of the Copperbelt as a region experiencing the transformation of African bush into Westernstyle towns, understood as an intensified and accelerated version of the Industrial Revolution. In 1941 RLI researcher Godfrey Wilson suggested that the growth of Northern Rhodesian mine towns such as Broken Hill (Kabwe) heralded a more balanced global economy

within the next generation ... in which ... more emphasis will inevitably be laid on secondary industry, on agriculture and on consumption; wages will inevitably rise all round - in Africa as elsewhere - industrial workers will, as often as not, be skilled supervisors of machinery; the world will need all the skill it can get; ... and the rivalry between skilled European and about-to-be skilled African will be at an end. ${ }^{12}$

Mine company publicity, for example the propaganda films produced by UMHK, conveyed the message that the Copperbelt was adopting Western-style modern industrial infrastructure, housing and societal norms and contrasted this to images of African rural poverty. ${ }^{13}$ The disproportionate attention given to 'advanced' workers by social scientists (Chapter 1) reinforced the idea that Copperbelt employees were rapidly achieving the employment and consumption patterns of their Western counterparts.

There were, however, many reasons why economic and demographic growth did not easily translate into Western-style industrialisation and development. The Copperbelt had been conceptualised from the start as a colonised region that would supply raw materials to the West's industrial heartlands, not itself become a region of industrial growth. While the post-World War Two period did see expansion in the local processing of copper ore, with refineries and smelters adding value by enabling the production of finished copper, this continued to be

10 UMHKA, 658, UMHK MOI Annual Report 1958, p. 64.

11 National Archives of Zambia (hereafter NAZ), WP 1/2/64, Special Commissioner for Western Province, Reports on Copperbelt, 1959-60, draft report on 'Municipalities and Towns', p. 1.

12 Wilson, Economics of Detribalization, pp. 29-30.

13 UMHK film, 'En Cinquante Ans' (1956): www.youtube.com/watch?v=9z4Gty CvlCg (accessed 7 May 2020). 
exported for use in products manufactured elsewhere. While conceptualisations of the Copperbelt as 'remote' are problematic in their reproduction of a Western-centred perspective, the region was indeed remote from its key markets, linked to them by a transport network controlled by colonial investors and states. As Parpart notes: '[m]ining equipment was usually purchased abroad; the skilled European labor force spent much of their large salaries on expensive imported goods; and transportation difficulties and poor land limited economic opportunities outside the line of rail'. ${ }^{14}$ The region's economy was a machine designed to transfer wealth from colony to metropole. Revenue flowed to mine companies based in Johannesburg, Brussels, London and later Salisbury, which mainly paid tax and royalties in those places. In 1938, 60 per cent of the tax levy on the Northern Rhodesian mining industry went to either the UK government or the British South Africa Company. ${ }^{15}$ Bézy noted that, despite Congo's growth, capital $-£ 60 \mathrm{~m}$ between 1948 and 1951 - was continually exported as dividend payments to the large companies (UMHK uppermost) that dominated the economy. ${ }^{16}$ The low taxes paid by mine companies meant that much of the increase in local developmental spending was financed by borrowing: Congolese government debt quintupled during the 1950s. ${ }^{17}$

After World War Two, consistent with the developmental turn, efforts were made to strengthen urban infrastructure and - in Haut-Katanga in particular - to stimulate secondary industry. By the mid-1950s Elisabethville was home to a wide range of manufacturing industries: cement, brickmaking, metal and carpentry, textiles, explosives and tobacco, as well as food and beverages. While officials were characteristically positive about these developments, they recognised that these goods were consumed by the mining industry, its workers and the wider community that depended on them. ${ }^{18}$ Late colonial policy, while seeking to expand urban economic and employment opportunities, equally wished to prevent accelerated migration from rural areas to the

14 Parpart, Labour and Capital, p. 25.

15 Official figures, cited in Heisler, 'Creation of a Stabilized Urban Society', p. 137.

16 Fernand Bézy, 'Belgian Congo 1951-52', Civilisations, 3, 2 (1953), pp. 293-7.

17 Jean-Philippe Peemans, 'The Social and Economic Development of Zaire Since Independence: An Historical Outline', African Affairs, 74, 295 (1975), pp. 148-79, p. 153.

18 Belgium Archives Africaines (hereafter BAA), 34 (6), Katanga Provincial Council (hereafter KPC) papers, Situation Politique et Administrative, March 1955, p. 11. 
towns. Across the Copperbelt there was continuing anxiety that, as missionaries and colonial officials had argued during the interwar period, the loss of productive (male) labour to urban areas would undermine rural societies. As discussed earlier, a key question for CEPSI researchers was whether African society could withstand the dislocating effects of rapid urbanisation. Doucy and Feldheim illustrated the dilemma of ensuring economic development in this context:

So on the one hand we are faced with an exodus of the indigenes to noncustomary environments, with all the dangers ... all the difficulties that this exodus contains in itself.... On the other hand, it is absolutely necessary to provide the labour to European companies because it is on this last resort that the prosperity of the colony depends on. ${ }^{19}$

There was, however, a powerful belief, in Belgian Congo at least, that development planning could overcome these problems. The pioneering Plan Décennal, adopted in 1950, set ambitious goals for higher African living standards and industrial output. By the early 1950s demand for workers in the capital Léopoldville and elsewhere soared, so that by 1952 more than one million workers were employed in Congo's towns. ${ }^{20}$ The number of workers in Katanga rose from 108,111 in 1945 to 144,184 in 1950 and 178,664 in 1954, with virtually all this increase taking place outside the mining industry. The population of the non-mine areas of Katanga's towns was, however, rising faster, from 242,537 in 1945 to 368,535 in 1950 and 509,327 in 1954 - so that a much larger urban population was dependent on the relatively modest growth in waged employment. ${ }^{21}$

Efforts were made to accelerate the growth of an indigenous middleclass Christian elite that, again following Western ideals, would stabilise urban society and act as a buffer against the influence of radical politics and religious extremism. ${ }^{22}$ In his annual report to the Provincial Council

19 Doucy and Feldheim, Problèmes du Travail, p. 12.

20 Government of Belgian Congo, Plan Décennal du Congo Belge (Brussels: Government of Belgian Congo, 1949); Leigh Gardner, 'The Fiscal History of the Belgian Congo in Comparative Perspective', in Frans Buelens and

Ewout Frankema (eds.), Colonial Exploitation and Economic Development: The Belgian Congo and the Netherlands Indies Compared (London: Routledge, 2013), pp. 130-52.

21 BAA, 34(6), KPC, Situation Politique et Administrative, March 1955.

22 Michael O. West, The Rise of an African Middle Class: Colonial Zimbabwe, 1898-1965 (Bloomington: Indiana University Press, 2002); Phyllis Martin, Leisure and Society in Colonial Brazzaville (New York: Cambridge University 
meeting in 1955, outgoing Katangese governor René Wauthion declared: 'A major factor in the stabilisation of these centres [CECs] lies in the presence of houseowners, of shops, restaurants, workshops etc. which constitute the embryo of a middle class that is, by definition, the enemy of adventure and disorder. ${ }^{23}$ As so often however, the idealised vision of African society clashed with the practical difficulty of securing the right type of advanced African. Of the 5,656 enterprises operating in Katanga in 1954, 2,764 - roughly half - were run by Congolese. ${ }^{24}$ The other half were run by European settlers, the number of whom tripled in post-World War Two Katanga, reaching 35,507 in $1958 .{ }^{25}$ The authorities were convinced that African-run businesses would struggle because of 'the general rudimentary training of many founders of indigenous crafts or industrial enterprises in our large CECs'. ${ }^{26}$ As noted in Chapter 1, a survey of indigenous business published by CEPSI in 1955 sought to analyse not African entrepreneurs' own experiences but instead their contact with European traders, who, it was assumed, they were imitating, for the following reasons:

The modern monetary economy into which we have plunged the Black without the transition that was experienced by generations of Europeans has provoked, among those living in the cities, a rupture with their clan links and a distortion of their customary rules.... one can consider trade a new technique for the Bantu, a technique for which they do not have a reference system.... The presence of commerce for the indigenes by the Europeans ... has favoured contacts between Europeans and Africans. The latter are very likely inspired by their methods. The survey will show how well these methods have been adopted and how they have been assimilated. ${ }^{27}$

By 1957, African members of the Provincial Council were requesting that European traders were banned from retail in the CECs, so as to open up opportunities for Africans. However, few African entrepreneurs had

Press, 1995); and Laura Fair, Pastimes and Politics: Culture, Community and Identity in Post-Abolition Zanzibar, 1890-1945 (Oxford: James Currey, 2001). BAA, 34(6), KPC, Situation Politique et Administrative, March 1955, p. 1.

Dibwe dia Mwembu, Histoire des Conditions de Vie, p. 48.

BAA, 35(1), KPC, Allocution D’Ouverture, 7 March 1956, p. 10.

27 Anon, 'Le Commerce Indigène au CEC d'Elisabethville', CEPSI Bulletin, 28 (1955), pp. xli-lxxv. 
access to sufficient capital or credit to run businesses such as petrol stations. $^{28}$

Indigenous commercial agriculture was a major focus of post-World War Two development planning across colonial Africa, consistent with 'take-off' models in which surplus generated by agriculture was then invested in nascent industry. ${ }^{29}$ As early as 1932, Katangese authorities had identified peri-urban areas near Elisabethville in which to encourage indigenous commercial agriculture. ${ }^{30}$ After 1945 , the expanded Institut National pour L'Étude Agronomique du Congo Belge (INÉAC) promoted scientific agriculture, with European experts charged with raising the living standards and knowledge of indigenous farmers. The Institut established a peri-urban development project in Kipopo that included a fishery. It also ran an experimental station at nearby Keyberg, seeking to overcome both Katanga's poor soil and its supposed degradation by indigenous farming methods:

The ancestral modes of agriculture were essentially and only needed to meet the strictly limited needs of subsistence. ... These conditions led the Bantu people to cultivate the land without worrying about the state in which they left it. As a result, they quickly and irreparably destroyed the productive potential of their lands. ${ }^{31}$

The multiple aims of these initiatives were, according to a 1956 CEPSI journal article by Governor Wauthion, the promotion of an indigenous middle class of commercial farmers, traders and artisans; improving the fresh food supply to Katanga's towns; and reducing the urban population by attracting city residents to these communities. Wauthion criticised previous efforts to promote commercial African agriculture, which were 'never strong enough to disengage the indigenous population from its primitive methods of work, so that they remained practically frozen in a subsistence economy'. ${ }^{32}$ The developmental projects of CEPSI in peri-urban areas near Elisabethville and Jadotville also faced familiar problems of low population density and poor soils, but also the

28 BAA, 35(4), KPC, Deuxième Séance, 21 March 1957.

29 Rostow, The Stages of Economic Growth.

30 BAA, 37(1), KPC, Session Extraordinaire, 1959, Allocution D’Ouverture du Commissaire Provincial M. Thilmany.

31 Institut National pour L'Étude Agronomique du Congo Belge (hereafter INÉAC), NILCO, 10045, report on soil conservation and fertiliser, n.d. but late 1950s.

32 Wauthion, 'Pour le Développement d'une Économie Rurale'. 
continued, if diminished, authority of chiefs over land use and allocation, which supposedly prevented its effective commercial utilisation. ${ }^{33}$ By 1955, CEPSI was co-ordinating government-funded programmes worth BFr35m in Katangese peri-urban communities. ${ }^{34}$ These efforts were complemented by UMHK's funding of health centres to make these areas desirable for retired workers and their families to relocate at the end of their working lives 'and to avoid in this way an increasing growth of the urban centres'. ${ }^{35}$ When such efforts failed to stem the tide of migration to town or to increase agricultural productivity, that failure could always be blamed on Congolese farmers' alleged lack of an enterprising mentality.

At least Belgian Congo had a plan for economic development. Northern Rhodesia's rural areas had historically been labour-sending areas: first to Katanga and then to its own mines, as well as to South Africa and Southern Rhodesia. Agricultural development in the Copperbelt, with its poor soil and low rural population, was a particularly low priority. ${ }^{36}$ Northern Rhodesia's integration into the Central African Federation in 1953 handed considerable political power to Southern Rhodesia's white commercial farmers, to whom state farming subsidies increasingly flowed and whose economic position rested on the marginalisation of their African counterparts. Retail opportunities for Africans were similarly limited by European domination and the predisposition of urban Africans for consumer goods:

There is a growing tendency for Africans to buy high priced goods, and it is the large European store rather than the small African trader who benefits from the prosperity of the Urban community. Few African traders seem to have any real business acumen. The large numbers of hawkers and pedlars, most of whom live in the African township, can no longer make a living because most Local Authorities are insisting that trading is done in recognised shops and markets. ${ }^{37}$

While official concern was expressed about rural-urban migration and the general failure of non-mining economic activities, no-one in power

33 Ibid., p. 9.

34 BAA, 35(1), KPC, Allocution d'Ouverture, 7 March 1956, p. 11.

35 UMHKA, 632, Annual Report 1956, p. 29; see also UMHKA, 631, Annual Report 1955.

36 ZCCM-IH, Copperbelt Development Plan, 1965, p. 1.29.

37 NAZ, WP 1/2/43, African Affairs Annual Report, Luanshya, 1957-60, Western Province African Affairs Annual Report, 1959, p. 10. 
seriously thought of Northern Rhodesia as a proto-national economy, or intervened to alleviate the territory's overwhelming economic dependency on Copperbelt mining.

\section{The Changing Nature of Mine Labour: Creating the Ideal Worker}

One of the major advantages of Copperbelt mines, relative to its global competitors, had always been cheap African labour, enabled by a colonial regime and the labour recruitment practices it facilitated. Mine companies across southern Africa established and/or employed recruitment agencies with preferential access to rural communities that needed to earn cash wages to pay colonial taxes. Labour initially took migrant form because unskilled men could be easily replaced and because African urban settlement was politically undesirable. Single African male mineworkers housed in temporary work camps and employed on short-term contracts were paid wages far below subsistence level, with housing and food ('rations') provided.

In Haut-Katanga, where industrial mining started in the 1910s, this approach changed at an early stage. From 1919, when the defeat of a European strike led to a shortage of skilled labour, UMHK gradually trained Africans to replace them. ${ }^{38}$ Once Africans were trained, it became useful to retain them for longer periods, to provide them with housing and services and to allow them to resettle their families - or find new ones - in town. The company's stabilisation policies meant the costs of employing African labour - while still lower than European workers - rose considerably. From the late 1930s, UMHK sought to reduce the number of African employees, seeking ongoing profitability via higher productivity. These efforts were accelerated by post-World War Two Belgian intervention: the governmental Commission Provincial pour le Travail et le Progrès des Indigènes (TEPSI) regulated not only salaries but also the provision of food and housing for workers and their families.

In sharp contrast, Northern Rhodesian mineworkers retained their essentially migrant status until the mid-to-late 1940s: although many thousands were skilled and experienced workers who moved from one

38 Higginson, A Working-Class in the Making; Perrings, Black Mineworkers in Central Africa. 
short-term contract to another in a circulatory migration pattern, their skills went unrewarded and they were legally prevented from permanent settlement. This changed with the advent of stabilisation, as Heisler notes: 'On the Copperbelt between 1948 and 1951 the number of African miners who lived with their wives in the towns owned by the mining companies increased by one half. ${ }^{39}$ Northern Rhodesian mine companies took longer to come around to the idea of a stabilised and skilful African labour force, and did so arguably only because metropolitan political pressure forced them to do so and because mineworkers secured better salaries and conditions by industrial combination and action (see Chapter 4).

In both cases, however, the cost of employing an increasingly skilled African labour force, living permanently in Copperbelt towns with their immediate families, had risen substantially by the early 1950s. It was then necessary to ensure that labour force was as productive as possible, something that companies sought to achieve by the production and application of knowledge. In Haut-Katanga, the UMHK's investment in copper processing and workforce training meant that, between 1942 and 1958, productivity grew four-fold while the number of mineworkers remained stable. ${ }^{40}$ The company justified its productivity demands by the privileged treatment it supposedly afforded its workers, as its 1952 annual report made clear:

the local labour force is expensive; every improvement in the provision of necessities for natives should therefore in the future be directly linked to an improvement in yield. In this regard, the workforce of our company finds itself clearly privileged, because by virtue of our traditional policy of improving the standard of living of our workers, we put at their disposal and that of their children, a whole system of education which will enable them to progressively access more and more qualified trades. ${ }^{41}$

The growing efficiency of UMHK was not mirrored in the wider economic development of Katanga and certainly not Congo, as the Provincial Council warned in 1957: 'The productivity of our industries needs to be improved. It is necessary that the secondary industries work

39 Heisler, 'Creation of a Stabilized Urban Society', p. 143.

40 Jean-Luc Vellut, 'Mining in the Belgian Congo', in David Birmingham and Phyllis M. Martin (eds.), History of Central Africa Vol. II (Longman, London, 1983), pp. 126-62, p. 139.

41 UMHKA, 265, UMHK Services d'Afrique, Report on Activities, 1952, p. 15. 
at full capacity and supply more and more exclusively the local market, at competitive prices'. ${ }^{42}$

In Northern Rhodesia, the sudden rise in African labour costs necessitated drastic action to improve productivity. In 1956 a report for AAC's Rhokana mine claimed that, consistent with UMHK's achievement, major increases in productivity could halve African mine employment. Its author, W. T. de Villiers, argued:

In the early days and even up to 1950 the wages of the African worker were very low. The African worker was and still is to a major extent regarded as 'black electricity', there for abundant use ... The productivity of African labour as used in the Mining Industry is extremely low.... the African still works at his own tempo ... Many supervisors of Africans still have the conception that African labour is cheap, inefficient and is only to be used on simple operations. ${ }^{43}$

De Villiers found that, while production by the mine's $c .10,000$ African workers had increased from 82,877 tons in 1944/45 to 92,033 tons in 1955/56, the cost per individual African shift worked had risen from $£ 25 s$ in 1945 to more than $£ 15$ in 1956 . If rising costs were not offset by increased productivity, current profits of $£ 84.2$ per ton would fall to $£ 27$ per ton by $1960 / 61$. The average length of service of each worker, which had risen from 3.42 years in 1954 to 4.48 years in 1956, needed to be significantly extended (by 1956, 39.6 per cent of UMHK workers had already worked for twelve years or more). ${ }^{44}$ De Villiers recommended the recruitment of more married workers to encourage stabilisation and incentivise long service, while 'higher standard' European personnel would need to make better use of and have better relations with African workers.

For this to be achieved, however, the divorcing of African workers from their rural societies needed to be accelerated. Although it had until recently been company policy to resist urban stabilisation, De

42 BAA, 35(7), KPC, Deuxième Session, Séance Pleniere et Vœux, 2 September 1957, p. 4.

43 ZCCM-IH, 3.8.1C, Utilisation of African Labour Report 1957, W. T. de Villiers, 'The Utilisation of African Labour: Cost Trends, Policy and Programme to Meet the Situation', 6 December 1956, pp. 4-11.

44 Ngandu Mutombo, 'Politiques de rémunération, de cotation et de classification des emplois comme facteurs de formation d'une catégorie sociale. Le cas des travailleurs de L'Union Minière du Haut-Katanga, 1947-1967', unpublished $\mathrm{PhD}$ thesis, University of Laval (1996), p. 58. 
Villiers blamed low productivity on an African mentality that remained wedded to 'rural' values and the southern African stereotype of the 'target' worker:

The African, therefore, can and does, follow his traditional way of life in the rural areas.... The knowledge that they can never be destitute while they have the security of their land is partly responsible for the attitude of a high proportion of Africans towards the question of constant employment. They do not work for the economic reasons governing the European. They are generally thriftless and work to earn a target figure to satisfy some present need - the purchase of a bicycle, or sewing machine etc., or for payment of a debt or bride-price. ${ }^{45}$

Achieving improved 'productivity' thus required not only technical changes but also a new mindset, enabling 'the gradual evolution of the individual African's productivity and approach to industrial work. ... a system under which a higher standard of living and progression can be earned ... This would necessitate changing not only employment practices but also the outlook of the African to industrial work'. This would, however, not be easy:

Imagine the dilemma of the African people when they were suddenly catapulted into a western civilisation based on quite opposite assumptions to their own society ... in which the social and economic position of an individual is determined by his earning power ... If this concept is not brought home to the African, years of recurring demands ... and consequent industrial unrest will follow. ${ }^{46}$

De Villiers was, however, pessimistic that such radical improvements could be achieved without increasing wages and conditions 'due to the political and union set-up'. Certainly, by 1964, Rhokana's African mine workforce still numbered 9,413, though its average length of

ZCCM-IH, 3.8.1C, Utilisation of African Labour Report 1957, W. T. de Villiers, 'The Utilisation of African Labour: Cost Trends, Policy and Programme to Meet the Situation', 6 December 1956, p. 29. The notion of a 'target worker' was a well-established idea in South Africa, which justified the low wages paid to migrant workers by asserting that they worked only to acquire specific goods, so paying them more would only enable them to meet their 'target' earnings in a shorter period: see Desmond Hobart Houghton, The South African Worker (Oxford: Oxford University Press, 1964), pp. 151-2. Ibid., p. 37. 
service had increased to seven years. ${ }^{47}$ By 1959 , it was also acknowledged that rising productivity would not be matched by increased investment, since global demand for copper was stabilising and more competitive mines elsewhere would meet limited additional demand:

Very much less capital will need to be spent between now and 1970. Between 1970 and 1980 it is even possible ... that no new copper mines will be needed on the Copperbelt at all. The pub cannot expect to remain full of bricklayers and carpenters once the building job down the street has been completed.... Thus the possible increases in copper production ... do not necessarily imply proportional increases in the number of men needed. Indeed it appears that much of the production forecasted could be achieved with only a few more men than we have on the Copperbelt now. ${ }^{48}$

The same report concluded: 'There is little prospect that any large industry will soon set itself up on the Copperbelt comparable with the mining industry. ${ }^{49}$

Delivering increased productivity, mine companies and their intellectual advisers believed, required the application of Taylorist techniques to the evaluation and design of job descriptions, training and recruitment processes. ${ }^{50}$ The pioneering job evaluation system introduced by UMHK attracted the attention of its counterparts to the south: in 1951 RST officials travelled to Haut-Katanga in the hope that they might be able to introduce such a system in their mines. They approvingly noted not only the sophisticated job evaluation structure but also the provision of education to mineworkers' children. While impressed, they concluded that introducing such a system would be impossible in Northern Rhodesia, where every change to wages and conditions was challenged by an African union with its own view of advancement. ${ }^{51}$

Hyden Munene, 'A history of Rhokana/Rokana Corporation and its Nkana Mine Division, 1928-1991', unpublished PhD thesis, University of the Free State, (2018), p. 101.

48 ZCCM-IH, 3.8.1C, First Report on Regional Survey of Copperbelt, 1959, Special Commissioner for the Western Province, 'A First Report of a Regional Survey of the Copperbelt', 1959, pp. 7-9.

Ibid.

50 For the history of Taylorism see Judith A. Merkle, Management and Ideology: The Legacy of the International Scientific Management Movement (Berkeley: University of California Press, 1980).

51 ZCCM-IH, 10.1.8F, 'African Labour: Wages', October 1950-December 1955. 
The company also pioneered the use of intelligence testing of its prospective workers and the children of its workforce, establishing its own Centre de Psychologie et Pédagogie in 1953. ${ }^{52}$ Potential recruits were given psychotechnical tests that theoretically evaluated their capacity for specific areas of employment. David Mupanga, for example, recalls being asked to dismantle a cylinder and put it back together, but also drawing a picture of a village on which one was evaluated on where one's house was pictured in relation to that of the chief. ${ }^{53}$ Mwanza Lukinde had to assemble parts into a cube and work out the most efficient route through town to buy specified products on a fixed budget. ${ }^{54}$ Stéphanie Mumba, who passed her test and was appointed as the head of the laundry at Panda's hospital, recalls that many women who failed such tests were employed in more junior roles, for example as cleaners. ${ }^{55}$ Even in the Northern Rhodesian mines, new employees had to pass aptitude tests by the early 1960s. They were then allocated by the companies to appropriate training and employment. ${ }^{56}$

\section{The Politics of Advancement}

As already noted, there was a disjuncture between the overwhelming focus on advanced workers or évolués in company reports and analysis by social scientists, and their relatively small numbers in the mine workforce. Notwithstanding UMHK's emphasis on skills training, in 1954, 61.4 per cent of the company's total African workforce of 20,762 was on its lowest employment grades numbered 4-7, and 78 per cent on grades 4-9. By 1958, by which time the workforce had expanded to 23,312, 54 per cent were employed on grades 4-7, but three-quarters were still in grades $4-9 .{ }^{57}$

In Northern Rhodesia, where a similar structure obtained among African mineworkers, debates over their 'advancement' were racially framed. In 1951, the entire wage bill for the African workforce was

52 UMHKA, 672, Centre de Psychologie et Pédagogie, 1954-5; Lauro, 'The British, the French and Even the Russians Use These Methods'.

53 Interview, David Mupanga, Likasi, 5 June 2018.

54 Interview, Mwanza Lukinde, Likasi, 5 June 2018.

55 Interview, Stéphanie Mumba, Likasi, 6 June 2018.

56 Interviews, Evans Nsabashi, Mufulira, 18 July 2018; Joseph Tumba Mwenzu, Mufulira, 9 August 2018.

57 UMHKA, 658, UMHK MOI Annual Report 1958, p. 64. 
c. $£ 3 \mathrm{~m}$, less than half that paid to the mine companies' approximately 7,000 European workers. ${ }^{58}$ Heated debates over the colour bar led to the 1954 Forster Inquiry into 'advancement'. Of the total African mine workforce of 37,287, 73.7 per cent were in the lowest groups 1 to 3 and were paid between $£ 4$ and $£ 7$ per month. ${ }^{59}$ The highest paid Group 8 African worker earned $£ 19$, and it was these workers, with the potential to advance into European-reserved jobs, that received most attention. But less than one thousand Africans were employed in Groups 7, 8 and the 'Special' category. The minimum European monthly salary was over $£ 99 .{ }^{60}$

Company representatives justified the racial wage gap by claiming that African workers were less adaptable, that their mechanical knowledge was inferior and that their periodic absence during visits to their villages meant they had to be trained afresh on their return to work. Some such limitations were 'inherent and would require to be bred out of the African ... Others, however could be eradicated by training'. ${ }^{61}$ Thus, Africans doing the same job as Europeans were seen as less productive and it was therefore justifiable to pay them less for a 'transitional' period: to do otherwise would threaten 'the national economy'. Although the main African Mineworkers' Union (AMWU) (and, for its own reasons, the European union) demanded 'equal pay for equal work', the Mines African Staff Association (MASA), which was subsequently recognised by the Chamber of Mines as the representative body for clerical and senior African staff (see Chapter 4), explained to Forster: 'Although they are all Africans, they do not belong to one class and they do not work under the same conditions.

58 Ibid., p. 25.

59 ZCCM-IH, 3.8.2E, Forster Board of Inquiry, Afr Advancement, September 1954, 'Report of the Board of Inquiry Appointed to Inquire into The Advancement of Africans in the Copper Mining Industry in Northern Rhodesia', p. 13, p. 48.

60 ZCCM-IH, 3.8.2E, Forster Board of Inquiry, Afr Advancement, September 1954, 'Report of the Board of Inquiry Appointed to Inquire into The Advancement of Africans in the Copper Mining Industry in Northern Rhodesia', 13-14. See also Epstein, Politics in an Urban African Community, pp. 244-5.

61 ZCCM-IH, 3.8.2E, Forster Board of Inquiry, Afr Advancement, September 1954, 'Report of the Board of Inquiry Appointed to Inquire into The Advancement of Africans in the Copper Mining Industry in Northern Rhodesia', pp. 20-1. 
Therefore they are not on the same level'. ${ }^{62}$ Partially accepting the logic of the mine companies' argument, MASA argued that Africans should be paid 75 per cent of the European rate for the job. ${ }^{63}$ Despite the continuing exclusion of Africans from training opportunities such as apprenticeships, Forster concluded that Africans were partly to blame for their low pay:

until Africans in general fully grasp the vital relationship between ... work on the one hand and advancement on the other and that the former must precede and justify the latter and until they behave accordingly ... the gap will, for the main majority of Africans, remain unbridgeable. ... there will be a proportion of exceptional Africans fitted for advancement, at first into work the value of which truly lies in the gap between the two wage structures and later into work which truly lies in the European wage structure. ${ }^{64}$

Significant improvements were made to Northern Rhodesian African wages and conditions in the subsequent decade, often in response to organised industrial action: a pension scheme was introduced in 1954. Yet mine companies continued to justify slow African advancement in evolutionary terms. Ernest Oppenheimer, Chairman of AAC's Nchanga Consolidated Copper Mines (NCCM), declared in March 1955:

The keynote of African advancement is - again - responsibility; this does not mean merely the acquisition of increased operative skill, but embodies as a fundamental concept the development of a sense of judgment and a measure of self-discipline. These are mental attributes which are not acquired overnight ... and so far as the African is concerned, must be achieved against an unfavourable background. Unlike the European, the African is lacking in industrial tradition - his whole past is bound up with the soil - and ... it will be a slow and evolutionary process. ${ }^{65}$

Under the Advancement agreement signed that year, 185 Africans employed by NCCM were promoted to jobs previously carried out

62 ZCCM-IH, 3.8.2E, Forster Board of Inquiry, Afr Advancement, September 1954, 'Report of the Board of Inquiry Appointed to Inquire into The Advancement of Africans in the Copper Mining Industry in Northern Rhodesia', p. 26.

63 ZCCM-IH, 3.8.2E, Forster Board of Inquiry, Afr Advancement, September 1954, MASA Submission to the Forster Board of Inquiry, p. 3.

64 Ibid., p. 18.

65 ZCCM-IH, NCCM Annual Report 1955, Chairman's Review, p. 6-7. 
by Europeans. ${ }^{66}$ By 1959 the three lowest employment groups still accounted for 65 per cent of the workforce. Only 4 per cent of Africans were employed in the most advanced categories. ${ }^{67}$ Powdermaker found that, although Northern Rhodesian mineworkers experienced a real terms increase in their 'income' - their wages, together with housing and social provision - between 1950 and 1960, they continued to perceive themselves as badly off, compared with the observable standard of living of the Europeans who supervised their work and to whose jobs they aspired. ${ }^{68}$ Despite strenuous efforts at the 'Zambianisation' of senior jobs in the 1960s and 1970s (Chapter 6), many thousands of whites continued to occupy most of the senior positions (and earn many times more money) until the late 1970s.

It is impossible to directly compare the wages of African mineworkers on either side of the border: as a general rule, cash wages were higher in Northern Rhodesia than in Haut-Katanga for the same mine job, but UMHK provided a greater proportion of compensation in non-cash form, for example food 'rations', housing and other benefits. This difference was significant however, since UMHK's use of non-cash wages meant that, alongside its lack of African union representation, it avoided direct engagement with its workforce over the value of its labour. Dibwe dia Mwembu notes that UMHK sought to manage the cost burden by providing different forms of cash and in-kind remuneration to each category of African worker: low-skilled workers received only a small cash wage with all other provisions in-kind; 'middle' workers received higher cash wages that now included their food costs; and more specialised workers under the 'global' system were paid entirely in cash. ${ }^{69}$ In these and other ways mine companies sought to avoid general improvements in wages and conditions across the workforce, and had a vested interest in promoting divisions among their workers that were justified through a meritocratic discourse. The UMHK's managers constantly likened the company to a family headed by benevolent patricians, but this was a metaphor entirely compatible with hierarchy and inequality.

66 ZCCM-IH, NCCM Annual Report 1956, p. 5.

67 Powdermaker, Copper Town, p. 89. ${ }^{68}$ Powdermaker, Copper Town, p. 91.

69 Dibwe, Histoire des Conditions de Vie, p. 50. A detailed analysis of UMHK salary structures is provided in Ngandu Mutombo, 'Politiques de rémuneration', pp. 229-41. 


\section{Unease, Inequality and Influx Control, 1957-1964}

Even during its great economic boom, therefore, the Copperbelt was never a region of generalised development or rising living standards. Capital outflow and mining's skewed relationship with the wider economy limited the creation of jobs and businesses. The highly uneven distribution of wages, housing and other rewards intersected with racial segregation and profoundly unequal power relationships between women and men, between skilled and unskilled mineworkers, mineworkers and other wage earners, and wage earners and the wider non-waged population - to create tension, conflict and social unrest. Northern Rhodesia's Copperbelt towns were thought by the authorities to have very high crime levels: in 1958, the Mufulira Native Court handled 3,524 cases for a population of c.30,000 adults. Half of these offences involved 'unauthorised residence' in municipal or mine township areas, the second highest category involving identity certificate and registration offences, with other crimes including house burglary, theft of bicycles and an increasing number of driving offences. Of particular concern was the rising number of crimes committed by African adolescents, up from 104 in 1957 to 123 in 1958, evidence for the authorities of the quintessential Western social malaise of the 1950s, growing 'juvenile delinquency'. ${ }^{70}$ Luise White details how rumours - about the kidnapping of children, poisonings and witchcraft of different kinds - circulated through tense and distrustful Copperbelt societies. Far from being a manifestation of rural superstition, such rumours reflected residents' experiences of an economic and social order that was permanently in flux. ${ }^{71}$ In Mufulira six cases were brought under the Witchcraft Ordinance in 1956, four of accusing others of practising witchcraft and two of claiming supernatural powers. ${ }^{72}$ This was also a region of increasing political unrest and sometimes violence, as will be discussed in Chapter 4 .

These tensions were heightened by a brief but punishing recession of 1957-8, when the global copper price fell dramatically and the assumptions underlying Copperbelt growth were severely tested. The 1958

70 NAZ, WP 1/2/45, Annual Report African Affairs Ndola. 1957-61, 'Annual Report of African Affairs, Mufulira, 1958', Ch. 8, np.

71 White, Speaking with Vampires, pp. 269-306.

72 NAZ, WP 1/2/45, Annual Report African Affairs Ndola. 1957-61, 'Annual Report of African Affairs, Mufulira, 1957', p. 17. 
Provincial Council meeting heard that 'Katanga, despite the relatively significant development of its secondary industry, remains very sensitive to the fluctuation in the prices of raw materials, the export of which represents for the Colony, one of the most important sources of income'. ${ }^{73}$ Unemployment manifested itself in Katanga's main towns, though the Provincial Council agreed that it could not be addressed as it was in Europe:

the problem of unemployment is not comparable with that in Belgium, since the economic system and structure of Congo was different. ... the solution of the problem does not consist in creating an unemployment fund, the establishment of which would be contrary to the interests of the rural population, but in remedying the situation, which is likely to become more and more serious, by finding an occupation for these unemployed. ${ }^{74}$

Programmes of public works were created to absorb the unemployed, who numbered c.3,500 in Elisabethville and 1,500-2,000 in Jadotville (later Likasi). Other actions included:

- rigorous measures to halt the influx into the towns;

- continuing the policy of ejecting from the towns in favour of return to the land;

- reduce the existing contrast between the living conditions in the towns and the rural milieu by raising the incomes of the rural Africans;

- inculcate in the young a love of manual labour. ${ }^{75}$

Katanga strictly controlled African movement, something that Northern Rhodesian officials desired to emulate. A meeting there on urban African unemployment in January 1958 proposed 'a comprehensive system of identification, including full finger-printing ... (on the Belgian Congo pattern)'. ${ }^{76}$ While official Katangese discourse tended towards optimism, identifying solutions in indigenous agricultural and peri-urban development, Northern Rhodesian officials worried about the negative effects of unemployment in both villages and towns. They called for

73 BAA, 36(3), KPC, Session Générale, Opening Statement, Governor Paelinck, September 1958.

74 BAA, 36(4), KPC, Session Générale, Commission Prépatoire No. 1, Séance, 2 September 1958, p. 1.

75 Ibid., pp. 1-2.

76 ZCCM-IH, 16.3.8C, Mine Township Mgt Board - Health Officers, July 1929November 1979, 'Chamber of Mines Mtg, Companies and Lab Commissioners, 24/1/58', 'to consider problems of African unemployment in urban areas', p. 1. 
development planning, as pioneered in Congo, but were more pessimistic that this would translate into an effective policy. C. Fourie, a senior government officer with responsibility for African affairs, stressed the need for a territory-wide approach to 'influx control' that would focus on 'the social and economic development of rural areas parallel with urban areas, to enable them to compete with the attraction of the towns'. ${ }^{77}$

During the recession, employers searched in vain for the right kind of workers, for example in Kitwe in 1958:

Africans are offering for work in great numbers. At the big mines, 600 to 700 Africans appear when men are being taken on. Really good labourers and domestic servants are in demand and in short supply. African drivers, building trade workers and clerks of poor quality abound and cannot get jobs. ${ }^{78}$

A 1958 conference of local government officials resolved that it was necessary to tackle urban unemployment in rural areas:

the best method of dealing with the problem .... was to start at the source, that is, the village itself and the Chief in charge, and that no African should be allowed to leave his own area unless the Chief had been advised that there was room for him in the peri-urban areas, or if there was a shortage of labour ... then Africans could be allowed to enter those areas. ${ }^{79}$

The tripartite African Labour Advisory Board heard from companies and unions on the issue: 'The three Employee Representatives agreed that the problem of work-shy parasites in employment centres was a big one.... ultimately the development of rural areas would be the best solution but [it was] agreed that this would take a considerable time to have its effect'. African trade union representatives expressed their personal familiarity with the problem: 'Each referred to his personal experience of having to accommodate and feed "brothers" who came to the Copperbelt and were extremely difficult to dislodge. ${ }^{80}$

77 NAZ, WP 1/11/2, African Social and Political Development in Urban Areas, 1951-6, C. Fourie, Officer for African Affairs to District Commissioner, Kitwe, 23 December 1955.

78 NAZ, WP 1/2/53, Labour: Dept of Labour monthly reports, 1958-60, Department of Labour Report for February 1959, p. 7.

79 NAZ, WP 1/2/61, Report of Director of African Affairs Chingola 1959, Decisions taken at 12 th Annual Conference, Municipal Association of Northern Rhodesia, 13-15 May 1959, p. 1.

80 ZCCMA, 16.3.7A, 'African Advisory Board, Feb 1951-Jan 1958', meeting 23 January 1957, pp. 1-2. 
Trade union backing was thought vital for action against the 'loafer' problem: by January 1959 c.6,000 African men had been 'repatriated' to their rural areas of origin, reducing the number of unemployed in Northern Rhodesian Copperbelt towns to c.5,000. It was, however, acknowledged that nothing could prevent them from returning. ${ }^{81}$

Although a higher copper price enabled the economy to bounce back by the start of the 1960s, this was essentially a jobless recovery. From this point on urban unemployment was consistently highlighted in government reports both in Northern Rhodesia and Katanga. In Luanshya in 1959, '[r]ecovery from the recession has been very slow ... There has been little expansion in secondary industry and African unemployment remains at a high level. When there is wind of work available the long queues at the local labour exchange are ample testimony'. ${ }^{82}$ In 1960 in Mufulira, 'the supply of labour exceeded the demand, and as activity slowed down towards the end of the year, so the position deteriorated and labour forces were reduced, with a resultant increase in the number of unemployed'. ${ }^{83}$ In Katanga, the 1959 Provincial Council meeting heard that unemployment had risen in Elisabethville to 7,142 and in Jadotville to 1,284. Katanga's employment figure had fallen from its 1954 peak of 197,443 to 160,776 in 1958, while the 'extra-customary' population had risen from 509,327 to $570,079 .{ }^{84}$ There was growing alarm at youth unemployment: 'The youth of our towns is one of our principal preoccupations. We are faced with a growing number, year on year, of young adolescent idlers who neither go to school nor are in work. It is estimated that there are at least 3,000 in Elisabethville at the moment'. There was then a need to 'create new sites in the periphery to encourage the return to the land of a large part of this workforce that will never find employment in existing businesses'. ${ }^{85}$ Indeed, right up to Congolese independence,

81 ZCCMA, 16.3.8C, Luanshya Mine Township Mgt Board - Health Officers, July 1929-November 1979, meeting between company representatives and Senior Provincial Commissioner, 17 January 1959, p. 2.

82 NAZ, WP 1/2/43, African Affairs Annual Report, Luanshya, 1957-60, 'Luanshya African Affairs Annual Report', 1959, np.

83 NAZ, WP 1/2/66, DCs reports 1960, 'Annual Report on African Affairs, Mufulira', p. 12.

84 BAA, 37(2), KPC, Session Extraordinaire, 1959, Allocution D’Ouverture du V. GG Schoeller, np.

85 BAA 37(1), KPC, Session Extraordinaire, 1959, Allocution D’Ouverture du Commissaire Provincial M. Thilmany, pp. 26-7. 
the CEPSI-linked initiative FULREAC (Fondation de L'Universite de Liège pour les Recherches Scientifiques au Congo Belge et au Ruanda-Urundi) continued agricultural activities in Mangombo, near Jadotville, one of a number of 'projets de decongestion des grands centres urbains. ${ }^{86}$

A census conducted in May-June 1963 revealed that in Northern Rhodesia there were 255,910 African men in paid employment, 275,570 who were self-employed and 74,480 'seeking paid employment'. ${ }^{87}$ Later that year a report identified 'unemployment' and 'the drift to the towns' as two of the three 'tremendous problems' facing Northern Rhodesia, 'bearing in mind that all those at present out of work in Kitwe will never be absorbed no matter what industrial expansion takes place'. ${ }^{88}$ Of the city's over-eighteen male population of 35,000, 8,936 were employed in mining, 20,000 in other jobs and 6,000 were unemployed. ${ }^{89}$ In Mufulira's municipal area there were, in 1961, twenty-eight licensed African businesses, compared with none in 1956. ${ }^{90}$ African entrepreneurship was, however, restricted by a lack of access to credit and by European and Asian domination of retail, and what existed was negatively perceived: 'The number of Africans hawking vegetables in the streets has increased considerably. They cannot make a living this way and are having an adverse effect on the legitimate marketeers'. ${ }^{91}$ The prospects were not promising. In Mufulira, where the mine employed c.9,000 workers, an existing population of c.66,000 was forecast to rise to 97,870 by 1971 , in a period when 'there is unlikely to be an upsurge in employment in the established mining industry'. ${ }^{92}$ GG Schoeller, pp. 21-2.

87 NAZ, LSS 1/22/30, Labour Consultative Committee, 1962-4, LCC Note for Members, meeting 27 February 1964.

88 NAZ, WP 1/2/74, Native Affairs, Annual Reports, 1963, 'Native Affairs Annual Report, Kitwe, 1963', p. 1.

89 Ibid., p. 5.

90 NAZ, WP 1/2/45, Annual Report African Affairs, Ndola, 1957-61, 'Annual Report of African Affairs, Mufulira, 1961', p. 13.

91 NAZ, WP 1/2/74, Native Affairs, Annual Reports, 1963, 'Native Affairs Annual Report, Kitwe, 1963', pp. 8-11.

92 NAZ, WP 1/2/45, Annual Report African Affairs, Ndola, 1957-61, 'Annual Report of African Affairs, Mufulira, 1961', p. 8; ZCCMA-IH, Copperbelt Development Plan, 1965, p. 1.66. 


\section{Uneven Development: Capital and Labour After Independence}

Ostensibly, national independence created the possibility of breaking from the colonial extractive model on which the Copperbelt had been built. Zambian independence fuelled confidence about future economic development and the government signalled that it would invest in the economy and create a large number of jobs. A 1965 Copperbelt Development Plan confidently stated:

With a settled National Government the Copperbelt ... can be expected to attract new industry and commerce and contribute, for many years, the major finance required to enable physical and social development to spread to the backward regions of the territory. ${ }^{93}$

The region's disadvantages for secondary industry, however, remained:

The entrepreneur is being encouraged to develop within the boundaries of the territory for a new and expanding market, and the Copperbelt region, with its larger concentration of population and growing reserve of skilled labour, is proving an attractive area ... for production of consumer goods. The Copperbelt is not, however, a natural centre for secondary industry, as long transport hauls are necessary to reach export markets, and, therefore, it is unlikely that any major concentration, outside the mining industry, will result. ${ }^{94}$

The post-independence governments of Zambia and DR Congo were fully aware of the difficulty of developing their economies beyond the mining industry. Early development plans warned about continuing dependency on mining and stressed the need for diversification. In the short term however, mineral production was expanded as the only way to raise revenue to fund a programme of diversification. ${ }^{95}$ Zambian copper production rose accordingly, from 568,000 tonnes in 1963 to 720,000 tonnes in 1969 . There was also a significant increase in African mine employment, from 36,946 in 1963 to 43,500 in 1969, with many new jobs coming not in production but in processing and areas such as social services and education. ${ }^{96}$ In Congo/Zaire, President

93 ZCCM-IH, Copperbelt Development Plan 1965, p. 1.5. 94 Ibid., p. 1.99.

95 United Nations/Economic Commission for Africa/Food \& Agriculture Organisation, Economic Survey Mission on the Economic Development of Zambia (Ndola: United Nations/Economic Commission for Africa/Food \& Agriculture Organisation 1964).

96 Daniel, Africanisation, Nationalisation and Inequality, p. 107; ZCCM-IH, Zambia Mining Yearbooks, 1965-8. 
Mobutu drove up mine production in the late 1960s despite the risk of over-supply to the global market. Copper production, which fell from 300,000 tonnes in 1960 to a low of 269,000 tonnes in 1963 during the secessionist conflict, rose to 406,000 tonnes in 1971. Gécamines employed 24,586 workers in 1971, including 1,007 women. Of its 2,129 senior employees, however, only 720 were African. ${ }^{97}$

The redirection of mine tax revenue to independent governments created the potential for investment in non-mining sectors, but this did not overcome an export dependency on copper and cobalt mining, with its limited linkages to the local economy. Development policy instead directed mine tax revenue into state-directed or state-owned industries and substantial infrastructural investment to support them. In the late 1960s, Zambia's Industrial Development Corporation (Indeco) oversaw nationalised and semi-nationalised companies outside the mining industry. ${ }^{98}$ But such initiatives were shaped by political rather than economic considerations: in Zambia, key industrial projects were distributed across the country rather than being concentrated in the Copperbelt. At a local level, '[n]o large scale industrial expansion is foreseen at Mufulira and its present light industrial service area should be adequate.' ${ }^{99}$

In newly independent Congo, the dislocating effects of the post-1960 crisis initially prevented meaningful development activity and led to the collapse of much of the rural health and educational provision built up in the late colonial period. The already fragmented 'national' economy was further disrupted by the Katangese secession. ${ }^{100}$ Peemans characterised Congo as having industries but not industrialisation: it had developed an internal market for consumer goods and Haut-Katanga had industries that served the needs of mining, but the economy was oriented to export earnings rather than integrated national development. Although mining taxes accrued to the growing state and funded development programmes, mine revenue continued to flow out as dividend payments and was not invested in Congo's wider economy, which lacked an effective local banking system that could have

97 Gécamines Annual Report, 1971, p. 13 and p. 30.

98 Andrew Sardanis, Africa, Another Side of the Coin: Northern Rhodesia's Final Years and Zambia's Nationhood (London: Bloomsbury, 2003), pp. 164-89.

99 ZCCM-IH, Copperbelt Development Policy, 1965, p. 147.

100 Peemans, 'Social and Economic Development of Zaire', pp. 155-6. 
provided credit to entrepreneurs. ${ }^{101}$ Under Mobutu, however, state control over the economy and society was consolidated and then considerably strengthened. In the late 1960s, the governments of both countries nationalised their mining industries, a topic explored in Chapter 6.

There was a post-independence expansion of education of all kinds, nationally and in the Copperbelt in particular: an expansion of primary and secondary school places, but also of vocational training to address the massive skills gap that was, especially in Zambia, a legacy of the colour bar. ${ }^{102}$ In Haut-Katanga the loss of many European educators, particularly in Catholic schools, did not substantially undermine UMHK-run primary schools, which workers' children could attend for free. Schemes such as the Zambia Youth Service provided training in areas such as carpentry, bricklaying and farming. ${ }^{103}$ In Luanshya in 1968, a Youth Development Scheme run by the Mine Townships Management Board provided training in carpentry, bricklaying, welding, driving, motor repair and light engineering to at least 100 young people. ${ }^{104}$ As well as primary schooling, mine companies provided adult literacy education; staff training for skilled work; apprenticeship schemes for aspirant 'advanced' Africans; and medical training for prospective hospital and clinic workers. ${ }^{105}$

Mine companies also gave preferential access to the children of existing employees in filling vacancies, a policy that continued into the 1980s. ${ }^{106}$ The UMHK built on its 'scientific' recruitment procedures in its schools to identify and shape the education of its future workforce. The company's schools were widely seen as better run and/or more disciplined than state schools, attracting the best teachers with higher wages. ${ }^{107}$ Although Zambian mines lacked equivalent

\footnotetext{
101 Ibid., pp. 149-50.

102 NAZ, WP 1/2/45, Annual Report African Affairs, Ndola, 1957-61, Annual Report of African Affairs, Mufulira', 1961, p. 17.

103 NAZ, WP 1/2/75, Native Affairs Annual Reports 1963-5, Department of Labour, Annual Report 1964, p. 2.

104 NAZ, LSS 1/22/24, Annual Reports, Labour Officer, Luanshya, 1947-67, LO S. D. Sacika, 13 January 1968.

105 NAZ, WP 1/2/74, Native Affairs Annual Reports, 1963, 'Kitwe District Annual Report on African Affairs', p. 14; NAZ, WP 1/2/75, Native Affairs Annual Reports 1963-5, Labour Department Annual Report 1964, p. 6.

106 Interview, Leonard Nkhuwa, Mufulira, 30 July 2018.

107 Interviews: Mwanza Lukinde; Jérôme Kipili Mulunda, Likasi, 4 June 2018.
} 
control over education, they ran an annual recruitment round of the minority of students who could afford to complete secondary school in the 1960s and 1970s. ${ }^{108}$ For the educated children of mineworkers on both sides of the border, the demand for increasingly skilled African workers in the first decade of independence represented a one-off opportunity for social advancement. Levy Chushi, whose father worked for the Mufulira mine, started work aged nineteen as an underground lasher in 1965 . He received training in mechanics, studied briefly at the new University of Zambia (UNZA) and, after successive promotions, acquired the senior position of Mine Captain in $1987 .{ }^{109}$ Owess Nkhama, whose Malawian father was a rockbreaker in the 1920s and 1930s, became the leader of a mine social club in 1959, studied youth management and sociology under company auspices in the 1960s and was later a senior personnel manager. ${ }^{110}$ Sara Léontine Bulanda became a Gécamines employee and managed the Panda canteen where her mineworker father had once eaten. ${ }^{111}$ In lieu of other opportunities, mine work remained one of the most attractive options for Copperbelt residents. While Zambian workers received cash-only wages after independence, the 'final' abolition of food rations in UMHK in 1962 was suddenly and permanently reversed in 1964 when, amidst soaring food prices, the company re-established indirect food supplies in the form of subsidised retail sales and canteen meals. ${ }^{112}$ This measure is widely recalled as an act of company generosity that showed it cared for its workers.

Despite the Copperbelt's lack of sustained development, it continued to attract tens of thousands of new migrants, motivated as much by the continued poverty of rural villages as the availability of employment opportunities. Many new arrivals and some of those born in town found ways of earning a living outside paid employment. Morris Chimfutumba, born in Mufulira in 1930, worked first as a petrol attendant and then as a company salesman, before buying a European-owned bottle store and selling fish he brought from

108 Simon Bwalya, whose father was an unskilled mine workman, was recruited directly from school in 1968: interview, Mufulira, 9 July 2018. See also interview, Cossam Chali, Mufulira, 21 July 2018.

109 Interview, Levy Chushi, Mufulira, 11 July 2018.

110 Interview, Owess Nkhama, Mufulira, 8 August 2018.

111 Interview, Sara Léontine Bulanda, Likasi, 6 June 2018.

112 Dibwe dia Mwembu, Histoire des Conditions de Vie, p. 60. 
Luapula Province. ${ }^{113}$ Thomas Kalimanshi, whose parents migrated from Katanga and whose father became a bricklayer and carpenter in Mufulira, started a taxi business in 1968 that became a highly successful transportation company, partly by providing transport services to ZCCM. ${ }^{114}$ Michel wa pa Bowa established a subcontracting company providing cleaning and refuse services to Gécamines' hospitals, schools and camps, aided by his brother's senior position in the company. ${ }^{115}$

For many, a mine company job remained the gold standard, delivering as it did not only a salary and a secure job but also access to housing, schooling for children and other social services. Simon Kampamba, who worked for a series of small companies as a carpenter, applied unsuccessfully for a job with the mines on three occasions in the 1970s, hoping to benefit from its superior retirement package. ${ }^{116}$ But for others, mining was a dangerous and low-status job to be avoided. Matthias Mutupa's mineworker father promised to find him a job in the mines, but he instead became first a salesman and then a delivery driver for the Olympic milling company. ${ }^{117}$ Evans Nsabashi chose to become a teacher, earning less than a mineworker, because teaching was less physically demanding. ${ }^{118}$ One's employment increasingly depended on one's education or training, which partly reflected ability and upbringing but also fortune - the death of a parent or relative might mean school fees could no longer be paid or that one had to leave education to provide for the family. ${ }^{119}$ Copperbelt towns were then places, if not of development along Western lines, then of possibility, whose residents envisaged progress and self-realisation in diverse ways, both within and beyond the constraints of formal employment. Kabwika Ntanda Kadisabula, whose mineworker father fled to his native Kasai with his young family during the secession, went on to work for the Banque Commerciale du Congo. In the mid-1970s he ran a petrol station, living and working in Kikula, and used this as

Morris Chimfutumba interview.

Interview, Thomas Kalimanshi, Mufulira, 30 July 2018.

115 Interview, Michel Mudimba wa pa Bowa, Likasi, 18 June 2018.

116 Interview, Simon Kampamba, Mufulira, 16 July 2018.

117 Interview, Matthias Mutupa, Mufulira, 19 July 2018.

118 Evans Nsabashi interview.

119 Simon Bwalya interview; interview, Dewys Mulenga, Mufulira, 20 July 2018; interview, François Kake, Likasi, 11 June 2018. 
a springboard to become a local MP. ${ }^{120}$ Musale Kibombo, whose father was also a mineworker, became a domestic worker for Europeans, a job he held throughout his entire working life. Rejecting the notion that this was a subservient position, Kibombo argues:

it is rather those who worked at Gécamines who did not have much independence, since they were interned in Gécamines homes and were forced to start work at six in the morning and finished late in the evening. I, a servant, am in the same plot as my boss and my house is next door. In the morning, before the boss left, he left a programme in the kitchen [and then] I am the manager of the house, I had all the keys and I watched everything. ... in town, there were civilised people. ${ }^{121}$

Even some successful mineworkers observed that, once trained and employed by ZCCM or Gécamines for specific jobs, they had no other option for local employment - there was nowhere else to go. But town was for many urban migrants a place not associated primarily with formal employment, which was in any case increasingly limited to those with schooling. Indeed, the education of one's children, who might by such means better themselves and care for you in later life, was arguably a greater motive for urban residence than salaried employment. $^{122}$

\section{Conclusion}

For government officials in particular, the Copperbelt boom was as much of a problem as it was a success: it brought to the region a growing population that was increasingly difficult to control and manage. Mine towns, designed initially for workers and then their immediate families, drew in a far larger population, prompted by rural poverty and the better life that could be achieved by a range of social and economic activities that were only indirectly related to the mining industry. This was in a context where employment opportunities were few and industrial development remained limited.

It must, however, be acknowledged that forecasts of stagnant or declining mine employment proved wide of the mark: both Zambian and Congolese/Zairian mine companies steadily increased their

120 Interview, Kabwika Ntanda Kadisabula, Likasi, 5 June 2018.

121 Interview, Musale Kibombo, Likasi, 21 June 2018.

122 See, for example, Maxwell Mukupa interview. 
workforce in the independence period. This partly reflected governmental pressure to increase production for the purposes of state revenue, against the advice of company management. The mines did not, however, become the basis of a more fully fledged industrial system: the independent governments of both countries, for different reasons, tended to direct new industries away from the Copperbelt (see Chapter 6). In any case, the growth of the region's population continued unabated and regardless of the availability of formal sector jobs: with the removal of colonial controls and in a context of continued rural stagnation, migration to the Copperbelt towns sharply accelerated after independence. Efforts to manage this population, as we will see in the next chapter, involved not only physical controls on their movement and settlement but also constant surveillance of the activities of legal residents. This was in turn underpinned by a highly moralistic discourse about those who did and did not deserve a place in the town, framed in the characteristically modernist terms of the Copperbelt imaginary. 


\section{Introduction}

Mining areas in the global South have often been characterised as 'enclaves' in which mineral extraction is spatially and politically separated from the country in which it takes place. ${ }^{1}$ The Copperbelt has often been understood as such an enclave, an island of urban industrial development in an otherwise remote rural interior, linked to the global economy by new communication channels - historically railways and, more recently, advanced telecommunications - that collapsed physical distance and enabled mine companies to avoid the obligations otherwise imposed upon commercial operations by the states and communities in which they operate. Certainly, twenty-first-century Copperbelt mine companies have sought to and been somewhat successful in off-shoring their profits and anonymising their in-country operations as a way of reducing local accountability. ${ }^{2}$ In contrast, the long-term operations of mid-to-late-twentieth-century Copperbelt mine companies involved a determined making and control of urban space. There is nonetheless often a 'taken for granted' acceptance that its companies were not only able to create new urban communities but also to impose their desired meaning on these spaces. This is, this chapter will show, belied by a history in which Copperbelt residents challenged company boundaries and invested these areas with meanings of their own.

1 Richard Auty, 'Mining Enclave to Economic Catalyst: Large Mineral Projects in Developing Countries', Brown Journal of World Affairs, 13, 1 (2006), pp. 136-45; Robin Bloch and George Owusu, 'Linkages in Ghana's Gold Mining Industry: Challenging the Enclave Thesis', Resources Policy, 3, 4 (2012), pp. 434-42.

2 Jan-Bart Gewald and Sebastiaan Souters, 'African Miners and Shape-Shifting Capital Flight: The Case of Luanshya/Baluba', in Alastair Fraser and Miles Larmer, Zambia, Mining, and Neoliberalism, Boom and Bust on the Globalized Copperbelt (New York: Palgrave Macmillan, 2010), pp. 155-83. 
The spatial turn, inspired by Lefebvre and disseminated across the humanities and social sciences in the 1990s and early 2000s, focussed attention on how space was created, determined and contested by social actors, as well as how it is defined and invested with meaning. ${ }^{3}$ Historians as a result better appreciate the centrality of space and place in historical change, while in African studies it helpfully challenged the hegemony of the colonial or nation-state and showed how sovereignty over space is mediated and contested - and the study of border regions such as the Copperbelt provides a particularly revealing example of this. ${ }^{4}$ Colonial efforts to maintain racial segregation and the 'migrant' status of urban workers were, for example, undermined by the latter's mobility and political agency. Likewise, historians of company towns elsewhere in the world have emphasised the ways in which company control of space was central to their power. ${ }^{5}$ The promotion of the modern urban lifestyle of mine townships required the continual policing of the boundaries between urban areas and of the nuclear families they were ostensibly designed for, a struggle for spatial and social control that continued into the independence era.

Copperbelt towns were, as we have seen, given meaning by a set of elite actors who attached to them their notions of urban modernity in order to differentiate them from their understanding of 'rural' Africa. In focussing on the arrangement of space in Mufulira and Likasi, this chapter will explore how segregated residential areas inhabited by African mineworkers and the wider African urban population were created, how their borders and communities were policed and how they were invested with meanings that changed over time. While racial and occupational hierarchies helped determine their initial segregation, the

3 Henri Lefebvre, The Production of Space (Oxford: Blackwell, 1991 [1974]).

4 For historical analysis, see: Charles W. J. Withers, 'Place and the "Spatial Turn" in Geography and History', Journal of the History of Ideas, 70, 4 (2009), pp. 637-58; Diarmid A. Finnegan, 'The Spatial Turn: Geographical Approaches in the History of Science', Journal of the History of Biology, 41 (2008), pp. 369-88; and Matthias Middell and Katja Neumann, 'Global History and the Spatial Turn: From the Impact of Area Studies to the Study of Critical Junctures of Globalization', Journal of Global History, 5, 1 (2010), pp. 149-70. For

African studies and the spatial turn's influence on African borderland studies see Ulf Engel and Paul Nugent (eds.), Respacing Africa (Brill: Leiden, 2010), esp. 'Introduction', pp. 1-10.

5 Marcelo J. Borges and Susana B. Torres (eds.), Company Towns: Labor, Space, and Power Relations across Time and Continents (New York: Palgrave Macmillan, 2012). 
chapter focusses on the divisions between African areas and the ways in which their residents engaged with the division between the ordered and well-managed mine township and the mixed and chaotic municipal areas that, particularly after independence, were their poor cousins. The political anomaly of enclaved mine townships in decolonising African states was itself the subject of political attention the chapter explores the abortive efforts to integrate Zambia's mine townships into Copperbelt towns in the early 1960s and the ongoing attempts by Zambia's rulers to bring these areas under their control. In HautKatanga, in contrast, UMHK/Gécamines' continued separate management of its 'camps', while central to its continued paternalistic control of its workforce and their families, ultimately helped secure domination of these areas by the Zairian state.

While Copperbelt mineworkers were initially housed in huts not dissimilar to those in rural villages, the construction in the 1940s and 1950s of brick-built housing estates laid out on grid systems was key to their orderly management and the projection of Copperbelt towns as places of modernity and Westernisation. Epstein notes Luanshya's careful segregation of mine areas, in which comfortable bungalows for Europeans were laid out on one side of the mine and African residences on the other side. The European area of the municipality actually bordered the European area of the mine, while the African municipal area was a mile apart from the African mine township. While the urban landscape emphasised the division between these areas, they were, Epstein rightly argues, symbiotic, linked by European control over African lives and labour, and the services provided by municipal African residents to mineworkers. ${ }^{6}$

Epstein also drew attention to Luanshya's system of workplace, housing and community services, overseen and controlled by the mine company. The regime of UMHK mine camps has been especially characterised as a holistic, disciplinary panopticon, a system of coercive or disciplinary paternalism. ${ }^{7}$ While Copperbelt mine companies certainly tried to carefully control and discipline the working and private lives of employees and their families, this intention was undermined by the actions of workers and their families, who constantly engaged with the wider town, both formal and informal, and with

6 Epstein, Politics in an Urban African Community, p. 2.

7 Vellut, 'Mining in the Belgian Congo'; Dibwe dia Mwembu, Bana Shaba. 
residents of the peri-urban and rural areas beyond the mine complex. From the start, mine camp residents compared their lot with their neighbours: Higginson records the comparisons drawn by striking UMHK workers and their wives in 1941 between their conditions and nearby 'squatter' areas where women were free to farm. They demanded that the controls imposed by the company on their agricultural activities needed to be compensated for. ${ }^{8}$

Notwithstanding Africa's centuries-long history of cosmopolitan urbanity, most southern African colonial towns were built from scratch in places whose official meaning was defined by their European planners. ${ }^{9}$ As the Special Commissioner for the Northern Rhodesian Copperbelt put it in 1959, " $[\mathrm{t}$ ] o build towns on this scale was necessary in order to get copper produced in a remote and primitive part of Africa'. ${ }^{10}$ Mine towns attracted migrants who provided vital labour but who were initially classified as the rural subjects of their chiefs. While UMHK's mining camps provided their residents with housing and services, they were simultaneously denied free movement within the growing Katangese urban milieu. In Northern Rhodesia, segregationist notions continued to deny rights to new urban settlers. Companies and colonial officials conceptualised mine towns as inherently Western spaces in which African residence was justified only by employment and certified by the carrying of a situpa or pass. While Ferguson rightly highlights how early migrants, and particularly women, evaded state and company controls and settled in town without official status, such evasion came at a price. Undocumented migrants had poorer access to services - housing, education, waged work - that constituted significant rights to the Copperbelt city. ${ }^{11}$ There were certainly many thousands of Copperbelt residents who made a life for themselves in town outside company and state controls, a number that rose as residency rules fell away with independence. Nonetheless, one's place in the town remained closely tied to employment, status and family life.

8 Higginson, Working-Class in the Making, pp. 189-91.

9 David M. Anderson and Richard Rathbone (eds.), Africa's Urban Past (Oxford: James Currey, 2000).

10 ZCCM-IH, 3.8.1C, First report on Regional Survey of Copperbelt, 1959, Special Commissioner for the Western Province, 'A First Report of a Regional Survey of the Copperbelt', 1959.

11 Ferguson, Expectations of Modernity, pp. 53-5. 
While the ethnic mixing - tshanga tshanga - of mine township populations invokes a sense of community and solidarity, Copperbelt towns in general and mine townships in particular were profoundly hierarchical places, in which workplace divisions were constantly reinforced by unequal access to housing and social opportunities. ${ }^{12}$ Powdermaker highlighted that, '[i]nstead of an egalitarian standard of living, the kind of house and the amount of pay determined the worker's place in the hierarchy'. ${ }^{13}$ The racial and occupational segregation of Copperbelt residents was certainly imposed by a colonial capitalist order, and sometimes resisted by those residents. But the notion that urban residence demanded certain standards of 'civilisation' and specific norms of behaviour, implicitly or explicitly associated with European modernity, continued to dominate the ideas that officials and many residents had about them. The relationship between workplace seniority, housing quality and differential social provision meant that, in Zambia in particular, social class mapped directly onto residential area. This chapter uses interview material to demonstrate the ways in which residents acted out and internalised their new class positions through their social behaviour in ways that were every bit as divisive as those between Africans and Europeans. There was, then, always a diversity of ways to belong in the Copperbelt city. Upwardly mobile residents sought to combine employment and educational opportunities, for themselves and especially for their children. Many of our interviewees achieved success by climbing the pyramid of 'advancement' but just as many experienced setbacks and hardship, outcomes that influenced the extent to which they today view town life as a meritocracy or as a place of inequality and injustice where one's fate was decided by race, ethnicity or other 'grounds for difference'. ${ }^{14}$

Garth Myers reveals how the mapping of cities such as Lusaka rendered invisible the 'peripheral' or 'peri-urban' areas where most of

12 For an important analysis of late colonial urban housing, including in Haut-

Katanga and Northern Rhodesia, see Martina Barker-Ciganikova,

Kirsten Ruther, Daniela Waldburger and Carl-Philipp Bodenstein (eds.), The Politics of Housing in (Post-)Colonial Africa: Accommodating Workers and Urban Residents (Berlin: De Gruyter, 2020).

13 Powdermaker, Copper Town, p. 93.

14 Rogers Brubaker, Grounds for Difference (Cambridge, MA: Harvard University Press, 2015). 
its people lived. ${ }^{15}$ Myers' work forms part of a flourishing literature on African cities that has sought to understand the continent's specific urban development while rejecting the association of its urban 'slums' with 'primordial' disorder. Filip de Boeck and AbdouMaliq Simone show how cities in the global South deemed chaotic or uninhabitable represent alternative forms of urban living that are not best understood through a idealisation of Western urbanisation that is itself a poor reflection of the historical experience of, for example, London, Los Angeles or Sydney. ${ }^{16}$ The dual nature of the 'right to the city' lies, then, both in challenging structural inequalities and in reimagining the city in wholly different ways. ${ }^{17}$ Consistent with the absence of informal settlements on maps, Copperbelt research focussed for many decades almost exclusively on the mine townships and, to a lesser extent, on its municipal areas. The RLI's scholars recognised in the late 1950s that informal residents of Lusaka provided important services for the city's official areas, but nonetheless saw 'squatter' areas as places of disorder and moral and political threat. ${ }^{18}$ Researchers affiliated to CEPSI worked, as we will see, with the colonial authorities to create new periurban communities that would alleviate the threat they saw as arising from urban unemployment and resultant disorder. There was little appreciation that Copperbelt towns always depended on services provided by charcoal burners and night soil men, denied residence in mine towns but central to their existence.

Ultimately, Copperbelt towns proved unable to meet the aspirations for modern urban living of most of those who sought it out. While some senior workers bought into the middle-class lifestyle that came with success, others rejected the controls and conformity of the mine township. The high price of participation in the urban dream led some to relocate to new informal areas that grew up in Copperbelt towns after independence. While recent anthropological work has focussed on Copperbelt communities' creative use of post-modern space, we lack

15 Garth Myers, African Cities: Alternative Visions of Theory and Practice (London: Zed Books, 2011), p. 23.

16 Among other works, see Filip de Boeck and Marie-Francoise Plissart, Kinshasa: Tales of the Invisible City (Leuven: Leuven University Press, 2014); AbdouMaliq Simone (ed.), Always Something Else: Urban Asia and Africa as Experiment (Basel: Basler Afrika Bibliographien, 2016).

17 Henri Lefebvre, Le Droit à la Ville (Paris: Anthropos, 1968); David Harvey, 'The Right to the City', New Left Review, 53 (2008, September/October).

18 Myers, African Cities, pp. 31-2. 
detailed histories of the informal settlements where many thousands of Copperbelt residents lived, something to which this chapter makes a modest compensatory contribution. ${ }^{19}$ Through the experience of Kawama, on the outskirts of Mufulira, the chapter demonstrates how, when the state failed to provide formal housing, Copperbelt residents created new farming and trading communities that could access urban services while avoiding their costs. This demonstrates that informality is not a manifestation of the region's recent decline but has always been the invisible underside to its formal existence. The evidence suggests that, while the policing of boundaries between the different areas of Copperbelt towns was central to elite knowledge about their function and to the identity of many residents, flows and linkages between these areas - richer and poorer, formal and informal were key to their historical reality.

\section{Counting and Housing the Copperbelt African, 1945-1964}

From 1940, Katangese mining towns were demarcated into separate residential areas for mine and non-mine African workers. ${ }^{20}$ Improved worker housing was central to the efforts of UMHK and its allies in the Catholic church to promote social hierarchy, stability and ordered family life and to challenge the threat of religious and political 'extremism'. The UMHK, like the railway company BCK (Chemin de fer $d u$ bas Congo au Katanga), substantially improved the infrastructure of its 'camps', a term suggestive of their authoritarian nature, overseen by chefs de camps and fenced off from the wider town. Centres Extra-Coutumiers (CECs) were the state-controlled residential areas in which the wider African population resided. Post-World War Two development policies (see Chapter 2) spurred improved housing provision in both areas. The colonial authorities decreed a fixed minimum habitable space per person, which was steadily increased from $4.93 \mathrm{~m}^{2}$ in 1953 to $7.17 \mathrm{~m}^{2}$ in $1960 .^{21}$ Camps that once housed single male migrants were, by the early 1950s, mainly home to growing families. Healthcare provided by UMHK ensured that natal mortality in its camps fell from

19 For the contemporary Zambian Copperbelt, see Mususa, 'There used to be order'.

20 Dibwe dia Mwembu, Histoire des Conditions de Vie, p. 19. ${ }^{21}$ Ibid. 
30.24 per cent in 1947 to 24.15 per cent in 1957 , and then continued to fall. ${ }^{22}$

While its stabilisation programme solved UMHK's labour supply problem, it created a new demographic one. The company provided larger houses to workers with more children, creating a tacit incentive for larger families. Jadotville's (Likasi) population in 1954 was 58,406, of whom 21,358 were men, 19,324 women and 31,276 children. The town's population was split roughly 50-50 between mine and nonmine areas but roughly 60 per cent of all children lived in UMHK's camps. ${ }^{23}$ The company's annual reports, while typically lauding its achievements in family housing and social provision, expressed growing concern about the resultant costs. In 1952, when UMHK camps housed 59,610 people, 18,217 were men, 14,526 women and 26,867 children or 45 per cent of the total. ${ }^{24}$ By 1957 , the total population was 92,547: 21,857 men, 18,956 women and 51,734 children, 55 per cent of the total. ${ }^{25}$ The resultant pressure on company housing was such that UMHK began facilitating the relocation of some workers to CEC areas, where they could buy plots and build their own houses. ${ }^{26} \mathrm{By}$ Congolese Independence, two-thirds of mine camp residents were children. ${ }^{27}$

Housing provision by UMHK, allocated 'according to the size of the family and almost never according to the status of the worker', was praised by foreign observers such as J. D. Rheinallt Jones, 'native affairs' adviser to the Northern Rhodesian government, who conducted research on the welfare of African workers in Katanga, Southern and Northern Rhodesia in April-May 1951. Stating that it was 'far in advance' of provision elsewhere, he noted, among its qualities, that UMHK houses had openable glass windows whereas those south of the border simply had holes for ventilation. ${ }^{28}$ Northern Rhodesian mine townships, while superior to urban housing elsewhere in the colony, were of significantly poorer quality. The belated official

22 Dibwe dia Mwembu, Histoire des Conditions de Vie, p. 22.

23 BAA, 34 (6), KPC papers, Situation Politique et Administrative, March 1955.

24 UMHKA, 265, Services d'Afrique, Activities Report, 1952, p. 16.

25 UMHKA, 633, MOI Annual Report 1957, p. 34.

26 UMHKA, 633, Annual Report 1957, p. 35.

27 Dibwe dia Mwembu, Histoire des Conditions de la Vie, pp. 17-21.

28 ZCCM-IH, 17.4.3B, 'Housing and Social Services (Commission of Inquiry)', 1951-66, 'The Welfare of African Workers', J. D. Rheinallt-Jones, AprMay 1951. 
acceptance of family stabilisation in the late 1940s meant that thousands of single mineworkers resided in hostels until after independence and married couples lived with their children in cramped two-room houses. The post-World War Two boom, coupled with the general failure of rural development and accelerated migration to town (Chapter 2), generated an official anxiety that contrasts sharply with the confident interventionism of the Katangese authorities. A 1954 Northern Rhodesia government report is typical:

Rapid expansion has intensified all the problems concerning African affairs. Housing shortages, inadequate social services, political development, influx to the towns with the consequent danger of large numbers of unemployable Africans, all provide the responsible authorities with a formidable task. ${ }^{29}$

This growing population would, officials feared, be incapable of making the necessary 'transition' to urban societal norms: 'Most people still regard their real home as being elsewhere and have not yet taken root. Half the population lives upon employment in the copper mining industry. A marked characteristic is the protracted hospitality which Africans extend to any tribal or clan relative who comes in from the country'. ${ }^{30}$

It was difficult even to measure this ever-expanding and unstable society. The official population of Northern Rhodesia's five urban Copperbelt districts rose from 200,100 in 1951 to 236,000 in 1953, but these figures confused work and residential status: Mufulira's mine employed 9,725 men but it is not clear what the other 1,318 'other' male adult residents did for a living. Reports identified 6,981 women 'employees' (i.e. registered residents of mine township houses) and 1,142 'other' women; and 34,200 children of employees and 5,295 'other' children - many of these figures were in any case 'estimates'. ${ }^{31}$

In both Haut-Katanga and Northern Rhodesia, municipalities had grown up around mine areas: these were officially separate from mine operations and housing but were commonly dependent on the mine for

29 NAZ, WP 1/2/23, Provincial Annual Reports on Native Affairs, WP African Affairs Annual Report 1953, Senior Provincial Commissioner, Ndola, 22 March 1954.

30 ZCCM-IH, 3.8.1C, First Report on Regional Survey of Copperbelt, 1959, Special Commissioner for the Western Province, 'A First Report of a Regional Survey of the Copperbelt', 1959, p. 16.

31 NAZ, WP/1/2/64, Special Commissioner for Western Province Reports on Copperbelt, 1959-60, Annual Report, African Affairs, Kitwe. 
provision of piped water and electricity. ${ }^{32}$ In the mid-1950s there was considerable investment in non-mine housing: in Mufulira's main African municipal area, Kamuchanga, 750 new houses were built in 1958-9 and the oldest housing, essentially huts, was demolished. ${ }^{33}$ New house building, however, slowed considerably in the five years before independence, as a growing gap emerged between expectations of urban development and the limited funds available for housing projects. ${ }^{34}$ Employers were legally obliged to provide housing for their workers but, lacking the resources to do so, many built slumlike temporary residences. The population of Northern Rhodesia's municipal Copperbelt areas was estimated in 1960 at 11,924 men, 6,790 women and 16,081 children, a total of $34,795 .{ }^{35}$ Yet these figures did not include 'about 11,000 men, women and children lodgers, visitors and floating population in the municipal areas' ${ }^{36}$ In Kitwe it was estimated in 1954 that 25 per cent of its council area residents were living there illegally. ${ }^{37}$

Across the Copperbelt, it was then necessary to police the borders not only of mine and non-mine areas but equally of workers' families. The 1958 Rules and Regulations for Northern Rhodesian mine employees gave eleven instances in which a worker could be instantly dismissed, most of which related to residential rather than workplace behaviour. These included fighting in an African township, brewing beer or having beer in your possession without authority and housing a non-mine employee in a mine house. ${ }^{38}$ Warnings were constantly issued that urban social provision was reserved for those with a legitimate reason to be in town, assumed to be a male worker and his immediate family. In October 1958, an awareness campaign in Northern Rhodesia's rural areas explained that only children whose

32 NAZ, WP 1/2/64, Special Commissioner for Western Province, Reports on Copperbelt, 1959-60, draft report on 'Municipalities and Towns', p. 3.

33 NAZ, WP 1/2/45, Annual Report African Affairs, Ndola, 1957-61, 'Annual Report of African Affairs, Mufulira, 1958', Ch. 8, np.

34 NAZ, WP 1/2/66, DCs Reports 1960, 'Annual Report on African Affairs, Mufulira', p. 13.

35 NAZ, WP 1/2/64, Special Commissioner for Western Province Reports on Copperbelt, 1959-60, Annual Report, African Affairs, Kitwe.

36 Ibid.

37 NAZ, ML, African Housing on the Copperbelt, 1950-60, minutes of a meeting of Copperbelt DCs, Kitwe, to discuss African Housing Problems, 4 March 1954.

38 ZCCM-IH, 17.2.3B, ZMU local dispute NCR, 1964-7, Press Release, Zambia Information Service, 9 June 1965. 
parents were in employment would obtain Copperbelt school places. ${ }^{39}$ The Copperbelt African Education Department issued explicit instructions:

The pressure on African schools on the Copperbelt is so great that certain regulations are in force to control entry.... In no circumstances are children from rural areas allowed to enter urban schools. It frequently happens that children come from a rural area to live with some relation, other than their biological parents, to seek entry to schools here. ${ }^{40}$

The willingness of African urbanites to police their family boundaries was itself considered a measure of their break from 'traditional' values:

Higher wages are alleged to have led to an increase of 'hangers on' and indigent relatives. The solution is not simple. Employers like to have a labour pool available; the African has traditional responsibilities to relatives and an intensification of the enforcement of pass laws is undesirable. The remedy lies in the hands of the Africans ... and they must realise that if their standard of living is to improve, they must be less tolerant to idle relatives and friends. ${ }^{41}$

Action was periodically taken against those illegally occupying houses. In Chingola, four raids were carried out by the Location Superintendent in July 1959, with 253 'loafers' detained, 188 charged and 55 homes made available. ${ }^{42}$ The model of a productive population of nuclear families had consequences for unmarried women. In Luanshya, the resultant dilemma was captured in a 1958 report:

Moral persuasion was tried to induce abandoned wives, old women and stray females to return to their villages, but resistance always proved strong. In any case many women cannot now be fairly returned to villages which they have never known ... The compounds must carry their proportion of sick, aged, immoral and workshy. The District Officer is very much concerned to contain the loafer problem, but he also remains, as in other spheres, the

39 NAZ, WP 1/3/3, 'General Policy on the Copperbelt 1957-67 (African Education)', African Education Department memo, 'Admission of Children of African Civil Servants to Schools on the Copperbelt', 8 October 1958.

40 NAZ, WP 1/3/3, 'General Policy on the Copperbelt (African Education)', Provincial Education Officer C. H. Green to all Departments, Western Province, 8 October 1958.

41 NAZ, WP 1/2/23, Provincial Annual Reports on Native Affairs, WP African Affairs Annual Report 1953, Senior Provincial Commissioner, Ndola, 22 March 1954.

42 NAZ, WP 1/2/61, Report of Director of African Affairs, Chingola, 1959, Municipal Council Chingola, African Affairs report, July 1959, p. 1. 
buffer between the mine and municipal authorities on the one part, who want the compounds as clean, hygienic and active as possible, and the people, who are naturally resistant to logical and perfectionist attitudes. ${ }^{43}$

In practice, then, many Copperbelt migrants had no right to be in town. Many interviewees initially lived with extended family members while they sought work or education. William Chinda arrived in Mufulira to stay with his mineworker uncle in Kankoyo. Although not an immediate family member, he benefited from foodstuffs supplied by the mine company; his uncle paid for his schooling while he searched for work. ${ }^{44}$ George Mwenda likewise stayed with his brother in Kankoyo Section 7 on arrival in $1957 .{ }^{45}$ Cyprien Ramazani came to stay with his aunt in Katanga in 1956: she lived with her husband in the BCK railway compound and Ramazani was able to obtain a job with the rail company after attending free company-provided schooling. ${ }^{46}$ Similarly, Edouard Nkulu arrived in Elisabethville in 1961 and stayed in the house of his brother, a UMHK employee, while he attended school. ${ }^{47}$ While mine companies insisted on the nuclear family model for housing their workers, evading its strictures was in practice central to the strategies of many migrants who came to work for them.

The true scale of Northern Rhodesia's unofficial urbanisation was only revealed in 1963, with the first census of Copperbelt towns: Kitwe's African population, estimated in 1962 as 98,781, was found to be 109,116 . The District Officer explained:

The reason for this discrepancy is that the number of 'unauthorised' residents was gravely underestimated. For example, in the Mine Townships it was thought that $10 \%$ of the residents might be unauthorised, whereas in fact the figure should have been $21 \%$. This ... underlines the fact that neither the Mine nor the Municipality have any control whatsoever over their housing areas. ${ }^{48}$

There was, unsurprisingly, a growing housing shortage 'that is never likely to be met'. ${ }^{49}$ Kitwe city council controlled 8,881 residential

43 NAZ, WP 1/2/43, African Affairs Annual Report, Luanshya, 1957-60,

'Luanshya Affairs Annual Report', 1958, Ch. 3, p. 3.

44 Interview, William Chinda, Mufulira, 8 August 2018.

45 Interview, George Mwenda, Mufulira, 7 July 2018.

46 Interview, Cyprien Ramazani, Likasi, 5 June 2018.

47 Interview, Edouard Nkulu, Likasi, 12 June 2018.

48 NAZ, WP 1/2/74, Native Affairs Annual Reports, 1963, 'Kitwe District Annual Report on African Affairs', p. 5.

49 Ibid. 
properties and had a waiting list of 3,036 families: 'The social evils to which this state of affairs gives rise needs no emphasis, and the provision of housing by itself is no solution to the problem [which] is not a municipal one but a national one'. ${ }^{50}$

At the other end of the social scale, attempts were made to develop specialist housing for 'advanced' Africans. In 1959 Mufulira's municipal council agreed that 'better class' homes for 'middle class Africans' needed to be located separately from its main African housing area. ${ }^{51}$ Such efforts were, however, undermined by racialised conditionalities that demanded the 'right kind' of African middle-class household:

some measure of social segregation is in practice desired by all races.... subleases must contain a suitable clause by which they covenant to use the houses for the accommodation of a limited number of persons only. ... an African shall accommodate only his immediate family. It is proposed that a breach of this covenant shall be a ground for the termination of the lease. ${ }^{52}$

Mine companies worried about the dislocating effects on 'advanced' Africans of relocation to hitherto whites-only areas:

Employees in this class will probably aspire to European social amenities; the welfare amenities, beer halls and clubs in the Mine Townships will not satisfy them. At the same time, they will not, initially at least, be acceptable in ordinary European circles ... There is a serious danger that Africans in this class will become embittered if their normal contacts with people of their own race are disrupted and they fail to gain acceptance in European circles. ${ }^{53}$

It was thought that modernisation training might be needed for newly promoted African families:

the Committee considered the possibility of familiarising Africans with modern standards of housing by the provision of 'transitional' houses for those who were noted as likely candidates for entry to European jobs. It was agreed

50 NAZ, WP 1/2/74, Native Affairs Annual Reports, 1963, 'Kitwe District Annual Report on African Affairs', p. 12.

51 Mufulira Council meetings, Town Development and Works Committee, 2 September 1959 , p. 4.

52 NAZ, ML, Control of Alienation to Africans in Urban Areas, 1954-8, 'Note for Exec Council, MLC Health, Lands and Loc Govt H. J. Roberts', 26 November 1954.

53 ZCCM-IH, 16.3.9C 'Special Sub-Ctte, Housing, Senior African', December 1960- August 1977, minutes of first meeting, 28 December 1960, p. 6. 
that African women generally tend to be more backward than their husbands, and that the facilities and conveniences available in modern houses tend to be disused or misused ... the Welfare department should consider giving special domestic training to the wives of employees selected for senior posts. ${ }^{54}$

As this suggests, mine companies invested heavily in socialising their workforce into the 'right' way to live in town. The UMHK's Mwana Shaba newspaper, started in 1957, published articles advising mineworkers and their families on how to manage their wages, socialise in 'civilised' ways while drinking in moderation and keeping their homes in a 'respectable' manner. Company-funded cultural groups provided theatrical and musical lessons on how to avoid marital conflict (Chapter 7). Women were advised and trained by company-employed social workers on how to be modern housewives and mothers, manage a household budget and keep a clean and respectable family home (Chapter 5). Children learned via company-sponsored sports and leisure activities how to accept rules and to play well in teams, and generally to avoid the temptations of idleness. ${ }^{5}$

Induction in town life was, as suggested, also provided by the extended urban community. Older relatives, uncles and brothers, helped their younger kin navigate the town and make a good life there. While there was significant disagreement about what that good life might involve (see below), there was a consensus that it was 'new' and could be instructively counterposed to that of the village. Guidance on urban marriage was provided by church elders, while ethnically based associations helped people manage the distinct burdens of an urban death. Diverse processes of socialisation were then at the heart of town life. While the late colonial Copperbelt saw efforts by mine companies and states to fix mobile Africans into designated spaces and rigid identities, many African urbanites engaged with and partly bought into the construction of this urban respectable identity, while also making it their own, something that is helpfully historicised by former senior railway official Emile Ngoy Muyondwe:

54 ZCCM-IH, 16.3.9C, 'Special Sub-Ctte, Housing, Senior African', minutes of second meeting, 17 January 1961, p. 3.

55 Interview, Josephine Lukwesa, Mufulira, 8 July 2019; Miles Larmer and Rachel Taylor, 'The Decolonisation of Community Development in Haut-Katanga and the Zambian Copperbelt, 1945 to 1990', in Larmer et al. (eds.), Across the Copperbelt, pp. 321-346. 
When the whites arrived, there was a distance between the colonizers and the colonized. The blacks had to have a permit and a good reason to come to town ... Over time, we started to understand that we had to make black people responsible, that's when we started talking about the evolué, that is to say those who were close to the European mentality by the way of dress, cleanliness, level of education. ${ }^{56}$

For some at least, African urban residency required a performance of modern living by African elites that would continue well after political independence.

\section{Maps and Meanings of the Late Colonial Mine Town}

Here it is useful to map the formal areas of the towns of Mufulira and Likasi (Figures 3.1 and 3.2). On both sides of the border, Copperbelt towns were divided into mine-controlled areas containing shafts and winding gear, overground plant and processing areas and mine townships or camps. The latter were then divided into areas for unskilled and skilled workers, as well as smaller areas for senior workers and managers, originally segregated by race. In Mufulira, Kankoyo, adjacent to the mine plant, housed most low-skilled African workers, while the older Kantanshi township housed the growing number of African skilled workers. Fairview, the area reserved for Europeans, was gradually opened up to the few senior Africans. In Likasi, Panda was the main African mine camp, Shituru housed workers employed in the UCS chemical factory that became part of Gécamines in the early 1970s and there was also a BCK (later SNCC/SNCZ) company camp that housed the town's railway workers and their families. ${ }^{57}$ Mufulira's main council-controlled area was initially known as 'the Location' and later as Kamuchanga. Chibolya was built by Costain to house construction workers and became home to many poorer salaried workers. ${ }^{58}$ In Likasi, the non-mine area was known as Kikula, a CEC cité where, like Kenya in Lubumbashi, many of those not directly employed by a large company resided.

56 Interview, Emile Ngoy Muyondwe, Likasi, 19 June 2018.

57 SOGECHIM (Société Générale Industrielle et Chimique du Katanga), a subsidiary company of UMHK that became UCS (Usines Chimiques de Shituru).

58 NAZ, WP 1/2/66, DCs reports, 1960, 'Annual Report on African Affairs, Mufulira', p. 5. 


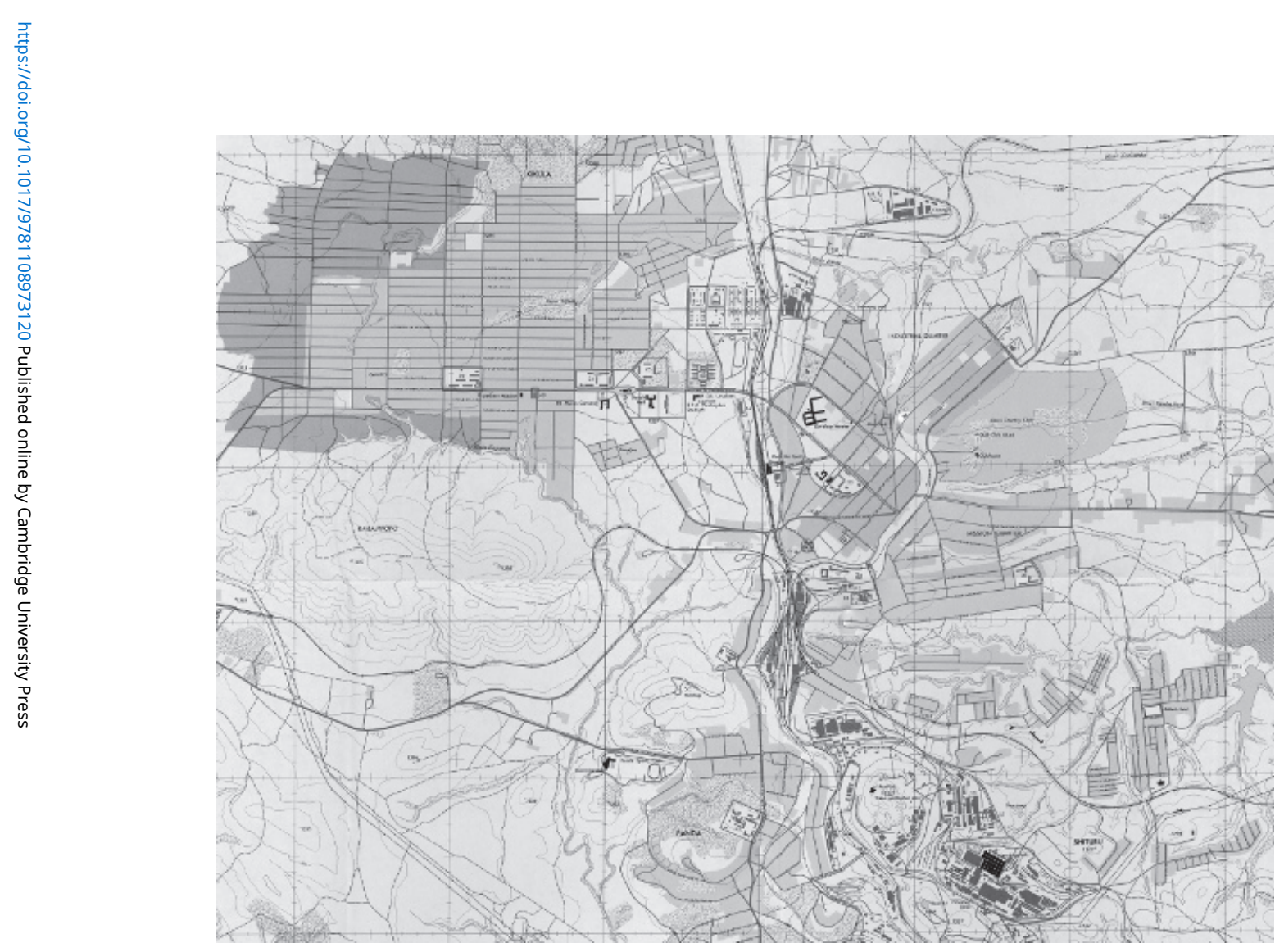

Figure 3.1 Map of Likasi, Zaire, 1980 (detail from). US Defense Mapping Agency. Courtesy of the University of Texas Libraries, The University of Texas at Austin. 


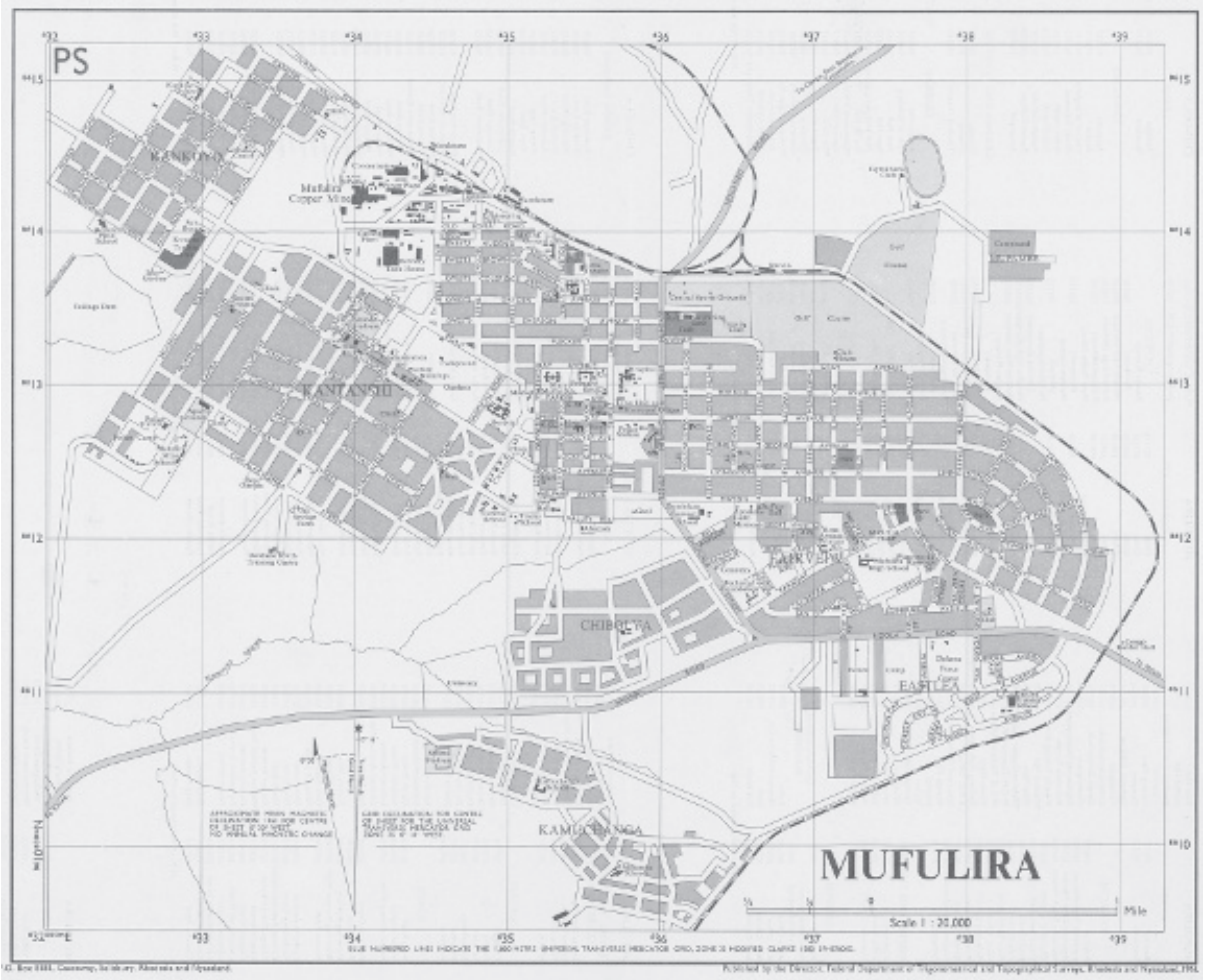

Figure 3.2 Map of Mufulira, 1961. Rhodesia and Nyasaland Federal Department of Trigonometrical and Topographical Surveys. Reproduced with the permission of the National Library of Scotland. CC-BY 4.0, https://creativecommons.org/licenses/by/4.0. 
These areas acquired distinct identities reflecting their ownership and control, but also the supposed character of their inhabitants. Powdermaker's description of her Luanshya research 'setting' captures the characteristics of mine township and municipality that is echoed in our interviews:

The African mine township also seemed to have more unity, more security, more parochialism than did the municipal location. ... the more heterogeneous life on the municipal location accompanied a greater sense of participation in the modern world and that, in general, these people were a bit more cosmopolitan in their orientation than were those who lived in the mine township. $^{59}$

Interviewees, while recalling that all urban areas used to be cleaner and better managed than today, emphasise the especially ordered nature of mine areas. ${ }^{60}$ Virtually all interviewees recalled mine townships/camps as places where the company managed public space, maintained housing and ensured residents' health by regular inspections of neighbourhoods and house interiors. ${ }^{61}$ Characteristically, former UMHK/ Gécamines residents express gratitude for such intrusive care. Some, such as David Kalabo Mupanga, born in company clinics and later pupils at its free primary schools, still characterise themselves as 'enfants Gécamines'. ${ }^{62}$ Former ZCCM workers, while praising the good housing and services of the past, recall these in more neutral terms, seeing them not only as the result of company generosity but also union demands (see Chapter 4). ${ }^{63}$

Life in Panda was, under the watchful company eye, a highly regimented existence. ${ }^{64}$ Until independence, a curfew ensured that residents were within the camp by $9 \mathrm{pm} .{ }^{65}$ It was forbidden to operate a private drinking place and making noise in the evening was prohibited to ensure

59 Powdermaker, Copper Town, p. 9.

60 Kabwika Ntanda Kadisabula, who grew up in Kikula as the child of a bank worker whose company housed him there, recalls it was cleaned regularly by the municipality: interview.

61 Likasi interviewees: Batho Nkomba, 6 June 2018; Sara Léontine Bulanda; Thérèse Kyola, 7 June 2018; Pami wa Kasongo, 7 June 2018; René Mwamba Kasongo, 8 June 2018. For Mufulira, Gertrude Dhaka, 2 August 2018.

62 Interview, David Kalabo Mupanga, Likasi, 5 June 2018.

63 Mufulira interviews: Boston Mwenya, 10 July 2018; Henry Longwane, 7 July 2018.

64 François Kake interview.

65 Interview, Ferdinand Kakompe, Likasi, 19 June 2018. 
workers were fresh for their morning shift. ${ }^{66}$ Non-mine areas were more relaxed: residents, unconstrained by the company monopoly over housing and leisure services, were freer to socialise on their own terms. Jacques Kibombo recalls that, "[i]n the evening ... everyone was in his plot ... In Likasi to have fun you had to go to the city centre ... People were disciplined in Panda, they did not take too much alcohol'. ${ }^{67}$ Séraphin Musoka also remembers visiting Kikula to drink beer: 'There is a difference between the [mine] camp and the city. At camp, you feel constrained; in the city, it's open; we are having fun'. ${ }^{68}$ In Mufulira, the council area was considered by Kankoyo residents as a place where 'rough people' lived, where mineworkers could drink and easily attract women with their monthly wages. ${ }^{69}$ Chibolya was a particularly neglected or 'dark' location where, William Chinda recalls, ' $[\mathrm{t}]$ here were a lot of thugs, fighting, molesting people'. ${ }^{70}$ There was, then, a symbiotic relationship, economic and social, between these ostensibly bounded spaces. Interviewees recognised that mineworkers' salaries provided a monthly windfall for the myriad small businesses and places of entertainment they frequented in non-mine areas. ${ }^{71}$ Those who were not employed by the company, even those who chafed at its paternalist controls, recognised that their fortunes and those of the whole town were tied to it.

The timeless contrasts drawn by interviewees between these areas tend to dehistoricise their evolution, reflecting changing notions of what was considered 'modern' as well as demands for improved housing and urban services by residents and activists (see also Chapter 4). A 1961 inquiry by the Northern Rhodesia 'urban African services committee' into township amenities concluded, for example, that pit latrines were now unsatisfactory and that 'there was justification for providing street lighting and tarred roads at least in parts of African Housing Areas'. Despite such improvements, municipal residents still seemed to be in perpetual transition to fully fledged urbanity:

A settled family and community life has not yet been achieved by the urban African and progress towards this objective has been retarded ... where

66 Interview, Banza Mutunda, Likasi, 4 June 2018.

67 Interview, Jacques Kibombo, Likasi, 11 June 2018.

68 Séraphin Musoka interview.

69 Interview, Chrispin Chani, Mufulira, 30 July 2018.

70 William Chinda interview.

71 Interview, Batho Musumba Nkomba, Likasi, 6 June 2018. 
populations comprise a mixture of people of many different tribal origins. African urban communities are partly detribalised but not yet fully urbanised and, consequently, are unsettled in their mode of living which follows a rather loose pattern falling somewhere between tribal and town life. ${ }^{72}$

In these unsettled circumstances, a close watch was kept on 'unauthorised compounds', preventing these consolidating themselves into permanent squatter camps. In Mufulira, scattered peri-urban residents were deliberately concentrated in Kansuswa, an area on the town's outskirts (and outside the mapped area shown in Figure 3.2) that was encouraged towards formal existence and regulation in the late $1950 \mathrm{~s}^{73}$ Initially regarded by officials as an uncontrolled place of drinking and wild living, it came to be recognised as a legitimate part of town:

One indication that the residents of Kansuswa now tend to look upon themselves as a single body with common interests, rather than as a sort of urbanised village [is that] ... [f] aced with the inevitable Copperbelt problem of heavy overcrowding in the school, the townspeople got together and built another school block ... entirely on their own initiative, and paid for mainly by money from their own pockets. ${ }^{74}$

\section{Decolonisation, Separation and Integration}

In the run-up to and following independence, African nationalists challenged the enclaving of mine company operations. This occurred economically via nationalisation (Chapter 6) but also spatially: why should mine townships be separated from the towns of the Copperbelt, with housing and social services controlled by companies rather than by elected authorities? In Haut-Katanga, demands for integration were relatively limited: mine camp residents participated in the elections of March 1960 and it proved impossible to isolate them from that year's political revolutions (see Chapter 4). Secessionist conflict did not spare mine areas: the violence directed at ethnic Kasaians drove 71,266

72 ZCCM-IH, 17.4.3B, 'Housing and Social Services (Commission of Inquiry)', 1951-66, 'Report of the Urban African Services Committee Appointed to Review the Financing of Services and Amenities Provided for Africans in Urban Areas', 1961.

73 NAZ, WP 1/2/45, Annual Report African Affairs, Ndola, 1957-61, 'Annual Report of African Affairs, Mufulira, 1958', p. 1.

74 NAZ, WP 1/2/45, Annual Report African Affairs, Ndola, 1957-61, 'Annual Report of African Affairs, Mufulira, 1957', p. 5. 
people out of Katanga in May-October 1962; UMHK lost nearly 8 per cent of its workforce. ${ }^{75}$ While UMHK mine camps never recovered their former depoliticised form, they continued to be distinct legal and economic entities, under both the secessionist state and the subsequent Mobutu regime. Johannes Fabian's ethnographic research in 1966-7 on the Jamaa Christian movement focussed on Musonoi, one of Kolwezi's mine camps. Fabian observed the authoritarian nature of Musonoi, its totalising system of control and welfare and, citing Moutoulle from 1946, its essentially unchanged 'colonial' nature in which the mine company system 'consists of all normal means for making the black worker like his work and stay attached to it as long as possible'. ${ }^{76} \mathrm{He}$ highlighted the intrusive powers of the Chef de Camp, noting that any large festive occasion required his permission and for which a guest list had to be provided in advance. Fabian conceded, however, that living standards were higher than in rural areas, particularly with the significant decline in village health and education services following independence. Some mineworkers appreciated its regime:

For them it worked as an effective and necessary means of protection against unwanted visitors and the usual crowd of parasites in a situation where resources are limited and the rights and duties of hospitality are no longer guaranteed by the sanctions of traditional society. ${ }^{77}$

In Northern Rhodesia, plans were developed to integrate mine townships into unified systems of municipal administration. In 1960 it was proposed that ownership and control of mine housing, as well as roads, medical, social and welfare services, would be transferred to relevant municipalities, leaving only the mine and production-oriented workplaces under company control. ${ }^{78}$ Detailed negotiations took place between government officials, keen to integrate mine communities into the nation-in-the-making, and companies, keen to divest themselves of townships that would, in the context of union demands and political pressure for elected representation of their populations, prove an increasing cost burden. In February 1962 the mine companies

75 Dibwe dia Mwembu, Bana Shaba, pp. 122-3.

76 Léopold Mouttoulle, Politique Sociale de L'UMH (Brussels: Mémoire de L'IRCB, 1946), p. 11, quoted in Johannes Fabian, Jamaa: A Charismatic Movement in Katanga (Evanston, IL: Northwestern University Press, 1971), p. 57.

77 Fabian, Jamaa, p. 63.

78 ZCCM-IH, 11.4.7E, 'Integration of Mine and Public Townships', March 1960, Mufulira Copper Mines, R. L. Prain to Directors, 1 March 1960. 
explained that their objectives in 'getting out of the housing business' (except European and senior African housing) were fourfold:

I to reduce pressure on the companies for better housing, particularly on the African side;

II to reduce possible future political interference by concentrating our activities on mining;

III to put more responsibility back on to employees;

IV to put the housing emoluments directly into pay packets. ${ }^{79}$

Although the change would involve an estimated $£ 3.1 \mathrm{~m}$ rise in annual costs arising from increased salaries to cover full household rents, companies would avoid the future outlay of capital on housing and other services. ${ }^{80}$ Though AAC was concerned about future pressure on companies to pay higher rates to municipalities, the security implications of losing control of the townships and the 'likelihood' of their decline into 'slum conditions', it was felt that the benefits would outweigh the risks. ${ }^{81}$ Opposition among African workers was anticipated but not expected to prove insurmountable and companies pursued rapid integration in the opportune moment of decolonisation. The companies would then be protected from demands by workers 'for better living standards which already have probably got a little out of hand ... The demands would in the future come on to house owners, e.g. municipalities ... and these bodies are expected more effectively to be able to withstand such demands than the companies'. ${ }^{82}$

In June 1964, as agreement with government seemed close, a substantial increase in rent designed to reflect actual housing costs was delayed because 'it will be important for the Companies not to be associated with the increases'. ${ }^{83}$ The companies agreed:

79 and Housing on the Copperbelt', notes for discussion with Head Office,

80 Ibid., p. 6.

81 ZCCM-IH, 14.2.9B, 'Mine Townships', January 1961-April 1964, 'Informal meeting of Head Office representatives of Anglo American and RST groups', 20 August 1963, p. 2.

82 ZCCM-IH, 14.1.2B, 'Housing (Labour Mine Township)', 1962-5, Memo, G. S. Brebner, 'Housing for Copperbelt Employees - Finance', 21 February 1962, p. 4.

83 ZCCM-IH, 14.1.2B, 'Housing (Labour Mine Township)', 1962-5, Inter-Group Housing Committee Meeting, 12 June 1964. 
We should make the proper show of reluctance to integrate our townships and put the responsibility firmly on Government to initiate the next stage. (If the companies take the initiative, it will inevitably be received with suspicion by the municipalities and employee organisations.) $)^{84}$

Presenting township integration in talks with government as a progressive step consistent with decolonisation enabled the companies to disguise their motives for divestment:

We appreciate that mine townships can be rightly regarded as paternalism and as such are apparently inappropriate to today's conditions. We accept that as the country develops, standards and priorities for housing and amenities should be decided by the people as a whole and not by a group of employers. ... we also accept that the position where a man's house is tied to his job should only be a transient phase in the development of the country. ${ }^{85}$

By independence in October 1964, the government and companies had agreed the main principles for incorporation. ${ }^{86}$ Draft legislation was drawn up in early 1965, interim arrangements put in place for the companies to support the municipalities in managing their increased responsibilities, and April 1965 agreed as a potential handover date. ${ }^{87}$ This date came and went, but in May 1965 Minister of Local Government Sikota Wina publicly restated, without explaining the delay, that integration remained the government's aim. ${ }^{88}$ The postindependence government, perhaps realising the political sensitivity and economic burden that managing the mine townships would bring, belatedly insisted that 'incorporation' should require the retention by the companies of the high density housing stock where most mineworkers and their families lived. ${ }^{89}$ Meanwhile, the mineworkers'

84 ZCCM-IH, 14.1.2B, 'Housing (Labour Mine Township)', 1962-5, 'Township Integration Inter-Group Meeting', 3 July 1964.

85 ZCCM-IH, 14.1.2B, 'Housing (Labour Mine Township)', 1962-5, Aide Memoire for Negotiations, 11 July 1964, pp. 1-2.

86 ZCCM-IH, 14.1.2B, 'Housing (Labour Mine Township)', 1962-5, Permanent Secretary Ministry of Local Government to Loder (AAC) and Reid (RST), 3 October 1964.

87 ZCCM-IH, 14.1.2B, 'Housing (Labour Mine Township)', 1962-5, 'Township Integration', RST VP Industrial Relations to President, 13 April 1965.

88 ZCCM-IH, 14.1.2B, 'Housing (Labour Mine Township)', 1962-5, 'Mine Townships Integration', Speech by Sikota Wina to Municipal Association, 19 May 1965.

89 ZCCM-IH, 14.1.2B, 'Housing (Labour Mine Township)', 1962-5, Companies to PS Ministry of Local Government, draft, n.d. but $c$.July 1965. 
union expressed concern that housing standards would decline following incorporation and insisted that the companies continue to provide all services. ${ }^{90}$ Integration did not take place and the mine townships continued to be owned and run as separate entities until the late 1990s, but this episode reveals that this was by no means inevitable. In HautKatanga, however, UMHK/Gécamines' commitment to the company township model endured; following the secession, and notwithstanding the tense relationship between the company and the Mobutu government (see Chapter 6), its centrality to the Congolese/Zairian economy meant that it continued to operate in relative political isolation. Contrary, however, to Fabian's assumptions that this would keep the camps, now officially referred to as cités, in a (post)colonial limbo, the company's authoritarian paternalism ultimately proved entirely compatible with the patriotic neo-paternalism of the Mobutu era.

\section{Keeping Up Appearances: Social Mobility and Hierarchy in the Postcolonial Mine Towns}

Political independence did not, then, transform the Copperbelt's spatial order: while the virtual collapse of influx control made it easier for rural migrants to settle in town, the many other divisions - between mine and non-mine areas and between unskilled and 'advanced' workers - continued to be central to the lived experience of residents. Certainly, interference by company officials in the households of Gécamines families did not lessen with independence and nationalisation. Jérôme Mulunda was a Chef de Cité in Panda during the 1970s, overseeing both workplace and township:

At Gécamines, a cité chief is practically a village chief.... I had two assistants who took care of the personnel management itself, that is to say the disciplinary regime. At Gécamines, it was a must: five minutes late, we send you back ... you stay at home and you will not be paid for that day.... We were taught to manage not only the staff but their families as well. In Panda here I had 3,300 workers. And the Panda population at the time was almost 20,000 people. Panda ... was better organized than the municipal office to the point that, at that time, to live in my cité, you needed a permit. If you are visitors, you come to us, we give you permission to stay, for example thirty

90 ZCCM-IH, 14.1.2B, 'Housing (Labour Mine Township)', 1962-5, 'Meeting with UN Mission on Urban Planning and Housing', 10 August 1965. 
days. ... So it taught us how to manage well, leadership and good governance. ${ }^{91}$

Many Likasi interviewees praised the company's intervention in their daily lives:

It was not a bad thing that Gécamines, through the Chef de Cité, got involved in the social life of its workers ... these houses belonged to Gécamines. We did not own them. And so, there were provisions to improve life in the Gécamines camps. In particular, ensuring the cleanliness of the environment, because a dirty environment promotes disease. ${ }^{92}$

Continual attempts were made to control the presence of unauthorised residents, practices framed by the imperatives of security and order. In 1972, for example, the company

reminds personnel/cadre that it is absolutely forbidden to house "personnes étrangers and their families in the houses placed at their disposal. A special dispensation will be accorded temporarily to limited stay by workers' parents.... These measures are enacted in the interest of all; their purpose is to limit the possibilities of theft and to maintain calm and security in the different quarters of the cité $^{.93}$

In Mufulira, likewise, interviewees praised company township management in the 1970s and 1980s in characteristically modernist terms. Jennifer Mulenga, who first stayed in Mufulira as a child in the 1960s and returned as a teacher in the 1980s, recalled: 'The place was more developed and the levels of civilisation improved.... the mine company was strict with cleanliness'. ${ }^{94}$ Patson Katwisi fondly recalls monthly house-cleaning competitions:

inspection was carried out home to home and if it was found that your surrounding was bad and your house was bad ... you got punished in one way or another. So that [was] inculcated so much in people's minds. We thought they were forcing it on us but eventually we realised to it was for our own good. They gave prizes given to the cleanest house. ${ }^{95}$

91 Interview, Jérôme Kipili Mulunda, Likasi, 4 June 2018.

92 Interview, Ilunga wa Kumwanza, Likasi, 26 June 2018. See also interview, Euphrasie Yowa, Likasi, 14 June 2018.

93 GCM Likasi Personnel Archives, Representant de la Direction Génerale a Likasi, 'Avis au Personnel de Cadre de Likasi', 13 June 1972.

94 Interview, Jennifer Mulenga, Mufulira, 13 July 2018.

95 Patson Katwisi interview, 3 July 2018. See also interview, Victoria Mwelwa, Mufulira, 17 July 2018. 
For some residents, however, such controls encouraged a passive mentality:

Here it's a town, people are free to do whatever they want and whenever they want. But in workers' camps, they ... depend on the regulations or the course of action of their companies. And, they only have their remuneration at the end of the month but in the cité people manage differently and they can get money at any time. ${ }^{96}$

The ultimate aim of many urbanites was acquiring a home of one's own in town. But housing status remained, until the 1990s, closely tied to and dependent on employment: in Zambia in particular, workers could only move to larger houses in more desirable areas when they were promoted. Emelia Banda, whose husband worked for the Olympic milling company in Mufulira, first lived in Chibolya in a single-room house with no electricity and a single communal tap for water. She was, however, able to move after independence to a bigger house in Kamuchanga with two bedrooms, a sitting room and a kitchen with its own water supply. ${ }^{97}$ For Mufulira's mineworkers, the move from Kankoyo, where the majority of unskilled workers lived, to Kantanshi, which after independence was home to the growing population of skilled African workers, was a visible sign of progress, giving some access to the better social amenities of the low-density areas originally created for whites. ${ }^{98}$ Zambian mineworkers were granted larger houses when they married - single men moved from old hostels and shared accommodation to small family houses with three or four rooms - but family size was less significant than in Haut-Katanga, where it remained the key determinate of house size. ${ }^{99}$

While modest pensions were paid to retiring mineworkers, they were still obliged to surrender their company houses on retirement. While some senior employees could afford to buy land and build their own properties, most retirees instead shifted to other areas of town, often informal settlements and peri-urban areas. Pensions were far from sufficient to live on - retirees eked out a precarious existence, depending on a combination of casual labour, farming and remittances from children. While conditions were difficult, very few interviewees

\footnotetext{
96 Pami wa Kasongo interview.

97 Interview, Emelia Banda, Mufulira, 16 July 2018.

98 Interview, Bobby Jackson Kabamba, Mufulira, 10 July 2018.

99 Interview, John Mule, Mufulira, 12 July 2018.
} 
seriously considered 'returning' to their village of origin. In HautKatanga many had now been in town for three generations and had few if any links to their place of origin. In Zambia, where some more recent migrants were still linked to rural areas by kinship migration and remittance payments, village retirement was, as Ferguson revealed, often a fraught process involving conflict with relatives and a struggle to come to terms with the hardships of rural life. ${ }^{100}$ As the gap grew between village and town life, many urban residents, like those Fabian met in Musonoi, sought to avoid the demands made upon them by kin. Evans Nsabashi, for example, moved from Kitwe to Mufulira precisely to lessen that load: 'I had stayed in Kitwe for a long time and hence did not want to stay close to my relatives.... Relatives would trouble me in terms of buying them things and keeping them as well. I needed some time to establish myself'. ${ }^{10}$

The most senior Zambian mineworkers, now resident in formerly whites-only areas such as Fairview, often adopted their 'middle-class' lifestyle. Patson Katwisi took up tennis on company-run courts and socialised with colleagues of a similar rank at the golf club. ${ }^{102}$ It was vital for those promoted to senior positions to socially distance themselves from ordinary workers: Kathbert Nchema, who moved from Kantanshi to Fairview in the early 1970s following his promotion to Shift Boss (one of the first Africans to hold this senior position), recalls that promotion depended on the company's assessment of you in and out of work:

How were you presenting yourself? Were you a person who would just drink in all these pubs in the township? ... as you were getting higher in the ranks, we were advised not to drink with our subordinates.... I opted not to drink in crowded places and I liked to go to maybe the rugby club, squash club and then I became a member of Royal Order of Buffaloes and I am still a life member and I still go there because I could have a few bottles with colleagues, mingle around with several friends there. So discipline was good for me. ${ }^{103}$

Likewise, former UNIP councillor Chrispin Chani recalls: 'As [a] member of [Mufulira] Blackpool [football] club I and my family members went to watch football matches free of charge and [were] sitting in VIP sections. The Country club was a drinking place for respectable members in

100 Ferguson, Expectations of Modernity, pp. 128-64.

101 Evans Nsabashi interview. 102 Patson Katwisi interview.

103 Interview, Kathbert Nchema, Mufulira, 9 July 2018. 
society. Belonging to these clubs also widened your political base' ${ }^{104}$ Senior staff in Zambian mines were entitled to loans to buy cars and houses, paid back from salary deductions. ${ }^{105}$ They could not, however, be members of trade unions and were discouraged by ZCCM from involvement in politics. ${ }^{106}$

Jacques Mangenda, who as a Gécamines chemist trained in the late 1960s to become a 'cadre', a managerial-level employee, was accordingly housed in an area still occupied mainly by whites: Africans living there, he explained, needed to show that they could behave in a civilised manner ('ils devaient montrer la civilisation'). ${ }^{107}$ Emile Ngoy Muyondwe argues that a 'respectable' worker could not socialise in Kikula because of the unruly behaviour of drinkers there. ${ }^{108}$ Ilunga wa Kumanza recalls envy directed against senior Gécamines officials: 'Jealousy existed, at Gécamines itself. Some junior workers there were jealous of me. Workers of other companies envied us. ... The unemployed also envied and were jealous of Gécamines workers'. 109

While social life in Haut-Katanga's post-independence mine townships was divided on a class basis, a degree of social integration was enabled by 'cultural associations', in a context in which ethnicity was tacitly central to political representation. ${ }^{110}$ While residential ethnic mixing continued to be company policy during his time as Panda Chef de Cité, Jérôme Kipili Mulunda saw no contradiction between this policy and his presidency of Ceproma (Cercle pour la Promotion de Marungu). In this group, he explains,

members of the Tabwa tribe, who hold positions of responsibility within different companies, facilitate the hiring of the children of their Tabwa brothers ... I greatly facilitated the integration of my Tabwa brothers who came to settle in Likasi, thanks to my knowledge. Thanks to me, they could easily find their tribal brothers who already lived in Likasi. ${ }^{111}$

\footnotetext{
104 Chrispin Chani interview, 16 July 2018. 105 Simon Bwalya interview.

106 Owess Nkhama interview.

107 Interview, Jacques Mangenda, Likasi, 7 June 2018.

108 Emile Ngoy Muyondwe interview.

109 Ilunga wa Kumanza interview, 26 June 2018.

110 For an analysis of the recent history and contemporary political manifestation of such associations, see Erik Gobbers, 'Ethnic Associations in Katanga Province, the Democratic Republic of Congo: Multi-Tier System, Shifting Identities and the Relativity of Autochthony', Journal of Modern African Studies, 54, 2 (2016), pp. 211-36.

111 Jérôme Kipili Mulunda interview.
} 
René Mwamba Kasongo and François Musenge Dikumbi were similarly active in Lwanzo Lwa Mikuba, an ethnic association for Sanga and Sanga-related communities. ${ }^{112}$ Albert Mutangala Tshibembe has long been involved in Sempya, an equivalent Bemba-speaking association:

It brings people together by language, so as not to lose culture. I've been in it for about 30 years. They existed at the time of Mobutu as long as they were not political.... We also help each other, in case of mourning, illness, we can turn to people with whom we have the same culture. It can also help as support, for vacancies, I'll first talk to people I know. ${ }^{113}$

Although such cultural associations did exist in the Zambian Copperbelt, their role was limited to activities such as organising 'tribal' dancing (see Chapter 7) and did not generally provide such pathways to employment opportunities. $^{114}$

\section{Beyond the Boundaries: Informality and Independence}

While many residents embraced the security of the mine township, others were stifled by it. Indeed, over time more Gécamines workers chose to relocate to Kikula, which offered greater potential to build and then expand one's own house and take advantage of its greater, if more precarious, opportunities. ${ }^{115}$ Euphrasie Yowa's husband left Gécamines, frustrated at not being promoted while those he trained were sent to Europe for further opportunities. He set up a carpentry business and opened a bar. Although the family lost the Gécamines ration as a result, Yowa preferred life in Kikula, where her husband earned more and could give her money every day. ${ }^{116}$ Pami wa Kasongo grew up in Likasi's railway camp and worked for Gécamines in the 1980s, but preferred to build his own house. He, like many interviewees, associates the mine areas less with social amenities and more with social control. ${ }^{117}$

With the post-independence collapse of influx control and the failures of rural development, the growing Copperbelt population could

112 René Mwamba Kasongo interview; interview, François Musenge Dikumbi, Likasi, 13 June 2018.

113 Interview, Albert Mutangala Tshibembe, Likasi, 16 February 2018.

114 Leonard Nkhuwa interview, 30 July 2018. 115 François Kake interview.

116 Euphrasie Yowa interview. ${ }^{117}$ Pami wa Kasongo interview. 
not be housed in existing municipal areas and high private rents proved prohibitive for most people. Kansuswa, on the outskirts of Mufulira, provided an increasingly attractive base for poorer residents and retirees from where they could commute to work in town while also farming. ${ }^{118}$ For Ana Chilufya, whose husband was a low-waged barman, town life was more difficult than the village because everything had to be paid for: in 1970 they found a two-bed house in Kansuswa with outside bathroom and toilet from where she supplemented her husband's salary by farming and trading. ${ }^{119}$ As a young electrician in the 1950s, Washeni Mweni was housed in the Chibolya area by his foreign employers. Later, working as a garbage collector, he couldn't pay the rent on his council accommodation and moved out to Kansuswa where he and his wife could also farm. ${ }^{120}$ Many of those who made a living by trading food or selling services recognised their indirect dependency on mining wages, since it was mainly mineworkers and their families who bought their goods and services. ${ }^{121}$

Other new urbanites established squatter camps on the edges of existing urban areas. In 1965, the Zambian authorities recognised the challenge:

Separately, and illegally, small squatter settlements have over the last few years appeared around the main towns, built by individuals unable to obtain work or pay for accommodation in the urban areas.... The problem of unemployment in the towns may result in greater concentrations of squatter settlements in the fringe area of the towns, and this aspect presents the greatest danger. ${ }^{122}$

By the early 1970s, Zambian councils were no longer able to build new housing: the Second National Development Plan restricted state housing aid to 'site-and-service' projects and councils were reluctant to initiate these when central government funding remained uncertain. ${ }^{123}$ Copperbelt councils continued to lobby for the integration of mine

118 Interview, Juliana Sakala, Mufulira, 11 July 2018.

119 Interview, Ana Chilufya, Mufulira, 11 July 2018.

120 Washeni Mweni interview.

121 For example, interview, Emery Bweupe, Mufulira, 19 July 2018.

122 ZCCM-IH, Copperbelt Development Plan, 1965, p. 1.53.

123 Government of Zambia, 'Second National Development Plan, 1972-1976' (Lusaka, 1971); Mufulira Council Minutes, Housing Committee Meeting, 8 March 1972, and Finance and General Purposes Committee Meeting, 29 May 1972. 
townships; a further attempt to implement this led to a major conflict between the labour movement and the government in 1980-1, as mineworkers resisted the likely decline in township services (see Chapter 8). ${ }^{124}$ As state funds for housing dried up, local UNIP leaders sponsored the (illegal) construction of informal compounds. Such projects provided new 'constituencies' for party officials like William Chinda: once a few informal houses were built by prospective residents, they would then lobby to legalise these properties and provide them with water and electricity. ${ }^{125}$ When senior Mufulira council clerk Joshua Mwape sought to have such houses demolished, he was overruled by the mayor and other officials, who saw such residents as potential political supporters, so compounds grew up without either plans or infrastructure. ${ }^{126}$ Kawama, previously a forestry zone on the outskirts of the town, was officially recognised as a squatter area by Mufulira council in the early 1970s, which it aimed to develop and integrate via the provision of infrastructure and services. ${ }^{127}$ The resources to do this were however both limited and diminishing and controlling Kawama's growth proved impossible. In October 1972 councillor S. M. Kapumpa reported that 'unless the siting of houses at [Kawama] was controlled, it would be difficult for the Council to carry out improvements such as roads and water'. It was agreed that the town engineer arrange for demarcation of plots as soon as possible 'to control [the] development of Kawama'.

In lieu of consistent official intervention, Kawama was developed mainly by its residents. Dewys Mulenga's grandfather had worked in Mufulira mine and lived in Kantanshi, but his death in a workplace accident in 1975 left seventeen-year-old Dewys without financial support. He was initially employed as a house servant but wanted to

124 Mufulira Council Minutes, Full Council Meeting, 22 March 1972; Nsolo N. J. Mijere, 'The mineworkers' resistance to governmental decentralisation in Zambia: nation-building and labor aristocracy in the Third World', unpublished PhD thesis, Brandeis University (1985); Michael Burawoy, 'The Hidden Abode of Under-Development: Labour Process and the State in Zambia', Politics and Society 11, 2 (1982), pp. 123-66, pp. 123-4;

Miles Larmer, Mineworkers in Zambia: Labour and Political Change in PostColonial Africa (London: IB Tauris, 2007), pp. 119-25.

125 William Chinda interview.

126 Interview, Joshua Mwape, Mufulira, 28 July 2018.

127 Mufulira Council Minutes, Full Council Meeting, 23 February 1972.

128 Mufulira Council Minutes, Housing, Planning and Works Committee Meeting, 4 October 1972. 
work for himself. When he married in 1979 he turned first to licensed charcoal burning in the Mutumbi forest and then to farming, on a plot rented from the forestry department. ${ }^{129}$ That year, he acquired a plot in nearby Kawama and built a house there. Although Mulenga recalls that the plot was allocated by the 'government', in practice the area's housing was 'organised' by the local UNIP branch chairman, who pressured residents to build quickly or lose the opportunity. Mufulira Council tried to have these self-built houses demolished in the early 1980s but resistance by their residents was endorsed by the Catholic church, which legally acquired land in Kawama on which it built a church. Electricity was also organised by the church in 1983 and Kawama steadily grew, its population attracted by the absence of house rents and tax payments and their ability to combine agricultural activities with access to Mufulira's schools and urban services. Foster Kunda, who had lived in Kamuchanga while her carpenter husband worked for the council, moved to Kawama in 1975. She favoured building her own house over renting, but had first to clear bush before helping establish the area's market, where she sold vegetables and other goods she bought in town. Her children walked four to five kilometres to the nearest school in Kamuchanga. 'Farming in town' was, however, discouraged by authorities that sought unsuccessfully, like their colonial predecessors, to maintain a clear division between rural and urban life:

During the Kaunda era we were refused ... farming in this area. At some point I was arrested and released later on after we paid. We were told that if we needed to farm we should go back to [the] village ... We used to buy from others who came from Mokambo [i.e. from Congo/Zaire, who] sold us vegetables. Also, we relied on my husband's salary. We also benefited from some extra income from selling of charcoal and other [goods]. We were allowed to grow some vegetables in our small yard. ... During [the] Chiluba era [the 1990s] we were allowed to start cultivating in this area. ${ }^{130}$

In the 1990s Dewys Mulenga, now ward chairman, oversaw the establishment of agricultural cooperatives in Kawama. The council gradually took over services such as water supply, but it was only in 2016 that most Kawama residents acquired title deeds to their properties. While life in Kawama is 'free' compared with much of Mufulira,

129 Dewys Mulenga interview.

130 Interview, Foster Kunda, Mufulira, 20 July 2018. 
Mulenga and Kunda both recognise the continued importance of the mine, whose employees are the largest single group of customers for the produce grown there. In this respect they, and the tens of thousands of other informal Copperbelt residents, have always been as central to the region's history as the quintessential urbanites of the municipality and the mine township.

\section{Conclusion}

In the late 1980s and 1990s, the increasing financial crisis affecting the mining industry would make itself felt in all areas of the urban Copperbelt. Council revenues from unprofitable mining collapsed and the mines' ability to provide electricity and water supplies was undermined. Mine companies increasingly struggled to maintain the preferential services delivered to their residents and to police the fragile boundaries between their townships and adjacent squatter areas, with which - as Chapter 8 will show - they were (and had always been) co-dependent.

While the segregation of Copperbelt towns was initiated by colonial states and mine companies, first on racial and then on social or economic lines, many of these divisions were enthusiastically maintained by both elite actors and many Copperbelt residents before and after political independence. The strong correlation between workplace seniority, family respectability and residential status made Copperbelt communities acutely aware of these linked hierarchies and the ways they were associated with influential political and moral ideas about the right way to live in town. In their own lives, however, many individuals implicitly or explicitly challenged these boundaries and hierarchies, moving between mine and non-mine areas for leisure and employment opportunities, and over the course of their lives. While some successful residents adopted 'modern' lifestyles and attitudes stereotypically associated with Western consumption, others - often but not only for financial reasons - relocated from the safe but stifling mine townships to reside in municipal areas or even the growing informal settlements in order to lead more precarious but, from their perspective, less constrained lives. 


\section{Political Activism, Organisation and Change in the Late Colonial Copperbelt}

\section{Introduction}

This chapter provides a social history of African labour and political organisation on the Central African Copperbelt between World War Two and the independence of the Democratic Republic of Congo in 1960 and Zambia in 1964. While Africa's decolonisation has been well documented by political scientists and political historians, it has often been presented in what Cooper has criticised as a teleological manner, working backwards from independence to explain inexorable progress towards it, in terms of the actions of European states and African nationalists. ${ }^{1}$ The specificities of associational life in late colonial Africa have often been drowned out by the beating clock of a hegemonic nationalism, against which all other forms of 'sectional' activism are treated as secondary.

This chapter does not provide a history of political institutions or individual leaders and does not assess the specific contribution of Copperbelt residents and their organisations to the achievement of independence. ${ }^{2}$ Instead, it explores how their ideas about political and social advancement intersected with the limited organisational

1 Cooper, Decolonization and African Society, pp. 6-9.

2 Many such studies are available. For Zambia see Rotberg, The Rise of Nationalism in Central Africa and the latter sections of both Richard Hall, Zambia, 1890-1964: The Colonial Period (London: Longman, 1976) and Andrew Roberts, A History of Zambia (London: Heinemann, 1976). For a later post-nationalist interpretation, see Jan-Bart Gewald, Marja Hinfelaar and Giacomo Macola (eds.), One Zambia, Many Histories: Toward a History of Post-Colonial Zambia (Leiden, Brill, 2008) and Gewald et al., Living the End of Empire. For Congo/Katanga see Crawford Young, Politics in the Congo: Decolonization and Independence (Princeton, NJ: Princeton University Press, 1965); Lemarchand, Political Awakening in the Congo; and, from a more social perspective, Georges Nzongola-Ntajala, The Congo from Leopold to Kabila: A People's History (London: Zed Books, 2002), especially pp. 61-93. 
forms - labour unions, welfare associations, ethnic associations and, only belatedly, political parties - available to them. While these ideas and movements sometimes coincided with and contributed to the achievement of independence, this was not usually their primary goal. ${ }^{3}$

The economically strategic Copperbelt mining industry was at the heart of each countries' decolonisation: exploitation of the region's globally significant mineral resources informed both colonial powers' desire to retain them and nationalist plans for their developmental transformation. However, the region's role in the two neighbours' struggles for independence provides a striking contrast. The Northern Rhodesian Copperbelt was in the 1950s the vanguard of the territory's anti-colonial movement: nationalist parties regarded organised labour and the mineworkers' union in particular as a powerful mass movement that, with its ability to paralyse the economy, could help loosen Britain's colonial grip. The urban social consciousness identified by RLI researchers informed how the labour movement was understood and characterised itself, marginalising 'rural' and 'ethnic' customs and identities in favour of a 'modern' materialist political consciousness. Despite disagreements and conflicts, Zambia's nationalist movement proved relatively unified and successful. Haut-Katanga's political leadership was far more divided: while the mining towns' multi-ethnic workforce was channelled into paternalistic participation in Indigenous Enterprise Councils (CIEs), the educated elites who joined the Catholic missions' cultural cercles were recognised as legitimately modern, yet given no meaningful political power. In Congo's chaotic rush to independence in 1959-60, an aspirant 'migrant' educated elite clashed with rural, 'autochthonous' leaders and their urban allies in ethnic associations, leading to both the Katangese secession and the violence experienced during it.

There are important structural explanations for these different outcomes, including the contrasting and changing metropolitan policies regarding decolonisation of these territories. While racial segregation in Northern Rhodesia, reflecting its integration into the settler-led Central African Federation in 1953, encouraged multi-ethnic unity and direct action, the outright ban in Belgian Congo on territorywide African political organisations fuelled the expression of political aspirations via ethnic associations. However, these differences also

3 Thomas Hodgkin, Nationalism in Colonial Africa (London: Frederick Muller, 1956). 
reflected the unfolding social history of the Copperbelt and the knowledge production process that was central to it. Policy responses to wartime labour unrest shaped the political institutions within which African mineworkers and their communities articulated their grievances and advanced their aspirations to a better life. Analysts assessed the role of these institutions and their leaders according to the extent to which they demonstrated a transition to modern norms. 'Elite' Africans sought to demonstrate their readiness for modern 'citizenship' but were prevented from taking up a junior position in the colonial administration, thereby encouraging an uneasy alliance with the urban masses from whom they otherwise sought to differentiate themselves.

Ethnic associations flourished on both sides of the Copperbelt border in the 1950s, as urban migrants sought to secure a foothold in the town via kinship support networks, but only in Haut-Katanga did they become a primary vehicle of 'modern' political organisation. Today, it is widely appreciated that politicised ethnicity across sub-Saharan Africa is a modern phenomenon, not a direct reflection of either precolonial identities or the colonial reconstructions of it. ${ }^{4}$ Supposedly 'modern' political parties and unions were influenced by ethnic thinking and mobilisation, but Zambian Copperbelt elites understood, partly as a result of their interaction with Western(ised) intellectuals, that this was considered illegitimate and incompatible with modernity. In contrast, many Katangese urbanites sought advancement via ethnic associations that were equally as 'modern' and 'urban' as Zambian parties and unions, insofar that they were specifically created to respond to the challenges and uncertainties of town life.

\section{A Working Class in the Making?}

James Ferguson has recently problematised the use of the term 'proletarian' to describe the very un-proletarian (in historical terms) South African working class, to draw attention to analogous terminology in 'taken-for-granted' processes of knowledge production. ${ }^{5}$ Analogous

4 Bruce J. Berman, 'Ethnicity, Patronage and the African State: The Politics of Uncivil Nationalism', African Affairs, 97, 388 (1998), pp. 305-41; Lynch, I Say to You.

5 James Ferguson, 'Proletarian Politics Today: On the Perils and Possibilities of Historical Analogy', Comparative Studies in Society and History, 61, 1 (2019), pp. 4-22. 
thinking drawn from the West's modern history was hugely influential in how policy makers and academic observers understood Africa's experience of social and political change in the mid-twentieth century, shaping the representation of Africans in 'modern' political institutions. However, because this Western history was itself only partially understood, open to interpretation and wrongly presented as an idealised experience of enlightenment and modernisation, the analogous lessons that were drawn varied substantially. Virtually all observers of social change in the late colonial Copperbelt assumed that existing forms of indigenous power, essentially chiefly authority, would be an inadequate or inappropriate basis for political legitimacy in this new urban milieu. Their ability to assess the pace and degree of political change, or to identify more suitable forms of political authority, was, however, powerfully shaped by a modernist mode of thought that counterposed rural communitarianism to urban individualism and equated Western institutions with modernisation.

As we saw in Chapter 1, Northern Rhodesian mine labour was widely characterised - by policy makers and in contemporary academic studies as an incipient 'working class in the making' that represented a threat not only to company profitability but ultimately to colonial control. Protests about specific grievances, for example over wages or conditions, were therefore interpreted as manifestations of this threat. Take, for example, the riots and strike action in May 1935 in the mining towns of Northern Rhodesia, prompted by a tax increase. The inquiry into these events concluded that the tax rise had been badly communicated, but also found that, at Luanshya, 'the elders of the mine compound, and also other responsible natives' had assured managers that 'no disturbances could possibly happen there'. ${ }^{6}$ This breakdown of 'traditional' authority was found to have contributed to a deterioration into violence in which the police opened fire, killing six and injuring two dozen workers. The inquiry report therefore focussed on whether new 'modern' forms of liaison were needed to replace the system of elders.

Initially, the mines adopted a more elaborate system in which older men, specifically selected for their patriarchal authority and expertise in specific 'tribal' customs, were appointed to the position of Tribal Representative. Morris Chimfutumba grew up in the Mufulira home of his brother-in-law, whose authority as a mine-company-appointed

6 Northern Rhodesia, ‘1935 Commission of Inquiry into Disturbances', p. 22. 
'tribal headman' rested on these attributes. ${ }^{7}$ Such expertise was, however, found wanting in the larger strike of 1940, in which African workers sought both jobs reserved for whites and the same wage those whites received. Tribal Representatives were marginalised in a strike led by an ad hoc 'Committee of Seventeen': it was violently suppressed, with seventeen men being killed and dozens injured. ${ }^{8}$

In the Haut-Katanga mining industry, as we have seen, greater and earlier attention was paid to the stabilisation and training of its African workforce and the provision of housing and limited social services. This did not, however, prevent periodic industrial unrest. Higginson explains a wave of protests, absconding, sabotage and theft by UMHK workers in the late 1930s and early 1940s as a response to demands for greater productivity and - during World War Two - increased output. These culminated in the December 1941 mineworkers' strike, prompted by UMHK's failure to control inflation of food prices, but interpreted by Higginson as workers' expression of betrayal by the supposedly philanthropic company. ${ }^{9}$ In Jadotville (later Likasi), alongside workers' demand for a pay rise, the strike saw their wives demanding the restoration of company provision of sewing machines and cloth, and the distribution of ration tickets to themselves as well as their husbands. ${ }^{10}$ A subsequent planned revolt by African soldiers in 1943 failed when évolués of mostly Kasaian origin, a driving force behind the mutiny, failed to gain wider community support, heightening ethnic tensions. ${ }^{11}$ There was, however, little practical connection between the emergent indigenous elite and the grievances of UMHK mineworkers. ${ }^{12}$

\section{Post-War Political Reform and African 'Leadership'}

The Copperbelt authorities nonetheless understood these diverse revolts and strikes as a profound challenge to their authority. The prominent role in protests of independent African churches, particularly the

7 Morris Chimfutumba interview.

8 Epstein, Politics in an Urban African Community, pp. 62-5.

9 Higginson, Working-Class in the Making, pp. 181-3.

10 Higginson, Working-Class in the Making, pp. 189-90.

11 Bruce Fetter, 'The Luluabourg Revolt at Elisabethville', African Historical Studies, 2, 2 (1969), pp. 269-77.

12 Fetter indeed notes that of 118 educated Africans who planned the revolt, only one was employed by UMHK: 'Luluabourg Revolt', p. 272. 
Kitawala religious movement, raised the prospect that such religious sects would combine with worker revolts to fuel unstoppable anticolonial revolt. ${ }^{13}$ This reinforced a growing official view that the political consequences of urbanisation could no longer be avoided and that political modernisation was necessary to address them. Analogous thinking meant that variations of the tripartite co-operation then being pursued in post-World War Two western Europe, with state intervention to limit capitalist freedom and manage class conflict, were the way ahead. Colonists and companies in both Copperbelt regions accepted that company decisions had at least to be better communicated to African workers, necessitating new intermediary institutions. The specific institutional forms adopted were, however, also shaped by contrasting beliefs concerning the central question of African 'adaptability' to modernity, particularly among so-called advanced Africans.

In Haut-Katanga following the 1941 strike, the influential Benedictine leader Monsignor de Hemptinne opposed the introduction of trade unions because he believed even educated Africans were not currently capable of running 'modern' organisations:

The native who has a fairly well-developed education or professional knowledge generally does not have enough freedom of mind or social sense to free himself from tribal influences. Susceptibility, jealousy and personal concerns prevent black people from impartially fulfilling a social role outside their usual environment. ${ }^{14}$

This view was legitimised by CEPSI research. Doucy and Feldheim attributed African interest in unions to a mimicry of European mineworkers: '[ $t$ ] he phenomenon of imitation must be taken into consideration because it is this, rather than a working consciousness, that drives certain natives to wish for a generalisation of unions'. ${ }^{15}$ They argued that establishing trade unions (as was briefly Belgian government

13 Karen E. Fields, Revival and Rebellion in Colonial Central Africa (Princeton, NJ: Princeton University Press, 1985); John Higginson, 'Liberating the Captives: Independent Watchtower as an Avatar of Colonial Revolt in Southern Africa and Katanga, 1908-1941', Journal of Social History, 26, 1 (1992), pp. 55-80; Nicole Eggers, 'Kitawala in the Congo: religion, politics and healing in 20th-21st century Central African History', unpublished PhD thesis, University of Wisconsin (2013).

14 Quoted in S. Mukala, Mémoire de licence en histoire, UNAZA, 1981; cited by Dibwe dia Mwembu, Histoire des Conditions de Vie, p. 42.

15 Doucy and Feldheim, Problems du Travail, p. 112. 
policy) before Africans possessed the consciousness required was damaging to the cause of labour. ${ }^{16}$ Although efforts were made to establish African unions in the immediate post-World War Two period, they could only operate under strict European supervision and were effectively excluded from UMHK's paternalistic system. ${ }^{17}$ Instead, alongside a massive expansion in spending on social welfare and family housing, legislation passed in 1946 compelled the company (and all other enterprises with 250 or more African workers) to establish Indigenous Enterprise Councils (CIEs): the UMHK CIE is analysed below.

In Northern Rhodesia, the best way to manage the threat of uncontrolled proletarianisation was widely debated. Many colonial and mine company officials, drawing on South African segregationist and migrant labour models, still sought to avoid permanent African urbanisation precisely because of the threat posed by a black proletariat. The Copperbelt Provincial Administrator argued that British policy must 'encourage the native to develop his own areas and his own form of government by gradually absorbing ideas of civilized government'. Urban society was 'a cancer that would destroy not only rural life but [also] the possibility of Africans finding their own way into the modern world'. ${ }^{18}$ Other officials believed that African adaptation to urbanisation could work if it was gradually and carefully controlled. Northern Rhodesia Governor Sir John Maybin argued that '[i]f Africans were stabilized in the urban society without an undue raising of their aspirations and capacities the economic conditions for a harmonious estate society would have been achieved'. ${ }^{19}$

More concretely, the 1940 strike was followed by the establishment the following year of an Urban Advisory Council, bringing together district commissioners with African appointees from both mine and municipal townships. This was reconstituted in 1949, with limited elections to select representatives from each section of urban society. Meanwhile an African Representative Council was established in 1946 to advise the Governor. These structures were dominated by

16 Doucy and Feldheim, Problems du Travail, p. 114.

17 Bogumil Jewsiewicki, 'La Contestation Sociale et la Naissance du Prolétariat au Zaïre au Cours de la Première Moitié du XXe Siècle', Canadian Journal of African Studies, 10, 1 (1976), pp. 47-71, p. 68; Nzongola-Ntajala, The Congo from Leopold to Kabila, pp. 73-6.

18 NAZ, SEC/NAT/92, 1 February 1940, quoted in Heisler, 'Creation of a Stabilized Urban Society', p. 134.

19 Quoted in Heisler, 'Creation of a Stabilized Urban Society', p. 133. 
'advanced' Africans and were not taken seriously as a representative body of African opinion. ${ }^{20}$ British company and colonial officials remained divided as to the best way to ensure effective advancement without political destabilisation, certainly compared with the relative cohesion of 'native policy' in urban Haut-Katanga overseen by the Catholic Church, mine company and state. ${ }^{21}$ It fell to metropolitan politicians to intervene decisively in Northern Rhodesian labour relations.

\section{AMWU and Its Analysts, 1947-1956}

The British government's decision to dispatch William Comrie of the Trade Union Congress to Northern Rhodesia to oversee the establishment of legal trade unions in 1947 reflected its hope that the political consequences of labour unrest could be addressed by institutional intervention. Comrie helped establish the African Mineworkers' Union (AMWU) in 1949 and an African Trade Union Congress in 1951. These bodies, British officials fondly believed, would negotiate rather than strike and act 'responsibly' in the interests not only of their members but also of wider society. By the early 1950s AMWU had established itself with an effective bureaucracy and able leaders, who became the subject of concern among colonial and company officials and of sympathetic attention from RLI researchers. As Epstein emphasised, 'by virtue of their education, their proficiency in English, and their more obvious approximation to European standards in dress and habit, they were ... the intermediaries between the mass of the African people and the European authorities'. ${ }^{22}$ As soon as AMWU secured recognition by the mine companies to negotiate over wage and workplace issues, it challenged the legitimacy of Tribal Representatives as a parallel form of dispute resolution. ${ }^{23}$ The Luanshya Labour Officer characterised its view thus:

20 Epstein, Politics in an African Community, pp. 71-2.

21 Guy Vanthemsche rightly warns that the degree of unanimity between this socalled 'triumvirate' has been overstated: Belgium and the Congo, 1885-1980 (Cambridge: Cambridge University Press, 2012), p. 71.

22 Epstein, Politics in an Urban African Community, p. xvi.

23 NAZ, LSS 1/26/33, Luanshya AMWU, 1949-65, Commissioner for Labour and Mines to Secretary for Native Affairs, 13 December 1949. 
while ... the Union recognises the necessity of the tribal loyalties and administration continuing in Rural areas for some time to come, they feel that the same necessities ... do not apply now in urban areas. They appear to feel that the time is perfectly ripe for what they called the urbanisation of populations on [the] Copperbelt.... there is a tendency to regard the Union as a potential and proper form of local or community government. ${ }^{24}$

While mine companies initially resisted the abolition of Tribal Representatives, AMWU's persistent campaigning on this issue led in 1953 to a referendum of mineworkers: with a turnout of 84.8 per cent of the mines' 35,000 -strong workforce, 96.9 per cent of those who voted supported abolition of the tribal representative system, ensuring that the union became the sole recognised organisation for African mineworkers. ${ }^{25}$

The potency of AMWU lay in the ability of its 'advanced' leadership to respond to and mobilise around the grievances of less educated mineworkers, most of whom (Chapter 2) did low-paid unskilled work. The AMWU leadership negotiated with mine managers over pay and conditions, but also held regular public meetings in mine townships, attended by thousands of mineworkers, their families and many non-members. ${ }^{26}$ Parpart records the prominence of women at such meetings; they helped shape union demands, not only for higher wages but also improved housing and other conditions of township life (see also Chapter 5). Branch officials challenged the dismissal of African workers following racial clashes between themselves and European supervisors, as well as other local management decisions. They also, Epstein shows, addressed community grievances arising from, for example, hospital visits and the arrest of women brewers. ${ }^{27}$ By such means AMWU became the dominant organisational force in township life. Official membership fluctuated wildly: in 1950, for example, the Luanshya branch had 8,700 members, of whom only 5,000 had union dues deducted from their pay. ${ }^{28}$ But the union was

NAZ, LSS 1/26/33, Luanshya AMWU, 1949-65, Labour Officer Luanshya to Commissioner for Labour and Mines, 18 February 1950.

25 The referendum is discussed in Epstein, Politics in an Urban African Community, p. 100.

26 Matthew Mwendapole, A History of the Trade Union Movement in Zambia up to 1968 (Lusaka: UNZA Institute for African Studies, 1968), pp. 30-1.

27 Epstein, Politics in an Urban African Community, pp. 124-5.

28 NAZ, MLSS 1/23/24, Annual Reports, Labour Officer, Luanshya, 1947-67, Labour Department Luanshya Annual Report 1950. 
generally able to mobilise the township population to support its actions, for example through mass picketing. ${ }^{29}$ The major 1952 strike over a pay rise was sustained by women's farmed produce following the withdrawal of company rations. ${ }^{30}$

The enthusiastic adoption of trade unionism among these mineworkers - and other workers in the 1950s - convinced analysts such as Epstein that advanced Africans could participate successfully in modern political structures. The union's officials, mostly clerks and the few more senior African skilled manual workers, were expected to provide a moderating and responsible leadership that would persuade members to accept the 'realities' of wage labour in a 'modern' workplace. Certainly, AMWU's senior leaders, notably its first president Lawrence Katilungu (1949-61), sometimes distanced themselves from their members' actions with the discourse of responsible leadership. In 1956, for example, Katilungu condemned an outbreak of unofficial strike action: 'the union, he said, controlled a very complex group of people, some of whose education and civilisation was low'. ${ }^{31}$ In negotiations, AMWU leaders characterised their members' demands as reflecting their progress as morally upright workers, progress that could be most effectively ensured by improved wages and conditions. ${ }^{32}$ Such demands were framed by the notion of a stable and respectable family life in town, characterised by the steady conversion of 'wants' into 'needs'. ${ }^{33}$ But AMWU's elite leaders also maintained their focus on poorer members: in 1952 they rejected a pay formula that did not increase wages for the vast majority of employees on Grades 1 to 3 and insisted on a flat-rate increase. ${ }^{34}$ This frustrated company attempts to incentivise productivity among skilled workers. While companies, policy makers and later African nationalists emphasised the 'advancement' of Africans into skilled

33 Parpart, 'The Household and the Mine Shaft', pp. 42-3.

34 Epstein, Politics in an Urban African Community, p. 97. 
jobs previously done by whites, AMWU recognised that this was less important to most members than generalised pay increases and improvements to housing and social provision. Epstein nicely captures the tension between unity and differentiation in the heterogeneous mine township (see also Chapter 3):

it is no longer possible to view the population of an African Mine Township as an undifferentiated mass. It includes the casual labourer and the relatively skilled worker; the migrant labourer and the urban dweller who was born and brought up in the towns; the illiterate and the highly sophisticated, and so forth. The population of the Township is held together by common interests created in the joint productive task, and its unity is expressed politically by the local branch of the Union. But since the population is also divided by cleavages ... these cleavages too must find their expression within the Union. ${ }^{35}$

Largely absent from Epstein's analysis is, however, the role of ethnicity within AMWU. The uneven provision of mission education in rural southern Africa meant that most clerks and other literate mineworkers were of Lozi and Nyasa origin, while the largest group of unskilled workers were Bemba speakers. This had the potential of dividing mineworkers and their union along intersecting class and ethnic lines. An uneasy unity found expression in AMWU's leaders: alongside many white-collar workers of non-Bemba ancestry, President Katilungu was a Bemba with aristocratic credentials. The continued colour bar, frustrating the promotion of skilled Africans to senior positions reserved for whites, certainly helped ensure African unity. But the downplaying of ethnic difference should also be understood as a consciously political position that found its way into research findings. Schumaker notes that, while RLI research assistant Simon Katilungu found evidence of 'tribal feelings' among Copperbelt Africans, he instead emphasised the importance of 'black nationalism' in their interactions with whites, reflecting the supposed diminishing of 'tribal' identities. ${ }^{36}$ Epstein, while accepting that ethnic differences had been significant in the recent past, stressed that in Luanshya 'people of many tribes are intermingled,

35 Epstein, Politics in an Urban African Community, p. 128.

36 S. C. Katilungu, 'A Study of Relations between Northern Rhodesia African Mine Workers Trade Union, and Mine Compounds Tribal Representatives and Copperbelt Mine Managers', p. 11, Mitchell Papers, cited in Schumaker, Africanizing Anthropology, p. 213. 
and new bonds of co-operation based on propinquity and neighbourliness are constantly being formed'. ${ }^{37}$

The union also asserted its right to negotiate over community as well as workplace issues, something that was strongly resisted by the mine companies, which insisted on a narrower and more conventional company-union relationship. The Chamber of Mines proposed new African mine township advisory committees but resisted AMWU calls for these bodies to be elected: 'The Companies were loath to establish African Mine Township Boards because they felt that any elected representation would inevitably be by members of the Union. ${ }^{38}$ The Boards that were ultimately established were composed entirely of appointed representatives, with AMWU restricted to just two members. As it became clear that AMWU was not playing the moderating role envisaged for it by British policy makers, the companies divided off white-collar workers into a separate Mines African Staff Association (MASA), both to weaken AMWU and to enable the aspirations of more educated and skilled workers to be expressed separately. ${ }^{39}$

The linked issues of union authority, advancement, productivity and representation came to a head in 1955 following a ballot in which 18,110 participants voted in favour of strike action and 365 against. ${ }^{40}$ The resultant strike was reinforced by mass township meetings attended by up to ten thousand men, women and children. At these meetings prayers were said and dance groups performed. Union representatives condemned strikebreakers, termed 'makobo' or tasteless fish, insisting that if striking workers were evicted from the townships they could build their own huts and draw water from mine Mufulira stream. ${ }^{41}$ The union's demand for a general wage increase was rejected by the companies, which insisted that all new pay rises must be linked to productivity improvements. The AMWU representatives articulated

Epstein, Politics in an Urban African Community, p. 9.

NAZ, WP 1/5/9, African Mine Townships Nkana, 1954-9, Commissioner for Labour C. E. Cousins to Secretary of Native Affairs, 3 June 1954.

39 Parpart, Labour and Capital, pp. 140-7.

40 For a summary of strike events, see Henry S. Meebelo, African Proletarians and Colonial Capitalism: The Origins, Growth and Struggles of the Zambian Labour Movement to 1964 (Lusaka: Kenneth Kaunda Foundation, 1986), pp. 287-96.

41 ZCCM-IH, 10.1.8F, African Labour - Trade Union, 1955-6, Reports of Mufulira AMWU Meeting, 25 January 1955 and Roan AMWU Meeting, 28 January 1955; Mwendapole, History of the Trade Union Movement, p. 25. 
their demands in aspirational terms, explaining that mineworkers' urban existence necessitated consumer goods and modern facilities including household electricity:

Mr Namitengo said that ... African employees were unable to provide the essential articles of furniture which they required. There was also the expenditure which the African incurred for candles and paraffin for lighting purposes because their houses were not supplied with electricity. Mr Puta said that through the efforts of the Welfare Departments the wives of employees were learning to sew and make clothing ... and this led to demands for sewing machines which they could not afford. Their wives and children were also acquiring a higher standard of living.... It was in the future interests of the Companies that the present children were brought up properly. ${ }^{42}$

Meanwhile, AMWU sought to restrict MASA's membership to supervisory staff while retaining the clerks who composed much of its senior leadership. Lengthy negotiations over which categories of workers should be represented by each body centred ultimately on conflicting definitions of the union's role. For AMWU General Secretary Matthew Nkoloma, theirs was 'an industrial Union which catered for everybody in the industry, including such employees as Hospital and clerical staff. The Companies were trying to split up the African community into two classes'. ${ }^{43}$ The private advice of the Chamber's industrial relations advisor demonstrated the limited extent to which mine companies had accepted the legitimacy of African unions, compared unfavourably with their Western counterparts:

Trade unionism for Africans has been tried, and has failed. It was artificially created and is rotten to the core. The strong and sound unions in more advanced countries were built up, slowly and laboriously ... by men of firm purpose and, in the main, integrity. ... Here the leaders are, at the least, lacking in intelligence and experience, and the mass of workers is but little removed from primitive savagery. ${ }^{44}$

Colonial district officers held similar views:

42 ZCCM-IH, 10.1.8F, African Labour - Trade Union, 1955-6, Chamber Executive Committee, 8th Meeting with NRAMWU, 19 August 1955, p. 4.

43 ZCCM-IH, 10.1.8F, African Labour - Trade Union, 1955-6, 8th Meeting with NRAMWU, 19 August 1955, p. 6.

44 ZCCM-IH, 10.1.8F, African Labour - Trade Union, 1955-6, Memo, Industrial Relations Advisor to Chamber of Mines, 24 November 1955. 
from what I have seen at Bancroft and at Chingola ... Militant Trade Unionism, which did so much for working conditions at home before the 1914 war, is not suited to this time and place. It is simply the duty of Government to see that justice is done between Employer and Servant. ${ }^{45}$

Such views underpinned the hardline stance of the companies, which in January 1955 temporarily dismissed all striking mineworkers and only reversed this decision when the Governor of Northern Rhodesia, concerned about the unrest (and metropolitan political criticism) that would follow the eviction of tens of thousands of mineworkers and their families, applied pressure for leniency. ${ }^{46}$ The relative failure of the 1955 strike, and the preventative rural detention of many AMWU leaders following the state of emergency invoked following industrial action in 1956, certainly weakened the union. ${ }^{47}$ In the late 1950 s, in a context of economic recession (see Chapter 2), the frustration of AMWU demands caused many mineworkers to turn to the increasingly militant campaign for self-government to address their aspirations.

\section{UMHK's Indigenous Enterprise Council (CIE), 1947-1958}

The Indigenous Enterprise Council (CIE) of UMHK was established in 1947 and met sixty-eight times in the period before independence in 1960. It was the main institutional link between the workforce and the company. It has not been possible to obtain the minutes of its meetings, so we must rely on UMHK reports of its activities, as well as the recollections of mine township residents. ${ }^{48}$ The CIE members were (s)elected for two-year terms; in contrast to AMWU, its councillors were elected to represent and address both workplace and township concerns. The company claimed that CIE members were 'appointed by the workers after consulting as many of them as possible and ensuring fair representation of the various departments'. ${ }^{49}$ The CIE candidates were likely to be longstanding mineworkers who were well-respected and skilled, that is, senior in either 'ethnic' or 'modern'

45 NAZ, WP, 1/2/18, Tour Reports Mine Districts, 1951-5, Tour Report no. 1 of 1954, Chingola District, 4 October 1954, DO R. J. Shaw.

46 ZCCM-IH, 10.1.8F, African Labour - Trade Union, 1955-6, 7th Executive Committee Meeting, 31 January 1955.

47 Meebelo, African Proletarians and Colonial Capitalism, pp. 310-27.

48 Dibwe dia Mwembu, Histoire des Conditions de Vie, pp. 51-3.

49 UMHKA, 658, MOI Annual Report 1958, p. 47. 
terms. These were identified by both company and community representatives and, as Dibwe dia Mwembu argues, they were also chosen on the basis of their docility vis-à-vis company authority. ${ }^{50}$

Underlying the CIE was then an assumption similar to that at work in the very different context in Northern Rhodesia: an advanced and experienced set of representatives would bring issues of concern to the company's attention in a 'modern' way, providing in so doing an example of responsible leadership to the wider community. They functioned, Dibwe dia Mwembu argues, less as community representatives than as informants about it, identifying problems that might otherwise create conflict. ${ }^{51}$ In 1958, the company explained that the council's role was to ensure contact between the employers and its indigenous personnel and to give the latter the opportunity to make their wishes known, but equally 'to be kept informed of the measures which contribute to them'. In this respect, however, it complained that 'advisers only very imperfectly fulfil their information role with their constituents and workers have often complained about [this failure]. A long educational effort will still be required in this area'. ${ }^{2}$

The CIE representatives articulated a wide range of both workplace and community grievances: poor treatment by Europeans, complaints over promotions, qualifications, pensions and payments, but also the electrification of workplace housing, the sale of beer and the provision of health care and drinking water. ${ }^{53}$ From the 1958 and 1959 UMHK reports, we can identify broad areas of concern - presented here in summary - without being able to accurately rank their significance to the CIE members who raised them:

- Housing: provision of materials to help UMHK employees build their own homes; electric lighting needed; interior doors to be installed in houses; the size and position of windows in new houses; household water supply.

- Transport: the need for a bus service to and from work; long queues at railway stations; provision of vehicles to move furniture and luggage.

50 Personal correspondence with Donatien Dibwe dia Mwembu, March 2020.

51 Dibwe dia Mwembu, Histoire des Conditions de Vie, p. 54.

52 UMHKA, 658, MOI Annual Report 1958, p. 47.

53 Dibwe dia Mwembu, Histoire des Conditions de Vie, p. 54. 
- Financial: demands for a pay rise; compulsory monthly savings scheme; pensions; salary payment dates.

- Township: electric lighting needed in streets and houses; the sale of more fish and meat in the market; the right of workers' wives to sell goods in markets; food distribution issues; security; the quality and cleanliness of facilities including water taps, toilets and roads; demands for public wastebins.

- Health, education and social welfare: insufficient local schools; transport of pupils to schools; provision of midwives; transport of pregnant women to hospitals.

- Workplace conditions: modification of working hours; provision of specialised clothing; complaints against Europeans still insulting African workers; sirens to ensure workers are on time; disciplinary issues; Africanisation of senior positions; leave problems.

It is also not possible to definitively assess how UMHK responded to all these complaints. In 1958, for example, the company reported it was expanding electric lighting and increasing the number and size of township markets, particularly as it moved more senior workers from in-kind to fully cash wages. Certainly, some areas of provision recalled by interviewees today as being among the best aspects of UMHK township life, for example cleaning and refuse collection services, were the subject of CIE complaints.

Meanwhile, and in sharp contrast to Northern Rhodesia, industrial peace reigned supreme in the Katangese mines: no significant industrial action occurred between the 1941 strike and independence. Whether this reflected the effectiveness of CIE consultation, the company's authoritarian control of mine townships and workplaces, or the relative contentment of mineworkers and their families with UMHK's increasing provision of housing and social services, it is difficult to gauge. It is clear, nonetheless, that the company was continually anxious: about whether CIE representatives were sufficiently advanced to play the educational and leadership role expected of them; about the cost of providing housing and social services to its expanding township population, particularly its children; and about its ability to exclude from its ordered camps the 'political difficulties' arising in Katanga and Congo as a whole.

The 'failure' of wartime unrest in Katanga and Congo to coalesce into a wider mass nationalist movement is something that historians 
have sought to explain. In 1976 Bogumil Jewsiewicki characterised this as a failure of leadership:

In the post-war period, under the 'preventive' legislation put in place in 1946, the black proletariat came under the tutelage of European trade unions, advisers, the administration and the missions. It dissolved in the mass of newcomers (in the prosperity of the early 1950s) [and] lost solidarity in the face of the rise of politicized ethnicity.... In the absence of its own social ideology, and of a group of leaders capable of waging a political and social struggle at the same time, African trade unionism was aborted. The black intelligentsia (the évolué) stood aside and weighed the advantages of collaboration against those of independence. ${ }^{54}$

It is unsurprising that wartime labour militancy, reflecting as it did acutely exploitative conditions, was not maintained during a post-war boom that enabled significant improvements in wages and social benefits. Certainly, the Belgian Congo's distinct failure to make political reforms akin to those in French and British-ruled Africa, and the ban on territory-wide political parties maintained until 1957, channelled Congolese frustrations and aspirations into increasingly politicised ethnic associations. ${ }^{55}$ The perceived failure of African leadership and the attempts of évolués to advance their own position within colonial society does not, however, make Congo unusual. Indeed, Northern Rhodesia's early native associations/welfare societies were just as elitist as their Congolese counterparts, adopting a more 'national' focus only when their sectional aspirations were threatened by the establishment of the Central African Federation. There was no natural journey towards nationalist unity among Northern Rhodesia's disparate political and social movements, representing as they did distinct social, economic and cultural interests.

\section{Haut-Katanga's Centres Extra-Coutumiers}

While UMHK and other companies closely policed their workers through mechanisms such as the CIEs, the Centres Extra-Coutumiers

54 Bogumil Jewsiewicki, 'La Contestation Sociale et la Naissance du Prolétariat au Zaïre au Cours de la Première Moitié du XXe Siècle', Canadian Journal of African Studies, 10, 1 (1976), pp. 47-71, p. 69.

55 Lemarchand, Political Awakening, pp. 192-7; Young, Politics in the Congo, pp. 232-72. 
were the subject of greater official anxiety. The Elisabethville CEC was established by decree in 1932 to house the growing African population, away from European residents. By the early 1950s, the area, by then known as 'Kenya', was home to c.20,000 or 57 per cent of Elisabethville's African population and was the subject of a major CEPSI study published in 1951. Ferdinand Grévisse, the former colonial administrator, painted a disparaging picture of this rapidly growing African area of a city that was otherwise the heart of the white Katangese settler community. ${ }^{56}$ Far from responding positively to the challenges of wage employment and modern urban life, the CEC's Africans had lost all the qualities of their rural communities and gained none of the advances of Western culture. They were, Grévisse asserted repeatedly, dull-minded wage slaves who lacked initiative and imagination, whose 'sense of responsibility is as obsolete as their moral sense'. ${ }^{57}$

Grévisse argued that urban associational authority could not replicate that in rural areas, since 'African intermediaries ceased to be emanations of the customary milieu' and could not then be an effective means of understanding or controlling 'the indigenous masses'. ${ }^{58}$ In line with social scientific thinking, Grévisse believed CEC residents were experiencing a transitional existence influenced by both rural/ tribal and urban/modern 'civilisations': 'the social body of the CEC is going through a period of transition. European civilization ... diffuses a set of cultural values too high, too strange and, above all, presented in a manner insufficiently positive to be immediately assimilable and transposable to daily life'. ${ }^{59}$ Unlike Epstein and his RLI colleagues, however, he had virtually nothing good to say about this process:

They [CEC residents] all maintain intense relations with their customary society, receive visits, accommodate nephews wishing to pursue studies, even if it means raising their little daughters in the village. They indulge in abundant exchanges of written or oral messages, gifts in kind and in money. Through all their sensitive, affective, intellectual ... fibres, they remain in contact with their native environment. ${ }^{60}$

56 Ferdinand Grévisse,Le Centre Extra-Coutumier D'Elisabethville: Quelques Aspects de la Politique Indigène du Haut-Katanga Industriel (CEPSI: Brussels, 1951).

57 Grévisse, Le Centre Extra-Coutumier, p. 281.

58 Grévisse, Le Centre Extra-Coutumier, p. 305.

59 Grévisse, Le Centre Extra-Coutumier, p. 379.

60 Grévisse, Le Centre Extra-Coutumier, p. 372. 
Yet the same CEC population, Grévisse noted, rode bicycles and took taxis, dressed up on a Sunday and attended cabarets, cinema, jazz concerts and sporting events. They sought out decent accommodation and bought European-style furniture for their new houses. These were not, for Grévisse, signs of a positive adjustment to European civilisation but instead disturbing evidence of a premature and crude materialism among an uneducated urban mass with worrying political aspirations: 'the natives are interested in the vague and dangerous abstractions which are called freedom, independence, democracy and especially race, even before they have been able to become aware of their immediate environment'. ${ }^{61}$

The solution to such problems was the nurturing of the advanced, intellectual évolués; Grévisse identified c.500-600 CEC residents with reasonable education and French language, but fewer than a hundred 'who really aim to maintain their knowledge and learn more'. ${ }^{62} \mathrm{He}$ praised the work of institutions such as the Cercle Saint-Benoit, founded by de Hemptinne's Saint Jean Mission in 1931, in providing 'an environment that is agreeable and conducive to the promotion of the moral and intellectual development of their members ... and an artistic, literary and cultural character'. ${ }^{63}$ The newspaper L'Echo $d u$ Katanga provided another outlet for elite African expressions of advancement within the considerable constraints of paternalistic colonialism. ${ }^{64}$ While the leadership of évolués in the Cercle was praised, Grévisse did not envisage that their resultant understanding of 'social questions, economic questions, literary and even scientific' issues would translate into effective political leadership to the wider CEC populace any time soon. ${ }^{65}$ Nonetheless:

Detached from the traditional environment ... the évolués crystallize no longer around their small social structure of yesteryear - the clan - but around broader conceptions, tribal or regional. ... men seek to federate in one form or another. All these steps are the prelude .... to the birth of Bantu nationalism. ${ }^{66}$

61 Grévisse, Le Centre Extra-Coutumier, p. 27.

62 Grévisse, Le Centre Extra-Coutumier, p. 393.

63 Grévisse, Le Centre Extra-Coutumier, p. 314.

64 Fetter, 'Lulabourg Revolt', p. 271.

65 Grévisse, Le Centre Extra-Coutumier, p. 362.

66 Grévisse, Le Centre Extra-Coutumier, p. 397. 
While Grévisse's relatively early study says more about his racialised worldview than about African society in Elisabethville, it reflects a wider pessimism among Belgian administrators regarding urban Africans that informed a reluctance to grant them a meaningful administrative role. An advisory body for the CEC, the 'Centre Council', had been established by statute: it included twelve African representatives and a 'Chef de Centre', a position to be held by an African who would advise the colonial administration. ${ }^{67}$ In practice, however, this pivotal position was vacant from 1936 and its role was effectively occupied by a senior Belgian colonial official. The deputy Chef de Centre position, also long vacant, was eventually filled in 1955 . However, as Caprasse documents, the African appointee, while being trained in aspects of colonial administration, lacked meaningful authority: 'This situation annoyed the opinion (especially of the 'educated' elite) who came to wonder what such a function was useful for. In addition, it left the deputy centre chief with a painful feeling of helplessness' ${ }^{68}$ The wider council was characteristically composed of the CEC's educated elite: its members were mostly clerks and tutors of various kinds who, Caprasse found in the late 1950s, were also involved in the leadership of both cultural cercles and tribal associations (see below). However, these councillors were unwilling or unable to advance the grievances and aspirations of the wider CEC population for fear of being seen as radicals, and the council was regarded as an ineffective consultative body. ${ }^{69}$

Meanwhile, évolués continued to experience daily discrimination at the hands of European settlers. Participation in educational and cultural activities such as the cercles raised the possibility of political change but did nothing to deliver it. Many évolués perceived themselves, as Grévisse suggested, as caught between an indigenous majority they regarded as primitive and a European authority that refused to recognise them as equal. ${ }^{70}$ 'Participatory' institutions such as the CEC council left meaningful authority in the hands of Europeans, whose

67 Grévisse, Le Centre Extra-Coutumier, p. 28.

68 Caprasse, Leaders Africains en Milieu Urbain, pp. 96-7.

69 Caprasse, Leaders Africains en Milieu Urbain, pp. 105-13.

70 See interview with Paul Lomani Tshibamba in Jeff Van Bilsen, Congo, 1945-1965: La Fin d'une Colonie (Brussels: CRISP, 1994), quoted in Dibwe dia Mwembu, Histoire des Conditions de Vie, p. 53. 
persistent approach to the ceding of real power to Africans can be summarised as 'not yet'.

\section{Race and Respectability on the Northern Rhodesian Copperbelt, 1957-1960}

Despite their contrasting approaches to African urban organisation, the underlying thinking of British and Belgian authorities had much in common. Across the Copperbelt, initiatives promoting 'partnership' between Europeans and Africans provided institutional roles to advanced or elite Africans, considered more modern and/or civilised and able thereby to provide leadership to the wider urban African population. The integration of this group into the consultative bureaucracy of the local state and the mining industry was envisaged as a break on the radical or 'unrealistic' demands of the African masses and as a mechanism through which this new African elite could educate this latter group.

Mission-educated Northern Rhodesian Africans, literate in English and occupying an increasing number of clerical and educational roles in Copperbelt society, played a major role in shaping political activism. ${ }^{71}$ Most such 'advanced' Northern Rhodesian urban Africans churchmen, head teachers and local government officials - worked outside the mine companies. Seeking to convert their educational and employment achievements into social and political advancement, they had created Welfare Associations in most towns in the 1930s and early 1940s. These established a Federation of African Welfare Societies in 1946, first led by Luanshya headteacher Dauti Yamba. ${ }^{72}$ It made strenuous attempts to position itself as 'non-political' but provided a training ground for leaders of the Northern Rhodesia African National Congress (NRANC), established in 1951.

While in Katanga the education and advancement of évolués was nurtured, particularly by Catholic bodies such as the Cercle SaintBenoît, British colonial officials were generally dismissive of educated

71 Roberts, History of Zambia, pp. 196-201; Hall, Zambia 1890-1964, pp. 58-70.

72 Mwelwa C. Musambachime, 'Dauti Yamba's Contribution to the Rise and Growth of Nationalism in Zambia, 1941-1964', African Affairs, 90, 359 (1991), pp. 259-81. 
Africans, as this 1951 analysis by a Copperbelt government official shows:

Political ambition, coupled with an awareness of their superiority, has developed in them a disagreeable 'hubris' derived from an exaggerated belief in their own capacity, and this in its turn has rendered them both sensitive and resentful of their treatment by the European community.... the intelligentsia have come also to believe themselves justified in ... intemperate demands for the immediate ... enhancement of their own political and economic position. $^{73}$

The comparative disregard of Northern Rhodesia's colonial leaders in nurturing moderate African elite opinion, and the settler campaign to convert the CAF into a segregated dominion, fuelled a turn towards mass campaigning in the mid-1950s, led by the NRANC's Harry Nkumbula, schoolteacher and former Secretary of the Mufulira Welfare Association. In the Copperbelt, racial discrimination manifested itself in the continuing colour bar in mines and other workplaces, and the 'petty apartheid' restricting African patronage of bars, restaurants and shops. The NRANC launched boycott campaigns against butchers in Lusaka and its leaders, Nkumbula and Kenneth Kaunda, were jailed in 1955. Growing racial tension and the more militant approach of Kaunda's United National Independence Party (UNIP), which split from the NRANC in 1958-9, culminated in the killing by UNIP activists of a white resident of Ndola, Lilian Burton, in April $1960 .^{74}$

Amidst this growing tension, a Race Relations Ordinance was passed in 1957, one measure of which was to establish local Race Relations Committees (RRCs) to promote good racial relations and to desegregate public facilities. They equally served as a vehicle for moderate African elites to demonstrate their credibility as responsible political leaders and to advance their demands for political progress. However, in Mufulira the new Race Relations and Conciliation Committee, meeting for the first time in December 1957, found its hands tied regarding the Mufulira Copper Mines' Recreation Club. Although

73 NAZ, WP 1/11/2, African Social and Political Development in Urban Areas, 1951 Report.

74 Walima Kalusa, 'The Killing of Lilian Margaret Burton and Black and White Nationalisms in Northern Rhodesia (Zambia) in the 1960s', Journal of Southern African Studies, 37, 1 (2011), pp. 63-77. 
this club explicitly refused membership to Africans, as a mine company facility 'the Club was not an institute over which the Committee had any jurisdiction or powers' ${ }^{75}$ The committee sought to promote mutual understanding by public education: it compiled a multi-racial list of 'lecturers' able to share knowledge on subjects including: European marriage customs; road safety; African medicine; African urban marriage problems; the effect of European culture on African traditional manners and customs; how Europeans bring up their children; African female education; juvenile delinquency; African labour problems; and African family budgets. ${ }^{76}$ In many of its discussions on racial exclusion from restaurants and hotel bars, African members expressed frustration at the stereotypes of lower-class Africans that informed these policies and compared Northern Rhodesia unfavourably with neighbouring Congo:

Mr Mukuka said the well-dressed African would not enter many of these establishments because of the behaviour of the Europeans. Bars and hotels in the Congo were inter-racial and there was no trouble, and he did not see why the same could not be done here. As to the objection that Africans were dirty, firstly this was not true of all Africans and secondly, he had observed some European mechanics and artisans coming straight from work to a café or bar in dirty and greasy overalls. ${ }^{77}$

As Mukuka's comment indicates, the displacement of racial divisions to those of class and 'civilisation' suffused these committees' discussions. At the Ndola RRC, the manager of the First Permanent Building Society denied that it operated a colour bar and stressed that a tradesmen's entrance was in use at the rear of the building: 'He thought that the main distinction would be dress: a decently dressed person would obviously use the lift, and a person not suitably dressed would use the stairs'. ${ }^{78}$ Likewise, the Northern Rhodesian Hotels Association agreed in January 1957 that '[n]on-Europeans who were properly dressed, knew how to behave, who could afford to pay the bill and wanted to

75 NAZ, WP 1/5/18, Mufulira Race Relations and Conciliation Committee, 1957-62, Minutes of First Meeting, 18 December 1957.

76 NAZ, WP 1/5/18, Mufulira Race Relations Committee, 1957-62, Minutes of Fourth Meeting, 21 March 1958.

77 NAZ, WP 1/5/18, Mufulira Race Relations Committee, 1957-62, Minutes of Third Meeting, 10 March 1958.

78 NAZ, WP 1/5/20, Ndola Race Relations Committee, 1958-62, Minutes of Fourth Meeting, 25 March 1958. 
use the hotels for legitimate purposes and not for political ends would be normally accepted'. ${ }^{79}$ African members accepted the right of establishments to exclude undesirable customers, but one argued: 'Many Africans could well afford, and had the wish, to purchase a decent meal properly served. African tea rooms were very crude, and a welleducated and well-dressed African wanted something better'. ${ }^{80}$ A subsequent Race Relations Ordinance, passed in September 1960, legally desegregated hotels, restaurants and cinemas. ${ }^{81}$

While late colonial advancement depended on the assumed ability of this elite indigenous leadership to moderate the political demands of the wider African population, this was undermined in both Congo/ Katanga and Northern Rhodesia by different restrictions on the advancement of elites. Évolués in Haut-Katanga, mission-educated and attaining skilled jobs, were frustrated by the lack of political reform despite demonstrating their advanced credentials in the cercles' intellectual and cultural activities and by their adoption of 'European' dress and language. Meanwhile, the continuing colour bar in the Northern Rhodesian mines reinforced a tendency towards radical nationalism and political participation, both among skilled African mineworkers and hitherto moderate intellectuals. The ability of elite Africans to advance their own position through a liberal discourse of respectability and civilisation was, in both colonies, giving way to a recognition that this could only be achieved by the transfer of political power.

\section{Copperbelt Political Identities on the Road to Independence}

As has been noted, social scientific analysis of the Central African Copperbelt generally assumed that, over time, ethnic identities associated with migrants' rural areas of origin would be displaced by 'modern' identities reflecting urban residence and changed material circumstances. Modern forms of organisation would displace the earlier forms of combination practised by new urban migrants, most

79 NAZ, WP 1/5/20, Ndola Race Relations Committee, 1958-62, Minutes of Sixth Meeting, 12 July 1958.

80 NAZ, WP 1/5/20, Ndola Race Relations Committee, 1958-62, Minutes of Seventh Meeting, 7 October 1958.

81 NAZ, WP 1/5/20, Ndola Race Relations Committee, 1958-62, Annual Report 1960. 
notably 'tribal' associations. On both sides of the border, as elsewhere in towns across Africa, self-help networks were established to assist new arrivals to town. While older interviewees recall being helped by family and kinship networks to find work and housing, or manage financial and family crises, these support networks evolved across the Copperbelt into more established mutual aid associations organised along ethnic lines. Nguni Tamarikzika's early years in Mufulira in the early 1960 s were, for example, eased by 'a Nsenga group so that if there was any problem, suffering or death then all the Nsenga people would come together and assist in that area' ${ }^{82}$ Integrationist policies ostensibly militated against overtly ethnic social or workplace segregation: workers were housed in multi-ethnic areas and worked in multi-ethnic and multi-racial groups. The AMWU and the CIE, in their different ways, were both organised across ethnic lines. 'Tribal' identity was, however, officially preserved in ways deemed appropriate for the colonial social order. Tours by African chiefs to visit their urban 'subjects' continued to be organised until the early 1960s: in 1960, for instance, four such visits took place to Kitwe. ${ }^{83}$

Unlike religious sects and more overtly political organisations, urban tribal associations were not a primary focus of either political surveillance or social scientific attention, based as they were on 'premodern' associational identities that were surely in decline. Yet by the late 1950s it was clear that the CEC's tribal associations, established initially as self-help and 'cultural' groups, were becoming increasingly politicised and combining into federations reflecting larger-scale ethno-regional migrant identities. Caprasse, writing shortly before Congo's independence, offers a compelling snapshot of the leadership of these associations, particularly those claiming to represent the largest ethnic groups: the Luba Kasai (28.6 per cent of the Elisabethville CEC's population); the Luba Katanga (18.1 per cent), the Lunda (6.3 per cent), the Bemba (4.3 per cent) and so on. ${ }^{84}$ These associations were often poorly organised, with irregular meetings and low official membership, but their 'spontaneous' character and lack of European involvement enabled them to act relatively autonomously. Caprasse demonstrated that the insecure conditions and precarious

82 Interview, Nguni Tamarikzika, Mufulira, 3 July 2018.

83 NAZ, WP/1/2/64, Special Commissioner for Western Province Reports on Copperbelt, 1959-60, Annual Report on African Affairs, Kitwe, 1960.

84 Caprasse, Leaders Africains en Milieu Urbain, pp. 23-4. 
employment of many urban migrants (see Chapter 2) meant that existing forms of solidarity modelled on 'the customary environment' were being 'adapted to the conditions of urban life', and 'modernized ... to current living conditions'. ${ }^{85}$ Continued ethnic identification and solidarity could be understood as an implicit protest against the harsh, impersonalised nature of urban life, fuelling a desire to preserve the supposedly communitarian values of the village.

Ethnic association leadership involved, Caprasse found, a mix of younger, primary-school-educated men (one rung lower on the social ladder than the most educated évolués) able to organise the bureaucratic paraphernalia of a recognisably modern organisation, alongside elders whose rural upbringing made them custodians of tribal culture and law, particularly where - as in the case of the Lunda association - key individuals were designated by the Lunda king, the Mwaant Yaav, to regulate conflicts among his urban 'subjects'. ${ }^{86}$ As political opportunities and threats emerged with the largely unheralded approach of Congolese independence, these organisations adopted apparently contrasting political aims: 'there are leaders who speak of resuscitating ancient kingdoms which have disappeared: on the other hand, other leaders have a realism which aims at immediate effectiveness: they seek to obtain for themselves and the members of their group certain positions in the current administrative system' ${ }^{87}$ For Caprasse this contrast could be explained, characteristically for his generation of Copperbelt social scientists, by the contradictions inherent in transition:

These tensions within associations are an indication that a society in transition guards the vestiges of its old values and social structures which collide with the new ones. On the one hand, age still confers a certain authority, while, on the other hand, change grants authority to leaders whose status and roles are new. ${ }^{88}$

Caprasse, seeking to counterpose the vertical appeal of tribal associations to the non-ethnic elite identity of the CEC's cercles, found, however, that even the latter were engaging in ethnically based

85 Caprasse, Leaders Africains en Milieu Urbain, pp. 29-30.

86 Caprasse, Leaders Africains en Milieu Urbain, p. 52.

87 Caprasse, Leaders Africains en Milieu Urbain, p. 34.

88 Caprasse, Leaders Africains en Milieu Urbain, p. 56. 
competition for leadership positions. ${ }^{89}$ Ethnic association was proving not to be a declining hangover of the rural-urban transition but rather a potent form of urban political mobilisation, whether on its own or combined with ostensibly 'modern' bases of belonging, along class or racial lines. This debate was played out in the pages of the new journal Katanga in which évolués of different ethnic background virulently attacked each other's visions of the country's national future. ${ }^{90}$

These very modern ethnic associations proved central to the political conflict that unfolded in Haut-Katanga in the run-up to independence. The 1957 election in Elisabethville of four bourgmestres (local mayors) of non-Katangese ethnicity suggested that future political authority would rest in the hands of mainly Kasian 'migrants'. ${ }^{91}$ This prospect was met with alarm by 'autochthonous' Katangese groups and prompted large ethnic federations, for example Gassomel (the Groupement des associations de l'empire lunda), to establish political parties including the Confédération des associations tribales $d u$ Katanga (Conakat). Conakat, fearing a post-independence loss of Katangese autonomy, bitterly opposed what it characterised as foreign domination by a Kasaian political elite allied with Patrice Lumumba's Mouvement Nationale Congolaise (MNC); Conakat leaders attacked local Kasaian leaders in an openly xenophobic way. ${ }^{92}$ In asserting their nationalist project, Conakat leaders harked back to a supposed golden age of pre-colonial Katanga in which its great kingdoms had become wealthy and powerful through regional trading networks in commodities including minerals: the copper croissette served as a national symbol on the flag and in the anthem of the Katangese state, which seceded from Congo days after independence in June 1960. ${ }^{93}$

Caprasse, Leaders Africains en Milieu Urbain, pp. 77-9. See also Young, Politics in Congo, pp. 293-4.

90 Omasombo Tshonda et al., Katanga Vol. 1, pp. 233-4.

91 It should be stressed that all urban residents were 'migrants' in the sense that all had their origin in rural areas outside the mining towns, including those from rural Katanga such as the Lunda and Bemba. The political distinction that was drawn was between these self-declared 'autochthonous' Katangese groups and those from outside Katanga, particularly the Kasai Luba, even those born in Katangese towns to migrant parents.

92 Lemarchand, Political Awakening in the Congo, pp. 238-9.

93 Godefroid Munongo, Comment est né le Nationalism Katangais, Elisabethville, 16 June 1962 (mimeo), cited in René Lemarchand, 'Katanga: background to secession', unpublished ms (1963); Erik Kennes and Miles Larmer, The 
The enabling of the Katangese secession by UMHK, by the redirecting of tax payments to the illegal state, sat uneasily with the company's attempts to preserve its mine townships as apolitical enclaves, unaffected by the political conflicts in which it was a key actor. ${ }^{94}$ By March 1960 its local management recognised it could not keep these events outside its gates, as two of its workers were killed and many injured in the ethno-political violence during pre-independence elections. ${ }^{95}$ There was, meanwhile, a politicisation of the demands advanced in the CIE: alongside familiar complaints about working hours, housing, township services, family allocations and the distribution of food, CIE representatives now demanded the Africanisation of senior positions; criticised racialised policing; and complained that the holding of political meetings required company authorisation. In relation to the Councils themselves, representatives requested an extension of their mandate from two to five years and that they be provided with the minutes of CIE meetings. Company officials commented on the changing profile of CIE representatives:

these councils, originally composed of old workers of high seniority, known in our cités as the village notables [have been replaced by] more young skilled workers, young clerks, young tutors, etc. ... as if, in the spirit of their mandates, such representatives were better able to present and defend their wishes. It should be added that tribalism this year, more than ever, dominates relations and directs the choice of all workers in this field. The present circumstances being what they are it is difficult to demand of an African that he is not influenced, consciously or not, by clan ties. ${ }^{96}$

Of course, many European observers understood such manifestations of ethnically based political mobilisation to be evidence of a failed or incomplete transition to modern identity and consciousness, but by 1960 it was no longer possible to argue that more time would be needed for African societies or leaders to complete an envisioned transition to the 'right' kind of African modernity.

In Northern Rhodesia, in contrast, Copperbelt political activism in the early 1960s, leading to Zambia's later independence in 1964, overtly rejected both ethnically based politics and moderate elite co-operation in

Katangese Gendarmes and War in Central Africa: Fighting Their Way Home (Bloomington: Indiana University Press, 2016), pp. 36-7.

95 UMHKA, 658, MOI Annual Report 1960. ${ }^{96}$ Ibid. 
favour of the militant but non-racial leadership of UNIP. The Copperbelt, and Bemba-speaking areas of northern Zambia linked to it by migration, saw in 1960-1 the greatest level of anti-colonial mass mobilisation and direct action against state property, which took its nominative inspiration - the 'Cha Cha Cha' rebellion - from the celebration of Congolese independence. ${ }^{97}$ Some interviewees recall their involvement in this anti-colonial activism as arising from personal experiences of racial discrimination. ${ }^{98}$ John Mule spent five months in prison for his UNIP activities. ${ }^{99}$ Elizabeth Malokoleta, UNIP Women's Regional Secretary in Kitwe while still a teenager, explains: 'We wanted to rule ourselves. Self-governance. We felt limited. We wanted schools and secondaries ... mostly white people went to school. When we started fighting for independence is when they started taking us'. ${ }^{100}$

This grassroots activism, which was central to the achievement of self-government, was, however, regarded uneasily by the UNIP leadership, which sought to benefit from its threat potential while retaining control of African political organisation. ${ }^{101}$ Central to these efforts was the use of political violence against its rivals in the NRANC, particularly in the latter's Copperbelt stronghold of Mufulira. Many interviews recall this as a dangerous period in which mainly Bembaspeaking UNIP supporters were deployed against NRANC members from southern and western Zambia, and vice versa. ${ }^{102}$

In the run-up to Zambian independence, AMWU was an unmistakably politicised body: branch meetings asserted that, in the new political dispensation, African mineworkers could ensure their equality and dignity at work under the protection of their new black government. In Luanshya in December 1962, a crowd of 6,000 heard national and branch leaders declare:

- Europeans who accept Black Government have nothing to fear

- If a European assaults an African, the African should 'hit the European back as hard as he could' and fight it out to the end

98

100

101

102

'Indépendance Cha Cha' was a hit song of 1960 by Joseph Kabasele's African Jazz group.

Interview, B. M. Chama, Mufulira, 6 July 2018. $\quad 99$ John Mule interview.

Interview, Elizabeth Malokoleta, Mufulira, 2 August 2018.

Larmer, Rethinking African Politics, pp. 40-3.

Mufulira Interviews: Levy Chushi; Emelia Banda; and Leonard Nkhuwa, 17 July 2018. See also Giacomo Macola, Liberal Nationalism in Central Africa (New York: Palgrave, 2010). 
- Africans must stop carrying food bags for European employees

- African mine employees must discontinue the so-called respectful approach to European mining employees - they must only say 'Ya' and no longer 'Ya bwana'. ${ }^{103}$

The challenges facing AMWU's leadership were meanwhile neatly summarised in a speech by Minister of Labour and Mines John Roberts to its 1960 conference:

Foreign investors are hard-boiled people who demand absolute proof of a country's good intentions before starting up new industries which we need if we are to prosper. ... one of the main factors to be considered is whether a country has a responsible and contented labour force. ... enlightened employers of today, like the mining companies ... go to considerable expense to provide all kinds of facilities for the benefit of their workers and their dependents.... These facilities go a long way towards satisfying the material and physical needs of urbanised Africans, but what about their spiritual needs? ... the vast majority of Africans on the Copperbelt are still not fully de-tribalised. ... In the village the spiritual needs of Africans are satisfied by their Chiefs, village headmen and tribal elders, but this system ... breaks down in urban areas. ... it is here that a sound trade union can contribute so much to the welfare of their members. The responsibility resting on trade union leaders is considerable... There are also many politicians who purely for their own ends would like to get a foothold in your organisation.... My advice to you is to resist this with all your might. A trade union with political aims weakens itself. ${ }^{104}$

While the Minister's warning against 'politicisation' was designed to moderate AMWU's political mobilisation, it was nonetheless prescient. Conflict emerged in the early 1960s between UNIP and AMWU as the former positioned itself as the party of workers and peasants and asserted the need for trade union loyalty and subordination to it. ${ }^{105}$ Most AMWU leaders strongly supported the more radical UNIP and ousted their moderate pro-NRANC president Lawrence Katilungu. They, however, equally sought to ensure they were not subject to

103 NAZ, LSS 1/26/33, Luanshya AMWU, 1949-65, Record Note, AMWU Public Meeting, 22 December 1962.

104 NAZ, LSS 1/26/184, N Rhodesia AMWTU, 1960-4, Minister's Speech, 26 May 1960.

105 Larmer, Mineworkers in Zambia, pp. 38-40. 
UNIP control, for example by rejecting its calls to organise a general strike in support of its independence demands in January 1962. ${ }^{106}$ Four months later, AMWU leaders were persuaded by UNIP to call off strike action because it might adversely affect planned elections. In the run-up to independence, UNIP fostered a United Mineworkers' Union (UMU) as a rival to AMWU, but this proved unsuccessful. ${ }^{107}$ The RLI's Peter Harries-Jones captured the intensity of the competition between AMWU and UNIP for the political loyalty of Luanshya's mineworkers during this period: local UNIP activists, making use of their kinship networks, sought to mobilise these communities over a range of social concerns and grievances, from literacy to funeral costs. To do so, however, necessarily involved party control over and repression of independent associations, of which AMWU was by far the most significant. ${ }^{108}$

Demands by AMWU for representation at pre-independence talks between the government, led from January 1964 by Prime Minister Kenneth Kaunda, and the mine companies concerning the industry's future, were rejected. Underlying such demands was the union's assertion of its right to represent the mining community in the emerging post-colonial political dispensation. In this context it used an unmistakably modernist discourse to pursue the 'advancement' of its members' living standards:

During the past thirty years the level of technological skill and ability of the African worker has greatly increased. Through African Advancement schemes individual workers have accepted higher levels of responsibility.... The Union regrets that the advancement of the thinking processes of the Mining Companies' policy makers has not kept pace with the advancement of their African employees. ... It is however high time that the mining companies recognised that they are faced no longer with the inexperienced people they first dealt with here on the Copperbelt. ${ }^{109}$

106 Meebelo, African Proletarians and Colonial Capitalism, pp. 453-78.

107 Northern News, 8 October 1964; Bates, Unions, Parties, and Political Development, pp. 149-51. The local manifestation of this struggle for union control is well documented in NAZ, LSS 1/26/33, Luanshya AMWU,1949-65, various documents.

108 Peter Harries-Jones, Freedom and Labour: Mobilization and Political Control on the Zambian Copperbelt (Oxford: Basil Blackwell, 1975), passim.

109 NAZ, LSS 1/26/184, N Rhodesia AMWTU, 1960-4, Notes of AMWU for negotiations, n.d. but February 1964. 


\section{Conclusion}

The growing urban communities of the Central African Copperbelt faced a wide range of difficulties and injustices as they sought to assert themselves in a rapidly changing post-World War Two context. Low wages, racial inequality and the wider limits placed on individual and societal ambitions led many to protest and combine to overcome injustice and discrimination and find a collective political voice. These efforts were resisted by colonial and company authorities, but also channelled into acceptably 'modern' forms of associational activity in which advanced Africans were expected to articulate community grievances within a participatory framework that simultaneously restrained the 'unrealistic' or 'premature' demands of the wider African population. The different approaches adopted in HautKatanga and Northern Rhodesia's mining industries produced contrasting outcomes. The AMWU, overcoming divisions within the mine workforce, emerged as a powerful political actor in Northern Rhodesia's mine townships by linking 'irresponsible' community activism with claims for improved wages and conditions that would enable mineworkers and their families to live respectable, 'civilised' lives. The proactive concession of improved wages and conditions to UMHK's workers, along with the incorporation of worker representation into the CIEs, delivered industrial peace. Neither mechanism, however, provided a sustainable resolution to underlying demands that African societies should exercise control of their own communities, extractive resources and ultimately nations.

Outside the mine townships, educated and more successful Africans both internalised and challenged the notion that 'advancement' meant progress along European lines. Participation in welfare associations, race relations committees and elite cultural groups provided opportunities for self-improvement and self-expression, but also necessitated distancing oneself from the wider urban community and offered meagre political and economic rewards. Meaningful political change required new forms of association and, in the global context of decolonisation into independent nation-states, the establishment of selfconsciously nationalist political organisations. Nationalist parties and the struggle for independence dominated the political narrative of the late 1950s and early 1960s, but this did not replace the associational expression of grievance and aspiration by trade unions, ethnic 
associations and other combinations in which diverse sections of the community engaged to improve their lot and to collectively express their distinct social identities. These collectives provided training grounds for party political activists. They often complemented and overlapped in their membership's concerns with those of nationalist parties, but also clashed with the latter's desire to monopolise political space and control the agenda.

The ways that these rapid, dislocating changes were understood and represented - by companies and colonists, social scientists and activists themselves - were marked by modernist conceptualisations of political and social change. These often provided a distorted understanding of a messy reality, in which multiple and often contradictory forms of identity and association - class, ethnicity, race and nation - combined in unpredictable ways that, while facilitating the political transition from colony to nation-state, did nothing to resolve those contradictions and little to address the inequalities and injustices that fuelled them. 


\section{Gendering the Copperbelt}

\section{Introduction}

Although the lived experiences of women have commonly been marginalised in Copperbelt studies, gender dynamics have long been understood to be at the centre of Copperbelt society. The imposition of a gendered division of work on their employees was central to mine company profitability and to the (re)production of labour on both a daily and long-term basis. The focus in early literature on male 'migrant' workers distracted from the fact that women were both present and economically active in Copperbelt towns, but the terms of their presence varied significantly over time and between the two territories. Authorities - mine companies, colonial states and their intellectual advisors - debated whether mineworkers' wives and families should stay in the village or move to the town. The positions they adopted towards women's residence, labour and fertility rested on patriarchal assumptions about the changing nature of male and female labour and on the notions of 'African tradition' and 'Western modernity' that were central to knowledge production about the Copperbelt.

In this context, the Copperbelt induced moral panic about the supposed breakdown of 'traditional' norms, where prostitution and 'urban wives' were undermining African tradition or the modern Christian family (or both) and where juveniles lacked adequate socialisation as a result. Mine companies wanted women to be housewives, but were uncertain if they were up to the task. Alongside their core business of mineral extraction, these companies engaged in the systematic production of housewives and nuclear families. Young women were taught by company propaganda, training courses and social welfare officers how to raise children, clean houses and keep their husbands happy and productive. This chapter explores the extraordinary degree of this intervention, locates it in the perpetual effort to 
manage gender (and, to some extent, generational) relations in the city and demonstrates that it reflected a perennial anxiety regarding the ability of Africans, and African women in particular, to transition to an idealised form of urban society.

From the 1970s, however, feminist labour researchers identified the historical importance of the wives of Northern Rhodesian/ Zambian mineworkers in industrial action in the 1950s and 1960s and, indirectly, in political and economic change. Social historians in Haut-Katanga focussed, in contrast, on the ways in which women's position as housewives and mothers reflected the centrality of natalist policies in Belgian Congo and post-colonial Zaire. This distinction in the production of knowledge about urban mine women reflected differences in the history of labour and company policies but also in the perception of what constituted women's work. The intellectual separation of analyses of domesticity and workplace neglected the fact that women's economic position, bound up with their secondary status as 'mineworkers' wives', was shaped by their husband's salary, their domestic labour and the considerable work they did to earn money and produce food for the household. The vast majority of Copperbelt women went about the business of urban work unnoticed: largely excluded from the mine itself, women kept house and raised families, farmed, traded and made and sold goods.

The chapter concludes with an analysis of the changing nature of post-colonial social welfare. Ferguson was struck in the late 1980s by the continued existence of company-run women's centres on the Zambian Copperbelt. ${ }^{1}$ In Haut-Katanga, likewise, an elaborate system of social welfare intervention in family disputes, child rearing and the education and socialisation of young women continued to be provided by Gécamines and other companies until the 1990s (and still continues in diminished form today). Drawing on interviews with former company social welfare officers in both regions, continuity and change in the assumptions underlying these services is analysed: while the late colonial problem of urban modernisation had largely disappeared, support for the role of the mine company in shaping the family has if anything grown following the post-privatisation closure of mine social services.

1 Ferguson, Expectations of Modernity, p. 167. 


\section{Men and Women on the Interwar Copperbelt}

Early African migration to mine towns, essentialised as men's wage work, depended on agricultural and reproductive labour performed by women, who officially remained in rural areas. Male migration prompted anxiety, particularly among missionaries, about the loss of male labour from rural areas but also its (assumed) negative impact on family life. As noted in Chapter 1, UMHK efforts to secure African labour led in the 1920s to the extension of mineworkers' contracts. This became, from 1928, a self-conscious programme of stabilisation, incentivising mineworkers to bring their wives and children to the mine, in the belief that married workers would not only stay longer and be more productive but also be more socially 'stable', with domesticity limiting tendencies towards violence or political action. This dovetailed with the Belgian colonial belief that African birthrates were worryingly low, the result of a toxic combination of 'primitive' customs such as polygamy and modern urban ills including alcoholism. ${ }^{2}$ This fuelled a co-ordinated natalist intervention towards the bodies and minds of young women. ${ }^{3}$ For its part, UMHK advanced 'bridewealth' payments to facilitate rural marriage for their workers, with the assistance of local colonial officials and the Catholic Church in general and de Hemptinne's Benedictine mission in particular. ${ }^{4}$ While the late colonial state substantially increased provision of developmental and welfare services across Belgian Congo, companies such as UMHK retained responsibility for delivering housing and social services to their workforce and their families.

The aim of improved productivity thus rested on essentialised gendered notions and - from the 1940s - the belief that industrial peace could be socially engineered by the production of appropriate family relations. Workers were provided with food rations and housing proportionate to family size. Health clinics, focussed on child and maternal care, were established. Women were compelled to give birth in company health facilities and to bring their infants for inoculations and periodic checks on their weight and general health. Non-compliance

2 Nancy Rose Hunt, A Nervous State: Violence, Remedies, and Reverie in Colonial Congo (Durham, NC: Duke University Press, 2016).

3 Hunt, 'La Bebe en Brousse'; Schalbroek, 'Commission for the Protection of Natives', p. 117.

4 Dibwe dia Mwembu, Histoires des Conditions de Vie, p. 17. 
could lead to the withholding of pay or rations. With church assistance, primary schools were established in every camp, free for the children of UMHK employees. Social centres ('foyers sociaux') were established that trained young women in keeping a respectable home as well as gendered skills such as sewing, knitting and cleaning. In the 1950s, Valérienne Ngoy Mudimbi taught the wives of senior African workers how to arrange their dining table for visitors and how their children should behave when eating. ${ }^{5}$ The interiors of mine houses and residential streets were regularly inspected for cleanliness, with prizes awarded for best-kept areas and sanctions for dirty and ill-kept homes. The company provided leisure centres and trained theatrical and musical groups that conveyed in their shows and songs moral lessons for family life (see Chapter 7). In these multiple and increasingly co-ordinated interventions into the domestic and recreational lives of their workers and their families, UMHK sought to both manage and increase their bodies' productive and reproductive value.

These sustained efforts certainly coincided with reduced labour turnover: the number of new recruits needed fell drastically from 6,582 in 1943 to 1,303 in 1958 . They also transformed the population of what were initially male-dominated mine camps. By the mid-1960s there were four women for every five men in UMHK townships and the proportion of both was dwarfed by the number of children - four on average for every woman - who made up 63.6 per cent of their populations. ${ }^{6}$ Housing and healthcare were steadily expanded at considerable cost to the company. The growing female population was also integrated into the UMHK system, not only as housewives but also as providers of foodstuffs from as early as the 1930s. As Dibwe dia Mwembu notes, women were 'incentivised' to grow vegetables by the threatened removal of their food ration and were forced to sell to the company at prices lower than those paid to European settler farmers: this then became part of the ration provided to workers. ${ }^{7}$

In Northern Rhodesia, however, legal restrictions on urban settlement meant male mineworkers continued to be treated as temporary migrants until the 1940s. Just as many men were able in practice to remain permanently employed by moving from one town job to another,

5 Interview, Valérienne Ngoy Mudimbi, Likasi, 9 June 2018.

6 Dibwe dia Mwembu, Histoires des Conditions de Vie, pp. 15-18.

7 Dibwe dia Mwembu, Histoires des Conditions de Vie, p. 21. 
many women made their way to town and stayed there by evading urban controls. ${ }^{8}$ Chauncey demonstrates that, to attract recruits, women (and children) were, in the late 1930s, allowed to enter some Northern Rhodesian mine compounds. ${ }^{9}$ However, they lacked the social provision accorded to their counterparts in Haut-Katanga and many survived by a combination of precarious 'urban marriages', unregulated agricultural and trading activities, and prostitution. Missionaries characteristically worried about what was labelled 'serial wifehood': a chapter in the landmark study by Merle Davis, Modern Industry and the African, found it to be common: 'Detection is difficult, and location managers find it discreet, unless serious family trouble should develop, not to inquire too closely into the marital relationships of their wards'. ${ }^{10}$ Parpart argues that women's presence in mine compounds was discreetly welcomed or at least tolerated by companies, but - because of opposition by government and 'native authorities' and because of their own desire to control costs - provision of services for families and women was piecemeal, reactive and ran well behind such provision in HautKatanga. ${ }^{11}$ Women (and men) nonetheless increasingly resided in Northern Rhodesian mine towns for longer periods in the 1930s and 1940s. While it is impossible to know what percentage of women migrated with their husbands, or met them in towns, it is certainly true that women made a substantial contribution to household income and reproduction by adapting their existing skills in brewing and farming to an urban setting. ${ }^{12}$

Chauncey was the first historian to identify the centrality of women's agricultural work for household reproduction: in Luanshya as early as 1935, 2,000 agricultural plots were allocated specifically to the wives of mineworkers, with some employing male workers on these plots. ${ }^{13}$ Township markets were established where women could sell farmed produce under company supervision and local Lamba farmer-traders

8 Ferguson, Expectations of Modernity, pp. 170-7.

9 George Chauncey Jr., 'The Locus of Reproduction: Women's Labour in the Zambian Copperbelt, 1927-1953', Journal of Southern African Studies 7, 2 (1981), pp. 135-64, p. 137.

10 Charles M. Coulter, 'The Sociological Problem', in John Merle Davis, Modern Industry and the African (London: Macmillan, 1933), cited in Parpart, 'The Household and the Mine Shaft', p. 40.

11 Parpart, 'The Household and the Mine Shaft', p. 41.

12 Chauncey, 'Locus of Reproduction', pp. 143-6.

13 Chauncey, 'Locus of Reproduction', p. 139-49. 
were excluded to facilitate this. Chauncey's interviewees in 1978 recalled successful African businesswomen who in the 1940s ran transport, restaurant and hotel services. ${ }^{14}$ However, as mine employment expanded in the late 1940s and 1950s, no attempt was made to expand the provision of agricultural plots across all mines and government officials looked at women's independent farming activities with suspicion:

a well defined characteristic of Copperbelt towns ... is the way Africans, especially the African women, go out and cultivate any bit of vacant land anywhere, without much regard for municipal regulations and certainly very little for its ownership. Air photographs show that cultivation covers from one to three thousand acres in and around each township.... It will take a very long time to wean the people of the desire to cultivate ... provision ... is needed in all the Copperbelt towns for some sort of outlet for peoples' energies in this direction. ${ }^{15}$

Despite the extraordinary scale and ubiquity of African Copperbelt agriculture (which is further discussed in Chapter 9), it was viewed by late colonial officials as a backward and essentially unhelpful activity. The fact that farming was mainly done by women served to demonstrate its backwardness. While commercial agriculture, for example, involved officially approved forestry and charcoal-burning initiatives, in Ndola in 1959

agriculture [was] no more than the sporadic planting of a few seeds, usually by women, whenever a patch of vacant land can be found. Both Rhokana Corporation and the Forestry Department have intensified patrols over the land bringing an increasing number of offenders before the Urban Native Court.... deputations of women from the Municipal Housing Areas [have been] told that it was not possible to reserve large gardening areas for them within easy reach of their houses. ${ }^{16}$

Some company officials desired a Katanga-style married and stabilised African labour force, but in Northern Rhodesia they had to reckon with the opposition of settler farmers and missionaries to

14 Chauncey, 'Locus of Reproduction', p. 153.

15 NAZ, WP 1/2/64, Special Commissioner for Western Province Reports on Copperbelt, 1959-60, Draft Report on Municipalities and Towns, n.d. but 1960.

16 NAZ, WP 1/2/64, Special Commissioner for Western Province Reports on Copperbelt, 1959-60, Annual Report, African Affairs, Ndola Urban, 1960. 
permanent stabilisation. African authorities equally sought to control and restrict women's mobility: recognised chiefs, mine-based 'tribal' elders/representatives and the African Representative Council, from its establishment in 1946, opposed women's migration, which, it believed, contributed to a moral crisis regarding marriage: 'Women ... find there will be no difficult $[\mathrm{y}]$ in the towns about getting married ... whom are they going to call, and who is going to receive the dowry? I have seen children who forget their parents and just think of the towns'. ${ }^{17}$ The high divorce rate was evidence for chiefs of the inauthenticity of urban marriages; bridewealth and other marriage customs were only loosely observed. ${ }^{18}$ The introduction of a pass system for women, in response to native authority demands, sought (unsuccessfully) to stem the flow of female migrants. In practice, companies issued passes to women who were vouched for by male workers and there was neither the capacity nor the stomach for checking women's registration documents.

The 1940 mineworkers' strike was, as already noted, a key event in persuading reluctant Northern Rhodesian company and government officials that stabilisation must now be embraced. With that came a belated investment in family housing and the social welfare systems pioneered north of the border. In contrast, the 1941 strike in HautKatanga was thought to have been caused by the poor conditions of mine camps: despite their far advanced development compared with those of Northern Rhodesia, officials still perceived them as places of disorganisation and promiscuity and there was, thereafter, a further expansion of family housing, services and surveillance. ${ }^{19}$

The underlying issue, for companies, the state and African elders, was effective control over women's productive and reproductive labour. When female settlement was officially accepted in the Northern Rhodesian mines in the late 1940s, it came - as it had in

NAZ, J. Sandasanda (Western), ARC II, 23 January 1951, quoted in Chauncey, 'Locus of Reproduction', p. 156.

Chauncey, 'Locus of Reproduction', p. 162. Male elders across mid-twentiethcentury sub-Saharan Africa warned of a growing moral crisis arising from women's urban migration: for East Africa, see Derek R. Peterson, Ethnic Patriotism and the East African Revival, c. 1935-1972 (Cambridge: Cambridge University Press, 2012). For southern Africa, see Teresa Barnes, 'The Fight for Control of African Women's Mobility in Colonial Zimbabwe, 1900-1939', Signs, 17 (1992), pp. 586-608.

19 Dibwe dia Mwembu, Histoire des Conditions de Vie, p. 27. 
Haut-Katanga - at a price: women in both regions were expected to fulfil a profoundly gendered role as housewife and mother. Their position in the mine township rested, officially at least, on their marriage to a man employed by the mines. ${ }^{20}$ They had no representation, to company or state officials, other than via their husbands. ${ }^{21}$ And they were expected by these officials and their social scientific advisers to play the leading role in creating and reproducing the modern urban nuclear family, which would be the foundation of a productive male workforce and the key to socialising future generations of urban youth.

\section{Gender in Social Scientific Research}

These gendered concerns were central to the efforts of the social scientific community in the 1940s and 1950s to produce applied knowledge about the new urban communities. In Katanga, CEPSI researchers such as Arthur Doucy not only worried about the capacity of families to make the transition to modernity, but - in line with the Institute's applied approach to social research - helped establish new social centres in the Elisabethville CEC to train them to do so. ${ }^{22}$ The CESPI researchers also assessed the colonial state's efforts to make customary law work in non-mine areas of Elisabethville in the early 1950s. While Vannes argued that '[c]ustom is certainly the form of law best suited to the rapid evolution of social and economic life in a CEC', he was, like rural chiefs, disparaging about its functioning in a city where there 'are rather a juxtaposition of particular customs; a shapeless mass whose imperatives collide without being able, very often, to integrate harmoniously with each other'. ${ }^{23}$ Although most people still married within their ethnic group, there were 'more and more young people in Elisabethville marrying people of diverse provenance', leading to confusion and conflict over which customs should apply to the resulting 'mulatto' family. For example, 'it is commonly accepted that only the husband can lodge a complaint for adultery by his spouse: but what

20 Jane L. Parpart, 'Class and Gender on the Copperbelt: Women in Northern Rhodesian Copper Mining Communities 1926-1964', Boston University African Studies Working Papers, 77 (1983). See also Parpart, 'The Household and the Mine Shaft', pp. 36-56.

21 Dibwe dia Mwembu, Histoire des Conditions de Vie, p. 26.

22 Rubbers and Poncelet, 'Sociologie Coloniale au Congo Belge', p. 98.

23 J. Vannes, 'De L'Evolution de la Coutume d'Elisabethville', CEPSI Bulletin, 32 (1956), pp. 223-68, p. 227. 
if the wife belongs to a [ethnic] group that does not repress this offense? ${ }^{24}$ Vannes found that married women, while lacking ownership rights to property and businesses that had to be in their husbands' names, were nonetheless funding house construction and ordering supplies for their businesses, and revealed that courts were awarding compensation to divorced women for property they had financed but didn't legally own. An attempt to ban the 'evil' of polygamy in town in April 1950 meant that all second marriages were null and void. Because polygamy was itself treated as a crime, wives in customary second marriages had no legal protection whatsoever.

Reflecting the general focus of research on formally employed male workers and their organisations and associations, women were rarely the direct subject of analysis. Epstein noted that during the 1952 mineworkers' strike, '[e]ach day the strikers and their womenfolk would go off en masse to cultivate their gardens'. He didn't, however, investigate the significance of this farming for household reproduction. ${ }^{25}$ Schumaker notes that attempts by RLI researchers to recruit African women to conduct research were adversely affected by their husbands' unwillingness to allow them to conduct urban fieldwork. ${ }^{26}$ As Ferguson notes, many Copperbelt residents were themselves heavily invested in activities associated with respectable family life, but it is also clear that the instances of performative 'civilised' behaviour in leisure and courtship highlighted by researchers - for example, the purchase of tailored Western-style clothes and leisure activities such as ballroom dancingreflected their disproportionate focus on the African elite. ${ }^{27}$ Epstein noted, however, that, contrary to the projections of the most optimistic observers, actually existing mine households were not occupied by discreet nuclear families but rather by 'a unit that was immediately tied into a wider set of kinship ties and obligations'. ${ }^{28}$ All the evidence suggests that Copperbelt residents both in and outside the mine areas continued to live in flexible family structures that were far from any nuclear norm: houses built for the envisaged nuclear families were consistently overcrowded with visiting rural relatives in search of

24 Vannes, 'De L'Evolution de la Coutume', p. 231.

25 Epstein, Politics in an Urban African Community, p. 96.

26 Schumaker, Africanizing Anthropology, pp. 210-1.

27 Ferguson, Expectations of Modernity, p. 175.

28 Epstein, Politics in an Urban African Community, p. 46, quoted in Ferguson, Expectations of Modernity, p. 173. 
employment and educational opportunities. As already noted, many migrants got jobs in town by initially staying with established family members, breaching the terms of the latter's leases leases in both mine and non-mine areas. As Ferguson argues, the apparent disjuncture between nuclear family ideals and the reality of such familial circumstances was resolved by RLI observers with the assumption that a 'trend' towards stabilisation was underway, the transitional phase emphasised by Epstein and many other researchers. ${ }^{29}$

Powdermaker's study of late colonial Luanshya, conducted in 1952-3, stands out for its privileging of African voices in general, and women's voices in particular, in their (and her) efforts to make sense of the social change unfolding around them. ${ }^{30}$ Powdermaker, influenced by but operating separately from the RLI, observed considerable tension and instability in marital relationships. She found that

the picture of family life and marriage on the mine township was ambiguous and complicated. Some traditional attitudes towards marriage, sexual relations, and the family persisted, a few in exaggerated form; others were in conflict with new attitudes; and there were many patterns of compromise. ${ }^{31}$

African marriage, Powdermaker explained, had been a contract between kindred groups, based on 'bride price', with polygamy aspired to by all men but achieved only by those of high status. Adultery was common and divorce 'an essential liberty'. ${ }^{32}$ In town, conflict arose over the husband's willingness to transfer part of his wages to his wife to spend on the necessities of urban sustenance that could only be acquired by purchasing goods for cash. In the mine towns, polygamy was difficult in family homes designed along monogamous, nuclear lines, while innovative 'inter-tribal' marriages brought new problems. There was a strong aspiration, amid much instability and conflict, to an individual family with a life partner of one's choice, at least 'among the intelligentsia and middle class'. ${ }^{33}$ Powdermaker provides extended first-person narratives of courtship, betrothal and marriage: conflicts arose between the costs of urban family life and male workers' obligations to support their rural kin in increasingly monetary terms. Divorce and remarriage were common. Powdermaker captures an exceptionally

29 Ferguson, Expectations of Modernity, pp. 172-4.

30 Powdermaker, Copper Town. 31 Powdermaker, Copper Town, p. 151.

32 Powdermaker, Copper Town, pp. 32-6.

33 Powdermaker, Copper Town, p. 152. 
detailed picture of gendered relationships, but her work contains equally striking absences. She asserts, along with some of our interviewees, that women preferred town life because they did not have to work so hard, but her account of a typical woman's life does not include agricultural or trading activities. ${ }^{34}$ While she is clear that most urban marriages were unstable hybrids of custom and modernity, she assumes this reflected the transition supposedly underway from one type of marriage - kinship-based, polygamous and rooted in 'superstitious' teachings about fertility - to another - nuclear, monogamous and based on a clear division between male breadwinners and female housewives.

\section{Late Colonial Social Welfare: Making the Urban Family}

The policy of stabilisation in Northern Rhodesian mine towns reflected belated recognition by the colonial authorities that marriages were being made in town outside customary authority and therefore needed to be subject to 'modern' regulation. In 1953, for example, despite opposition from African authorities, Urban Native Courts were authorised to issue marriage certificates without Native Authority permission. ${ }^{35}$ Alongside this, the rapid expansion of social services was a response to the marital tensions that resulted from the failure of urban employment to provide families with the life to which they aspired. As Parpart notes, company provision of marital counselling and courses in household economics was attractive to women, who regularly sought intervention by social case workers. Maintaining one's marriage, rather than opting for divorce, became a more attractive option when men were provided not only with wages but also housing and social benefits for their families. ${ }^{36}$

The late colonial period saw, as elsewhere in British-ruled Africa, a considerable expansion in state-directed welfare provision. In the mine areas of Copperbelt towns, however, companies jealously guarded control over social provision and leisure opportunities for

34 Powdermaker, Copper Town, pp. 189-90. Our interviewee Fridah Mwale (Mufulira, 6 July 2018) recalled: 'The work in the village was very difficult. We had to do things such as drawing water, grinding millet and getting grass to thatch the huts but most of those things were not being done here'.

35 Chauncey, 'Locus of Reproduction', p. 163.

36 Parpart, 'The Household and the Mine Shaft', p. 53. 
their employees. ${ }^{37}$ New mine welfare departments were established, for example in Luanshya in $1952 .{ }^{38}$ The burgeoning social welfare community drew lessons from the expansion of state welfare in post-World War Two western Europe but also believed that local circumstances called for specific expertise. Conferences brought together government officers with responsibility for town planning, policing and social welfare, alongside sociologists and anthropologists. Participants asserted the centrality of urban life to Africa's future development, but worried about towns' ability to provide social security for the old, socialisation for the young and the reproduction of stable family life. Ostensibly technocratic discussions were underpinned by moralistic notions, for example the need to restrict urban residence to those in employment and their immediate families while excluding unemployed 'loafers' (see also Chapter 2).

While Northern Rhodesian companies' social services were less developed compared with Haut-Katanga, by 1954 the Northern Rhodesian Council for Social Services (NRCSS) was co-ordinating provision by churches, mine companies and European women's groups. ${ }^{39}$ Council members worried that the limited opportunities for education and jobs for juveniles would cause delinquency and social unrest. By the late 1950s, Northern Rhodesian mine companies were providing youth centres and sports training. Powdermaker provides a snapshot of the early development of Luanshya's services: headed by a male European welfare officer and composed of 'several [male] African assistants' and two European 'lady welfare officers', their expanding services included reading and writing rooms, 'literacy classes, day nurseries for preschool children; classes for women in cooking, sewing, knitting, nutrition, and infant care; girls' clubs; and other social and educational pursuits'. ${ }^{40}$ But the work involved was ever expanding and the gathering of knowledge vital:

37 For an instructive British colonial comparison, see Andreas Eckert, 'Regulating the Social: Social Security, Social Welfare and the State in Late Colonial Tanzania', Journal of African History, 45, 3 (2004), pp. 467-89. Hansen, 'After Copper Town', p. 442.

39 NAZ, MLSS 1/12/5, Northern Rhodesia Council of Social Services 1967-8 [incorrect dates], 'Northern Rhodesia Council of Social Services', 9 August 1954.

40 Powdermaker, Copper Town, pp. 106-7. 
Bewildering changes are taking place in the pattern of family life, in economic life and ideas about ... leisure ... it is of fundamental importance that the social worker be equipped to understand and estimate the situation. He must be able to know how to conduct a social survey in order to get all the true facts.... Through the medium of sociological research he must know how to discover the FELT NEEDS of those with whom he has to work. ${ }^{41}$

A central area of concern and knowledge production was, as noted, African marriage customs and the ways in which they had changed - or would need to change - in town. At the 1961 NRCSS conference, a presentation on research by the Native Courts Department demonstrated that urban marriages were based on 'tribal practices' that were not in fact fixed but had been evolving steadily since the 1930s. Divorce cases dominated the work of such courts because 'in urban areas there is no one tribal custom and also, a large proportion of the unions are either inter-tribal marriages or mere concubinage'. ${ }^{42}$

It became increasingly clear that effective urban social welfare would require its own indigenised workforce: 'In any scheme the educated Africans must carry the message to their own people. They were essential co-workers'. ${ }^{43}$ There was, however, a tension between, on the one hand, the need for such a cadre, representative of the advanced class of urbanised Africans and able to educate and socialise new urban residents and, on the other hand, the belief that urban migrants needed to be kept in touch with their rural or 'tribal' culture during transition, and that (unlike whites) advanced Africans had access to customary knowledge that they could deploy in a developmental way in town. The result of these rapid changes was to bring to the fore a new generation of African welfare officers in both mine and government employment, whose understanding of African advancement and development chimed in many respects with the Copperbelt's indigenous elites. This understanding was articulated in the address to the NRCSS 1960 conference by Steack Mwale, Northern Rhodesia's first African senior welfare officer. Mwale told the conference:

NAZ, MLSS 1/12/5, Northern Rhodesia Council of Social Services 1967-8 [incorrect dates], NRCSS Social Workers' Conference, 25 September 1958. Emphasis in original.

42 Ibid, p. 12.

43 NAZ, MLSS 1/12/5, Northern Rhodesia Council of Social Services 1967-8 [incorrect dates], NRCSS Social Workers' Conference, 25 September 1958, Doctor Donnolly, Medical Officer of Health, Lusaka Municipality. 
African society before the advent of the white man ... was a self-contained and self-sufficient tribal pattern of life. ... [which] depended largely on kinship ties ... [in] communities [with] a somewhat static social order. [A] sense of belonging kept people observing community standards of conduct and behaviour. ... The impact of western culture with its ... dynamic social order ... has brought to the African a transitional period in which he is experiencing revolutionary social changes, giving rise to the need for social services. ${ }^{44}$

Mwale criticised the failure of European social welfare providers to engage with African elites, which meant Africans perceived social services 'as foreign and unwanted'. ${ }^{45}$ Africans, he argued, needed to be given opportunities for 'active participation' via 'popular and natural leaders of their own choice'. The transition to a sustainable urban social order would, it was clear, require African political leadership at the highest level. It would also require what were initially termed female African 'welfare assistants': most potential female recruits lacked the formal education necessary to qualify as social workers, but Lusaka's new Oppenheimer College of Social Services would, from 1961, train an expanded cadre of professional African social workers.

The question of how to marry well in the city was, it should be stressed, one that concerned other African observers. A central theme of Namusiya in the Mines (see Chapter 1) is the baleful influence of prostitution, itself presented as an immoral imitation of European styles: 'Prostitutes have many ways of attracting men. They paint their lips and cheeks with red paint they see European women using, and sometimes use white powder on their faces.... Some of them also wear trousers or shorts. They copy every fashion they see European women adopting' ${ }^{46}$ Namusiya is, however, saved from such temptations by a good marriage:

He wanted a suitable woman who was a Mwiila [his 'tribe']. Mixed marriages, he realised, led to all sorts of complications. Children born of such a marriage would belong to neither one tribe nor the other ... In the event of a divorce, who would look after the children? ... [but] he did not wish to marry a woman with whom he was not acquainted.... The folk at home may choose a woman who is quite unattractive to the man. ${ }^{47}$

44 NAZ, MLSS 1/12/7, N R Council of Social Services, 1960-2, Report on 1960 Annual Conference.

45 Ibid., p. 5.46 Kaavu, Namusiya at the Mines, p. $54 .{ }^{47}$ Ibid. 
Namusiya ultimately finds a bride who is of his tribe, recently arrived in the mine compound, who he marries in church and not according to village customs.

In real life, Copperbelt residents, like Namusiya, searched for knowledge on how to make successful relationships and reconcile rural custom with urban life. This search, particularly for the region's growing literate elite, led them to newspapers in general and their advice columns in particular. Kallmann's analysis of these publications in late colonial Zambia argues that they projected a universally desirable model of urban African womanhood, that was, however, drawn from the experiences of a tiny group of privileged women who served, like indigenous elites in general, as an ideal to which to aspire for all African women. ${ }^{48}$ A particularly valued source was 'Josephine', a wise African woman whose column in the Central African Mail provided advice to those 'men and women ... [who] are having to adjust to sudden changes of outlook and custom'. ${ }^{49}$ Two typical letters read:

I work underground in the mine with no chance of returning home to get married, so for the present I have a half-wife here. She is not of my tribe ... but she tells me she loves me ... In fact I love her too. Shall I marry her, or wait a year or two til I go home and get a tribe-wife? ${ }^{50}$

I am from Barotseland and the girl of my choice is not. I wrote to my parents trying to explain but they say I must leave the girl alone. They say, We have found a girl for you to marry - just send your picture and the money for 'lobola' [bride price]. I was in town soon after birth, educated in town and have never visited my tribal home, so know nothing of it. Can I have a girl without my parents' consent, or must I obey and send money and picture for a girl? ${ }^{51}$

It is noteworthy that 'Josephine' was herself not the stylish African woman depicted in the column photo, but in fact Barbara Hall, the British-born wife of the newspaper's editor. In his introduction to the edited collection of these letters, published months before Zambian independence in 1964, soon-to-be President Kenneth Kaunda expressed his hopes and fears about social change:

48 Deborah Kallman, 'Projected Moralities, Engaged Anxieties', pp. 71-117.

49 Barbara Hall (ed.), Tell Me Josephine (London: Andre Deutsch, 1964), Frontispiece.

50 Hall, Tell Me Josephine, p. 68. 51 Hall, Tell Me Josephine, pp. 66-7. 
time will fuse together elements from our traditional African culture and values with the attitude and morality of Europe and other continents. Whether Africa will be able to take the best of the cultures of more 'advanced' countries, and resist the worst ... we must wait and see.... in times of breakneck change, the pressures are immense, especially on young people. Old values are falling away, and little that is solid exists to replace them. In such conditions of bewilderment, in crowded towns, young people can turn all too easily to delinquency and immorality. ... Not enough, I fear, is being done to examine the roots of the troubles and to suggest bold solutions. Most intensive research is needed, and the findings must be implemented swiftly. ${ }^{52}$

In Haut-Katanga, advice was provided by Mwana Shaba, UMHK's monthly newspaper for its workforce and their families. Mwana Shaba sought to project the image of an idealised mine family in posed photos of senior workers and their families. A regular advice column, 'Baraza ya Bibi' ('Women's Forum' in Kiswahili), explained in painstaking detail how to wash and sew clothes, clean homes and access childcare in the mine towns. While the gender values on display were similar to those in the contemporaneous West, they were underlain with a strong evolutionary characterisation of African society, alongside a projection of UMHK's all-seeing benevolence. A story encouraging the feeding of formula milk to children was headlined, 'Are you a good father to your family?' It explained that the cash supplement now paid to senior UMHK workers instead of rations (see Chapter 4) was equivalent to 'the amount that a UMHK worker, married and father of two children, receives for each day of work in order to feed his family'. This cash replacement was only provided in the first instance to more experienced workers since 'the Company knew that they would support their families. Weren't they used to living in the camps and managing their budget? This is not the case for many Congolese who do not know how to avoid unnecessary expenses or buy at the best price'. The company was, however, concerned that its trust was misplaced:

The Company has therefore shown its confidence in the best of its workers. Was it wrong to trust? Yes to a certain extent, since the doctors maintain that there are sick and weak inhabitants of our cités, because of lack of nutrition. ... Some workers may spend all their income on selfish 
amusements; it also happens that they drink beer in large quantities, without thinking of the abandoned and hungry family. ${ }^{53}$

Similar rhetoric infuses a 1958 story about alcoholism: 'Truly my friends, if some Congolese continue to drink like this, they will not be able to progress and sooner or later they will disappear like the millions of American Indians who drank the fire water ... that killed them all'. ${ }^{54}$ In a series of articles in late 1958 and early 1959, Mwana Shaba devoted extensive attention to the question of African urban marriage (far more than to the political upheaval that would soon bring about independence). These articles drew on the correspondence of readers, not only on the ideal marriage but also the social problems associated with it in the new urban milieu. Wives were enjoined:

Do not let your husband dress in a badly patched shirt or trousers with holes because it is you who will bear the mockery of his friends.... Do not spend more money than your husband earns and especially never blame him for earning too little. On the contrary, encourage him to progress in his profession to improve his situation, give him confidence in his abilities, be proud of him and try to justify this pride. ${ }^{55}$

Husbands were instructed not to treat their wives as slaves or possessions but as companions and to avoid infidelity, alcoholism and 'unjustified jealousy'. 56 Marriages between those of mixed 'tribal' origins created problems, in particular for children of divorced parents because of their family's differing customs. ${ }^{57}$ Mwana Shaba was particularly scathing about the commercialisation of the dowry:

the objects [previously] given as dowry have been replaced bit by bit with money ... this way of falsifying the customary conception of the dowry has made it possible to believe, wrongly, that the delivery of dowry could be akin to a purchase.... Some parents ... must curb their thirst for money and stop selling their daughters like goats. ${ }^{58}$

Belgian BAA, Mwana Shaba, No. 5, May 1957, 'Etes-Vous Bons Peres de Famille?'

BAA, Mwana Shaba, No. 3, March 1957, 'Alcoholism: the Mortal Enemy of the Congolese'.

BAA, Mwana Shaba, No. 6, June 1958, 'Pour un Foyer Heureux'.

BAA, Mwana Shaba, No. 5, May 1959, 'Du Mariage'.

BAA, Mwana Shaba, No. 7, July 1959, 'Du Mariage'.

BAA, Mwana Shaba, No. 3, March 1959, 'Du Mariage'. 
Polygamy was equally criticised by the newspapers' writers but, like social scientists such as Powdermaker, Mwana Shaba's editorial line was that it would not be an enduring problem: 'we will not speak of it, since polygamy tends gradually to disappear with the advancement of Congolese society and because only monogamous marriage finds help and protection in the law'. ${ }^{59}$

For their part, Mwana Shaba's readers, whose letters increasingly featured in its pages, both shared and dissented from the newspaper's projection of a confident modern future in which 'backward' customs would wither away. Alongside a confidence in the capacity of modern institutions and instruction to facilitate progressive social change was a characteristic anxiety about what was being lost in this transition. In January 1959 Mwana Shaba quoted at length the views of reader M. A. Kabunda regarding the transmission of customary knowledge about family life:

We learned from the mouths of our grandparents their customs without having seen them.... If our ancestors did not know civilization, they were nevertheless wiser than us for certain things. They led a peaceful life in their household: the wife was subject to the husband, the husband liked her and good relations prevailed between the spouses.... Therefore there were not as many divorces as today.... I ask the young people who read me to return to the teaching of our ancestors so that they can live without great difficulty. ${ }^{60}$

The desire to both modernise urban family life and to adhere to custom in some altered form was, then, not simply a late colonial construct: it was articulated by many members of Copperbelt society. Far from being a transitory moment between one stable familial order and a new one, the enduring tumult of the urban social order would continue to make itself felt in the post-colonial Copperbelt.

\section{Women as Workers, Women as Wives: Gender in Copperbelt Social History}

In the 1970s and 1980s a generation of social historians turned to the study of what was by then the recent history of the late colonial Copperbelt family, influenced by the rise of women's history and keen to write gender and the private sphere into a Copperbelt literature

59 BAA, Mwana Shaba, No. 2, February 1959, 'Au Mariage’.

60 BAA, Mwana Shaba, No. 1, January 1959, 'Au Mariage’. 
hitherto dominated by mining, men and work. They, like social historians everywhere, were challenged by the absence of women's voices in the official record and read against the grain of that invisibility while also gathering oral histories of the women concerned. ${ }^{61}$ The foci of this research, however, took strikingly distinct forms in the two Copperbelt regions, reflecting both their own social history but also how identity and knowledge about it had previously been constructed.

In the Zambian Copperbelt, where a social identity rooted in politicised organised labour had been established (Chapter 4), historians studied women as economically and politically significant labourers in mine communities. Chauncey, for example, showed that women's labour was central not only to childrearing but to 'daily reproduction of labour power, that is, the daily maintenance of the worker'. ${ }^{62}$ Karen Tranberg Hansen identified the failure of officials to recognise domestic labour as work: 'When colonial authorities complained that urban African women were idle and lazy, they failed to recognize the timeconsuming tasks of food processing and preparation and the constant demands that children and their care placed on women'. ${ }^{63}$

The most important historian of the late colonial Zambian Copperbelt, Jane Parpart, built on Epstein and Powdermaker's research to show how strikes and protests in the 1950s were community events, playing out as much in the township as in the mine itself and influenced by the grievances of both women and men. ${ }^{64}$ This was still the case at the time Parpart was researching and writing: postindependence union meetings remained public events held in mine townships and attended by entire families. Women questioned and criticised union leaders for their alleged failure to meet their financial needs via wage increases for their husbands. ${ }^{65} \mathrm{My}$ own research shows that women took their protests over, for example, health provision directly to company officials, who refused to meet them 'because the company does not recognise dependants as representing employees on

61 Among a rich literature see, for example, Sherna Berger Gluck and Daphne Patai (eds.), Women's Words: The Feminist Practice of Oral History (New York:

Routledge, 1991).

62 Chauncey, 'The Locus of Reproduction'.

63 Karen Tranberg Hansen, 'Body Politics: Sexuality, Gender, and Domestic Service in Zambia', Journal of Women's History 2, 1 (1990), pp. 120-42.

64 Parpart, Labour and Capital; Parpart, 'The Household and the Mineshaft'.

65 Larmer, Mineworkers in Zambia, pp. 112-3. 
any matters' ${ }^{66}$ This lack of direct representation paradoxically made it easier for women to demonstrate their discontents without fear of reprisal. As one of the mineworkers' union's first female branch officials explained: 'that woman is not recognised by the Company.... Even if they're to cry out, Management would not look at them, because they don't know them. When you fight, nobody will apprehend you'. ${ }^{67}$ This was clearly demonstrated during protests over food shortages in July 1981 (Figure 5.1), when mineworkers' wives wearing their husbands' overalls and hard hats mounted pickets to prevent their husbands working. ${ }^{68}$ While the Times of Zambia warned mineworkers to resist 'petticoat incitement' to strike action, some male mineworkers themselves reportedly donned dresses, headscarves and false breasts to disguise their presence in female-dominated pickets that physically attacked employees who sought to work. ${ }^{69}$

A quite different dynamic can be seen in parallel studies of the role and participation of women in Haut-Katanga's mine towns. From the 1970s, the social scientific study of urban Haut-Katanga at the University of Lubumbashi (see Chapter 6) focussed not on workerist or class dynamics but rather on familial and gender relations. Donatien Dibwe dia Mwembu, in historicising the development of the UMHK/ Gécamines ideal family, showed that women used their subordinate role as company wives to secure and advance their socio-economic position in town. From the 1950s until the 1980s, the extensive social wage provided to the workers and families of Gécamines (and to some extent other companies such as SNCC/Z, the state-owned railways) meant that some women could live a comparatively secure life as housewives and mothers without needing additional earnings. This position, however, rested on their fulfilment of a different kind of work, their participation in the childcare and reproductive systems established by the company. Gécamines continued the natalist policies

66

Mineworkers' Union of Zambia (hereafter MUZ), Luanshya, 'Meetings with Management, 1975-78', Asst Personnel Superintendent, MUZ Officials, and Women Representatives of Demonstrators, 15 March 1978.

67 Interview, Rodah Matoba, Luanshya, 21 January 2003, quoted in Larmer, Mineworkers in Zambia, p. 114.

68 Times of Zambia (hereafter ToZ), 1 July 1981.

69 Interview, George Mukoma, Chiliabombwe, 11 February 2003, quoted in Miles Larmer, 'Zambia's mineworkers and political change, 1964-1991', unpublished PhD thesis, University of Sheffield (2004), p. 205. 


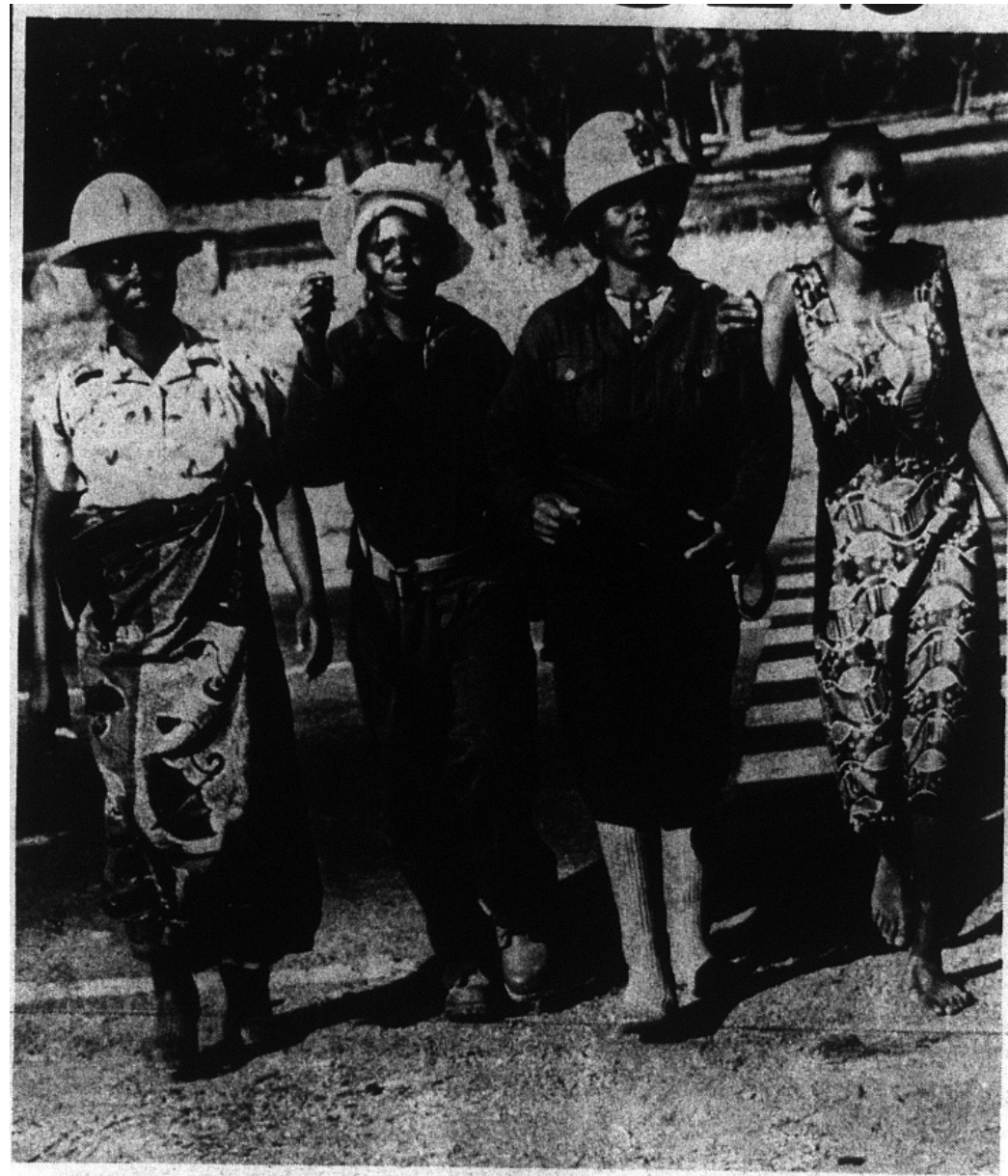

- MINERS' wives [from left] Mrs Mary Slame, Mrs Jane Chisanga, Mrs Beletina Mwaba and Mrs Chimwemwe Mufuni march to No. 3 shaft.

Figure 5.1 Protesting wives of mineworkers. Times of Zambia, 7 July 1981. Picture courtesy of the Times of Zambia.

pioneered by UMHK, obliging women to give birth in hospital and to bring children in for regular health checks. ${ }^{70}$

Despite this maternal labour, mineworkers' wives, like their Zambian counterparts, lacked direct representation with the company that dominated their lives: as Dibwe dia Mwembu puts it, 'The husband is the

70 Interview, Agnès Njamba, Likasi, 16 July 2019. 
representative of the company in his family.... While the man works, the woman, excluded from the modern world of work, takes care of the household'. ${ }^{71}$ Wives needed to obtain their husbands' assent to open a bank account, obtain a trading licence and - in relation to the company's maternal services - to have themselves sterilised. In HautKatanga, however, this exclusion does not appear to have prompted outright challenge of the sort witnessed in Zambia. Indeed, wives were kept subjugated by the privileged position of their husbands: 'fidelity and submission by women to their husbands was the condition sine qua non to avoid being rejected and replaced by the numerous women who were waiting in the cité ${ }^{72}$ The ability of salaried husbands to pick and choose their wives was emphasised in popular culture: Dibwe dia Mwembu cites the song 'Balimwatsh' by the Kolwezi-based group L'Orchestre Safari Nkoyi about a covetous woman who was unsatisfied with the salary her husband brought home at the end of the month and who, because of her demands, was divorced. ${ }^{73}$

This does not mean, however, that the Katangese company system was able by such means to produce stable family structures. Far from reducing family size to the 'two child' standard promoted by Mwana Shaba (above), the average Gécamines household (including adults) grew from 3.7 people in 1962 to 4 in 1967 and 6 by the end of the 1980s. ${ }^{74}$ Company policies designed to promote nuclear families by the provision of maternal and welfare services in practice incentivised workers to have more children. Despite its best efforts, Gécamines was not able to exclude extended family members from its mine cités and, while direct evidence is inherently hard to obtain, it seems likely that at least some children registered under the company system were not the progeny of both the husband and his 'official' wife. Dibwe dia Mwembu indeed suggests that the prosperity of (mostly male) Gecamines' employees gave them the ability to 'keep' second wives in non-mine areas, unrecognised by the company and unable to access its social services. A new Zairian marriage code of 1987 decreed that children from illegitimate marriages should have the same access to

71 'Le mari est le représentant de l'entreprise dans sa famille. ... Alors que l'homme travaille, la femme, exclue au début du monde moderne du travail, s'occupe du ménage.' Dibwe dia Mwembu, Les Conditions dans la Vie, p. 26.

72 Dibwe dia Mwembu, Bana Shaba, p. 128.

73 Cited in Dibwe dia Mwembu, Bana Shaba, pp. 129-30.

74 Dibwe dia Mwembu, Bana Shaba, p. 145. 
services as their legitimate counterparts. As a result, companies were obliged to provide benefits to mineworkers' children from any and all marriages, for example schooling and medical care. This created a distinct intra-familial inequality, since second wives were still not entitled to company services. ${ }^{75}$

The new marriage code sought to shore up male authority in Zairian marriage in other ways, for example by placing the financial management of both spouses' assets in the hands of the husband. It also prohibited polygamy, in line with earlier (colonial) legislation proclaiming the sanctity of monogamous marriage. ${ }^{76}$ Dibwe dia Mwembu demonstrates, however, that the new code unintentionally strengthened polygamous families: he cites a case in which a man, married to his first wife in 1981, took a second wife when the first became sterile after giving birth to two children. Having had five further children with his second wife, rations obtained from Gécamines for all seven children were in practice shared across both households. This actually strengthened the status within the marriage of the second wife, while for many first wives their family life was destabilised. Dibwe dia Mwembu puts it thus: 'We are still witnessing (since the colonial period) the resistance of African manners, deeply rooted in the Congolese spirit in the face of modern laws in matrimonial matters'. ${ }^{77}$ Alternatively, it might be argued that polygamy has in urban Katanga shown itself to be a modern practice in its ability to adapt to and work around a radically altered system of residence, work and economic incentives.

This body of research thus demonstrated that both Zambian and Katangese Copperbelt women were excluded from direct representation by the companies that relied on them to reproduce their husbands' labour, but they reacted to that exclusion in contrasting ways. That difference, while not preventing the considerable agency of Katangese women, did help reinforce the notion of Gécamines as an effective totalitarian regime and its ubiquitous characterisation as the father and mother of its workers and the description by interviewees of themselves as 'children of the company'. ${ }^{78}$ While today many former Zambian mineworkers and their family members characterise ZCCM

75 Dibwe dia Mwembu, Bana Shaba, p. 119.

76 Dibwe dia Mwembu, Bana Shaba, pp. 138-9.

77 Dibwe dia Mwembu, Bana Shaba, pp. 139-41.

78 Rubbers, Le Paternalisme. Interviews: Gaston Mutiti, Likasi, 4 June 2018; Pami wa Kasongo. 
as a company that cared for its workers, this familial analogy is not one that arises in interviews or wider popular discourse: it was rather a company on which mine families themselves made demands.

\section{Women's Work in the Post-Colonial Copperbelt}

While the historiography of late colonial and post-colonial Copperbelt women varies considerably, studies of both Zambia and Haut-Katanga tend to treat wage labour (gendered as male) and non-waged income as separate spheres and - despite the social history turn - continued to focus on mine areas rather than the wider urban Copperbelt society to which they were inextricably linked (Chapter 3). In practice, households earned a range of income types, which were certainly valued in different ways: mine companies paid cash wages to (mostly male) employees, but also provided food (consistently in Haut-Katanga, intermittently in Zambia) and a wide range of services and subsidies ranging from housing to free primary education to leisure activities. Households in general and women in particular grew foodstuffs not provided by companies, but women also earned cash by selling harvested produce to mine companies and to their neighbours. They also traded clothes and other manufactured items and sold sewn and knitted items that they often learned to make in company-run social centres. Notwithstanding the different orientations of the social history literature on Zambia (women's work as labour) and Katanga (women's work in the Gécamines family), their socio-economic and familial activities were similar to the extent that most women, unsurprisingly, juggled the double burden of domestic and non-domestic work.

The ubiquity of women's work challenges the observations of some analysts. Powdermaker, as noted, found agricultural cultivation among women in mining communities to be largely non-existent or in decline, but archival evidence and interviews suggest its ubiquity. Cultivation was banned by UMHK in the yards of workers' houses to prevent mosquitoes and, in any case, most yards were too small to allow anything but the smallest garden. Elsewhere in the mine towns it was, however, common to cultivate unoccupied land to supplement wages or to sell in the market or to neighbours. ${ }^{79}$ Daniel Henk found in

79 Interviews: Marie Jeanne Ngoy Mwamba and Valérienne Ngoy Mudimbi, both Likasi, 9 June 2018. 
the late 1980s that, while small plots had been cultivated by women in the 1950s, they were not now common because of dependence on formal wages. ${ }^{80}$ It is noteworthy that Henk's informants were themselves married male mineworkers, not their wives. Our interviewees suggest that, while farming may have briefly been less common among Katangese mineworkers' wives in the 1960s and 1970s, agriculture and trading in farmed produce was a widespread activity among women in Mufulira, Likasi and the wider urban Copperbelt, with much of the farming taking place in nearby rural and peri-urban areas where land was simply 'found' or leased from village chiefs on a quasi-sharecropping basis. ${ }^{81}$ Dibwe dia Mwembu, while stressing that women had always contributed to household economies, dates the increasing adoption of 'marginal' activities such as farming and trading to the economic difficulties from the mid-to-late 1970s onwards. ${ }^{82}$ While many interviewees did indeed start farming in earnest in response to decreasing real wages and increasingly precarious employment (see Chapter 8), many others had sought to farm in town from the time of their arrival and most of this activity was carried out by women. Kathbert Nchema, who grew up in Kitwe in the 1960s, recalls:

Most of the people in Kitwe had [farms].... Coming from a [rural] background where my parents enjoyed farming, we never saw any difference. From these gardens we were able to grow sweet potatoes, maize and other crops and we would even take the grain to the grinding mill and get mealie meal. In most cases people were not getting a lot of money [from employment] to sustain themselves and their families. Therefore, as a way of improving their livelihood, ladies usually, had to go in the gardens to fetch firewood because some people would not even manage to buy charcoal. ${ }^{83}$

Although Victoria Mwelwa remembers the distribution of food rations in Kitwe in the 1950s, she nonetheless grew crops 'on a free land - land which was unoccupied ... and earned extra income which helped us especially when the salary for my husband [was] delayed'. ${ }^{84}$

80 Daniel W. Henk, 'Kazi ya Shaba: choice, continuity, and social change in an industrial community of southern Zaire', unpublished $\mathrm{PhD}$ thesis, University of Florida (1988), p. 475.

81 Interviews: Nathan Mwamba, Mufulira, 7 July 2018; François Batabata Nsenga.

82 Dibwe dia Mwembu, Bana Shaba, pp. 132-3.

83 Kathbert Nchema interview, 9 July 2018. ${ }^{84}$ Victoria Mwelwa interview. 
Having initially described his mother as 'just a housewife', Simon Bwalya then explained that in the 1970s she 'was industrious and contributed to the family by selling munkoyo [a fermented maize drink]'. ${ }^{85}$ Boston Mwenya's 'housewife' mother equally bought vegetables wholesale from an Asian-owned store in Luanshya and resold them in a local market. ${ }^{86}$ Juliana Sakala arrived in Mufulira in 1979 and immediately started gardening 'to supplement the salaries we got to meet our family needs'. ${ }^{87}$ Farming was not the only means by which women earned money. In the 1970s and 1980s, Dorothy Musisha traded clothes in a business that involved periodic visits (conducted with groups of 'fellow women') to South Africa, Rhodesia/Zimbabwe and Malawi. She also visited Luapula Province to buy fish that she would then sell on the Copperbelt. ${ }^{88}$ André Kabinda Kasengo's job on Congolese railways (SNCC/Z) enabled his wife to travel to towns along the line of rail, selling clothing and other items and bringing back oil to sell in Likasi. ${ }^{89}$ Dieudonné Kalenga's wife converted the homemaking skills she learnt at the foyer social to make money doing sewing jobs for neighbours. ${ }^{90}$ Ana Chilufya, as well as farming maize, cassava and groundnuts for consumption and sale, travelled back and forth to her home area of Kawambwa on buses and lorries, bringing clothes from town to sell and buying foodstuffs which she then sold in the Mufulira council-run market. With the income, 'I used it to educate our children and supplement my husband's monthly salary'. ${ }^{91}$ Women's earnings were often earmarked for specific purposes and many interviewees used them to pay school fees. ${ }^{92}$

By the 1980s, many women were also doing salaried work. Gécamines, for example, had 1,744 female employees in 1979, just under 5 per cent of a workforce of $35,818 . .^{93}$ By 1988, women accounted for 10 per cent of its salaried staff or 'cadres'. ${ }^{94}$ As well as nurses, teachers and clerical workers, a significant number of these

\footnotetext{
85 Simon Bwalya interview. 86 Boston Mwenya interview.

87 Juliana Sakala interview.

88 Interview, Dorothy Musisha, Mufulira, 12 July 2018.

89 Interview, André Kabinda Kasengo, Likasi, 4 June 2018.

90 Dieudonné Kalenga interview. 91 Ana Chilufya interview.

92 Primary school was free for the children of Gécamines workers and, in many cases, for those of ZCCM, but secondary school was commonly paid for by workers themselves.

93 African Studies Centre, Leiden, Gécamines Annual Report 1979.

94 Dibwe dia Mwembu, Bana Shaba, p. 138.
} 
women were employed in the social centres that continued to train women in household skills and became social workers intervening in 'problem families', the subject to which we now turn.

\section{Post-Independence Social Welfare: Continuity and Change ${ }^{95}$}

In independent Zambia and Zaire, companies continued to provide extensive social services to their employees. In Haut-Katanga, social provision encompassed schooling and health care, as well as youth and women's centres, leisure services, company stores, maintenance and sanitation teams and policing common to both Copperbelt regions. In 1973, Gécamines' social services department ran fourteen social centres, eight girls' centres and twelve entertainment centres, alongside youth clubs and sports arenas. ${ }^{96}$ In 1975 , the company provided 42,649 free primary places for the children of its employees. ${ }^{9}$

While social intervention was, in the colonial period, predicated on the assumption that the supposed paternalistic 'customs' of rural African societies would be displaced by urban modernisation, postindependence social workers, mostly recruited from Copperbelt societies and many themselves the children of mineworkers, rejected such a characterisation in interviews. They rather identified ways in which 'custom', albeit in reconstructed forms, was an everyday part of urban life. They did, however, believe there were right and wrong ways to live in town and explained how and why they intervened in the family lives of employees to ensure their notion of social order. Social workers were strongly invested in the principle that companies should care for their workers and families and that this required intervention in family life to see that a worker's dependents were well cared for. Social workers saw their job as preventing divorce or separation in order to ensure that children were raised by a married couple. The motivation was, as retired senior social worker Mark Masumbuko suggests, 'to put harmony into the township: the most important thing was that miners, when they came home, they should find a habitable situation'. ${ }^{98}$

95 An extended analysis of the issues explored in this section can be found in Larmer and Taylor, 'The Decolonisation of Community Development', in Larmer et al., Across the Copperbelt.

96 African Studies Centre, Leiden, Gécamines Annual Report 1973.

97 African Studies Centre, Leiden, Gécamines Annual Report 1975.

98 Interview, Mark Masumbuko, Kitwe, 4 July 2019. 
Masumbuko linked this to the broader social peace of mining settlements:

If a miner knocked off, and he didn't find the wife [had] already prepared food, that would arise into talking. Or, if the wife was not at home, without telling the husband ... that would create problems. Or the miner himself knocks off, goes for a beer before getting home, he goes home drunk, that would create a problem. So, noise would start, and we would get involved. ${ }^{99}$

His former colleague Victor Chishala confirmed: 'A happy marriage will make the breadwinner perform his duties successfully'. ${ }^{100}$ Most Zambian social workers utilised similar explanations of their work that linked domestic content to an effective workplace.

Social welfare officers regularly investigated family disputes. Intervention was commonly prompted by a wife's complaint to a social worker - or, in Haut-Katanga, the chef de cité - that she was not receiving sufficient funds from her husband's wage to provide for the family. This might be because he was drinking too much alcohol or keeping another woman or even a second family. In a few cases husbands brought complaints about their wives for failing to maintain their households or drinking too much. A personnel officer could contact a social worker to investigate if an underperforming worker had domestic difficulties. ${ }^{101}$ Social workers arranged informal meetings with wives and husbands, discussed difficulties and obtained from them pledges about their future conduct: husbands might have to agree to hand a specific share of their wage to their wife. When spouses failed to agree what their problem was, social workers might contact their neighbours to ascertain what was causing conflict. Ultimately, backed by the company's authority as employer and landlord, part or even all the husband's salary could be directly paid to his wife to ensure the family was maintained. ${ }^{102}$

In both parts of the Copperbelt, company-run women's centres provided adult education. Women were trained in managing the household budget, something that supposedly ensured domestic harmony and prevented spousal conflict. ${ }^{103}$ Implicit in such training was still

\footnotetext{
99 Mark Masumbuko interview.

100 Interview, Victor Chishala, Kitwe, 6 July 2019.

101 Interview, Joseph Tumba Mwenzu, Mufulira, 11 July 2019.

102 Mark Masumbuko interview.

103 Josephine Lukwesa interview; Mark Masumbuko interview.
} 
a sharp distinction in the socialisation of young women in town compared with rural areas, both in the necessary skill set and in the shift from instruction by older female relatives to educated female trainers. ${ }^{104}$ These centres also continued to instruct women in domestic tasks: cooking, tailoring, cleaning the family home and raising children. ${ }^{105}$ Thérèse Kyola worked in a foyer social in Likasi from the 1960s until the 1990s: initially trained by white women to teach knitting, cooking and childcare, she went on to instruct the wives of railway workers to do some of these tasks:

At the end of the training, the learners tasted the recipe of the day and brought the leftovers for their spouses back to their respective homes. There were also days devoted to how to clean a house: the walls and the windows. There were also days devoted to unplanned visits to workers' homes, to assess the degree of mastery and the application of lessons learned. ${ }^{106}$

For Kyola, this training helped both men and women live up to the ideal gender roles previously advanced in Mwana Shaba: 'At the time, a good wife stood out through her good deeds: obedience, respect and submission to her husband. A good husband is one who knows how to listen to his wife. He cannot give me a course of action to follow and ignore mine'. ${ }^{107}$

During the late 1960s and 1970s, such training acquired a new purpose, that is, to generate income. Whereas male wages were initially characterised as sufficient to raise a family, it was increasingly recognised that women's earnings were an important source of income to the household and to the woman in particular. Women who received such training recall the skills they acquired with considerable pride. ${ }^{108} \mathrm{By}$ the 1980s, such training was understood as primarily for 'income generation', to the extent that its earlier, essentially 'domestic' role had been largely forgotten by interviewees.

Women's centres, some witnesses recall, also provided opportunities for unofficial forms of socialisation and the sharing of advice among women: one asserted that women were taught how to space their children without the use of contraception, which was not widely available. ${ }^{109}$ By the late 1980s 'women's rights' had in Zambia become part of some training courses. This did not mean that wives should not

104 Mark Masumbuko interview. 105 Ibid. 106 Thérèse Kyola interview.

107 Ibid. 108 Interview, Astrid Musumbi, Likasi, 6 August 2019.

109 Mark Masumbuko interview. 
obey their husbands, but efforts were made to help educated women assert their right to paid employment as a positive contribution to the household and to balance their health against giving birth to children. ${ }^{110}$

Custom, seen by late colonial observers to be a rigid barrier to effective adjustment to 'modern' life, proved to be flexible and responsive to the realities of urban living. Mine township residents adjusted to and managed potential differences in custom as the influence of the village diminished. Initiation ceremonies of children into adulthood took place either on brief visits to the village or in a reinvented urban form that 'was part of life in town'. ${ }^{111}$ Similarly, inter-ethnic marriages had become common: for Victor Chishala, his ability to counsel 'intertribal' couples was aided by his own upbringing as the child of an ethnically mixed Copperbelt marriage. ${ }^{112}$ Joseph Tumba Menzu describes a 'fusing' of marital customs: an implicit choice was made about which customs would be 'performed', without social conflict arising. Links to rural areas were declining and people were developing 'mixed customs'. ${ }^{113}$ While they did not pose the existential challenges to family life feared by many late colonial observers, they could certainly be the focus of marital and familial conflict.

As noted above, polygamy was ostensibly incompatible with company provision of housing and support: as Mark Masumbuko put it, if a man had more than one wife, 'you marry outside the system of the mines'. ${ }^{114}$ Yet it is clear that polygamy continued to be practised in Haut-Katanga across and outside the company system in the ways described by Dibwe dia Mwembu. In Zambia, ZCCM would only intervene if polygamy led to conflict in the mine township. ${ }^{115}$ A second wife could not inherit her husband's pension and other benefits on his death. While social workers sought to safeguard widows' inheritance rights and ensure that they received the payment due after a husband's death in service, this could be undermined, as Ferguson noted for Zambia, by mineworkers' desire to pay benefits to their extended kin as well as or instead of their nuclear family. ${ }^{116}$

\footnotetext{
110 Josephine Lukwesa interview. 111 Mark Masumbuko interview.

112 Victor Chishala interview.

113 Joseph Tumba Menzu interview, 11 July 2019.

114 Mark Masumbuko interview.

115 Interview, Leonard Chola, Kitwe, 4 July 2019.

116 Ferguson, Expectations of Modernity.
} 
Across the Copperbelt, bereaved families had to leave their company house once all benefits had been paid: the remit of social intervention ran only to the termination of employment and there remained an entirely unrealistic assumption that surviving family members would 'return' to their rural areas. ${ }^{117}$

Unsurprisingly, the sustained intervention by companies into the marriages and households of their workers brought about neither an ideal modern urban family nor resolved ongoing conflicts over the relationship between wage and household labour, child-rearing and obligations towards individual family and kinship networks. The continuing provision of elaborate systems of social intervention attests less to the benevolence of company and state officials and more to their continuing anxiety over the disruptive effects of social conflict in mine communities. When Ferguson conducted his research in the late 1980s, marital relations were still beset by conflicts over the distribution of scarce resources between the wives and children of Copperbelt workers and their extended kin. Wives in multi-ethnic marriages were anxious about 'retiring' to their husband's village for fear of poisoning or witchcraft. Copperbelt residents still sought an ideal marriage based on 'modern' notions such as romance, fidelity and partnership, while experiencing the tensions arising from familial conflict and financial hardship. ${ }^{118}$ Henk tellingly found that, while many of his informants - male mineworkers in Kolwezi - had made inter-ethnic marriages, they nonetheless regarded such marriages as problematic and a cause of high divorce rates. Variations in what might previously have been termed 'custom' were now characterised as ethnic differences in the 'mentality' of wives regarding dowry and the role of the extended family. ${ }^{119}$ The idealised future urban marriage that was to have resulted from effective social intervention had, in a context of economic decline, become a thing of the past, associated with the steady jobs and company generosity of the golden age.

Research on the twenty-first-century Copperbelt indicates that the virtual collapse of the company system has, with the loss of the norm of male waged labour (a norm, it should be noted, only available to

117 Leonard Chola interview.

118 Ferguson, Expectations of Modernity, pp. 175-6.

119 Henk, 'Kazi ya Shaba', pp. 423-5, p. 516. 
a minority of actual Copperbelt residents), reconstructed gender relations in new ways. As Bobby Kabamba puts it:

Not so many people are working. Those who are living alright are those who are doing fine on the land .... in most cases, what I have observed is that women are looking after men. They are paying for school children through the use of markets and business and so forth. ${ }^{120}$

Researchers and interviewees alike identify the growing importance of women breadwinners, but disagree about whether this is raising the status of women or imposing on them a typical 'double burden' of entrepreneurship alongside household management. ${ }^{121}$ The loss of formal employment is equally associated with a crisis of masculinity in which the inability of ex-workers to attract a wife and/or provide for their families is counterposed to a recent past in which marriage could be formed on a romantic and not a material basis. ${ }^{122}$

\section{Conclusion}

While understandings of gendered relations and the urban Copperbelt family have altered dramatically in the last sixty years, one thing has remained constant: actually existing relationships have been unstable and often conflictual. This has generated anxieties - among officials, chiefly authorities, social scientists, religious leaders, welfare officers and residents themselves - that faulty marital and familial relations, resulting variously from the sinful temptations of town life, incorrect adaptation to Western modernity or the injustices and inequalities of urban life, needed to be addressed by official intervention in the private lives of Copperbelt residents. Comparison has been drawn between such real relationships and idealised family types associated either with the recent past and/or the imminent future: a normative 'pre-colonial'

120 Bobby Jackson Kabamba interview.

121 For the former, see Alice Evans, "Women Can Do What Men Can Do": The Causes and Consequences of Growing Flexibility in Gender Divisions of Labour in Kitwe, Zambia', Journal of Southern African Studies, 40, 5 (2014), pp. 981-98. For the latter, see Patience Mususa, 'Contesting Illegality', pp. 185-208.

122 Benjamin Rubbers, 'Claiming Workers' Rights', pp. 329-44. For the centrality of gender in artisanal mining in Katanga see Jeroen Cuvelier, 'Men, mines and masculinities: the lives and practices of artisanal miners in Lwambo (Katanga province, DR Congo)', unpublished PhD thesis, University of Ghent (2011). 
rural patriarchy, or a modern nuclear urban family, providing clear gender divisions between productive and reproductive roles and enabling the culturally appropriate education and socialisation of children.

If we accept that family life and relationships have always been unstable and prone to conflict as a result of tensions between women and men and between older and younger generations, over the division of labour and of wealth, conflicts in which custom has been constantly invoked and continually challenged, and in which many participants assumed past family life was always more stable, then it is possible to reconsider the ways in which the gathering and dissemination of knowledge about the apparent transformation of gender relations in Copperbelt societies both reflected and shaped those relationships. Certainly, the increased adoption of wage labour, residence in mine company houses and the mixing of peoples with different ideas about sexual and social relations was perceived by most observers and experienced by many Copperbelt residents as a process of profound dislocating change, though not necessarily a singular or self-evident transition from a traditional to a modern way of doing things.

Social scientists at different times observed social and marital conflict arising from practices deemed by religious and political authorities as incompatible with modern urban life and argued they were dying out, or would soon do so. Respondents sometimes agreed about the impossibility of polygamy in the mine township, or the incompatibility of custom with inter-ethnic marriage, but polygamy, inter-ethnic marriage and other customary practices continued to be practised in town in different forms, without the dissonance between 'tradition' and 'modernity' ever being resolved. All this took place amid continuing social conflict, instability and the breakdown of some marriages, not because of an impending transition to, nor as the aftermath of, a stable urban social order, but rather as central features of a perpetually unstable urban reality in which evolving socio-cultural practices variously regarded as 'traditional', 'modern' or 'mixed' - rubbed uneasily alongside each other without ever being resolved. All the time, women, like men, worked - as housewives, farmers and traders selling their labour and putting to use skills learned in the 'traditional' sector or for the 'modern' household in creative and unpredictable ways. 


\section{Nationalism and Nationalisation}

\section{Introduction}

The Central African Copperbelt was profoundly affected by the national independence of Zambia and the Democratic Republic of Congo. Here, as elsewhere in Africa, political independence created the potential for the realisation, not only of new national identities, but also the myriad material and ideational aspirations associated with them by sections of new national societies. ${ }^{1}$ The shift from colony or protectorate to nationstate also changed the legal status of the region's mine companies, significantly diverted the flow of the Copperbelt's mine revenue and altered the significance of the border that divided it. A Copperbelt that had in many respects been autonomous to the colonial territories in which it was integrated was now governed by interventionist national authorities determined to harness its mineral wealth for new state-led development projects. Yet, as we shall see, there were powerful continuities in the experience of Copperbelt communities in their relationships to economic and political power, and in the nature of the ideas about the region's distinctive identity that continued to circulate after independence as they did before it. While these nation-states sought to increase the policing of the border and to discipline their Copperbelt citizens into new national ways of doing things, the border equally served as a basis for comparison and exclusion between the new nation and what was 'foreign'.

Frederick Cooper and others have shown that the independence period saw a flourishing of alternative projects of decolonisation in which the redrawing of colonial borders was widely envisaged. ${ }^{2}$ As

1 Frederick Cooper, Decolonization and African Society.

2 Frederick Cooper, 'The Dialectics of Decolonization: Nationalism and Labor Movements in Post-War French Africa', in Frederick Cooper and Ann Stoler 
I have argued with Baz Lecocq, the extent to which these projects were clearly resolved with the formal establishment and sovereignty of new nation-states has been overstated. Alternative nationalisms continued to trouble dominant recognised ones, nowhere more so than in HautKatanga, where the memory of the secession continued to be invoked by aspirant and opposition political forces. ${ }^{3}$ The Katangese secession and Congo's conflictual experience of decolonisation has been widely documented, as has the wider impact of its specific experience of secession on decolonisation and nationalism in sub-Saharan Africa as a whole. ${ }^{4}$ In Zambia and, for example, Tanzania, the secession provided a warning of the dangers of multi-party democracy and the need for state control over 'traditional' authorities. ${ }^{5}$

The Katangese secession from Congo, eleven days after its independence on 30 June 1960, represented a profound challenge to the unitary project of Congolese nationalism advanced by its founding Prime Minister Patrice Lumumba. The secession, financially underwritten by UMHK, allied the company with self-declared autochthonous leaders of Katangese societies; as the governing Conakat party, the latter sought to reverse the growing political influence of migrant communities in general and the Kasai Luba in particular, whose presence was in significant part the result of UMHK operations over the past forty years. The defeat of the secession in 1963 by UN and Congolese forces enabled Katanga's uneasy integration into what became President Mobutu's Zaire, and the nationalisation of UMHK and the creation of its successor Gécamines promised a new relationship between the country's most important strategic resource and its economic

(eds.), Tensions of Empire: Colonial Cultures in a Bourgeois World (Berkeley: University of California Press, 1997), pp. 406-35.

3 Miles Larmer and Baz Lecocq, 'Historicising Nationalism in Africa', Nations and Nationalism, 24, 4 (2018), pp. 893-917.

4 For the secession, see René Lemarchand, 'The Limits of Self-Determination: The Case of the Katanga secession', American Political Science Review, 56, 2 (1962), pp. 404-16; and Miles Larmer and Erik Kennes, 'Rethinking the Katangese Secession', Journal of Imperial and Commonwealth History, 42, 4 (2014), pp. 741-61. For its wider impact in southern Africa see Timothy Scarnecchia, 'The Congo Crisis, the United Nations, and Zimbabwean Nationalism, 1960-1963', African Journal on Conflict Resolution, 11, 1 (2011), pp. 63-86; and Lazlo Passemeiers, Decolonisation and Regional Geopolitics: South Africa and the 'Congo Crisis', 1960-1965 (Abingdon, UK: Routledge, 2019).

5 Steven Feierman, Peasant Intellectuals: Anthropology and History in Tanzania (Madison: University of Wisconsin Press, 1990), p. 230. 
development. However, the secession's legacy meant that Katanga, renamed Shaba Province, continued to be treated as an occupied region, alien to Zaire while vital to its national development.

The situation in Zambia was ostensibly very different: the violence of the Congo crisis provided for its first leader Kenneth Kaunda a warning sign of what might befall his new nation if it was not unified. The Copperbelt was, as we have seen (Chapter 4), in the forefront of Zambia's relatively peaceful anti-colonial activism and its leaders, many Bemba-speaking migrants, played a leading role in the nationalist movement and Kaunda's government. Yet the subordination of the region to UNIP's vision of national development, itself rooted in the party's uneasiness with urban modernity, clashed with the Copperbelt's labour-influenced political culture that regarded adequate economic recompense for hazardous mine labour as one of the aims of self-rule. In the late 1960s the Zambian labour movement and Bemba political leaders became the vanguard of opposition to UNIP, combining class and ethno-regional grievances against what they regarded as the illegitimate distribution of Copperbelt wealth and authority towards the capital Lusaka. Unlike the Katangese secessionists, however, they imagined themselves the defenders of the Zambian national project at the moment of its betrayal. While mine nationalisation, as in Zaire, sought state control over the country's globally strategic mineral assets, it was in its timing an essentially political project that sought to outflank this opposition movement and should be understood as of a piece with the introduction of the Zambian one-party state in December 1972.

Alongside nationalisation of these strategic resources, both nationstates sought to achieve the nationalisation of knowledge production about their countries and the Copperbelt region in particular, to underwrite the process of making new national subjects that were fixed in place and living moral lives according to national beliefs. Following decades of Western intellectual analysis of social change that was shaped by its colonial origins, it seemed necessary and desirable to study the region in new 'decolonised' ways that would create an authentic Africanist knowledge of the Copperbelt. In Zaire this was embodied by the new University of Zaire (UNAZA), integrating the country's institutions of higher learning but reserving for its Lubumbashi campus the study of human society. This would briefly flourish as a centre of Africanist research, analysing the realities of Katanga's urban modernity and creating an important legacy for later 
researchers, while engaging uneasily with Mobutuist authenticité. In Zambia, post-colonial knowledge production initially focussed on the new University of Zambia (UNZA), briefly a bastion of student opposition to UNIP. State intellectuals such as Henry Meebelo, linked to both the ruling party and UNZA's Institute of African Studies - the successor to the Rhodes-Livingstone Institute (RLI) - produced historical works reflective of UNIP's nationalist narrative. This body of work promoted Humanism as a national ideology and took as a central subject the dangers of urban materialism and the alleged political failure of the labour movement that the Copperbelt had generated.

Neither legal nationalisation of the mines nor the ideational nationalisation of the Copperbelt region were, however, effective in achieving the goals of post-colonial nationalists. The mining industry's dependence on fluctuating global markets was not meaningfully altered by nationalisation and the ability of Zambia and Zaire's leaders to impose their national visions on the region was limited by Copperbelt society's existing sense of identity generated in part by the ongoing interaction of knowledge production with its ever-unfolding social history.

\section{Making Nations in a Cross-Border Mining Region ${ }^{6}$}

The flourishing study of African borderlands has demonstrated that, notwithstanding the conversion of problematic colonial divisions into sovereign nation-state borders, the continent's border regions have proven a particularly fertile space for the imposition, contestation and remaking of individual and collective identities. ${ }^{7}$ Going beyond older questions of whether African borders unhelpfully divide existing African societies or are so weak and/or artificial as to offer no effective

6 This section of the chapter draws on my article, 'Nation-Making at the Border: Zambian Diplomacy in the Democratic Republic of Congo', Comparative Studies in Society and History, 61, 1 (2019), pp. 145-75. I am grateful to the editors for approving the reproduction of material here.

7 For the history of Africa's colonial and national borders see

Simon Katzenellenbogen, 'It Didn't Happen at Berlin: Politics, Economics and Ignorance in the Setting of Africa's Colonial Boundaries', in Paul Nugent and Anthony I. Asiwaju (eds.), African Boundaries: Barriers, Conduits and Opportunities (Edinburgh: Edinburgh University Press, 1996), pp. 21-34; and Geert Castryck (ed.) 'The Bounds of Berlin's Africa: Space-Making and Multiple Territorialities in East and Central Africa', International Journal of African Historical Studies, 52, 1 (2019), special issue, in particular the articles by David Maxwell on Katanga and Achim van Oppen on Barotseland. 
constraint on societal interaction, borderland studies have demonstrated, among other things, the unequal nature of frontier flows and blockages, the ways in which borders themselves constitute resources that enable new forms of belonging and the growth of cross-border urban conglomerations that are, in Africa as elsewhere, both mutually constitutive and profoundly unequal. ${ }^{8}$

The Copperbelt was, we have seen, a region closely linked across colonial borders by economic, demographic and cultural flows. Its peoples and its neighbouring regions had been tied by trade in copper and other commodities for centuries, and by shared cultures and societal identities that were, however, affected by radical political change and conflict. ${ }^{9}$ In the colonial era the border was traversed by labour migrants, capital flows, mineral ore, soldiers and weapons and intelligence and ideas about all these things expressed in various forms. Separating out and bringing a statist order to these linked regions did not begin with nationalism: as noted in Chapter 1, reform of the Congolese industry from the 1920s sought to radically reduce employment of 'foreign' African (and European) workers and replace them with Congolese and Belgian ones. We will never know how many Copperbelt residents continued to live, work and make families and communities on both sides of the border, since the effective evasion of such controls is by definition impossible to measure.

The Katangese secession depended for its survival on the links of its leaders not only to global capital - including British investors in

8 For an overview of literature see the African Borderlands Network Bibliography: www.aborne.net/bibliography (accessed 21 September 2020). The approach adopted in this study has been influenced by, among other works: Gregor Dobler, 'The Green, the Grey and the Blue: A Typology of Cross-Border Trade in Africa', The Journal of Modern African Studies, 54, 1 (2016), pp. 145-69; Paul Nugent, Sara Dorman and Daniel Hammett (eds.), Citizenship in Africa: Creating Nations, Making Strangers (Leiden: Brill 2007); Paul Nugent, Boundaries, Communities and State-Making in West Africa: The Centrality of the Margins. (Cambridge: Cambridge University Press, 2019); Karen Büscher and Gillian Mathys, 'Navigating the Urban "In-Between Space": Local Livelihood and Identity Strategies in Exploiting the Goma/Gisenyi Border', in Benedikt Korf and Timothy Raeymaekers (eds.), Violence on the Margins: States, Conflicts and Borderlands (New York: Palgrave, 2013), pp. 119-42; and Francis Musoni, Border Jumping and Migration Control in Southern Africa (Bloomington: Indiana University Press, 2020).

9 David M. Gordon, 'Kingdoms and Associations: Copper's Changing Political Economy During the Nineteenth Century', in Larmer et al., Across the Copperbelt, pp. 155-78. 
UMHK - but also political and military support from conservative Anglophone actors in the region. The Welensky government of the Central African Federation facilitated the flow of mercenaries and weaponry across the Copperbelt border that helped keep the Katangese state in power. ${ }^{10}$ Katanga's 'national' army recruited soldiers from among Northern Rhodesian Lundas who felt a stronger affiliation to Moïse Tshombe and the Lunda king, the Mwaant Yaav, than to either their colonial state or its anti-colonial opponents. As Macola demonstrates, the Northern Rhodesian ANC (NRANC) had significant links with Tshombe's Katanga government, with party officials regularly visiting Elisabethville and receiving financial and logistical aid. ${ }^{11}$ The United National Independence Party and its supporters denounced these links that, the African Mail alleged, involved the recruitment and training of 'ANC soldiers' for the Katangese armed forces. ${ }^{12}$ Katanga thus presented a threat to the unitary nationalism promoted by the leaders of both Congo and soon-to-be independent Zambia: Tshombe indeed stressed the pre-colonial unity of colonially divided African societies, for example in his July 1962 claim that 'before the Europeans came Katanga and Rhodesia formed one vast territory'. ${ }^{13}$ Following the ending of the secession in January 1963, UNIP established a party office in Elisabethville to mobilise electorally the tens of thousands of Katangese residents of 'Zambian' origin in the run-up to Zambian independence. ${ }^{14}$

This experience of conflictual decolonisation shaped Kaunda's vision of Zambian nationalism. 'Balkanisation' was considered a major threat by UNIP. As the party emerged victorious from its occasionally violent struggle with the NRANC to take power at independence (Chapter 4), it outlined its new nation-in-the-making with reference to the tenets of Kaunda's proto-national philosophy of Humanism and in regard to its neighbours. In January 1965, for example, a mass rally heard Kaunda declare 'that our society in Zambia shall be non-tribal, non-racial, and

10 Matthew Hughes, 'Fighting for White Rule in Africa: The Central African Federation, Katanga, and the Congo Crisis, 1958-1965', International History Review 25, 3 (2003), pp. 596-615.

11 Macola, Liberal Nationalism in Central Africa, pp. 84-7.

12 'ANC “Soldiers” in Katanga?', African Mail, 8 May 1962. See also 'ANC Soldiers in Katanga', African Mail, 31 July 1962.

13 'ANC Soldiers in Katanga', African Mail, 31 July 1962.

14 Larmer, 'Nation-Making at the Border', pp. 157-62. 
that our society in Zambia shall judge each and every individual according to his behaviour'. ${ }^{15}$ Kaunda went on:

The Congo is a very bad example, because people refused to respect God's creation ... Look what is happening there - innocent men and women and children of all tribes, of all races, are dying every minute. ... We don't rejoice that such things happen in the Congo ... The task of building a nation cannot be and is not an easy one. ... This is how we intend to go forward as one nation in Zambia. There are no two ways about it. ... There must be one nation only in this big country of Zambia. ${ }^{16}$

Local party officials on the Copperbelt drew the same comparison: in September 1961 one C. G. Makelo told a party meeting in Itimpe, north of Kitwe: 'We do not want troubles as they were in Congo. That is not the way of getting self government' ${ }^{17}$

A key tenet of Humanism was an emphasis on rurality as a norm of African and Zambian identity. Although UNIP's most active support was in the Copperbelt, Kaunda romanticised a mythic rural precolonial Africa, warned that urbanisation would encourage materialism and class divisions and promoted a 'back to the land' policy for Zambian youths. In this he drew on and articulated in nationalist form the historical concerns of missionaries and colonial officials regarding the dangers of urbanisation and rural decline (Chapter 1). In September 1963, for example, Kaunda addressed an Industrial Relations course on social security:

People in agriculture, for instance, are not usually in fear of starvation - even a bad crop will often give them enough to provide substance for themselves and their families. But when a man and his family are dependent on a weekly wage which may suddenly be curtailed by sickness or age, then they need a system to protect them against the worst evils. In our villages or tribal systems we have always had a system of social security with relatives looking after their own in time of need. ${ }^{18}$

Kaunda's Humanism was tested in the run-up to independence by Alice Lenshina's Lumpa church: UNIP saw the church's villages, which

15 Kenneth Kaunda, 'Mobilizing a Nation' in Zambia: Independence and Beyond (London: Thomas Nelson, 1966), p. 204.

16 Kaunda, 'Mobilizing a Nation', p. 205.

17 NAZ, WP 1/1/104, UNIP Meetings, 1960-1, 'Itimpe Compound', 15 September 1961.

18 Kaunda, 'People Rather than Plans', in Zambia: Independence and Beyond, p. 21. 
refused to recognise either the state or the party, as a threat to its authority. Two thousand Northern Rhodesian troops were deployed to destroy Lumpa communities in 1964, operations in which about 650 church members were killed. ${ }^{19}$ Despite Lenshina's detention, her church still presented such a challenge to the new Zambian nation that it had to remove itself, settling - at the invitation of then Congolese Prime Minister Tshombe - across the border in Mokambo, forming new Congo-based Lumpa communities that, by the mid-1960s, had grown to fifteen to twenty thousand people. Underlying the ostensibly tolerant tenets of Zambian Humanism, then, was a distinctly authoritarian morality that demanded unswerving loyalty from the country's diverse and mobile communities.

Increased post-independence efforts to police the Copperbelt border meanwhile revealed the extent of the continuing cross-border lives of its residents, many of whom maintained strong economic and familial connections in both regions. Thompson Sichula, for example, who was raised in Chingola, pursued his trade as a trained car mechanic in Elisabethville in the early 1960s. He maintained connections with Congolese musicians who would regularly travel to Zambia to perform:

you would find Zambians everywhere in Congo [such] that there is no proper Congolese and you would not differentiate a Congolese and a Zambian ... I have a brother-in-law and a sister in Congo. So it is difficult to know a real Congolese because you may find that one is a Zambian but likes staying in Congo and gets the papers to stay in Congo and vice versa. ${ }^{20}$

By the mid-1960s, however, the enforcement of customs and immigration controls began to tell. One day in 1966, Peter Fwalanga crossed from Zambia into the DR Congo. A veteran worker at Kitwe's Rhokana mine, Fwalanga had retired to Congo shortly before independence. Resident in Lubumbashi, he visited Zambia each month to collect his pension of $£ 45$, which he converted into Congolese Francs in Mufulira before returning home. On this occasion, however, his money was seized by customs officials, who explained that he had been contravening regulations for many years, since the export of currency

19 For a detailed analysis of the Lumpa church see David M. Gordon, Invisible Agents: Spirits in a Central African History (Athens: Ohio University Press, 2012), pp. 145-67.

20 Interview, Thompson Sichula, Mufulira, 28 July 2018. 
was illegal in both countries. ${ }^{21}$ Terese Tshilema, aged 57, was a Congolese national settled in Kitwe for 27 years. On returning to Congo with her property converted into cash and watches, Tshilema had her assets seized by Zambian customs officials. ${ }^{22}$

Government officials also concerned themselves with what they regarded as cross-border moral irregularities. In 1966, Zambia's Consul in Elisabethville approached the District Secretary in the Zambian mining town of Bancroft about Lubumbashi resident Samuel Musotolwa, whose wife of twenty-five years had left him caring for ten children while she went on 'leave'. Musotolwa believed his wife had become 'illegally married' to one Mwape Kalusa, formerly of Lubumbashi but now resident in Bancroft. The Consul, W. K. C. Kamwana, sought prompt but unspecified action against the export of Congolese immorality: 'As it is not our wish to encourage people to make Zambia as [a] hiding place for such mischievous immorals [sic] which are Part and Parcel of their lives here, we shall ... be praised if such kind of behaviour could be stamped out completely'. ${ }^{23}$ Kamwana subsequently reported a second similar case of spousal abandonment, declared himself troubled by the increasing mobility of Zambian women since independence and reflected nostalgically on the colonial way of handling such problems:

When the British looked after the interests of the now Zambians the system used to be that of sending those involved in [the] dispute to their home areas when the relatives of both parties were consulted before a decision was reached ... But since we became independent Zambians are finding it hard to maintain their homes, in most cases, women ... [are] ... being induced by other men ... against their husbands and ... corrupting those in authority in order to gain a favour ... most of the women get away with it. ${ }^{24}$

Kamwana bemoaned the inability of Congolese courts to resolve such cases and sought guidance on Zambian marriage law. A year earlier, his predecessor Wilson Chakulya had likewise noted that the British colonial Consul had practised a system of 'tribal' representation for Zambians in Katanga; older men, regarded as custodians of custom,

21 NAZ, MFA 1/1/24, Zambia Missions Congo, 1964-8, PS MoFA to Controller of Customs and Excise, 6 September 1966.

22 NAZ, MFA 1/1/24, Zambia Missions Congo, 1964-8, DRC Embassy Lusaka to Ministry of Foreign Affairs, 31 March 1967.

23 NAZ, MFA 1/1/24, Zambia Missions Congo, 1964-8, W. K. C. Kamwana to DS Bancroft, 6 April 1966.

24 Ibid. 
were employed to guide their 'tribesmen' in instances of social conflict. ${ }^{25}$ Such tribally based representation had been abolished in Northern Rhodesian mines in 1953 (Chapter 4). More than a decade later, the Consul concluded that the reintroduction of such 'traditions' would help Zambia regain the support of its Katangese residents whose loyalties, he regretfully noted, had been extended to Tshombe. ${ }^{26}$ Chakulya was, however, faced with the disconnection between potential diaspora tribal representatives and their 'home' chiefs in what had, since their departure, become Zambia. Neither could officials look to the Congolese courts for adjudication since there was in them an 'absence of the knowledge of Zambian Customary Law'. ${ }^{27}$ Zambia's ambassador to Congo Timothy Kankasa rejected recognition of customary authority and, in line with UNIP ideology, the 'tribalism' it ostensibly constituted. He nonetheless recommended

[t]hat negotiations be entered into with the Congolese Government as a matter of urgency; so as to facilitate posting of Zambian Court assessors to Katanga to deal with cases of Customary Law in nature and that these assessors be attached to Katangese Law Courts. After all Bemba or Lunda Customary Law is not different in Katanga to that in Zambia. ${ }^{28}$

Zambia's Ministry of Foreign Affairs rejected both proposals and it appears no such intervention was carried out. This debate shows that political independence did not immediately resolve the tension between 'modern' and 'customary' law, generating as a result the concept of 'Zambian customary law', oxymoronic since national and 'tribal' customary laws were ostensibly separate legal spheres.

Following the defeat of the secession, the independent Congolese state imposed control over Haut-Katanga: retributive violence was carried out by the Congolese National Army (ANC) against civilians believed to have supported the secession. ${ }^{29}$ Following Mobutu's

25 NAZ, MFA 1/1/24, Zambia Missions Congo, 1964-8, Zam CG Chakulya to PS MOFA, 28 June 1965.

26 Ibid

27 NAZ, MFA 1/1/24, Zambia Missions Congo, 1964-8, Zam CG Chalulya, 12 July 1965.

28 NAZ, MFA 1/1/24, Zambia Missions Congo, 1964-8, T. J. Kankasa to PS MoFA, 5 August 1965.

29 US State Department archives, RG 84, E3363 (Foreign Service Posts), Box 1, File, 'Political Affairs and Rel., Pol 7, Visits and Meetings', 1963, Elisabethville to Secstate, 7 November 1963. 
seizure of power in November 1965, Katangese politicians who had re-entered political life were either executed or otherwise marginalised, seen as representing a continued threat to the Congolese state - a genuine threat considering the continuing manoeuvring for power by Tshombe, who had in 1964 been temporarily brought into the Congolese premiership by Western powers and who continued to organise, from his exile in Spain, for a return to power until his abduction by Algerian authorities in June $1967 .{ }^{30}$ The uneasy post-secession incorporation of elements of the Katangese military into the Congolese army likewise ended with internecine clashes in 1966, and an uprising by Katangese forces and its repression, alongside the detention of Katangese leaders. In 1967, Mobutu centralised all authority in Congo into the one-party system of his Mouvement Populaire de la Révolution (MPR) party, which remained in place until 1990. While Mobutu showed considerable political acumen in incorporating into his regime representatives of most of Congo's provinces, Shaba Province remained under effective occupation, symbolised by the appointment of a succession of loyalist MPR governors from outside the province. $^{31}$

In 1967, coincident with his centralisation of political authority, President Mobutu announced new regulations that ostensibly clarified who was - and wasn't - a citizen. This disproportionately affected thousands of Haut-Katanga's residents, many of whom had only ever lived in Congo but who were now forced to claim Zambian citizenship. It also took openly patriarchal form: those with Congolese mothers and Zambian fathers suddenly discovered they were non-citizens. Many turned to the Zambian Consulate in Elisabethville (Lubumbashi) for help. In April 1967, the Zambian Consul E. M. Mwamba was approached by

a number of teachers who are Zambian nationals, but [who] have been living in the Congo some for many years and most know no English but only French and Bemba, etc. They expressed to me their anxiety on the future, because of the present Congolese Central Government trend to dismiss thousands of Katangese Civil Servants and those Zambian Nationals who have been

30 Lise Namikas, Battleground Africa: The Cold War and the Congo Crisis, 1960-1965 (Stanford, CA: Stanford University Press, 2013), pp. 194-204.

31 Young and Turner, Rise and Decline, pp. 54-63; Kennes and Larmer, Katangese Gendarmes, pp. 74-9. 
working as policemen. Already 6,000 civil servants who were employed after 1960 independence have been dismissed, while about over 600 Zambians who have been working even before independence have been dismissed. ${ }^{32}$

Mwamba claimed there were $c .250,000$ Zambians in Congo and asked what Zambia might do for them. Zambian officials identified the political sensitivity of the crisis given its origins in the mutiny of 'Katangese' soldiers (see above), of whom 'about 1,000 are Zambians or can claim Zambian citizenship by descent'. ${ }^{33}$ The dismissal of secession-era civil servants was now extended to all those classified as Zambian under the new citizenship laws:

[T] he Central Government's wrath against the Zambian residents stems from tribal connections between Zambians and the majority of the tribes in Katanga, and also from the fact that Katangese Zambians were staunch supporters of Mr. Moise Tshombe, and many of them saw active service or lost their brothers and sons in the Katanga secession wars. ${ }^{34}$

Zambia thus faced the challenge of these 'destitutes' - unable to bring Congolese savings with them - crossing into the economically strategic Copperbelt, with implications for national security. ${ }^{35}$ Strikingly, no effort was made to challenge or reject the new Congolese citizenship laws and Zambia accepted the potential burden of these new nationals without complaint. Most were long-term urban residents, but the policy response, reflecting Kaunda's idealised notion of rurally defined identity, directed them away from Zambia's own Copperbelt towns and towards a 'return' to their supposed rural areas of origin. In July 1967, the Ministry of Labour's J. B. Nyirongo argued against special treatment for 'repatriates':

Zambian citizens who are being repatriated from the Congo should, where possible, be persuaded to go straight to their villages where they will be able

32 NAZ, MFA 1/1/144, Zambian Nationals in the Congo 1966-7, E. M. Mwamba, CG Lub to Mwanakatwe, MoEd, 20 April 1967.

33 NAZ, MFA 1/1/144, Zambian Nationals in the Congo 1966-7, S. K. Bwalya, Asst Labour Commissioner, n.d. but $c .7$ June 1967, 'Dismissal of Zambians working in Katanga of the Congo Republic'.

Ibid.

35 NAZ, MFA 1/1/144, Zambian Nationals in the Congo 1966-7, S. K. Bwalya, Asst Labour Commissioner, n.d. but c.7 June 1967, 'Dismissal of Zambians Working in Katanga of the Congo Republic'; NAZ, MFA 1/1/24, Zambia Missions Congo, 1964-8, Acting Regional Secretary Western Province R. S. Thompson to PS MoFA, 13 November 1967. 
to leave their wives and children, and if they desire to get employment they could apply for it through their District Secretaries. In this way, only those persons who receive offers of employment would be expected to come to the line of rail. ${ }^{36}$

It should be emphasised that most such 'citizens' had never visited the villages to which they were now to be 'returned'. Such policies, however, reflected UNIP's general attempts to discourage rural-to-urban migration and to promote rural villagers as quintessential Zambians.

In the Zambian Copperbelt too, this was a period in which the national identity of Copperbelt residents needed to be resolved. Zambianisation, a political initiative that ostensibly involved the replacement of senior white mineworkers with 'Africans', was reimagined to equally involve the replacement of 'foreign' Africans with 'Zambians'. While removing skilled European workers and replacing them with newly trained Zambians proved a difficult, controversial and slow process, the actors involved - the government, mine companies and trade unions - could agree on the desirability of removing African foreigners. Identifying who was and who was not a Zambian in such circumstances was, however, deeply problematic, given that many lacked birth certificates. Parallel to the situation in Congo/Zaire, new citizenship laws excluded those born in colonial Zambia to Zambian mothers and non-Zambian fathers and were used to remove from employment thousands of Copperbelt mineworkers now deemed to be Malawian or Tanzanian. ${ }^{37}$ Duncan Money reveals that between 1964 and 1971 the number of non-Zambian Africans employed by the Zambian mines fell from 9,276 in 1964 to 5,824 in 1971, a period when the overall African workforce rose substantially. ${ }^{38}$ Thus, while Zambia positioned itself in opposition to Zaire as a more welcoming and multi-ethnic society, it engaged in its own exclusionary project of nation-making that equally focussed on the Copperbelt's mobile and mixed population and sought to impose on it a new national identity.

NAZ, MFA 1/1/24, Zambia Missions Congo, 1964-8, Perm Secretary Ministry of Labour J. B. Nyirongo to Assistant Labour Commissioner, Ndola, n.d. but July 1967.

37 Duncan Money, “"Aliens” on the Copperbelt: Zambianisation, Nationalism and Non-Zambian Africans in the Mining Industry', Journal of Southern African Studies, 45, 5 (2019), pp. 859-75, pp. 868-9.

38 Money, “"Aliens” on the Copperbelt', pp. 867-8. 


\section{The Labour Politics of the Post-Colonial Copperbelt}

The Copperbelt mining region had for decades experienced the extraction of its wealth to Western mining companies and exchequers. It was, partly for this reason, central to the contrasting dynamics of both Zambia and Congo's anti-colonial movements (Chapter 4). Now their new independent governments sought to legitimate a not dissimilar extraction to other areas of the economy within a new framework of 'national development'.

In Zambia the importance of state control over the mining industry, responsible for nearly half of GDP, 53 per cent of government revenue and 92 per cent of export earnings in 1964, was symbolised by eve-ofindependence negotiations that redirected royalties hitherto paid to the British South Africa Company to the Zambian state. ${ }^{39}$ In channeling copper revenue to its new national development plans, the Kaunda government relied on a cohort of Western development advisors, funded by international organisations, whose production of knowledge was central to government plans and policies. Diversification of the economy away from mineral dependency was seen as crucial in the medium term, but funding that diversification depended on the continued short-term maximisation of mine revenue. This necessitated both expansion of production and close co-operation with the mining companies AAC and RST. The main barrier to economic development was, for government advisors, not foreign control of the mining industry but rather the wages of urban workers. The 1964 UN 'Seers' Report, which provided the basis for Zambia's first development plan, stated: 'The wage and salary question is perhaps the most serious problem facing the Government'. ${ }^{40}$ The wage demands of Copperbelt mineworkers not only drained income that might otherwise accrue to the state but also provided 'wage leadership' to other urban workers an increasing number employed by the growing state - who demanded similar increases.

Like many other newly independent countries, Zambia quickly passed laws designed to drastically curtail the autonomy of labour movements. The Trade Unions and Trades Disputes (Amendment) Act, passed three months after independence, gave the government

39 Marcia Burdette, 'Nationalization in Zambia: A Critique of Bargaining Theory', Canadian Journal of African Studies, 11, 3 (1977), pp. 471-96.

40 United Nations, Economic Survey Mission, p. 33. 
sweeping powers over a newly constituted Zambia Congress of Trade Unions (ZCTU). AMWU, first renamed the Zambia Mineworkers' Union (ZMU) and later the Mineworkers' Union of Zambia (MUZ), criticised these controls and, when it reluctantly joined the ZCTU in 1965, requested that its leaders be elected by members rather than appointed by the government. A new Industrial Relations Act in 1967 further increased government and ZCTU control over unions: it decreed that there would only be one union in any industry, leading to the abolition of the staff association and forcing white-collar mine employees into MUZ. This attempt to ensure more effective control over MUZ had the unintended result of forcibly uniting mineworkers with ostensibly different interests: the minority of 'advanced' employees whose primary aspiration was parity with whites earning three times their salary for the same job and the majority of mineworkers with little prospect of real-terms improvements in either wages or conditions, except those that could be won by industrial action.

The MUZ, financed by its members and with a strong administration and independent ethos, was able to partly resist direct state control. Its leaders, while still composed largely of more skilled and white-collar workers, defended their members' right to take locally organised strike and protest action to challenge racial discrimination on the ground. ${ }^{41}$ While companies and government agreed that racist practices and pay inequalities needed to end, the state insisted that this should be achieved by statute and negotiations. Mineworkers and local UNIP activists, however, launched wildcat strikes to defend MUZ members provoked into violence by racist European supervisors. ${ }^{42}$ The government, while pressing for rapid Zambianisation of senior posts, accepted that the industry would need to continue to employ thousands of expatriates for the foreseeable future and pay them higher wages than Zambians promoted to do the same job. While the companies argued that foreign workers hired in a global job market needed to be paid a higher wage than Zambians hired locally, union representatives

41 Larmer, Mineworkers in Zambia, pp. 66-7.

42 ZCCM-IH, 17.1.6C, MJIC-ZMTU, 1964-5, CISB to Companies, Record of 1st MJIC meeting, 11 January 1965. Peter Harries-Jones captures the rivalry between local UNIP and union activists for political control of Luanshya's mine townships in the mid-1960s: "Home-Boy" Ties and Political Organisation in a Copperbelt Township', in James Clyde Mitchell (ed.), Social Networks in Urban Situations: Analyses of Personal Relationships in Central African Towns (Manchester, UK: Manchester University Press, 1969), pp. 297-347. 
argued that all workers doing the same job should receive the same pay. Speakers at public meetings referred to the mineworkers' role in the anti-colonial movement to justify their advancement: 'We fought for the liberation of the country, now we want to enjoy the benefits and for this reason we are demanding higher wages' ${ }^{43}$ National independence was, for Copperbelt mineworkers, bound up with racial equality and material improvements at the workplace.

A wave of wildcat strikes came to a head in 1966 when a major dispute arose over the first post-independence pay claim: when the ZMU accepted the companies' offer under government pressure, a series of unofficial strikes marked by heavy picketing spread across the Copperbelt. The government responded with the Brown Commission of Inquiry, which - as with such inquiries in the late colonial period provided an opportunity not only to review wages but for actors to articulate their understanding of Copperbelt society. Many Commission witnesses identified the unruly nature of 'union' meetings held in mine townships and participated in by the entire community as a major problem, and characterised the union movement as in need of reform.

The answer, for company and government officials and their international advisors, was the expansion of industrial relations training and the modernisation by such means of 'responsible' shop stewards and branch officials. ${ }^{44}$ The International Labour Organisation (ILO) provided further evidence to aid the government's case: its 1969 report argued that rises in urban wages were partly responsible for rural stagnation and that labour productivity had fallen since independence because 'the colonial system of labour discipline has broken down and nothing has yet developed to take its place'. ${ }^{45}$ This was then in many respects continuous with colonial state and company attempts to use technical means to bring about a disciplined, modern labour movement (Chapter 4).

In Haut-Katanga, the effective incorporation of the labour movement in newly independent Congo was hardly a problem. The weak

43 ZCCM-IH, 17.2.3B, ZMU Local Disputes NCR, 1964-7, NCR Manager

N. G. Wright to CISB, 18 October 1965.

44 NAZ, LSS1/15/279, Annual Report Assistant Labour Commissioner, Kitwe, 1962-9, Report for 1965.

45 International Labour Office Report to the Government of Zambia on Incomes, Wages and Prices in Zambia, 1969, quoted in Michael Burawoy, The Colour of Class on the Copper Mines (Lusaka: UNZA Institute of African Studies), p. 56. 
existent unions in UMHK, which had played little or no meaningful role during the secession, were in 1967 incorporated into a new Union Nationale des Travailleurs du Zaire (UNTZA), a wing of Mobutu's ruling MPR. While UNTZA's local branches played a formal role in the negotiations of pay and conditions, these were decided in a more or less unilateral way by UMHK and government officials, albeit sometimes in response to local demands. While there is some evidence of locally organised strike actions that secured pay rises, the formal Zairian labour movement did not play the prominent role in postindependence industrial relations that its counterpart in Zambia did.

\section{Nationalising the Copperbelt Mines}

The prominent role of UMHK in the Katangese secession meant that it was an early target for Mobutu's incorporative state. During the secession, copper production had surprisingly been maintained at 300,000 metric tonnes per annum, generating vital revenue that underwrote the Conakat government. In early 1963, UMHK had quickly redirected tax and royalties payments to the Congolese state, amounting to 50 per cent of government revenue and 70 per cent of foreign exchange earnings. ${ }^{46}$ Negotiations now began regarding the ownership of the country's strategic mineral resources, leading in May 1965 to a revised ownership structure in which the Congolese state held just under 18 per cent of UMHK. ${ }^{47}$ Under Mobutu, who came to power in November 1965, UMHK was pressurised to increase mine output. This was despite international market fears that such expansion would cause over-production and that rising prices would prompt copper's replacement with alternative conductive metals such as aluminium. In Congo/Zaire as in Zambia, the diversification paradox made itself felt: it was imperative that these national economies diversify away from copper dependency, but doing so would require the careful investment of increased copper revenue.

In Zambia, where copper production rose from 632,000 tonnes in 1964 to 747,000 tonnes in 1969, relations with the two mine companies RST and AAC were comparatively amicable. ${ }^{48}$ In Zaire, however,

46 Young and Turner, Rise and Decline, p. 289.

47 Jean-Jacques Saquet, De L'Union Minière du Haut-Katangà a la Gecamines (Paris: L'Harmattan, 2001), p. 134.

48 Roberts, History of Zambia, p. 229. 
the legacy of the secession poisoned relations between the government and UMHK. Following a series of tax hikes on the company in 1966, Mobutu suddenly announced the rapid nationalisation of the mines with the creation of a new company, the Societé Générale Congolaise des Minerais, sparking a diplomatic dispute with the Belgian government. ${ }^{49}$ However, Zaire's inability to implement a truly 'national' policy was exposed by its continued dependence on UMHK's 1,600 expatriate employees and an inability to attract alternative minority investment partners. Agreement was ultimately reached with UMHK's owners via the creation of a new Belgian company, the Société Générale des Minerais (SGM), a subsidiary of the vast Belgian Société Générale, to market Zairian copper. ${ }^{50}$ The SGM received 6.5 per cent of mineral sales for the next two decades in what amounted to a compensation payment to UMHK's former shareholders: they continued by these means to make considerable profits from Zairian minerals well into the 1970s. ${ }^{51}$

Although this public confrontation undermined the confidence of some of Mobutu's Western backers, it enabled the President to present himself as a radical nationalist. Zaire's 1967 economic plan involved relatively orthodox economic policies, but the subsequent use of mining revenue as a 'cash cow' to fund socio-economic projects across Zaire deprived the industry of necessary reinvestment. As Young and Turner argue, state ownership of the new state-owned mine company Gécamines not only enabled Mobutu to increase production but also implement his wider project of state-based development. ${ }^{52}$ In practice, however, by the late 1970s, 'development' projects increasingly accrued benefits solely to a tiny ruling clique at the head of the MPR and its president in particular.

In Zambia, UNIP's initiatives in economic nationalisation initially focussed on non-mine companies, so Kaunda's August 1969 speech

49 A detailed account of the negotiations can be found in Saquet, De L'Union Minière du Haut-Katanga, pp. 133-53. See also Jules Gérard-Libois, 'L'Affaire UMHK', Centre de Recherche et D'Information Socio-Politiques-INEP, Congo 1967 (Brussels/Kinshasa: CRISP, 1969), pp. 471-85; and Young and Turner, Rise and Decline, pp. 288-96.

50 Saquet, De L'Union Minière du Haut-Katanga, pp. 155-208; 'Union Minière Wins Case - in All but Name', The Times, 18 February 1967. Gécamines was initially known as Gécomin, or the Génerale Congolaise des Minerais, until 1971.

51 Young and Turner, Rise and Decline, p. 293.

52 Young and Turner, Rise and Decline, pp. 293-6. 
'requesting' the sale by AAC and RST of 51 per cent of their assets to the government was something of a surprise. Nonetheless, subsequent negotiations secured a comparatively favourable deal for their owners, with full compensation via bond redemptions, guarantees over profit externalisation and specific rights over the appointment of directors. The nationalisation of Zambia's copper mines - its timing, the financial arrangements involved and its causes - have been the subject of extensive analysis, both contemporaneous and retrospective. ${ }^{53}$ While it is clear that mine nationalisation in both countries should be understood as an essentially political project, most observers failed to appreciate the extent to which it was an internally driven nationalist initiative designed to give state leaders in Lusaka and Kinshasa effective control over the mineral-rich Copperbelt region. In his speech announcing the 51 per cent nationalisation of the copper mining industry, Kaunda claimed it would create a 'classless society' that would allow ordinary Zambians to control their economy. ${ }^{54}$ This had important consequences for industrial relations:

The State ... holds industrial investments, not for its own good, not merely for the good of those directly employed in the State enterprises, but for the benefit of Zambians everywhere. Thus, for a union to push a claim against the State is to push a claim against the people. ${ }^{55}$

In this new system, workers could no longer pursue narrow economic interests at the supposed expense of their rural cousins. Kaunda condemned wildcat strikes and, in the same speech, declared an immediate wage freeze and a temporary ban on all strikes. ${ }^{56}$ The AAC and RST received a '[c]ategorical statement that takeover of mines was between Government and shareholders only, and would not affect employees, management and running of mines at all. ${ }^{57}$ The mine companies did

53 Michael Bostock and Charles Harvey, Economic Nationalism and Zambian Copper: A Case Study of Foreign Investment (New York: Prager, 1972);

Michael L. O. Faber and James G. Potter, Towards Economic Independence: Papers on the Nationalization of the Copper Industry in Zambia (Cambridge: Cambridge University Press, 1971); Burdette, 'Nationalization in Zambia'; Sardanis, Africa, Another Side of the Coin, pp. 229-39.

54 Zambia, Towards Complete Independence (Lusaka: Government Printers, 1969).

55 Ibid., p. 44. Emphasis in original. ${ }^{56}$ Ibid., p. 54.

57 ZCCM-IH, 15.2.1C, 'Government Takeover, 1969-1971', McCourt, Mufulira to CISB Kitwe, 4 September 1969. 
indeed continue to be run with little or no political interference and according to the strictures of global markets throughout the 1970s. Kaunda's rhetoric regarding nationalisation replicated in a postindependence form many of the assumptions underlying the late colonial orthodoxy discussed in Chapter 1. He counterposed normative ideas of rural and urban societies, characterising the former in a romanticised form as communal and productive and associating the latter with materialist consumerism and Westernisation. The Copperbelt's distinct urban culture, having first been deemed 'unAfrican' by social scientists, was now reconstructed by its national leader as unpatriotic, rendering invisible the continued dynamic social and economic links between village and town.

This perspective had significant support among the development experts who were the dominant producers of Western knowledge about Zambia in the early post-colonial period. Such experts reconstituted these ideas as 'urban bias', the notion that urban residents benefited disproportionately from African state decisions because of their supposed advantageous capacity to influence policy at the expense of rural communities. ${ }^{58}$ Zambia, with its relatively urbanised population and copper-dependent economy, provided a key case for academic advocates of this idea, such as the political scientist Robert Bates. In this they proved curious intellectual bedfellows with Marxist analysts who saw Zambian mineworkers as a primary example of a 'labour aristocracy', with interests more closely aligned to their employers than to the majority of Zambian peasants. ${ }^{59}$

58 Michael Lipton, Why Poor People Stay Poor: Urban Bias in World Development (Cambridge, MA: Harvard University Press, 1977); Robert H. Bates, Markets and States in Tropical Africa: The Political Basis of Agricultural Policies (Berkeley: University of California Press, 1981). For a critique see Vali Jamal and John Weeks, Africa Misunderstood: Or Whatever Happened to the Rural-Urban Gap? (London: Macmillan, 1993). See also Ashutosh Varshney (ed.), 'Beyond Urban Bias', a special issue of Journal of Development Studies, 29, 4 (1993). For a critique of its application to the Zambian Copperbelt, see Deborah Potts, 'Counter-Urbanisation on the Zambian Copperbelt? Interpretations and Implications', Urban Studies, 42, 4 (2005), pp. 583-609.

For the labour aristocracy debate in general see: Arrighi and Saul (eds.), Essays on the Political Economy of Africa; Sandbrook and Cohen (eds.), Development of an African Working-Class; and Peter Waterman, 'The "Labour Aristocracy" in Africa: Introduction to an Unfinished Controversy', in Dennis L. Cohen and John Daniel (eds.), Political Economy of Africa (London: Longman, 1981). For its application to Zambia, see Parpart, 'The Labour Aristocracy in Africa'; and Mijere, 'The mineworkers' resistance to governmental decentralisation'. 
Government policy explained continued migration from rural to urban areas in precisely these terms: Zambia's Second National Development Plan, published in 1971, stated: 'The estimates of the ruralurban breakdown of the country's population bring out the fact that the dimensions of the drift of the rural population to urban areas has assumed such proportions as to dictate urgent attention to reducing this movement'. ${ }^{60}$ The Plan declared the need for a strict cap on wage rises and a link between wage rises and productivity with the objective of 'narrowing the gap between urban and rural living standards' ${ }^{61}$ In this context, Bates noted approvingly that mine nationalisation 'clarified the link between the conduct of labor and the success of development efforts, and strengthened the government's resolve to curtail the militancy of labor'. ${ }^{62}$ Unlike Bates, whose research was based largely on interviews with political and union leaders, the sociologist Michael Burawoy's 1972 study 'The Colour of Class on the Copper Mines' drew directly on the ethnographic techniques of his RLI predecessors. Burawoy's embedded research revealed that rank-and-file mineworkers regarded their pay and conditions as little improved from the colonial period and he argued that 'the proposed nationalisation ... cemented [the companies'] co-operation and identification with the Zambian government, giving them much greater security if faced with opposition from ... their black labour force'. ${ }^{63}$

In this context the Copperbelt's unionised workers and its political leaders constituted a continued threat to UNIP authority. While postBrown measures had brought the MUZ under a degree of government control, grassroots mine union leaders consistently challenged the pace and degree of post-independence reforms. A new job evaluation initiative, resembling the technocratic systems in place in HautKatanga since the 1950s, prompted anger among more skilled workers awarded lower salaries than whites doing the same job. ${ }^{64}$ They organised a boycott of 1971's May Day celebrations, a cornerstone of public unity between the state and labour. Fifteen dissident MUZ leaders and one hundred striking workers were detained. ${ }^{65}$ Copperbelt union

60 Government of Zambia, Ministry of Development Planning and National Guidance, Second National Development Plan, January 1972-December 1976 (Lusaka: Government of Zambia, 1971), p. 50.

61 Ibid., p. 11. ${ }^{62}$ Bates, Unions, Parties, and Political Development, p. 213.

63 Burawoy, The Colour of Class, p. 90.

64 Daily Mail (Zambia), 31 March 1970. $\quad 65$ ToZ, 26 May 1971. 
activists linked such grievances to the unresolved post-independence transformation of the mining industry and the perceived marginalisation of UNIP's Copperbelt Bemba-speaking leaders. The latter grievance had been growing since the resignation of UNIP/Zambia Vice President Simon Kapwepwe in August 1969 and found expression in opposition to changes to UNIP provincial representation in 1970. These effectively neutralised the numerical advantage of Copperbelt and Northern Province membership, arising from the party's history of mass activism in these areas (Chapter 4). ${ }^{66}$ Prominent Copperbelt party leaders, including former ZMU president John Chisata, pressed Kapwepwe to break from UNIP, which he did in August 1971 with the establishment of his new United Progressive Party (UPP). The Copperbelt became the locus of inter-party conflict: hundreds of local UNIP officials defected to the new party, attracted by Kapwepwe's criticisms of UNIP's undemocratic structures and failure to bring prosperity to the masses. Physical violence and intimidation by UNIP activists were combined with state repression, involving the arrest and detention of hundreds of known UPP supporters. Mufulira, long a centre of conflict between UNIP and the ANC, was equally a focus of this power struggle. In December 1971, Kapwepwe, despite extensive intimidation, won a parliamentary by-election in Mufulira West against the UNIP candidate, MUZ Vice President Alexander Kamalondo. The UPP, meanwhile, attracted the active support of MUZ dissidents who campaigned against Kamalondo on the basis of the unpopular job evaluation agreement. ${ }^{67}$ Samson Chama, a prominent local UNIP figure, recalls this as a time of tension that continued in Mufulira until Kapwepwe's death in 1980. ${ }^{68}$

For this brief period, the Copperbelt's mineworkers and political activists, expressing discontent at the perceived maldistribution of mining revenue and the failure to resolve grievances that were, for

Cherry Gertzel (ed.), Carolyn Baylies and Morris Szeftel, The Dynamics of the One-Party State in Zambia (Manchester, UK: Manchester University Press, 1984), p. 14; this conflict is explored at greater length in Larmer, Rethinking African Politics, pp. 62-90.

67 NAZ, HM77/UNIP/1/4, Papers of Peter Matoka, MUZ Head Office

(Confidential), 'Summary of circumstances which led to the loss of the Mufulira West constituency seat in the Parliamentary by-elections by a UNIP candidate Comrade Alexander Kamalondo', 17 January 1972.

68 Interview, Samson Chama, Mufulira, 6 July 2018. 
them, at the heart of Zambia's anti-colonial movement, presented a significant challenge to UNIP's hold on national political power in a way that their counterparts in Haut-Katanga (and indeed organised workers across Africa) did not generally do to post-independence ruling parties. ${ }^{69}$ The repression of this movement necessitated state and party violence and intimidation, culminating in the declaration of a one-party state in December 1972. It did not, however, enable the ruling party to establish effective control of a region that, both because of its strategic mineral wealth and local ideas about its equitable distribution, continued to challenge UNIP hegemony over the next two decades.

\section{The Limits of Nationalisation}

The early 1970s saw further efforts to gain effective state control of the post-colonial economies of both Copperbelts, in a context in which 'Third World' governments realised the limits of political independence and sought more effective ways to challenge their countries' global economic marginalisation. A new Intergovernmental Council of Copper-Exporting Countries (CIPEC) was established in 1967, bringing together Zambia and Zaire with Peru and Chile, producers of 40 per cent of world copper output and 75 per cent of copper exports. But it was only following the 1973 oil crisis that its members sought to influence the international market for copper. An agreement reached in Lusaka to co-ordinate reductions in copper exports by 10 per cent and later 15 per cent failed to increase prices, partly because CIPEC members in general and Zaire in particular failed to abide by an agreement at odds with Mobutu's strategy of maximising Katangese production. ${ }^{70}$ In 1973 a second phase of Zambian mine nationalisation, involving the redemption of $£ 90$ million of bonds held by foreign mining companies, enabled the state to take a greater stake in the industry and more direct control of mine management and copper

69 For a useful overview of Africa-wide post-independence state-union relations, see Akua O. Britwum and Leyla Dakhli, 'Labour and the State', in Stefano Bellucci and Andreas Eckert (eds.), General Labour History of Africa (Oxford: James Currey, 2019), pp. 495-522, pp. 508-16.

70 Kenji Takeuchi, 'CIPEC and the Copper Export Earnings of Member Countries', The Developing Economies, 10, 1 (1972), pp. 3-29; World Bank online archives (hitherto WB), International Bank for Reconstruction and Development (IBRD), 'The Economy of Zaire', July 1975, p. 58. 
sales. It is today widely recognised that this was a significant financial error, involving as it did risky and in retrospect ruinously expensive borrowing on international markets. ${ }^{71}$ A new phase of Zairianisation in 1973 meanwhile sought to place non-mining businesses into local ownership, but in practice most ended up in the hands of political office holders, alienating investors. ${ }^{72}$ This was followed in 1975 by an incoherent radicalisation programme that threatened longstanding Belgianowned businesses with government takeover; when these measures threatened national bankruptcy they were reversed with compensation costs of $c$.US $\$ 700 \mathrm{~m}^{73}$ The mineral economy of both countries was also adversely affected by the national liberation wars raging in neighbouring Angola and Rhodesia, leading to the closure of railways that were vital for mineral exports.

Mineral price fluctuations in the mid-1970s led to contrasting efforts to manage the situation: Zaire continued to maximise production, receiving warnings when prices were falling but short-term benefits when prices rose: copper production increased from 365,000 tonnes in 1969 to 460,000 tonnes in $1974 .{ }^{74} \mathrm{Zambia}$, where production costs were continually rising and ore grade qualities were falling, could not do the same. The country also struggled with the aftermath of the September 1970 Mufulira mine disaster: 89 mineworkers were killed when a tailings dam collapsed and one million tonnes of waste flooded their underground workspace. Production at Mufulira, then the single largest generator of Zambian tax revenue, was substantially disrupted for a number of years.

\section{Nationalising Knowledge Production}

Just as nation-state leaders believed it was vital to bring the Copperbelt's mineral production under their control, so the production of knowledge about Copperbelt history, society and political economy - hitherto

71 William A. Stoever, 'A Business Analysis of the Partial Nationalization of Zambia's Copper Industry, 1969-1981', Journal of International Business Studies, 16, 1 (1985), pp. 137-63; Sardanis, Africa, Another Side of the Coin, pp. 268-75.

72 Young and Turner, Rise and Decline, pp. 326-50.

73 Young and Turner, Rise and Decline, pp. 350-62.

74 WB, IBRD, 'Report and Recommendation of the President to the Executive Directors on a Proposed Loan to La Générale des Carrières et des Mines with the Guarantee of the Republic of Zaire for a Mining Expansion Project', 2 January 1975 , p. 8. 
dominated by Western scholars - needed to be wrested from foreign domination and brought under national purview. This process was characterised by questions and contradictions that paralleled the indigenisation of strategic mineral resources. What would indigenous control of a global phenomenon historically dominated by the West look like? How would the assertion of a new national context and consciousness change the way that the Copperbelt was understood? How could a nation-state stimulate African intellectuals to discover new ways of understanding the region that would produce original knowledge that was also of value to the nation-state? In the same way that academic research had provided powerful legitimising effect to the modernising dynamics of the Copperbelt mining industry, academic history provided a powerful accompanying role for African leaders' nation-building projects.

The establishment of 'national' universities in the decolonising period provided important lessons as to how knowledge production was to be indigenised: this has been the subject of important recent studies. Toyin Falola shows how universities in post-colonial Africa were shaped by debates over the Africanisation of knowledge and the role of higher education in furthering independence and national development. ${ }^{75}$ Tim Livsey has demonstrated how Nigeria's Ibadan University was shaped by the interplay of political independence and the contested Africanisation of university space, power and ideas. ${ }^{76}$ For African academics, training in Western universities or by Western scholars in African ones promised both intellectual enlightenment and advancement but also involved tacit acceptance of the superiority and hegemony of Western systems of knowledge production. Meanwhile, African leaders, like their Western counterparts, saw national universities as a tool for development, generating local manpower to overcome their dependence on foreign personnel and, in some cases, to provide intellectual endorsement of their new national ideologies. Student activism has been shown to be an important space for the expression in this period of debates on how to decolonise the university. ${ }^{77}$ Dan Hodgkinson has investigated the social and personal

75 Toyin Falola, Nationalism and African Intellectuals (Rochester, NY: University of Rochester Press, 2004), esp. chapters 5 and 6.

76 Tim Livsey, Nigeria's University Age: Reframing Decolonisation and Development (London: Palgrave Macmillan, 2017).

77 See the volume edited by Dan Hodgkinson and Luke Melchiorre on 'Student Activism in an Era of Decolonization', special issue of Africa, 89, S1 (2019), in 
histories of generations of student activists in Zimbabwe. For Congo, Pedro Monaville reveals the ways in which the country's student movement engaged with Mobutu's Africanist turn and the wider 'global 1968 ' moment, before its murderous repression. ${ }^{78}$

These dilemmas were particularly pronounced in the production of knowledge about the Copperbelt region. Its characterisation as a 'modern' urban space defined by its relationship with global capital had, as we have seen, led to it being understood in Western social science as distinct from and/or opposed to a norm of African rural society in a problematic intellectual context that conflated historical progress with Westernisation. The indigenous study of the Copperbelt regions in a post-colonial context created an opportunity for research that better reflected and took seriously local notions of knowledge and understanding in shaping Copperbelt society. The extent to which intellectual space would be provided that could enable 'decolonised' knowledge production was of course debatable. Congo's universities were established before independence while those of Zambia were established afterwards, but in both countries they continued to be dominated by Western scholars and approaches in the immediate postcolonial period.

The history of Congo's universities began in the late 1940s with planning for what became the Jesuit-run Lovanium University, which opened in 1954 on the outskirts of Léopoldville (later Kinshasa). Monaville highlights the contrast between Lovanium's deliberately secluded rural setting and Elisabethville's urban university, which opened its doors to an exclusively white student body in 1956 . Renamed the Universite d'Etat during the Katangese secession, it was closely linked to UMHK and the Katangese government, which saw its role as producing indigenous graduates with the technical skills needed by the new nation. ${ }^{79}$ After the secession it became, in turn, the official

particular Hodgkinson's article in that issue: 'Nationalists With no Nation: Oral History, ZANU(PF) and the Meanings of Rhodesian Student Activism in Zimbabwe', Africa, 89, S1 (2019), pp. S40-S64.

78

Pedro Monaville, 'Decolonizing the university: postal politics, the student movement, and global 1968 in the Congo', unpublished PhD thesis, University of Michigan (2013).

79 Monaville, 'Decolonizing the university', p. 174; Donatien Dibwe dia Mwembu, 'Le Rôle Social de L'Université de Lubumbashi', in Bogumil Jewsiewicki and Véronique Klauber (eds.), Université de Lubumbashi 1990-2002: Société en Détresse, Pari sur L'Avenir (Paris: L'Harmattan, 2003), pp. 1-120, p. 11. 
state university of the Congo but in August 1971 - following the violent repression of student uprisings at Lovanium - it was, with Lovanium and the Free University in Kisangani, integrated into a single University of Zaire (UNAZA). Each campus would lead in a specific subject area and Lubumbashi was given the focus on humanities and social sciences, building on but equally challenging the earlier work of European researchers through continued links with Belgian universities such as the University of Liège and the Université Libre de Bruxelles.

The creation of UNAZA was bound up with President Mobutu's project of authenticité, a broad challenge to Western domination of Africa that encompassed the indigenisation of people's names and place names, the adoption of non-Western clothing styles and the promotion of specific forms of culture and history as the building blocks of Zairian national identity. Mobutu's authenticité initiative challenged the notions of European academic practice and, Benoit Henriet suggests, briefly provided a space for real experimentation in Africanist knowledge production. ${ }^{80}$ Authenticité was, at face value, a project enabling African intellectuals to reject the Western colonial and academic construction of the continent as 'other', exotic and inherently inferior to a modern West, and enable them to develop modes of knowledge production that could root the continent's contemporary development in its culture, traditions and history. Historians at UNAZA, for example, removed 'ethnohistory' from the curriculum in 1974 as a way of challenging the earlier construction by Western historians of African society as inherently tribal and drew on social history techniques to study the urban culture of Lubumbashi (see also Chapter 7). The construction of class identities in Haut-Katanga's mining towns was equally a subject of investigation, though here the arguments of Augustin Malela, in identifying a lack of class consciousness among workers, strikingly resemble the political economy school that saw such workers as an aristocracy of labour. ${ }^{81}$

Meanwhile, Valentin Mudimbe, one of Africa's most important post-colonialist thinkers, born in Likasi and initially based at

80 Benoît Henriet, 'Making the Post-Colonial University: Authenticité, Decolonality and Knowledge Production in Lubumbashi, 1971-1981', article under review, 2021.

81 Henriet, 'Making the Post-Colonial University'; Augustin Mwabila Malela, Travail et Travailleurs au Zaïre. Essai sur la Conscience Ouvrière du Proletariat Urbain de Lubumbashi (Kinshasa: Presses Universitaires du Zaïre, 1979). 
Lovanium, identified the construction of 'Africa' in Western knowledge production and sought in his writings to reveal the process of its construction. ${ }^{82}$ In works published while at UNAZA, Mudimbe argued that Africans needed to move away from the Western systems of thought hitherto internalised by African scholars. Mudimbe's ideas resonated with authenticité concepts even while he avoided endorsement of the MPR's more rigid Zairianisation initiatives and the nationalisation of identity and culture that Mobutu advocated. ${ }^{83}$ Henriet details the ambiguities in UNAZA scholars' engagement with authenticité in their efforts to break from colonial/Eurocentric epistemologies and their ultimate inability to avoid the imposition of MPR structures and strictures on campus. Ultimately, Zairianisation required the creation of an authentic pre-colonial national history, free from external imposition or engagement, in which distinct 'tribes' supposedly co-existed peacefully. In so doing it ironically perpetuated colonial categories of tribal identity that social historians were then in the process of dismantling. ${ }^{84}$

At the same time, UNAZA continued to play a more practical role in indigenisation, training geologists, chemists and metallurgists for Gécamines and thereby enabling the Africanisation of the company's professional ranks. ${ }^{85}$ In 1981 UNAZA was abolished - just one aspect of the wider failed experiment of authenticite - and the University of Lubumbashi achieved a new independent existence. From this time on Mobutu's embrace of intellectual space declined and, in the following decade, the MPR sought to extend its ideational control of HautKatanga and its university via the steadily increasing authority of its youth wing.

As in the Belgian Congo, proposals for a Northern Rhodesian institute of higher education first developed in the 1940s, but the Central African Federation focussed attention on the University College of Rhodesia and Nyasaland in Salisbury (Harare). The University of Zambia (UNZA) opened only in 1965; it was partly funded by local (Lubumbashi: Éditions du Mont Noir, 1972); Pierre-Philippe Fraiture, 'VY Mudimbe: From the "Nation" to the "Global" - Who is the Master?', Journal of Historical Sociology, 27, 3 (2014), pp. 324-42.

84 Henriet, 'Making the Post Colonial University'.

85 Donatien Dibwe dia Mwembu, 'Le Rôle Social', p. 12. 
voluntary subscriptions by ordinary Zambians and was an unmistakably nationalist project, with President Kaunda its first Chancellor. The first students at UNZA, however, criticised and protested against government policies on southern African liberation and clashed with state forces and UNIP-organised youth activists. ${ }^{86}$ In the 1970s UNZA provided a stimulating intellectual environment in which foreign and Zambian academics rubbed shoulders with liberation movement activists as they debated the relationship between African nationalism, socialism and Pan-Africanism. As the detention and deportation of British Marxist political economist Lionel Cliffe in 1976 showed, academic free speech was heavily restricted in Zambia when it came to criticism of UNIP. ${ }^{87}$ On the Copperbelt meanwhile, higher education was restricted to the technical sphere: the Zambia Institute of Technology (ZIT) was established in Kitwe under UNZA auspices to meet the skills shortage in the mining industry and the wider economy. The Zambia Institute of Technology subsequently became the Copperbelt University (CBU) but it was only in the twenty-first century that it developed a fully-fledged social science programme. Meanwhile, the Rhodes-Livingstone Institute was incorporated into UNZA from 1971 as the Institute for African Studies (IAS). ${ }^{88}$ It initially turned towards pure research but was then funded to conduct applied projects in, for example, the study of languages in Zambian education. ${ }^{89}$ While the IAS continued to attract expatriate scholars such as Burawoy, Mwelwa Musambachime notes its relative failure 'to address itself to the economic, political, and social realities of post-independence Zambia. It was very clear that the Institute lacked a strategy to enhance and indigenize science research in Zambia'. ${ }^{90}$

Meanwhile, UNIP sought to promote Kaunda's theory of 'Humanism' as a national ideology that could underpin understanding of Zambian

86 Larmer, Rethinking African Politics, pp. 68-9.

87 Peter Lawrence and Morris Szeftel, 'Obituary: Lionel Cliffe, 1936-2013', Review of African Political Economy, 41, 104 (2014), pp. 288-91.

88 It was renamed the Institute of Social and Economic Research (INESOR) in 1996.

89 Sirarpi Ohannessian and Mubanga E. Kashoki (eds.), Language in Zambia (London: International African Institute, 1978); Mwelwa C. Musambachime, 'The University of Zambia's Institute for African Studies and Social Science Research in Central Africa, 1938-1988', History in Africa, 20 (1993), pp. 237-48.

90 Musambachime, 'University of Zambia's Institute for African Studies', p. 244. 
society and guide its progress. Kaunda's international reputation as a thinker rested on his status as a liberation movement and 'Third World' leader and his championing by Westerners such as Colin Morris. ${ }^{91}$ Unlike in Zaire, however, little sustained effort was made to establish Humanism in Zambia's universities. It was rather promoted in the country's school curriculum and by the Ministry of National Guidance via the country's media and in political speeches. One notable exception to this rule was the work of Henry Meebelo who, as well as curating Kaunda's own writings, sought to strengthen Humanism's intellectual cutting edge, as the ruling party came under renewed pressure in the context of economic stagnation and political opposition in the 1970s. Meebelo, Director of UNIP's Research Bureau (and a government minister in the early 1980s), wrote a series of works on Humanism and history, each an important intervention into the nationalisation of knowledge production. In Reaction to Colonialism (1971) Meebelo provided a clear and accessible history of colonial-era Zambia typical of the nationalist historiography of its time. He characterised anticolonial injustice and exploitation as stimulating the coming together of diverse peoples into the 'modern' social and political movements that would inexorably become the basis of a united Zambian nation. ${ }^{92}$

Meebelo's Main Currents of Zambian Humanist Thought (1973), published when its author was Permanent Secretary in the Ministry of National Guidance, was the only important work on Humanism not written by Kaunda and Morris. Seeking to present the ideology as more than the ideas of a single leader, Meebelo characteristically counterposed 'African traditional thought' to European Humanist thinking and sought to root Zambian Humanism in a common African experience that was now threatened by capitalism and Western urbanisation. ${ }^{93}$ As Sholto Cross argued in a thoughtful 1974 review article:

If this were the case, then one would have expected an upward flow of ideas behind Zambian humanism, a grassroots consciousness or populism

91 For example, in Kenneth D. Kaunda, A Humanist in Africa: Letters to Colin M. Morris from Kenneth D. Kaunda (London: Longmans, 1966).

92 Henry S. Meebelo, Reaction to Colonialism: A Prelude to the Politics of Independence in Northern Zambia 1893-1939 (Manchester, UK: University of Manchester Press/Institute of African Studies, University of Zambia, 1971).

93 Henry S. Meebelo, Main Currents of Humanist Thought (Oxford: Oxford University Press, 1973). 
articulated through the middle level ranks of political spokesmen. But Zambian humanism has all the hallmarks of an ideology announced from the top and imposed downwards, succeeding only in providing the language of debate and not its substance, and never really penetrating the grassroots. $^{94}$

Indeed, Humanism had much in common with the social scientific and missionary knowledge production that informed its anti-materialism and its conflation of urbanisation with Westernisation. While it was not a popular movement, it certainly represented an important strand of indigenous elite thought in the post-independence era.

Meebelo's third major work, African Proletarians and Colonial Capitalism, published in 1986 by another state body, the Kenneth Kaunda Foundation, provides a key example of the nationalisation of intellectual thought and, not coincidentally, focusses on the history of the Zambian Copperbelt. ${ }^{95}$ It provides an impressive analysis of colonial-era mining and the development of trade unionism and anticolonial nationalism in the region, but its main objective is to critically analyse AMWU's disagreements with the nationalist parties over strategy and tactics (see Chapter 4). Nationalist politics is presented as normative and alternative political ideas to it, particularly those of AMWU President Lawrence Katilungu, are dismissively characterised as apolitical or anti-political. Meebelo concludes: 'the AM[W]U, the wealthiest, the best organised and the most powerful African trade union in the country was, for all its might and its strategic position ... apparently too inward-looking to play the rightful political role against colonial exploitation and oppression'. ${ }^{96}$ In a period of continuing conflict between the post-independence trade union movement and the government, Meebelo sought to delegitimise the former through the ostensibly disinterested realm of historical knowledge production.

94 Sholto Cross, 'Politics and Criticism in Zambia: A Review Article', Journal of Southern African Studies, 1, 1 (1974), pp. 109-15.

95 The Kenneth Kaunda Foundation had in the late 1960s been funded by the Peace with Freedom organisation run by Robert Gabor, which was covertly backed by the CIA. See Anon, 'East African Shadows', Africa Confidential, 16 February 1968, pp. 3-4; and Editors, 'AMSAC's Afros', Ramparts magazine, June 1969 (Menlo Park CA), pp. 26-33. I am grateful to Daniel Branch for drawing my attention to this information.

96 Meebelo, African Proletarians and Colonial Capitalism, p. 419. 


\section{Conclusion}

In the 1980s, the indigenisation of knowledge production experienced a period of decline, consistent with the region's political conflicts and economic crisis. Funding to universities in both countries was reduced, and some of their most brilliant minds - for example Valentin Mudimbe and Mwelwa Musambachime - took up positions in Western universities. The flow of international scholars to the region also reduced. The University of Lubumbashi, however, remained a bastion of important and influential social scientific research in the face of political repression, economic decline and social conflict. As Chapter 8 will explain, the dominant story of the Copperbelt, once one of modernisation and rapid development, was becoming one of decline, crisis and how to stem it.

Meanwhile, the effective incorporation of the Copperbelt region into its respective nation-states continued to prove problematic, as will be examined in Chapter 8. The Shaba wars of 1977 and especially 1978 provided an existential challenge to Mobutu's hold on power: the brief seizure by former Katangese gendarmes of Kolwezi threatened the mining industry and brought about both economic and political reforms that indirectly gave voice to a new internal political opposition. ${ }^{97}$ The threat posed by the Mobutu regime of a revival of Katangese opposition meant that Shaba Province continued to be closely policed, which in the 1980s involved a further penetration by party structures into the running of mine communities. In Zambia, underground political opposition, mainly focussed in the Copperbelt, meanwhile found expression in the 1980-1 conflict over local government of mine areas and a sustained period of conflict between the union movement and the one-party state that ultimately led to the labour movements' prominent position in the multi-party democracy movement of 1990-1. In different ways, the 1990s would see the reversal of the Copperbelt's marginalisation and subjugation by nationalism and the emergence of the region as a centre of political power, albeit in a context of economic crisis and - in Zaire/DRC - a resurgent ethnic and political violence.

97 Miles Larmer, 'Local Conflicts in a Transnational War: The Katangese Gendarmes and the Shaba Wars of 1977-78', Cold War History, 13, 1 (2013), pp. 89-108. 


\section{Copperbelt Cultures from the Kalela Dance to the Beautiful Time}

\section{Introduction}

The Copperbelt has long been associated with distinctive cultural production, particularly in the fields of music, dance and (in HautKatanga) visual arts. Migrants brought to its towns their artistic practices which, as they interacted with different African cultures and European influences, enabled them to create new syncretic forms. Musicians incorporated the Western guitar and visual artists took up the paintbrush and the canvas. European analysts emphasised the social functions of culture, connecting urbanites to the society they had left behind and teaching them how to live in town. From the start, however, Copperbelt culture was collected and curated in distinctive ways that shaped its form and content. In Haut-Katanga, ateliers and European collectors of 'primitivist' art trained local painters and sculptors to produce works for the gallery and the market: this partly enabled artistic works that became some of Africa's most renowned cultural outputs. Mine companies provided spaces and opportunities for theatrical, dance and musical performance, with UMHK in particular employing hundreds of performers to entertain and educate its workers. Social anthropologists such as Clyde Mitchell used cultural activities such as the Kalela dance to assess the urban mentality of Copperbelt residents. Copperbelt musicians, however, resisted the insistent classification by ethnomusicologists into 'authentic' and 'urban' styles and constantly developed innovative forms that both utilised and commented on the connection between local and global cultures.

Academic and cultural commentators sought, as a corollary of the wider modernist binaries that shaped Copperbelt knowledge production, to distinguish between 'high' and 'popular' art. Painting was classified as either the product of trained academicians influenced by 
and produced for European observers or popular painting of village scenes for the local audience; theatre likewise meant either performances of Shakespeare or Molière or the spectaculars and comedies put on by company-sponsored troupes to entertain and educate workers. This hierarchical division was, however, reversed when it came to music: early collectors reified 'authentic' rural music and bemoaned the influence of European culture in Copperbelt towns. The independent nation-states of Zambia and Zaire sought to create and manage idealised national cultures, with profound and unforeseen consequences for the artists and musicians of the region.

There was, however, no clear division between art and commerce for many of those involved: a canvas painting sold to a collector might bring the same financial reward as a wall painting to promote a new nightclub. Similarly, in the music scene, distinctions between expressing 'tribal' or 'national' identity, pleasing an audience and being paid for one's work, were commonly blurred. Mine company patronage influenced not only cultural opportunities but also outputs. Artistic influences flowed across the Copperbelt border in ways shaped by shared cultural understandings but also by the differential opportunities provided for and constraints created by collectors, colonial and post-colonial states, mine companies and local art markets, undermining any easy categorisation into ethnic, regional or national forms, or the distinction of form from function.

These diverse cultural outputs helped Copperbelt residents to articulate and reach shared understandings of society, morality and human behaviour in a rapidly changing world. They can theoretically be read by historians as contemporaneous commentaries or popular knowledge production, enabling comparison of the similarities and contrasts both between new Copperbelt cultures and between these and older African societies. However, our access to these outputs is heavily mediated by the cultural curation to which they have been subject. Put simply, we only have access to a tiny sliver of what was sung, danced, painted and performed by Copperbelt residents, a sliver that has been preserved for specific reasons by various elite producers of knowledge - collectors, ethnomusicologists, museums, mine companies, states, recording companies, publishers and so on. These actors, albeit engaged with artists and musicians themselves (they were sometimes the same individuals), collected and disseminated Copperbelt cultures for diverse purposes. One theme, however, dominates their otherwise diverse thinking: the 
nature and extent of changes to (supposedly authentic, essentially rural) African cultures as a result of their encounters with (supposedly modern, essentially urban) Western culture. While earlier collectors believed it was possible to discover forms of authentic African art untouched by Westernisation, it is evident that what can be studied today are the cultural outputs produced as the result of engagements between artists and curators, musicians and collectors.

This chapter cannot provide anything approaching a comprehensive cultural history of the Copperbelt: the brief analysis here both draws on and engages with the extensive research into the region's art and music (and, to a lesser extent, theatre) from the 1950s to the 1990s, without discussing artistic form and style in any technical way. ${ }^{1}$ It rather charts, with the use of diverse archival material and interviews with Copperbelt artists and musicians, a narrow path through some of its most prominent artistic movements, their curation and characterisation by cultural knowledge producers, while focussing on the ongoing debate between artists, collectors and wider society about the nature of the relationship between authenticity and hybridity, high and popular art, the 'African' and the 'modern', that in Copperbelt society was the dominant topic of cultural conversation.

\section{Company Culture, Worker Entertainment}

The migrant residents of Copperbelt mine towns produced cultural outputs for artistic and entertainment purposes that commented on

1 Among the most important works on Katangese art and music are: Leon Verbeek (ed.), Les Arts Plastiques de L'Afrique Contemporaine: 60 Ans D'Histoire à Lubumbashi (R-D Congo) (Paris: L'Harmattan, 2008); Johannes Fabian, Remembering the Present: Painting and Popular History in Zaire (Berkeley: University of California Press, 1996) and Power and Performance: Ethnographic Explorations Through Proverbial Wisdom and Theater in Shaba, Zaire (Madison: University of Wisconsin Press, 1990); numerous works by Bogumil Jewsiewicki, including Mami Wata: La Peinture Urbaine au Congo (Paris: Gallimard, 2003); and Sarah Van Beurden, Authentically African: Arts and the Transnational Politics of Congolese Culture (Athens: Ohio University Press, 2015). There is a comparative vacuum in historical analysis of Zambian arts. For a popular history of Zambian music see Leonard Koloko, Zambian Music Legends (Morrisville, NC: Lulu.com, 2012); for tourist art see Bennetta Jules-Rosette, The Messages of

Tourist Art: An African Semiotic System in Comparative Perspective (New York: Springer, 1984). For a recent analysis of the region's visual art, see Enid Guene, 'Artistic Movements: Painting and Cross-Border Exchange on the Central African Copperbelt' (2021), article under review. 
and helped make sense of their new environment. They drew on cultural forms from their own societies, as well as those they found in these new communities and elsewhere. Dance bands were created in the 1930s and 1940s that - as across southern Africa's urban and mining centres - performed localised versions of commercial Western music. ${ }^{2}$ In 1941, Luanshya's Roan City African Dancing Club held a Saturday night dance at the Native Welfare Hall Mine Compound to raise funds for British towns devastated by Luftwaffe bombing raids. ${ }^{3}$ Touring dance bands visited Copperbelt towns: in August 1951 the Bulawayo Sweet Rhythm Band visited Elisabethville and sought to play at Northern Rhodesian mine venues. ${ }^{4}$

As part of its efforts to create stable urban workplaces and communities, UMHK pioneered the provision and sponsorship of cultural venues and activities. These took an unmistakably paternalistic form, as the company tried to adjust workers and their families to new urban 'realities', but equally allowed significant space for Africans to express their own ideas. In comparison, the Northern Rhodesian mines consistent with their belated and grudging embrace of urbanisation did much less to actively shape the cultural attitudes and output of Copperbelt societies. Nonetheless, by the late 1950 s they too provided a range of cultural and leisure activities for mineworkers and their families.

In each mine camp in the 1940s, UMHK began constructing large recreation halls. These provided space for both entertainment - film shows, dancing and concerts - and instruction. The company sponsored and directly employed musicians who performed at such venues and at open-air events and parades, such as its annual 'Mangeurs de Cuivre' festival. Large shows known as 'Spectacles Populaires' combined 'traditional', religious and contemporary music, 'tribal' dances and comedy sketches, providing opportunities for young performers,

2 For South Africa, see articles by Christopher Ballantine, especially 'Music and Emancipation: The Social Role of Black Jazz and Vaudeville in South Africa Between the 1920s and the early 1940s', Journal of Southern African Studies, 17, 1 (1991), pp. 129-52.

3 ZCCM-IH, 16.3.7A, 'African Traditional Dancing Music, Bands, Arts Luanshya Cultural Committee, Oct 40-Nov 70', letter, 15 September 1941.

4 ZCCM-IH, 16.3.7A, 'African Traditional Dancing Music, Bands, Arts Luanshya Cultural Committee, Oct 40-Nov 70', Bowbrick to Roan Antelope Mines, 21 August 1951. 
some of whom became household names. ${ }^{5}$ The company used these shows to disseminate moral messages concerning work discipline and familial values that complemented the socialisation lessons provided in Mwana Shaba (see Chapter 5). 'Mufwankolo', aka Odilon Kyembe Kaswili, gave his name to a semi-improvised theatrical sketch format that poked gentle fun at authority, commented on urban society and offered life lessons. ${ }^{7}$ One performance involved Mufwankolo instructing his wife to cook milonge (smoked fish) then, having failed to leave money for her to buy it, being angered at her failure to provide dinner. ${ }^{8}$ Adolphe Kisimba, who went on to perform with the Mufwankolo group, started at Elisabethville's Cercle Saint Benoit (see Chapter 4), directing an adapted form of 'tribal' dance and sketches based on close observation of everyday life as it played out in the city's streets, buses and law courts. ${ }^{9}$

Catholic schooling was a foundational influence on Haut-Katanga's distinct performance culture: Guene finds that many performers received their early musical education in choirs, for example at $\mathrm{St}$ Boniface College in Elisabethville's CEC. ${ }^{10}$ Joseph Kiwele's Petits Chanteurs à la Croix de Cuivre, established in 1947, became internationally renowned: Kiwele, a member of Elisabethville's CEC council (Chapter 4), went on to perform for Belgian royalty and compose classical works, notably his 'Katangese Mass' and the Katangese national anthem. ${ }^{11}$ Masengu Katiti, another choir member, established

5 Interview, Odilon Mufwankolo, Lubumbashi, 9 July 2018. Mufwankolo is the subject of research by Johannes Fabian, most particularly Power and Performance. See also Donatien Dibwe dia Mwembu, 'Lets Laugh It Off: Mufwankolo's Theatre and the Quest for Morality', in Danielle de Lame and Ciraj Rassool (eds.), Popular Snapshots and Tracks to the Past: Cape Town, Nairobi, Lubumbashi (Tervuren: RMCA, 2010), pp. 141-62.

6 Interview, Barney Kanjela, Kitwe, 23 August 2018.

7 Johannes Fabian, Moments of Freedom: Anthropology and Popular Culture (Charlottesville: University of Virginia Press, 1998), pp. 66-8. The best-known Mufwankolo plays can be found on the 'Archives of Popular Swahili' website, for example Power is Eaten Whole: http://lpca.socsci.uva.nl/aps/lepouvoirse mangeentierintro.html (accessed 13 April 2020).

8 Interview, Georgette Ntumba, Likasi, 12 June 2018.

9 Interview, Adolphe Kisimba, Lubumbashi, 9 July 2018; interview, Eliot Mujinga, Lubumbashi, 30 June 2018.

10 Guene, 'Artistic Movements'.

11 Kishilo w'Itunga, 'Une Analyse de la "Messe Katangaise” de Joseph Kiwele', African Music, 6, 4 (1987), pp. 108-25; interview, Arthur Kalunga, Lubumbashi, 4 July 2018. 
the Jecoke dance group (its name is an acronym for the 'jeunes comiques de Kenya', the Elisabethville CEC township) with Edouard Masengo. The alternative routes taken by Kiwele and Katiti show both the interrelationship between high and popular culture in the trajectories of performers but equally the vital hierarchical distinction between them in artistic categorisation. Practitioners trained in classical and choral music and inculcated into late colonial European theatre circles clearly viewed these as superior to the popular culture of the townships. European theatre was scripted in French or English and classical music (such as Kiwele's work) was written down, whereas African urban theatre or music was partly improvised, performed in African languages and, while informed by Western music such as jazz, equally drew on the story-telling oral 'traditions' associated with rural communities. ${ }^{12}$

Creativity and innovation were arguably easier in areas such as Kenya and Katuba than in the closely supervised company townships: mineworkers and other urban residents flocked at the weekend to the CEC areas for unsupervised fun. Jecoke performances, however, became a mainstay of UMHK Spectacles; like Mufwankolo plays, they conveyed social teaching focussed on, for example, abstention from alcohol and the need to provide money to wives to avoid conflict. ${ }^{13}$ Its surviving performers, however, trace its origins to Northern Rhodesia and/or Bemba migrants who brought their dance styles to the Katangese towns that were then adopted and adapted. ${ }^{14}$ Eliot Mujinga, a former Jecoke performer, recalls:

This music comes from Zambia ... this is how we copied this music from the Zambians and the language in which they sang. Since we heard what they said in their songs, this is how easy it was for us to embrace this style of music. ... Lubumbashi is a city belonging to the Bemba and Lamba tribes. ${ }^{15}$

As Northern Rhodesian provision of social activities expanded, venues were constructed (funded by the sale of low-cost alcohol) that could be used for entertainment. In keeping with their lower developmental

12 Interviews: Fabien Kabeya, Lubumbashi, 30 June 2018; Marcel Yabili, Lubumbashi, 6 July 2018.

13 Jean-Marie Maga, Lubumbashi, 30 June 2018.

14 Interviews: Jean-Marie Maga; David Beni, Likasi, 27 June 2018.

15 Eliot Mujinga interview. 
ambitions for their workers, AAC and RST focussed less on cultural enlightenment than on keeping township residents busy. These companies did not establish permanent cultural troupes and greater effort went into the organisation of sports to watch and play. ${ }^{16}$ Theatre was, until independence, largely restricted to European audiences and performers and African cultural expression was not, as in Haut-Katanga, patronised by white residents. By the 1950s, however, Northern Rhodesian radio was broadcasting short plays, for example those of Edwin Mlongoti, which provided vignettes of urban life and educational messages. Powdermaker found that Luanshya residents were listening to programmes about town life and about the village, about customs and modern life and the interplay between them: 'the radio took the listener from one to the other, without giving him any sense of disparity'. 17

Mine companies had long encouraged displays of the 'tribal' dancing that migrants had brought with them, as a link to their home area. By the 1950s these activities were organised and competitive: dance associations were established and public areas set aside for groups to perform for the wider community. In Luanshya in April 1956, plans were drawn up for 'an arena for tribal dancing in the African Township' that would cost $£ 1,550 .{ }^{18}$ Performing a 'tribal' dance to a multi-cultural urban community necessarily involved a contextual change to the performance and the form of these dances evolved in significant ways. This was recognised by J. Clyde Mitchell and his research assistant Sykes Ndilila in their landmark study The Kalela Dance. ${ }^{19}$ Clyde Mitchell characterised the dance, associated with Bemba communities but now performed in Western clothing and sung in the simplified Copperbelt version of Bemba by mostly Bisa residents, as a 'paradox': 'The dance is clearly a tribal dance in which tribal differences are emphasized but the language and the idiom of the

16 Hikabwa D. Chipande, 'Mining for Goals: Football and Social Change on the Zambian Copperbelt, 1940s-1960s', Radical History Review, 12 (2016), pp. 55-73.

17 Powdermaker, Copper Town, pp. 234-5.

18 ZCCM-IH, 16.3.7A, 'African Traditional Dancing Music, Bands, Arts Luanshya Cultural Committee, Oct 40-Nov 70', Memorandum, Resident Engineer to African Personnel Manager, 16 April 1956.

19 The prominent role of Ndilila is identified by Schumaker: Africanizing Anthropology, p. 174. 
songs and the dress of the dancers are drawn from an urban existence which tends to submerge tribal differences. ${ }^{20}$

Mitchell explained this paradox by charting the dance's origin story from Bemba 'mbeni' through the influence of military recruitment and parades and the adoption of the name 'kalela', a dance of pride. The wearing of 'European' dress turned the dance into a pantomime of the white community and a protest against African exclusion from urban elites. However, by 1951 (when this research was conducted), senior African workers themselves aspired, as we have seen, to upward mobility, partly by dressing and behaving culturally like Europeans. Clyde Mitchell shows that African workers' class and ethnic relationships were situationally specific and that the form 'tribal' identities took was altered by urban experience and relations with European society:

in certain situations Africans ignore either class differences or tribal differences (or both), and in other situations these differences become significant ... the set of relationships among a group of tribesmen in their rural home is something very different from the set of relationships among the same group when they are transposed to an urban area. ${ }^{21}$

This explanation may seem obvious to a contemporary reader familiar with notions of inter-sectionality but, in a context where racial, ethnic and class identities were both essentialised and understood via either/or binaries (rural/urban, traditional/modern, tribe/class), the relational and contextually specific Kalela dance provided a significant and influential insight, revealing the capacity of cultural performance to explain social change.

\section{Art and Modernity in Late Colonial Haut-Katanga}

The collection of material culture and its classification as 'art' or 'artefacts' was central to knowledge production processes that were themselves central to European colonialism. Belgium was particularly concerned with exhibiting African objects in the metropole: characterising such objects as 'primitive' and juxtaposing them, explicitly or implicitly, to Western art, helped justify a supposedly civilising mission. Belgian society engaged directly (if always problematically) with

21 Clyde Mitchell, 'The Kalela Dance', pp. 43-4. 
Congolese culture and the Royal Museum of Central Africa (RMCA) was one of Belgium's most visited museums. Sarah van Beurden argues that, by the 1950s, continued Belgian colonialism was publicly justified by guardianship of supposedly 'endangered' culture: African traditions facing extermination because of Westernisation were preserved with ethnographic zeal and 'scientific' methods. ${ }^{22}$ As Van Beurden puts it: 'Colonial modernity was both the threat from which collectors sought to safeguard these "authentic" cultures and the source of their authority to rescue and properly value the objects that represented this cultural authenticity'. ${ }^{23}$ Such intervention was necessary because modernising elite Africans could not be relied on to preserve their own culture.

Curators at RMCA emphasised the artistic value of Congolese works, mainly wooden sculpture, classifying them by geographic/ethnic area. An ethnographic mindset that classified African material culture into distinct ethnic groups - for example 'Kuba art' - was central to collecting across the colonised continent: this approach could equally be seen in Northern Rhodesia's flagship Livingstone Museum. ${ }^{24}$ Belgian investment in cultural imperialism, however, raised the profile of Congolese art to particularly prominent attention on the inter-war global stage. Elisabethville in the 1950s was meanwhile home to a thriving public arts scene, with regular exhibitions that attracted Western and increasingly - African attendance. The construction of a bold new modernist home for the Leopold II (later Lubumbashi) Museum was funded by UMHK, though its collection was primarily pre-historical and archaeological. ${ }^{25}$ Couttenier finds that the museum was visited by tens, even hundreds of thousands of 'native' visitors in the 1950s, but little is known about their engagement with its collections. For its curator Burkhart Waldecker, the museum provided urbanised Africans, ' $[s]$ eparated from their villages by the imperatives of industrial life and modern economy', with a link to their 'authentic' culture, typically organised along ethnic lines. ${ }^{26}$ Waldecker shared the hegemonic view that African cultural artefacts should be studied not for aesthetic reasons

22 Van Beurden, Authentically African, pp. 1-2.

23 Van Beurden, Authentically African, p. 40.

24 Schumaker, Africanizing Anthropology, pp. 140-1. See also Friday Mufuzi, 'Establishment of the Livingstone Museum and its Role in Colonial Zambia, 1934-1964', Historia, 56, 1 (2011), pp. 26-41.

25 Van Beurden, Authentically African, pp. 86-7.

26 Maarten Couttenier, 'Between Regionalization and Centralization: The Creation of the Musée Léopold II in Elisabethville (Musée National de 
but for their social purpose; understanding their function was key to interpretation. ${ }^{27}$ An evident tension existed between such a functionalist approach and a global art market that valued African masks and sculpture as decontextualised works of aesthetic beauty.

Meanwhile, Belgian settlers organised the Amis de l'Art Indigène (AAI) that sought to 'preserve' Congolese art from Western influence and encouraged artists to engage with their 'authentic' culture. ${ }^{28}$ Belgian instructors, building on interest generated by the global primitivist movement, established workshops to train students with potential for African self-expression in Western art techniques. In 1951, the Académie des Beaux-Arts de Lubumbashi (aka 'The Hangar') was established by Pierre Romain-Desfossés. Desfossés sought to curate a new African art movement in which Congolese trainees, while learning Western canvas painting techniques, would produce art that was 'naïve', authentic and reflected supposedly distinct 'tribal' perspectives on the natural world. ${ }^{29}$ François Amisi, one of the first artists to study there, recalls learning a distinctive approach to Katangese art rooted in individual creativity, which he contrasts to the more internationalised context within which art from Léopoldville was produced. ${ }^{30}$ Fabian's interviewees explained that their engagement with such institutions was motivated less by learning from European experts than in identifying a market for 'authentic, African' art. ${ }^{31}$

The growing commercialisation of African art, coupled with imminent decolonisation, created an urgency among curators to identify and preserve the 'authentic' that was supposedly at risk of being lost in the Western-oriented modernisation of the continent. Such a position can be detected in Mwana Shaba's issue of July 1960, published at the moment of independence. In an article titled 'Congolese Art',

Lubumbashi), Belgian Congo (1931-1961)', History and Anthropology, 25, 1 (2014), pp. 72-101, p. 83.

Couttenier, 'Between Regionalization and Centralization' pp. 88-90.

28 Van Beurden, Authentically African, pp. 65-71.

29 Bogumil Jewsiewicki, 'A Century of Popular Art in the Congo', in Gitti Salami and Monica Blackmun Visona (eds.), A Companion to Modern African Art (Chichester, UK: Wiley Blackwell, 2013), pp. 330-46, p. 336; Johannes Fabian and Ilona Szomati-Fabian, 'Folk Art From an Anthropological Perspective', in Ian M. G. Quimby and Scott T. Swank (eds.), Perspectives on American Folk Art (New York: W. W. Norton, 1980), pp. 247-92, pp. 280-1.

30 Interview, Francois Amisi, Lubumbashi, 3 July 2018.

31 Jewsiewicki, 'Century of Popular Art', p. 337. 
F. X. Goddard sought to situate the new country's artistic heritage in decorated functional objects such as pottery and stools:

Although its population remained for long centuries apart from civilization, material manifestations of its art reached a high level. Art can very well extend to the basic things of existence: habitation and everyday objects among others. It then becomes applied art. ... until relatively recently, European artisans sought to make beautiful the everyday objects they manufactured. ... The spread of industrial manufacturing in Europe has killed applied art in less than a century, and ... if Africa does not react, its fate will be similar. However, Europe and the East have kept ... immortal testimonies from their past, from which young generations can draw their culture and form their taste. Africa and in particular the Congo have only a thin and fragile heritage. That is why it is so important to preserve it so that the intellectual elite of tomorrow learns to be proud of the past of their race. ${ }^{32}$

Haut-Katanga's network of cultural patronage, provided by both Belgian curators and UMHK, had encouraged a wave of distinctive artistic production that was matched in few other parts of the continent, and certainly not the Zambian Copperbelt where there was an absence of any comparable art scene. As will be seen, the curation and classification of Copperbelt culture would provide an important if problematic foundation for subsequent attempts to define a national identity.

\section{Hugh Tracey's International Library of African Music}

In 1951 Hugh Tracey appealed to Northern Rhodesian and Katangese mine companies to fund his new 'International Library of African Music' (ILAM):

Music is an important means of improving social and industrial morale.... [but] the use of the wrong kind of material ... may be ... harmful, and add to the disintegrating tendencies witnessed in the youth of many African communities. In rural surroundings, music ... create[s] and propagate[s] social sanctions. Even in urban areas such as ... the mining regions of the southern Congo and Rhodesia, the more stable members of African communities still use morality songs to ... inculcate codes of good behaviour amongst young people. ${ }^{33}$

32 Mwana Shaba (July 1960), F. X. Goddard, 'L'Art Congolais', pp. 6-8.

33 ZCCM-IH, 16.3.7A, 'African Traditional Dancing Music, Bands, Arts Luanshya Cultural Committee, Oct 40-Nov 70', ILAM: 'Appeal for Capital Funds'. 
Based on these assumptions, ILAM, funded by mine companies across southern Africa to the tune of tens of thousands of pounds, manufactured and dispatched recordings of 'traditional' music to be played over loudspeakers in Copperbelt mine townships. Company officials, however, had conflicting views about their value. Some senior managers thought 'traditional' music could counter subversive political messages in modern songs. ${ }^{34}$ Compound managers were less convinced: 'They point out that good music is being broadcast from Lusaka every day but this does not prevent the circulation of political hymns of hate and they doubt whether any activities on the part of the mine could counter that activity'. ${ }^{35}$ The rural recordings of ILAM were, they reported, not as popular as contemporary 'jive' music. ${ }^{36}$

Tracey is a prominent and controversial figure in African ethnomusicology, whose work has been analysed both for its understanding of African musical form and political context, particularly in South Africa. ${ }^{37}$ Pauline Coetzee explores Tracey's ambiguous relationship with colonial authorities and ideas: he rejected characterisations of African music as simple or 'exotic', insisting on its artistic value. Yet his writing often makes sweeping ahistorical characterisations regarding 'Africans' in general and specific 'tribes' in particular. ${ }^{38}$ In both private correspondence and public broadcasting, Tracey emphasised the creativity of African musicians, whose ability to meet their societies'

34 ZCCM-IH, 16.3.7A, 'African Traditional Dancing Music, Bands, Arts Luanshya Cultural Committee, Oct 40-Nov 70', ILAM: 'N. R. Finn to Various', 11 June 1958.

35 ZCCM-IH, 16.3.7A, 'African Traditional Dancing Music, Bands, Arts Luanshya Cultural Committee, Oct 40-Nov 70', D. A. Etheridge AAC to N. Finn (RST), 29 July 1958.

36 ZCCM-IH, 16.3.7A, 'African Traditional Dancing Music, Bands, Arts Luanshya Cultural Committee, Oct 40-Nov 70', R. H. Page, Secretary RAM to GM RAM Luanshya, 8 April 1959.

37 Diane Thram, For Future Generations: Hugh Tracey and the International Library of African Music (Grahamstown, South Africa: ILAM, 2010); Garrett Felber, 'Tracing Tribe: Hugh Tracey and the Cultural Politics of Retribalisation', South African Music Studies, 30-31, 1 (2010), pp. 31-43; Noel Lobley, 'The social biography of ethnomusicological field recordings: eliciting responses to Hugh Tracey's “The Sound of Africa” series', unpublished PhD thesis, University of Oxford (2010).

38 Paulette Coetzee, 'Dancing with Difference: Hugh Tracey on and in (African) Music', Safundi, 16, 4 (2015), pp. 396-418; and 'Hugh Tracey, African Music and Colonial Power: Correspondence with Government Officials in the 1950s', South African Music Studies, 36-37, 1 (2018), pp. 83-109. 
cultural needs was being undermined by the industrial production and promotion of Western music. ${ }^{39}$ In this respect Tracey can be usefully likened to Alan Lomax, a seminal figure in the collection of (African-) American 'folk' music, who sought to capture a similarly authentic culture in danger of being swept away by capitalist commercialisation. ${ }^{40}$ Like Waldecker and other visual art curators, Tracey understood African 'arts' in terms of their social functionality: 'for music to be effective it must bear a direct relationship to the mentality of the people, their intrinsic spiritual values, their traditional art symbols, their age groups, their environment and the way in which they prefer to cope with that environment'. ${ }^{41}$

Indeed, when Tracey addressed the British Royal Africa Society in 1954, his theme was the social role of music. In this address he voiced his opposition to the teaching of Western classical music in African schools and the proliferation of radio stations, which will 'open up the floodgates of foreign dance music and destroy that sense of continuity which is so vital an element in true progress, and in maintaining a sense of well-being in the swiftly changing circumstances of Africa today'. ${ }^{42}$ It was incumbent on Western authorities to ensure this fragile continuity:

Whenever a stronger culture impinges upon a weaker one ... the influence of the stronger culture upon the weaker is often pronounced.... African musicians ... have already been influenced by contact with Europeans, Arabs and Indians, a weakness which is clearly shown in most towns, schools and industrial centres ... African pre-occupation with foreign forms of music has ... destroyed the primary objective of their indigenous music-making social integration ... The average African ... has not yet developed an adequate subjective sense of guilt which would prevent his offending against society without outside pressure, hence the increasing family morality problems in most of our African townships where men and women have left

ZCCM-IH, 16.3.7A 'African Traditional Dancing Music, Bands, Arts -

Luanshya Cultural Committee, Oct 40-Nov 70', Tracey to Finn, 20 May 1959.

40 Benjamin Filene, “"Our Singing Country”: John and Alan Lomax, Leadbelly, and the Construction of an American Past', American Quarterly, 43, 4 (1991), pp. 602-24.

41 ILAM Archives (hereafter ILAMA), Hugh Tracey, 'The Music of Southern Africa', SABC broadcast transcript, n.d.

42 Hugh Tracey, 'The Social Role of African Music', African Affairs, 53, 212 (1954), pp. 234-41, p. 240. 
behind them in their villages the active imposition of normal social sanctions. ${ }^{43}$

Tracey praised the popular visits to Copperbelt towns by rural 'Ng'om[b]a' musicians. Generally, however, he contrasted the negative situation in Northern Rhodesia to that in Haut-Katanga:

It is a sad reflection upon the educated and urban classes that their music is so imitative and poor in quality in comparison with that composed by the untutored. One only has to go over into the Congo Copperbelt to find a very different state of affairs, where music of all kinds from the purely traditional to the latest adaptations, naturally evolving within well defined rules, are entertaining the whole community. ${ }^{44}$

Tracey drew the same comparison in his South African radio broadcasts, in which he presented a popular ethnography of African 'tribal' music in the context of foreign influence and ethnic mixing:

Although there was quite a number of different tribes at Kolwezi, there was nothing like so many as you find in any one of the copper mines of Northern Rhodesia. This, a Belgian friend of ours explained, was due to the fact that Kolwezi is well out in the blue and draws most of its labour from the tribes nearby. This makes [for] ... a continuity of tribal and traditional way of living. ${ }^{45}$

In Northern Rhodesian mining towns, there was

a vogue of popular songs, largely introduced to them on gramophone records, recorded by town dance bands far away down south ... so musical standards gradually get lower and lower, simpler and simpler ... only a few of the Miners bring their musical instruments with them, and that does not help to keep African music alive and active. ${ }^{46}$

Tracey's methodology has been questioned, by Coetzee in particular. His wide-ranging collection tours involved only brief stays in each place and, as suggested above, he depended on colonial or company

43 ZCCM-IH, 16.3.7A 'African Traditional Dancing Music, Bands, Arts -

Luanshya Cultural Committee, Oct 40-Nov 70', Tracey to RST, n.d. but the beginning of 1960.

44 ZCCM-IH, 16.3.7A 'African Traditional Dancing Music, Bands, Arts Luanshya Cultural Committee, Oct 40-Nov 70', Tracey to RST, n.d. but the beginning of 1960 .

45 ILAMA, 'Music of Southern Africa', Series III Episode 9, 'The Music of Kolwezi in the Belgian Congo', 27 November 1957.

46 Ibid. 
officials and their African interlocutors for access to and knowledge about local musicians. Record cards for each song, containing fieldnotes taken by his wife Peggy Tracey, provide revealing but inconsistent information on the musicians involved (sometimes named but sometimes not, for example 'Luchazi men and women'), the place of recording and lyrical subject matter. Lyrical topics encompassed, among other things, the nature of Copperbelt society, the societal impact of ruralurban migration, gender relations and political conflict, for example:

- This mine song is about men who leave home and stay a long time in the Copper Belt. ${ }^{47}$

- She had a child in the Luanshya hospital and was buried there, never to go home again in her village. ${ }^{48}$

- Matinda was too lazy to cook for her husband - that was no good. Women who run about and do not devote themselves to their housework will die childless. ${ }^{49}$

- This song is sung when external signs of mourning are taken off. It is an example of an old social custom now being featured in song on a European instrument. ${ }^{50}$

- These hymns are typical of those which are now being compiled by separatist congregations. Most of the [Western] melodies have been absorbed, digested and handed on in the oral folk tradition, so that it is now nearly impossible to trace their parentage. ${ }^{51}$

- This song contains an account of the troubles between the Trades Union and the Mine Company. ${ }^{52}$

- A poor boy says: 'I have no father, no mother. I am very poor. I have nothing to eat, what shall I do today'. ${ }^{53}$

47 ILAMA, 'Machona', Luvale/Chokwe, Bernard Sachinati and Chokwe men, Mufulira mine, 27.4, n.d.

48 ILAMA, 'Nakapenda womaseza mu Luanshya', Luvale/Chokwe, Chipwili Saini with Chokwe men and women, Luanshya, 27.1, n.d.

49 ILAMA, 'Matinda ba munatile yowe', Lozi, Kabunda Sishumba (woman) with Lozi men and women, Nkana, 24.52, n.d.

50 ILAMA, 'Masengu', Kasongo Adalbert, Luba/Kabongo, Cité Indigene, Shinkolobwe, 22.14, 1957.

51 ILAMA, 'Pachimane-cho chabekeshya' and 'Shiwifulunganye ifunde', Bemba, Bancroft 7th Day Adventist Choir, 23.21, 1957.

52 ILAMA, 'Ari Nkumbula na Katilungu balisha-myondo', Aushi, group of 11 Aushi men, Roan Antelope Mine, 24.43, 1957.

53 ILAMA, 'Nalongama maani', Luba/Shankadi, Kaseba Anatole, Kolwezi, 27.61, 1957. 
Each recording was classified by Tracey's personal and, Coetzee notes, inconsistently applied system:

- A - of genuinely African origin

- U - of urban, industrial, or non-folk origin

- $\mathrm{F}$ - of patently foreign origin

- M-of special musical value

- $\mathrm{m}$ - of normal musical value. ${ }^{54}$

Coetzee also shows that, despite his views, many of Tracey's Copperbelt recordings were evidently marked by 'Western' and/or commercial influences. ${ }^{55}$ Even in rural areas he recorded songs that discussed the impact of urban migrancy on marital relations: one Luchazi lyric warned: 'If you do not send me clothes from wherever you are on the mines, I will refuse to write to you. So don't you forget'. ${ }^{56}$ In one broadcast Tracey empathetically analysed the changes in musical form and lyrical content of the Kalela dance, suggesting it features 'interesting modern developments of ... the tribal tradition'. ${ }^{57}$

This engagement can equally be seen in his recordings of and relationship with individual musicians, which bears comparison with Lomax's championing of Huddie Ledbetter, aka Leadbelly. ${ }^{58}$ Jean Bosco Mwenda migrated from Bunkeya to Jadotville/Likasi when his father began working in the mine. Already a relatively senior African employee in UMHK's housing department and a successful local musician, Mwenda was 'discovered' by Tracey in 1951, who recorded his seminal song 'Masanga'. ${ }^{59}$ He became a truly global artist, appearing, for example, at the Newport jazz festival in 1969 at the invitation of Pete Seeger and maintaining an international profile into the 1980s. Tracey likewise recorded Stephen 'Tsotsi' Kasumali in Kitwe in 1957, an Aushi singer and guitarist who performed in many languages. Kasumali, Tracey wrote, sings 'popular songs of his own composition which give him plenty of scope to introduce local gossip between

54 Difference', p. 409.

55

56

MA, 'The Sound of Africa', Series III Programme 2, p. 4.

ILAMA, 'The Sound of Africa', Series III Programme 7, 'The Music of Three Mines', p. 8.

58 Filene, 'Our Singing Country'.

59 David Racanelli, 'Revisiting the Katanga Guitar Style(s)', Black Music Research Journal, 36, 1 (2016), pp. 31-57. 
verses. He is assisted by 2 or 3 friends who share his bohemian life wandering from compound to compound along the Copperbelt'. ${ }^{60}$ Kasumali's song 'Ematambo Waifwe Bantu' expresses typical Copperbelt themes, counterposing a 'loafer' to the honest worker he exploits by bringing prostitutes to his home, and stressing the importance of family ties and children who will support you in old age. ${ }^{61}$ One of Tracey's collaborators, Alick Nkhata, would go on to become a leading figure in Zambia's post-independence national musical culture (see below).

While Tracey bemoaned the effects of 'Westernisation', it was precisely those artists who blended European, African and American musical forms, instruments and lyrics who came over time to embody a quintessential Copperbelt urban style. ${ }^{62}$ The tapping of a glass bottle for rhythmic accompaniment, viewed by Tracey as a novel influence reflecting Westernised consumption, over time became associated with an 'authentic' regional sound, along with the innovative picking of acoustic guitar strings, guitars that would soon be replaced by electric ones. Through a period of economic, political and social change, innovative musicians commented on the dynamic relationship between past and present, rural and urban identities and evolving notions of tradition and modernity in creative ways far removed from the preservationist concerns of Western collectors.

\section{The Cross-Border Copperbelt's Music Scene at Independence}

European observers of late colonial Copperbelt music almost universally interpreted its specific manifestations as reflecting the rupture between a disappearing rural past and a powerful but disruptive urban future. Jack Dahn, in the mining magazine Horizon in 1960, characteristically praised Zambian 'traditional' music with wistful nostalgia for the passing of a pastoral idyll:

There is an echo of earlier times in much of the folk music handed down from past generations: the ploughman sings to his oxen; a gang of labourers make

60 ILAMA, 'Kabula nuna kamushalila', Stephen Tsotsi Kasumali and two friends, Aushi, Nkana Mine, 27.61, 1957.

61 Koloko, Zambian Music Legends, p. 13.

62 See the characterisation of Copperbelt music on websites, for example: www .allmusic.com/album/from-the-copperbelt-zambian-miners-songsmw0000875573 (accessed 16 April 2020). 
their work easier by chanting to combine their effort; the hunter sings to his bow; the mother croons to her child. ... It is in such music that Zambia is rich. It is a body of music that belatedly perhaps, is winning recognition as a culture in its own right and which has something new and stimulating to offer a jaded world. ${ }^{63}$

In reality, Copperbelt mine towns were a dynamic melting pot of both innovative and derivative musical expression, with influences flowing across their shared border and from southern Africa, the United States, Europe and Latin America. Just as Northern Rhodesian migrants influenced Katangese Jecoke, there was in the early 1960s a fertile exchange between musicians playing in mine clubs and private bars in both countries. Guitarist Victor Kasoma, whose father worked in both Zambian and Congolese mines, recalls:

Congo was very near and we had an infusion of the Congolese and they brought bands and some of us went to Congo. Congolese music influenced Zambia ... It is porous, some of our people are in Congo and some of the Congolese are in Zambia and because of that, whatever they brought we embraced and they embraced, so there is that infusion. ${ }^{64}$

Thompson Sichula performed in and promoted bands playing both Copperbelt and Western pop music: '[the] Copperbelt had a mixture because we had people who came from different provinces and no one would say that this music belongs to which and who'. ${ }^{65}$ Koloko, however, argues that, as young Zambian Copperbelt musicians embraced Western pop styles and played in venues frequented by Europeans and wealthier Africans, Congolese musicians found favour with the patrons of township bars. ${ }^{66}$

David Racanelli's musicological analysis of Copperbelt guitar musicians, following Ferguson, distinguishes Kasumali's 'localist' style from the Four Pals, influenced by South African kwela jazz, and the still more cosmopolitan Jean-Bosco Mwenda. Yet he emphasises that Copperbelt 'guitar accommodated musical localism with strong rural connections as well as intra-African and international cosmopolitan features' ${ }^{67}$ In practice most musicians played a range of musical styles, either by

63 Quoted in Koloko, Zambian Music Legends, p. 2.

64 Interview, Victor Kasoma, Kitwe, 17 August 2018.

65 Interview, Thompson Sichula, Mufulira, 20 July 2018.

66 Koloko, Zambian Music Legends, p. 22.

67 Racanelli, 'Revisiting the Katanga Guitar Style(s)', p. 45. 
choice or because of audience demands. Nonetheless, African consumers learned to distinguish between modern and authentic musical labels. White's analysis of Kinshasa's music scene documents the local division between 'la musique moderne', played on Western instruments and performed in commercial settings in Lingala or French, and 'folklore', performed on adapted 'traditional' instruments and sung at social gatherings. In practice, the development of 'tradi-moderne' and 'urban-traditional' sub-genres indicates the extent to which all urban music was essentially syncretic, but also the enduring hegemony of such typologies. $^{68}$

Copperbelt culture was also marshalled by anti-colonial nationalists: the secessionist state's finance minister Jean-Baptiste Kibwe was chairman of Adolph Kisimba's Jecoke group, whose Honorary President was Katangese president Moïse Tshombe. ${ }^{69}$ Keith Kabwe's Dark Knight band performed songs critical of British rule and played at political meetings in the run-up to Zambian independence and Thompson Sichula performed with Alick Nkhata in initiatives to promote and support UNIP in its role in government. The politicisation of artistic expression would increase after independence as African leaders sought to use music and other art forms to disseminate new national identities.

\section{National Cultures and Their Copperbelt Discontents}

Congo and Zambia's status as emergent modern nations was marked by visits to the Copperbelt by global superstars, notably Louis Armstrong (1960), James Brown (1970) and Duke Ellington (1973). ${ }^{70}$ Many Zambian musicians responded to these influences by performing Western music and adopting names resembling pop bands such as the Beatles or the Rolling Stones. ${ }^{71}$ As Koloko recalls, listening to Western music was seen by young cosmopolitan Copperbelt residents as a marker of sophistication, but fierce debates ensued between

68 Bob White, Rumba Rules: The Politics of Dance Music in Mobutu's Zaire (Durham, NC: Duke University Press, 2008), pp. 32-4.

69 Arthur Kalunga interview.

70 Andy DeRoche, 'KK, the Godfather, and the Duke: Maintaining Positive Relations between Zambia and the USA in Spite of Nixon's Other Priorities', Safundi, 12, 1 (2011), pp. 97-121.

71 Interviews: Hector Sithole, Mufulira, 10 July 2019; Emanyeo 'Jagari' Chanda, Lusaka, 2 July 2019. 
its fans and advocates of local music. ${ }^{72}$ Such debates also played out at an official level, as post-colonial political leaders mobilised culture to give legitimacy to their new nation-states.

In the early 1970s, President Mobutu, in line with his policy of authenticité (Chapter 6), attacked foreign cultural influence as a legacy of colonialism and invested state resources to promote 'national' Zairian culture. 'Traditional' art provided, van Beurden suggests, a 'natural resource' comparable with revenue from extractive minerals in providing a vital 'usable past' for Mobutu's nationalist project. ${ }^{73}$ Van Beurden shows that central to the intellectual framework of authenticité was the reification of a mythic rural tradition that drew closely upon colonial notions of 'primitive modernism', valuing artistic works for their function in supposedly distinct precolonial African societies. ${ }^{74}$ Nonetheless, cultural authenticité, as with its intellectual equivalent, initially provided some Congolese artists with a meaningful opportunity for creative expression and access to state sponsorship and patronage. It, however, had the effect of centralising cultural capital (in all senses of the term) in Kinshasa, excluding many Katangese artists and forcing some to migrate there for training and funding. ${ }^{75}$ As one aspect of this policy, Mobutu demanded restitution for and the return of artworks from the Tervuren RMCA, to be housed in a new national museum in Kinshasa. ${ }^{76}$ This project marginalised the existing Lubumbashi museum, which was incorporated into a single Institute of National Museums of Zaire (IMNZ) in an organisational structure resembling the University of Zaire (Chapter 6). ${ }^{77}$ Thefts of valuable works from the museum in the early 1970s, and the likely smuggling of these across the border into Zambia, only reinforced centralised control from Kinshasa. ${ }^{78}$

72 Koloko, Zambian Music Legends, pp. 18-24.

73 Terence O. Ranger, 'Towards a Usable African Past', in Christopher H. Fyfe (ed.) African Studies since 1945: A Tribute to Basil Davidson (London:

Longman, 1976), pp. 28-39.

74 Van Beurden, Authentically African, pp. 107-15.

75 Interview, Kanteng Mayal, Lubumbashi, 19 July 2018.

76 Van Beurden, Authentically African, p. 106.

77 Interview, Philippe Mikobi, Lubumbashi, 5 July 2018; Van Beurden, Authentically African, p. 119.

78 Van Beurden, Authentically African, p. 143. The Kinshasa national museum was never completed, a victim of falling mineral revenue in the late 1970s. 
Katangese musicians equally experienced a cultural 'Zairianisation', as Mobutu sought to repress the earlier mobilisation of cultural history by the secessionist state. Zairian cultural policy led to the dominance of a single musical form - Congolese rumba - that, despite its own syncretic origins in African and Latin musical forms (and notwithstanding the leading role played in its development by Katangese musicians like Mwenda), came to be associated with Kinshasa, the Lingala language and world-famous performers such as Franco (Luambo Makiadi)'s OK Jazz band, whose stardom rested partly on praise songs for and patronage by Mobutu. ${ }^{79}$ David Beni identifies this as the 'moment that Kinshasa music gained momentum and began to assert itself in Katanga and everywhere else'. ${ }^{80}$ The resultant flood of Kinois Lingala rumba recordings - characterised by interviewees variously as 'imperialist' and an 'invasion' - marginalised musical production in Haut-Katanga, where there was no recording studio. ${ }^{81}$

Music was equally central to the promotion of a specific national understanding of Zambian culture, in which a leading role was played by Alick Nkhata. In the early 1950s, Powdermaker noted the popularity of Nkhata's songs about town life, performed on the radio and combining 'traditional music' with the guitar. ${ }^{82}$ Thinking resembling that of Tracey can be detected in Nkhata's speech to Lusaka's Listeners Club in 1952:

I have heard educated Africans say that African music is the music of backward people and that therefore it is no good. ... Perhaps ... they have heard Europeans say that the African music is no good.... music is one of the most important things in the culture of a people. And a people without culture are lost. If you lose your culture ... then you will be primitive. ${ }^{83}$

Nkhata remained a prominent Copperbelt performer into the 1960s, producing songs praising the late colonial UNIP-led government. ${ }^{84} \mathrm{He}$

79 White, Rumba Rules. See also Gary Stewart, Rumba on the River: A History of the Popular Music of the Two Congos (London: Verso, 2003).

80 David Beni interview.

81 Jean-Marie Maga interview; Eliot Mujinga interview.

82 Powdermaker, Copper Town, pp. 233-4. Robert Heinze explains the prominence of Nkhata in his history of late colonial Zambian radio: " Men Between": The Role of Zambian Broadcasters in Decolonisation', Journal of Southern African Studies, 40, 3 (2014), pp. 623-40.

83 Alick Nkhata, 'African Music Clubs', The African Music Society Newsletter, 1, 5 (1952), pp. 17-20. Emphasis in original.

84 Thompson Sichula interview, 28 July 2018. 
reworked 'traditional' songs as educational parables: 'Iсиро' pokes fun at a rural woman, newly married to a town husband, who struggles to understand modern goods such as powdered milk. 'Abanakashi ba Mwunjanji' criticises urban women for adopting immoral activities such as beer drinking and prostitution, idealising and essentialising the 'traditional' African woman. ${ }^{85}$ Having worked for the colonial Central African Broadcasting Services as well as Voice of America, in 1966 Nkhata became the first Director General of the Zambia Broadcasting Corporation, an organisation closely controlled by the government. ${ }^{86}$ Nkhata's Big Gold Six Band performed songs with lyrics praising Kaunda and his government's achievements such as 'more primary schools, more secondary schools (UNIP, Yes!) ... new hospitals throughout the country (UNIP, Yes!)'. Later songs had titles such as 'Four Year Plan' and dealt with the threat posed by UDI-era Rhodesia; 'Copper Ebuboni' highlighted mining's centrality to the national economy. ${ }^{87}$

In the early 1970s, the (renamed) Zambian Broadcasting System (ZBS) opened its own studio in Kitwe; a 1971 song recorded there by Kasama Bantu Actors, 'Mwa Ombe ni Kaunda', praised Kaunda for liberating Zambia. ${ }^{88}$ Other recordings warned about witchcraft and the need for self-help - archetypal UNIP messages and evidence of how political priorities shaped musical production in a context where the state controlled broadcasting, private recording studios were virtually non-existent and vinyl records and equipment was expensive. By this time, however, the expansion of welfare services in Zambia's mine townships gave more young residents, like their Katangese counterparts a decade earlier, access to instruments and instruction and opportunities to perform in venues such as Mufulira's Chawama Hall. $^{89}$

In June 1975 in his 'Watershed' speech - a landmark moment in UNIP's radicalisation - president Kaunda ordered ZBS to play 90 per cent Zambian music and challenged musicians to express their national identity

85 Koloko, Zambian Music Legends, p. 8.

86 Heinze, 'Men Between', pp. 636-7.

87 Koloko, Zambian Music Legends, pp. 10-11.

88 Koloko, Zambian Music Legends, p. 6.

89 Interviews: Leonard Koloko, Mufulira, 27 August 2018; Keith Kabwe, Kitwe, 2 August 2018. 
to promote and enhance the dignity of our culture and the moral foundation upon which Zambian culture is built. Any erosion of our cultural values is a threat to the Zambian personality. While we are free to borrow positive aspects of other cultures to enrich our own, we must defend ourselves against undermining our nationhood through cultural conquest. ${ }^{90}$

As discussed in Chapter 6, Zambian identity was itself ambiguous: while UNIP extolled supposedly 'national' values such as self-reliance rooted in a romanticised rural productivity, its anti-tribalist ethos meant that overtly ethnic cultural manifestations such as 'traditional' ceremonies were relegated to 'heritage' status, leaving space for urban musicians to assert their ideas of a Zambian sound. Kaunda's declaration stimulated demand for recorded music and the Copperbelt provided the lion's share of new supply, recorded at NCCM's Malachite Studio in Chingola, but also at Ndola's new Teal Studio, affiliated with South Africa's Gallo Records. A key role was played by Zimbabwean promoter Edward Khuzwayo's Zambian Music Parlour. ${ }^{91}$ The local pressing of vinyl records transformed the fortunes of bands such as W.I.T.C.H. (aka 'We Intend to Cause Havoc') that had previously travelled to Nairobi for this purpose. Teal also provided loans, enabling musicians to buy instruments on credit. ${ }^{92}$ Much of the 'ZamRock' music recorded during this boom period combined, as its name suggests, local guitar styles - themselves the result of the influences and interactions described above - with Western rock and African American soul and funk. 'Jagari' Chanda of W.I.T.C.H. explains it thus: 'Zamrock, you're playing rock and roll in Zambian style, trying to play rock music but with the feel of African music. The melody could be African ... that's a simple African call and response'. ${ }^{93}$ Koloko makes the following distinction:

Unlike Western rock songs, which had lyrics that posed danger to the youth with themes hanging on sex, drugs, violence and Satanism, Zambian Rockers had to follow the principles of humanism and traditional cultural norms as demanded by the Party and its Government. Their songs, hence, were mostly educative and touched on human problems, conditions and emotions. ${ }^{94}$

90 Kenneth Kaunda, Watershed speech, 1 June 1975, quoted in Koloko, Zambian Music Legends, p. 28; interview, Patson Katwisi, Mufulira, 1 August 2018.

91 Interviews: Victor Kasoma; Keith Kabwe; Leonard Koloko.

92 Emanyeo 'Jagari' Chanda interview. 93 Ibid.

94 Koloko, Zambian Music Legends, p. 28. 
In practice, however, ZamRock was far from the national(ist) music Kaunda envisaged. Musicians combined Western rock and funk and Jamaican reggae with Zambian musical forms that hardly demonstrated a national culture resistant to 'conquest'. Band names W.I.T.C.H., The Black Jesus and so on - and their members' lifestyles and appearance (for example, dreadlocks) offended UNIP's conservative views on young people's public appearance and dress. ${ }^{95}$ While some songs promoted patriotic messages, criticised the smoking of marijuana and praised agricultural self-sufficiency, others focussed on sexual attraction and behaviour. ${ }^{96}$ In the 1980s, the Gaula Band courted controversy with their song 'Kwacha Yapena', blaming the falling value of the currency for social problems - it and another Gaula Band song criticising corrupt politicians were banned from the radio. $^{97}$

By this time ZamRock had been displaced by the popularity of Kalindula: this was an overtly localist musical genre whose advocates reacted against both ZamRock's globalism and the growing popularity of Western disco records. Kalindula took its name and original form from a rural music/dance style from Luapula associated with mourning, but this was now combined with various musical influences. New Kalindula bands used the handmade instruments common in rural areas alongside electric guitars, played rapidly for dancing. ${ }^{98}$ Kalindula songs touching on social mores and appropriate behaviour were likewise adapted to comment on social and political change. ${ }^{99}$ Koloko highlights the work of Spokes Chola, a blind Bemba ' $n g o m b a$ ' musician resident in Chingola whose songs praised opposition leader Simon Kapwepwe and bemoaned the 1970 Mufulira mine disaster. Dickson Mponda, a former mineworker, sang in 'BaShimaini' of the industry's dangerous conditions and the poverty faced by mineworkers

95 Periodic controversies arose in late 1960s Zambia over, for example, the wearing of mini-skirts: calls were made for them to be banned on the basis of their supposedly 'foreign' origins and sexually provocative nature: Times of Zambia, 17 and 21 February 1969. For an analysis of this phenomenon across East and Central Africa, see Audrey Wipper, 'African Women, Fashion, and Scapegoating', Canadian Journal of African Studies, 6, 2 (1972), pp. 329-49. Koloko, Zambian Music Legends, pp. 27-37.

97 Koloko, Zambian Music Legends, p. 34.

98 Interview, Gulda el Magambo, Lubumbashi, 24 June 2018.

99 Thompson Sichula interview, 28 July 2018. 
in retirement. Rocky Kapya's 'Chipayeni' commented on shortages of food and essential commodities. ${ }^{100}$ Despite its ostensibly localist orientation, Kalindula was also influenced by Congolese rumba, particularly by the growing number of Congolese/Zairian musicians living and working in Zambia. Congolese rumba bands, including Orchestra Super Mazembe, played in Zambian Copperbelt nightclubs while Zambians recorded their own rumba tracks: for example, Max Mwansa's Black Power Band bemoaned the overweening power of local UNIP officials in 'Imisango ya ba Chairman'. ${ }^{101}$

'Karindula' (as it was known) was equally popular in Haut-Katanga, commonly played on a locally made 'bandio' guitar. ${ }^{102}$ Interviewees stress both cross-border commonalities and exchanges in explaining Karindula's development:

The Karindula played in the [Zambian] Copperbelt, was also played here in Katanga. All the peoples on the border of Zambia-DRC are the same people, from the cultural point of view. The Karindula we have here and the same as that of Zambia. Because the Bemba, Kaonde, Lamba are here and there. ${ }^{103}$

The combined effect of the rumba revolution and the economic downturn led many Katangese musicians to pursue commercial opportunities in Kenya and Tanzania, but also across the border in the thriving Zambian Copperbelt music industry. ${ }^{104}$ Here their supposedly 'authentic' sound found a ready audience among poorer township residents who preferred it to more Westernised Zambian musical styles. Interviewees such as Chrispin Chani recall performances by Congolese musicians in Mufulira's beerhalls. ${ }^{105}$ Many Zambian artists and musicians attest to both the flow and influence of Congolese migrants into their respective industries, though not all were identified as 'foreigners':

the guys who were coming here to smuggle out the maize and mealie meal would bring a lot of music with them and some of them settled here and they were expanding their culture on to our own culture ... especially the

\footnotetext{
100 Koloko, Zambian Music Legends, p. 52.

101 Koloko, Zambian Music Legends, p. 117.

102 Interview, Paul Tshimambe Kombodji, Lubumbashi, 4 July 2018.

103 Interview, Ernest Shibati, Lubumbashi, 3 July 2018. See also interview, Francesco Nchikala, Lubumbashi, 18 July 2018.

104 Guene, 'Artistic Movements'; Keith Kabwe interview.

105 Chrispin Chani interview, 30 July 2018.
} 
Congolese Bembas ... blended in very well and some of them could speak Bemba ... We had a lot of culture implant. ${ }^{106}$

Congolese musicians were seen as more serious and business-oriented, something that helped explain their success and the marginalisation of their Zambian counterparts. ${ }^{107}$

In Katanga, Gécamines remained a vital source of cultural patronage but was now under the direction of the Mobutuist state. Company festivals such as the Mangeurs du Cuivre were supplemented in the 1980s by 'animations politiques', events displaying popular loyalty to MPR authority, increasingly watched by Katangese urbanites on new televisions. ${ }^{108}$ These involved parades featuring majorettes and Gécamines-sponsored bands, such as Sukisa from Likasi and Coulé-Coulé from Kolwezi. ${ }^{109}$ Workers started the day with songs and dances in praise of Mobutu and the MPR. ${ }^{110}$ Gécamines theatre continued to provide instruction on the right and wrong ways of family life: Fabien Kabeya's theatre group sensitised workers on social issues directed by the company's 'bureau de la coordination des actions sociales'. ${ }^{111}$ Meanwhile, Mufwankolo had made the transition first to radio and then, in the 1970s, to television: Fabian describes his broadcasts as 'the talk of the town' in Lubumbashi. ${ }^{112}$ In the context of the cultural demands of Mobutu-era authenticité, Mufwankolo's supposed continuity with pre-colonial storytelling traditions enabled his comedic plays to offer an implicit critique of the distribution of wealth and power that resonated with audiences, which was not, however, perceived as a threat by the authorities. ${ }^{113}$

In Zambia's mine townships meanwhile, 'tribal' dances thrived long after the late colonial context (see above) in which they had begun. An area in each township was still set aside for the dances of specific 'tribes' every Sunday, which provided, interviewees stressed, a way for each community to understand each other's culture. ${ }^{114}$ In Kitwe these events

106 Bob Nkosha, interview, Kitwe, 26 August 2018; see also Keith Kabwe interview.

107 Leonard Koloko interview; Keith Kabwe interview.

108 Likasi interviews: Séraphin Musoka; Thérèse Kyola.

109 GCM Likasi personnel archives, MPR Gecamines, 'Organisation du 1er Festival Animation Politique Gécamines’, 1 June 1984; Ernest Shibati interview; Paul Tshimambe Kombodji interview.

110 Likasi interviews: Thérèse Kyola; Gaston Mutiti.

111 Fabien Kabeya interview.

112 Georgette Ntumba interview; Fabian, Moments of Freedom, p. 137.

113 Fabian, Moments of Freedom, pp. 66-8.

114 Chrispin Chani interview, 30 July 2018; Barney Kanjela interview. 
were sponsored by the mine company, which provided cash prizes for the best performances. ${ }^{115}$ An equally popular source of cultural knowledge was 'Kabusha', a radio programme that discussed social problems and how they were addressed in 'traditional' society. Henry Longwane was one of many interviewees who recalled it fondly:

I loved listening to a programme called Kabusha.... being on the Copperbelt and coming from different areas with different customs and traditions and beliefs, it was so important to know about others. ... if a Bemba wants to marry someone from the Luvale, they need to know what those people believe in, what they stand for and so is the case for any other tribe. ${ }^{116}$

This interest in rural 'tribal' culture in the Zambian Copperbelt provided knowledge of ethnic diversity and thereby reinforced its residents' sense of urban cosmopolitanism.

\section{Popular Painting and Its Meanings in Haut-Katanga}

Parallel to individual and state sponsorship of Katangese and later Zairian art workshops, a local Katangese market developed for what became known as 'popular painting', also referred to as 'urban', 'naïve' or 'genre' painting, first by Europeans and then among more 'advanced' African workers. The latter decorated their homes with such paintings, bought in local markets or on city streets, visually confirming their aspiration to or attainment of the respectable lifestyle of the modern household. ${ }^{117}$ Popular painting was not valued by curators because it lacked the attributes of 'high art' and because like Copperbelt music - it incorporated European motifs and imagery and was therefore seen as derivative and inauthentic. Many of our Katangese interviewees decorated their homes with such paintings, as well as with designs in embossed copper typical of the region. The most popular images were those associated with village life and 'customary' ways. ${ }^{118}$ Marie Ngoy Mwamba fondly recalled pictures showing 'the villages where there is a woman who has a load on her head and who

115 Chrispin Chani interview; interview, Wesa Sakabaso, Mufulira, 12 July 2018.

116 Henry Longwane interview. See also Mufulira interviews with Nguni Tamarikzika; Bobby Jackson Kabamba; Leonard Nkhuwa, 30 July 2018; and Evans Nsabashi, 18 July 2018.

117 Jewsiewicki, 'Century of Popular Art', p. 337; interview, Pamphile Kapiteni, Lubumbashi, 25 June 2018.

118 Jewsiewicki, 'Century of Popular Art', pp. 340-1. 
cooks' ${ }^{119}$ François Musenge Dikumbi's parents decorated their house with paintings of dances and hunting scenes that evoked the villages from which they had migrated. ${ }^{120}$ In contrast to the modernist primitivism taught in art schools, popular painting also portrayed recent and contemporary history including political events and leaders such as Lumumba. The visual collapsing of periodisation of, for example, political violence challenged the conventional division between the colonial and independent periods. ${ }^{121}$ Such works were, unsurprisingly, excluded from official state patronage, not only for their lack of 'authenticité but also for presenting in Katanga historical narratives from the perspective of the secessionist state. ${ }^{122}$

In the vast literature on the political economy of Zambia's development and mining industry produced in the 1970s and 1980s, there is a notable neglect of cultural analysis. In contrast, in debates about Africanisation and authenticité at Lubumbashi's university (Chapter 6), Katangese popular painting attracted significant academic attention, which can only be briefly summarised here. In rejecting the notion that African art must separate itself from external influences, Mudimbe asserted the richness of cultural expression that engaged with European political and cultural impacts in innovative ways, enabling artists to interpret and articulate their experiences to local communities. ${ }^{123}$ Jewsiewicki likewise insisted on the legitimacy of the incorporation of Western forms into the work of African artists, just as European artists had long done with 'primitive' African forms. ${ }^{124}$ Extensive conversations with genre painting artists informed ground-breaking analyses by Fabian and Szombati-Fabian, which interrogated conventional aesthetic valuations and helpfully problematised 'folk' artistry in Haut-Katanga's urban industrial society. ${ }^{125}$ They sought to understand popular painting through the 'relations of production' that informed its creation and defined it as 'a complex process in which a society articulates and

119 Marie Jeanne Ngoy Mwamba interview.

120 François Musenge Dikumbi interview. 121 Guene, 'Artistic Movements'.

122 Jewsiewicki, 'Century of Popular Art', p. 341.

123 Mudimbe, 'Popular Art', in The Invention of Africa, pp. 164-74.

124 Bogumil Jewsiewicki, 'This is Not a Painting', in Bambi Ceuppens and Sammy Baloji (eds.), Congo Art Works: Popular Painting (Tielt: Lannoo, 2016), pp. 19-45.

125 These conversations can be accessed at: http://lpca.socsci.uva.nl/aps/vol12/ka tangagenrepaintingintro.html (accessed 13 April 2020); the same website hosts relevant articles. 
communicates its consciousness of its origins, its past and its present predicament'. ${ }^{126}$ The fact that most popular paintings were 'unsigned' prompted reconsideration of the validity of attribution and, consistent with globally influential pop artists such as Andy Warhol, challenged the conceptual boundary between high and popular art, individual creativity and generic reproduction. Fabian's collaboration with Tshibumba Kanda-Matulu provided a new visual history of Congo as well as an ethnographic analysis of how popular art recounted that history. ${ }^{127}$

Precisely because these analysts raised awareness of and gave intellectual legitimacy to this body of work, some popular painters came to be feted by international collectors. Tshibumba Kanda-Matulu became particularly famous for his paintings charting the history of Congo/ Zaire in the second half of the twentieth century, produced in the tumultuous context of the late 1970s. ${ }^{128}$ Despite the efforts of Fabian and others to reject the assessment of Congolese art according to the criteria and discourse of individual creativity used by the global art market, it was that market that ultimately selected individual artists' work for curating, exhibiting and sale. Popular painting's global appeal then inspired future generations of Congolese artists, at a time when the internal market for popular painting was collapsing along with the Copperbelt's wider political economy. ${ }^{129}$

There was in Zambia an absence of any equivalent visual art scene: while Lusaka-based collectors and galleries emerged in the postindependence period, they were still overshadowed by the two regional artistic centres of Salisbury/Harare and Lubumbashi and no distinct visual 'Zambian Copperbelt' style emerged. Many younger artists blame this on the lack of artistic schooling and patronage compared with Congo, but also draw on national stereotypes, comparing Congolese streetwise 'hustlers' with 'docile' Zambians. ${ }^{130}$ Indeed,

126 Fabian and Szombati-Fabian, 'Folk Art From an Anthropological Perspective', pp. 266-8; Ilona Szombati-Fabian and Johannes Fabian, 'Art, History, and Society: Popular Painting in Shaba, Zaire', Studies in the Anthropology of Visual Communication, 3, 1 (1976), pp.1-21, p. 2 and p. 17.

127 Fabian, Remembering the Present.

128 Observe how Tshibumba's work as an individual artist is presented online, for example at www.contemporaryand.com/magazines/history-is-never-just-a-sto ry (accessed 13 April 2020).

129 Jewsiewicki, 'Century of Popular Art', p. 342.

130 Interview, Matthew Mudenda and Davies Sichinsambwe, Kitwe, 17 August 2018; Pamphile Kapiteni interview. 
many of the artists who in the 1980s and 1990s identified the potential for a popular art market in Zambia were Congolese migrants fleeing economic decline and conflict. ${ }^{131}$ This stimulated the Zambian art scene in important ways. As Guene shows, Katangese migrant artists produced 'art' both for galleries and for tourist markets. They abandoned historically specific images with no resonance in Zambia and focussed on more universalist ones, particularly idealised rural utopias that appealed to the urban market for nostalgic imagery, as well as the ubiquitous 'mami wata' or 'mamba mutu', the mermaid. These images were then taken up by Zambian artists such as Matthew Mudenda. ${ }^{132}$

\section{Cultures of Nostalgia and 'Being Left Behind'}

In the 1990s, the Kalindula music scene was devastated by the onset of the HIV/Aids pandemic, heralding the collapse of the last recognisably distinct Zambian Copperbelt music style. ${ }^{133}$ Political conflict in Katanga equally shaped the region's artistic history: during the political violence of the early 1990s, Leon Verbeek bought thousands of popular paintings, preserving them for posterity and analysis. ${ }^{134}$ The economic collapse of urban mining societies across the Central African Copperbelt in the 1990s (see Chapter 8) destroyed the company sponsorship, purchasing power and coherent urban communities that had sustained and provided subject matter for the region's distinct cultural expression. In both the Zambian and Katangese Copperbelts, the region's 'golden age' became the focus of retrospective, nostalgic cultural activities, though in very different ways. ZamRock's 1970s heyday has in recent years become the subject of Western attention, fuelling a partial revival. The band W.I.T.C.H., described by Wikipedia as having been 'formed during Zambia's golden post-independence days', was re-formed with the collaboration of Dutch musicians. ${ }^{135}$ The group has toured the USA and Europe to widespread hipster acclaim and is the subject of a 2019 documentary by Italian filmmaker

131 Matthew Mudenda interview. The presence and influence of Congolese artists in Zambia was mentioned by many interviewees: Guene, 'Artistic Movements'. Guene, 'Artistic Movements'; Matthew Mudenda interview; interview, Dominique Bwalya, Lubumbashi, 17 July 2018.

133 Bob Nkosha interview; Koloko, Zambian Music Legends, p. 45.

134 Verbeek, Les Arts Plastiques.

135 https://en.wikipedia.org/wiki/Witch_(Zamrock_band) (accessed 16 April 2020). 
Gio Arlotta. ${ }^{136}$ A commercial music that once challenged notions of national authenticity is now a nostalgic emblem of a musical golden age. While this revival has brought belated acclaim to 'Jagari' Chanda and his fellow musicians, there is virtually no audience in Zambia for such bands.

Haut-Katanga has remained a centre of the African art movement, the Lubumbashi Biennale continuing to attract global attention to its cultural events, organised by new artistic centres. ${ }^{137}$ These structures are, however, financially dependent on support from Belgium and the wider world; contemporary mine companies no longer sponsor cultural activities. Haut-Katanga's artists have been at the forefront of commentary on the region's decline and marginalisation and have produced powerful art in the shadow cast by the Copperbelt's former prosperity. Sammy Baloji's work explores the 'beautiful time' of urban Katanga's golden age, squandered by corrupt leaders. ${ }^{138}$ His photomontages bring the Copperbelt's supposed past glories and contemporary ruins together, juxtaposing the region's history and memory. ${ }^{139}$ In a different way, Fiston Mwanza Mujila's 2014 novel Tram 83 collapses the region's urban past and present in a picaresque portrayal of a nightclub in a secessionist state where casualised mineworkers rub shoulders with starving students, child soldiers and prostitutes and struggling writers seek the patronage of Western publishers. However, it opens with a quintessential Copperbelt origin story:

In the beginning was the stone, and the stone prompted ownership, and ownership a rush, and the rush brought an influx of men of diverse appearance who built railroads through the rock, forged a life of palm wine, and devised a system, a mixture of mining and trading. ${ }^{140}$

Katanga's history is glimpsed in brief vignettes about its exploitative and extractive economy, as are the moral hazards typical of urban

\footnotetext{
136 www.imdb.com/title/tt5666750 (accessed 6 April 2020).

137 https://biennaledelubumbashi.org (accessed 14 April 2020). The two leading Katangese artistic centres or associations are Picha (http://picha-association.org) and Waza (www.centredartwaza.org) - (both accessed 16 April 2020).

138 Bogumil Jewsiewicki, The Beautiful Time: Photography by Sammy Baljoi (Seattle: University of Washington Press, 2010).

139 Bogumil Jewsiewicki, 'Photographe de L'Absence: Sammy Baloji et les Paysages Industriels Sinistrés de Lubumbashi', L'Homme, 198-9, 2 (2011), pp. 89-103.

140 Fiston Mwanza Mujila, Tram 83 (Dallas, TX: Deep Vellum, 2014), p. 1.
} 
society; but here, unlike for Namusiya seventy years earlier, there is no hope of moral salvation, only the ever-present agonies of town life and the passing pleasures of sex, alcohol and - of course - music.

The production of academic knowledge about urban Katanga's past has equally cohered around memories of its 'golden age'. Dibwe dia Mwembu and Jewsiewicki's 'Mémoires de Lubumbashi' is a landmark project that, as noted in the Introduction, intentionally collapses the conventional division of academic and popular history by treating Lubumbashi's popular cultural outputs - theatre, painting and music - as not only the subject of their historical research, but as themselves legitimate forms of historical narration. ${ }^{141}$ The project has brought together university historians, artists and community residents in exhibitions and events that seek to co-create the city's distinct history. As well as recording hundreds of life histories of Lubumbashi residents, it has also created cultural 'lieux de memoire' in which Jecoke and Kalindula groups revived the old songs and dances, providing in so doing a new form of patronage for veteran performers and younger musicians seeking to engage with their communities' cultural heritage. ${ }^{142}$ A provocative parallel might be drawn between the preservationist tendencies of late colonial observers such as Waldecker and Tracey, who feared the loss of authentic culture in the face of unstoppable Westernisation, and those who today seek to preserve the fragile 'folklore' of the Copperbelt's industrial heyday in the face of global neo-liberalism's devastating impact on its economy and communities.

\section{Conclusion}

In providing a necessarily truncated history of cultural expression in the late colonial and post-colonial Copperbelt, this chapter has sought to demonstrate that understanding and curation of the region's arts and music was shaped by a particular version of the ideas about modernity analysed more widely in this study. The training of Africans in conventionally Western artistic techniques and attempts to preserve 'authentic' and socially functional African culture were

141 Among many important outputs, Dibwe dia Mwembu and Jewsiewicki, Le Travail Hier et Aujourd'hui.

142 Interview, Maisha, Lubumbashi, 17 July 2018. During the 2018 conference of the 'Comparing the Copperbelt' project in Lubumbashi, a local Karindula group performed for the participants. 
both marked by a distinction between high and popular art that was, however, applied differently to visual art and music.

State and company curation of Katangese urban culture had significant but also ambiguous effects on its development: late colonial art workshops, UMHK/Gécamines 'spectacles' and Zairian state patronage all shaped the ways that cultural expression was curated, funded and communicated to Copperbelt and wider publics. In comparison, while Zambian Copperbelt music was collected by the ILAM and later stimulated by Kaunda's nationalist broadcasting policies, its visual art was neglected and little documented, something that is only now being rectified. The decades-long curatorial and intellectual knowledge produced about Katangese art has certainly stimulated artistic creativity and brought it to the attention of international art markets, but has also shaped it in significant ways beyond the control of either its artists or collectors.

Cross-border artistic innovation was shaped by the region's shared societal and linguistic cultures, but also by changing migratory patterns shaped by labour policies, border controls, state patronage and/or interference in artistic expression, and economic fortunes. While some Copperbelt artists stress the region's common cultural identity, rooted both in its distinct communities and history of multi-ethnic urbanisation, over time many have come to identify with or against 'national' cultural forms, such as Congolese rumba or ZamRock.

While there is overwhelming evidence that generations of innovative Copperbelt musicians consistently combined local, regional and global notation and instrumentation in creating syncretic musical forms, they themselves have consistently engaged in debates about musical origin and function that reflect aspects of the local vs global debate. This is both because their industry and the markets it serves have long been organised into such classificatory frameworks and because changing ideas about origin, identity and belonging have been a central subject of their songs. Similarly, popular painting, theatre and other manifestations of Copperbelt culture have taken as their primary subject the processes of social change associated with migration, urbanisation and the lifestyles, values and societal dynamics associated with town and village life as they have evolved since the 1950s.

Throughout this long period, Odilon Mufwankolo, pioneer of popular theatre in the 1950 s, performed to Katangese audiences in person, on TV and (until 2006) on national radio. When Gécamines 
experienced near collapse in the early 2000s, his live performances sought to sensitise workers to the harsh realities of redundancy, but on one occasion a hostile audience in Kolwezi tried to physically attack his troupe for bringing such an unpopular message home to them. ${ }^{143}$ As we have seen, recent Katangese artworks have focussed on and been produced in relation to a context of decline and crisis, a context that has informed the region's history for at least twenty-five years. The next chapter will focus on the social history of the Copperbelt's decline, how it has been explained and periodised on both sides of the border and how the production of knowledge about this decline has shaped understanding of the region's history.

143 Odilon Mufwankolo interview; Maisha interview. 


\section{Decline and Fall: Crisis and the Copperbelt, 1975-2000}

\section{Introduction}

A Copperbelt boom of three decades was followed by a period of severe and sustained economic decline, involving the collapse of international mineral prices, growing corporate and state indebtedness, political manipulation of company operations and the increasing role of international financial institutions (IFIs) in the mining industry. From the late 1970s until the early 2000s, mineworkers and their families and, in different ways, the wider Copperbelt communities, experienced a profound decline in living standards. This was a period not only of falling real wages and the loss of tens of thousands of formal sector jobs but also the decline and then collapse of much of the quasi-governmental control of residential areas and social provision that characterised company operations during the Copperbelt's 'golden age'.

This chapter briefly explores the causes and effects of this decline, identifying how debt conditionality enabled the IFIs - the International Monetary Fund and the World Bank - to play an increasingly prominent role in managing the region's mines, periodically co-operating and clashing with state elites over control of operations and revenue. The Copperbelt was closely studied by IFI experts, who characterised both its industry and society as in urgent need of adjustment. The chapter uses IFI documents to explore the economic and social effects of decline on Copperbelt communities and to explain how they became central to elite knowledge and discourse about the region. In discussing interviewees' characterisation of the timing, causes and consequences of these interlinked economic, social and political crises, the chapter identifies both common themes and cross-border differences in how this period of historical decline is remembered. In the early 1990s, partly as a result of their regimes' inability to resolve their economic crises, both Zambia and the DRC experienced movements for political 
reform. While the Zambian Copperbelt's history of autonomous trade unionism and self-conscious cosmopolitanism helped enable the relatively peaceful transition of the country to a liberal democracy, HautKatanga's strategic and troublesome position within the Zairian body politic made it a key focus of state repression and politically mobilised ethnic violence, which together effectively derailed political reform. The contrasting outcomes of these movements were partly shaped by the different perceptions of the relationship between Copperbelt societies, mineral wealth and urban identities explored in previous chapters.

In both countries, however, elite actors, national and international, agreed that the Copperbelt needed urgent reform: corporations and communities that had once been characterised as the cutting edge of African modernity were now inefficient, uncompetitive and a constraint to the new modernising forces of globalisation and entrepreneurship. It was therefore necessary to divest soon-to-be privatised companies of their societal obligations. This process, implemented before and during the privatisations of the late 1990s and early 2000s, involved ostensibly rational economic processes in which responsibility for social provision was handed to Copperbelt communities themselves. These processes were, however, marked by official anxiety that Copperbelt residents lacked the entrepreneurial skills and mindset for this new form of modernity.

The chapter does not analyse the problematic and at times corrupt privatisation of ZCCM and Gécamines, which has been documented elsewhere. ${ }^{1}$ Nor does it address in detail the post-2000 Copperbelt that has evolved in the wake of privatisation and in the context of a Chineseled mining boom that has once again transformed the fortunes of the region's mining industry and, to a lesser extent, its communities. ${ }^{2}$ It

1 Rubbers, Paternalisme en Question; John Craig, 'Evaluating Privatisation in Zambia: A Tale of Two Processes', Review of African Political Economy, 27, 85 (2005), pp. 357-66; Rights and Accountability in Development (RAID), Zambia, Deregulation and the Denial of Human Rights: Submission to the Committee on Economic, Social and Cultural Rights (Oxford: RAID, 2000).

2 For the contemporary Copperbelt see, in particular, the WorkInMining project: www.workinmining.ulg.ac.be (accessed 21 July 2020); and the works of Patience Mususa. For China and Central Africa see Devon Curtis, 'China and the Insecurity of Development in the Democratic Republic of the Congo (DRC)', International Peacekeeping, 20, 5 (2013), pp. 551-69; Yan Hairong and Barry Sautman, "“The Beginning of a World Empire”? Contesting the Discourse 
does, however, draw on interviews, alongside archival material, to explore contemporary understanding of the impact of neo-liberalism on Copperbelt society. While many interviewees agree that this was a period in which shared prosperity and company paternalism was destroyed, some believe the era of liberalisation created new opportunities for individual freedom and self-mastery. In articulating their memories of the Copperbelt's decline, interviewees have, as always, framed their characterisation of this and earlier periods in relation to their understanding of the present day. From the late 1980s, the decline in living standards of Copperbelt mineworkers and their families provided the context for historical and ethnographic studies that identified how those populations characterised their precarious and diminished existence in relation to a fondly remembered golden past - a past that, as this study has shown, was never the reality for most Copperbelt residents. Ferguson's seminal ethnography of Luanshya in the late 1980s captured the mood of dissonance, pessimism and nostalgia rooted in a memory of better times associated with high wages and company social provision. ${ }^{3}$ Mususa's mid-2000s anthropological study of Luanshya explored the precarious lives of Copperbelt residents, particularly women, as they struggled to survive in a neo-liberal environment where mine company services had withered or entirely disappeared. Mususa engages more critically than Ferguson with the periodisation of decline articulated by her respondents, noting how the need to supplement low mine salaries with trading was a sign of economic decline even in the 1980s. ${ }^{4}$

In Haut-Katanga, Dibwe dia Mwembu's interviews in the late 1990s and early 2000s provide similar evidence of nostalgia, there rooted in the notion that company services reflected a genuine if authoritarian paternalism. ${ }^{5}$ Rubbers' research shows how this assertion of an unproblematic 'golden age' enables retrenched workers to make claims

of Chinese Copper Mining in Zambia', Modern China, 39, 2 (2013), pp. 131-64; and Dan Haglund, 'In It for the Long Term? Governance and Learning among Chinese Investors in Zambia's Copper Sector', China Quarterly, 199 (2009), pp. 627-46.

3 Ferguson, Expectations of Modernity.

4 Patience Mususa, "Getting By": Life on the Copperbelt After the Privatisation of the Zambia Consolidated Copper Mines', Social Dynamics, 36, 2 (2010), pp. 380-94.

5 Dibwe dia Mwembu, Bwana Shaba. For a comparative analysis of service provision in company-run towns, see Borges and Torres, Company Towns. 
on the companies that had abandoned them. ${ }^{6}$ Dibwe dia Mwembu's Katangese interviewees overwhelmingly situate the region's decline in the post-1990 period, during which the linked political and economic crises that brought the mining industry to its knees were followed by war and a disastrous privatisation process. It is, however, clear to many of our interviewees that the roots of these crises lay in the unresolved tensions of the Mobutu period, during which company social infrastructure was already in decline. Our interviewees provided explanations for this rooted in the political manipulation of the mining industry, but disagreed about who was to blame.

The impact of nostalgia on memory is widely seen as a problem for historians to overcome but it is arguably no more problematic than the assumption of historical progress, which was, until recently, hegemonic in social scientific research. While nostalgia is in contemporary African studies often linked to a longing for the colonial era, in the Copperbelt it is more closely associated with the post-colonial period of corporate welfarism, recalled in comparison with its recent decline. ${ }^{7}$ Certainly, capturing a history that encompasses both real experiences of social and economic decline and memories of it shaped by nostalgic narratives carries with it the challenge of accounting for the ways in which popular discourse about the past has been shaped by both the common and specific experiences of diverse sections of the Katangese and Zambian Copperbelt's communities, something to which this chapter makes a modest contribution. The juxtaposition of material decline to nostalgia for better times is not, however, designed to expose the accuracy of respondents' memories or to counterpose historical 'reality' to the fallibility and political utility of nostalgia. ${ }^{8}$ Rather, the aim is to draw attention to the ways in which the different meanings of this 'better past' and characterisations and explanations of 'decline' reflect diverse interpretations and experience, particularly for those residents whose interests were only indirectly linked to mining. While it is evident that mine companies provided far better services to their workers and immediate families in the remembered past than either companies or states do today, the historical significance of such

Rubbers, Paternalisme en Question.

William Cunningham Bissell, 'Engaging Colonial Nostalgia', Cultural Anthropology, 20, 2 (2008), pp. 215-48.

8 Stephanie Coontz, The Way We Never Were: American Families and the Nostalgia Trap (New York: Basic Books, 2016 [1992]). 
provision and its loss are more varied. While many interviewees highlight positive aspects of company paternalism, others recall the 'golden age' as one of suffocating control and emphasise the opportunities created by its demise.

\section{Cross-Border Decline, 1975-1989}

From the mid-1970s, the central African Copperbelt became associated with economic decline and, within a few years, was characterised as an uncompetitive dinosaur, requiring radical reform to survive. The collapse of international mineral prices, coupled with a general adverse shift in the terms of trade, caused Zambia's GDP to fall 25 per cent between 1974 and 1977. The mistaken belief that this was a reversible hiatus led to stimulatory spending and, via mechanisms such as the 1976 IMF standby agreement, enduring indebtedness. Zambia already had an effectively unpayable debt by $1978 .^{9}$ Likewise in Zaire, the World Bank provided Gécamines with a US\$100m loan to bridge what was wrongly assumed to be a brief slowdown: '[m]edium term prospects for export earnings and government revenues are good. After a decline in 1975, world copper prices are expected to recover substantially over the remainder of the decade'. ${ }^{10}$ Copperbelt mineral production was also hurt by the increasing cost and difficulty of exports, greatly disrupted by the closure of the Lobito export route as a result of the Angolan conflict and Zambia's closure of its border with Rhodesia in 1973.

In this context, political tension grew between Zaire and Zambia, reflecting both countries' economic difficulties, as well as their divergent political alignments in the context of an increasingly violent southern African liberation struggle. For example, in 1977, statecontrolled Zambian newspapers decried Zairians' use of Zambian schools and hospitals, alongside allegations that Zairian military planes had dropped bombs inside Zambian territory. ${ }^{11}$ The border

9 International Monetary Fund Archives (hereafter IMFA), C/Zambia/810 Mission, Russo to MD IMF, 'Zambia - Special Consultations', 10 January 1979.

10 WB online archives, 'Report and Recommendation of the President to the Executive Directors on a Proposed Loan to Gécamines', Report P-1551-CK, 2 January 1975.

11 ToZ, 13 April 1977; 23 July 1977; 16 August 1977; 17 August 1977; 13 September 1977; 6 December 1977. 
itself became a means of survival and a source of scarce goods: at Mokambo, Zambian women traders bought textiles that were in short supply south of the border, while shortages in Zaire were offset by the smuggling of price-controlled Zambian goods such as maize meal, clothing and petrol. ${ }^{12}$ Zairian residents of Zambia were periodically detained and deported, despite their claims that they had been living in Zambia since before independence (see also Chapter 6). ${ }^{13}$

Zaire's mining-dependent economy was badly hit by the May 1978 Shaba II invasion. This brief occupation of Kolwezi by ex-Katangese gendarmes, the killing of European workers taken hostage and its violent repression by Western military forces, exposed the vulnerability of the Zairian regime. ${ }^{14}$ In the midst of Shaba II, Mobutu accused Zambia of harbouring Katangese rebels, something angrily denied by President Kaunda. ${ }^{15}$ The participation of 200 Katangese dissidents in Zambia's foiled 1980 coup attempt ran alongside continued allegations of military incursions and soldiers' involvement in smuggling, looting and vehicle theft. ${ }^{16}$ The end of Zimbabwe's liberation war brought about limited rapprochement, marked by summits bringing together Kaunda, Mobutu and other southern African leaders, for example in Lubumbashi in July $1980 .{ }^{17}$ The two countries sought to co-operate in managing the sale of cobalt and in 1981 a joint border commission was established to address tensions. ${ }^{18}$ Nonetheless, the periodic harassment and rounding up of 'illegal aliens' and allegations about the smuggling of price-controlled goods continued to the late 1980s. ${ }^{19}$ A stereotype emerged among Zambians of their Zairian neighbours as materialistic, corrupt and involved in illegal activities, enabled by possession of Zambian national identity cards. ${ }^{20}$ For some interviewees, rising crime and cross-border insecurity were characteristic of the crisis:

12 ToZ, 31 March 1982; 11 October 1982. Mufulira interviews: Dennis Tembo and Ennis Zulu, 6 July 2018; Fridah Mwale, 6 July 2018.

13 ToZ, 23 June 1982. 14 Larmer, 'Local Conflicts in a Transnational War'.

15 ToZ, 27 May 1978. 16 ToZ, 14 May 1981; 13 June 1981; 4 March 1982.

17 ToZ, 5 September 1981; 4 November 1981; 7 November 1981; Mwana Shaba, 299, July 1980.

18 ToZ, 3 September 1981; 21 February 1984.

19 ToZ, 13 January 1986; 9 August 1986; 20 October 1986; 12 March 1987.

20 Mufulira interviews: Bobby Jackson Kabamba; Juliana Sakala; Chrispin Chani, 16 July 2018; Foster Kunda; Mary Nomba, 27 July 2018. 
It was in 1982 or 1983. The whole of Copperbelt they started putting [burglar bars on windows and doors] ... because burglars would come and break the window pane then come in... During Mobutu's era, it was real terrible. ... We used to lose three to four vehicles every night here in Mufulira ... the next day it's in Congo. ${ }^{21}$

Mining was sheltered from the worst aspects of decline until the mid1980 s, as states, IFIs and donors sought to ring-fence this crucial economic sector. Economic diversification was increasingly urgent but, in the immediate term, mining continued to be the region's economic lifeline. In practice, the mining sector served as a cash cow that was drained to feed other economic priorities, whether the patronage projects of senior politicians or debt repayment to donors. The limited availability of foreign exchange resulted in an exodus of skilled expatriate staff and shortages of expensive mine equipment that adversely affected production. While many attempts at reform and austerity were announced, few were effectively implemented.

\section{Haut-Katanga: Corruption, Conflict and Control}

In Zaire, economic decline was exacerbated by the political manipulation of mining revenue, the primary source of foreign exchange earnings. The establishment of SOZACOM (Société Zairoise de Commercialisation des Minerals) in 1974 enabled the Mobutu regime to conduct off-the-book cobalt sales and divert revenue from Gécamines. ${ }^{22}$ In 1981, former Prime Minister Nguza Karl I Bond testified to the US Congress regarding the massive corruption involved, as the Wall Street Journal reported: 'Mr. Nguza claims that President Mobutu himself skimmed tens of millions of dollars last year from the state-owned Gécamines mining company and from foreign aid'. ${ }^{23}$

By the late 1970s, when Zaire already owed Western governments US\$4.7bn, IFI reform efforts focussed on Gécamines. The IMF found that its workers' living standards had declined considerably:

21 Patson Katwisi interview.

22 'Cobalt Price has Skidded, and Big Factor is Unofficial Sales by Zaire, Dealers Say', Wall Street Journal, 13 September 1979.

23 'Zaire's Ills, Changed French Attitudes Signal Challenges to U.S. Africa Goals', Wall Street Journal, 14 September 1981. 
purchasing power, between $01 / 07 / 74$ and $01 / 01 / 79$, had fallen by $50.1 \%$ for senior African personnel ... Following the devaluation of the Zaire, social tension had become such that the Management Committee had to take provisional measures to reduce this tension ... a decision was taken, in February 1979, to increase the additional allowance from 15,000 to 35,000 Z. Last March, a base salary increase of $25 \%$ was granted. ${ }^{24}$

Donor officials were continually frustrated by such ad hoc pay rises as a response to rampant inflation. ${ }^{25}$ In its relationship with Western powers and IFIs, Zaire adopted what Young and Turner memorably term the 'diplomacy of bankruptcy': seeking to avoid loan conditions by bilateral appeals to Mobutu's Cold War allies, the United States and France. ${ }^{26}$ Acquiring accurate financial data was virtually impossible for an economy where 'corruption' was sanctioned and practised at the top of government. Unrealistically high targets for copper production - necessary to support unfounded claims that the company could balance its books over the medium-term - were continually missed. Gécamines underwrote the railway company SNCZ and the electricity generator SNEL, as well as politically prestigious construction projects. ${ }^{27}$ The company was, like ZCCM, starved of the foreign exchange it needed to purchase equipment and pay expatriate workers. $^{28}$ In a typical IFI analysis from 1978, a World Bank official reported

that the autonomy of the company was threatened and that due to political interference from above, there was no follow up on expenses while some receipts were diverted ... there was a total erosion of management, no control over productivity, morale was very low ... serious problems of staffing were threatening the production level in the coming months.... Gécamines does not control either its receipts or its expenditures. ${ }^{29}$

24 IMFA, Zaire - 831, Gécamines, 1977-8, Gécamines Council Process-Verbal, 19 April 1979.

25 IMFA, 'Zaire - Implementation of 1979 Program', 1979-80, E. L. Bornemann, 'Call from Mr Walker', 14 September 1979, and Christine Bindert, 'Zaire Monitoring of Stand-By Program', 19 September 1979.

26 Young and Turner, Rise and Decline, pp. 378-86.

27 IMFA, Zaire - Implementation of 1979 Program, 1979-80, 'Zaire-Gécamines', 8 November 1979.

28 IMFA, Zaire - 831 - Gécamines, 1977-8, Bindert, 'Zaire - Meeting with the IBRD and the Zairian Delegation', 29 September 1978.

29 IMFA, Zaire - 831 - Gécamines, 1977-8, Bindert, 'Zaire - Meeting with the IBRD and the Zairian Delegation', 29 September 1978, pp. 1-2. 
Mobutu's corrupt governance provides for many Copperbelt interviewees a powerful explanation of decline, characterised both by its economic effects and the daily humiliations of authoritarian rule:

We suffered with Mobutu. The officials of Mobutu, who had not even studied, disturbed, humiliated, extorted. You can't buy a shirt with your own money: when leaving the store, a Mobutu agent asks you to present your baptism document, for example. We needed freedom. ${ }^{30}$

Gécamines Chef de Cité Jérôme Mulunda, however, balances the negative experience of political repression with the comparative economic stability of the period. ${ }^{31}$ Others, like Mwanza Lukinde, have only positive memories of life under Mobutu:

President Mobutu's period, for us from Gécamines, was a good period.... we had our salary every month. We had our allowances as it should be, the labour code was well respected. We had advantages that allowed us to live well. ... we had food, we could buy vehicles; in short, it was good. ${ }^{32}$

For Musale Kibombo, Katanga's economic decline resulted not only from Mobutu's exploitation but also his unwelcome opening of the province to outsiders: 'When Mobutu came to power, with his slogan of one country, one father, one mother, people came from all over to Katanga. This is where it started to degenerate'. ${ }^{33}$ Gaston Mutiti explains Gécamines' decline in the context of its longstanding 'exploitation' by external Congolese actors and its occupation by foreign soldiers during and after the Shaba wars:

[They] ... resented the Katangese, Mobutu and all those around him.... the problem started with the two [Shaba] wars ... during this period, we, all Congolese, we did what we called the war effort. So you know, the people [were] being very badly paid ... When a minister came here on a mission, he was paid on a mission but he had to arrive at Gécamines, asking that he be given some money ... The guesthouses are Gécamines. So, everything weighed on Gécamines, so much so that the company found itself in the situation, people were so badly paid, everything was finished. ${ }^{34}$

Zaire's indebtedness and Mobutu's increasingly limited room for manoeuvre led to the abolition of SOZACOM in 1984 and to a more

30 Banza Mutunda interview. 31 Jérôme Kipili Mulunda interview.

32 Mwanza Lukinde interview, 5 June 2018. 33 Musale Kibombo interview.

34 Gaston Mutiti interview. 
transparent mineral sales system. International financial institutions promoted economic liberalisation policies - devaluation, price decontrols and spending controls - that had a deflationary effect, as the World Bank acknowledged in 1986: 'Soaring debt service payments in local currency terms, have necessitated massive cuts in salaries, expenditures on goods and services, and investment expenditures in real terms'. ${ }^{35}$ The IFIs increasingly directed Gécamines management decisions, for example by vetting senior appointments and overseeing the hiring of a Belgian customs team to investigate smuggling. ${ }^{36} \mathrm{~A}$ new 1986 World Bank loan of US $\$ 110 \mathrm{~m}$ was conditional on the full autonomy of Gécamines' management from state authority. ${ }^{37}$ That agreement characterised the company's social wage as a problem to be addressed:

compensation policies need to be reviewed. While salaries have not kept up with inflation, the company offers generous fringe benefits (free housing, schooling and medical care and subsidized food prices). As a result, absenteeism has been growing and low salaries are a deterrent to hiring competent technical personnel. ${ }^{38}$

In 1989 it was agreed that 'all dividend payments by GÉCAMINES must obtain prior approval from the World Bank'. ${ }^{39}$ That year, Katanga's largest underground mine at Kamoto collapsed, causing a huge loss in mineral production. Attempts at external financial regulation proved insufficient to arrest the growing economic and political crisis that would soon engulf Zaire.

While Mobutu's regime struggled to maintain control over Gécamines finances in the face of IFI intervention, it was more successful in controlling political expression in Katanga/Shaba. In the late 1970s and early

35 WB online archives, 'Report and Recommendation of the President of the IBRD to the Executive Directors on a Proposed Loan ... ', Report P-4268-ZR, 27 March 1986.

36 IMFA, Zaire - 831 - Gécamines, 1977-8, WB Office Memorandum, 'Gecamines, Loan 1090-ZR, Negotiation of Amending Agreement - May 28-29 Back-to-Office Report', 4 June 1979.

37 Rubbers, Le Paternalisme, p. 46.

38 WB online archives, 'Report and Recommendation of the President of the IBRD to the Executive Directors on a Proposed Loan', Report P-4268-ZR, 27 March 1986.

39 IMF online archives, 'Zaire - Structural Adjustment Facility, Policy Framework Paper, April 1989-March 1992', 17 May 1989, p. 18. 
1980s, the MPR strengthened its presence in mine cités, building on and merging with the company's existing structures. Officials of the party and its youth wing, the Jeunesse $d u$ Mouvement Populaire de la Révolution (JMPR), were closely involved in overseeing mine communities. This enlarged conceptualisation of nationalised company paternalism is evident in Gécamines CEO Umba Kayamitala's New Year message to workers in 1976:

1975 has certainly been a difficult year, characterised mainly by the fallout from the economic crisis which shook the whole world. To deal with this crisis, the Guide to the Zairian Revolution [Mobutu] took drastic measures and invited us all to make sacrifices. I owe it to you to share with you the pride I feel in the discipline, in the self-denial, in a word the militancy that you have shown in this difficult and momentary conjuncture. ${ }^{40}$

With the establishment that year of JMPR committees in workplaces, party control of the company was strengthened: 'The Gécamines family indeed wants to be strong, united, counting on each of its children. ... May the year 1976 find you armed with a will to do well the work entrusted to you in order to achieve the objectives assigned by the nation'. ${ }^{41}$ Workers were enjoined, at workplace party seminars and in the pages of Mwana Shaba, to make 'revolutionary' sacrifices in the national interest. ${ }^{42}$ Meanwhile, the Gécamines' cultural events that invoked company paternalism had morphed into 'animations politiques', parades with marching bands and singing that celebrated both the company and Mobutu (Chapter 7$).{ }^{43}$

It was, however, increasingly clear that, as Gécamines CEO Robert Crem admitted in Mwana Shaba in 1983, company social services would be severely cut:

The fact that Gécamines houses its staff, provides medical treatment, sells items at reduced prices in order to safeguard the purchasing power of the worker ... leads the company to be given the unflattering epithet of paternalism. ... as a historical phenomenon, paternalism could well be justified at its beginnings, but not indefinitely. ${ }^{44}$

40 Mwana Shaba, 245-246-247, January-March 1976, p. $1 . \quad{ }^{41}$ Ibid.

42 See, for example, Mwana Shaba, 261, 15 May 1977, p. 1 and p. 7, and 324, 10/ 82 , p. 1 and p. 5.

43 GCM Likasi, 'Organisation du 1er Festival d'Animation Politique', 1 June 1984.

44 Mwana Shaba, 333, July 1983, p. 6. 


\section{Zambia: Liberation, Losses and Labour Unrest}

In the late 1970s, Zambia experienced a similarly devastating economic downturn, together with an increased military threat from racist southern African regimes. Kaunda was lauded internationally for supporting regional liberation movements but - for some interviewees - this support came at their expense, as they experienced food and commodity shortages. ${ }^{45}$ Dennis Tembo recalls: 'Kaunda used to tell us to suffer so that we can help liberate the neighbouring countries' ${ }^{46}$ Henry Longwane links falling real wages to the same issue:

[We were] [w]worse off, those days during the Kaunda era, we would even be paid amounts which could not even buy a bag of charcoal. ... Kaunda was taking out a lot of money to go and fight for independence for other countries such as Zimbabwe and Namibia and this was known by everyone countrywide. ${ }^{47}$

The widespread labour unrest of Zambia's First Republic was a thing of the past, as formal sector employment stagnated and real wages fell. As the World Bank reported, the value of ZCCM salaries collapsed between 1970 and 1983:

mineworkers (ZCCM) have gone through a much larger decline in real wages than other groups of workers. Whereas mineworkers used to be much better paid than government unskilled workers in 1970, by the early 1980s their wages had fallen to a level in line with other better-paid unskilled workers. ${ }^{48}$

Although the characterisation of mineworkers as a labour aristocracy was no longer viable, donor policy continued to be influenced by the notion that Zambia had a uniquely problematic urban society whose residents benefited from consumption subsidies that damaged the rural economy and fuelled urban migration. Bates and Collier argued that Zambia's political system 'induced a systematic bias in favour of the formation of state industries, the conferral of consumer subsidies, and the control of prices. The pattern of policy bias systematically favoured

45 Chrispin Chani interview, 16 July 2018. ${ }^{46}$ Dennis Tembo interview.

47 Henry Longwane interview, 10 July 2018.

48 WB online, 'Zambia: Wage Policy and the Structure of Wages and Employment', Report 5727-ZA, 7 May 1986, p. 59. 
urban consumers'. ${ }^{49}$ Potts later showed that population growth in Copperbelt towns was, by the 1980s, lower than the national average and that the population of some towns, including Mufulira, was actually falling. ${ }^{50}$ Nonetheless, the IFIs' increasingly influential neo-liberal policy recommendations viewed state-led industrial development as inherently problematic. ${ }^{51}$ 'Market reforms' and the resultant huge rises in living costs were seen as a necessary price to pay to create a free market economy.

These policies shaped conflict between the Zambian state and Copperbelt labour unions over the long delayed integration of mine townships into local government structures in 1980-1 (see also Chapter 3$).{ }^{52}$ This integration, designed to reduce the quality and cost of social service provision to mineworkers and their families, prompted a major wave of industrial action and led the government to suspend most ZCTU and MUZ leaders. ${ }^{53}$ Striking mineworkers rioted and some were shot by police - 58 people were seriously wounded and $\mathrm{K} 20 \mathrm{~m}$ (c.US\$15m) of mine production was lost. ${ }^{54}$ In August 1981, four senior labour leaders, including MUZ officials and ZCTU Chairman Frederick Chiluba, were detained, accused of using the strike action for political ends. ${ }^{55}$ Zambian mine townships and, to a lesser extent, the wider Copperbelt, were from this point forward the centre of unofficial opposition to UNIP.

By the early 1980s the IFIs were convinced that the main barrier to establishing a more market-oriented economy was the government's inability to make its urban population poorer:

Since the mid-1970's, Zambia has attempted a succession of adjustment programs supported by Fund arrangements, but most have foundered because of unexpected declines in copper prices and the inability to reduce domestic expenditure in line with the fall in income and export earnings. ${ }^{56}$

49 Robert H. Bates and Paul Collier, 'The Politics and Economics of Policy Reform in Zambia', Journal of African Economies, 4, 1 (1995), pp. 115-43, p. 141.

50 Potts, 'Counter-Urbanisation on the Zambian Copperbelt?'.

51 World Bank, Accelerated Development in Sub-Saharan Africa: An Agenda for Action (Washington, DC: World Bank, 1981).

52 Mijere, 'The mineworkers' resistance to governmental decentralisation'; Burawoy, 'The Hidden Abode of Under-Development', pp. 123-4.

53 ToZ, 10 January 1981. 54 ToZ, 7 February 1981.

55 ToZ, 18 September 1981.

56 IMFA, 'Zambia 011 - Economic Situation and Prospects', 1974-5, Bhatia to Callendar, 30 October 1984. 
The establishment of Zambia Consolidated Copper Mines (ZCCM) in 1982, an initiative driven by donor demands for greater efficiency in the loss-making industry, is recalled by many mineworkers as consolidating state elites' manipulation of mining:

There was a time when they just combined all the divisions and it became ZCCM, that was the time when there was a problem because all the monies that was supposed to end here was taken to Lusaka and they could share there. So here, there were times when the operations were paralysed because money was not enough to run the mining operations. ${ }^{57}$

The failure of economic liberalisation was blamed by IFIs on mine companies characterised as inefficient and unproductive, whose managers were unable or unwilling to implement the 'painful' measures necessary to 'modernise' their operations and workforce. A 1984 report stated: 'there is a general lack of discipline among mine workers attributable to the weaknesses of the managerial structure and to the lack of incentives built into the wage structure'. The necessary 'rationalisation' of ZCCM operations involved the 'closing of uneconomical operations and permanent or temporary release of some labor, with their far-reaching social consequences'. ${ }^{58}$ The wider reform programme necessitated reducing urban living standards in general and on the Copperbelt in particular. A far-reaching adjustment programme implemented under World Bank auspices from 1986 involved the removal of price controls, a new auction system to allocate foreign exchange and other market-oriented reforms. ${ }^{59}$ Kaunda justified the resultant hardships in a characteristically ruralist speech that replicated typically colonial perspectives regarding urban unemployment:

Every Zambian has a village to go back to.... If you have no job in town you are not supposed to be here. You are supposed to be at your village, producing crops. Life has become hard for the urban dweller because of the high prices. On the other hand, the high prices of agricultural crops now make

57 Boston Mwenya interview.

58 WB online archives, 'Staff Appraisal Report, Zambia, Export Rehabilitation and Diversification Project', Report 4624-ZA, 22 February 1984, p. 8.

59 ZCCM-IH, 2.5.4I, World Bank, Program Performance Audit Report Zambia - Industrial Reorientation Project, 30 June 1992. 
agriculture more attractive. ... Loafers, look out! It may soon be too expensive for you to stay in town. ${ }^{60}$

In December 1986 the removal of subsidies caused a doubling in the maize meal price, panic buying, shortages and widespread rioting on the Copperbelt. ${ }^{61}$ A curfew was imposed in Kitwe and fifteen people were killed by the police. ${ }^{62}$ Following ZCTU criticism of the IMF, the price rises were reversed. Workers sought compensatory wage increases for rising prices through unofficial strikes. Kaunda initially claimed 'the initiators of the strikes were politically motivated'. ${ }^{63}$ However, the entire IMF programme was cancelled on May Day 1987, demonstrating the ability of popular mobilisation to change government policy and the weakness of the one-party state regime.

A subsequent UNIP 'home-grown' reform programme, including measures such as a minimum wage, was opposed by the IFIs because it 'would have an adverse effect on investment and growth' ${ }^{64}$ By 1989 , the government again accepted the need to implement reforms demanded by donors, including the removal of all food subsidies and the steady alignment of official and market exchange rates. Cuts were implemented to government budgets, but IMF officials presented a profoundly pessimistic view of Zambia's economic prospects, partly because of urban resistance to its policies:

Zambia's main copper mine will be depleted in about a decade and we project that the purchasing power of Zambia's copper exports at the turn of the century will be only 20 percent of what it is today. ${ }^{65}$

It is clear that, even with the best of intentions, Zambia cannot fully service its external arrears and due maturities on a sustainable basis without causing serious dislocations to the economy and probably internal social unrest. ${ }^{66}$

60 IMFA, 'Zambia 012 - Government and Politics', 1985-6, Kaunda national press conference, 8 January 1986.

61 ToZ, 10 December 1986. 62 ToZ, 15 December 1986.

63 ToZ, 4 April 1987; Per Nordlund, Organising the Political Agora: Domination and Democratisation in Zambia and Zimbabwe (Uppsala: Uppsala University, 1996), p. 91.

64 IMFA, 'Zambia - SAF III', 1988-90, 'IMF Staff Report for the 1988 Article IV Consultation', May 1988, p. 36.

65 IMFA, 'Zambia - SAF III', 1988-90, 'Zambia-Fund Staff Statement for Donors Meeting', Paris, 28 July 1989 , p. 3.

66 IMFA, 'Zambia - SAF III', 1988-90, 'Zambia: Economic and Financial Policy Framework, 1989-93', 25 August 1989, p. 5. 
Despite this, mining remained, in IFI policy assumptions, the economic mainstay in the medium term. Although copper's contribution to GDP had fallen from 38 per cent in 1970 to 15 per cent in 1988, it still represented 85 per cent of exports. ${ }^{67}$

\section{Manifestations of the Crisis}

On the ground, the growing crisis manifested itself in a substantial decline of economic and social conditions across the Copperbelt. The value of real wages had fallen drastically and some skilled African workers, like their European counterparts, implemented exit strategies. Patson Katwisi took early retirement aged 53, in a period of job cuts: 'at that time the mines became far much worse. Miners started facing a lot of problems. So the so called suffering found in [mine] companies taught me to be on my own'. ${ }^{68}$

Mine companies produced evidence not only of this decline but also of their own reduced control over their communities. In 1988 an inventory was compiled by Gécamines officials of informal and illegal activities taking place in the company-owned houses of Likasi mineworkers. These included churches and small businesses; in some cases, new structures had been built to house these activities. ${ }^{69}$ Meanwhile, school classes were taking place in classrooms without doors or glass in windows and some workers were not receiving their food rations. ${ }^{70}$ Management meetings involving company, MPR and union representatives provided a forum for complaints about the deteriorating quality of township life. A single meeting in March 1989 in Likasi discussed rising insecurity, water supply problems, infestations of cockroaches and mosquitos, the lack of glass in windows and doors for houses, waste disposal problems, the theft of taps and transportation problems. These actors disputed and sought to identify who was to blame. Citoyen Muzinga, a JMPR representative, asserted: 'There are too many cases of theft being reported in our cités. We suspect that people are coming from outside. They steal everything including the copper

IMFA, 'Zambia - SAF III', 1988-90, 'Zambia: Economic and Financial Policy Framework, 1989-93', 25 August 1989, p. 1.

68 Patson Katwisi interview.

69 GCM Likasi, Panda Chief of Personnel, 13 October 1988.

70 GCM Likasi, $P V$ de la Réunion $d u$ Comité Cellulaire MPR/DSA/DGP, 28 March 1989, p. 2. 
alloy waste on the mine site'. ${ }^{71}$ While company officials accused workers of complicity in the theft of materials, union representatives criticised the corrupt allocation of jobs by senior state and company officials to their relatives and friends and asked rhetorically what workers who did not have friends in high places could do. ${ }^{72}$

In 1987, prompted by the December 1986 'food riots' (see above) in which mine township youth had played a prominent role, ZCCM conducted a major investigation into community services. This sought ' $[t]$ o establish the youth population in each Mine township by reviewing the number of dependent children under the age of 25 years per household'. ${ }^{73}$ The report found that 59.1 per cent of the township population were below fifteen years of age and 71.9 per cent were twenty-five or under. This knowledge production exercise was noteworthy for going beyond company-controlled territory to investigate conditions in the 'shanty townships bordering Mine areas'. The report, which focussed on Nkana/Kitwe, offered a devastating account of decline: mine 'townships are in an advanced state of decay; the remains of what once used to be roads are clogged with refuse; open sewerage systems and gutters pollute the atmosphere and pose a real health hazard to inhabitants' ${ }^{74}$ Houses had broken windows, rotten fittings and had (as in Likasi) been adorned with 'illegal extensions'. Soccer pitches and tennis courts were overgrown and cinema halls were disused.

The team observed, in all mine townships visited, that large groups of youths and children gathered on street corners and at markets, bars and bus stops, making some areas inaccessible to outsiders and ZCCM officials. ${ }^{75}$ They controlled markets and 'charge protection money (rent) and impose their own version of law and order'. ${ }^{76}$ In five shanty towns neighbouring ZCCM townships, there were no community

71 GCM Likasi, PV Meeting MPR/DSA/DGP, 28 March 1989.

72 GCM files, $P V$ de la Réunion $d u$ Comité Cellulaire MPR/DSA/DGP, 28 March 1989 and 30 October 1989.

73 ZCCM-IH, 6.2.5I, 'ZCCM Study to Investigate Industry Community Services', 1987, p. 1.

74 ZCCM-IH, 6.2.5I, 'ZCCM Study to Investigate Industry Community Services', 1987, p. 4.

75 ZCCM-IH, 6.2.5I, 'ZCCM Study to Investigate Industry Community Services', 1987, p. 6.

76 ZCCM-IH, 6.2.5I, 'ZCCM Study to Investigate Industry Community Services', 1987 , p. 5. 
services and just one health clinic, which lacked permanent staff or facilities. Recognising that disease did not obey official demarcations, ZCCM was already spraying for mosquitos in two of the shanty towns. The breakdown of distinctions between township and informal settlements was also manifest in the fact that shanty dwellings were built from company materials such as 'metal roofing, mainly drumsheets most of which were labelled "ZCCM"'.77 The report perceptively noted: '[a] symbiotic relationship exists between Mine Townships ... and shanty townships'. ${ }^{78}$ Acts of 'vandalism of houses in Mine townships for window/door frames and roofing materials [were carried out to enable their] sale in the shanty townships', while 'shanty townships provide cheap accommodation for unhoused Mine employees, domestic servants, security guards and general workers'. ${ }^{79}$ Strikingly, the research team was initially greeted with hostility in informal settlements when they were thought to be UNIP or government officials: co-operation followed when it became clear that they were from ZCCM. The opposite occurred in the mine townships, whose 'inhabitants are hostile towards ZCCM officials and property because they believe that the Company has ceased to care about them, ${ }^{80}$

The report found that women's programmes and youth development schemes lacked qualified staff and vital equipment; 'vandalism and thefts ... have reduced community centres in some townships to shells'. ${ }^{81}$ Spending on community services in Nkana and Mufulira had fallen by 33-50 per cent between 1975 and 1986. The report identified that the 'problem' of unemployed youths arose from '[1]arge families (average size 9) and polygamy [that] mitigate[s] against the provision of effective supervision and guidance of children by parents'. ${ }^{82}$ It recommended that 'the Company should take measures

77 ZCCM-IH, 6.2.5I, 'ZCCM Study to Investigate Industry Community Services', 1987, p. 12.

78 ZCCM-IH, 6.2.5I, 'ZCCM Study to Investigate Industry Community Services', 1987, p. 13.

79 ZCCM-IH, 6.2.5I, 'ZCCM Study to Investigate Industry Community Services', 1987, p. 14.

80 ZCCM-IH, 6.2.5I, 'ZCCM Study to Investigate Industry Community Services', 1987, p. 14.

81 ZCCM-IH, 6.2.5I, 'ZCCM Study to Investigate Industry Community Services', 1987 , p. 5.

82 ZCCM-IH, 6.2.5I, 'ZCCM Study to Investigate Industry Community Services', 1987, p. 7. 
to control the number of dependants outside the immediate family to ease pressure on services' and conduct family planning campaigns. ${ }^{83} \mathrm{It}$ also sought the '[s]trict enforcement of the provisions of the Tenancy Agreements' and the '[d]emolition of all illegal structures' in mine townships. $^{84}$

\section{Political Transition and Conflict, 1990-1993}

The early 1990s saw a movement for political and economic change sweep across Africa, inspired by the fall of communism but driven primarily by local discontent with the social and political order. ${ }^{85}$ While Zambia experienced a largely peaceful transition from oneparty state to liberal democracy, the pro-democracy movement in Zaire was violently suppressed by state forces and derailed by Mobutu's divide-and-rule tactics and the fuelling of ethnic violence. ${ }^{86}$ Zambian Copperbelt actors in general, and its labour movement in particular, were central to the success of the Movement for Multi-party Democracy (MMD) in ousting UNIP and establishing a new government led by ZCTU leader Frederick Chiluba. As I have argued elsewhere, the MMD's success was partly built on the successful defence of labour movement autonomy in the 1980s and its ability to resist ethno-regional divide-and-rule was informed by the self-conscious

83 ZCCM-IH, 6.2.5I, 'ZCCM Study to Investigate Industry Community Services', 1987, pp. 27-8.

84 ZCCM-IH, 6.2.5I, 'ZCCM Study to Investigate Industry Community Services', 1987, p. 17.

85 Michael Bratton and Nicolas Van de Walle, Democratic Experiments in Africa: Regime Transitions in Comparative Perspective (Cambridge: Cambridge University Press, 1997); Leonard Villalon and Peter Von Doepp (eds.), The Fate of Africa's Democratic Experiments (Bloomington: Indiana University Press, 2005); Gabrielle Lynch and Gordon Crawford, 'Democratization in Africa 1990-2010: An Assessment', Democratization, 11, 2 (2011), pp, 275-310.

86 For Zambia see Lise Rakner, Political and Economic Liberalisation in Zambia 1991-2001 (Uppsala: Nordic Africa Institute, 2003) and Miles Larmer, 'Zambia Since 1990: Paradoxes of Democratic Transition', in Abdul R. Mustapha and Lindsay Whitfield (eds.), Turning Points in African Democracy (James Currey: Oxford, 2009), pp. 114-33. For Zaire, see Ernest Wamba-dia-Wamba, 'Democracy, Multipartyism and Emancipative Politics in Africa: The Case of Zaire', Africa Development, 18, 4 (1993), pp. 95-118; Georges Nzongola-Ntajala, From Zaire to the Democratic Republic of Congo (Uppsala: Nordic Africa Institute, 2004); and William Reno, 'Sovereignty and Personal Rule in Zaire', African Studies Quarterly, 1, 3 (1997), pp. 39-64. 
cosmopolitanism of Copperbelt political discourse. ${ }^{87}$ The Zambian labour movement, rooted in Copperbelt urban society, was, as a result, able to play a far more significant political role than on the continent in general and certainly when compared with its Congolese counterpart.

While the Zambian Copperbelt was, in late 1991, celebrating the MMD's victory, the mining towns of Haut-Katanga/Shaba were consumed in a growing crisis that would ultimately be resolved only by the armed overthrow of Mobutu in 1997 by Laurent Kabila and his regional backers. Following Mobutu's legalisation of a multi-party system in April 1990, initiatives to bring about democratic change focussed on an opposition-led Sovereign National Conference (CNS) that, however, failed to reach agreement on the country's political future. Zaire's Gécamines-dependent economy was, meanwhile, collapsing. Management's attempt to radically reduce costs included a 20 per cent cut in its workforce, but this was, as Rubbers states, 'thwarted by strikes by workers, provoked by the deterioration in their standard of living, and looting, which razed the entire fabric of small and medium-size enterprises in 1991, ${ }^{88}$ In September and October that year, the central retail areas of Lubumbashi, Likasi and Kolwezi were looted and burnt, in attacks that, it is widely believed, were orchestrated by the Mobutu regime. ${ }^{89}$ Popular opposition was, meanwhile, brutally crushed. In May 1990, security forces killed at least one hundred students at the University of Lubumbashi who were demonstrating for political reform. ${ }^{90}$

Mobutu maintained his precarious hold on power by an increasingly short-term manipulation of mineral wealth and of latent ethnic tensions. When the CNS appointed Étienne Tshisekedi as Prime Minister in August 1992, the opposition had already been weakened by defections from the UFERI (Union des Fédéralistes et Républicains Indépendants) party. Prominent UFERI leader Gabriel Kyungu wa Kumwanza was appointed Shaba governor in November 1991.

87 Larmer, Rethinking African Politics, chapter 7.

88 Rubbers, Le Paternalisme, p. 47.

89 Mwana Shaba, 433, November 1991; Dibwe dia Mwembu, 'Historical Knowledge Production at the University of Lubumbashi (1956-2018)', in Larmer et al., 'Across the Copperbelt', pp. 296-320.

90 Human Rights Watch, 'Africa, Human Rights Developments, Zaire', 1993: w ww.hrw.org/reports/1993/WR93/Afw-11.htm (accessed 20 July 2020). 
Mwana Shaba, reporting Kyungu's arrival in hagiographic tones, celebrated his appointment as the first governor of local origin in twentyfour years and emphasised

his deep attachment to his region of origin. His determination to defend its interests was not without harsh criticism and even the antipathy of those who considered Shaba as a conquered territory whose tribute had to be taken, whatever the cost.... as soon as he got off the plane, he bowed and kissed the ground, a way for him to worship ancestors and express his attachment to the land that nourished him since childhood. ${ }^{91}$

Kyungu, having promised to govern Shaba's people regardless of region or ethnicity, unleashed a campaign of intimidation and violence against Katangese residents of Kasaian origin. Gécamines was targeted by UFERI militants; thousands of its long-standing workers and their families were forced to flee. ${ }^{92}$ Kyungu also organised unofficial shipments of cobalt to Zambia by Mobutu's Division Spéciale Présidentielle (DSP) that provided the presidency with a precious source of revenue. ${ }^{93}$

For some interviewees such as Thérèse Kyola, this violence marked the end of the company community: 'This has been ever since the period of inter-ethnic conflicts; before, we were all together. With the Katangese-Kasaian conflicts, for example, people started to be afraid of being killed'. ${ }^{94}$ François Kake recalls: 'My wife is from Kasai and with these politicized wars, I could not for example tolerate that people kill my wife or my children. . . It was difficult to live at that time'. ${ }^{95}$ For others, the communitarianism of this period is explained as a normal human response to crisis, for example by Emile Ngoy Muyondwe:

When there is a crisis, very often we rally around the closest. When the crisis came, I remember there were selected payments, since the money was not enough for everyone. Under these conditions, the officials tended to select their friends, their brothers from the same tribe. We experienced that. The crisis can lead to tribalism. ${ }^{96}$

91 Mwana Shaba, 433, November 1991, p. 2.

92 Rubbers, Le Paternalisme, p. 47; a harrowing account of their experiences is provided in Dibwe dia Mwembu, Bana Shaba, pp. 201-29. See also Gauthier de Villers with Jean Omasombo Tshonda, Zaire: La Transition Manquée (1990-1997) (Tervuren-Paris: Institut Africain-L'Harmattan, Cahiers Africains 27-29, 1997); and Ch. Didier Gondola, The History of Congo (Westport, CT: Greenwood Press, 2002), pp. 156-7.

93 Reno, 'Sovereignty and Personal Rule'. 94 Thérèse Kyola interview.

95 François Kake interview. 96 Emile Ngoy Muyondwe interview. 
On both sides of the border, the early 1990s saw the value of cash wages decline drastically and there were periodic food shortages. Philippe Kalenda remembers: 'We even sold household items like televisions to find food. We traded with villagers from neighbouring villages'. ${ }^{97}$ Farming as a survival measure carried its own dangers: Marie José Kapya Katolo recalls an attempted sexual assault by a soldier in 1992 while she was farming. ${ }^{98}$ Zambian nurse Mary Nomba recalls: 'people suffered from kwashiorkor, malnutrition and they were brought in the hospital and we fed children from the hospital who had such cases'. ${ }^{99}$ Lesa Kanyanta reports that, as MUZ's Kitwe Branch Chairman, he negotiated with ZCCM to provide maize meal directly to mineworkers, a reversal of the cash-only wages that had, in the early 1960s, been a symbol of Zambian mineworkers' modernity. ${ }^{100}$

\section{Selling the Copperbelt: Liberalisation and Privatisation}

Zaire's crisis continued throughout the 1990s. Copper production, which had peaked at 538,000 tonnes in 1986, collapsed to just 48,000 tonnes in 1993. Nine thousand workers left Gécamines that year as a result of ethnic violence. ${ }^{101}$ 'Crisis actions' necessitated sweeping cuts to the company's social provision: food supplies were significantly reduced and all cultural and sporting events cancelled to address the catastrophic financial situation. The country experienced a 42 per cent decline of GDP per head between 1990 and $1993 .{ }^{102}$ Governmental paralysis was resolved only in 1994 with the appointment of Prime Minister Kengo wa Dondo, who had little choice but to accept the World Bank's plans for restructuring and partly privatising Gécamines. Mobutu's overthrow in 1997 by Katangese leader Laurent Kabila raised hopes that he would revive the province's economic fortunes. Kabila, however, ceded control of the mining industry to the forces that kept his regime in power once he fell out with his

97 Interview, Philippe Kalenda, Likasi, 11 June 2018.

98 Interview, Marie José Kapya Katolo, Likasi, 23 June 2018.

99 Interview, Mary Nomba, Mufulira, 27 July 2018.

100 Interview, Lesa Kanyanta, Kitwe, 3 July 2019.

101 IMFA, Executive Board Meeting, 13 November 1992; IMF, 'Zaire - Recent Economic Developments', 13 May 1994, p. 4.

102 IMFA, Executive Board Meeting, 18 December 1995, p. 11. 
Rwandan and Ugandan backers in 1998. ${ }^{103}$ Billy Rautenbach's appointment to lead Gécamines' 'recovery committee' symbolised the effective mortgaging of the company to Zimbabwean military and business interests. While the company was looted at the top, on the ground Gécamines' operations were opened up to artisanal diggers, some themselves former company workers. ${ }^{104}$ Rubbers details the return of the World Bank to the DRC in 2001 to oversee the partial privatisation of the company in the early 2000s. This process involved the dismissal of tens of thousands of workers and the dismantling of most of Gécamines' remaining social and welfare provision. ${ }^{105}$

In Zambia in the early 1990s, the new MMD government, consistent with its own neo-liberal thinking and IFI debt conditionality, implemented one of Africa's most radical economic liberalisation programmes. While many Copperbelt residents believed their democratically elected government would protect the mining industry from political interference, they did not anticipate the generalised decline in living standards that resulted from the removal of subsidies and the privatisation of most state-owned companies. Chiluba's government was praised internationally for its willingness to meet donor demands, but the ultimate test of its neo-liberal credentials would be the privatisation of the mining industry. ${ }^{106}$ The IFIs focussed on what they regarded as ZCCM's unduly high social and labour costs:

The [IMF] mission was concerned that the economy as a whole would not benefit from the current high price of copper, but that instead it would be used, as in the past, to subsidize inefficient practices and unduly high labor costs. [It] ... questioned the 25 per cent April wage increase, given the company's very precarious financial situation. ZCCM management responded that ... the unions had viewed the wage award as minimal in the light of inflation over the last year, and that [with] anything less there would have been an intolerable degree of labor unrest. The [IMF] staff representatives emphasised that such actions reinforced the necessity of moving ahead swiftly with the privatization of ZCCM. ${ }^{107}$

103 Among his measures, Kabila renamed the province officially known as Shaba with the name Katanga.

104 Cuvelier, 'Men, mines and masculinities'.

105 Rubbers, Le Paternalisme, pp. 49-51.

106 Rakner, Political and Economic Liberalisation, pp. 72-9.

107 IMF online archives, 'Zambia - Staff Report for the 1994 Article IV

Consultation and Midterm Review of Rights Accumulation Program',

9 September 1994. 
Privatisation required 'a program of joint-venturing and divestiture of ZCCM's under-utilised or unused assets.... ZCCM would also reduce its involvement, through a variety of divestiture methods, in housing, transportation, schools, health service facilities as well as in other services which it currently operates' ${ }^{108}$ Early attempts at commercialising Mufulira's worker canteens foundered on the supposed lack of a commercial mindset among the women recruited to run them: 'Raw materials were not purchased from the cheapest sources and in short the enterprise did not meet the essential criteria of a viable commercial enterprise. ... I anticipate that we would encounter the ever present problem of finding a suitably commercially minded person to take charge of the operation'. ${ }^{109}$ As this indicates, being modern now meant being entrepreneurial and self-sufficient. The ZCCM publication Mining Mirror, covering a crime wave in Luanshya in 1996, proclaimed that the ' $[\mathrm{t}]$ ime for ZCCM to be over-protective of its employees is a matter for the historians. Employees are being asked to take care of themselves'. ${ }^{110}$ Company withdrawal from social and community service provision was presented as 'decentralisation' and 'empowerment':

it has been the practice for mining companies to provide community development services and recreational facilities to cater for the welfare of employees and their dependants [and] free housing to employees. However, in line with the changed national perspective, the Company's present policy is to encourage home ownership. ... the policy statement aims at encouraging coordinated activity and full participation of communities to enable them [to] contribute fully to national development. ${ }^{111}$

While the sale of company housing to sitting tenants was widely popular among mineworkers, some company officials worried that new houseowners were insufficiently prepared for their new status: as

108 World Bank online, 'Memo and Recommendation to IDA for Proposed Credit for Mining Sector Technical Assistance Project', request P-5496-ZA, 23 May 1991.

109 ZCCM-IH, 1.5.3F, Running of Mine Recreation Clubs and Canteens at Work Places, 1990-9, J. R. Oliver to M. D. Sichula, Copper Mining Enterprise Trust Ltd, 'Eating Facilities - ZCCM', 10 July 1990.

110 Mining Mirror, April 1996, p. 11.

111 ZCCM-IH, 12.8.8F, Report on the Findings and Recommendations of the Committee on the Future of ZCCM Schools, Hospitals and Other Social Services, ZCCM, July 1996, p. 3. 
Nkana's General Manager wrote in 1998, 'no attempt has been made to educate the labour force in the responsibilities and costs associated with home ownership'. ${ }^{112}$ In the midst of the insecurity created by decline and privatisation, the sale of mine houses provided income via rental or a physical base for a small business. As Mususa explains, this measure radically transformed 'mine' townships: from an area where virtually all heads of household worked in the mines, by 2008 only half of the fifty-six households she surveyed had a resident employed in the formal sector. ${ }^{113}$ By such means, many former mineworkers secured a permanent if fragile hold on urban residence that they never had as ZCCM employees, who lost their housing on retirement.

Comparison of the Kaunda era with the Chiluba presidency (1991-2001) provides, for many Zambians, a prism for interpreting the shift from state/company corporatism to democratic individualism, with the acquisition of houses its most prominent symbolic reference. For Simon Kampamba,

Kaunda was a dictator. We did not have a lot of things such as groceries and other stuffs. That is why God chose Chiluba who brought [the] open market and things started coming from other countries. It was during Chiluba's era when I bought this house. The government realised that the houses were too old and needed to be sold to sitting tenants so that they can also own some property. ${ }^{114}$

Victoria Mwelwa credits Chiluba for the sale of houses and for liberalisation in general: 'During [the] Kaunda era, the government focussed on constructing roads and schools. During Chiluba, we were sold houses. Chiluba focussed on urban places [rather] than rural areas.... Through privatisation, Chiluba improved the socio-economic lives of people'. ${ }^{115}$ Philip Mwape captures the ambiguous impact of liberalisation on many Copperbelt residents, wherein an era of shortages was followed by the availability of commodities for those with money: 'Chiluba improved the transport system. Second, he paved way for people to buy things even

112 ZCCM-IH, 5.1.2I, Sale of ZCCM Houses, 1998, GM Nkana Division C. G. Belshaw to Director HR, 10 March 1998, 'Recovery of Costs for Township Services'.

113 Mususa, 'Getting By', p. 384.

114 Simon Kampamba interview, 16 July 2018.

115 Victoria Mwelwa interview. Similar sentiments were expressed by interviewee Francis Chanda, 16 July 2018. 
from outside. Third, police brutality was stopped when Chiluba came to power and road-blocks reduced. There was now freedom of movement under Chiluba. But money became difficult to access despite availability of goods'. ${ }^{116}$

Thus, for many interviewees who otherwise decry the loss of the services previously provided by ZCCM, the personal benefits of home ownership and the availability of goods and services are perceived as having improved economic opportunities, if not their actual living standards.

\section{Diverse Memories of the 'Golden Age'}

Privatisation was followed by an unanticipated resurgence in mineral demand from China, which drastically reshaped the industry's fortunes. Between 2002 and 2008 copper prices soared, bringing a wave of new investment, the opening of new mines and increased production at others. This did not, however, bring new formal-sector jobs or social provision: contemporary mining technology requires a smaller number of highly skilled workers and this core workforce is commonly combined with outsourcing to sub-contracting companies with significantly worse pay and conditions. In Zambia today, the mining industry, which produced 711,000 tonnes of copper in 2015, employs 28,933 'direct' workers and 27,896 'contract' workers. ${ }^{117}$ Contemporary mine investors have sought to avoid direct provision of housing and other services and are often accused of favouring foreign contractors over local businesses. Gécamines remains an important if much diminished representative of state interests in the Katangese mining industry, while ZCCM-Investment Holdings, which manages the 15-20 per cent state ownership in Zambia's privatised mines, otherwise presides over the unprofitable legacy of the older industry.

This largely 'jobless' boom has shaped political and social change in the region in ways that can only be summarised here. In Zambia, the failure of new mine investors to provide secure jobs and 'care' for their workers fuelled opposition leader Michael Sata's populist political movement. Sata's Patriotic Front (PF), by articulating

116 Philip Mwape interview, 17 July 2018.

117 https://miningforzambia.com/a-concentrated-mining-sector; http://mines .org.zm/employment-figures (both accessed 22 July 2020). 
a contemporary version of an enduring Copperbelt political discourse demanding the equitable distribution of mine wealth, succeeded in capturing the Zambian presidency in 2011. ${ }^{118}$ Meanwhile, Moïse Katumbi became governor of Katanga province in 2007; he reestablished governmental oversight of the anarchic post-war mining industry and created incentives for and restrictions on mine company operations that increased local tax revenues. While avoiding the exclusionary rhetoric of Kyungu, Katumbi nonetheless invoked the Katangese secession by, for example, erecting a prominent statue of Tshombe in central Lubumbashi. While Katangese politicians, like their Zambian counterparts, articulate a collective sense of injustice that wealth produced by their region continues to be enjoyed elsewhere - whether by off-shore mine companies or ruling politicians in distant capitals - such invocations may (in a context where ethnic associations remain central to political mobilisation) reawaken the autochthonous definition of Katangese identity associated with previous waves of anti-Kasaian violence. ${ }^{119}$ On the Zambian Copperbelt, despite the willingness of the current PF government to deploy overtly ethnic politics, the popular consensus of interviewees remains that the region has never suffered ethnic violence because of its cosmopolitan nature. ${ }^{120}$ These different trajectories reflect the two regions' distinct histories, but equally show how those histories have shaped and been shaped by popular understandings of Copperbelt society that bear only

118 Miles Larmer and Alastair Fraser, 'Of Cabbages and King Cobra: Populist Politics and Zambia's 2006 Election', African Affairs, 106, 425 (2007), pp. 611-37; Sishuwa Sishuwa, “Join Me to Get Rid of This President”: The Opposition, Civil Society and Zambia's 2011 Election', in Tinenenji Banda, O'Brien Kaaba, Marja Hinfelaar and Muna Ndulo (eds.), Democracy and Electoral Politics in Zambia (Leiden: Brill, 2020), pp. 11-33; Guy Scott, Adventures in Zambian Politics: A Story in Black and White (Boulder, CO: Lynne Rienner Publishers, 2019).

119 Sandrine Vinckel, 'Violence and Everyday Interactions', pp. 78-102;

Donatien Dibwe dia Mwembu, 'La Réharmonisation des Rapports entre les Katangais et les Kasaïens dans la Province du Katanga (1991-2005)', Anthropologie et Sociétés, 30, 1 (2006), pp. 117-34; Erik Gobbers, 'Ethnic Associations in Katanga Province, the Democratic Republic of Congo: Multi-Tier System, Shifting Identities and the Relativity of Autochthony', Journal of Modern African Studies, 54, 2 (2016), pp. 211-36.

120 Lee M. Habasonda, 'Corruption, Ethnicity and Violence as a Triple Political Strategy: The Changing Face of Politics in Zambia', Institut Français des Relations Internationals (Ifri), September 2018: www.ifri.org/sites/default/file s/atoms/files/habasonda_zambia_2018.pdf (accessed 21 July 2020). 
a tangential relationship to historical reality but which are central to residents' sense of identity. ${ }^{121}$

This is the context in which memories of the Copperbelt's history of growth and decline were articulated by our interviewees between 2017 and 2019. Unsurprisingly, many respondents counterpose today's parlous economic opportunities to a prosperous past when mine companies 'provided employment for a lot of people including young people'. ${ }^{122}$ François Batabata Nsenga emphasises the pervasive impact of historical company activities:

At the time, with Gécamines, when its workers were paid there was an impact on everyone. ... With today's mining companies, you don't really feel the impact.... Gécamines had good hospitals serving the whole population, good schools and good teachers. The current mining company has no schools, hospitals and workers are not paid well. ${ }^{123}$

Trader Emery Bweupe recalls that the people who bought her goods were 'families of the mineworkers. A lot of people were in employment and there was a lot of money way back'. ${ }^{124}$ Andre Kasengo characterises the circulation of wages and benefits as a form of social solidarity:

If you had brothers who are Gécamines workers, they will share their rations with you! Since Gécamines employed a lot of people $(35,000$ workers), in the event of a crisis, it was all of Likasi that was also hit; but the day that Gécamines paid its workers, everyone benefitted; money flowed everywhere. ${ }^{125}$

For Thompson Sichula, privatisation 'has affected my business in many ways. Under ZCCM I used to have contracts with the mines, not now when the process is dominated by foreigners. There is also corruption. Way back we used to apply and the process was transparent, not now, you need strong connections'. ${ }^{126}$

Many interviewees emphasise, like Victoria Mwelwa, the decline of once clean and well-ordered townships: 'Yes, way back it used to be

121 A brilliant recent analysis asserts that the Zambian Copperbelt's collective discourse of cosmopolitanism and anti-tribalism is itself rooted in a distinctly Bemba sense of identity and values: Robby Kapesa and Tom McNamara, "We Are Not Just a Union, We Are a Family": Class, Kinship and Tribe in Zambia's Mining Unions', Dialectical Anthropology, 44 (2020), pp. 153-72.

122 Emery Bweupe interview. 123 François Batabata Nsenga interview.

124 Emery Bweupe interview. 125 André Kabinda Kasengo interview.

126 Thompson Sichula interview, 20 July 2018. 
very clean but now it has become dirty. Way back they used to even inspect our houses, spray the area. Now they do not take care of the homes and this has increased diseases' ${ }^{127}$ Others, however, criticise the historical provision of such services:

There was a dependency syndrome on the mines. ... You couldn't buy something as simple as a bulb, you had to call maintenance. Because of that kind of life people were so relaxed they wouldn't do anything but a fraction of things. ... Such simple skills like fixing a light bulb was hard because of such dependency. A lot of our young people still can't develop simple skills to help them think of ways to earn a living. ${ }^{128}$

Pami wa Kasongo, while acknowledging the personal advancement he experienced as a result of mine employment, equally emphasises its constraining nature: 'What I have become is thanks to Gécamines. The small investment I made from my salary allowed me to build this house ... [working for Gécamines] ... opened my mind and I learned a lot that ... allowed me to escape this mentality of Gécamines workers'. ${ }^{129}$ For William Chinda, liberalisation has removed inequality between mineworkers and other residents:

Such [a] type of living made people lazy. Wives to miners just stayed home. Except those in Chibolya, they would work. This time the market is even filled because everybody is a general worker. We had two classes. The miners and then us who weren't part of the mine. Now we are all the same. ${ }^{130}$

Other interviewees analyse lost company services such as youth and women's centres by comparing contemporary disorder with a somewhat romanticised past. Evans Nsabashi, for example, complains about crime and insecurity: 'Long ago we had this extended family which was very helpful and I benefited from it. But now it has been eroded by [a] new culture. That is why in Kaunda's time we did not have street kids but now we have more because of the demise of an extended family'. ${ }^{131}$ Bobby Jackson Kabamba argues:

Today, problems are very bad.... Children of today, because of films and Western culture are very bad; they are not like we used to be when I was a child. Not so many people today have got money, only a few and the few who have got that money are not as helpful as it used to be in the

127 Victoria Mwelwa interview.

129 Pami wa Kasongo interview.

128 Gertrude Dhaka interview.

130 William Chinda interview.

131 Evans Nsabashi interview. 
past ... Thereafter, these girls for example are turning to prostitution to make more money and the boys are using odd crooked means of making money. ${ }^{132}$

Many agree that gender roles have changed, a belief that is commonly predicated on an inaccurate belief that women did not work in the past. Whether this change is for good or ill is, however, a matter of disagreement:

At the time, we felt like men, a father, because there was ease, there were fewer problems at home. It wasn't until the 1990s that everything started to deteriorate. We had food provided by the employer ... But today, this is no longer the case, you have to suffer to find food.... children in primary school studied for free, all my children went through there. Today, you have to pay ... the father has difficulty meeting all the needs of his household, and I think that he cannot ... call himself a father or a man. ${ }^{133}$

For Justine Karumb however, the economic disaster that has befallen many Gécamines workers has unexpectedly positive effects:

When a person worked at Gécamines, he had a good salary. Some may not have been able to manage their wages to cope well with the crisis. Since at Gécamines there was schooling for the children of workers, health insurance, supplies, in addition to a good salary. And you could see how the workers used to drink ... But since the crisis, they have mastered themselves to manage well. It was certainly the crisis that had changed their behaviour. ${ }^{134}$

\section{Conclusion}

There is, then, no agreement about the meaning or significance of the ending of the corporatist 'golden age' of Copperbelt mining communities, apart from the fact that it has ended. Beyond a consensus that the region has experienced a devastating economic decline and profound social dislocation, respondents disagree about its specific timing, causation and impact on themselves and their communities. Their analysis is, unsurprisingly, affected by their own positionality, personal experience during and since the period of decline and their memory of that history, shaped by their communities and the ways in which this experience has been explained and mobilised by local elites. Residents

132 Bobby Jackson Kabamba interview. 133 Emile Ngoy Muyondwe interview. 134 Interview, Justine Karumb, Likasi, 23 June 2018. 
sometimes highlight common themes in the history of decline both across the Copperbelt as a whole and within its two constituent parts. The enduring exploitation of the region's resources and labour by outside forces is a primary trope in such explanations; those forces may be national political elites or foreign-owned mining companies, but the IFIs that played a major role in dictating macro-economic and company policies over twenty-five years are not today identified as a primary actor in this decline. These narratives are historically significant, not only because they help us understand the period of decline itself, but also because this lengthy period of stagnation, crisis and modest recovery is now as central to the Copperbelt's historical experience as its better-known era of growth and prosperity. Adding it to the historical record then requires a similar attention both to the actual experience of historical decline and to how knowledge about it has been produced, by international and national elites, academics and members of the communities themselves, as this chapter has sought to do.

While interviewees can point out where in Mufulira or Likasi company-run leisure centres used to stand, or identify the health clinics that have now been turned into private bars or evangelical churches, younger Copperbelt residents have grown up in the absence of any such provision. In general, the shadow cast by the industry's past is of little relevance or interest to the region's young adults, for whom mine employment is little more than one potential pathway out of poverty, of no more significance than a career in accountancy or hairdressing. In one important respect, however, the Copperbelt's extractive history remains ever present in the experiences and perceptions of its current (and likely future) communities, as the final chapter will explain. 


\section{Remaking the Land: Environmental Change in the Copperbelt's History, Present and Future}

\section{Introduction}

For seventy years, the Copperbelt's surface land and subterranean mineral wealth were regarded as 'natural' resources, freely available for use by humankind in general and commercial exploitation by companies in particular. Nation-states, mine communities and international donors attributed different kinds of value to these resources, but - in retrospect - extraordinarily little thought was given to the ways in which minerals and mining shaped human experience and society. Partly because the region was essentialised as urban, a place where mine-created wealth was the sole basis of development and employment, mining's impact on land and especially on agricultural activities on which tens of thousands of Copperbelt residents depended - was almost entirely absent from policy or intellectual consideration.

The impact of mineral extraction on the environment has, in the twenty-first century, become the central theme in analysis of (former) mining sites. Western countries' attempts to address the legacy of mining's despoliation of air, water and land has focussed on identifying human responsibility for historical pollution. ${ }^{1}$ Academic analysis has, with the anthropocenic turn, come to appreciate that, while human agency was once considered able to subordinate the natural world to its will, non-human agents and forces should now be understood to have historical agency. ${ }^{2}$ While this can appear an abstract conceptualisation,

1 See, in particular, Timothy J. LeCain, Mass Destruction: The Men and Giant Mines That Wired America and Scarred the Planet (New Brunswick, NJ: Rutgers University Press, 2009).

2 John Robert McNeill and Peter Engelke, The Great Acceleration: An Environmental History of the Anthropocene Since 1945 (Cambridge, UK: Belknap, 2014); Christophe Bonneuil and Jean-Baptiste Fressoz, The Shock of the Anthropocene: The Earth, History and Us (Brooklyn, NY: Verso, 2016). 
one only needs to consider the unforeseen consequences of mineral extraction and the ways in which smelting, fracking and the use of mercury disrupt and pollute the living world in ways that humans barely understand and certainly do not control. Applying anthropocenic approaches to mining history enables a deeper consideration of its multiple timeframes, including the relevance of geological time to the comparatively brief period of extractive mining operations, as well as its long-term legacies. While mining booms and busts have conventionally been periodised in terms of economic cycles, environmental studies of mining necessarily extend forward into an uncertain future during which their impact will continue to be felt. An obvious example is the tendency for disused mines to flood with rain or river water that mixes with chemicals used in the production process and that, in the absence of expensive pumping operations, spills into communities resident on land above and adjacent to former mine sites. ${ }^{3}$

While environmental concerns are increasingly integrated into histories of mine sites and communities in the Western world, this is less true for the global South and Africa in particular. ${ }^{4}$ Corey Ross's important environmental history of the British empire, building on the pioneering work of Alfred Crosby, demonstrates the centrality of ecological exploitation to imperial economies and the way it was justified by modernising discourses that celebrated the 'civilisation' of the wilderness and 'development' of the non-Western world. ${ }^{5}$ Ross's work contains an exemplary analysis of the colonial-era Central African Copperbelt's linked ecological and social change, which helpfully complements this chapter's focus on the late and post-colonial period. ${ }^{6}$

The rising tide of (initially Western) environmental activism meant that by the 1970s and 1980s, mining and industrial activities were

3 Sara E. Pratt, 'All That Glitters ... Acid Mine Drainage: The Toxic Legacy of Gold Mining in South Africa', Earth Magazine, October 2011: www .earthmagazine.org/article/all-glitters-acid-mine-drainage-toxic-legacy-goldmining-south-africa (accessed 4 August 2020).

4 One important exception is Gabrielle Hecht, Being Nuclear: Africans and the Global Uranium Trade (Cambridge, MA: MIT Press, 2012).

5 Alfred Crosby, Ecological Imperialism: The Biological Expansion of Europe, 900-1900 (Cambridge: Cambridge University Press, 2004 [1986]); Corey Ross, Ecology and Power in the Age of Empire: Europe and the Transformation of the Tropical World (Oxford: Oxford University Press, 2017).

6 Corey Ross, 'Peripheral Centres: Copper Mining and Colonized Environments in Central Africa' in Ecology and Power, chapter 6. 
increasingly regulated in Western Europe and north America, but still operated in less regulated ways in non-Western countries, an early stage of what is now understood as the offshoring of pollution to the global South. ${ }^{7}$ Analogous to this, Western approaches to environmental management and concerns, and the production of knowledge about them, were, as Ann Hironaka shows, transplanted from the West via international organisations to 'less developed countries'. Environmental protection was, then, the latest iteration of the elite bodies of knowledge that, this book has shown, have provided frameworks for understanding Copperbelt societies. The new international attention on mining's environmental effects in the early 1990s provided Copperbelt communities with a novel discursive framework within which to express their concerns. This prompted the establishment of new environmental bodies, some funded by international organisations, that sought to hold mining companies to account for polluting activities. The adoption of increasingly stringent environmental standards in Copperbelt mines was partly driven by donor conditionalities, prompting new legislation and the documentation by companies of their impact.

Yet these regulations had an ambiguous relationship with Copperbelt history. Mine companies and the legal regime governing them sought to distinguish between new environmental effects and those that had already occurred: 'legacy' pollution was characterised as belonging to the past - and therefore the legal and financial responsibility of an earlier corporate regime - despite the obvious and overwhelming evidence of its contemporary negative effects in communities also affected by contemporary mine pollution. Residual state corporations and the states themselves were made responsible for 'cleaning up' historical pollution, at a time when they were least financially equipped to do so. Mine privatisation also involved the eviction of tens of thousands of 'squatters' from 'mine land', productive farmers whose agricultural activities continued to be represented as out of place.

7 Xiaoyang Li and Yue Maggie Zhou, 'Offshoring Pollution while Offshoring Production', Strategic Management Journal, 38, 11 (2017), pp. 2310-29.

8 Ann Hironaka, 'The Globalization of Environmental Protection: The Case of Environmental Impact Assessment', International Journal of Comparative Sociology, 43, 1 (2002), pp. 65-78. 
Copperbelt societies have always had their own understanding and conceptualisation of environmental concerns concerning land and water usage and the effects of mine pollution on them; these, however, went largely unrecorded, even unspoken, during the mid-to-late twentieth century boom. Iva Peša's studies for the 'Comparing the Copperbelt' project demonstrate how both the environmental impact of the region's mining industry and the ubiquity of its 'urban agriculture' were silenced during the Copperbelt's 'golden age' and then 'discovered' during its decline in problematic ways that reinforced misunderstandings about both their novelty and how to respond to them effectively. ${ }^{9}$ This chapter builds on Peša's work to explain how Copperbelt agriculture was understood by its practitioners and producers of knowledge. While farming was represented as inappropriate for the quintessentially urban Copperbelt and treated as a necessary 'hardship' during the region's long period of decline, for many Copperbelt residents it has always been central to their livelihoods and identities.

Copperbelt communities' memories of historical pollution and its relationship to current environmental concerns are, therefore, far from straightforward. Just as conventional historical periodisation is challenged by the temporal relationship of past acts of pollution to their present-day and future manifestations, interviewees disagree about the extent and form of environmental problems in the past and, in particular, about how communities understood and responded to them. The fact that mining continues across the Copperbelt further complicates the ability of analysts to distinguish between past and present manifestations of environmental damage, as does the ongoing importance of mining to state revenues and livelihoods.

This chapter, then, focusses on the recent discovery of mine pollution as a central element of the region's history. It explores the paradox that such 'pollution', hidden in plain sight, was nonetheless central to the lived experience of Copperbelt societies, intrinsic to the endeavour of extracting minerals from the earth and commodifying them by industrial and chemical processes that equally necessitated the application of human labour, provided by communities that were poisoned by them. It first steps back briefly into the Copperbelt's recent past to establish

9 Iva Peša, 'Crops and Copper: Agriculture and Urbanism on the Central African Copperbelt, 1950-2000', Journal of Southern African Studies, 46, 3 (2020), pp. 527-45; 'Mining, Waste and Environmental Thought',

Environment and History (2020). 
the way patterns of land use, official and unofficial, shaped industry and society's impact on the environment. It briefly explains how and why widespread pollution existed during the region's post-World War Two boom alongside a relative silence about it. Finally, it identifies how changing attitudes to the environmental effects of mining and changing perceptions of urban agriculture have generated new understandings of the relationship between society, production and the 'natural world'. It explains how recent struggles over the past and present effects of Copperbelt mining have been characterised by elite actors - states, mine companies and international environmental actors - and by communities themselves.

\section{Land Use and Farming in the 'Golden Age'}

As we have seen, colonially connected mine companies acquired exclusive use of vast concessionary territories, deliberately preventing other activities such as settler or indigenous agriculture. Ross demonstrates the deep and sustained environmental impact of copper mining, in which scientific innovation enabled local refinement in facilities such as UMHK's leaching plant in the Shituru area of Jadotville (Likasi) that opened in $1929 .{ }^{10}$ The company's emphasis on open pit production, which enabled the substantial reduction in its workforce discussed in Chapter 1, left vast scars on the Katangese landscape that contrasted with the mainly underground mines south of the border. Ross emphasises the cutting-edge technological prowess that placed the Copperbelt, in the imagination of mine engineers, at the scientific 'frontier', highlighting the supposed chasm between this new industrial modernity and rural societies dependent on subsistence agriculture. ${ }^{11}$

The notoriously poor quality of agricultural land across the central African Copperbelt justified the marginalisation of commercial farming in official policies. African agriculture was consistently characterised as unproductive or backward and, as discussed in Chapter 5, gendered as carried out primarily by women, reinforcing its supposedly 'traditional' nature. In Haut-Katanga, women were encouraged to produce foodstuffs to feed the growing mines, while in Northern Rhodesia indigenous agriculture was generally discouraged as an uncontrollable and unproductive activity that threatened to encroach

Ross, Ecology and Power, p. 171. 11 Ross, Ecology and Power, pp. 172-5. 
on mine-owned land. While late colonial officials and research institutions in Haut-Katanga promoted indigenous agriculture as an alternative to scarce mine employment (Chapter 2), mine areas themselves remained exclusive industrial domains in which farming in household gardens was explicitly banned, partly because it was viewed as a malaria risk. The continuing provision of company rations was predicated on the assumption that mineworker households could not feed themselves: the stereotypical UMHK housewife sewed and cleaned, but never farmed. So, while Katangese authorities provided opportunities for African farmers to supply the urban market, their idealised and highly regulated notion of urban life ensured that independent African farmers had no legitimate place in town.

While RST did provide houses with garden plots to some of its workers, particularly in Luanshya, they were never seen as anything other than a minor contribution to household subsistence, which was Northern Rhodesian mine companies believed - ensured by rations and then wholly cash wages. Colonial reports were consistently dismissive of the contribution of indigenous agriculture to the economy and community welfare, for example in a 1960 report on Kitwe: 'There is no real African agriculture in the district although as always every available and suitable piece of vacant ground is hoed and planted with mealies, ground nuts, etc. ${ }^{12}$ A 1959 report on Luanshya demonstrates the extent to which African farming was 'out of place' in town and needed to be controlled:

There never can be much to fill a chapter about agriculture in an urban district. All attempts at agriculture are for one reason or another on a small scale.... cultivation must not be allowed in future to reach the point where drastic action has to be taken to prevent erosion and excessive tree-cutting. It is not easy to survey cultivation nor for that reason to discover just how much land is under the hoe. ${ }^{13}$

Plans were in hand to conduct aerial surveys of the problem, but neither companies nor colonial officials had the capacity to effectively control small-scale African farming. As this report indicates however, officials frequently criticised its damaging environmental effects. This tendency

12 NAZ, WP 1/2/64, Special Commissioner for Western Province Reports on Copperbelt, 1959-60, Annual Report, African Affairs, Kitwe.

13 NAZ, WP 1/2/43, African Affairs Annual Report, Luanshya, 1957-60, 'Luanshya African Affairs Annual Report', 1959, n.p. 
to assume that autonomous African activities such as farming and charcoal burning were environmentally damaging is consistent with Moore and Vaughan's critique of colonial and anthropological understanding of rural 'citemene' agriculture and, as Peša argues, revealingly inconsistent with their tolerance of mine pollution. ${ }^{14}$

There was a significant degree of continuity of such attitudes into the early independence era. Post-colonial state officials shared the negative attitude of mine companies to 'urban agriculture', emphasising a clear division between the urban industrial Copperbelt and 'rural' areas where agriculture was practised. Farming was, for President Kaunda, emblematic of a productive African society, ideationally bound up with his notion of a communal societal order. Amid persistent concerns about unchecked rural-urban migration (Chapter 3), authorities sought to control specific instances of agricultural activity on mine land. In 1965, for example, seventy 'individual subsistence farmers' applied for government assistance to establish a vegetable growing co-operative on AngloAmerican land. A government request to AAC's Bancroft Mines company for permission for this initiative made it clear that any such development would 'take place on the understanding that at no time will they prejudice mining operations, and that Bancroft Mines Limited will have the right to give these societies, say, six months' notice to leave the area altogether without compensation for any damage to crops that may occur'. ${ }^{15}$ Despite these reassurances, the company refused permission because 'there may be some difficulty in clearing the settlers from the area when prospecting is due to commence'. ${ }^{16}$

That year, new guidelines were introduced by RST for land usage, encompassing its allocation for employees' gardens, the risks posed by 'unauthorised cultivation and charcoal burning' and the legal powers at the company's disposal to deal with 'squatters'. ${ }^{17}$ Its officials were

14 Henrietta Moore and Megan Vaughan, Cutting Down Trees: Gender, Nutrition, and Agricultural Change in the Northern Province of Zambia, 1890-1990 (Oxford: James Currey, 1994); Peša, 'Mining, Waste and Environmental Thought', pp. 14-15.

15 ZCCM-IH, 17.3.3A, Land Use, Squatters and Co-operatives 1956-67, Asst District Secretary Bancroft to GM Bancroft Mines Limited, 11 June 1965.

16 ZCCM-IH, 17.3.3A, Land Use, Squatters and Co-operatives 1956-67, Chief Geologist (Zambia) Anglo-American to W. M. Younger, Mining Titles Department, 10 August 1965.

17 ZCCM 12.1.7A, 'Regional Development, Land Policy and Land Usage', 1963-5, Lands Memorandums Nos. 1 and 3. 
encouraged to avoid taking direct action against those cultivating or otherwise illegally occupying company land, but equally instructed on the specific offences of, for example, theft committed by charcoal burners or 'intentional damage' caused by digging up land or cutting down trees. ${ }^{18}$

Mine companies thus retained vast territories for potential future exploitation, much of which was never utilised, and sought to keep Africans off mine land. They and government officials continued to stereotype Copperbelt agriculture, despite the sale of produce by women in urban marketplaces, as unproductive 'subsistence' farming. It is nonetheless clear that farming was a dominant economic activity carried out by tens of thousands of Copperbelt residents, including mineworkers' wives, but also those living outside mine areas in the wider Copperbelt towns. Many interviewees recall their experiences of acquiring access to farm land to which they had no legal claim, for example Nathan Mwamba: 'Following the laws and rules, farming in those areas was illegal and they were so strict such that if they found you, they would even grab your tools. It's just that the people were forcing themselves to do the farming. It still is unaccepted to farm on that land'. ${ }^{19}$

Such activities, particularly in Haut-Katanga, remain largely undocumented, but our interviewees provide glimpses into the ubiquity of urban farming for the period from the 1970s onwards (see below).

\section{Pollution and Environmental Impact - Hiding in Plain Sight}

The assertion of sovereignty over company territory equally applied to the 'problem' of pollution: while the dangers of poisonous emissions in underground mining in particular were well established by the early twentieth century, less attention was paid to the spread of pollutants to residential areas that housed mineworkers and their families, often built adjacent to the mines. The influence of mine unions and the ILO led to the adoption of workplace health and safety rules and awareness campaigns, concerned with industrial accidents and addressing the dangers of gas and other pollutants. ${ }^{20}$ However, corporate responsibility for the effects

18 ZCCM 12.1.7A, 'Regional Development, Land Policy and Land Usage', 1963-5, Lands Memorandums No. 4.

19 Nathan Mwamba interview.

20 For the ILO in Africa see Daniel Roger Maul, Luca Puddu and Hakeem Ibikunle Tijani, 'The International Labour Organization', in Stefano Bellucci 
of pollutants generally evaporated once they flowed out of production sites, even as they passed into the communities where the same workers lived. Many of the worst risks arose from the processing of ore to add value, for example the use of local smelters. Although the Zambian mineworkers' union regularly raised 'community' concerns (such as health and education provision) in their negotiations with mine companies, there is a striking absence regarding any similar concern about pollution in the minutes of their meetings. ${ }^{21}$ The same applies to the tripartite forums overseeing Gécamines' cités management in the 1980s.

The fact that air pollution was known about is, however, evidenced by the geographical positioning of European and/or skilled worker quarters relative to those of unskilled workers. In Mufulira, for example, Kankoyo sits directly adjacent to the plant and has long been affected by air pollution, as well as the damage caused to its houses by underground mining (see below). European and more senior African workers were housed further from the plant in areas that were not downwind of these fumes. ${ }^{22}$

Peša has painstakingly recovered evidence of how companies managed pollution and avoided responsibility for its effects on water and air, in a context where newly independent states prioritised mine production over environmental considerations. Company engineers and managers were always confident that technical solutions would be found in the future to address environmental problems being created today, particularly the steady build-up of waste deposits across the region's landscape. ${ }^{23}$ Many reports and publications explained that the inevitable 'global' problem of mine-related pollution, including effluent discharge and erosion of old tailing dams, was being addressed by the gathering of data by mine companies using the latest scientific methods, so as to avoid the damage already suffered by fully industrialised countries. ${ }^{24}$ The

and Andreas Eckert, General Labour History of Africa (Oxford: James Currey, 2019), pp. 223-64.

21 Larmer, Mineworkers in Zambia, pp. 150-1.

22 ZCCM-IH, METS, ZCCM Copperbelt Environmental Project, Volume 2.5, Mufulira EIA, p. 4, cited in Jennifer Chibamba Chansa, 'Houses Built on Copper: The Environmental Impact of Current Mining Activities on "Old" and "New" Zambian Copperbelt Communities', in Larmer et al., Across the Copperbelt, pp. 233-63.

23 Peša, 'Mining, Waste and Environmental Thought', p. 13.

24 ZCCM-IH, 5.14.5B, 'Konkola Division Water Quality Evaluation'; H. Matschke, 'River Pollution by Mine Effluence in the Kitwe Region', Zambia Geographical Association Handbook (Lusaka: ZGA, 1974), pp. 125-8. 
Industry Pollution Adviser for NCCM, H. Matschke, while raising concerns about occasional breaches of discharge limits, generally conveyed a sense of a system carefully designed to mitigate dangerous pollution. $^{25}$

In 1972, NCCM Nkana's Superintendent of Metallurgical Control, G. Armstrong-Smith, attended the landmark UN Conference on the Human Environment in Stockholm. He subsequently reflected that 'metallurgical processes on this scale mean ... [t] hese operations are inevitably actual or potential sources of pollution'. His solution to such problems was typically technical, involving, for example, the more efficient collection of sulphur gases and their conversion into sulphuric acid, for which there was a local market. Taller smoke stacks, including the $100 \mathrm{~m}$ chimney then under construction in Kitwe, would dissipate the remaining gas into the atmosphere, thus avoiding ground pollution. ArmstrongSmith stated with confidence:

the Zambian mining industry will continue to strive to take advantage of any new technological developments to increase the efficiency of its operations and ... this policy is more likely to lead to better control of fumes emission than to worsen it. ${ }^{26}$

Similarly, quality controls for the rivers on which most Copperbelt residents relied for drinking water involved 'the most searching monitoring system for water in the country ... [with] ... chosen sampling points stretching from above Konkola Mine to below the confluence of the last Copperbelt effluent downstream of Kitwe'. ${ }^{27}$ The author concluded 'that, at present, fume emissions can intermittently give rise to local pollution, [but] the extent of this cannot be described as an "unacceptable risk"'. Such risks had to be set against mining's centrality to national development:

Whatever earnings it spends on projects that directly or indirectly do not contribute to the making of saleable metal are, in effect, so much lost for financing the country's needs. ... the industry has a duty to restrict its

25 ZCCM-IH, 5.14.5B, Pollution general correspondence up to 1984.

26 ZCCM-IH, 5.14.5B, 'Konkola Division Water Quality Evaluation', G. Armstrong Smith, 'Pollution and the Mining Industry', 12 July 1972.

27 ZCCM-IH, 5.14.5B, 'Konkola Division Water Quality Evaluation', G. Armstrong Smith, 'Pollution and the Mining Industry', 12 July 1972, p. 5. 
expenditure on the non-productive, usually costly, means of controlling pollutants so that the nation is not needlessly deprived of essential revenue. ${ }^{28}$

When asked about their experiences of pollution during the 'golden age', interviewees mainly recall the sulphur gases (known as 'senta' or ' $k a c h o m a$ ') released into the atmosphere by smelters. As well as poisoning the air, sulphur dioxide emissions damaged vegetation and buildings. Fridah Mwale recalls:

When the emission was too high, it used to cause windows to have cracks and the roofs used to have holes.... Sometimes the [tap] water got mixed with the acid which they brought and sometimes we were informed not to draw water because it was mixed with acid. ${ }^{29}$

Likewise, Stephanie Mumba remembers: 'We have experienced moments of air pollution caused by kachoma from Gécamines ... People were coughing, the vegetation was affected; nothing was growing because of this smoke'. ${ }^{30}$ In Likasi, such pollution particularly affected the Shituru area, with its leaching plant and smelter. ${ }^{31}$ Emile Ngoy Muyondwe explains:

If you look at the environment near the factories, it is rare to see a tree above two metres. When we burned sulphur in these factories there was a suffocating smoke that we called kachoma, it means dirty. It stung and it was the whole camp - SNCZ, Shituru, UCS - that was affected ... The chimney was lengthened so that the smoke went further but there were also people there [living in the location where the smoke now reached]. ${ }^{32}$

Asked to periodise this phenomenon, interviewees give diverse responses that in some respects reflect the official silence of mine pollution in the region's boom period. Washeni Mweni argues, for example, that although sulphur pollution has long been present, nobody spoke about it in the past. ${ }^{33}$ Samson Chama claims: 'Senta has been there. It is not a big challenge because even when I came in 1959 I found senta. It was more than it is now. It hasn't been a very dangerous thing as some people would say'. ${ }^{34}$ Chama believes that more recent claims regarding its damaging effects have been driven by

ZCCM-IH, 5.14.5B, 'Konkola Division Water Quality Evaluation',

G. Armstrong Smith, 'Pollution and the Mining Industry', 12 July 1972, p. 6.

29 Fridah Mwale interview. 30 Stéphanie Mumba interview.

31 Séraphin Musoka interview. 32 Emile Ngoy Muyondwe interview.

33 Washeni Mweni interview. 34 Samson Chama interview. 
outside intervention (see below). Other interviewees associate the start of pollution with the departure of Europeans from the mining industry: 'Back when we were with white people, we couldn't even smell the gas; not even the smoke. At the slightest detection of smoke, all the engineers were mobilized to remedy this anomaly. ... The pollution started with the departure of the whites'. ${ }^{35}$

Levy Chushi, like other interviewees, characterises senta as an unavoidable problem in mine areas: 'People have been complaining but nothing much gets to be done, you know mining is a major economic activity in Zambia. ${ }^{36}$ Mwanza Lukinda remembers 'timid' complaints being made to Gécamines by its workers. ${ }^{37}$ Cyprien Ramazani explains the problem thus:

Gécamines worked 24 hours a day and there was smoke. It started from the chimney around $8 \mathrm{pm}$ to $9 \mathrm{pm}$, the windows and doors had to be closed. And the smoke reached everyone ... [a]ccording to the wind direction.... pollution worried everyone. ... the answer [from the authorities] was that, the country must work, people must live, the state must have money. People were forced to go to the hospital from time to time for medical check-ups. It was easy for company workers but hard for the unemployed when it came to covering medical costs.... The workers talked about it, the doctors talked about it, the population in the city talked about it, everyone talked about it. There were even delegations that were sent to Kinshasa ... but without success. ${ }^{38}$

Nathan Mwamba similarly recalls for Zambia:

We used to complain about it saying that the senta was too much. We just used to be told that they have heard and would see what they can do but it always just used to end there. It also used to affect our crops and destroy them a bit but we still used to go ahead and eat them. ${ }^{39}$

Evans Nsabashi argues that Copperbelt residents tacitly accepted pollution as the price they paid for mine company employment. ${ }^{40} \mathrm{William}$

35 Dieudonné Kalenga interview. Similar sentiments were expressed by interviewees Ilunga wa Kumwanza (8 June 2018) and Nathan Mwamba. Periodising this 'departure' is, however, difficult, as it may be variously associated with the Africanisation policies of the late 1960s and early 1970s or the economic decline of the late 1970s and 1980s.

36 Levy Chushi interview. 37 Mwanza Lukinde interview.

38 Cyprien Ramazani interview.

39 Nathan Mwamba interview. Similar accounts of complaints about unheeded crop damage are made by interviewees Emery Bweupe and Ana Chilufya.

40 Evans Nsabashi interview. 
Chinda puts it succinctly: 'Because we were enjoying we were not complaining. ${ }^{41}$ Former Mufulira councillor Chrispin Chani dates the worst period of senta pollution to the 1990s, during which he was involved in legal action about its effects:

It was really worse around Kankoyo area. And nothing can grow in that area.... At some point it even went as far as our farms and destroyed all our crops. This was in the 1990s. We even took the mines to the courts and we were compensated. Farmers would complain to us as councillors. We took the case to the council. The council took the case to the mines who reported it to the [Environmental Council of Zambia] ECZ ... Then the cases would end up with compensation. ${ }^{42}$

While it is impossible to know if Chani's account reflects actual pollution levels, it is consistent with the increasing authority of official bodies to challenge environmental damage in the 1990s, as is discussed below.

\section{Urban Agriculture During 'Decline': Commercial Enterprise and Coping Mechanisms}

Although urban agriculture had been an important economic activity on the Copperbelt from the mid-twentieth century, the region had never been self-sufficient in food. Maize in particular was supplied by largely settler farms in southern Zambia and northern Katanga. Katangese towns were subsequently supplied by imports from as far as South Africa and, both legally and by smuggling, from Zambia. However, in the 1970s and 1980s, the gradual recognition that farming was a useful supplement to the declining value of mine wages led to a greater willingness to encourage agricultural production within and near Copperbelt towns. Copperbelt farming took diverse forms: some mineworkers' families produced small quantities of maize, vegetables and chickens in their 'gardens', while many women (and some men) acquired access to plots of land in nearby areas that could be reached by foot or bicycle. Those who moved to peri-urban informal settlements such as Kansuswa (see Chapter 3) saw farming as central to their livelihood strategy. They entered into a variety of relationships with

41 William Chinda interview.

42 Chrispin Chani interview, 16 July 2018. See below for the establishment of these organisations. 
chiefs or authorities in areas demarcated as 'rural' or participated in the growing number of projects that, like INÉAC in the 1950s (Chapter 2), promoted peri-urban commercial agriculture. Many European farmers, meanwhile, departed as a result of indigenisation policies and general economic decline, adversely affecting maize production but also opening up opportunities for local entrepreneurs. ${ }^{43}$ Gécamines and ZCCM, as part of their wider developmental obligations to their respective states, supported a range of agricultural projects, aimed at retired workers and the children of employees, as well as establishing commercial food production programmes of their own. In HautKatanga, the Gécamines subsidiary, the Centre d'exécution des programmes sociaux et économiques (CEPSE) - a successor to CEPSI that oversaw social service provision in mine cités - became responsible for company agricultural production. Starting in 1975, it produced $2,200 \mathrm{MT}$ of maize, rising to $9,200 \mathrm{MT}$ in 1977 . The aim was to make Shaba/Katanga, which imported $168,000 \mathrm{MT}$ of maize in 1978, selfsufficient in food by the mid-1980s. ${ }^{44}$ In 1983 CEPSE was abolished and its agricultural programme transferred to a new Société AgroIndustrielle (AGRIS), a state-driven initiative to bolster local food production at a time when foreign exchange was increasingly scarce. $^{45}$ The AGRIS initiative produced 20,798MT of maize in 1983-4, but also purchased 20,929MT from local farmers, evidence of the latter's ability to respond to local markets. ${ }^{46}$

Bruneau's useful study of Katangese farming activities identified a general expansion of agricultural activity on the outskirts of mine towns in the mid-1980s. He was, however, dismissive, like many earlier analysts, of the productive capacity of many new small farms owned by local businessmen, which he compared unfavourably to the 'handful of real farms and dairies managed by expatriates'. ${ }^{47}$ But the economic crisis of this period seems to have generated an extraordinarily rapid increase in small-scale food production:

43 Jean-Claude Bruneau, D'Ici et D'Ailleurs: Quand les Immigrés se Font Autochtones: Citadins et Paysans du Haut Katanga (Yaoundé: Presses Universitaires de Yaoundé, 1999), p. 153.

44 Gécamines, Annual Report 1978, p. 28.

45 Gécamines, Annual Report 1983, pp. 36-7.

46 Gécamines, Annual Report 1984, p. 49.

47 Bruneau, D'Ici et D'Ailleurs, p. 155. 
The officially imported tonnage no longer represented even a quarter of the approximately 200,000 tonnes of maize consumed by the copper towns.... a good third of the total [came] from the mining area itself where, unprecedentedly, cereals can be found. Local contributions came in part from the mechanized production of Gécamines, but even more perhaps from the largely spontaneous food 'halo' around the copper towns. According to official statistics, the production of Haut-Katanga maize doubled from 1983 to 1984 . There is also cassava, edible leaves and charcoal, which come entirely from the immediate hinterland. And all this is confirmed by the tens of thousands of cultivated hectares visible on satellite images, the tens of thousands of urban gardens, the proliferation of artisanal mills in Lubumbashi, Likasi and Kolwezi. ${ }^{48}$

Bruneau suggests this explosion of local production was prompted by the devaluation of the Zaire, which quintupled the local price of maize, and the reduction of food imports by Gécamines.

As Peša explains, the expansion of urban farming during this period was officially characterised as either welcome if belated evidence of diversification away from mining dependency or a symptom of the region's economic decline, in which the 'ruralisation of the city' saw urbanites return to the fields of their ancestors. Despite evidence that local farmers were responding to local market conditions and feeding the urban population, 'agriculture' could still not be incorporated into observers' conventional ideas about the city. ${ }^{49}$ While farming was commonly characterised as a (backward) step away from waged labour, it was often practised by more prosperous urban residents, those whose success in business or senior employment meant they had savings to invest in commercial agriculture. Many had been doing so well before the period of decline, to guard against the everyday uncertainties of urban life. Morris Chimfutumba used his savings to buy 150 hectares when NCCM sold some land in the early 1970s. He was assisted by extension workers from Zambia's National Agricultural Marketing Board (Namboard), which also supplied him with fertiliser. ${ }^{50}$ Ennis Zulu's family acquired a plot of land when they first arrived in town in 1970: 'It was important at all times because it's

48

id., pp. 158-9. It is possible that Bruneau's assumption that local agricultural production was hitherto low partly reflected the failure of earlier policymakers to recognise the productive capacity of informal indigenous farming.

49

50 Peša, 'Crops and Copper', pp. 540-2.

50 Morris Chimfutumba interview, 13 July 2018. 
a source of food and income and there were times when we would have shortages at the mine and we used to depend on that [farming],. ${ }^{51}$

Henry Longwane started farming to supplement his 'low' salary. He grew maize on a small plot located near Mufulira mine and joined an agricultural co-operative that helped him obtain fertiliser. ${ }^{52}$ In 1987 , schoolteacher Thérèse Kyola was provided with a hectare of land $12 \mathrm{~km}$ from her Likasi home by the NGO Shalamo, which received a percentage of the crop as payment; she fed her family with the food produced and sold part of it to pay school fees. ${ }^{53}$ George Mwenda turned to farming on mine company land in 1984 to supplement his family's diet: 'We used to wake up very early around 4 am to start cultivating the land up to 6 am or 7 am because if we went beyond that time the mine police would get us and grab our hoes and other tools that we were using. ${ }^{54}$ Others, like Defa Ngoma, recall farming on unused mine land: 'We could just identify barren land, clear it up and cultivate since it was a mine area. ${ }^{55}$ William Chinda turned to Copperbelt farming because retiring to his village of origin no longer seemed attractive:

I thought if you retire you go back to your home ... But as time went by home became where you were. So we started buying farms and plots.... because there in Kasama [in Zambia's Northern Province] I wouldn't have achieved as much and my children wouldn't be educated. But here I have allowed them to go to school. ${ }^{56}$

Patson Katwisi applied to Mufulira district council in 1996 and was granted farm land $16 \mathrm{~km}$ from his house on which he and his family grew maize and tomatoes:

My wife was very instrumental. She was always looking ahead of me.... I used to say no we shall go to the village.... eventually she said we get a farm as it is the only item that you never go wrong with. With a house, there is depreciation. There is no depreciation with a farm and besides when you have a farm, the whole family can come and take over, they can utilise it. ${ }^{57}$

Certainly, small-scale farming provided many with a coping mechanism once mining entered its extended period of decline. In 1986 the

\footnotetext{
51 Ennis Zulu interview. ${ }^{52}$ Henry Longwane interview, 10 July 2018.

53 Thérèse Kyola interview. 54 George Mwenda interview.

55 Interview, Defa Ngoma, Mufulira, 3 July 2018.

56 William Chinda interview. 57 Patson Katwisi interview.
} 
inability of Haut-Katanga to feed its one million urban residents led to a World Bank 'Agricultural Development Project' to provide supplies and extension services to 38,000 smallholders and 50 larger farms. Routing this aid via new local NGOs overwhelmed their management capacity and the project was eventually completely derailed by Zaire's early 1990s political and economic crisis (Chapter 8). ${ }^{58}$ During that crisis, farming enabled some urban residents to survive in the absence of either cash wages or rations. International NGOs such as World Vision assisted Copperbelt communities to feed themselves and, to a limited extent, to produce for the market. ${ }^{59}$ Séraphin Musoka recalls: 'in 1993, we were struck by a major crisis which we were able to overcome thanks to our small field'. There was, he remembers, '[s]uffering, misery. If you didn't grow, you didn't eat. You could only eat that which you cultivate'. ${ }^{60}$ For many this provided a painful but salutary lesson in the unreliability of mining income and the need to work hard to support one's family:

Agriculture had come to support the mining activity. We know that mining is exhaustible. While agriculture is still renewable. People understood that they had to be in agriculture.... For Gécamines workers, it is complicated since they were used to a more or less easy life, they were given almost everything. So working in the field with all that it entailed was painful for them. ${ }^{61}$

Copperbelt farming, while far less constrained by state and company controls, was, however, increasingly affected by pollution - not necessarily because pollution was worse, but because access to increasingly populated land was more difficult, making it hard to find good soil that was not affected by mine emissions.

\section{'Discovering' Pollution in the 1990s}

Various factors combined in the early 1990s to make environmental concerns a key focus of policy and knowledge production. The deteriorating economic situation of mine companies undermined confidence in their technical capacity to solve pollution. It equally led to

58 World Bank online, South Shaba Agricultural Development Project Completion Report, 31 May 1995.

59 Interview, Justine Karumb, Likasi, 23 June 2018.

60 Séraphin Musoka interview.

61 Interview, Gérard Mwaba, Likasi, 18 June 2018. 
the intervention of IFIs in mine management (Chapter 8), which were at this time making loans increasingly conditional on environmental sustainability. The more rigorous environmental standards for mining introduced in Western countries in the 1970s and 1980s were now incorporated into the Environmental Impact Assessments (EIAs) that became central to extractive ventures globally. ${ }^{62}$ As IFIs underwrote loss-making mine operations while they prepared for privatisation, EIAs became compulsory for new mining ventures. New buyers of older mines sought to avoid the potential ongoing costs of legacy pollution and to guard against the 'polluter pays' principle that was, for example, written into US legislation and overseen by that country's powerful Environmental Protection Agency (EPA). ${ }^{63} \mathrm{New}$ state agencies were created and/or strengthened, for example the Environmental Council of Zambia (ECZ), established in 1992. Although lacking capacity, the ECZ was able to identify breaches by ZCCM of water and air pollution standards and fined the company accordingly. ${ }^{64}$ Meanwhile, international environmental NGOs worked alongside new local bodies that sprang up to represent community voices in such assessments. All this prompted a new wave of knowledge production about the region's mining history in order to appreciate its existing environmental impact and its likely legacy for the future.

An early example of this approach can be found in a 1989-91 study of water pollution in Zambia's Kafue river basin by the government's National Council for Scientific Research and Department of Natural Resources. This followed the enactment of the Environmental Protection and Pollution Control Bill in 1990 and took place amid 'growing concern on the observed and potential negative impact of the various development activities on the environment in the Basin'. ${ }^{65}$ The study found that ' $[t]$ here is no coordinated approach to the problems of

62 Hironaka, 'Globalization of Environmental Protection'.

63 For the history of the EPA and documentation of its interventions in former mining sites, see its website, for example: www.epa.gov/superfund/whatsuperfund (accessed 29 July 2020).

64 John Lungu, 'Socio-Economic Change and Natural Resource Exploitation: A Case Study of the Zambian Copper Mining Industry', Development Southern Africa, 25, 5 (2008), pp. 543-60.

65 ZCCM-IH, 5.14.5B, 'Konkola Division Water Quality Evaluation', National Council for Scientific Research, 'Development of Institutional Consortium for the Management of Inter-Related Effects of Pollutants and Other 
environmental degradation due to fragmentation of responsibilities' and that ' $[\mathrm{m}]$ ost industries are not paying adequate attention to the environmental degrading effects of their effluences and other activities'. ${ }^{66}$ The public had not been made aware of these effects and the media was criticised for failing to educate them.

The contrasting political situation of Zambia and the DRC in the 1990s led to divergent timings regarding environmental assessment of mining activity and liberalisation. In Haut-Katanga, economic and political collapse meant that effective environmental assessment was delayed until the early 2000s. In Zambia, the participatory politics of the Third Republic created a comparatively open context for discussion of environmental concerns. Media coverage of pollution on the Copperbelt increased dramatically. The Times of Zambia reported in October 1994:

With the benefits of industry come the problems of waste and we are using the environment as a dumping ground for industrial and human waste, destroying other living creatures and in destroying them, destroying ourselves. ... Industrial effluent - discharged into our rivers, streams and lakes is responsible for illnesses resulting in loss of school-time, loss of worktime, loss of income and therefore increasing poverty.... ZCCM caused that with careless discharges and 'accidents' from its processing plant in Chingola. Poisonous gases ... are discharged into the air daily throughout the world including right here in Zambia. All the major industries are guilty. ${ }^{67}$

It was reported, however, that ZCCM was co-operating closely with the ECZ in improving its environmental management systems. ${ }^{68}$ The company sought to portray itself as environmentally friendly, for example in its newspaper Mining Mirror: 'ZCCM ... seeks to establish and perpetuate a sustainable balance between the generation of wealth and protection of the environment for the present and future generations'. ${ }^{69}$ The introduction of new environmental laws was, however, not matched by substantially increased monitoring capacity in state bodies such as the ECZ and the Ministry of Mines. On the Copperbelt, the once powerful labour movement was profoundly

Environmental Degrading Activities in the Kafue River Basin', 5 November 1991.

66 Ibid., p. 6.67 'Soiling our Nest: Pollution Dilemma', ToZ, 31 October 1994.

68 'ZCCM Acts to Stem Pollution', ToZ, 16 December 1993.

69 Mining Mirror, February 1996, p. 4. 
weakened by the decline of formal sector employment. In its place emerged new local NGOs such as Citizens for a Better Environment (CBE), founded in 1997 by Peter Sinkamba. The international championing of 'civil society' provided international NGOs and IFIs with positive stories about the capacity of charismatic community activists such as Sinkamba to hold multi-national corporations to account for their environmental impact. ${ }^{70}$

\section{Privatising Production, Nationalising Waste}

The sale of mine companies in the late 1990s and early 2000s ostensibly transformed the relationship between mining operations and the vast tracts of land that companies had always controlled but commonly under-utilised. New mine owners focussed on mine production and sought to externalise the social aspects of their operations. Nonetheless, in Zambia prospective owners sought to retain ZCCM's unused mine land that had been occupied over time by 'squatters'. As part of ZCCM's hasty efforts to prepare for privatisation, it forcibly relocated populations living in informal settlements abutting mine operations (see also Chapter 8):

The Company has had illegal settlers on its land for quite some time and this has been compounded by the lack of a political will to address the issue effectively and decisively in the past. ZCCM is being privatised, therefore, on the assumption that the new investors will bring with them enough capital to develop these mines further, the squatters that had been 'allowed' to settle on mine land cannot now continue to do so at the expense of developing the mines. $^{71}$

These communities, totalling c.44,556 people, were characterised as engaged in agricultural activities, such as 'peasant farming' and fishing, that were considered inimical to the latest iteration of privatised

70 See, for example, the portrayal of Sinkamba in Forbes magazine (www .forbes.com/sites/ashoka/2012/10/03/meet-a-playboy-entrepreneur-who-wentfrom-making-millions-to-making-an-impact/\#1068ddc04579) and the characterisation of his activities in his capacity as an Ashoka fellow (www .ashoka.org/en-gb/fellow/peter-sinkamba) (both accessed 17 August 2020). The author has known Sinkamba since 2001. For the history of global civil society see Mary Kaldor, 'The Idea of Global Civil Society', International Affairs, 79, 3 (2003), pp. 583-93.

71 ZCCM-IH, 18.4.7F, 'Report on Illegal Settlements in Mine Areas', 1997, n.p. 
Copperbelt modernity. Company officials worried that they would resist relocation to designated resettlement areas because farming land was not available there. Funds were set aside for the rapid resettlement of the residents of places such as St Anthony's compound, an 'eyesore ... located in the surface rights area ... to entice them to vacate the land as soon as possible'. ${ }^{72}$

Between 1993 and 1997 meanwhile, Environmental Impact Statements (EIS) - a truncated version of an EIA conducted in locations with a significant environmental problem - were produced by Steffen, Robertson and Kirsten (SRK), a South African-based international mine consulting company, for the twelve sections of ZCCM to be sold. As the World Bank itself subsequently reported, these revealed the vast legacy of mine pollution and ensured that new investors made their purchase of Zambia's mines conditional on being freed from responsibility for it:

Given the extent and seriousness of environmental and public health impacts documented in the EISs, the KCM Consortium [and following its lead, other aspirant mineowners] was unwilling to accept any legal responsibility for historical environmental liabilities, most notably downstream impacts on populations and ecosystem functions.... GRZ [the Government of Zambia] and ZCCM-IH remain responsible for future third party liability claims arising from past environmental damage. ${ }^{73}$

The privatisation process thus enabled the mines' new owners to divest the resultant companies not only of their social assets but also their environmental legacy. As part of the confidential Development Agreements signed between the Zambian government and the new owners, a process overseen by the IFIs, ZCCM-Investment Holdings, the state minority shareholder, acquired sole responsibility for the industry's historical liabilities, such as tailings dams and waste heaps. ${ }^{74}$

The World Bank, having helped ensure that new investors could avoid these liabilities, then provided funding for a Copperbelt Environment Project that would help the state manage these

72 Ibid., p. 8.

73 World Bank online archives, 'Project Appraisal Document on a Proposed Credit and Grant to the Republic of Zambia for the Copperbelt Environment Project', 14 February 2003, p. 6.

74 For the Development Agreements, see Alastair Fraser and John Lungu, For Whom the Windfalls? Winners and Losers in the Privatisation of Zambia's Copper Mines (Lusaka: Civil Society Trade Network of Zambia, 2007). 
'environmental externalities'. These included the 'deterioration of ecological functions in the Kafue catchment of the Zambezi River system, pollution of water supply with contaminated mine leakage and runoff, and contamination of soil by lead, [polychlorinated biphenyls] PCBs, radioactive material and other toxic substances'. ${ }^{75}$ Typically for its time, the assessment carried out for this project involved discussions with 'stakeholders and NGOs', both local (CBE was a key partner organisation) and international (e.g. Oxfam). Such participatory planning processes ostensibly presented a new model in which communities were empowered to participate in knowledge production about themselves. This process, however, found that '[a]ffected communities are generally not aware of the impacts of pollution from mines on their health, except for sulfur dioxide which is visible and odorous. This lack of awareness was an impediment to effective participation from communities on project design'. ${ }^{76}$

As Chansa argues, the post-privatisation regulatory regime was weakened by this separation of historical and contemporary pollution. The ECZ struggled to hold Mopani Copper Mines, which now owned Mufulira's mine, to account for water pollution and smelter emissions of sulphur dioxide. ${ }^{77}$ In 2009, as Chansa documents, the 'ECZ reported that sulphur dioxide emissions from the mine were up to 70 times in excess of those stipulated by the WHO' ${ }^{78}$ Although a new acid plant finished in 2014 is said to capture the vast bulk of emissions, periodic releases have occurred since, leading to a number of deaths.

Equivalent analysis of Haut-Katanga's environmental problems waited until military conflict had (mostly) ended in the early 2000s and was equally carried out in the context of mine privatisation. A major World-Bank-funded study conducted following the enactment of the new 2002 Mining Code surveyed thirty-seven Gécamines' mining and processing sites, thirteen of which were found to have a 'severe' environmental problem and only nine of which did not represent

75 World Bank online archives, 'Project Appraisal Document on a Proposed Credit and Grant to the Republic of Zambia for the Copperbelt Environment Project', 14 February 2003, p. 9.

76 World Bank online archives, 'Project Appraisal Document on a Proposed Credit and Grant to the Republic of Zambia for the Copperbelt Environment Project', 14 February 2003, p. 29.

77 Chansa, 'Houses Built on Copper', pp. 236-7. See also Lungu, 'Socio-Economic Change', pp. 552-3.

78 Chansa, 'Houses Built on Copper', p. 236. 
a meaningful problem. ${ }^{79}$ The Canadian analysts noted a policy context that protected new investors from historical liabilities; an emphasis on self-regulation in a context of reduced government budgets; and decentralisation of environmental oversight to local regulators that, however, lacked capacity. Their report identified five major environmental issues: tailing dams incompatible with modern practice, with walls having collapsed allowing runoffs near settlements; liquid effluents that were released untreated; the carrying of waste by wind into inhabited areas, causing lung and eye irritation; the proliferation of small artisanal gold mines using mercury; and the disrepair of obsolete industrial facilities, such as the UCS Shituru plant in Likasi, one of the thirteen severe problems identified: ${ }^{80}$

All the installations are dilapidated. Piles of scrap, waste industrial and debris are common.... The exterior appearance of the acid plant and the emanations from it show that this installation is falling apart. The fumes from the acid plant are such that it makes it difficult for visitors to the complex to breathe. These traces of acid are occasionally noticeable even in the heart of the town of Likasi. ${ }^{81}$

Mine tailings were accumulating in the Likasi, Buluo and Panda rivers; significant residues were found in a $14 \mathrm{~km}$ stretch of river that nearby villagers used for their domestic water supply. It was estimated that making Shituru safe, building a new tailing pond, restoring its waste site and cleaning $30 \mathrm{~km}$ of rivers would cost between US\$9.5 and US $\$ 15.5 \mathrm{~m}$. The estimated cost for cleaning up all thirty-seven sites was US\$290-US\$575m. ${ }^{82}$

\section{Pollution Past and Present: Contemporary Attitudes and Campaigns}

On both sides of the Copperbelt border, documentation of and campaigning on mine pollution - by politicians, donors, international and local NGOs and activists - means that there is now much greater

79 SNC-Lavallin International, 'Étude sur la Restauration des Mines de Cuivre et de Cobalt, République Démocratique du Congo', Preliminary Report, April 2003.

80 SNC-Lavallin International, 'Étude sur la Restauration des Mines de Cuivre et de Cobalt, République Démocratique du Congo', Preliminary Report, April 2003, pp. iii-iv.

81 Ibid., pp. 67-8. ${ }^{82}$ Ibid., pp. iv-v. 
awareness of the environmental effects of both historical and contemporary mining. In Haut-Katanga, human rights organisations such as the Association africaine des droits de l'homme (Asadho) and Le Comité de Suivi pour la Contribution des Communautés et Eglises à la Transformation Humaine (Cosccet) publicise periodic breaches of environmental standards by private companies, for example the discharge of acid effluents by the Société Minière du Katanga (Somika) in 2017: 'As a consequence, all the residential houses located downstream of the site have been invaded by these acidic waters causing the death of poultry, small livestock and causing burns on the skin of those who have touched this water, as well as the pollution of well water'. ${ }^{83}$ In Zambia, the group Green and Justice has worked with international NGOs including Action Aid to campaign for the relocation of communities in Kankoyo severely affected by mine operations. ${ }^{84}$ Meanwhile, the UK law firm Leigh Day brought legal action in the British courts on behalf of 2,500 Zambians for water pollution by Konkola Copper Mines (KCM), resulting in the settling of their claim by KCM's parent company Vedanta Resources in January 2021. This demonstrates both the ability of local campaigners to act globally but also the limited capacity of the Zambian justice system to hold companies to account. ${ }^{85}$

This awareness raising has affected how respondents characterise the periodisation and causation of mine pollution. While some interviewees insist (see above) that pollution in general and senta in particular was always there, those who are most involved in campaigning, such as Margaret Waya, see things differently:

In the 1980 s there was what we call senta.... we had no problem with it and it had no impact on human life. [When] Mopani bought ZCCM, they brought a number of problems, our lives have been impacted negatively. When we complain they say the government should move us from Kankoyo

83 http://cosccet.org/node/76 (accessed 30 July 2020).

84 www.facebook.com/AAZambia/posts/relocation-of-kankoyocommunityactionaid-today-joined-other-civil-society-organi /2796990223649640 (accessed 10 August 2020).

85 'Vedanta Resources Settles Zambia Copper Mine Pollution Claim', Reuters, www.reuters.com/article/us-zambia-mining-vedanta-idUSKBN29O1EL (accessed 23 March 2021); Leigh Day, 'Legal Claim by More Than 2,500 Zambian Villagers in a Case Against Vedanta Resources Limited', www .leighday.co.uk/latest-updates/news/2021-news/legal-claim-by-more-than-2-50 0 -zambian-villagers-in-a-case-against-vedanta-resources-limited (accessed 23 March 2021). 
and find us another area because they pay tax and it isn't their problem. We went to Ndola, Radio Icengelo and ZNBC [Zambia's state-owned broadcaster) to complain. ... The government however does not listen.... The houses here are completely destroyed because of blasting, all because of Mopani.... Here, plants cannot be grown because of the acid, green leaves turn yellow the minute they release this acid. But Mopani says it bought the mine, not the houses. ${ }^{86}$

Damion Kachusa, however, articulates a contrasting historical narrative:

In the 1970s there was complaining but no-one heard. It was colonial rule a long time ago and a black man never really had a voice but now we have human rights and we can air out our complaints. Now it is damaging communities. We have high deaths because of this pollution.... They [the mine companies] now use any method to quickly produce more. It is about the money. We expect more deaths now as a result of fumes due to high production. Trade unions are powerless, they are also employees of that company, and are afraid of being retrenched.... With huge unemployment, if people complain too much they scare the investors. ${ }^{87}$

Kachusa praises the work of groups like Green and Justice on environmental and social issues: 'Pollution, bad state of housing, no decent water, unemployment and environmental matters. So we speak through these organisations. The government has neglected us so through these NGOs our voices can be attended to'.

In Likasi, Gastonie Ngoy Kalala, who grew up in Shituru, recalls that in the past the sulphur dioxide smoke killed all vegetation but that 'they [residents] did not understand that it was pollution. It is now that the information is popularised that they realize it ... it is today that we understood why we cough a lot' ${ }^{89}$ Emile Ngoy Muyondwe believes falling fish numbers and vegetable production has brought about awareness of environmental problems: 'Today we're talking about the environment, we fought for that to be the case. A company must take care of the environment and the people who work there'. ${ }^{90}$ Shituru residents like Séraphin Musoka have a bitter-sweet relationship with the decline of Katanga's mining industry, the jobs it once provided and

86 Interview, Margaret Waya, Mufulira, 6 August 2018.

87 Interview, Damian Kachusa, Mufulira, 6 August 2018.

89 Interview, Gastonie Ngoy Kalala, Likasi, 22 June 2018.

90 Emile Ngoy Muyondwe interview. 
the impact it had on residents' health, following the closure of the plant: 'now that ... UCS no longer works, we breathe a little more pure air', he states. ${ }^{91}$ Ilunga wa Kumwanza, who has lived in the area since the early 1960s, offers a long-term perspective:

When we arrived here in Likasi, there was greenery everywhere here in the UCS District and in the surrounding areas. However, as the plant operated, it was found that this ... vegetation began to gradually disappear. It is only now, since Gécamines is almost completely on the ground, that the trees begin to grow back. ... Fortunately, Gécamines is dead, it no longer produces; and therefore, it no longer pollutes. We are saved. ${ }^{92}$

As this indicates, improved environmental conditions sometimes result from economic decline. The jobs and pollution associated with Copperbelt smelting have moved south as, for the first time in its history, the region's mineral processing has been integrated with much of Haut-Katanga's ore sent to the Zambian Copperbelt for processing. ${ }^{93}$ While Zambia has historically sent agricultural produce north to feed Katanga's mining towns, its ability to do so has been adversely affected by the wider impact of climate change: where once southern Zambia was a regional bread basket, increasingly frequent droughts have caused periodic food shortages and famine conditions in some areas. ${ }^{94}$ The changing climate has also rendered the vast hydroelectric operations on the Kafue and Zambezi rivers incapable of generating sufficient power for either Copperbelt mines or communities. ${ }^{95}$ Despite the efforts of its new owners, the inability of the industry to separate its operations from the physical environment in which it operates is evident to all observers.

Today, the physical remnants of the Copperbelt's historical mining activities mark its subterranean and surface landscape, providing

91 Séraphin Musoka interview. 92 Ilunga wa Kumwanza interview.

93 In 2019, however, the Shituru plant started producing copper cathodes or sheets again: https://miningandbusiness.com/2019/10/01/gecamines-fait-a-nouveaupartie-du-club-ferme-des-miniers-en-rdc-capable-de-produire-du-cuivre-pur-a9996-2 (accessed 10 August 2020).

94 'Climate Change has Brought Parts of Zambia to the Brink of Famine', the BBC: www.bbc.co.uk/news/av/world-africa-50976829/climate-change-has-broughtparts-of-zambia-to-the-brink-of-famine (accessed 13 August 2020).

95 'Zambia's Power Supply Deficit Worsens as Water Levels Sink', Reuters: www .reuters.com/article/us-zambia-electricity/zambias-power-supply-deficitworsens-as-water-levels-sink-idUSKBN1YG1DZ (accessed 6 August 2020). 
potent reminders to its communities of its past even as contemporary companies retreat from their obligations to them. These represent an intertwined legacy of environmental threat and economic promise. As Kristien Geenen powerfully explains, the city of Kolwezi sits directly above of its former underground mine: residents' homes, undermined by underground extraction and adversely affected by the pollutants beneath their feet and in the waste heaps around them, nonetheless provide a precarious access point to that wealth. In 2014, the city's Kasulo area experienced its own boom as residents dug shafts through their floors to access and sell cobalt ore to mainly Chinese traders, feeding the voracious global market. ${ }^{96}$

As Mususa identified, the vicissitudes of global markets and new technologies influence changing patterns of what constitutes mine waste and what is considered a valuable resource. A decade ago she found that women who picked through the waste dumps left behind by the Copperbelt's golden age and that mark the region's landscape were criminalised when rising mineral prices increased the market value of these materials. ${ }^{97}$ Today, the contested control over Zambian waste dumps is a major political issue in communities such as Kankoyo (in Mufulira) and Wusakile (Kitwe), adjacent to these so-called 'black mountains'. In June 2019 hundreds of 'jerabos', members of local mining co-operatives, marched through Mufulira to demand access to the town's waste heaps. ${ }^{98}$ Zambian politicians, acutely aware of the enduring centrality of the region's copper wealth (and its distribution) to electoral competition, have opportunistically supported these demands. ${ }^{99}$ As in Kolwezi, the authorities turn a blind eye to these activities, representing as they do one way in which local communities have reclaimed their share of the region's mine wealth even as it continues to pose a threat to their health. Indeed, as Chansa argues, 'According to Kankoyo residents, the air and soil pollution they experience as a result of the presence of the slag dump gives them the right to exploit the resource'. ${ }^{100}$

Kristien Geenen, 'Gnawing Away at the City: Narratives of Domestic Precarity in a Congolese Mining Town', African Studies Review (2020), doi:10.1017/ asr.2020.65.

97 Mususa, 'Contesting Illegality'.

98 www.lusakatimes.com/2019/06/26/jerabos-march-on-the-streets-of-mufulirato-demand-the-black-mountain (accessed 10 August 2020).

99 Chansa, 'Houses Built on Copper', pp. 248-9. 100 Ibid., p. 249. 


\section{Conclusion}

The 'discovery' of environmental pollution in the last twenty-five years should not, of course, be taken to mean that mine communities were hitherto unaware or unconcerned about the effects of mine pollution on their health, livelihood or environment. Oral histories presented in this chapter show that, for example, acid pollution had a devastating effect on agricultural produce and did generate complaints. But the economic and ideational dominance of mining production meant that pollution was not generally the focus of Copperbelt communities' concern or activism during the 'golden age'. New international attention on the environmental effects of mining in the early 1990s provided Copperbelt communities with a public discursive framework within which to express their concerns.

The Central African Copperbelt's profound and enduring environmental crisis has, as well as presenting an ongoing threat to the lives and livelihoods of its residents today and for the imaginable future, shattered ideational boundaries that shaped how the region was understood for a century. Privatisation processes, while sloughing off historical environmental effects (which, however, continue to affect today's communities) and removing agriculturally productive 'squatters', attempted to impose new boundaries between productive commercial space and that which new companies considered 'waste': not only the mineral and chemical residues left behind by historical mining but also the now unwanted communities created by it. These new operations equally sought to impose a new legalistic periodisation, directly at odds with the ways in which historians now understand the interaction between environmental change and human society. The 'old Copperbelt', already characterised as 'un-modern' and uncompetitive in neo-liberal terms, was now separated from the present day, while an envisioned future industry would, by legal fiat, separate itself from this past, despite the fact that many of its operations and workers were, in reality, continuous with it. Indeed, as Peša shows, the supposed watershed in environmental scrutiny of mining often masks a striking continuity in an unwarranted faith-based approach that a technocratic future will solve environmental problems, despite its historical failure to do so. ${ }^{101}$ 
These attempts have been challenged, to some extent by the Zambian and Congolese states but above all by Copperbelt communities, both as social movements and as local actors who, in various ways, seek access to the mining wealth that continues to be produced all around them. Commercial attempts to define and police company boundaries, challenged by agriculturalists and squatters for many decades, have been fatally undermined by popular recognition that the waste created by mining flows through water and air to mine communities, the wider Copperbelt and far beyond. While new private mine owners successfully off-shored responsibility for historical pollution liabilities, they face ongoing challenges to their operations from better informed and increasingly mobilised societies for whom mine pollution is no longer a price most are prepared to pay, unsurprisingly given the few social or economic benefits that flow from today's extractive companies.

This environmental awareness equally undermines the modernist assumptions underlying representations of historical and social change during the period under analysis in this study. The residual effects of acid pollution poison the soil and water from which tens of thousands of Copperbelt residents seek to extract a living. Waste heaps, composed of rocks forged in the Phanerozoic eon and industrially processed in the mid-to-late twentieth century, tower over the region's landscapes, providing contested opportunities for precarious wealth creation today and a potential if poisonous insurance against the region's highly uncertain future. Not only is Copperbelt history no longer one of inexorable growth and 'development', it is one in which both recent and deeper ecological pasts fundamentally shape its contemporary social realities and its communities' fears and hopes for the future. 


\section{Conclusion}

\section{Introduction}

This study has demonstrated that taking a comprehensive and inclusive approach to the history of Copperbelt society reveals a much wider set of experiences than have generally been reflected in the otherwise rich historical and social scientific analysis of the region. Bringing the experience of the majority of residents who were not mineworkers into historical view not only adds those experiences to the record, but also necessitates reconsideration of the central assumptions of the Copperbelt meta-narrative, with its emphasis on the transformative effects of capital investment, formal employment and the wider panoply of modernisations associated with the cash economy, the nuclear family and the paternalistic corporate provision of housing and social services. The reality of Copperbelt society during its supposed golden age of growth and development was that most of its residents including the families of most mineworkers - lived precarious lives in which their livelihoods involved a mix of employment, entrepreneurship and farming, much of which was informal or illegal. Company provision of housing, seen as central to shaping the Copperbelt's urban landscape, did not contain the complex reality of most Copperbelt 'families', which in their diverse forms straddled company houses, informal settlements and continually reconstituted rural and periurban areas.

These and other such misperceptions certainly resulted from the everyday limitations of research that often relied on and/or took at face value the documentary evidence of official bodies and the claims of elites regarding the transformative effects of urban modernisation. More significantly, however, they reflected the broad modernist outlook about social change in Africa shared by political and intellectual elites for much of this period. As identified by Moore and Vaughan, and 
elaborated by Ferguson, the assumption that a binary transformation was underway in the Central African Copperbelt from (an idealised version of) rural traditional order to an (equally idealised) urbanised modern society powerfully shaped the foci, methods and findings of research communities and institutions from the late 1940s until the early 1960s. ${ }^{1}$ This did not always result in inaccurate findings per se, but it certainly skewed research towards certain subjects and contributed to a distorted understanding of both the form and extent of social change then underway.

As this book has argued, drawing on Schumaker and others, this characterisation would not have taken the form it did were it not for the active participation of African research assistants and Copperbelt residents as they sought to articulate and represent their own ideas about their societies in interactions with Western officials and researchers. ${ }^{2}$ In historicising these processes, this study has shown that sections of African societies reached distinctive understandings of the changes they experienced as a result of urban migration and settlement, which both reflected their experience and their attempts to give meaning to it. These understandings informed their participation in the knowledge production activities undertaken by academics and authorities, not because they wilfully sought to distort reality, but because they understood that the knowledge produced by these powerful elites had realworld consequences for the policy context that partly determined their social and economic reality.

This study has, however, demonstrated that this was not a unique moment in which late colonial modernism's influence on academic and policy research distorted underlying societal realities. It rather set the scene for an enduring pattern of unequal engagement between elite knowledge production about the Copperbelt, and the partial participation of some Copperbelt residents in that production process, over the next seventy years. These research dynamics, shaped by intellectual innovation and changing political ideas - encompassing, among other themes, gender equality, neo-liberalism and environmental awareness generated insightful findings about many aspects of Copperbelt society, while simultaneously imposing specific ways of understanding that

1 Moore and Vaughan, Cutting Down Trees; Ferguson, Expectations of Modernity.

2 Schumaker, Africanizing Anthropology. 
mirrored some aspects of modernist characterisations of the region (and about urban Africa more generally) even as they rejected others.

Meanwhile, Copperbelt communities themselves sought to express their diverse ideas about life in town in varied forms: in public political speeches and the private discussions of the cercles, in trade union negotiations and ethnic associational activity, in divorce cases, letters to newspaper editors and the lyrics of popular songs, among others. Although only some of these expressions were regarded as significant by Western and/or elite observers, most such local discourses drew on or engaged with (but were not determined by) the dominant modernist ideas about Copperbelt society that more directly influenced company and state policies and declarations by which their lives were governed. In these forums, as well as in undocumented everyday conversations in workplaces, markets, streets and homes, an underlying theme was how to navigate Copperbelt society's challenges, take advantage of its opportunities and find how best to live well in town. If there was general agreement that urban life was in many ways different to that in the village, the ways in which this new reality was perceived and found expression itself reflected the variegated experiences of these diverse and unequal communities.

\section{Cross-Border Commonalities and Comparisons}

In order to identify common and disparate themes in the ongoing interaction between social history and knowledge production, while understanding the latter as an inherent component of the former, this study has sought to identify commonalities and differences through its historical analysis, both holistic and comparative, of the Copperbelt's two parts. While these areas of Zambia and the DRC have much in common and have been characterised in similar (though not identical) ways, considerable variations in their historical development reflect both differences in (among other things) their geology, the policies of their respective mining companies and colonial states, the social organisation of their respective migrant societies and - as importantly - how these differences came to be understood and articulated as germane to social identities and organisation by their respective societies and the intellectuals who analysed them.

Haut-Katanga's pre-World War Two mining industry built on the region's pre-colonial mineral wealth. The rapid stabilisation of its 
mixed migrant urban population was enabled by the adoption of open cast mining and a sustained programme of housing and social provision for its mineworkers, shaped in part by Belgium's distinct approach to colonial welfare. By the 1940s, therefore, a relatively coherent system of authoritarian paternalism had been established in Haut-Katanga's mining towns. Residence and belonging in non-mine areas (CECs) was also highly regulated; the cercles created by colonial elites and missionaries in particular provided a clear if narrow basis for membership of an indigenous elite, but there was no serious consideration of the concession of authority to this elite until shortly before Congo's chaotic decolonisation in 1960.

In Northern Rhodesia, 'being urban' on the Copperbelt meant, for many of its African residents, overcoming and/or evading the official controls imposed by mine companies and the state. These companies provided housing and social services only after pressure from labour unions (established following metropolitan imperial intervention) that provided a strikingly independent voice for African mineworkers and, indirectly, their families. By the late 1950s, both Copperbelt regions possessed considerable urban infrastructure for their growing and increasingly permanent populations. Researchers on both sides of the border emphasised that these were 'towns-in-the-making', but reached contrasting conclusions regarding the extent to which their populations were themselves becoming 'modern'. The attitudes of their residents to these ideas also varied substantially. Many Northern Rhodesians saw late colonial social and political reforms as belated and inadequate steps to urban citizenship, which could only be fully realised by political independence. The region was, politically and economically, at the centre of Zambian anti-colonialism, even as tensions arose between labour and nationalist leaders that pre-figured post-independence conflicts over the distribution of power and wealth and the appropriate relationship between the new nation's rural and urban areas. Haut-Katanga's equal importance for the Congolese and Belgian economies shaped attempts to isolate its mines and their workers from 'dangerous' political ideas. Reflecting Belgium's late colonial attempt to ensure Congo's economic development while denying meaningful political reform, it reinforced the ideational separation of mine 'camps' from non-mine cités and Haut-Katanga's own separation from the rest of Congo, fuelling the fragmentation of political identities and aspirations that shaped the country's ill-starred independence. 
As has been emphasised, the conscious downplaying of 'ethnicity' as a primary form of collective identity on the Zambian Copperbelt does not mean that ethnic difference has not often informed political competition or social distinctions, but 'tribalism' was considered illegitimate or incompatible with Zambian Copperbelt cosmopolitanism. This latter identity was then a powerful myth that shaped societal reality, for example severely limiting the influence of ethnic associations on political expression and instead emphasising a broad anti-elitist moral economy perspective that criticised the exploitative consumption of Copperbelt wealth by foreign companies and unaccountable political elites alike. The enduring importance of ethnic association and identity to Katangese social advancement and political representation can, by comparison with its Zambian neighbour, be shown to be not at all the inevitable consequence of ethnic mixing in poor urban communities, but rather the result of (dis)incentives towards alternative forms of political organisation and identity that themselves reflected the gathering and dissemination of knowledge about new urban African societies and their supposed relationship to rural areas of origin.

As Chapter 6 explains, the Copperbelt region's centrality to the assertion of national identity and the goal of economic development in both countries was experienced in very different ways. HautKatanga's strategic significance led to its secession and made effective control over it vital to the authorities in Kinshasa. While Congolese nationalism and UMHK's corporate model initially competed for control over the region's mineral wealth and workforce, Gécamines ultimately enabled a distinctly Zairian form of corporate paternalism that ensured the flow of that wealth directly to the country's self-identified patron, President Mobutu. Collective political expression, certainly of a pan-Katangese form, was ruthlessly suppressed, but the tacit integration of ethnic associational activity into state and corporate structures ensured that it commonly provided the most practical form of protection and support in what was, for most, a precarious social and economic environment. In Zambia, by contrast, antagonism towards the continued exploitation of the productive Copperbelt by a Lusakabased UNIP elite and its allies in both foreign mining companies and regional liberation movements was articulated by union activists and expressed in oppositional political activity that took a range of forms which consistently emphasised combination and community-based organisation and protest. 
As the region experienced a profound and dislocating economic and social decline from the late 1970s onwards, these shared and contrasting social histories and understandings of societal identity influenced the diverse responses of Zambian and Congolese Copperbelt residents to its effects. Most families were already used to 'getting by' via a precarious combination of low-paid wage labour, trading and agriculture, but the drastic reduction in the local circulation of mineral wealth prompted many to resort to new survival strategies and to respond, collectively and individually, to the imposition of increasingly severe austerity measures. ${ }^{3}$ In Zambia, this took the form of antiliberalisation protests and then coalesced into a pro-democracy movement that, once in power, itself imposed radical economic liberalisation that had a devastating effect on collective organisation and living standards. If these actions were ultimately unable to prevent the region's further decline, its protest movement was not, as in HautKatanga, derailed by incumbent politicians who, building on the region's history of autochthonous and secessionist politics, successfully scapegoated ethnic 'outsiders' for the drastic decline in living standards caused by the fall in international mineral prices and political mismanagement and corruption.

While these generalisations about each Copperbelt region clearly do not hold true for all their residents at all times, they certainly reflected and informed the collective self-identities of Zambia and Katangese Copperbelt communities as they sought to articulate and project their own sense of what it meant to be 'urban' and 'modern' throughout this period. They shaped and were shaped by the unfolding of social history and its interpretation by local and elite producers of knowledge about that history, as well as their assertions about the relationship between the region's past and present.

\section{Understanding the Self-Conscious Copperbelt}

During a research visit to the Zambian Copperbelt town of Kitwe in July 2019, a former mineworker and footballer showed me the ruins of the former ZCCM sporting facilities in Wusakile township that he and friends were trying to rehabilitate. During our conversation, he

3 Mususa, 'Getting By'. 
mentioned in passing that he had once met and worked with another Western researcher, Robert Bates. When I asked him what exactly he did in his work with Bates, he replied, somewhat uninterestedly, 'Ah, the same as with you'. Western researchers and, today, African ones, are an enduring and familiar part of the Copperbelt landscape: hundreds of social scientists and historians have visited the region over the past seventy years in order to capture what has always been regarded as a society of special significance - firstly as an unusually urbanised space in a continent stereotyped as rural and agrarian; as an early indicator of modernising processes thought to be sweeping sub-Saharan Africa; and later as a place of crisis or decline, in need of understanding and/or intervention. African research assistants and interviewees have participated in and shaped this research, seeing in it an opportunity to advance their own standing and/or careers as well as to highlight their perceptions or concerns about their society.

The resulting presuppositions about Copperbelt society were, this book has argued, at best a partial reflection of reality and at worst a major distortion of it. Researchers - many employed or funded by states, companies or international financial institutions - focussed unduly on specific sections of that society and/or tended to assess it in relation to a normative characterisation of 'Western' modernisation and urbanisation, sometimes to demonstrate that it was following that Western path and sometimes to show it was deviating from it. Yet this characterisation of the Copperbelt's distinctive urban nature was not simply imposed upon it from without by Western researchers. From the 1940s, many Africans saw the new mining towns as places distinct from rural society and themselves sought to describe and explain those differences to each other.

It was always thought to be necessary to initiate new arrivals into Copperbelt society, and to establish associations through which to do this, because its rules and conventions were understood to be different from those of the communities from which migrants had come. Many residents enthusiastically engaged with innovative organisational forms - labour unions or intellectual cercles, for example - introduced and/or promoted by Western authorities, because they provided opportunities for advancement but also for the expression of new forms of identity that appeared to be of specific relevance in these new urban spaces. Correspondents with company newspapers, and the composers of popular songs, sought to explore or capture both the 
links and the differences between village and town society, marriage, family and life, celebrating the possibilities and promise of urban life while equally expressing their concerns or fears over what was being lost or destroyed in what they agreed was a tumultuous process of social change. Among the markers of this distinctiveness were the dominance of formal sector employment, housing and services linked to jobs, the dominance of the cash economy, multi-cultural and linguistic mixing and new 'modern' forms of authority, belief and organisation. Interviewees, respondents and participants in generations of social scientific research drew upon the notion that Copperbelt society was distinct and different, both from what had existed in the past and from rural African societal norms. Like the Western researchers with whom they interacted, they often conflated contemporary African rurality with their understanding of the pre-colonial past.

The presence and attention of those social scientists reinforced their sense that there was something special about Copperbelt society that needed to be explained. This does not mean that there was a unified characterisation of this distinctiveness, nor that African characterisations were necessarily more reflective of its underlying realities than those provided by Western academics - for they also tended to privilege the experiences of formally employed men and those with sufficient education to express themselves in written European languages and to be of use as research assistants or participants. As elsewhere in late colonial Africa, aspirant elites asserted their readiness for full citizenship and political freedom in ways that tacitly accepted the superiority of aspects of Western 'civilisation' and/or sought to articulate a universal and/or Africanist version of it. On a more quotidian level, the forms and discourses in which urban society was explained and portrayed were themselves perceived as new and either Western in form or as a Westernised form of something African. Copperbelt societies did, however, in seeking to make sense of the lived experience of themselves, their families and their communities, articulate a more diverse and open-ended sense of the possibilities of urban social change than did the modernist frameworks that constrained the thinking of most social scientists.

While all this might have been expected to change with decolonisation, the reification of an idealised African rural society by nationalist leaders tended to reinforce the notion that the form of urbanism to be found on the Copperbelt was variously exceptional, problematic, out 
of place and certainly in need of explanation. The fact that African societies had always changed and innovated, had constantly come into contact with different cultures with which they engaged in conflictual and co-operative ways, was often lost or downplayed in this process. This fed a hegemonic belief that inaccurately counterposed dynamic urban society to a rural Africa that, despite its experience of massive social, economic and cultural changes across the twentieth century, continued to be invoked as an unchanging, authentic control group against which to test the modernist experiment of the Copperbelt.

Yet this does not mean that these ideas should be understood as reflecting a passive internalisation of a well-established or singular Western view. Africans certainly engaged with and drew on Western ways of seeing and understanding the Copperbelt, but from the start they invested in and articulated their own understandings of what the region meant to them. While some migrants engaged compliantly with wage labour and time discipline, others sought to advance their position and that of their families by evading company controls and the characterisations of a good urban life that underwrote them. Among African residents, diverse views emerged of the right way to live in town, perspectives that rested, explicitly or implicitly, on reflections of their own experience and/or memories of a rural African past. These viewpoints then influenced the thinking of those Western actors who regarded Africans as useful sources of information about this new urban society, drawing on their assertions as influences on their latest iteration of official and/or academic knowledge of the Copperbelt, a process of exchange and knowledge production that has continued to this day. Over time, any distinction between 'Western' and 'African' forms of knowledge about the region has become ever less helpful. Just as nation-states sponsored and asserted their own ideological interpretations of societal change and of their relationship to their history, so African intellectuals and elites came to play increasingly prominent roles in international organisations such as the IMF and World Bank that, implicitly or explicitly, shaped the Copperbelt's future by producing knowledge about it.

This study does nevertheless identify an ongoing distinction between 'elite' or 'official' forms of knowledge production and the popular discourses that generally inform Copperbelt residents about their 
societies. The extent to which there was an active and mutually informative exchange between these two frameworks of knowledge production varied considerably, depending on the actors and subjects concerned. Everyone, for example, thought the copper mining industry needed to be productive and profitable for the region to thrive, even if they disagreed about the optimal distribution of mining wealth between mineworkers, their communities, the wider Copperbelt, the national economy and the global mining industry. There was likewise significant agreement that the region was a place of opportunity, advancement and modernity, though the particular ways in which this was pursued varied greatly. Indeed, the ways that most residents sought their share of the Copperbelt's wealth were generally viewed by elite observers as antithetical to the 'modern' industrial mining complex that was central to its identity.

The gendered nature of these activities represents the greatest area of dissonance between the region's social history and its elite and popular representation. While women always farmed and worked, they were constantly 'discovered' to be working and farming for the first time, a disjuncture that was reinforced by the popular perception that women 'had always been' housewives, held by most men and indeed many women who themselves worked. Likewise, the belief that in the recent 'past' - a past that has inevitably moved over time but which is generally understood to be within the living memory of older Copperbelt residents - society was more ordered and stable, with shared generational norms and parental authority resting on an 'authentic' culture, is belied by evidence of chaotic change in exactly that past, a past during which residents equally believed their earlier past had in turn been one of order and stability. It is, however, noteworthy that the specific content of this nostalgia has changed over time: a belief in and (sometimes) a yearning for a mythic fixed rural order, which was common among many Copperbelt residents in the 1950s and 1960s, had been replaced by the 1980s and 1990s with a nostalgia for an early post-colonial urban order that was, as explained, experienced by many as an era of disruption and precarity but which was now remembered as one of stability and paternalism. While Thompson once found an English working-class nostalgic 'for the pattern of work and leisure which obtained before the outer and inner disciplines of industrialism settled upon the working man', there is today nostalgia for the certainties of the disciplines of industrialisation that were, we must 
remind ourselves, the reality for only a minority of Copperbelt residents. ${ }^{4}$

Analysing such disparities between social history and perceptions of it is not, in my view, best achieved by counterposing 'historical reality' to a 'nostalgia' or a supposedly 'false consciousness' about it. Consistent with this study's approach to the production of knowledge about society, widely held popular beliefs about the changing social order should be understood as a central part of social reality, informing, among other things, the ways in which demands are placed on mine companies or states to improve or at least stabilise Copperbelt residents' parlous living conditions. ${ }^{5}$

\section{Unifying Knowledge Production and Social History - Lessons and Prospects}

This study has sought to analyse the role of knowledge production in social history by treating the production of knowledge about society as an essential part of its history. What are the consequences, methodological and historiographical, of analysing knowledge production and social history within a single analytical framework? Clearly, it is important not to lose sight of the profound inequalities between the different producers and types of knowledge under production. Unsurprisingly, powerful European men were best placed to easily disseminate their (often very limited understanding) of Copperbelt society, while the voices and experiences of its female African residents were ignored by outsiders (and, as our interviews show, by many insiders) for many decades. Policy documents, such as those produced for colonial governors, national leaders and the president of the World Bank, were more influential on official decision-making than letters written by Copperbelt residents to newspapers or the images of popular paintings. This study has tried to identify particularly significant instances of knowledge production, but more generally seeks to understand the Copperbelt as an unequal intellectual milieu in which new, diverse and contested ideas about how to live (and how to live better) circulated unevenly, taking many forms and

4 E. P. Thompson, The Making of the English Working Class (London: Victor Gollancz, 1963), p. 357.

5 Rubbers, Le Paternalisme en Question. 
influencing each other in ways that are often impossible to trace. In this respect, the fact that many interviewees spontaneously recalled the moral lessons taught by Mufwankolo theatre, or the cultural traditions discussed on the Kabusha radio programme, indicates that the ideas they expressed were 'useful' in helping them understand and explain to others the ways in which they lived and how their society was constituted.

At the same time, this study rejects the counterposing of 'wrong' elite knowledge production produced by outsiders to 'authentic' insider understanding of the 'real' Copperbelt society. This is for a number of reasons:

- Elite producers of knowledge did not usually start from a desire to wilfully distort societal reality. Many such analysts engaged closely with local providers of knowledge and sincerely believed they were producing an accurate view of society within the intellectual and political framework within which they were operating. In doing so, they were often influenced by existing 'indigenous' understandings of Copperbelt urbanism.

- Outsider knowledge did not remain 'outside': it filtered into indigenous elite and even popular understandings and representations of Copperbelt society in many ways. Taking just one example, the entirely new social order created by company and colonial officials in Haut-Katangese mine communities, encompassing workplaces, housing, healthcare and leisure facilities, had at its heart a selfconscious projection of an idealised urban society, rooted in the extended metaphor of the paternalist corporation, that had never existed anywhere in the world. Despite its evident internal contradictions and limited applicability to the messy realities of the lives of mineworkers and their families, the notion of the UMHK/ Gécamines 'family', associated with comparatively high living standards and 'generous' social provision, was taken up by this community and remains both a central part of how interviewees explain their experience and a political strategy through which they seek to defend their living standards, decades after it was abandoned by those who first envisaged it.

- The diversity of Copperbelt society means there is no single 'insider' perspective about it. As has been argued here, the focus on formal sector male employees (and belatedly their wives) has created 
a tendency to generalise from their experience and views in ways that silenced the ideas of, for example, urban farmers and 'squatters'. Ferguson's distinction between 'cosmopolitan' and 'localist' understandings of Copperbelt urbanism provides a useful starting point for appreciating its inherently double-edged mixture of the opportunities provided and threats posed to residents, but extending analysis to incorporate this much wider population on both sides of the border, and the impact of social change over an extended period of 'boom' and 'bust', results in a far more open-ended characterisation of the diverse ways in which locals understood and articulated their understanding of their complex society.

- Insider knowledge is, like that of academics and external elites, produced to assert a specific characterisation of society: it is neither neutral nor natural, waiting to be picked from the ground by researchers like ripe fruit. Every one of our interviewees, like their thousands of predecessors, conveyed to us not only their memory of 'things that happened in the past' but their understanding of the significance of these social changes for themselves, their families and their wider communities. They engaged with us for their own reasons, sought to teach us lessons about the past, emphasised certain aspects of their experience while downplaying others and not only misremembered but also - as Luise White explained some time ago - distorted the historical record while doing so. This is partly because distorting the 'facts' for external researchers is arguably a central aspect of Copperbelt social scientific experience, but also because people lie about the past - to other members of their own society as well as outsiders, and even to themselves. ${ }^{6}$

It remains to be seen whether the approach utilised and advocated here proves, as is hoped, useful for the practice of social historians more generally. The specificity of Copperbelt urbanisation may mean that some lessons of this study do not apply to long-established African societies, where indigenous views of custom and culture may be more usefully counterposed to their external representation. Yet even here, the impact of political, social, economic and cultural change, both over the longue durée and during the period analysed herein, has surely generated new ways of characterising the impact of such changes on,

6 Luise White, 'Telling More: Lies, Secrets, and History', History and Theory, 39, 4 (2000), pp. 11-22. 
for example, morality, custom and social mores, and new forms of knowledge produced to assess and give expression to those changes.

\section{Lacunae and Limitations: Towards a Provisional History of the Central African Copperbelt}

It is evidently impossible to produce a social history of this period and range that is genuinely comprehensive, whether thematically or in terms of its coverage of the Copperbelt's diverse population. This study, while wide-ranging in some respects, only scratches the surface in explaining the everyday experiences and worldview of many of its residents. The importance of spirituality in general, and Christian teaching in particular, in informing views regarding morality and society, would certainly justify a chapter in this study, indeed a full-scale work in itself. ${ }^{7}$ Coverage of the role of ethnic factors and associations in informing identity is not as thorough as would be desirable. ${ }^{8}$ Despite its attempt to reflect all parts of the Copperbelt community, the historical experiences of its most marginalised members remain less well represented than those with formal education and employment. Any truly comprehensive study of the quintessentially migrant experience of the region would involve analysis of and interviews with the many thousands of former Copperbelt residents who either 'returned' to the rural areas or migrated on to other towns and countries.'

The most evident way in which this study remains incomplete is that, in emphasising the ways in which successive waves of knowledge production have sought to explain Copperbelt society, it has highlighted the perennially provisional nature of our understandings of that society. While an earlier generation of academic observers could be confident that this new urban society was one best understood in terms of the colonial and class-based interactions between mine companies and (largely male) African workers, subsequent insights have revealed the centrality of agricultural activities and the (mainly) women

7 Among existing studies of Copperbelt religious belief and practice, see Fabian, Jamaa; Haynes, Moving by the Spirit; and Lämmert, 'Reimagining the Copperbelt as a Religious Space' in Larmer et al., Across the Copperbelt, pp. 347-372.

8 Gobbers, 'Ethnic Associations in Katanga Province'; Kapesa and McNamara, 'We Are Not Just a Union'.

9 For an exemplary study of such open-ended dynamics, see Zoe R. Groves, Malawian Migration to Zimbabwe, 1900-1965: Tracing Machona (London: Palgrave Macmillan, 2020). 
who carried them out. Where analysts once 'knew' that an older indigenous African culture was being steadily displaced by a globalised Western set of cultural norms and practices, today it is more widely understood that syncretic cultural practices are not only a normal product of cosmopolitan societies, but also that such cosmopolitan syncretism did not arrive in Africa with colonialism but is rather as old as African human history itself. Whereas mine production was in the past known to be central to 'development' and the raising of living standards, it is now appreciated that it has brought about longterm environmental destruction and endangered the health and quality of life of many if not most Copperbelt residents.

This might optimistically suggest that, even as we increasingly appreciate the constraints that modernist thinking has historically placed on our understanding of lived social reality, we are moving towards a more complex, open-ended and ultimately more sophisticated appreciation of the underlying realities of Copperbelt society. But, if we appreciate that we, the current generation of Copperbelt historians and social scientists, are simply the latest in a long genealogy of researchers to believe this about themselves, then it is logical to assume that in the near future a new generation will, using innovative techniques and interpretations, excavate new layers of historical understanding from beneath the Copperbelt's surface. In doing so they will no doubt render our findings superfluous, faulty and inherently bound up with the distorting lens through which we currently view Copperbelt society. It is a perverse kind of optimism to believe that such a development will indicate the continuing ability of Copperbelt communities and scholars to generate new ways to ask old questions about, among other things, the capacity of mineral wealth to raise living standards, the distribution of that wealth between workers, communities, states and companies, the value of the labour - both direct and indirect - required to produce that wealth, and the nature of the moral and political order of such a society, both in its realities and in its aspirations. But it is exactly this kind of stoical persistent optimism that has always been displayed by the long-term Copperbelt residents who, despite dangers and setbacks, keep trying to create a better life for themselves, their families and their communities. 


\section{References}

\section{Interviews}

The interviews listed below were carried out (with a few exceptions) between 2017 and 2019 by members of the 'Comparing the Copperbelt' research team: Miles Larmer, Iva Peša, Benoît Henriet, Enid Guene and Rachel Taylor. Pierrot Monzi Kalonga in Likasi and Grant Chisapa in Mufulira played a central role in identifying potential interviewees, facilitating their participation and sometimes translating interviews.

\section{Likasi}

François Batabata Nsenga, 7 June 2018.

David Beni, 27 June 2018.

André Kabinda Kasengo, 4 June 2018.

François Kake, 11 June 2018.

Ferdinand Kakompe, 19 June 2018.

David Kalabo Mupanga, 5 June 2018.

Philippe Kalenda, 11 June 2018.

Dieudonné Kalenga, 8 June 2018.

Marie José Kapya Katolo, 23 June 2018.

Justine Karumb, 23 June 2018.

Jacques Kibombo, 11 June 2018.

Musale Kibombo, 21 June 2018.

Jérôme Kipili Mulunda, 4 June 2018.

Jérôme Kipili Mulunda, 4 June 2018.

Pami wa Kasongo, 7 June 2018.

Ilunga wa Kumwanza, 8 June 2018 and 26 June 2018.

Thérèse Kyola, 7 June 2018.

Sara Léontine Bulanda, 6 June 2018.

Mwanza Lukinde, 5 June 2018.

Jacques Mangenda, 7 June 2018. 
Michel Mudimba wa pa Bowa, 18 June 2018.

Stéphanie Mumba, 6 June 2018.

David Mupanga, 5 June 2018.

François Musenge Dikumbi, 13 June 2018.

Séraphin Musoka, 6 June 2018.

Batho Musumba Nkomba, 6 June 2018.

Astrid Musumbi, 6 August 2019.

Albert Mutangala Tshibembe, 16 February 2018.

Gaston Mutiti, 4 June 2018.

Banza Mutunda, 4 June 2018.

Gastonie Ngoy Kalala, 22 June 2018.

Valérienne Ngoy Mudimbi, 9 June 2018.

Marie Ngoy Mwamba, 9 June 2018.

Emile Ngoy Muyondwe, 19 June 2018.

Gérard Mwaba, 18 June 2018.

René Mwamba Kasongo, 8 June 2018.

Agnès Njamba, 16 July 2019.

Batho Nkomba, 6 June 2018.

Edouard Nkulu, 12 June 2018.

Kabwika Ntanda Kadisabula, 5 June 2018.

Georgette Ntumba, 12 June 2018.

Cyprien Ramazani, 5 June 2018.

Euphrasie Yowa, 14 June 2018.

\section{Mufulira}

Emelia Banda, 16 July 2018.

Simon Bwalya, 9 July 2018.

Emery Bweupe, 19 July 2018.

Cossam Chali, 21 July 2018.

B.M. Chama, 6 July 2018.

Samson Chama, 6 July 2018.

Francis Chanda, 16 July 2018.

Chrispin Chani, 16 July 2018 and 30 July 2018.

Ana Chilufya, 11 July 2018.

Morris Chimfutumba, 13 July 2018.

William Chinda, 8 August 2018.

Levy Chushi, 11 July 2018.

Gertrude Dhaka, 2 August 2018.

Bobby Jackson Kabamba, 10 July 2018.

Damian Kachusa, 6 August 2018.

Thomas Kalimanshi, 30 July 2018.

Simon Kampamba, 16 July 2018. 
Patson Katwisi, 3 July 2018 and 1 August 2018.

Leonard Koloko, 27 August 2018.

Foster Kunda, 20 July 2018.

Henry Longwane, 7 July 2018 and 10 July 2018.

Josephine Lukwesa, 8 July 2019.

Elizabeth Malokoleta, 2 August 2018.

Maxwell Mukupa, 11 July 2018.

John Mule, 12 July 2018.

Jennifer Mulenga, 13 July 2018.

Dewys Mulenga, 20 July 2018.

Dorothy Musisha, 12 July 2018.

Matthias Mutupa, 19 July 2018.

Fridah Mwale, 6 July 2018.

Nathan Mwamba, 7 July 2018.

Joshua Mwape, 28 July 2018.

Philip Mwape, 17 July 2018.

Victoria Mwelwa, 17 July 2018.

George Mwenda, 7 July 2018.

Washeni Mweni, 13 July 2018.

Boston Mwenya, 10 July 2018.

Kathbert Nchema, 9 July 2018.

Defa Ngoma, 3 July 2018.

Owess Nkhama, 8 August 2018.

Leonard Nkhuwa, 17 July 2018 and 30 July 2018.

Mary Nomba, 27 July 2018.

Evans Nsabashi, 18 July 2018.

Wesa Sakabaso, 12 July 2018.

Juliana Sakala, 11 July 2018.

Thompson Sichula, 20 July 2018 and 28 July 2018.

Hector Sithole, 10 July 2019.

Nguni Tamarikzika, 3 July 2018.

Dennis Tembo and Ennis Zulu, 6 July 2018.

Joseph Tumba Mwenzu, 9 August 2018 and 11 July 2019.

Margaret Waya, 6 August 2018.

\section{Kitwe}

Victor Chishala, 6 July 2019.

Leonard Chola, 4 July 2019.

Keith Kabwe, 2 August 2018.

Barney Kanjela, 23 August 2018.

Lesa Kanyanta, 3 July 2019.

Mark Masumbuko, 4 July 2019. 
Matthew Mudenda and Davies Sichinsambwe, 17 August 2018. Bob Nkosha, 26 August 2018.

\section{Lubumbashi}

François Amisi, 3 July 2018.

Dominique Bwalya, 17 July 2018.

Fabien Kabeya, 30 June 2018.

Arthur Kalunga, 4 July 2018.

Pamphile Kapiteni, 25 June 2018.

Victor Kasoma, 17 August 2018.

Adolphe Kisimba, 9 July 2018.

Jean-Marie Maga, 30 June 2018.

Gulda el Magambo, 24 June 2018.

Maisha, 17 July 2018.

Kanteng Mayal, 19 July 2018.

Philippe Mikobi, 5 July 2018.

Odilon Mufwankolo, 9 July 2018.

Eliot Mujinga, 30 June 2018.

Francesco Nchikala, 18 July 2018.

Ernest Shibati, 3 July 2018.

Paul Tshimambe Kombodji, 4 July 2018.

Marcel Yabili, 6 July 2018.

\section{Other}

Rodah Matoba, Luanshya, 21 January 2003.

George Mukoma, Chililabombwe, 11 February 2003.

Emanyeo 'Jagari’ Chanda, Lusaka, 2 July 2019.

\section{Archival Sources}

\section{African Studies Centre, Leiden}

Gécamines Annual Report, 1971.

Gécamines Annual Report, 1973.

Gécamines Annual Report, 1975.

Gécamines Annual Report, 1978. 
Gécamines Annual Report, 1979.

Gécamines Annual Report, 1983.

Gécamines Annual Report, 1984.

\section{Archives Générales du Royaume (AGR)2 Brussels, UMHK Records}

File 672, Centre de psychologie et pédagogie, 1954-8. 658, UMHK MOI Annual Reports 1958 and 1960. 632, UMHK MOI Annual Report 1956. 631, UMHK MOI Annual Report 1955. 265, UMHK Services d'Afrique, report on activities, 1952. 633, UMHK MOI Annual Report, 1957.

\section{Belgium Archives Africaines (BAA), Katanga Provincial Council (KPC) Papers}

File 34 (6), KPC, 'Situation Politique et Administrative', March 1955. 35(1), KPC, Allocution d'Ouverture, 7 March 1956.

35(4), KPC, deuxième séance, 21 March 1957.

35(7), KPC, deuxième session, Séance pleniere et vœux, 2 September 1957.

36(3), KPC, Session Générale, Opening Statement, Governor Paelinck, September 1958.

36(4), KPC, Session Générale, Commission Prépatoire No. 1, Séance, 2 September 1958.

37(1), KPC, Session extraordinaire, 1959, Allocution d'ouverture du commissaire provincial M. Thilmany.

37(2), KPC, Session extraordinaire, 1959, Allocution d'ouverture du V. GG Schoeller.

\section{Gécamines (GCM) Likasi Personnel Archives}

Représentant de la Direction Générale à Likasi, 'Avis au Personnel de Cadre de Likasi', 13 June 1972.

MPR Gécamines, 'Organisation du $1^{\text {er }}$ Festival Animation Politique Gécamines', 1 June 1984.

Panda Chief of Personnel, 13 October 1988. 
PV de la Réunion du Comité Cellulaire MPR/DSA/DGP, 28 March 1989. PV meeting MPR/DSA/DGP, 28 March 1989.

PV de la Réunion du Comité Cellulaire MPR/DSA/DGP, 30 October 1989.

Institut National pour l'Étude Agronomique du Congo Belge (INÉAC) Archives

NILCO, 10045, report on soil conservation and fertiliser, n.d. but late 1950s.

International Library of African Music (ILAM), Rhodes

University, Grahamstown

\section{Broadcast Scripts}

Hugh Tracey, 'The Music of Southern Africa', SABC broadcast transcript, n.d. 'The Music of Southern Africa', Series III Programme 9, The Music of Kolwezi in the Belgian Congo, 27 November 1957.

'The Sound of Africa', Series III Programme 2, p. 4, n.d. but 1957.

'The Sound of Africa', Series III Programme 7, The Music of Three Mines, p. 8 n.d. but 1957 .

\section{Catalogue Cards}

'Ari Nkumbula na Katilungu balisha-myondo', Aushi, group of eleven Aushi men, Roan Antelope Mine, 24.43, 1957.

'Kabula nuna kamushalila', Stephen Tsotsi Kasumali and two friends, Aushi, Nkana Mine, 27.61, 1957.

'Machona', Luvale/Chokwe, Bernard Sachinati and Chokwe men, Mufulira mine, 27.4, n.d.

'Masengu', Kasongo Adalbert, Luba/Kabongo, Cité Indigene, Shinkolobwe, 22.14, 1957.

'Matinda ba munatile yowe', Lozi, Kabunda Sishumba (woman) with Lozi men and women, Nkana, 24.52, n.d.

'Nakapenda womaseza mu Luanshya', Luvale/Chokwe, Chipwili Saini with Chokwe men and women, Luanshya, 27.1, n.d.

'Nalongama maani', Luba/Shankadi, Kaseba Anatole, Kolwezi, 27.61, 1957.

'Pachimane-cho chabekeshya' and 'Shiwifulunganye ifunde', Bemba, Bancroft 7th Day Adventist Choir, 23.21, 1957. 


\section{Other Documents}

'Sounds of Africa Series' catalogue (1973).

\section{International Monetary Fund (IMF) Archives, Washington, DC}

File 61661, C/Zambia/810 Mission, Russo and Staff, NovemberDecember 1978. 55676, Zaire - 831, Gécamines, 1977-8. 49275, 'Zaire - Implementation of 1979 Program', 1979-80. 62393, 'Zambia 011 - Economic Situation and Prospects', 1974-85. 62395, 'Zambia 012 - Government and Politics', 1985-6.

\section{International Monetary Fund (IMF) Online Archives}

File 89909, 'Zaire - Structural Adjustment Facility, Policy Framework Paper, Apr 1989-Mar 1992', 17 May 1989.

84925, Executive Board meeting, 13 November 1992; IMF, 'Zaire Recent Economic Developments', 13 May 1994.

117845, 'Zambia - Staff Report for the 1994 Article IV Consultation and Midterm Review of Rights Accumulation Program', 9 September 1994. 31129, IMF Executive Board meeting, 18 December 1995.

\section{National Archives of Zambia (NAZ)}

WP 1/2/64, Special Commissioner for Western Province, Reports on Copperbelt, 1959-60.

WP 1/2/43, African affairs annual report Luanshya, 1957-60, 'Western Province African Affairs Annual Report', 1959.

WP 1/2/45, Annual Report African affairs Ndola, 1957-61.

WP 1/11/2, African Social and Political Development in Urban Areas, 1951-6.

WP 1/2/53, Labour: Dept of Labour monthly reports, 1958-60.

WP 1/2/61, Report of Director of African Affairs Chingola 1959.

WP 1/2/66, DCs reports 1960. 
WP 1/2/74, Native Affairs, Annual Reports, 1963.

WP 1/2/75, Native Affairs Annual Reports 1963-5.

WP $1 / 2 / 23$, Provincial Annual Reports on Native Affairs.

WP 1/3/3, General policy on the Copperbelt 1957-67 (African Education).

WP 1/1/104, UNIP meetings, 1960-1.

ML, African Housing on the Copperbelt, 1950-60.

ML, Control of Alienation to Africans in Urban Areas, 1954-8.

LSS 1/22/30, Labour Consultative Committee, 1962-4.

LSS 1/22/24, Annual Reports, Labour Officer, Luanshya, 1947-67.

LSS 1/26/33, Luanshya AMWU,1949-65.

LSS 1/26/184, N Rhodesia AMWTU, 1960-4.

LSS 1/23/24, Annual Reports, Labour Officer, Luanshya, 1947-67.

LSS1/15/279, Annual Report Assistant Labour Commissioner Kitwe, 1962-9.

WP 1/5/9, African Mine Townships Nkana, 1954-9.

WP, 1/2/18, Tour Reports Mine Districts, 1951-5.

WP 1/5/18, Mufulira Race Relations and Conciliation Committee, 1957-62.

WP 1/5/20, Ndola Race Relations Committee, 1958-62.

MLSS 1/12/5, Northern Rhodesia Council of Social Services 1967-8

[incorrect dates].

MLSS 1/12/7, N R Council of Social Services, 1960-2.

MFA 1/1/24, Zambia Missions Congo, 1964-8.

MFA 1/1/144, Zambian Nationals in the Congo 1966-7.

HM77/UNIP/1/4, Papers of Peter Matoka.

\section{Mufulira Town/District Council Minutes}

Town Development and Works Committee, 2 September 1959.

Full Council meeting, 23 February 1972.

Full Council meeting, 22 March 1972.

Housing Committee meeting, 8 March 1972.

Finance and General Purposes Committee meeting, 29 May 1972.

Housing, Planning and Works Committee meeting, 4 October 1972.

\section{Mineworkers' Union of Zambia, Luanshya Branch}

Meetings with Management, 1975-8. 
US State Department (USSD) Archives, Maryland

RG 84, E3363 (Foreign Service Posts), Box 1, File, 'Political Affairs and Rel., Pol 7, Visits and Meetings', 1963.

\section{World Bank/International Bank for Reconstruction and Development (IBRD) Online Archives}

IBRD, 'Report and Recommendation of the President to the Executive Directors on a Proposed Loan to La Generale des Carrieres et des Mine with the Guarantee of the Republic of Zaire for a Mining Expansion Project', 2 January 1975.

IBRD, 'The Economy of Zaire', July 1975.

'Report and Recommendation of the President to the Executive Directors on a Proposed Loan to Gécamines ...', Report P-1551-CK, 2 January 1975.

'Report and Recommendation of the President of the IBRD to the Executive Directors on a Proposed Loan ...', Report P-4268-ZR, 27 March 1986.

'Zambia: Wage Policy and the Structure of Wages and Employment', Report 5727-ZA, 7 May 1986.

'Staff Appraisal Report, Zambia, Export Rehabilitation and Diversification Project', Report 4624-ZA, 22 February 1984.

'Memo and Recommendation to IDA for proposed credit for Mining Sector Technical Assistance Project', request P-5496-ZA, 23 May 1991. South Shaba Agricultural Development Project Completion Report, 31 May 1995.

'Project Appraisal Document on a Proposed Credit and Grant to the Republic of Zambia for the Copperbelt Environment Project', 14 February 2003.

\section{ZCCM-IH Archives, Ndola}

- 16.3.7A, 'African Labour - Recruiting and Unemployment, Labour Exchanges, Oct 1960-Dec 1980'.

- 16.3.7A, 'African Advisory Board, Feb 1951-Jan 1958'.

- 16.3.8C, Mine Township Mgt Board - Health Officers, July 1929November 1979.

- 3.8.1C, Utilisation of African Labour Report, 1957. 
- 3.8.1C, First report on Regional Survey of Copperbelt, 1959.

- 10.1.8F, 'African Labour: Wages', October 1950-December 1955.

- 10.1.8F, African Labour - Trade Union, 1955-6.

- 3.8.2E, Forster Board of Inquiry, Afr Advancement, September 1954.

- Copperbelt Development Plan, 1965.

- Copperbelt Development Policy, 1965.

- NCCM Annual Report 1955.

- NCCM Annual Report 1956.

- Zambia Mining Yearbooks, 1965-8.

- 17.4.3B, 'Housing and Social Services (Commission of Inquiry)', 1951-66.

- 17.2.3B, ZMU local dispute NCR, 1964-7.

- 16.3.9C, 'Special Sub-Ctte, Housing, Senior African', December 1960August 1977.

- 11.4.7E, 1960, 'Integration of Mine and Public Townships', March 1960.

- 14.2.9B, 'Mine Townships', January 1961-April 1964.

- 14.1.2B, 'Housing (Labour Mine Township)', 1962-5.

- 6.3.2F, AMWTU (Vol. 9), September 1955-June 1956.

- 17.1.6C, MJIC-ZMTU, 1964-5.

- 17.2.3B, ZMU local disputes NCR, 1964-7.

- 15.2.1C, 'Government Takeover, 1969-71'.

- 16.3.7A, 'African Traditional Dancing Music, Bands, Arts Luanshya Cultural Committee, Oct 1940-Nov 1970'.

- 2.5.4I, World Bank, Program Performance Audit Report - Zambia Industrial Reorientation Project.

- 6.2.5I, 'ZCCM Study to Investigate Industry Community Services'.

- 1.5.3F, Running of Mine Recreation Clubs and Canteens at Work Places, 1990-9.

- 12.8.8F, Report on the Findings and Recommendations of the Committee on the Future of ZCCM Schools, Hospitals and Other Social Services, ZCCM, July 1996.

- 5.1.2I, Sale of ZCCM Houses, 1998.

- 17.3.3A, Land Use, Squatters and Co-operatives 1956-67.

- 12.1.7A, 'Regional Development, Land Policy and Land Usage', 1963-5.

- 5.14.5B, 'Konkola Division Water Quality Evaluation'.

- 5.14.5B, Pollution general correspondence up to 1984.

- 18.4.7F, 'Report on Illegal Settlements in Mine Areas', 1997. 


\title{
Newspapers and Periodicals
}

\author{
African Mail (Northern Rhodesia) \\ Daily Mail (Zambia) \\ Earth Magazine (USA) \\ Mining Mirror (Zambia) \\ Mwana Shaba (Belgian Congo/Zaire/DR Congo) \\ Northern News (Northern Rhodesia) \\ The Times (UK) \\ Times of Zambia (Zambia) \\ Wall Street Journal (USA)
}

\section{Primary Written Sources}

Anon, 'Report on the Conference on Urban Problems in East and Central Africa held at Ndola, Northern Rhodesia, in February, 1958', Journal of African Administration, 10, 4 (1959), pp. 182-252.

Anon, 'East African Shadows', Africa Confidential, 16 February 1968, pp. $3-4$.

Government of Belgian Congo, Plan Décennal du Congo Belge (Brussels: Government of Belgian Congo, 1949).

Government of Great Britain, 'Report of the Commission Appointed to Inquire into the Disturbances in the Copperbelt, Northern Rhodesia. October, 1935' (London: HMSO, 1935).

Government of Zambia, 'Second National Development Plan, 1972-1976' (Lusaka: Government of Zambia, 1971).

Human Rights Watch, 'Africa, Human Rights Developments, Zaire', 1993: www.hrw.org/reports/1993/WR93/Afw-11.htm (accessed 20 July 2020).

International Crisis Group, Katanga: The Congo's Forgotten Crisis (Nairobi/ Brussels: International Crisis Group, 2006).

International Labour Office (ILO), 'Report to the Government of Zambia on Incomes, Wages and Prices in Zambia' (Geneva: ILO, 1969).

Maquet, Jacques J. 'Aspects Sociaux de L'Industrialisation a Elisabethville, Cycle d'Etude sur les Problèmes D'Urbanisation en Afrique', UNESCO conference, Addis Ababa, 25 April-5 May 1962.

Rights and Accountability in Development (RAID), Zambia, Deregulation and the Denial of Human Rights: Submission to the Committee on Economic, Social and Cultural Rights (Oxford: RAID, 2000).

SNC-Lavallin International, 'Étude sur la Restauration des Mines de Cuivre et de Cobalt, République Démocratique du Congo', Preliminary Report, April 2003. 
United Nations/Economic Commission for Africa/Food \& Agriculture Organisation, Economic Survey Mission on the Economic Development of Zambia (Ndola: United Nations/Economic Commission for Africa/ Food \& Agriculture Organisation, 1964).

UNESCO, Social Implications of Industrialisation and Urbanization South of the Sahara (Paris: UNESCO, 1956).

World Bank, Accelerated Development in Sub-Saharan Africa: An Agenda for Action (Washington, DC: World Bank, 1981).

Zambia, Towards Complete Independence (Lusaka: Government Printers, 1969).

Zambia, Ministry of Development Planning and National Guidance, 'Second National Development Plan, January 1972-December 1976' (Lusaka: Government Printers, 1971).

\section{Secondary Sources: Books, Journal Articles, Book Chapters and Theses}

Anon, 'Le Commerce Indigène au CEC d'Elisabethville', CEPSI Bulletin, 28 (1955), pp. 61-75.

Adam, Christopher, Paul Collier and Michael Gondwe (eds.), Zambia: Building Prosperity from Resource Wealth (Oxford: Oxford University Press, 2014).

Adam, Christopher S. and Antony M. Simpasa, 'The Economics of the Copper Price Boom in Zambia', in Alastair Fraser and Miles Larmer (eds.), Zambia, Mining, and Neoliberalism: Boom and Bust on the Globalized Copperbelt (New York: Palgrave Macmillan, 2010), pp. 59-90.

Adu Boahen, Albert, African Perspectives on European Colonialism (Baltimore, MD: Johns Hopkins University Press, 2011).

Afigbo, Adiele Eberechukwu, The Warrant Chiefs: Indirect Rule in Southern-Eastern Nigeria 1891-1927 (London: Longman, 1972).

Anderson, David M. and Richard Rathbone (eds.), Africa's Urban Past (Oxford: James Currey, 2000).

Arrighi, Giovanni and John S. Saul (eds.), Essays on the Political Economy of Africa (New York: Monthly Review Press, 1973).

Auty, Richard, 'Mining Enclave to Economic Catalyst: Large Mineral Projects in Developing Countries', Brown Journal of World Affairs, 13, 1 (2006), pp. 136-45.

Azhar, Shahram and Danish Khan, 'Rethinking Informal Labor in Peripheral Capitalism: The Dynamics of Surplus, Market, and Spatiality', Labor History, 61, 3-4 (2020), pp. 320-34.

Balandier, Georges, Afrique Ambiguë (Paris: Plon, 1957). 
Ballantine, Christopher, 'Music and Emancipation: The Social Role of Black Jazz and Vaudeville in South Africa Between the 1920s and the Early 1940s', Journal of Southern African Studies, 17, 1 (1991), pp. 129-52.

Bandeira Jerónimo, Miguel and Damiano Matasci (eds.), 'Imperialism, Internationalism and Globalisation in Twentieth Century Africa', special issue of the Journal of Imperial and Commonwealth History, 48, 5 (2020), pp. 793-804.

Bandeira Jerónimo, Miguel and José Pedro Monteiro, 'Internationalism and the Labours of the Portuguese Colonial Empire', Portuguese Studies, 29, 2 (2013), pp. 142-63.

Bank, Andrew and Leslie J. Bank (eds.), Inside African Anthropology: Monica Wilson and Her Interpreters (New York: Cambridge University Press, 2013).

Barber, Karin, Print Culture and the First Yoruba Novel: I. B. Thomas's 'Life Story of Me, Segilola' and Other Texts (Leiden: Brill, 2012).

Barker-Ciganikova, Martina, Kirsten Ruther, Daniela Waldburger and CarlPhilipp Bodenstein (eds.), The Politics of Housing in (Post-)Colonial Africa: Accommodating Workers and Urban Residents (Berlin: De Gruyter, 2020).

Barnes, Teresa, 'The Fight for Control of African Women's Mobility in Colonial Zimbabwe, 1900-1939', Signs, 17 (1992), pp. 586-608.

Bates, Robert H., Unions, Parties and Political Development: A Study of Mineworkers in Zambia (New Haven, CT: Yale University Press, 1971).

Bates, Robert H., Markets and States in Tropical Africa: The Political Basis of Agricultural Policies (Berkeley: University of California Press, 1981).

Bates, Robert H. and Paul Collier, 'The Politics and Economics of Policy Reform in Zambia', Journal of African Economies, 4, 1 (1995), pp. 115-43.

Berger, Elena, Labour, Race and Colonial Rule: The Copperbelt from 1924 to Independence (Oxford: Oxford University Press, 1974).

Berger Gluck, Sherna and Daphne Patai (eds.), Women's Words: The Feminist Practice of Oral History (New York: Routledge, 1991).

Berman, Bruce J., 'Ethnography as Politics, Politics as Ethnography: Kenyatta, Malinowski, and the Making of Facing Mount Kenya', Canadian Journal of African Studies, 30, 3 (1996), pp. 13-44.

Berman, Bruce J., 'Ethnicity, Patronage and the African State: The Politics of Uncivil Nationalism', African Affairs, 97, 388 (1998), pp. 305-41.

Bernards, Nick, 'Placing African Labour in Global Capitalism: The Politics of Irregular Work', Review of African Political Economy, 46, 160 (2019), pp. 294-303. 
Bézy, Fernand, 'Belgian Congo 1951-52', Civilisations, 3, 2 (1953), pp. 293-7.

Bierschenk, Thomas, 'Sedimentation, Fragmentation and Normative Double-Binds in (West) African Public Services', in Thomas Bierschenk and Jean-Pierre Olivier de Sardan (eds.), States at Work: Dynamics of African Bureaucracies (Leiden: Brill, 2014), pp. 221-45.

Bissell, William Cunningham, 'Engaging Colonial Nostalgia', Cultural Anthropology, 20, 2 (2008), pp. 215-48.

Bloch, Robin and George Owusu, 'Linkages in Ghana's Gold Mining Industry: Challenging the Enclave Thesis', Resources Policy, 3, 4 (2012), pp. 434-42.

Bonneuil, Christophe and Jean-Baptiste Fressoz, The Shock of the Anthropocene: The Earth, History and Us (Brooklyn, NY: Verso, 2016).

Borges, Marcelo J. and Susana B. Torres (eds.), Company Towns: Labor, Space, and Power Relations Across Time and Continents (New York: Palgrave Macmillan, 2012).

Bostock, Michael and Charles Harvey, Economic Independence and Zambian Copper: A Case Study of Foreign Investment (New York: Praeger, 1972).

Bratton, Michael and Nicolas Van de Walle, Democratic Experiments in Africa: Regime Transitions in Comparative Perspective (Cambridge: Cambridge University Press, 1997).

Brenner, Robert, The Economics of Global Turbulence (London: Verso, 2006).

Brion, René and Jean Louis Moreau, De la Mine à Mars: La Génèse d'Umicore (Tielt: Lanoo, 2006).

Britwum, Akua O. and Leyla Dakhli, 'Labour and the State', in Stefano Bellucci and Andreas Eckert (eds.), General Labour History of Africa (Oxford: James Currey, 2019), pp. 495-522.

Brown, Carolyn, 'We Were All Slaves': African Miners, Culture, and Resistance at the Enugu Government Colliery (Portsmouth, NH: Heinemann, 2003).

Brubaker, Rogers, Grounds for Difference (Cambridge, MA: Harvard University Press, 2015).

Bruneau, Jean-Claude, D'Ici et D’Ailleurs: Quand les Immigrés se Font Autochtones: Citadins et Paysans du Haut Katanga (Yaoundé: Presses Universitaires de Yaoundé, 1999).

Burawoy, Michael, The Colour of Class on the Copper Mines: From African Advancement to Zambianization (Lusaka: UNZA Institute of African Studies, 1971).

Burawoy, Michael, 'The Hidden Abode of Under-Development: Labour Process and the State in Zambia', Politics and Society, 11, 2 (1982), pp. 123-66. 
Burdette, Marcia, 'Nationalization in Zambia: A Critique of Bargaining Theory', Canadian Journal of African Studies, 11, 3 (1977), pp. 471-96.

Büscher, Karen and Gillian Mathys, 'Navigating the Urban "In-Between Space": Local Livelihood and Identity Strategies in Exploiting the Goma/ Gisenyi Border', in Benedikt Korf and Timothy Raeymaekers (eds.), Violence on the Margins: States, Conflicts and Borderlands (New York: Palgrave Macmillan, 2013), pp. 119-42.

Bustin, Edouard, Lunda under Belgian Rule (Cambridge, MA: Harvard University Press, 1975).

Caprasse, Pierre, Leaders Africains en Milieu Urbain (Brussels: CEPSI, 1959).

Castryck, Geert (ed.), 'The Bounds of Berlin's Africa: Space-Making and Multiple Territorialities in East and Central Africa', special issue of the International Journal of African Historical Studies, 52, 1 (2019), pp. 1-158.

Chakrabarthy, Dipesh, Provincializing Europe: Postcolonial Thought and Historical Difference (Princeton, NJ: Princeton University Press, 2000).

Chanock, Martin, Law, Customs and Social Order: The Colonial Experience in Malawi and Zambia (Cambridge: Cambridge University Press, 1985).

Chatterjee, Partha, The Nation and Its Fragments: Colonial and Postcolonial Histories (Princeton, NJ: Princeton University Press, 1993).

Chatterjee, Partha, Nationalist Thought and the Colonial World: A Derivative Discourse (Minneapolis: University of Minnesota Press, 1993 [1986]).

Chauncey Jr., George, 'The Locus of Reproduction: Women's Labour in the Zambian Copperbelt, 1927-1953', Journal of Southern African Studies, 7, 2 (1981), pp. 135-64.

Chibamba Chansa, Jennifer, 'Houses Built on Copper: The Environmental Impact of Current Mining Activities on "Old" and "New" Zambian Copperbelt Communities', in Miles Larmer, Enid Guene, Benoît Henriet, Iva Peša and Rachel Taylor (eds.), Across the Copperbelt: Urban and Social Change in Central Africa's Borderland Communities (Oxford: James Currey, 2021), pp. 233-63.

Chipande, Hikabwa D., 'Mining for Goals: Football and Social Change on the Zambian Copperbelt, 1940s-1960s', Radical History Review, 12 (2016), pp. 55-73.

Clémens, René, 'Le Développement des Sciences Sociales et le Congo Belge', CEPSI Bulletin, 31 (1955), pp. 87-96.

Coetzee, Paulette, 'Dancing with Difference: Hugh Tracey on and in (African) Music', Safundi, 16, 4 (2015), pp. 396-418.

Coetzee, Paulette, 'Hugh Tracey, African Music and Colonial Power: Correspondence with Government Officials in the 1950s', South African Music Studies, 36-37, 1 (2018), pp. 83-109. 
Cohen, Abner, Custom and Politics in Urban Africa: A Study of Hausa Migrants in Yoruba Towns (Abingdon, UK: Routledge, 2004 [1969]).

Coleman, James S., Nationalism and Development in Africa: Selected Essays (Berkeley: University of California Press, 1994).

Coontz, Stephanie, The Way We Never Were: American Families and the Nostalgia Trap (New York, Basic Books, 2016 [1992]).

Cooper, Frederick, Decolonization and African Society: The Labor Question in French and British Africa (Cambridge: Cambridge University Press, 1996).

Cooper, Frederick, 'The Dialectics of Decolonization: Nationalism and Labor Movements in Post-War French Africa', in Frederick Cooper and Ann Stoler (eds.), Tensions of Empire: Colonial Cultures in a Bourgeois World (Berkeley: University of California Press, 1997), pp. 406-35.

Cooper Frederick, and Randall M. Packard (eds.), International Development and the Social Sciences: Essays on the History and Politics of Knowledge (Berkeley: University of California Press, 1998).

Coulter, Charles M., 'The Sociological Problem', in John Merle Davis, Modern Industry and the African (London: Macmillan, 1933), pp. 31-87.

Couttenier, Maarten, 'Between Regionalization and Centralization: The Creation of the Musée Léopold II in Elisabethville (Musée national de Lubumbashi), Belgian Congo (1931-1961)', History and Anthropology, 25, 1 (2014), pp. 72-101.

Craig, John, 'Evaluating Privatisation in Zambia: A Tale of Two Processes', Review of African Political Economy, 27, 85 (2005), pp. 357-66.

Crine-Mavar, Bruno, 'Histoire Traditionnelle du Shaba', Cultures au Zaïre et en Afrique, 1 (1973), pp. 17-26.

Crosby, Alfred, Ecological Imperialism: The Biological Expansion of Europe, 900-1900 (Cambridge: Cambridge University Press, 2004 [1986]).

Cross, Sholto, 'Politics and Criticism in Zambia: A Review Article', Journal of Southern African Studies, 1, 1 (1974), pp. 109-15.

Curtis, Devon, 'China and the Insecurity of Development in the Democratic Republic of the Congo (DRC)', International Peacekeeping, 20, 5 (2013), pp. 551-69.

Cuvelier, Jeroen, 'Men, mines and masculinities: the lives and practices of artisanal miners in Lwambo (Katanga province, DR Congo)', unpublished $\mathrm{PhD}$ thesis, University of Ghent (2011).

Daniel, Philip, Africanisation, Nationalisation and Inequality (Cambridge: Cambridge University Press, 1979).

Darwin, John, 'What Was The Late Colonial State?', Itinerario, 23, 3-4 (1999), pp. 73-82.

Daviron, Benoit, 'Mobilizing Labour in African Agriculture: The Role of the International Colonial Institute in the Elaboration of a Standard of 
Colonial Administration, 1895-1930', Journal of Global History, 5, 3 (2010), pp. 479-501.

de Boeck, Filip and Marie-Francoise Plissart, Kinshasa: Tales of the Invisible City (Leuven: Leuven University Press, 2014).

DeRoche, Andy, 'KK, the Godfather, and the Duke: Maintaining Positive Relations between Zambia and the USA in Spite of Nixon's Other Priorities', Safundi, 12, 1 (2011), pp. 97-121.

Dethier, Robert, Une Famille de Citadins au Katanga (Liège: Institut de Sociologie, 1961).

Dibwe dia Mwembu, Donatien, Bana Shaba Abandonnés par Leur Père: Structures de L'Autorité et Histoire Sociale de la Famille Ouvrière au Katanga, 1910-1997 (Paris: L'Harmattan, 2001).

Dibwe dia Mwembu, Donatien, Histoire des Conditions de Vie des Travailleurs de L'Union Minière du Haut Katanga/Gécamines (1910-1999) (Lubumbashi: Presses Universitaire de Lubumbashi, 2001).

Dibwe dia Mwembu, Donatien, 'Le Rôle Social de l'Université de Lubumbashi', in Bogumil Jewsiewicki and Véronique Klauber (eds.), Université de Lubumbashi 1990-2002: Société en Détresse, Pari sur L'Avenir (Paris: L'Harmattan, 2003), pp. 1-120.

Dibwe dia Mwembu, Donatien, 'État de la Question sur le Conflit KatangaisKasaien dans la Province du Katanga (1990-1994)', in Bogumil Jewsiewicki and Leonard N'Sanda Buleli (eds.), Constructions, Négociations et Dérives des Identités Régionales dans les États des Grands Lacs Africains: Approche Comparative (Laval: Université Laval, 2005), pp. 9-48.

Dibwe dia Mwembu, Donatien, 'La Réharmonisation des Rapports entre les Katangais et les Kasaïens dans la Province du Katanga (1991-2005)', Anthropologie et Sociétés, 30, 1 (2006), pp. 117-34.

Dibwe dia Mwembu, Donatien, 'Let's Laugh It Off: Mufwankolo's Theatre and the Quest for Morality' in Danielle de Lame and Ciraj Rassool (eds.), Popular Snapshots and Tracks to the Past: Cape Town, Nairobi, Lubumbashi (Tervuren: RMCA, 2010), pp. 141-62.

Dibwe dia Mwembu, Donatien, 'Historical Knowledge Production at the University of Lubumbashi (1956-2018)', in Miles Larmer, Enid Guene, Benoît Henriet, Iva Peša and Rachel Taylor (eds.), Across the Copperbelt: Urban and Social Change in Central Africa's Borderland Communities (In Press, Oxford: James Currey, 2021), pp. 296-320.

Dibwe dia Mwembu, Donatien and Bogumil Jewsiewicki, Le Travail Hier et Aujourd'hui: Mémoires de Lubumbashi (Paris: L'Harmattan, 2004).

Dobler, Gregor, 'The Green, the Grey and the Blue: A Typology of Cross-Border Trade in Africa', Journal of Modern African Studies, 54, 1 (2016), pp. 145-69. 
Doucy, Arthur and Pierre Feldheim, Problèmes $d u$ Travail et Politique Sociale au Congo Belge (Brussels: Editions de la Librairie Encyclopédique, 1952).

Eckert, Andreas, 'Regulating the Social: Social Security, Social Welfare and the State in Late Colonial Tanzania', Journal of African History, 45, 3 (2004), pp. 467-89.

Editors, 'AMSAC's Afros', Ramparts magazine, June 1969 (Menlo Park CA), pp. 26-33.

Eggers, Nicole, 'Kitawala in the Congo: religion, politics and healing in 20th21st century Central African history', unpublished PhD thesis, University of Wisconsin (2013).

Engel, Ulf and Paul Nugent (eds.), Respacing Africa (Brill: Leiden, 2010).

Epstein, Arnold L., Politics in an Urban African Community (Manchester, UK: Manchester University Press, 1958).

Evans, Alice, "Women Can Do What Men Can Do": The Causes and Consequences of Growing Flexibility in Gender Divisions of Labour in Kitwe, Zambia', Journal of Southern African Studies, 40, 5 (2014), pp. 981-98.

Faber, Michael L. O. and James G. Potter, Towards Economic Independence: Papers on the Nationalization of the Copper Industry in Zambia (Cambridge: Cambridge University Press, 1971).

Fabian, Johannes, Jamaa: A Charismatic Movement in Katanga (Evanston, IL: Northwestern University Press, 1971).

Fabian, Johannes, Power and Performance: Ethnographic Explorations Through Proverbial Wisdom and Theater in Shaba, Zaire (Madison: University of Wisconsin Press, 1990).

Fabian, Johannes, Remembering the Present: Painting and Popular History in Zaire (Berkeley: University of California Press, 1996).

Fabian, Johannes, Moments of Freedom: Anthropology and Popular Culture (Charlottesville: University of Virginia Press, 1998).

Fabian, Johannes, Time and the Other: How Anthropology Makes Its Object (New York: Columbia University Press, 2014 [1983]).

Fabian, Johannes and Ilona Szomati-Fabian, 'Folk Art From an Anthropological Perspective', in Ian M. G. Quimby and Scott T. Swank (eds.), Perspectives on American Folk Art (New York: W. W. Norton, 1980), pp. 247-92.

Fair, Laura, Pastimes and Politics: Culture, Community and Identity in PostAbolition Zanzibar, 1890-1945 (Oxford: James Currey, 2001).

Falola, Toyin, Nationalism and African Intellectuals (Rochester, NY: University of Rochester Press, 2004).

Feierman, Steven, Peasant Intellectuals: Anthropology and History in Tanzania (Madison: University of Wisconsin Press, 1990). 
Felber, Garrett, 'Tracing Tribe: Hugh Tracey and the Cultural Politics of Retribalisation', South African Music Studies, 30-31, 1 (2010), pp. 31-43.

Ferguson, James, Expectations of Modernity: Myths and Meanings of Urban Life on the Zambian Copperbelt (Berkeley: University of California Press, 1999).

Ferguson, James, 'Proletarian Politics Today: On the Perils and Possibilities of Historical Analogy', Comparative Studies in Society and History, 61, 1 (2019), pp. 4-22.

Fetter, Bruce, 'The Luluabourg Revolt at Elisabethville', African Historical Studies, 2, 2 (1969), pp. 269-77.

Fetter, Bruce, The Creation of Elisabethville (Stanford, CA: Hoover Institution Press, 1976).

Fields, Karen E., Revival and Rebellion in Colonial Central Africa (Princeton, NJ: Princeton University Press, 1985).

Filene, Benjamin, "Our Singing Country": John and Alan Lomax, Leadbelly, and the Construction of an American Past', American Quarterly, 43, 4 (1991), pp. 602-24.

Finnegan, Diarmid A., 'The Spatial Turn: Geographical Approaches in the History of Science', Journal of the History of Biology, 41 (2008), pp. 369-88.

Fraiture, Pierre-Philippe, "VY Mudimbe: from the "Nation" to the "Global" - Who is the Master?', Journal of Historical Sociology, 27, 3 (2014), pp. 324-42.

Fraser, Alastair and John Lungu, For Whom the Windfalls? Winners and Losers in the Privatisation of Zambia's Copper Mines (Lusaka: Civil Society Trade Network of Zambia, 2007).

Freund, Bill, Capital and Labour in the Nigerian Tin Mines (Harlow, UK: Longman, 1981).

Gardner, Leigh, 'The Fiscal History of the Belgian Congo in Comparative Perspective', in Frans Buelens and Ewout Frankema (eds.), Colonial Exploitation and Economic Development: The Belgian Congo and the Netherlands Indies Compared (Abingdon, UK: Routledge, 2013), pp. 130-52.

Geenen, Kristien, 'Gnawing Away at the City: Narratives of Domestic Precarity in a Congolese Mining Town', African Studies Review (2020), pp. 1-22. doi:10.1017/asr.2020.65.

Gérard-Libois, Jules, Katanga Secession (Madison: University of Wisconsin Press, 1966).

Gérard-Libois, Jules, ' $L$ 'Affaire $U M H K$ ' in Centre de Recherche et d'Information Socio-Politiques-INEP, Congo 1967 (Brussels/Kinshasa: CRISP, 1969), pp. 471-85. 
Gertzel, Cherry (ed.), Carolyn Baylies and Morris Szeftel, The Dynamics of the One-Party State in Zambia (Manchester, UK: Manchester University Press, 1984).

Gewald, Jan-Bart, Marja Hinfelaar and Giacomo Macola (eds.), One Zambia, Many Histories: Toward a History of Post-Colonial Zambia (Leiden: Brill, 2008).

Gewald, Jan-Bart, Marja Hinfelaar and Giacomo Macola (eds.), Living the End of Empire: Politics and Society in Late Colonial Zambia (Leiden: Brill, 2011).

Gewald, Jan-Bart and Sebastiaan Souters, 'African Miners and ShapeShifting Capital Flight: The Case of Luanshya/Baluba', in Alastair Fraser and Miles Larmer (eds.), Zambia, Mining, and Neoliberalism: Boom and Bust on the Globalized Copperbelt (New York: Palgrave Macmillan, 2010), pp. 155-83.

Gille, Albert and Ferdinand Grévisse, 'The Social and Scientific Role of C.E. P.S.I.', African Affairs, 49, 195 (1950), pp. 151-57.

Gluckman, Max, Custom and Conflict in Africa (Oxford: Basil Blackwell, 1956).

Gluckman, Max, 'Tribalism in Modern British Central Africa', Cahiers d'études africaines, 1, 1 (1960), pp. 55-70.

Gobbers, Erik, 'Ethnic Associations in Katanga Province, the Democratic Republic of Congo: Multi-Tier System, Shifting Identities and the Relativity of Autochthony', Journal of Modern African Studies, 54, 2 (2016), pp. 211-36.

Gondola, Ch. Didier, The History of Congo (Westport, CT: Greenwood Press, 2002).

Gordon, David M., Nachituti's Gift: Economy, Society, and Environment in Central Africa (Madison: University of Wisconsin Press, 2006).

Gordon, David M., Invisible Agents: Spirits in a Central African History (Athens: Ohio University Press, 2012).

Gordon, David M., 'Kingdoms and Associations: Copper's Changing Political Economy During the Nineteenth Century', in Miles Larmer, Enid Guene, Benoît Henriet, Iva Peša and Rachel Taylor (eds.), Across the Copperbelt: Urban and Social Change in Central Africa's Borderland Communities (Oxford: James Currey, 2021), pp. 155-178.

Grévisse, Ferdinand, Le Centre Extra-Coutumier D’Elisabethville: Quelques Aspects de la Politique Indigène du Haut-Katanga Industriel (Brussels: CEPSI, 1951).

Grévisse, Ferdinand, 'Notes Ethnographiques Relatives à Quelques Populations Autochtones du H-K Industriel', CEPSI Bulletin, 32 (1956), pp. 65-207.

Groves, Zoe R., Malawian Migration to Zimbabwe, 1900-1965: Tracing Machona (London: Palgrave Macmillan, 2020). 
Gruhn, Isebill V., 'The Commission for Technical Co-Operation in Africa, 1950-65', Journal of Modern African Studies, 9, 3 (1971), pp. 459-69.

Guene, Enid, 'Copper's Corollaries: Trade and Labour Migration in the Copperbelt (1910-1940)', Zambia Social Science Journal, 4, 1 (2013).

Guene, Enid, Copper, Borders and Nation-Building: The Katangese Factor in Zambian Political and Economic History (Leiden: African Studies Centre, 2017).

Guene, Enid, 'Artistic Movements: Painting and Cross-Border Exchange on the Central African Copperbelt' (2021), article under review.

Habasonda, Lee M., 'Corruption, Ethnicity and Violence as a Triple Political Strategy: The Changing Face of Politics in Zambia' [policy paper], Paris: Institut Français des Relations Internationals (Ifri), 2018, September.

Haglund, Dan, 'In It for the Long Term? Governance and Learning among Chinese Investors in Zambia's Copper Sector', China Quarterly, 199 (2009), pp. 627-46.

Hairong, Yan and Barry Sautman, “"The Beginning of a World Empire”? Contesting the Discourse of Chinese Copper Mining in Zambia', Modern China, 39, 2 (2013), pp. 131-64.

Hall, Barbara (ed.), Tell Me Josephine (London: Andre Deutsch, 1964).

Hall, Richard, Zambia, 1890-1964: The Colonial Period (London: Longman, 1976).

Harries, Patrick, Work, Culture and Identity: Migrant Laborers in Mozambique and South Africa, c.1860-1910 (Portsmouth, NH: Heinemann, 1994).

Harries-Jones, Peter, "Home-Boy" Ties and Political Organisation in a Copperbelt Township', in James Clyde Mitchell (ed.), Social Networks in Urban Situations: Analyses of Personal Relationships in Central African Towns (Manchester, UK: Manchester University Press, 1969), pp. 297-347.

Harries-Jones, Peter, Freedom and Labour: Mobilization and Political Control on the Zambian Copperbelt (Oxford: Basil Blackwell, 1975).

Harvey, David, 'The Right to the City', New Left Review, 53 (2008, September/October).

Haynes, Naomi, Moving by the Spirit: Pentecostal Social Life on the Zambian Copperbelt (Oakland: University of California Press, 2017).

Hecht, Gabrielle, Being Nuclear: Africans and the Global Uranium Trade (Cambridge, MA: MIT Press, 2012).

Heinze, Robert, "'Men Between": The Role of Zambian Broadcasters in Decolonisation', Journal of Southern African Studies, 40, 3 (2014), pp. 623-40. 
Heisler, Helmuth, 'The Creation of a Stabilized Urban Society: A Turning Point in the Development of Northern Rhodesia/Zambia', African Affairs, 70, 279 (1971), pp. 125-45.

Henk, Daniel W., 'Kazi ya Shaba: choice, continuity, and social change in an industrial community of southern Zaire', unpublished $\mathrm{PhD}$ thesis, University of Florida (1988).

Henriet, Benoît, 'Making the Post-Colonial University: Authenticité, Decolonality and Knowledge Production in Lubumbashi, 1971-1981' (2021), article under review.

Higginson, John, A Working-Class in the Making: Belgian Colonial Labor Policy, Private Enterprise, and the African Mineworker, 1907-1951 (Madison: University of Wisconsin Press, 1989).

Higginson, John, 'Liberating the Captives: Independent Watchtower as an Avatar of Colonial Revolt in Southern Africa and Katanga, 1908-1941', Journal of Social History, 26, 1 (1992), pp. 55-80.

Hironaka, Ann, 'The Globalization of Environmental Protection: The Case of Environmental Impact Assessment', International Journal of Comparative Sociology, 43, 1 (2002), pp. 65-78.

Hobart Houghton, Desmond, The South African Worker (Oxford: Oxford University Press, 1964).

Hodgkin, Thomas, Nationalism in Colonial Africa (London: Frederick Muller, 1956).

Hodgkinson, Dan, 'Nationalists with no Nation: Oral History, ZANU(PF) and the Meanings of Rhodesian Student Activism in Zimbabwe', Africa, 89, S1 (2019), pp. S40-S64.

Hodgkinson, Dan and Luke Melchiorre (eds.), 'Student Activism in an Era of Decolonization', special issue of Africa, 89, S1 (2019).

Hughes, Matthew, 'Fighting for White Rule in Africa: The Central African Federation, Katanga, and the Congo Crisis, 1958-1965', International History Review, 25, 3 (2003), pp. 596-615.

Hunt, Nancy Rose, “Le Bebe en Brousse”: European Women, African Birth Spacing and Colonial Intervention in Breast Feeding in the Belgian Congo', International Journal of African Historical Studies, 21, 3 (1988), pp. 401-32.

Hunt, Nancy Rose, A Nervous State: Violence, Remedies, and Reverie in Colonial Congo (Durham, NC: Duke University Press, 2016).

Hunter, Emma, Political Thought and the Public Sphere in Tanzania: Freedom, Democracy and Citizenship in the Era of Decolonization (Cambridge: Cambridge University Press, 2015).

Jamal, Vali and John Weeks, Africa Misunderstood: Or Whatever Happened to the Rural-Urban Gap? (London: Macmillan, 1993). 
Jennings, Michael, 'Building Better People: Modernity and Utopia in Late Colonial Tanganyika', Journal of Eastern African Studies, 3, 1 (2009), pp. 94-111.

Jewsiewicki, Bogumil, 'La Contestation Sociale et la Naissance du Prolétariat au Zaïre au Cours de la Première Moitié du XXe Siècle', Canadian Journal of African Studies, 10, 1 (1976), pp. 47-71.

Jewsiewicki, Bogumil, Mami Wata: La Peinture Urbaine au Congo (Paris: Gallimard, 2003).

Jewsiewicki, Bogumil, The Beautiful Time: Photography by Sammy Baloji (Seattle: University of Washington Press, 2010).

Jewsiewicki, Bogumil, 'Photographe de L'Absence: Sammy Baloji et les Paysages Industriels Sinistrés de Lubumbashi', L’Homme, 198-9, 2 (2011), pp. 89-103.

Jewsiewicki, Bogumil, 'A Century of Popular Art in the Congo', in Gitti Salami and Monica Blackmun Visona (eds.), A Companion to Modern African Art (Chichester, UK: Wiley Blackwell, 2013), pp. 330-46.

Jewsiewicki, Bogumil, 'This is Not a Painting', in Bambi Ceuppens and Sammy Baloji (eds.), Congo Art Works: Popular Painting (Tielt: Lannoo, 2016), pp. 19-45.

Jules-Rosette, Bennetta, The Messages of Tourist Art: An African Semiotic System in Comparative Perspective (New York: Springer, 1984).

Kaavu, Enoch, Namusiya at the Mines (London: Longman, 1949).

Kaldor, Mary, 'The Idea of Global Civil Society', International Affairs, 79, 3 (2003), pp. 583-93.

Kallmann, Deborah, 'Projected Moralities, Engaged Anxieties: Northern Rhodesia's Reading Publics, 1953-1964', International Journal of African Historical Studies, 32, 1 (1999), pp. 71-117.

Kalusa, Walima T., 'Death, Christianity, and African Miners: Contesting Indirect Rule in the Zambian Copperbelt, 1935-1962', International Journal of African Historical Studies, 44, 1 (2011), pp. 89-112.

Kalusa, Walima T., 'The Killing of Lilian Margaret Burton and Black and White Nationalisms in Northern Rhodesia (Zambia) in the 1960s', Journal of Southern African Studies, 37, 1 (2011), pp. 63-77.

Kapesa, Robby and Tom McNamara, "“We Are Not Just a Union, We Are a Family": Class, Kinship and Tribe in Zambia's Mining Unions', Dialectical Anthropology, 44 (2020), pp. 153-72.

Kapferer, Bruce, 'Situations, Crisis, and the Anthropology of the Concrete: The Contribution of Max Gluckman', Social Analysis, 49, 3 (2005), pp. 85-122.

Katzenellenbogen, Simon, 'It Didn't Happen at Berlin: Politics, Economics and Ignorance in the Setting of Africa's Colonial Boundaries', in Paul Nugent and Anthony I. Asiwaju (eds.), African Boundaries: 
Barriers, Conduits and Opportunities (Edinburgh: Edinburgh University Press, 1996), pp. 21-34.

Kaunda, Kenneth D., A Humanist in Africa: Letters to Colin M. Morris from Kenneth D. Kaunda (London: Longmans, 1966).

Kaunda, Kenneth, Zambia: Independence and Beyond (London: Thomas Nelson, 1966).

Kennes, Erik and Miles Larmer, The Katangese Gendarmes and War in Central Africa: Fighting Their Way Home (Bloomington: Indiana University Press, 2016).

Koloko, Leonard, Zambian Music Legends (Morrisville, NC: Lulu.com, 2012).

Lämmert, Stephanie, 'Reimagining the Copperbelt as a Religious Space', in Miles Larmer, Enid Guene, Benoît Henriet, Iva Peša and Rachel Taylor (eds.), Across the Copperbelt: Urban and Social Change in Central Africa's Borderland Communities (Oxford: James Currey, 2021), pp. 347-72.

Larmer, Miles, 'Zambia's mineworkers and political change, 1964-1991', unpublished $\mathrm{PhD}$ thesis, University of Sheffield (2004).

Larmer, Miles, Mineworkers in Zambia: Labour and Political Change in Post-Colonial Africa (London: IB Tauris, 2007).

Larmer, Miles, 'Zambia Since 1990: Paradoxes of Democratic Transition', in Abdul R. Mustapha and Lindsay Whitfield (eds.), Turning Points in African Democracy (Oxford: James Currey, 2009), pp. 114-33.

Larmer, Miles, Rethinking African Politics: A History of Opposition in Zambia (Farnham: Ashgate, 2010).

Larmer, Miles, 'Local Conflicts in a Transnational War: The Katangese Gendarmes and the Shaba Wars of 1977-78', Cold War History, 13, 1 (2013), pp. 89-108.

Larmer, Miles, 'Permanent Precarity: Capital and Labour in the Central African Copperbelt', Labor History, 58, 2 (2017), pp. 170-84.

Larmer, Miles, 'Nation-Making at the Border: Zambian Diplomacy in the Democratic Republic of Congo', Comparative Studies in Society and History, 61, 1 (2019), pp. 145-75.

Larmer, Miles and Alastair Fraser, 'Of Cabbages and King Cobra: Populist Politics and Zambia’s 2006 Election', African Affairs, 106, 425 (2007), pp. 611-37.

Larmer, Miles and Erik Kennes, 'Rethinking the Katangese Secession', Journal of Imperial and Commonwealth History, 42, 4 (2014), pp. 741-61.

Larmer, Miles and Baz Lecocq, 'Historicising Nationalism in Africa', Nations and Nationalism, 24, 4 (2018), pp. 893-917. 
Larmer, Miles and Rachel Taylor, 'The Decolonisation of Community Development in Haut Katanga and the Zambian Copperbelt, 1945 to 1990', in Miles Larmer, Enid Guene, Benoît Henriet, Iva Peša and Rachel Taylor (eds.), Across the Copperbelt: Urban and Social Change in Central Africa's Borderland Communities (Oxford: James Currey, 2021), pp. 321-46.

Lauro, Amandine, 'The British, The French and Even the Russians Use These Methods: Psychology, Mental Testing and (Trans)Imperial Dynamics of Expertise Production in Late Colonial Congo', in Miles Larmer, Enid Guene, Benoît Henriet, Iva Peša and Rachel Taylor (eds.), Across the Copperbelt: Urban and Social Change in Central Africa's Borderland Communities (Oxford: James Currey, 2021), pp. 267-95.

Lawrance, Benjamin, Emily L. Osborn and Richard L. Roberts (eds.), Intermediaries, Interpreters, and Clerks: African Employees in the Making of Colonial Africa (Madison: University of Wisconsin Press, 2006).

Lawrence, Peter and Morris Szeftel, 'Obituary: Lionel Cliffe, 1936-2013', Review of African Political Economy, 41, 104 (2014), pp. 288-91.

LeCain, Timothy J., Mass Destruction: The Men and Giant Mines That Wired America and Scarred the Planet (New Brunswick, NJ: Rutgers University Press, 2009).

Lefebvre, Henri, Le Droit à la Ville (Paris: Anthropos, 1968).

Lefebvre, Henri, The Production of Space (Oxford: Blackwell, 1991 [1974]).

Lemarchand, René, 'The Limits of Self-Determination: The Case of the Katanga Secession', American Political Science Review, 56, 2 (1962), pp. 404-16.

Lemarchand, René, 'Katanga: background to secession', unpublished manuscript (1963).

Lemarchand, René, Political Awakening in the Congo (Berkeley: University of California Press, 1964).

Li, Xiaoyang and Yue Maggie Zhou, 'Offshoring Pollution While Offshoring Production', Strategic Management Journal, 38, 11 (2017), pp. 2310-29. Lipton, Michael, Why Poor People Stay Poor: Urban Bias in World Development (Cambridge, MA: Harvard University Press, 1977).

Livsey, Tim, Nigeria's University Age: Reframing Decolonisation and Development (London: Palgrave Macmillan, 2017).

Lobley, Noel, 'The social biography of ethnomusicological field recordings: eliciting responses to Hugh Tracey's “The Sound of Africa” series', unpublished PhD thesis, University of Oxford (2010).

Lungu, John, 'Socio-Economic Change and Natural Resource Exploitation: A Case Study of the Zambian Copper Mining Industry', Development Southern Africa, 25, 5 (2008), pp. 543-60. 
Lynch, Gabrielle, I Say to You: Ethnic Politics and the Kalenjin in Kenya (Chicago, IL: Chicago University Press, 2011).

Lynch, Gabrielle and Gordon Crawford, 'Democratization in Africa 1990-2010: An Assessment', Democratization, 11, 2 (2011), pp. 275-310.

Macmillan, Hugh, 'The Historiography of Transition on the Zambian Copperbelt - Another View', Journal of Southern African Studies, 19, 4 (1993), pp. 681-712.

Macola, Giacomo, 'Imagining Village Life in Zambian Fiction', Cambridge Anthropology, 25, 1 (2005), pp. 1-10.

Macola, Giacomo, Liberal Nationalism in Central Africa (New York: Palgrave, 2010).

Macola, Giacomo, The Gun in Central Africa: A History of Technology and Politics (Athens: Ohio University Press, 2016).

Mamdani, Mahmood, Citizen and Subject: Contemporary Africa and the Legacy of Late Colonialism (Princeton, NJ: Princeton University Press, 1996).

Mann, Gregory, "What was the Indigénat? The "Empire of Law" in French West Africa', Journal of African History, 50, 3 (2009), pp. 331-53.

Martin, Phyllis, Leisure and Society in Colonial Brazzaville (New York: Cambridge University Press, 1995).

Matschke, H., 'River Pollution by Mine Effluence in the Kitwe Region', in Zambia Geographical Association Handbook (Lusaka: ZGA, 1974), pp. 125-8.

Maul, Daniel Roger, Luca Puddu and Hakeem Ibikunle Tijani, 'The International Labour Organization', in Stefano Bellucci and Andreas Eckert (eds.), General Labour History of Africa (Oxford: James Currey, 2019), pp. 223-64.

Mbembe, Achille, On the Postcolony (Berkeley: University of California Press, 2001).

McNeill, John Robert and Peter Engelke, The Great Acceleration: An Environmental History of the Anthropocene Since 1945 (Cambridge, UK: Belknap, 2014).

Meebelo, Henry S., Reaction to Colonialism: A Prelude to the Politics of Independence in Northern Zambia 1893-1939 (Manchester, UK: University of Manchester Press/Institute of African Studies, University of Zambia, 1971).

Meebelo, Henry S., Main Currents of Zambian Humanist Thought (Oxford: Oxford University Press, 1973).

Meebelo, Henry S., African Proletarians and Colonial Capitalism: The Origins, Growth and Struggles of the Zambian Labour Movement to 1964 (Lusaka: Kenneth Kaunda Foundation, 1986). 
Merkle, Judith A., Management and Ideology: The Legacy of the International Scientific Management Movement (Berkeley: University of California Press, 1980).

Merle Davis, John, Modern Industry and the African (London: Macmillan, 1933).

Middell, Matthias and Katja Neumann, 'Global History and the Spatial Turn: From the Impact of Area Studies to the Study of Critical Junctures of Globalization', Journal of Global History, 5, 1 (2010), pp. 149-70.

Mijere, Nsolo N. J., 'The mineworkers' resistance to governmental decentralisation in Zambia: nation-building and labor aristocracy in the Third World', unpublished PhD thesis, Brandeis University (1985).

Mitchell, J. Clyde, 'The Kalela Dance: Aspects of Social Relationships Among Urban Africans in Northern Rhodesia', Rhodes Livingstone Institute Papers No. 29 (Manchester, UK: Manchester University Press, 1959).

Mitchell, J. Clyde, Cities, Society and Social Perception: A Central African Perspective (Oxford: Clarendon Press, 1987).

Monaville, Pedro, 'Decolonizing the university: postal politics, the student movement, and global 1968 in the Congo', unpublished $\mathrm{PhD}$ thesis, University of Michigan (2013).

Money, Duncan, “"No matter how much or how little they've got, they can't settle down": a social history of Europeans on the Zambian Copperbelt, 1926-1974', unpublished DPhil thesis, University of Oxford (2016).

Money, Duncan, “"Aliens” on the Copperbelt: Zambianisation, Nationalism and Non-Zambian Africans in the Mining Industry', Journal of Southern African Studies, 45, 5 (2019), pp. 859-75.

Moore, Henrietta and Megan Vaughan, Cutting Down Trees: Gender, Nutrition, and Agricultural Change in the Northern Province of Zambia, 1890-1990 (Oxford: James Currey, 1994).

Mouttoulle, Léopold, Politique Sociale de L'UMHK (Brussels: Mémoire de L'IRCB, 1946).

M'Passou, Denis, Mindolo: A Story of the Ecumenical Movement in Africa (Lusaka: Baptist Printing Ministry, 1983).

Mudimbe, Valentin Y., Autour de la 'Nation': Leçons de Civisme. Introduction (Lubumbashi: Éditions du Mont Noir, 1972).

Mudimbe, Valentin Y., The Invention of Africa: Gnosis, Philosophy and the Order of Knowledge (Bloomington: Indiana University Press, 1988).

Mufuzi, Friday, 'Establishment of the Livingstone Museum and Its Role in Colonial Zambia, 1934-1964', Historia, 56, 1 (2011), pp. 26-41.

Munene, Hyden, 'A history of Rhokana/Rokana Corporation and its Nkana Mine Division, 1928-1991', unpublished PhD thesis, University of the Free State (2018). 
Musambachime, Mwelwa C., 'Dauti Yamba's Contribution to the Rise and Growth of Nationalism in Zambia, 1941-1964', African Affairs, 90, 359 (1991), pp. 259-81.

Musambachime, Mwelwa C., 'The University of Zambia's Institute for African Studies and Social Science Research in Central Africa, 1938-1988', History in Africa, 20 (1993), pp. 237-48.

Musoni, Francis, Border Jumping and Migration Control in Southern Africa (Bloomington: Indiana University Press, 2020).

Mususa, Patience, 'Contesting Illegality: Women in the Informal Copper Business', in Alastair Fraser and Miles Larmer (eds.), Zambia, Mining, and Neoliberalism: Boom and Bust on the Globalized Copperbelt (New York: Palgrave Macmillan, 2010), pp. 185-208.

Mususa, Patience, "Getting By": Life on the Copperbelt After the Privatisation of the Zambia Consolidated Copper Mines', Social Dynamics, 36, 2 (2010), pp. 380-94.

Mususa, Patience, 'There used to be order: life on the Copperbelt after the privatisation of the Zambia Consolidated Copper Mines', unpublished PhD thesis, University of Cape Town (2014).

Mutombo, Ngandu, 'Politiques de rémunération, de cotation et de classification des emplois comme facteurs de formation d'une catégorie sociale. Le cas des travailleurs de L'Union Minière du Haut-Katanga, 1947-1967', unpublished PhD thesis, University of Laval (1996).

Mwabila Malela, Augustin, Travail et Travailleurs au Zaïre: Essai sur la Conscience Ouvrière du Proletariat Urbain de Lubumbashi (Kinshasa: Presses Universitaires du Zaïre, 1979).

Mwanza Mujila, Fiston, Tram 83 (Dallas, TX: Deep Vellum, 2014).

Mwendapole, Matthew, A History of the Trade Union Movement in Zambia up to 1968 (Lusaka: UNZA Institute for African Studies, 1968).

Myers, Garth, African Cities: Alternative Visions of Theory and Practice (London: Zed Books, 2011).

Namikas, Lise, Battleground Africa: The Cold War and the Congo Crisis, 1960-1965 (Stanford, CA: Stanford University Press, 2013).

Newell, Stephanie, Literary Culture in Colonial Ghana: 'How to Play the Game of Life' (Bloomington: Indiana University Press, 2002).

Newell, Stephanie, 'Articulating Empire: Newspaper Readerships in Colonial West Africa', New Formations, 73 (2011), pp. 26-42.

Nkhata, Alick, 'African Music Clubs', African Music Society Newsletter, 1, 5 (1952), pp. 17-20.

Nordlund, Per, Organising the Political Agora: Domination and Democratisation in Zambia and Zimbabwe (Uppsala: Uppsala University, 1996). 
Ntarangwi, Mwenda, Mustafa Babiker and David Mills (eds.), African Anthropologies: History, Critique and Practice (London: Zed Books, 2006).

Nugent, Paul, Boundaries, Communities and State-Making in West Africa: The Centrality of the Margins (Cambridge: Cambridge University Press, 2019).

Nugent, Paul, Sara Dorman and Daniel Hammett (eds.), Citizenship in Africa: Creating Nations, Making Strangers (Leiden: Brill 2007).

Nzongola-Ntajala, Georges, The Congo from Leopold to Kabila: A People's History (London: Zed Books, 2002).

Nzongola-Ntajala, Georges, From Zaire to the Democratic Republic of Congo (Uppsala: Nordic Africa Institute, 2004).

Ohannessian, Sirarpi and Mubanga E. Kashoki (eds.), Language in Zambia (London: International African Institute, 1978).

Omasombo Tshonda, Jean, Pierre Kalenga Ngoy, Médard Kayamba Badie, Joris Krawczyk and Mohamed Laghmouch (eds.), Katanga Vol 1, Peuples et L'Occupation de L'Espace, Monographies des Provinces de la RD Congo (Tervuren: Musée Royal de l'Afrique Centrale, 2018).

Parpart, Jane L., Labour and Capital on the African Copperbelt (Philadelphia, PA: Temple University Press, 1983).

Parpart, Jane L., 'Class and Gender on the Copperbelt: Women in Northern Rhodesian Copper Mining Communities 1926-1964', Boston University African Studies Working Papers, 77 (1983).

Parpart, Jane L., 'The Labour Aristocracy in Africa: The Copperbelt Case 1924-1967’, African Economic History, 13 (1984), pp. 171-91.

Parpart, Jane L., 'The Household and the Mine Shaft: Gender and Class Struggles on the Zambian Copperbelt, 1926-1964', Journal of Southern African Studies, 2, 1 (1986), pp. 36-56.

Passemeiers, Lazlo, Decolonisation and Regional Geopolitics: South Africa and the 'Congo Crisis', 1960-1965 (Abingdon, UK: Routledge, 2019).

Peemans, Jean-Philippe, 'The Social and Economic Development of Zaire since Independence: An Historical Outline', African Affairs, 74, 295 (1975), pp. 148-79.

Perrings, Charles, Black Mineworkers in Central Africa: Industrial Strategies and the Evolution of an African Proletariat in the Copperbelt, 1911-1941 (New York: Africana Publishing, 1979).

Peša, Iva, 'Crops and Copper: Agriculture and Urbanism on the Central African Copperbelt, 1950-2000', Journal of Southern African Studies, 46, 3 (2020), pp. 527-45.

Peša, Iva, 'Mining, Waste and Environmental Thought', Environment and History (2020), https://doi.org/10.3197/096734019X15755402985703. 
Peterson, Derek R., Ethnic Patriotism and the East African Revival, c.1935-1972 (Cambridge: Cambridge University Press, 2012).

Pollen, Gabriel, 'From total factor productivity to structural change: interrogating economic growth and structural transformation from a developing country perspective with reference to Zambia', unpublished PhD thesis, SOAS (2018).

Poncelet, Marc, L'Invention des Sciences Coloniales Belges (Paris: Karthala, 2008).

Potts, Deborah, 'Counter-Urbanisation on the Zambian Copperbelt? Interpretations and Implications', Urban Studies, 42, 4 (2005), pp. 583-609.

Powdermaker, Hortense, Copper Town: Changing Africa (New York: Harper and Row, 1962).

Powdermaker, Hortense, Stranger and Friend: The Way of an Anthropologist (New York: W. W. Norton, 1966).

Racanelli, David, 'Revisiting the Katanga Guitar Style(s)', Black Music Research Journal, 36, 1 (2016), pp. 31-57.

Rakner, Lise, Political and Economic Liberalisation in Zambia 1991-2001 (Uppsala: Nordic Africa Institute, 2003).

Ranger, Terence O., 'Towards a Usable African Past', in Christopher H. Fyfe (ed.), African Studies Since 1945: A Tribute to Basil Davidson (London: Longman, 1976), pp. 28-39.

Ranger, Terence O., 'The Invention of Tradition in Colonial Africa', in Eric Hobsbawm and Terence Ranger, The Invention of Tradition (Cambridge: Cambridge University Press, 1983), pp. 211-63.

Ranger, Terence O., 'The Invention of Tradition Revisited: The Case of Colonial Africa', in Terence O. Ranger and Olufemi Vaughan (eds.), Legitimacy and the State in Twentieth Century Africa. Essays in Honour of A. M. H. Kirk-Greene (London: Palgrave Macmillan, 1993), pp. 62-111.

Reno, William, 'Sovereignty and Personal Rule in Zaire', African Studies Quarterly, 1, 3 (1997), pp. 39-64.

Roberts, Andrew, A History of Zambia (London: Heinemann, 1976).

Ross, Corey, Ecology and Power in the Age of Empire: Europe and the Transformation of the Tropical World (Oxford: Oxford University Press, 2017).

Rostow, Walt W., The Stages of Economic Growth: A Non-Communist Manifesto (Cambridge: Cambridge University Press, 1960).

Rotberg, Robert I., The Rise of Nationalism in Central Africa: The Making of Malawi and Zambia, 1873-1964 (Cambridge, MA: Harvard University Press, 1967). 
Rubbers, Benjamin, 'Claiming Workers' Rights in the Democratic Republic of Congo: The Case of the Collectif des Ex-Agents de la Gécamines', Review of African Political Economy, 37, 125 (2010), pp. 329-44.

Rubbers, Benjamin, Le Paternalisme en Question: Les Anciens Ouvriers de la Gécamines Face à la Libéralisation du Secteur Minier Katangais (RD Congo) (Paris: L'Harmattan, 2013).

Rubbers, Benjamin and Marc Poncelet, 'Sociologie Coloniale au Congo Belge: Les Études sur le Katanga Industriel et Urbain à la Veille de L'Indépendance', Genèses, 2, 99 (2015), pp. 93-112.

Said, Edward, Orientalism (London: Pantheon, 1978).

Sandbrook, Richard and Robin Cohen (eds.), Development of an African Working-Class (London: Longman, 1975).

Saquet, Jean-Jacques, De L'Union Minière du Haut-Katanga à la Gecamines (Paris: L'Harmattan, 2001).

Sardanis, Andrew, Africa, Another Side of the Coin: Northern Rhodesia's Final Years and Zambia's Nationhood (London: Bloomsbury, 2003).

Scarnecchia, Timothy, 'The Congo Crisis, the United Nations, and Zimbabwean Nationalism, 1960-1963', African Journal on Conflict Resolution, 11, 1 (2011), pp. 63-86.

Schalbroek, Eva Renate M., 'The Commission for the Protection of the Natives and Belgian colonialism in the Congo (1908-1957)', unpublished DPhil thesis, University of Cambridge (2020).

Schumaker, Lyn, Africanizing Anthropology: Fieldwork, Networks, and the Making of Cultural Knowledge in Central Africa (Durham, NC: Duke University Press, 2001).

Scott, Guy, Adventures in Zambian Politics: A Story in Black and White (Boulder, CO: Lynne Rienner Publishers, 2019).

Scott, James S., Seeing Like a State: How Certain Schemes to Improve the Human Condition Have Failed (New Haven, CT: Yale University Press, 1999).

Sharkey, Heather J., 'African Colonial States', in John Parker and Richard Reid (eds.), Oxford Handbook of Modern African History (Oxford: Oxford University Press, 2013), pp. 151-70.

Siegel, Brian, "The "Wild" and "Lazy" Lamba: Ethnic Stereotypes on the Central African Copperbelt', in Leroy Vail (ed.), The Creation of Tribalism in Southern Africa (Oxford: James Currey, 1989), pp. 350-71.

Simone, AbdouMaliq (ed.), Always Something Else: Urban Asia and Africa as Experiment (Basel: Basler Afrika Bibliographien, 2016).

Sishuwa, Sishuwa, “Join Me to Get Rid of This President”: The Opposition, Civil Society and Zambia's 2011 Election', in Tinenenji Banda, 
O'Brien Kaaba, Marja Hinfelaar and Muna Ndulo (eds.), Democracy and Electoral Politics in Zambia (Leiden: Brill, 2020), pp. 11-33.

Spear, Thomas, 'Neo-Traditionalism and the Limits of Invention in British Colonial Africa', Journal of African History, 44, 1 (2003), pp. 3-27.

Stanard, Matthew G., Selling the Congo: A History of European Pro-Empire Propaganda and the Making of Belgian Imperialism (Lincoln: University of Nebraska, 2012).

Stewart, Gary, Rumba on the River: A History of the Popular Music of the Two Congos (London: Verso, 2003).

Stoever, William A., 'A Business Analysis of the Partial Nationalization of Zambia's Copper Industry, 1969-1981', Journal of International Business Studies, 16, 1 (1985), pp. 137-63.

Stoler, Ann Laura, Along the Archival Grain: Epistemic Anxieties and Colonial Common Sense (Princeton, NJ: Princeton University Press, 2008).

Szombati-Fabian, Ilona and Johannes Fabian, 'Art, History, and Society: Popular Painting in Shaba, Zaire', Studies in the Anthropology of Visual Communication, 3, 1 (1976), pp. 1-21.

Takeuchi, Kenji, 'CIPEC and the Copper Export Earnings of Member Countries', The Developing Economies, 10, 1 (1972), pp. 3-29.

Thompson, E. P., The Making of the English Working Class (London: Victor Gollancz, 1963).

Thornberry, Elizabeth, 'Virginity Testing, History, and the Nostalgia for Custom in Contemporary South Africa', African Studies Review, 58, 3 (2015), pp. 129-48.

Thram, Diane, For Future Generations: Hugh Tracey and the International Library of African Music (Grahamstown, South Africa: ILAM, 2010).

Tilley, Helen, Africa as a Living Laboratory: Empire, Development, and the Problem of Scientific Knowledge, 1870-1950 (Chicago, IL: University of Chicago Press, 2011).

Tödt, Daniel, 'The Lumumba Generation: African Bourgeoisie and Colonial Distinction in the Belgian Congo' (In Press, Berlin: De Gruyter, 2021).

Tracey, Hugh, 'The Social Role of African Music', African Affairs, 53, 212 (1954), pp. 234-41.

Hansen, Karen Tranberg, Karen, 'Body Politics: Sexuality, Gender, and Domestic Service in Zambia', Journal of Women's History, 2, 1 (1990), pp. 120-42.

Hansen, Karen Tranberg, Karen, 'After Copper Town: The Past in the Present in Urban Zambia', Journal of Anthropological Research, 47, 4 (1991), pp. 441-56.

Vail, Leroy (ed.), The Creation of Tribalism in Southern Africa (Oxford: James Currey, 1989). 
Van Beurden, Sarah, Authentically African: Arts and the Transnational Politics of Congolese Culture (Athens: Ohio University Press, 2015).

Van Bilsen, Jeff, Congo, 1945-1965: La Fin d'une Colonie (Brussels: CRISP, 1994).

Van Donge, Jan Kees, 'Understanding Rural Zambia Today: The work of the Rhodes Livingstone Institute', Africa, 55, 1 (1985), pp. 60-76.

Vannes, J., 'De L'Evolution de la Coutume d'Elisabethville', CEPSI Bulletin, 32 (1956), pp. 223-68.

Van Onselen, Charles, 'Worker Consciousness in Black Miners: Southern Rhodesia, 1900-1920', Journal of African History, 14, 2 (1973), pp. 237-55.

Vansina, Jan, Kingdoms of the Savannah (Madison: University of Wisconsin Press, 1966).

Vanthemsche, Guy, Belgium and the Congo, 1885-1980 (Cambridge: Cambridge University Press, 2012).

Varshney, Ashutosh (ed.), 'Beyond Urban Bias', Journal of Development Studies, 29, 4 (1993), special issue, pp. 3-258.

Vellut, Jean-Luc, Les Bassins Miniers de L'Ancien Congo Belge: Essai D'Histoire Économique et Sociale (1900-1960), Les Cahiers du CEDAF (Brussels: CEDAF, 1981).

Vellut, Jean-Luc, 'Mining in the Belgian Congo', in David Birmingham and Phyllis M. Martin (eds.), History of Central Africa Vol. II (Longman, London, 1983), pp. 126-62.

Verbeek, Leon (ed.), Les Arts Plastiques de L'Afrique Contemporaine: 60 Ans D'Histoire à Lubumbashi (R-D Congo) (Paris: L'Harmattan, 2008).

Villalon, Leonard and Peter Von Doepp (eds.), The Fate of Africa's Democratic Experiments (Bloomington: Indiana University Press, 2005).

de Villers, Gauthier with Jean Omasombo Tshonda, Zaire: La Transition Manquée (1990-1997) (Tervuren-Paris: Institut Africain-L'Harmattan, Cahiers Africains, 27-29, 1997).

Vinckel, Sandrine, 'Violence and Everyday Interactions Between Katangese and Kasaians: Memory and Elections in Two Katanga Cities', Africa, 85, 1 (2015), pp. 78-102.

Wamba-dia-Wamba, Ernest, 'Democracy, Multipartyism and Emancipative Politics in Africa: The Case of Zaire', Africa Development, 18, 4 (1993), pp. 95-118.

Waterman, Peter, 'The "Labour Aristocracy" in Africa: Introduction to an Unfinished Controversy', in Dennis L. Cohen and John Daniel (eds.), Political Economy of Africa (London: Longman, 1981), pp. 119-29. 
Wauthion, René, 'Pour le Developpement d'une Economie Rurale dans L'Hinterland des Grands Centres Industriels du Haut-Katanga: Contribution a une Initiative du CEPSI', CEPSI Bulletin, 34 (1956), pp. 5-21.

Werbner, Richard P., 'The Manchester School in South-Central Africa', Annual Review of Anthropology, 13 (1984), pp. 157-85.

West, Michael O., The Rise of an African Middle Class: Colonial Zimbabwe, 1898-1965 (Bloomington: Indiana University Press, 2002).

White, Bob, Rumba Rules: The Politics of Dance Music in Mobutu's Zaire (Durham, NC: Duke University Press, 2008).

White, Luise, Speaking with Vampires: Rumor and History in Colonial Africa (Berkeley: University of California Press, 2000).

White, Luise, 'Telling More: Lies, Secrets, and History', History and Theory, 39, 4 (2000), pp. 11-22.

Willis, Justin, 'The Administration of Bonde, 1920-60: A Study of the Implementation of Indirect Rule in Tanganyika', African Affairs, 92, 366 (1993), pp. 53-67.

Wilson, Godfrey, 'Anthropology as a Public Service', Africa, 13, 1 (1940), pp. 43-61.

Wilson, Godfrey, The Economics of Detribalization in Northern Rhodesia (Livingstone, Zambia: Rhodes Livingstone Institute, 1941).

Wipper, Audrey, 'African Women, Fashion, and Scapegoating', Canadian Journal of African Studies, 6, 2 (1972), pp. 329-49.

Withers, Charles W. J., 'Place and the "Spatial Turn" in Geography and History', Journal of the History of Ideas, 70, 4 (2009), pp. 637-58.

w'Itunga, Kishilo, 'Une Analyse de la "Messe Katangaise” de Joseph Kiwele', African Music, 6, 4 (1987), pp. 108-25.

Wolpe, Harold, 'Capitalism and Cheap Labour-Power in South Africa: From Segregation to Apartheid', Economy and Society, 1, 4 (1972), pp. 425-56.

Young, Crawford, Politics in the Congo: Decolonization and Independence (Princeton, NJ: Princeton University Press, 1965).

Young, Crawford, The African Colonial State in Comparative Perspective (New Haven, CT: Yale University Press, 1994).

Young, Crawford and Thomas Turner, The Rise and Decline of the Zairian State (Madison: University of Wisconsin Press, 1985).

\section{Online References and Resources}

Action Aid Zambia: www.facebook.com/AAZambia/posts/relocation-ofkankoyo-communityactionaid-today-joined-other-civil-society-organi/27 96990223649640 (accessed 10 August 2020). 
African Borderlands Network Bibliography: www.aborne.net/bibliography (accessed 21 September 2020).

$B B C$ News. 2020. 'Climate Change has Brought Parts of Zambia to the Brink of Famine', BBC News, 3 January: www.bbc.co.uk/news/av/world-africa -50976829/climate-change-has-brought-parts-of-zambia-to-the-brink-offamine (accessed 13 August 2020).

British Library Endangered Archives Project, UNIP archives: https:/eap .bl.uk/project/EAP121/search (accessed 21 August 2020).

cosccet.org. Le Comité de Suivi pour la Contribution des Communautés et Eglises à la Transformation Humaine: http://cosccet.org/node/76 (accessed 30 July 2020).

Environmental Protection Agency (US): www.epa.gov/superfund/whatsuperfund (accessed 29 July 2020).

'From the Copperbelt' album: www.allmusic.com/album/from-the-copperbelt -zambian-miners-songs-mw0000875573 (accessed 16 April 2020).

'Katangan Genre Painting': http://pca.socsci.uva.nl/aps/vol12/katangagenre paintingintro.html (accessed 13 April 2020).

Larmer, Miles. 'Comparing the Copperbelt' project website: https://copper belt.history.ox.ac.uk (accessed 21 August 2020).

Leigh Day. 2021. 'Legal Claim by More Than 2,500 Zambian Villagers in a Case Against Vedanta Resources Limited', Leigh Day, 18 January, www .leighday.co.uk/latest-updates/news/2021-news/legal-claim-by-more-than -2-500-zambian-villagers-in-a-case-against-vedanta-resources-limited (accessed 23 March 2021).

Lusaka Times, 2019. 'Jerabos March on the Streets of Mufulira to Demand the Black Mountain', Lusaka Times, 26 June: www.lusakatimes.com/20 19/06/26/jerabos-march-on-the-streets-of-mufulira-to-demand-the-black -mountain (accessed 10 August 2020).

Mining and Business website: https://miningandbusiness.com/2019/10/01/g ecamines-fait-a-nouveau-partie-du-club-ferme-des-miniers-en-rdccapable-de-produire-du-cuivre-pur-a-9996-2 (accessed 10 August 2020).

Mining for Zambia: https://miningforzambia.com/a-concentrated-miningsector (accessed 22 July 2020).

Ministry of Mines, Government of Zambia: http://mines.org.zm/employ ment-figures (accessed 22 July 2020).

Picha: http://picha-association.org (accessed 16 Apr 2020).

Pratt, Sara E., 'All That Glitters ... Acid Mine Drainage: The Toxic Legacy of Gold Mining in South Africa', Earth Magazine, October 2011: www .earthmagazine.org/article/all-glitters-acid-mine-drainage-toxic-legacygold-mining-south-africa (accessed 4 August 2020).

Reuters. 2019. 'Zambia's Power Supply Deficit Worsens as Water Levels Sink', Reuters, 12 December: www.reuters.com/article/us-zambia- 
electricity/zambias-power-supply-deficit-worsens-as-water-levels-sinkidUSKBN1YG1DZ (accessed 6 August 2020).

Reuters. 2021. 'Vedanta Resources Settles Zambia Copper Mine Pollution Claim', Reuters, 19 January, www.reuters.com/article/us-zambia-miningvedanta-idUSKBN29O1EL (accessed 23 March 2021)

Peter Sinkamba, online profiles: www.forbes.com/sites/ashoka/2012/10/03/ meet-a-playboy-entrepreneur-who-went-from-making-millions-tomaking-an-impact/\#1068ddc04579 and www.ashoka.org/en-gb/fellow/p eter-sinkamba (both accessed 17 August 2020).

Tshibumba Kanda-Matulu artworks: www.contemporaryand.com/maga zines/history-is-never-just-a-story (accessed 13 April 2020).

UMHK film, En Cinquante Ans (1956) at: www.youtube.com/watch?v=9 z4GtyCvlCg (accessed 7 May 2020).

University of Vienna. 'Employment-tied housing in (post)colonial housing' project website: https://housing.univie.ac.at (accessed 21 August 2020).

Waza: www.centredartwaza.org (accessed 16 April 2020).

We Intend to Cause Havoc, film: www.imdb.com/title/tt5666750 (accessed 16 April 2020).

W.I.T.C.H. Wikipedia page: https://en.wikipedia.org/wiki/Witch_(Zam rock_band) (accessed 16 April 2020).

'WorkInMining' project website: www.workinmining.ulg.ac.be (accessed 16 August 2020). 


\section{Index}

Académie des Beaux-Arts de

Lubumbashi, 236

African art, 229, 236, 254, 257

African Labour Advisory Board, 86

African Mail, 176, 200

African Mine Township Boards, 140

African Mineworkers' Union (AMWU), 81, 136-7, 139-40, 141-2, 153, 157-60, 209, 225

African music, 238, 240, 247, 249

African Proletarians and Colonial

Capitalism (Meebelo), 225

African Representative Council, 135, 168

African Trade Union Congress, 136

Africanisation, 144, 156, 219, 222, 254 agriculture, 69, 73, 167, 186, 201, 275, 295, 296-9, 304, 306, 308, 326,

See also farming

alcoholism, 164, 178

Amis de l'Art Indigène (organization), 236

Anglo-American Corporation (AAC), 6, 117, 208, 211, 213, 233

Anglophone, 11, 200

Angola, 218

anti-colonial movement, 130, 210, 217

army, 200, 205, See also military

Association africaine des droits de

l'homme (organization), 315

authenticité, 221, 222, 246, 252

Balandier, Georges, 45

Balimwatsh (song), 183

Baloji, Sammy, 257

Bancroft Mines Limited, 298

Bancroft, Zambia, 69, 203

Bandeira, Miguel Jerónimo, 14

Bates, Robert, 214, 327

Belgian Congo, 4, 5, 9, 30, 38, 45, 71, $74,85,130,145,163,164,222$
Belgium, 5, 10, 50, 53, 234, 257, 324

businesses, 218, 235

colonial, 14, 39, 40, 164

government, 134, 148-9, 212

rule, 39,75

Bemba people, 5, 7, 52, 139, 157, 197, 233

Beurden, Sarah van, 235

Bézy, Fernand, 70

black nationalism, 139

Bond, Prime Minister Nguza Karl I, 267

Brazzaville, Republic of Congo, 45

Britain, 8-10

companies, 136, 199

government, 56, 70, 136, 140, 149, 203

rule, 14, 41, 45, 135, 145, 172, 245

British South Africa Company, 70, 208

Broken Hill mining compound, 46

Brown Commission of Inquiry, 210

Bruneau, Jean-Claude, 305, 306

Burawoy, Michael, 215

Burton, Lilian, 150

Caprasse, Pierre, 56, 148, 153-4

Catholic Church, 7, 11, 38, 40, 52, 91, 102, 127, 130, 136, 149, 164, 231

Central African Broadcasting Services, 248

Central African Copperbelt, 24, 29, 34, 37, 42, 45

Central African Federation (CAF), 9, 16, 74, 130, 145, 150, 200

Centre d'Etudes des Problemes Sociaux Indigènes, 11, 44, See also CEPSI

Centre d'exécution des programmes sociaux et économiques (CEPSE), 305

Centres extra-coutumier (CEC), 40, 102-3, 146-8, 153, 154, 169, 232 
CEPSI, 12, 15, 21, 34, 44-6, 48, 50-1, 52-4, 72, 73, 74, 88, 101, 146, See also CEPSI researchers

CEPSI researchers, 11, 15, 25, 45, 51, 53, 56, 59, 63, 71, 169

Cercle Saint-Benoit (institution), 40, 147, 149, 231

Cha Cha Cha rebellion, 157

Chakulya, Wilson, 203, 204

Chama, Samson, 216, 302

Chamber of Mines, 81, 140

Chanda, Jagari, 249, 257

Chani, Chrispin, 122, 251, 266, 304

Chansa, Jennifer, 313, 318

Chauncey, George, 42, 166-7, 180

Chemin de fer du bas Congo au Katanga (BCK), 102, 107

Chiluba, Frederick, 273, 279, 283, 285-6

China, 286

Chipata, Zambia, 18

Chisata, John, 216

Chola, Spokes, 250

Christianity, 46, 62

Citizens for a Better Environment (CBE), 311, 313

Clémens, René, 45, 50, 53, 54, 58

Cliffe, Lionel, 223

Coetzee, Pauline, 238, 240, 242

colonial period, 10, 11, 30, 60, 90, 172, 188, 202, 210, 215, See also colonialism

colonial rule, $35,36,48$

colonial state, 13, 41, 164, 200, 210

colonialism, 11, 22, 36, 40, 55, 147, $234,235,246,324,335$

colour bar, 6, 9, 41, 81, 91, 139, 150, 151, 152, See also segregation

Colour of Class on the Copper Mines, The (Burawoy), 215

Combined Commission for Technical Cooperation in Africa South of the Sahara, 14

communism, 43, 279

Comparing the Copperbelt project, 295

Comrie, William, 136

Confédération des associations tribales du Katanga (Conakat), 58, 155, 196
Congo, 54, 67, 86, 90, 151, 155, 220, 245, 324, See also Democratic

Republic of Congo

Congo Free State, 38

Congolese art, 235-7, 255

Congolese copperbelt, 4

Congolese National Army (ANC), 57, 200, 204, 216

Cooper, Frederick, 129, 195

Copperbelt African Education

Department, 106

Copperbelt boom, 94, 261

Copperbelt Environment Project, 312

Copperbelt society, 3-4, 8-9, 13, 19,

24, 29, 32, 34, 58, 60, 63, 149,

$229,263,322,323,327,332,335$

and women, 162, 185, 331

colonial, 10, 38, 179

historical change, 32, 62, 287

knowledge production, 24, 198, 334

studies of, 59, 210, 220, 321

cosmopolitanism, 253, 262, 280, 325

coup d'état, 266

Crem, Robert, 271

Crine-Mavar, Bruno, 58

Crosby, Alfred, 293

Cross, Sholto, 224

Dahn, Jack, 243

de Boeck, Filip, 101

de Hemptinne, Father Jean Felix, 39, 50, 134

de Villiers, W.T., 77-8

decolonisation, 50, 54, 98, 117-18, 129-31, 160, 195, 200, 236, 324, 328

Democratic Republic of Congo (DRC), 1, 5, 129, 261, 283, 310, 323, See also Zaire

desegregate, 150, 152

Dethier, Robert, 54

Dibwe dia Mwembu, Donatien, x, 23, 39, 83, 143, 165, 181-4, 186, 191, 258, 263, 264

Dondo, Prime Minister Kengo wa, 282

Doucy, Arthur, 45, 47, 50, 54, 58, 71, 134, 169 
Elisabethville, DRC, 14, 39, 51, 53, 70, 73, 87, 146, 155, 169, 220, 235, See also Lubumbashi, DRC

Ematambo Waifwe Bantu (song), 243

Environmental Council of Zambia (ECZ), 309, 310, 313

Environmental Impact Assessments (EIA), 27, 309, 312

Environmental Protection and Pollution Control Bill, 309

Epstein, Arnold, 11, 47, 54, 55, 58, 98, 136, 137-9, 170, 180

Europe, 47, 173, 294 civilisation, 39, 45, 49, 50, 147 culture, 50, 151, 228

knowledge production, 59, 62 workers, 70, 75, 81, 207, 266, 300

European Mineworkers' Union, 6

Europeans, 10, 35, 51, 60, 94, 98, 110, 143, 151-2, 200, 234, 253, 303

jobs, $6,81,83$

music, 239, 244, 247

relations with Africans, 36, 55, 72, 100, 144, 149, 157

évolués (elites), 39-41, 54, 55, 57, 80, $133,145,147,148-50,152$, 154-5

expatriates, 212, 223, 267, 268, 305

Expectations of Modernity (Ferguson), 17

Fabian, Johannes, 24, 116, 119, 122, 236, 252, 254-5

Falola, Toyin, 219

farming, 1, 73, 74, 91, 102, 121, 125, 167, 282, 296-7, 299, 304-7, 308, 311

by women, $167,170,186-7,330$ urban, 13, 61, 166, 295, 306, 307

Federation of African Welfare Societies, 149

Feldheim, Pierre, 47, 50, 71, 134

Ferguson, James, 3, 12-13, 17, 19, 23, 29, 62, 99, 122, 131, 163, 171, $192,263,333$

Forster Commission (1940/1), 43-4

Forster Inquiry into Advancement (1954), 81-2

FULREAC, 88, See also agriculture

Fwalanga, Peter, 202
Gaula Band, 250

Gécamines, 9, 91, 98, 110, 196, 259, 262, 267-8, 281, 282-3, 286, 290, 300, 305, 306, 313

and World Bank, 265, 270

families, 119, 181, 183, 185

paternalism, 20, 184, 271, 325

pollution, 302, 303

social welfare, 163,271

state control of, 212, 252

workers, 90, 94, 123-4, 187

See also UMHK

Geenen, Kristien, 318

Gille, Albert, 49

Gluckman, Max, 48

Great Depression, 42

Green and Justice (organization), 315, 316

Grévisse, Ferdinand, 51-2, 146-9

Guene, Enid, ix, 231, 256

Hall, Barbara, 176

Hansen, Karen Tranberg, 180

Harries-Jones, Peter, 159

Haut-Katanga, 1, 8, 13, 14, 16, 18, 19, $29,37,41,44,53,98,115,130$, 133, 136, 215, 231, 254, 325 arts, 237, 247, 257 ethnic conflict, 27, 155, 262, 326 farming, 296, 299, 305, 308 mine strikes, 44, 75 mining towns, 39, 119, 323 nationalism, 196, 204-5, 210, 222, 324

pollution, 310, 313-14

social services, 166, 185, 188

Henk, Daniel, 185, 192

Higginson, John, 99, 133

Hironaka, Ann, 294

Hiroshima, Japan, 2

HIV/Aids, 256

Hodgkinson, Dan, 219

Horizon, 243

Humanism, 198, 200-2, 223-5

Ibadan University, 219

imperialism, 10, 14, 235

independence, $1,58,59,67,68,87,92$, 95, 99, 103, 115, 118, 129, 144, $154,155,245,266,324$ 
Congo, 130, 220

DRC, 89, 195

Katanga, 155, 196

Zambia, 16, 89, 156, 176, 195, 206, 223, 243

Indigenous Enterprise Council (CIE), 130, 135, 142, 143-4, 153, 156, 160

Industrial Development Corporation, 90

Industrial Relations Act, 209

Industrial Revolution, 69

industrialisation, 11, 44, 45, 52, 65,90

Institut national pour l'étude agronomique du Congo belge (INÉAC), 73

Institute for African Studies (IAS), 223

Institute of National Museums of Zaire, 246

Intergovernmental Council of CopperExporting Countries (CIPEC), 217

International Colonial Institute, 13

International financial institution (IFI), 261, 268, 270, 273, 275-6, 283, 291, 309, 327

International Labour Organisation (ILO), 14, 26, 68, 210, 299

International Library of African Music (ILAM), 237-8, 259

International Monetary Fund (IMF), 30, 261, 265, 267, 275, 329, See also World Bank

Jadotville, DRC, 73, 103, 133, 296, See also Likasi, DRC

Jecoke dance group, 232, 258

Jeunesse du Mouvement Populaire de la Révolution (JMPR), 271

Jewisewicki, Bogumil, 23, 145

Kaavu, Enoch, 62

Kabila, Laurent, 280, 282

Kabusha (radio programme), 253, 332

kachoma, 27, 302, See also senta

Kachusa, Damion, 316

Kalela dance, 227, 234, 242

Kalela Dance, The (Mitchell), 233

Kalindula (music), 250, 256, 258
Kallmann, Deborah, 176

Kamalondo, Alexander, 216

Kanda-Matulu, Tshibumba, 255

Kankasa, Timothy, 204

Kankoyo, Zambia, 107, 114, 121, 300, 315, 318

Kansuswa (township), 115, 125, 304

Kantanshi (township), 110, 121

Kapwepwe, Simon, 216, 250

Kasumali, Stephen 'Tsotsi', 242, 244

Kaswili, Odilon Kyembe, 231

Katanga, 5, 8, 28, 43, 58-9, 72, 73, 76, $79,83,87,90,116,121-2,166$, $177,191,200,258,269$

culture, 227, 233, 240, 247, 254, 256-7

education, 91, 149

mining towns, 27, 104, 123, 317

secession, 16, 130, 156, 196, 206

social welfare, 163, 168, 189

strikes, 5, 134

unemployment, 85, 87

workers, 71, 103

working women, 181, 183, 184-5

Katanga journal, 155

Katanga Provincial Council, 71, 72, 76, 85,87

Katangese copperbelt, 16, 29, 184, 256, 326

Katilungu, Lawrence, 138-9, 158, 225

Katilungu, Simon, 139

Katiti, Masengu, 231

Katumbi, Moïse, 287

Kaunda, Kenneth, 150, 159, 176, 200-1, 206, 212-13, 223, 266, 298 and culture, 248, 250, 259

and Humanism, 201, 223, 224

economic decline, 272, 274

government of, 197, 208, 248, 285

Kawama (township), 102, 126-8

Kayamitala, Umba, 271

Kenneth Kaunda Foundation, 225

Kenya (township), 146, 232

Kibwe, Jean-Baptiste, 245

Kikula (township), 93, 110, 124

Kinshasa, DRC, 220, 245, 246, 247, See also Léopoldville, Congo

Kisimba, Adolphe, 231

Kiswahili (language), 40, 177 
Kitwe, Zambia, x, 86, 88, 105, 107, 153, 186, 275

Kiwele, Joseph, 231

knowledge production (definition), 3, 10, See also production of knowledge

Koloko, Leonard, 244, 245, 249-50

Kolwezi, DRC, 53, 192, 226, 266, 318

Kyungu wa Kumwanza, Gabriel, 280

L'Echo du Katanga (newspaper), 147

labour movement, 126, 130, 197, 198, 210, 279, 310, See also unions

Lamba people, 1, 9, 52

Lefebvre, Henri, 97

Lenshina, Alice, 201, 202

Leopold II museum, 235

Leopold, King of Belgium, 38

Léopoldville, Congo, 71, 220, 236

liberalisation, 263, 270, 274-5, 283, $285,289,310,326$

Likasi, DRC, 28, 31, 97, 110, 114, 186, 276, 291

Livingstone Museum, 235

Livsey, Tim, 219

Lovanium University, 220

Luanshya, Zambia, 18, 87, 91, 98, 106, 132, 139, 166, 171, 233, 263, 284

Luba Kasai people, 52, 196

Luba kingdom, 5, 36

Lubumbashi Biennale, 257

Lubumbashi museum, 235, 246

Lubumbashi, DRC, 30, 205, 221, 252, 266, 287

Lukhero, M. B., 57

Lumpa church, 201

Lumpa communities, 202

Lumumba, Prime Minister Patrice, 155, 196, 254

Lunda kingdom, 1, 5, 36, 59, 154, 200

Lusaka, Zambia, 14, 100, 101, 197

Macola, Giacomo, 62, 200

Main Currents of Zambian Humanist Thought (Meebelo), 224

Malokoleta, Elizabeth, 157

Mangeurs de Cuivre festival, 230, 252

Masanga (song), 242

Maybin, Sir John, 135

Meebelo, Henry, 198, 224-5
Mémoires de Lubumbashi project, 23, 25,258

Merle Davis, John , 41, 42, 166

migrants, 1, 7, 12, 20, 46, 53, 61, 63, 92, 99, 102, 107, 165, 168, 171, 227, 233, 244, 329

African, 5, 35, 41-2, 50, 60

Bemba-speaking, 197, 232

Congolese, 251, 256

Kasaian, 27, 155

labour, 57, 199

rural, 119, 122

urban, 94, 131, 152-3, 174

migration, 1, 6, 7, 17, 39, 47, 60, 62, 70, 74, 95, 104, 157, 164, 168,

207, 215, 241, 259, 272, 298, 322

military, 205, 234, 265, 266, 272, 283, See also soldiers

mine companies, 2, 8, 29, 41, 43, 62, $67,70,79,82,83,94,116,136$, $137,140,149,195,213,311,316$

and culture, 233, 238, 257

and farming, 298-9

and unions, 141, 159

and women, 162, 185

and workers, 48, 334

communities, 96, 98, 107, 109-10, 128

economic decline, 274, 276, 288

education, 91

Northern Rhodesian, 34, 76, 173, 297

pollution, 26, 294, 296, 300, 308

social services, 264, 324

Zambian, 207, 211

Mine Townships Management Board, 91

mines, $1,15,18,37,52,75,79,93,128$, 132, 150, 167, 198, 213, 276, 286, 293, 294, 304, 309, 314, 317

Katangese, 5, 7, 34

Northern Rhodesian, 6, 68, 168, 204, 240

Zambian, 91, 123, 207, 213, 312

Mines African Staff Association (MASA), 81, 140, 141

mineworkers, viii, 12, 23, 40, 84, 94, 109, 114, 116, 124-6, 141, 142, 191, 208, 209, 216, 218, 230, 232, 250, 263, 273, 276, 282, 284, 288, 304, 321 
African, 10, 15, 17, 42, 48, 67, 80, 97, 131, 137, 152, 157, 324

children, 79, 92, 184, 188

economic decline, 261, 263

European, 6, 134

Northern Rhodesian, 75, 83, 165

social services, $8,9,324$

UMHK, 133, 144, 160

unions, 118, 130, 138

unmarried, 39, 75, 104

white, 41, 53, 207

wives of, 30, 162-3, 166, 181-2, 186, 299

Zambian, 121-2, 184, 214

Mineworkers' Union of Zambia (MUZ), 30, 209, 215-16, 273

mining camps, 6, 20, 38, 61, 99

Mining Mirror (newspaper), 284, 310

mining towns, $1,7,12,27,39,46,53$, $95,99,101,130,164,171,177$, 181, 185, 221, 229, 244, 280, 305. 324, 327

missionaries, 7, 34, 37, 41-2, 71, 164, 166, 201, 324

Mitchell, J.Clyde, 11, 45, 50, 55, 57, 227, 233

Mobutu, President Joseph, 90, 119, 212, 217, 246, 247, 266, 269, 280, 282,325

authenticité, 221, 246, 252

democratic reform, 279-80

MPR, 205, 211, 222, 252

nationalisation, 91, 196, 212

regime, 28, 116, 205, 226, 267, 270

Modern Industry and the African

(Davis), 166

modernity, 2, 3, 8, 13, 21, 36, 46, 52, 59, 98, 131, 134, 169, 172, 194, $235,243,258,282,312,330$

African, 156, 262

European, 34, 55, 100

industrial, 28, 296

urban, 12, 13, 18, 46, 59, 97, 197

Western, 162, 193

Mokambo, Zambia, 127, 202, 266

Monaville, Pedro, 220

Money, Duncan, 207

Mopani Copper Mines, 313

Mouvement Nationale Congolaise, 155
Mouvement Populaire de la Révolution (MPR), 205, 211, 212, 222, 252, 271, 276

Movement for Multi-party Democracy (MMD), 279-80, 283

Mudimbe, Valentin, 221, 226

Mudimbi, Valérienne Ngoy, 165

Mufulira mine disaster, 218, 250

Mufulira Native Court, 84

Mufulira Welfare Association, 150

Mufulira, Zambia, 29, 31, 87-9, 97, 105, 108, 110, 115, 120, 127, 150, $186,216,273,278$

Mufwankolo group, 231, 232, 332

Mufwankolo, Odilon, 231, 252, 259

Mulenga, Dewys, 126-7

multi-party democracy, 196, 226, 280

Mulunda, Jérôme, 119, 123, 269

Musambachime, Mwelwa, 223, 226

Musonoi mine camp, 116

Mususa, Patience, 26, 263, 285, 318

Mwanza Mujila, Fiston, 257

Mwaant Yaav (Lunda king), 58, 154, 200

Mwale, Steack, 174

Mwamba, E.M., 205

Mwana Shaba (newspaper), 109, 177-9, 183, 190, 231, 236, 271, 281

Mwenda, George, 107, 307

Mwenda, Jean Bosco, 242, 244, 247

Mweni, Washeni, 61, 125, 302

Myers, Garth, 100

Nabulyato, Robinson, 63

Nagasaki, Japan, 2

Namusiya at the Mines (Kaavu), 61-2, 175-6, 258

nationalisation, $1,10,115,119,213,215$

nationalism, 7, 9, 15, 129

nationalist movement, 14, 130, 144, 197

nationalists, 115, 129, 138, 198, 245

Nchanga Consolidated Copper Mines, 82

Ndilila, Sykes, 233

Ndola, Zambia, x, 167, 249

Nkhata, Alick, 243, 245, 247-8

Nkoloma, Matthew, 141 
Nkumbula, Harry, 150

Northern Rhodesia, 4, 8, 17, 41, 68, 74, 77, 79, 83, 107, 116, 135, 143, 149, 151, 156, 167, 232, 296

Copperbelt, 37, 42, 130

government of, 15, 45, 85, 103, 168 mine towns, $69,84,132,160,166$, 172,240

mines, 52, 80, 152

segregation, 99, 130, 152

unemployed, 86-8

white labour, 6, 41

Northern Rhodesian African National Congress (NRANC), 16, 149-50, 157,200

Northern Rhodesian Council for Social Services (NRCSS), 173-4

Northern Rhodesian Hotels Association, 151

Nyasaland, 9, 222

Nyirongo, J.B., 206

OK Jazz band, 247

one-party state, 197, 217, 226, 279

Oppenheimer College of Social Services, 175

Oppenheimer, Ernest, 82

Orientalism, 22

Panda (township), 80, 110-14, 119

Parpart, Jane, 70, 137, 166, 172, 180

paternalism, 39, 50, 119, 263, 265, $271,324,325,330$

Patriotic Front (PF), 286-7

Peemans, Jean-Philippe, 90

peri-urban, 53, 61, 73-4, 85-6, 99, 100, $115,121,186,304,321$

Perrings, Charles, 15

Peša, Iva, 295, 298, 300, 306, 319

Petits Chanteurs à la Croix de Cuivre (choir), 231

police, 61, 132, 273, 286

Politics in an Urban African Community (Epstein), 55

pollution, 26, 27, 292, 294-5, 299-300, 301-3, 308-10, 312-15, 317,320 , See also senta

polygamy, 38, 164, 170, 171, 179, 184, 191, 194

Poncelet, Marc, 25, 50, 53, 54, 57, 58 popular painting, 228, 253-5, 259

post-World War II, 2, 8, 14, 20, 28, 34, $44,47,54,65,67,68,69,72,75$, 102, 104, 134, 160, 173, 296

Powdermaker, Hortense, 47, 50, 57, $83,100,113,171,173,179,180$, 185, 233, 247

privatisation, $1,21,27,163,262$, 283-5, 286, 294, 312, 313, 319

production of knowledge, 16, 22, 52, 59, 63, 163, 208, 218-20, 260, 294, 331

propaganda films, 69

prostitution, 37, 62, 162, 166, 175, 248, 290

Racanelli, David, 244

Race Relations Committees, 150

Race Relations Ordinance, 150, 152

radicalisation, 8

Rautenbach, Billy, 283

Reaction to Colonialism (Meebelo), 224

researchers, ix, 12, 18, 23, 24, 30-1, 34, 47-8, 54, 163, 193, 198, 322, 324, 333,335

African, 17, 32

European, 16, 221

Western, 17, 327, 328

Rheinallt Jones, J.D., 103

Rhodesia, see also Zimbabwe, 218, 265

Rhodesian Selection Trust (RST), 6, 79, 208, 211-13, 233, 297, 298

Rhodes-Livingstone Institute (RLI), 11-12, 17, 21, 25, 29, 34, 44-5, 52, 54, 55-6, 58, 63, 101, 198, 223, See also RLI researchers

Rhokana mine, 77,78

riots, 43,132

RLI researchers, 15, 46, 50, 56-7, 130, 136,170

Roan City African Dancing Club, 230

Roberts, John, 158

Romain-Desfossés, Pierre, 236

Ross, Corey, 293, 296

Round Table conference, 58

Royal African Society, 239

Royal Museum of Central Africa (RMCA), 235, 246

Ruanda-Urundi, 5 
Rubbers, Benjamin, 16, 23, 25, 50, $53-4,57,58,263,280,283$

Said, Edward, 22

Sata, Michael, 286

Schumaker, Lyn, 17, 25, 56-7, 63, 139, 170,322

secession, 90, 196-7, 199, 211, 220, 325

Second National Development Plan, 125

Seers Report, 208

segregation, 40-1, 55, 84, 97-9, 100, 108, 128, 130, 153

Sendwe, Jason, 58

senta, 27, 302-4, 315, See also pollution

Shaba II invasion, 266

Shaba Province, 197, 205, 226

Shaba wars, 226, 269

Simone, AbdouMaliq, 101

Sinkamba, Peter, 311

situpa (documents/internal passports), $38,61,99$

social centres, $169,185,188$

social services, 8, 49, 89, 93, 104, 115, 133, 144, 163-4, 172-5, 183, 188, 271,324

social welfare, 9, 30, 45, 135, 144, 162, $163,168,173,174,175$

social workers, 109, 175, 188-9, 191

Socialism, 11, 223

Société Agro-Industrielle (AGRIS), 305, See also agriculture

Société Générale Congolaise des Minerais (company), 212

Société Nationale d'Electricité (SNEL), 268

Société Nationale des Chemins de Fer du Zaire (SNCZ), 268

Societe Zairoise de Commercialisation des Minerals (SOZACOM), 267, 269

soldiers, 133, 199, 200, 206, 257, 266, 269

South Africa, 74

Southern Rhodesia, 9, 74

Sovereign National Conference (CNS), 280

state control, 9 state schools, 91

Steffen, Robertson and Kirsten company, 312

Strikes (worker), 34, 132, 133, 138, 159, 180, 211, 213, 273, 275, 280

of $1919,5,39,75$

of $1940,8,43,133,135,168$

of $1941,8,44,133,134,144,168$

of $1952,138,170$

of $1955,140,142$

of 1966,210

sub-Saharan Africa, 6, 65, 131, 196, 327

Third Republic, 310

Times of Zambia, 181

Tracey, Hugh, 24, 237-43, 247, 258

Trade Union Congress, 136

Tram 83 (Mwanza Mujila), 257

Tshibambe, Germain Ngoie, $\mathrm{x}$

Tshisekedi, Prime Minister Étienne, 280

Tshombe, Moïse, 58, 200, 202, 204-5, 206, 211, 245, 287

UMHK, 5, 6, 15, 45, 52, 69, 75, 76, 80, 116, 119, 133, 156, 160, 177, 185, 211, 230, 235, 296, 325

and the Catholic Church, 7, 38

culture, 227, 230, 237, 259

housing, 102-3, 143

mining camps, 8 , 44, 98-9

paternalism, 9, 20, 83, 135, 332

schools, 91

secession, 196, 211-12, 220

social services, $74,144,164$

workforce, 67, 68

See also Union Minière du Haut-

Katanga

unemployment, 67, 85-8, 101, 125, 274, 316, 344

Union Church, 42

Union des Fédéralistes et Républicains Indépendants (UFERI), 280

Union Minière du Haut-Katanga

(UMHK), 5

Union Nationale des Travailleurs $d u$ Zaire (UNTZA), 211

unionism, 8,50

unions, 7, 123, 134, 136, 141, 207, 209, 211, 273, 299, 324 
UNIP, 126, 157, 158, 197, 200, 201, 207, 209, 212, 215, 217, 223, 245, $247,249,273,275,279,325$

United Mineworkers' Union, 159

United Missions to the Copperbelt, 42

United National Independence Party, 28, 150, See also UNIP

United Nations (UN), 14, 196, 301

United Nations Educational, Scientific and Cultural Organization (UNESCO), 45

United Progressive Party, 28, 216

United States, 53

Université d'Etat (university), See also Lovanium University

University of Liège, 55

University of Lubumbashi, 23, 181, 197, 221, 222, 226, 254, 280

University of Zaire (UNAZA), 197, 221-2, 246

University of Zambia (UNZA), 92, 198, 222-3

Urban Advisory Council, 135

urbanisation, 6, 11, 13, 37, 45, 59, 65, 71, 101, 107, 134, 135, 137, 201, 224-5, 230, 259, 327, 333

van Beurden, Sarah, 246

Vannes, J., 169

Waldecker, Burkhart, 235

Wall Street Journal, 267

Watchtower society, 134

Wauthion, René, 72, 73

We Intend to Cause Havoc

(W.I.T.C.H.), 249, 250, 256

westernisation, 98

white supremacist, 9

White, Luise, 84, 333

Wilson, Godfrey, 46-8, 69

Wina, Sikota, 118

Witchcraft Ordinance, 84

World Bank, xv, 30, 261, 265, 268, 270, 272, 274, 282-3, 308, 312-13, 329, 331

World Vision, 308

World War Two (WWII), 42, 65, 70, 129, 133, See also post-World War II
Yamba, Dauti, 149

Youth Development Scheme, 91

Zaire, 28, 163, 188, 197, 207,211,218, 228, 265, 267, 279, 282, 308

Zairianisation, 218, 222, 247

Zambia, 1, 5, 62, 66, 90, 98, 100, 121, 129-30, 157, 183, 188, 190, 204, 211, 214, 218, 220, 223, 226, 245, 254, 265, 272, 275, 286, 310, 317, 323

colonial, 176, 224

culture, 228, 255, 256

government of, 89, 125, 215

immigration, 202-3, 205-7

independence, 157, 200

nationalisation, 198, 200, 208

political reform, 261, 279, 283

secession, 195-7

trade unions, 208, 211, 325

Zambia Broadcasting Corporation, 248

Zambia Congress of Trade Unions (ZCTU), 209, 273, 275

Zambia Consolidated Copper Mines (ZCCM), 20, 94, 123, 184, 191, 262, 272-4, 277, 278, 282, 283, 285, 305, 309, 310, 311,312

Zambia Institute of Technology, 223

Zambia Mineworkers' Union (ZMU), 209-10

Zambia National Agricultural Marketing Board, 306

Zambia National Council for Scientific Research and Department of Natural Resources, 309

Zambia Youth Service, 91

Zambia's Second National Development Plan, 215

Zambian Copperbelt, 4, 9, 16, 17-18, 20, 28

Zambianisation, 83, 207, 209

ZamRock, 249-50, 256, 259

Zimbabwe, 220, 266 